Dissertação de Mestrado

\title{
Conflito Cognitivo e Metas de Realização: uma Experiência nas Aulas de Física do Ensino Médio
}

Sérgio Antônio da Silva

Orientador: Prof. Dr.: Alberto Villani 
Dedicatória

Ao amor da minha vida, Adriana, pois no momento do meu maior fracasso, disse-me: "Eu só sei que vou continuar te amando".

Aos meus pais pela vida.

A minha Sogra Ivani, e, o meu Sogro Jubeci, que proporcionaram a tranquilidade junto aos meus filhos.

A compreensão dos meus filhos, Serginho e Sofia.

Ao meu grande amigo Wellington, companheiro de jornada. 


\section{Agradecimentos}

Ao Professor Villani, agradeço-lhe por ter acreditado em mim e em meu trabalho de pesquisa, e, pela enorme paciência.

Aos colegas do grupo de pesquisa.

A Diretora Marisa e o Vice-Diretor Valter, da unidade escolar, por permitirem a realização deste trabalho.

Aos alunos que participaram desta pesquisa. 


\section{Resumo}

$\mathrm{O}$ ensino de ciências ligado às propostas sócio-construtivistas possui como um dos seus conceitos básicos o envolvimento ativo do aluno no processo de aprendizagem.

Ainda que não muito bem compreendido o significado deste conceito, o envolvimento poderia ser conseguido por meio de atividades em que o sujeito vivenciasse o conflito cognitivo proposto por Piaget ou a Insatisfação com suas idéias diante de uma experiência crucial, proposta por Posner em seu Modelo de Mudança Conceitual.

Entretanto, diversas pesquisas nas últimas décadas têm capta do um ruído de fundo relativo a déficits motivacionais provocados por essas estratégias. Portanto, buscando entender esses resultados anômalos e contribuir para o debate em torno da construção do conceito acima, este trabalho apresenta a Teoria de Metas de Realização, oriunda da psicologia da educação e explicita como obter informações e quais critérios utilizar para classificar os alunos em uma das metas.

Em particular, a presente dissertação relata, analisa e interpreta uma experiência didática em Ensino de Física, na qual um grupo de alunos do segundo grau do ensino médio vivenciou um conflito sócio cognitivo. Os resultados apontam que os alunos, apesar de trabalharem no mesmo grupo, apresentaram desempenho e reações motivacionais diferentes, em boa parte compatíveis com os critérios de classificação de cada um deles. 


\begin{abstract}
The teaching of science related to socio-constructivists proposals has as one of its basic concepts "active involvement of students" in the learning process.

Although not very well understood the significance of this concept, the involvement could be achieved through activities where the subject perceptions the cognitive conflict proposed by Piaget or dissatisfaction with their ideas front a crucial experiment, proposed by Posner, in his Model of Change Conceptual.

However, several search in recent decades has captured a "back ground noise "relation the motivational deficits produced by these strategies. Therefore, seeking understanding these anomalous results to contribute to the debate surrounding the construction of the concept above, this work presents Achievement Goal Theory from education psychology and explains how to obtain information and what criteria to use to classify students into one of the goals.

In particular, this thesis reports, analyzes and interprets a teaching experience in Physics Teaching, in which a group of high school students high school experienced a cognitive social conflict. The results indicate that students, even though they working the same group showed different performance and motivational reactions largely consistent with the classification criteria of each.
\end{abstract}




\section{Índice}

\section{Introdução}

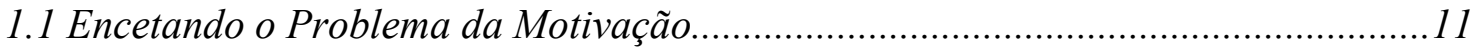

1.2Pergunta da Pesquisa ................................................................................................ 17

\section{Referencial teórico}

2.1 A Motivação Necessária para AprenderCiências..... .18

2.2 A Motivação Intrínseca: O Grande Sonho das Propostas Construtivistas de Piaget e Vygotski...... .23

2.3 As Diferentes Fases da Vida e a Demanda Social. 25

2.4O Modelo de Mudança Conceitual (M.M. C): O Ponto de Inflexão nas Metodologias Sócio-Construtivistas. 27

2.5A Crise Motivacional e Afetiva Provocada Pelas Propostas Sócio-Construtivistas..28

2.6 As Metas de Realização e o Sujeito Aprendente. .31

2.7 O Sujeito Epistemológico Piagetiano e uma possível Ecologia Conceitual...............38

2.8 Redefinindo a Pergunta da Pesquisa ......................................................................43

3. O Universo da Pesquisa

3.1 Caracterização da Escola...... 44

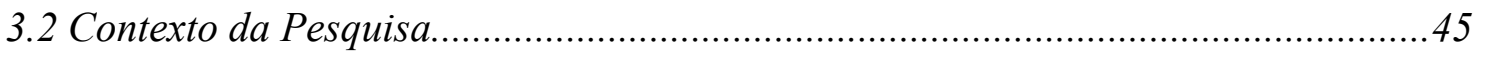

3.3 Primeira Fase da Pesquisa - Caracterização do Perfil de Realização......................45

3.4 Segunda Fase da Pesquisa - Capturar as Percepções Motivacionais.....................46

4. Metodologia

4.1 Instrumentos para Caracterização do Perfil de Realização. 48

4.2 Questionário de acesso as Metas de Realização

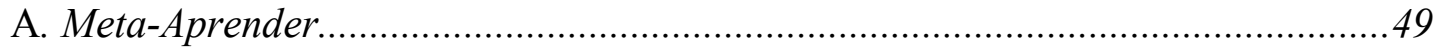

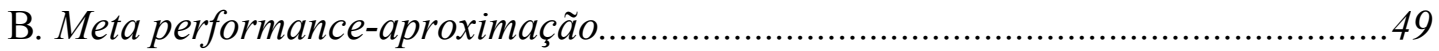

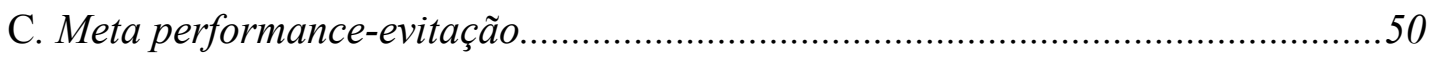

4.3 Entrevista de Validação do Perfil Motivacional de Realização..................................53

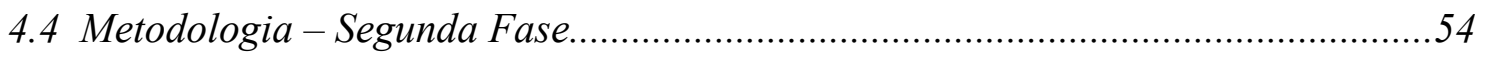

4.41 - Entrevista sobre a Percepção Motivacional.......................................................55

5. Apresentação e Análise dos Dados - Primeira Fase

5. Primeira Fase: Sujeitos Del, Ms e M. 
5.1 Diário de Campo, Questionário de Acesso as Metas de Realização e Resultado da Análise da Entrevista de Validação do Perfil Motivacional de Realização - Del

5.12 Diário de Campo - A escolha dos Sujeitos de Pesquisa. .58

5.13 Diário de Campo - Sujeito Del.........................................................................59

5.14 Questionário de Acesso às Metas de Realização - Sujeito Del..........................60

5.15 Resultados da Análise dos dados da Entrevista de Validação do Perfil

Motivacional de Realização do Sujeito - Del: "Sem guerra, não há vitória.". 62

5.2 Diário de Campo, Questionário de Acesso as Metas de Realização e Resultado da Análise da Entrevista de Acesso ao Perfil de Realização - Ms.

5.21 Diário de Campo - Sujeito Ms. .65

5.22 Questionário de Acesso às Metas de Realização - Sujeito Ms. .66

5.23 Resultados da Análise dos dados da Entrevista de Validação do Perfil

Motivacional de Realização do Sujeito - Ms: “Devia ter nascido, tudo aprendido. ”......67

5.3 Diário de Campo, Questionário de Acesso as Metas de Realização e Resultado da Análise da Entrevista de Acesso ao Perfil de Realização - M

5.31 Diário de Campo - Sujeito M. .69

5.32 Questionário de Acesso às Metas de Realização - Sujeito M. .70

5.33 Resultados das Análise dos dados da Entrevista de Validação do Perfil Motivacional de Realização do Sujeito - M: "Prefiro ser light, hehe...".

6.0 Avaliação da Metodologia de Acesso ao Perfil de Realização

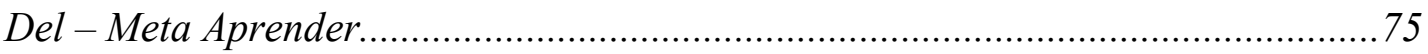

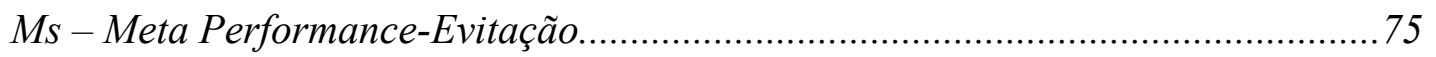

M- Meta Performance-Aproximação............................................................ 75

6.1 Considerações Finais Sobre a Avaliação da Metodologia........................................76

7. Segunda Fase da Pesquisa

7.0 Encontro do Grupo - Sujeitos: Au, Ga, En e Des ................................................... 77

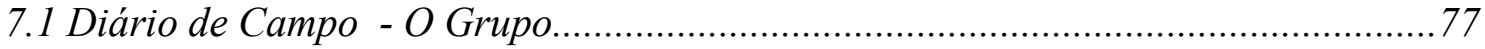

7.2 Caracterização do Perfil Motivacional de Realização do Sujeito Au........................78

7.21Resultados da Análise dos dados da Entrevista de Validação do Perfil

Motivacional de Realização do Sujeito Au .79

7.3 Caracterização do Perfil Motivacional de Realização do Sujeito Ga 81

7.31 Resultados da Análise dos dados da Entrevista de Validação do Perfil

Motivacional de Realização do Sujeito - Ga. 
7.4 Caracterização do Perfil Motivacional de Realização do Sujeito En . .83

7.41 Resultados da Análise dos dados da Entrevista de Validação do Perfil

Motivacional de Realização do Sujeito - En.. 84

7.5 Caracterização do Perfil Motivacional de Realização do Sujeito Des. .87

7.51 Resultados da Análise dos dados da Entrevista de Validação do Perfil

Motivacional de Realização do Sujeito - Des..

8. Fase Final - Percepção Motivacional dos Sujeitos

8.0 - Análise dos dados da Entrevista sobre a Percepção Motivacional: Au, Ga, En e Des.

8.1 - Análise dos Dados da Entrevista sobre a Percepção Motivacional de Au.......90

8.12- Resultado da Análise dos Dados da Entrevista sobre a Percepção

Motivacional do Sujeito Au.

8.13 - Expectativas Epistemológicas Sobre Aprender-Ensinar. 113

8.14-Expectativas Epistemológicas e Metafísicas sobre a Ciência. 115

8.2 - Análise dos Dados da Entrevista sobre a Percepção Motivacional de Ga. 117

8.21-Resultado da Análise dos Dados da Entrevista sobre a Percepção Motivacional de Ga. 136

8.22-Expectativas Epistemológicas Sobre Aprender-Ensinar de Ga. 137

8.3 - Análise dos Dados da Entrevista sobre a Percepção Motivacional de En. 139

8.31Resultado da Análise dos Dados da Entrevista sobre a Percepção Motivacional de En. 154

8.32Expectativas Epistemológicas Sobre Aprender-Ensinar En. 155

8.4 Análise dos Dados da Entrevista sobre a Percepção Motivacional do Des. 159

8.41Resultado da Análise dos Dados da Entrevista sobre a Percepção Motivacional de Des. 163

8.42Expectativas Epistemológicas Sobre Aprender-Ensinar..... 163 8.43Expectativas Epistemológicas e Metafísicas sobre a Ciência. 164

\section{Conclusão}

9.0 Considerações Finais.. 165

9.1Considerações Gerais Sobre os Sujeitos da Pesquisa. 165

9.2Outras Considerações Finais..... 167

9.21 Ensino de Ciências e a Motivação. 168 
9.3 Conflito Cognitivo: Herói ou Vilão das Estratégias de Ensino Sócio-

Construtivistas?.

9.4 O M. M. C. e as Metas de Realização

9.41 O M. M. C e a Meta-Aprender. 183

9.42 O M. M. C e a Meta Performance-Aproximação..............................................190

9.43 O M. M. C e a Meta Performance-Evitação......................................................197

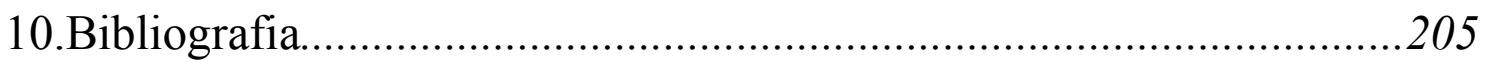

Apêndices

Apêndice - I: Instrumentos de Pesquisa Primeira Fase

Questionário de acesso às Metas de Realização............................................................

Tradução do Questionário (Primeira Versão)...............................................................4

Questionário de Acesso às Metas de Realização (Versão Final)..................................5

Entrevista de Validação do Perfil Motivacional de Realização....................................6

Análise da Entrevista de Validação do Perfil Motivacional de Realização.................. 7

Apêndice - II: Instrumentos de Pesquisa Segunda Fase

Entrevista sobre a Percepção Motivacional..............................................................13

Apêndice - III

Quais Fatores que Impossibilitam o Resultado Conclusivo do Questionário de Acesso às Metas de Realização.

Apêndice - IV

Apresentação da Atividade Experimental para ser Realizada pelo Grupo.................24

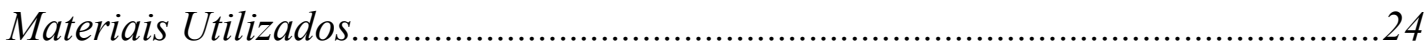

Atividade Experimental: Colheres de plástico, madeira e metal..............................24

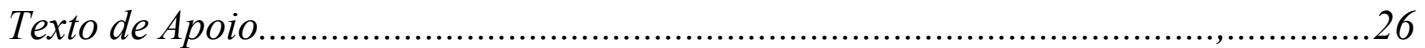

Descrição e Pequena Análise da Atividade Experimental .........................................27

Apêndice - $V$

Entrevistas Primeira Fase - Perfil de Realização: Sujeito Del, Ms e M

Análise dos dados da Entrevista de Validação do Perfil Motivacional de Realização do Sujeito Del.

Análise dos dados da Entrevista de Validação do Perfil Motivacional de Realização do Sujeito Ms. 68

Análise dos dados da Entrevista de Validação do Perfil Motivacional de Realização do Sujeito M. 
Apêndice - VI

Questionários,Entrevistas - Segunda Fase - Perfil de Realização: Sujeito Au, Ga, En e Des

Questionário de Acesso às Metas de Realização do Sujeito

$A u$.

Análise dos dados da Entrevista de Validação do Perfil Motivacional de Realização

do Sujeito Au

Questionário de Acesso às Metas de Realização do Sujeito Ga

Análise dos dados da Entrevista de Validação do Perfil Motivacional de Realização

do Sujeito Ga

138

Questionário de Acesso às Metas de Realização do Sujeito En. .154

Análise dos dados da Entrevista de Validação do Perfil Motivacional de Realização do Sujeito En.

Questionário de Acesso às Metas de Realização do Sujeito Des. 186

Análise dos dados da Entrevista de Validação do Perfil Motivacional de Realização do Sujeito Des.

Resumo da Análise da Entrevista de Validação do Perfil Motivacional de Realização do Sujeito Des......

Dados da Entrevista de Validação do Perfil Motivacional de Realização do Sujeito Des. 


\section{Introdução}

\subsection{Encetando o Problema da Motivação}

Este trabalho busca tentar entender a motivação dos alunos nas aulas de Física do ensino médio, mais precisamente, quando vivenciam a insatisfação, um dos primeiros passos propostos pelo Modelo de Mudança Conceitual para a evolução das concepções espontâneas do aprendiz em direção ao saber científico.

O interesse em entender a motivação iniciou-se ainda no Ensino Médio, principalmente no curso pré-vestibular, onde para aprender era necessário resolver listas infindáveis de exercícios. Afinal, pelo menos no meu entender à época, passar no vestibular, de um modo geral, se resumia a saber resolver os exercícios da prova. Não obstante, também na universidade, a questão não era muito diferente, a não ser pela motivação, pois agora estava ligada à necessidade de se obter competência. Todavia, o caminho para este objetivo também passava por motivadores extrínsecos como resolver as inúmeras listas propostas pelos professores e tirar uma nota acima de cinco nas provas, a cada novo semestre.

Todavia, é natural supor para aqueles que escolhem uma carreira, seja ela científica ou não, além da necessidade em se tornarem profissionais competentes ser um dos principais motivadores, não podemos deixar de levar em consideração outros motivadores intrínsecos, tais como: possibilidade do indivíduo responder suas próprias dúvidas, dar vazão a sua curiosidade e interesse, bem como entrar em contato com uma metodologia que permita a intervenção, seja nos objetos ou em processos sociais.

Durante o curso de Bacharelado, comecei a ministrar aulas de Física para o ensino médio: nesse momento, a motivação mudou de endereço.Agora, o aluno era o foco, exigindo questionamentos mais complexos, como por exemplo: porque meu aluno realizará a atividade que proponho, principalmente se não tiver interesse em física? Como posso despertar o interesse para minha disciplina? Como conseguir motivá-lo sem necessidade de notas ou do fantasma da repetência, ou ainda da obrigação de passar no vestibular? 
No início, eu ingenuamente acreditava que bastava uma boa explicação para que o aluno aprendesse e isto por si só seria um potente motivador, pois, se aquele entendesse os conceitos, consequentemente, iria manter-se interessado em aprender mais. Por meu turno, eu me julgava bem preparado: enfim, estudava em uma das melhores universidades do país, portanto acreditava que faria a diferença. Quanto engano! Explicava uma, duas, três vezes e nada.Apesar de construir um bom modelo explicativo, não entendia que aquela explicação era minha e o máximo que o aluno poderia fazer era se apropriar dela sem ter realizado a reflexão necessária para que pudesse elaborar a sua. Para mim, um grande termômetro deste equívoco é quando o professor pergunta: alguma dúvida? E o silêncio é geral, ou passado os quinze minutos inicias, os alunos começam apresentar certo ar de sonolência, muitos até deixam escapar um bocejo, dalí a pouco, surge um burburinho no fundo, indicadores que o assunto começa a perder o interesse ou não causou o impacto desejado.

Impulsionado por esses fracassos, iniciei um movimento à procura de respostas. Encontrei algumas quando li o livro 'Pedagogia do Oprimido' de Paulo Freire e identifiquei minha prática com a denominada educação bancária ligada ao modelo tradicional de ensino (Freire, p. 59):

a. o educador é o que educa; os educandos, os que são educados;

b. o educador é o que sabe; os educandos, os que não sabem;

c. o educador é o que pensa; os educandos, os pensados;

d. o educador é o que diz a palavra; os educandos, os que a escutam docilmente.

e. o educador é o que atua; os educandos, os que têm a ilusão de que atuam, na atuação do educador;

f. o educador identifica a autoridade do saber com sua autoridade funcional, que opõe antagonicamente à liberdade dos educandos; estes devem adaptar-se às determinações daquele;

g. o educador, finalmente, é o sujeito do processo; os educandos, meros objetos.

Esta leitura forneceu-me a justificativa que faltava, mesmo porque, segundo o pensador, educar não é um ato livre de significados, não é algo que se faz sem uma intencionalidade, por mais que alguns insistam na neutralidade do conhecimento. Portanto, acredito que educar não pode se resumir à transmissão de conhecimentos através do ato de depositar no aluno o que lhe falta, utilizando a cópia e a memorização. 
Outra tese, para mim desconcertante, é a ideia de homem que este modelo carrega implicitamente em seu cerne:

[...]A questão está em que pensar autenticamente é perigoso. O estranho humanismo desta concepção "bancária" se reduz à tentativa de fazer dos homens o seu contrário - o autômato, que é a negação de sua ontológica vocação de ser mais.”(Freire, p. 61).

Neste momento, confesso, não sabia o que queria, mas pelo menos tinha ideia clara do que não queria. Assim, me mudei para a licenciatura. Eu estava desanimado com a sala de aula, sentia-me bastante desmotivado até que iniciei o curso de Metodologia de Ensino; acreditava que este forneceria respostas para a minha prática em sala de aula e obtive algumas, o curso proporcionou-me contato com teorias sócioconstrutivistas e seus principais pressupostos:

- O aluno é o principal construtor de seu próprio conhecimento;

- A aprendizagem se dá através do ativo envolvimento do aprendiz na construção do conhecimento (Mortimer, 1996);

- O conhecimento é um contínuo, isto é, todo conhecimento é construído a partir do que já se conhece;

- O conhecimento a ser ensinado deve partir do conhecimento que o aluno traz para a sala de aula (Carvalho apud Abib, 1996, p. 34).

Por conseguinte, o aluno deixava de ser objeto das ações do professor, trocavase a heteronímia, por outra qualidade, a autonomia; o indivíduo, agora era promovido de ouvinte passivo das palavras do mestre, para um sujeito que se envolve ativamente na construção do conhecimento. Em razão da promoção, foi reconhecido como detentor de conhecimentos, bem diferente de uma tabula rasa que deveria ser preenchida. Já não bastaria, para tal feito, um professor que dominasse bem os conteúdos e estabelecesse um clima de autoridade e obediência. Portanto, a motivação, antes extrínseca e legitimada pela atuação do professor, ganhava novo sítio: o interior do sujeito.

Tanto para Piaget quanto para Vygotski, o sujeito age de acordo com suas necessidades, portanto, intrinsecamente. O sujeito cognoscente piagetiano, em razão de sua atuação no ambiente, muitos vezes se vê diante de um conflito cognitivo que o desequilibra. Para voltar à condição anterior deverá reestruturar seu pensamento através 
da assimilação e acomodação de novos conhecimentos capazes de satisfazer a nova realidade.

Por outro lado, Vygotski olha o desenvolvimento do homem através das condições sócio-históricas; são as necessidades específicas produzidas em cada fase da vida, em cada momento histórico que nos impelem a ação; o desejo de satisfação é o que nos motiva exigindo novas formas de pensar, portanto, desenvolvendo o intelecto.

Portanto, o modelo sócio-construtivista é muito mais do que uma forma de ensinarmos os alunos, pois com ela nasce uma nova concepção de homem, um homem integrado as suas necessidades cognitivas, afetivas e sociais, um homem não mais coisificado, um homem atuante e detentor de sua própria historia. Notadamente, é em nome dessa utopia o que tem me motivado a querer entender quais os problemas relacionados à efetivação desta metodologia nas salas de aula.

Nas últimas décadas, as pesquisas e as propostas sobre o ensino de ciências sofreram profundas influencias pelas ideias de Posner em seu Modelo de Mudança Conceitual(MMC) (Posner et al, 1982). Um de seus pressupostos básicos sugere que para o aluno modificar seus conhecimentos prévios deverá vivenciar um sentimento de insatisfação. Condição esta, que seria provocada por uma anomalia em uma experiência crucial. Sendo o primeiro passo de um total de quatro para a possível acomodação de um conceito científico no lugar de um espontâneo.

Portanto, a insatisfação com os conhecimentos espontâneos frente a uma experiência crucial produziria a motivação intrínseca necessária para que o indivíduo se engajasse na solução das inconsistências de seu pensamento. Todavia, por mais linear e lógico que o modelo se apresentasse em sua proposição original, as pesquisas começaram a captar um "ruído de fundo" referente às reações afetivas e motivacionais dos alunos.

Em vez de se envolverem, muitos alunos apresentam comportamentos, reclamações ou preocupações que escapam ao escopo estritamente cognitivo:

1. Muitas vezes, o aluno ignora o fracasso (refere-se ao fato de que realiza a experiência e não percebe que o resultado esta em desacordo com suas crenças); 
2. Fica perplexo e guarda a dúvida;

3. "Arranja explicações ad-hoc" (Chinn \& Brewer, apud Villani \& Cabral, 1997, p. 4);

4. "Quer agradar o professor" (Villani, 1999);

5. "Busca obter notas boas" (Pintrich et al, 1993);

6. "Identificar-se com uma figura famosa" (Pintrich et al, 1993);

7. "Pretende ser reconhecido pelos colegas" (Pintrich et al, 1993);

8. "-Lá vem esse professor com as experiências dele..., caramba!!!... Eu achava que sabia alguma coisa, agora não sei mais de nada" (relacionada à minha prática em sala de aula).

9. “-Ah!! Professor tem que pensar!!”(Baird et al apud Villani, 2001)

10.“-Se o senhor já sabe, porque não dá logo a resposta!!!” (relacionada à minha prática em sala de aula).

Em vista destes resultados, muitos pesquisadores têm se aprofundado no estudo do MMC. Podemos dividi-los em três vertentes: preocupados com a dimensão epistemológica, como Posner \& Strike (1992) e Cunha (1999); ligados à psicologia cognitiva, como Mortimer \& Carvalho (1996), Pozo (2002), Abib (1996). Por fim, ligados à psicanálise como em Villani \& Freitas (2002) e Cabral (1998).

Por meu turno, quando me deparei em sala de aula com esses resultados anômalos, fiquei perplexo: simplesmente os negligenciei e optei por creditar o fracasso a minha pouca habilidade ou experiência em trabalhar com o modelo. De tal modo que o mestrado significaria desenvolver competências para que a minha incompetência não fosse comprometedora, pois nesse momento, não tinha maturidade suficiente para admitir falhas no modelo. Somente durante as disciplinas realizadas no mestrado e com as leituras de parte dos artigos acima, principalmente os de Mortimer e de Villani \& Cabral, tive a convicção que os resultados anômalos não estavam ligados exclusivamente a minha atuação.

Todavia, o que me provocava maior perplexidade não era o fato de as concepções espontâneas dos alunos não se modificarem como o previsto. O que me causava maior estranheza era a queda motivacional. Eu que pretendia com o modelo 
produzir o envolvimento do aluno, ou seja, sua motivação em direção ao conhecimento, estava produzindo justamente o contrário.

Portanto, motivado pela insatisfação com o modelo, optei por tentar entender a motivação do aluno, primeiro dentro do modelo sócio-construtivista e, por fim, nos constructos teóricos advindos da psicologia da educação.

A psicologia da educação, de um modo geral, procura entender as razões ou os processos que levam ou não os alunos a se envolverem nas atividades escolares. Dentre as diversas linhas teóricas, escolhi trabalhar com a ligada às metas de realização. Basicamente, esta admite como um de seus pressupostos a constatação de que o ser humano tem uma capacidade específica em direcionar seus esforços para a realização de metas definidas mentalmente, o que justificaria, por exemplo: um aluno de Física que mesmo não gostando de um certo tópico de Cálculo IV fique enclausurado em um domingo ensolarado, não só porque será objetivo de prova, mas principalmente, por saber que o domínio deste saber é fundamental para o seu futuro como profissional.

Segundo Boruchovitch \& Bzuneck, (2001) o aluno pode orientar seu comportamento em direção a duas metas de realização qualitativamente diferentes, a primeira, definida como meta aprender, onde aluno busca adquirir conhecimentos. A segunda, denominada meta-performance, na qual sua principal preocupação é o julgamento do outro. Dependendo da qualidade deste julgamento esta meta se subdivide em duas: meta performance-aproximação e meta performance-evitação.

Orientado à meta aprender, o aluno aborda as tarefas que realiza com objetivo de melhorar seus conhecimentos e habilidades. Os erros ou fracassos são encarados como inerentes ao processo. Acredita que seu sucesso está ligado ao seu esforço e envolvimento nas tarefas escolares. O aluno, assim orientado, aproxima-se bastante de quem atua com motivação intrínseca.

Por outro lado, o aluno orientado à meta performance-aproximação visa parecer inteligente a professores e colegas de classe. Quando erra, é por motivos externos: o professor não explicou direito, ou o assunto é muito chato; assim preserva seu status de inteligência. Como é inteligente, acredita que para aprender não é necessário muito esforço; portanto, tem dificuldade em aprender com profundidade. 
Infelizmente, os orientados à meta performance-evitação estão preocupados em evitar serem considerados incapazes. Logo, possuem uma auto-imagem extremamente negativa, pois acreditam-se impossibilitados de realizar tarefas ou os desafios propostos pelos professores. Muitas vezes parecem estar alienados do processo de aprender; mesmo tendo dúvidas, muitos não perguntam. Os erros e fracassos estão diretamente ligados a sua suposta incapacidade intelectual, o que contribui para reafirmar sua baixa auto-estima.

\subsection{Pergunta da Pesquisa}

Em resumo, este trabalho procura responder à seguinte pergunta:

- As metas de realização: meta aprender, meta performance-aproximação $e$ meta performance-evitação ajudam-nos a entender a percepção motivacional que os alunos apresentam, após vivenciarem o conflito cognitivo ou a insatisfação proposta pelos modelos sócio-construtivistas? 


\section{Referencial Teórico}

\subsection{A Motivação Necessária para Aprender Ciências}

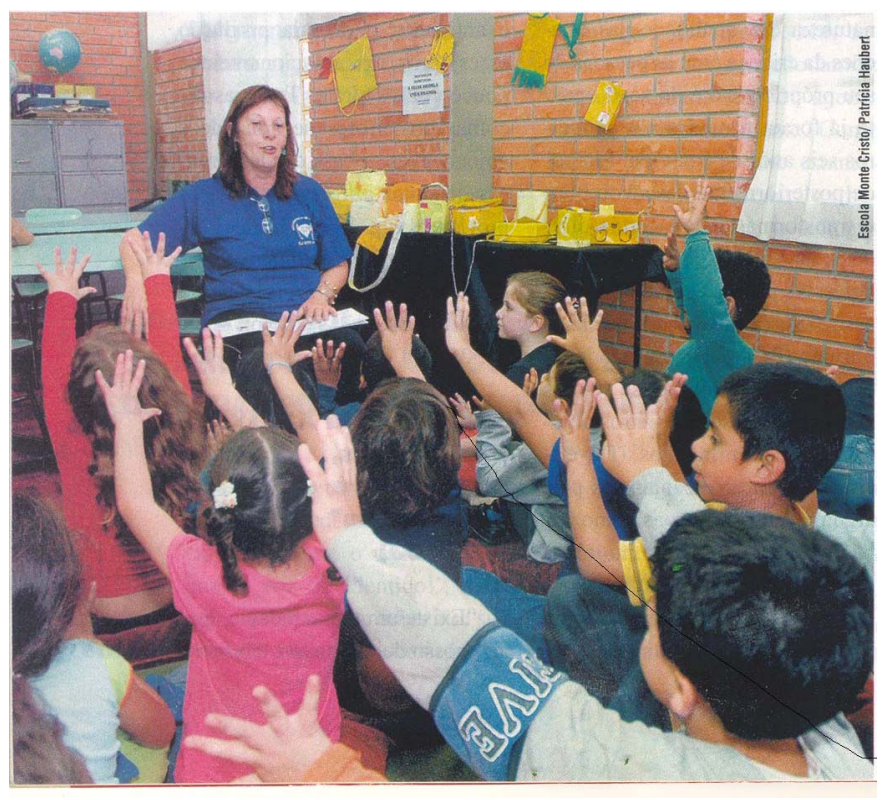

Como esta imagem ${ }^{1}$ inquieta nos professores! Melhor dizendo, nos incomoda, pois parece forçar o olhar para o outro lado, como se nos lembrasse da raridade de tais momentos. Principalmente, em se tratando de alunos de mais idade, como os do ensino médio e que participaram deste trabalho.

Contudo, pesquisas nos reconfortam, pois indicam que conforme os alunos avançam em escolaridade tendem a apresentar queda em sua motivação como nos revela o trecho a seguir (Cordova \& Lepper apud Boruchovitch \& Bzuneck, 2001, p. 16):

[...]Como todos os pais sabem, a aprendizagem pode ser divertida. Desde a persistente dedicação das crianças para aprender a andar e a voracidade por aprender os nomes dos objetos até a insaciável curiosidade do pré-escolar que quer saber os porquês de tudo, observadores astutos, de Platão a Piaget, têm comentado o amor intrínseco pela aprendizagem por parte dessas crianças....

Apenas uns poucos anos mais tarde, porém, assim que essas mesmas crianças entrarem na escola, sua motivação para aprender começa a apresentar alguns problemas. Muitas delas parecem achar as atividades de aprendizagem tolas e aborrecidas, e uma quantidade substancial delas poderá ser rapidamente diagnosticada como portadora de déficits motivacionais. Além disso, essas dificuldades parecem aumentar ainda mais à medida que tais crianças avançam nas séries escolares. Numa variedade de contextos e com o emprego de diferentes medidas, vários pesquisadores têm comprovado um decréscimo sensível da motivação intrínseca das crianças, pelo menos a partir da terceira série.

\footnotetext{
${ }^{1}$ Retirada da Revista Educação Especial no 1 :Biblioteca do Professor - Freud Pensa a Educação - p. 72
} 
A pobre condição relatada acima nos possibilita um relativo conforto, afinal o problema não está ligado à pratica exclusiva deste ou daquele professor ou mesmo disciplina. No entanto, a mesma linha de pesquisa nos adverte que um dos maiores entraves à melhora da motivação dos alunos são as crenças negativas, muitas delas, baseados no senso comum dos professores. A mais nociva e muito frequente é a concepção de que o professor nada pode fazer pela motivação do aluno.

Este pré-conceito surge, pois muitos acreditam que a motivação é algo como um objeto, o sujeito tem ou não tem e ponto. Afinal, gostar ou não da disciplina, simpatizar ou não pelo professor diz respeito ao foro íntimo de cada um, portanto não pode ser alvo de reflexões ou até modificações externas. Pior ainda, quando o professor acredita que apesar de realizar um bom trabalho, outros interesses concorrem diretamente pela atenção do aprendiz tendo maior poder de sedução, como assistir televisão, jogar vídeogame etc. Por conseguinte, na visão simplista destes professores, existe uma miríade de estímulos e situações prontos para capturar o interesse e a atenção do aluno.

Outros professores com o desejo de cooptar o aluno utilizam-se, muitas vezes, de estratégias ingênuas, passando ao largo do quão complexo são os processos relacionados à motivação e do quanto necessitam de serem conhecidos e estudados pelos educadores (Boruchovitch \& Bzuneck, obra citada, p. 29):

[...]Intuitivamente, as pessoas podem achar que o elogio sempre é benéfico à autoestima e favorece a motivação; e a censura prejudica a autoestima e favorece a desmotivação. Ora, as pesquisas mostram que os efeitos do elogio e da censura às vezes são contrários ao que aparece nessa suposição. Há casos em que o elogio é contraproducente e a censura incrementa a motivação (Brophy, 1983; Pintrich e Schunk,1996). Além disso, algumas professoras acreditam que para se ter alunos motivados é suficiente criar um clima emocional positivo em classe, o que se consegue simplesmente sendo uma pessoa agradável, atenciosa, toda desvelo e carinho. Sem diminuir a importância dessas qualidades positivas, deve se ter presente que os alunos precisam ser motivados para tarefas significativas, desafiadoras, mesmo que sejam árduas, não prazerosas, exigentes e sob cobrança externa. (Grifo nosso)

Em razão do sublinhado acima, façamos um breve exame em nossas reminiscências e provavelmente encontraremos algum mestre que ousou esperar de nós mais que o mínimo, independente de nosso interesse ou não pela disciplina e acabou por 
conseguiu retirar aquilo que pensávamos não possuir, pois exigiu um pouco mais de esforço e dedicação.

A palavra motivação, segundo Boruchovitch \& Bzuneck, (obra citada p. 9)tem sua origem no latim tardio "motivum" evoluindo para nosso termo aproximado que é: "motivo". Ou como os autores escreveram: “[...] Assim, genericamente, a motivação, ou o motivo, é aplicável a qualquer ramo da atividade humana é aquilo que move uma pessoa ou que a põe em ação ou a faz mudar o curso."Portanto, o motivo é aquilo que nos singulariza, o que nos tipifica. Este pode ser consciente ou não, verdadeiro ou ilusório. É por fim, o que nos torna humanos, preenchendo o vazio entre a ação e o objetivo. Não existe ação sem motivo. Naturalmente, não estamos interessados em todo tipo de motivação, tais como: o que leva uma pessoa a colecionar cartões telefônicos, ou selos. Nosso referencial teórico se circunscreve a motivação estritamente ligada ao aprender. Ou seja, todo aluno sabe da importância de realizar tarefas específicas propostas pelo professor ligadas a este processo; seja para se apropriar de um conceito, uma metodologia ou ainda uma nova atitude. A motivação necessária para a aprendizagem é bem diferente daquela produzida para atividades mais simples, como por exemplo, a prática de esportes, onde o importante seria: a disposição, a quantidade de energia e a atenção. Por outro lado, dentro da sala aula, por exemplo, sabemos que um aluno que aparenta estar compenetrado na fala do professor, pode estar com o pensamento em outro lugar.

Sabe-se, ainda, que altos índices de motivação podem, rapidamente, acarretar cansaço. Muitas vezes, este pode vir acompanhado de emoções negativas. Não raro ouvirmos depoimentos, em que mesmo o aluno tendo se preparado para uma prova, apresente o seguinte comentário: “não sei o que aconteceu, na hora esqueci tudo!!”, fato comprovado em pesquisas, conforme trecho abaixo (Naveh-Benjamim, Mckeachie \& Lin apud Boruchovitch \& Bzuneck, obra citada, p.18):

[...] Mas o mais grave é que aí surge a emoção negativa da alta ansiedade, cujo componente de preocupação prejudica o raciocínio e a recuperação de informações armazenadas na memória e, portanto, o desempenho acadêmico e a até a própria aprendizagem. Por isso, ao lado da ausência ou de um nível muito baixo de motivação, outro problema consiste exatamente em um aluno apresentar níveis excessivos de motivação, que implicam em alta ansiedade frente às exigências escolares. 
Portanto, em se tratando da quantidade de motivação, um nível considerado como satisfatório não pode ser nem baixo, nem muito alto. Afinal, não adianta termos um aluno sem nenhuma motivação, ou por outro lado, aquele que apresente um nível tão alto que se esvai rapidamente. Nesse sentido, um nível positivo de motivação deve ser considerado como uma motivação mediana, adaptada equilibradamente a própria especificidade do exigido. Todavia, no tocante à qualidade, devemos esperar o maior nível possível de envolvimento conforme trecho a abaixo: (Maehr e Meyer,Boruchovitch, Pintrich e Garcia apud Boruchovitch \& Bzuneck, obra citada, p. 12).

[...] lembram que a motivação positiva na escola implica em qualidade do envolvimento, ou seja, o investimento pessoal deve ser o da mais alta qualidade possível. Não basta, portanto, que o aluno aplique algum esforço, porém exige-se que enfrente as tarefas desafiadoras que, por sua natureza, cobram maior empenho e perseverança. Mais ainda, a qualidade de investimento pessoal implica no emprego de estratégias de aprendizagem, cognitivas, metacognitivas e de gerenciamento de recurso, o que significa que os novos conhecimentos serão construídos mediante o que se denomina processamentos por profundidade.

Não tão grave quanto à ausência de motivação, mas não menos preocupante, podendo até dificultar o aprendizado mais profundo ou um processamento por profundidade, é o escolar apresentar um desvirtuamento das razões que o motivam a realizar uma tarefa. Ou seja, o alvo é outro, sua ação não condiz com objetivo, não está preocupado em aprender, mas com objetivos não pertencentes à atividade idealizada pelo professor, conforme os condicionantes abaixo (Boruchovitch \& Bzuneck, obra citada, p. 18):

- Realiza a atividade, apenas com o intuito de livrar-se dela, mesmo apresentando baixa qualidade, o que não lhe incomoda;

- Preocupa-se apenas com as notas, com diploma ou certificados;

- Age somente para evitar notas baixas ou a repetência;

- Preocupa-se em não parecer incompetente;

- Busca o reconhecimento de professores e colegas;

- Termina rápido a tarefa, pois acredita que será entre os melhores da classe.

Infelizmente, mesmo sem saber, muitos professores acabam reforçando alguns destes posicionamentos, utilizando-se de estratégias coercitivas como a aplicação de 
notas baixas ou mesmo o fantasma da repetência para conseguir que o aluno realize as tarefas. Ainda em relação às notas, não raro, ouvirmos que em algumas escolas existe uma verdadeira cultura em vangloriar os melhores alunos, utilizando-se das notas para a comprovação do mérito de alguns em relação aos demais. Em alguns casos, instala-se uma atmosfera competitiva, contribuindo para exacerbar posturas individualistas.

Afinal, podemos supor que será difícil esperar solidariedade, quando um aluno busca superar o outro ou ser o melhor da classe. Isto sem falar, do outro lado da moeda, pois, não existem os melhores sem sua negação, o seu antônimo, ou seja, os piores da classe, reforçando o prejudicial sentimento de ansiedade.Este tipo de distorção até pode vir a prejudicar o ensino de ciências. Pois, a metodologia contemporânea recomenda que os alunos trabalhem em grupo, principalmente no tocante ao conceito de zona de desenvolvimento proximal. Na qual, graças à interação social, os alunos podem atuar mutuamente no desenvolvimento de suas capacidades cognitivas, conforme Souza \& Pessoa de Carvalho (2005, p.13):

[...] No trabalho em grupo, o aluno tem a oportunidade de trocar experiências e proposições, ver suas ideias confrontadas e lidar com opiniões e atitudes diferentes das suas. O trabalho em grupo favorece a aprendizagem de conceitos - uma vez que seus integrantes podem trocar hipóteses e rever seus conceitos iniciais e também suas atitudes: No grupo, o aluno tem oportunidade de colaborar, ajudar, discordar, refletir sobre suas atitudes. Influenciar e ser influenciado pelo outro.

Voltando ao referencial teórico, este pretende esclarecer o envolvimento do aluno e as possíveis interações quando está diante de uma tarefa a ser realizada, tais como:

- O aluno tem interesse intrínseco pelo assunto?

- Qual sua expectativa para a realização da tarefa: a de aprender ou simplesmente concluí-la e livrar-se dela?

- Pretende mesmo aprender, ou age com a intenção de aparecer para o professor ou para o grupo, ou ainda, obter sucesso com o mínimo de esforço?

- Sua maior preocupação é a nota?

- Possui a crença que para aprender é necessário esforço e dedicação?

- Acredita que possui capacidade cognitiva para enfrentar o desafio?

- Vê as atividades escolares como desafiadoras e se sente em condições de realizála? 
Em razão do primeiro item, não é de se espantar que a motivação leve em consideração o interesse do aluno. Afinal, todo o professor sabe que um aluno interessado consegue resultados muitas vezes surpreendentes e, por outro lado, um inteligente, mas que pouco se empenhe apresenta, muitas vezes, um rendimento pífio.

Sabemos, também, que ao acertamos a atividade a ser desenvolvida pelo aluno, independente da afinidade pela disciplina ou pelo professor, não raro os alunos surpreenderem-se com o conhecimento adquirido, se sentindo valorizados e recompensados pelo esforço que realizaram. Neste momento, não são poucos os que reconhecem a maestria do professor.

Notadamente, também o ensino de ciências procura desenvolver atividades interessantes através de situações problematizadoras, a fim de envolver os alunos. Em resumo, a literatura especializada em motivação é clara ao apontar a direção que os esforços dos aprendizes devem tomar quando estão envolvidos no ato de aprender: as ações e seu desenvolvimento devem implicar em um maior envolvimento pessoal do aluno, com o objetivo em adquirir habilidades, competências, maior complexidade e conhecimento nas tarefas que realizam, independente de motivadores externos - notas, certificados, pressão do professor. Por mais pretensiosa que seja esta condição, esta motivação existe e é denominada de motivação intrínseca. Ou pelo menos, o mais próximo possível desta: a meta de realização denominada meta aprender.

\subsection{A Motivação Intrínseca: O Grande Sonho das propostas Construtivistas de Piaget e Vygotski.}

Antes de apresentarmos a meta aprender e suas principais diretrizes,optaremos por percorrer as teorias sócio-construtivistas envolvidas no ensino de ciências, procurando a motivação nos escritos de dois de seus maiores expoentes, Piaget e Vygotski, e no modelo de mudança conceitual proposto por Posner \& Strike, pois acreditamos que a motivação intrínseca é um dos grandes sonhos e um dos objetivos envolvidos nessas teorias.

A formação como biólogo levou Piaget a conceber o desenvolvimento cognitivo como um processo evolutivo contendo quatro estágios de desenvolvimento: estágio sensório motor de (0-2 anos), pré-operacional (2-7 anos), o operacional concreto (7- 12 
anos) e o operacional formal (12 anos em diante), cada estágio corresponderia a uma lógica própria, uma forma peculiar com a qual a criança entende o ambiente e age sobre os objetos ao seu redor.Daí resulta, a importância em se trabalhar com as concepções espontâneas dos alunos. Pois, atrás de uma concepção, existem estruturas cognitivas capazes, graças às compensações sucessivas, de se desenvolverem com uma lógica própria. Alguns a chamam de lógica simples (Perkins \& Grotzer apud Aguiar, 2006, p. 5). Eu prefiro identificá-la como uma lógica em formação ou ainda como uma lógica em potencial, por dois motivos: o primeiro, pela condição estática que a denominação lógica simples nos remete, e o segundo na tentativa de aproximá-la do conceito de desenvolvimento proximal de Vygotski, onde a lógica do indivíduo é um vir a ser constante, podendo ser desenvolvida inter-psiquicamente pelo outro.

O modelo construtivista proposto para o desenvolvimento da inteligência evolução dos estágios, até a lógica do adulto - baseia-se na relação que o organismo mantém com o ambiente e a constante necessidade de se adaptar. Este mecanismo adaptativo apresenta dois processos distintos e complementares: a assimilação e a acomodação. A assimilação estaria envolvida na incorporação de novas informações à estrutura mental e a acomodação seria o mecanismo necessário em promover mudanças nas estruturas cognitivas.

Para Piaget, segundo Palangana (2001), o sujeito está adaptado, ou seja, em equilíbrio quando os dois processos estão em harmonia ocorrendo simultaneamente tanto à assimilação quanto a acomodação. Por outro lado, o desequilíbrio seria provocado quando o sujeito, passando por uma experiência em que sua lógica não pudesse dar conta da realidade, se veria obrigado a reformular suas estruturas cognitivas para a apreensão do novo. Este mecanismo, responsável em produzir uma mudança em direção a um estado superior e mais complexo de equilíbrio, foi denominado de “equilibração majorante”.Portanto, a mola propulsora do desenvolvimento, ou melhor, da equilibração majorante - modificação das estruturas cognitivas sempre para melhor, em extensão e complexidade - está intrinsecamente ligada ao desequilíbrio,obrigando"um sujeito a ultrapassar o seu estado atual e procurar seja o que for em direções novas" (Piaget,1977, p. 23).

Ou seja, é o desequilíbrio que produz a motivação intrínseca necessária para o sujeito buscar o conhecimento capaz de promover o retorno à sua condição de 
equilíbrio. É a urgência em restabelecer sua capacidade de organizar a experiência, de interpretá-la, que alimenta os esforços em direção a uma equilibração de melhor qualidade e alcance. Para Piaget (1977, p. 103.):

[...] a necessidade traduz-se, por outro lado, na forma de $<<$ interesse >>, e isto em dois aspectos indissociáveis: por um lado, o interesse é uma relação entre as necessidades do sujeito e os caracteres do objeto, que se torna $<<$ interessante $>>$ na medida em que satisfaz as necessidades, por outro lado, o interesse como dizia Claparède, é um dinamogeneizador que liberta as energias dos sujeito e o anima a ação na direção do objeto.

Por conseguinte, nesse modelo, o sujeito epistêmico piagetiano se desenvolve na atuação direta com o objeto ou com o meio em que está inserido. Em síntese, o "interesse", engendrado pela necessidade, funciona como um elemento capaz de possibilitar ao sujeito aplicar sua energia na direção de atender suas demandas:

[...] é por isto que, por exemplo, os escolares alcançam um rendimento infinitamente melhor quando se apela para seus interesses e quando os conhecimentos propostos correspondem as suas necessidades (Piaget, 2006, p. 37).

Portanto, para Piaget, para desenvolver atividades intrinsecamente motivadoras é preciso que elas contemplem as necessidades do aluno e possuam alguma espécie de desequilíbrio ou obstáculo cognitivo para ser solucionadas.

\subsection{As Diferentes Fases da Vida e a Demanda Social}

Em Vygotski o pensamento também se desenvolve, e este desenvolvimento está intrinsecamente ligado às interações sociais. Em sua concepção, o homem não tem acesso direto aos objetos, mas um acesso mediado pela cultura, mais especificamente, pela linguagem: um dos atributos básicos do sistema simbólico.

Nessa perspectiva, no contato com a cultura, o indivíduo desenvolve os sistemas simbólicos de representação da realidade e é esse processo que possibilita ao indivíduo internalizar formas socialmente aceitas de comportamento. Por conseguinte, o que antes era externo transforma-se em atividades internas, ou seja, intrapsicológicas, graças às relações interpessoais. Portanto, as funções psicológicas superiores, representadas pelas operações com sistemas simbólicos, são construídas de fora para dentro do indivíduo. (Oliveira, 1993, p. 38). 
Para Vygotski existem dois níveis de desenvolvimento: nível real ou efetivo e o nível potencial. O primeiro refere-se ao que a criança sabe, ou seja, os problemas que esta pode resolver sozinha. O segundo diz respeito ao desenvolvimento potencial que a criança pode vir a realizar. Este nível pode ser representado pelos problemas que a criança não consegue resolver. Entre estes dois níveis, existe um espaço chamado de zona de desenvolvimento proximal.

Em suma, é neste lugar, onde é possível a atuação do outro, mas não um outro qualquer, um outro mais capaz, podendo ser representado por uma criança mais experiente ou pelo adulto. Por conseguinte, o outro tem a tarefa fundamental de ajudar na transformação em desenvolvimento real daquilo que existia somente como potencialidade, através da internalização de uma forma mais elaborada de cognição. Conclui-se, então, que é na interação social que o indivíduo se modifica, ou seja, desenvolve suas capacidades cognitivas.

No pensamento de Vygotski, o motivo também está ligado às necessidades devendo ser satisfeitas pelo indivíduo, ou seja, cada fase da vida reserva-nos necessidades específicas, entendidas como tudo aquilo que nos motiva para a ação. Assim, o sujeito epistemológico vygotskiano também atua, mas sua atuação não está diretamente ligada ao objeto ou ao meio no qual está inserido. O acesso ao objeto é um caminho mediado pelo sistema simbólico (linguagem), pois surge através do discurso de outros sujeitos sobre o objeto; logo, este discurso é datado historicamente. Portanto, é a interação social o mecanismo responsável pela internalização de formas cognitivas mais desenvolvidas por parte do indivíduo.

De qualquer maneira, é a interação social o constructo responsável pela internalização desta forma de ação mais elaborada. Portanto, a motivação intrínseca surge devido à urgência sentida pelo sujeito em dar resposta a uma necessidade interna ou uma demanda externa (social): logo, é neste momento que o sujeito poderá liberar sua energia para a transposição do obstáculo.

Em suma, Vygotski nos chama a atenção para a importância das relações interpessoais para o desenvolvimento do indivíduo. Por outro lado, nos adverte que este desenvolvimento não pode estar muito além da zona de desenvolvimento proximal. E por fim, a atividade realizada pelo sujeito deverá levar em consideração as necessidades 
específicas exigidas em cada fase da vida e esta também deverá conter um obstáculo que deve ser superado pelo aprendiz.

\section{4 - O Modelo de Mudança Conceitual (MMC): O Ponto de Inflexão nas Metodologias Sócio-Construtivistas.}

Na década de 70, mais precisamente no ano de 1978, Driver \& Easley, segundo Mortimer (1995), publicaram um artigo criticando a excessiva ênfase ao desenvolvimento das estruturas lógicas por parte de Piaget e apontando que não era dada a devida importância ao grande manancial referente às concepções espontâneas dos indivíduos. Além disso, diversas pesquisas constataram que mesmo alunos universitários conservavam estas concepções. A partir de então, o modelo se deparou com a necessidade de procurar modificar as concepções de senso comum dos alunos.

No ano de 1982, Posner e colaboradores, propuseram o Modelo de Mudança Conceitual (MMC). O modelo foi construído levando-se em consideração as ideias desenvolvidas por Kuhn, Lakatos e Toulmin, filósofos da ciência, preocupados em entender as mudanças na evolução do pensamento científico. Os idealizadores do modelo propuseram uma analogia entre as mudanças produzidas pela comunidade cientifica em seu pensamento e as mudanças que os alunos deveriam realizar no tocante as suas concepções espontâneas quando em processo de aprendizagem nas aulas de ciência. Assim, no momento no qual seus conceitos entrassem em crise diante de uma experiência crucial poderia ocorrer a acomodação, ou seja, a aceitação dos novos conceitos científicos em detrimento dos espontâneos. Em particular, seriam necessárias quatro condições básicas:

I. Insatisfação: o aluno deveria experimentar um sentimento de insatisfação em relação aos seus conhecimentos espontâneos, ou seja, vivenciar a presença neles de anomalias ou contradições.

II. Inteligibilidade: o novo conceito ou conhecimento deveria fazer sentido para o aprendiz,abrindo espaço para que possa ser incorporado aos seus conhecimentos.

III. Plausibilidade: o novo conceito deveria aparecer como aceitável, ou seja, compatível com outras ideias do aprendiz. 
IV. Fertilidade: a nova concepção deve conduzir a novas descobertas, mostrando seu potencial de ser estendida a novas áreas. Dessa forma o novo conhecimento ganharia em estabilidade

Além dessas quatro condições, adotou-se mais uma denominada de ecologia conceitual. Esta condiçãose refere à relação de compatibilidade entrea nova concepção e os compromissos epistemológicos e a crenças metafísicas que o indivíduo possui. Naturalmente, a ecologia conceitual se constitui uma extensa e profunda rede de significados e estes podem influenciar fortemente a inteligibilidade e a plausibilidade de um novo conceito. Todavia, acreditava-se que, satisfazendo as quatro condições lógicas e a ecologia conceitual, o conjunto de conhecimentos que o aluno possuía deveria mudar radicalmente, ocorrendo a acomodação de uma nova concepção ao universo conceitual do aluno.

\section{5 - A Crise Motivacional e Afetiva Provocada Pelas Propostas Sócio- Construtivistas.}

$\mathrm{O} \mathrm{MMC}$, graças à sua racionalidade, gozou de um período de ampla aceitação, sendo alvo de intensa pesquisa. Não obstante, não tardou em perder seu caráter heurístico, recebendo diversas e pesadas críticas, principalmente no tocante à simplificação com que se referia ao intrincado processo de aprendizagem escolar envolvido nas aulas de ciências (Aguiar, 2001). Até mesmo seus idealizadores, Strike e Posner, em 1992, propuseram diversas modificações e apontaram como falhas as poucas considerações sobre a ecologia conceitual do aluno. Principalmente, no tocante aos motivos e às metas que os aprendizes têm em mente querer alcançar e às questões afetivas presentes no cotidiano escolar (Villani \& Cabral, 1997).

Gunstone (1992, p.133), afirma que não só as concepções espontâneas impactam o processo de aprender os novos conceitos. Sobretudo, as concepções sobre ensino-aprendizagem que os alunos carregam também podem se constituir verdadeiras barreiras ao processo, podendo vir a inviabilizá-lo, conforme trecho abaixo.

[...] De Jong, um professor de física de uma escola secundária Victoriana, explorando o impacto da reconstrução de seu método de ensino em torno de princípios construtivistas, encontrou um número considerável de estudantes que acreditam que, para aprender física, é necessário possuir dois atributos: ser muito inteligente e possuir boa 
memória. Estes atributos foram vistos como coisas que você tem ou não tem; nada poderia ser feito para adquiri-los (De Jong \& Gunstone, 1988)." 2

Em vista do escrito acima, imaginemos um aluno convicto de não possuir inteligência suficiente para aprender física. Seria natural supor que este ao vivenciar a insatisfação ou o conflito cognitivo proposto pelo modelo, reafirme sua condição de inferioridade e isto venha a impactar em sua motivação.

Além disso, devemos levar em consideração que o aluno toma suas concepções como sendo verdadeiras e com forte apego afetivo. Portanto, apresenta grandes dificuldades em considerar suas ideias apenas como conjecturas sobre a realidade, precisando ser verificadas. Vosniadou \& Ioannides "destacam que as crianças e jovens aprendizes são bons formuladores de teorias, mas não costumam considerar suas explicações como hipóteses a serem examinadas racionalmente" (Aguiar, 2001 p. 4).

Não podemos esquecer, em se tratando do levantamento de hipóteses, tão caro ao pensamento científico, que este recurso epistemológico é típico do "modus tolens" do cientista não ocorrendo de forma espontânea na estrutura conceitual do aluno. $\mathrm{O}$ cientista está acostumado a colocar à prova seu paradigma na forma de assertivas sobre determinado fenômeno, pois esta é a natureza de seu trabalho, ou pelo menos assim deveria ser. Por outro lado, a sala de aula é um lugar bastante diverso se comparado ao laboratório do cientista. O fracasso no laboratório pode representar um desafio às habilidades do pesquisador constituindo-se, muitas vezes, um potente motivador. Pelo contrário, no universo do aluno o erro tende a ganhar outra conotação: a sensação de fracasso. Em alguns casos, pode acabar reafirmando algum sentimento negativo quanto à própria capacidade, assim, em vez de instigá-lo à procurapode até provocar, em alguns casos, déficits motivacionais.

Nesse sentido, foi proposto que até mesmo o conceito de "fertilidade" fosse expandido para englobar aspectos motivacionais extrínsecos as concepções dos alunos,

\footnotetext{
${ }^{2}$ Tradução do autor; Texto original:

De Jong, a Victorian secondary school physics teacher, in a exploration of the impact reconstructing his teaching around constructivist principles, found a number of his students believing that successful learning of physics required two attributes: High intelligence and a good memory. These attributes were seen as things you either had or did not have; nothing could be done to acquire them (De Jong \& Gunstone, 1988)."
} 
como por exemplo: querer obter boas notas, ou agradar o professor, ou ser reconhecido pelos colegas, ou se identificar com uma figura famosa, etc. (Thorley \& Stofflet apud Villani \& Cabral, obra citada, p.4).

Em virtude da forte reação que os alunos apresentam no momento em que vivenciam a insatisfação ou o conflito cognitivo alguns dos cânones básicos do modelo começaram a ser questionados, Mortimer (obra citada), aponta o próprio conflito como o principal responsável pelo baixo rendimento dos educandos:

[...] Outro tipo de problema nesses tipos de estratégia de ensino é a dificuldade que os alunos enfrentam em reconhecer e vivenciar conflitos.Isso poderia explicar a improdutividade de certas discussões em grupo na sala de aula,...

[...] A aplicação dessas estratégias em sala de aula tem resultado numa relação de custo-benefício altamente desfavorável. Gasta-se muito tempo com poucos conceitos, e muitas vezes esse processo não resulta na construção de conceitos científicos, mas na reafirmação do pensamento de senso-comum.

Estas constatações parecem depor contrariamente a existência do sujeito epistemológico piagetiano e, por conseguinte, do conceito de equilibração majorante como mecanismo de desenvolvimentos das estruturas cognitivas do indivíduo na sala de aula. Afinal, se é tão pouco natural que alguns alunos possam suportar o desequilíbrio cognitivo, como chegaram ao desenvolvimento cognitivo atual? Eles não viveram estes conflitos em seu cotidiano? Ou, por outro lado, seriaa sala de aula um lugar tão especial com uma epistemologia tão característica que impossibilita ou no mínimo dificulta a presença da criança piagetiana?

No que se refere ao sujeito epistemológico vygotskiano a dificuldade surge no tocante à interação social. Afinal, admitimos este constructo como sendo responsável pela internalização dos processos cognitivos mais elaborados por parte do sujeito. Como podemos aceitar, com naturalidade, que uma parte considerável destas interações não produza o efeito desejado? Esta questão é bastante grave, pois sabemos o quão trabalhoso é gerenciar espaços onde os alunos possam trocar ideias livremente. Cabe aqui uma ressalva, não esperamos que todo o desequilíbrio provoque mudança nas estruturas cognitivas, pois mesmo Piaget nos adverte sobre as equilibrações compensatórias que muitas vezes não levam os alunos a uma equilibração majorante. Nem, tampouco, acreditamos que toda discussão, mesmo com um sujeito mais capaz, 
leve o aluno a re-significar seus conceitos espontâneos. Todavia, o que nos chama atenção é que estes mecanismos deveriam ocorrer naturalmente na vida do indivíduo; logo não deveriam provocar tamanha estranheza por parte dos alunos. Portanto, parece que devemos procurar entender o que acontece dentro da sala de aula no tocante à interação social que tem tornado estes importantes instrumentos de ensino de ciências ineficazes para muitos alunos.

Enfim, independente das especificidades teóricas dos constructos apresentados até aqui, todos levam à motivação intrínseca, pressupondo um envolvimento ativo do aprendiz. Todavia, há um sem número de pesquisas que apontam as metodologias sócio-construtivistas como responsáveis por produzir junto aos alunos déficits motivacionais ou reações afetivas indesejadas.

Apresentaremos a seguir a psicologia educacional ligada às metas de realização dos estudantes, em que um dos constructos apresentados sugere um novo sujeito: o Sujeito Aprendente. E este sujeito, segundo nosso entendimento, é capaz de manter níveis de esforço e perseverança suficientes para dar conta do desafio envolvido no ato de aprender.

\subsection{As Metas de Realização e o Sujeito Aprendente.}

A psicologia educacional apresenta a motivação intrínseca como uma condição vivenciada pelo indivíduo quando da escolha e realização de uma determinada atividade por sua própria causa, por esta ser atraente, ou de alguma forma geradora de satisfação.

Por conseguinte, realizar a tarefa é um fim em si mesmo e representa uma necessidade para o sujeito: este condicionante interno que impele o indivíduo a ação é diferente daqueles envolvidos quando se procura realizar uma tarefa para a obtenção de notas, de diploma, vontade de agradar professores ou mesmo colegas. Um indivíduo nesta situação busca novidade, entretenimento, satisfação da curiosidade e oportunidade para desempenhar tarefas desafiadoras; tudo isto, associado ao prazer derivado do próprio processo.

Realizar atividades em que se está intrinsecamente motivado gera maior satisfação e há indicadores de que esta condição facilita a aprendizagem e o desempenho. Isto ocorre porque o aluno apresenta maior nível de atenção às instruções 
exigidas para a consecução da tarefa, principalmente em buscar e organizar o novo conhecimento de acordo com suas concepções, além de tentar aplicá-lo em outras situações (Boruchovitch \& Bzuneck, obra citada, p. 38).

Um aluno assim motivado apresenta os seguintes comportamentos:

- Perde a noção do tempo, pois se encontra altamente concentrado;

- Aquilo que não se relaciona com a atividade não é capaz de desviar sua atenção;

- Autodeterminado, não permite que a ansiedade ou emoções negativas provocadas por pressões atrapalhem seu desempenho;

- O resultado do trabalho não é seu principal objetivo, mesmo que o orgulho e a satisfação pelo reconhecimento de seu desempenho sejam esperados;

- Busca novos desafios após atingir certos níveis de competência;

- Os erros cometidos instigam-no a buscar a solução.

Sabemos que este tipo de comportamento é raro em se tratando de atividades escolares. Acreditamos, entretanto, que os pressupostos teóricos envolvidos nas metodologias sócio-construtivistas buscam desenvolver atividades em que os alunos possam experimentar certos níveis de autodeterminação.

Muitos pesquisadores da área têm procurado desenvolver trabalhos nesta direção, seja mediante perguntas desencadeadoras (Abib, 1996), que despertem nos alunos a curiosidade e a necessidade da resposta, seja por meio de atividades de laboratório aberto, onde estes participam do processo de planejamento das experiências. $\mathrm{Ou}$, ainda, no desenvolvimento de projetos escolares em que os alunos possam desenvolver um conceito científico de seu interesse.

A psicologia da educação trabalha com uma teoria moderna denominada: Teoria de Metas de Realização. Um de seus pressupostos consiste em que as metas ou o propósito que a pessoa tenha em mente atingir possam ser considerados como um dos maiores motivadores humanos.A Motivação à Realização é um conceito que contempla a relação entre motivação, metas ou objetivos diversos. Voltando a sala de aula, os mais importantes podem ser: desenvolver competência, parecer inteligente ou evitar o 
fracasso. Em particular, um aluno que apresente sua meta orientada a evitar o fracasso pode ter seu comportamento de realização, no momento em que aborda uma tarefa, afetado de forma negativa.

A moderna teoria pressupõe que a motivação à realização não é estável, não podendo ser considerada como um traço de personalidade. Estas metas podem ser influenciadas por características próprias da sala de aula, ou mesmo na forma como as tarefas são propostas ou devem ser desenvolvidas. Por exemplo: caso o professor proponha que em terminando a tarefa os alunos possam sair mais cedo, pode ocorrer que um indivíduo inicialmente orientado a obter competência realize a tarefa de forma superficial. Portanto, segundo Boruchovitch \& Bzuneck “[...] o referencial teórico é considerado sócio-cognitivista, por acolher tanto elementos originários do cognitivismo como por considerar relevantes as influências de natureza socioambiental em seu desenvolvimento, manutenção ou mudança.”(obra citada, p. 59),

Existem praticamente duas metas qualitativamente diferentes que orientam o comportamento das pessoas quando pretendem realizar atividades escolares: a meta aprender e a meta performance. No tocante à primeira, a pessoa age querendo obter conhecimentos para aumentar seu grau de competência. Já na segunda, o foco é o julgamento do outro. Dependendo da qualidade deste julgamento, esta meta se subdivide em duas: meta performance-aproximação, onde a preocupação está em garantir uma imagem positiva dos outros sobre o sujeito, como parecer inteligente para professores e colegas, e meta performance-evitação, na qual o comportamento é orientado a evitar uma imagem negativa dos outros, como não parecer incapaz para os demais membros da classe.

A meta aprender está relacionada a modos de pensar e a reações afetivas semelhantes aos de um aluno motivado intrinsecamente, entretanto não se trata do mesmo constructo. Afinal, o aluno intrinsecamente motivado age pela escolha autodeterminada da ação, pois pretende responder a necessidades internas, podendo ser estas subjetivas ou não. Enquanto que na meta aprender, o aluno pode se empenhar em realizar uma lista de exercícios de Cálculo, não porque as ache interessantes ou desafiadoras, mas por saber o quanto é importante para se formar. 
Durante nossa atividade como professores, devemos ter percebido que alguns alunos, independente do professor ou dos conteúdos a serem estudados, conseguiam bons resultados. Villani (2005), citando os casos analisados por Cobern \& Aikenhead parece nos apresentar uma aluna orientada a esta meta.

[...] Ann, pelo contrário, era uma aluna esforçada e inteligente, que conseguia se sair bem na disciplina de Química, apesar de afirmar detestá-la. Seu desempenho aponta claramente para uma diferença entre conhecer e envolver-se..., ela recusou se envolver com o conhecimento proposto pelo professor, apesar de revelar que seu desejo implícito estava bastante próximo do desejo do saber.

Segundo Boruchovitch \& Bzuneck, os alunos assim orientados almejam o sucesso na realização de tarefas escolares tendo como objetivo principal obterem maior conhecimento e habilidades. Agem procurando dominar sempre mais conteúdos, com inovação e criatividade. Consequentemente, o grau de exigência presente nas tarefas escolares é entendido como capaz de fazê-los crescerem intelectualmente.Estes alunos têm a convicção ou crença de que o êxito conseguido em suas tarefas está intrinsecamente ligado ao seu esforço e empenho. Estes atributos são internos e ligados ao investimento pessoal e estritamente sob seu controle: logo, o sucesso após esforço e empenho produz um sentimento de orgulho e realização reforçando uma autoimagem positiva. Não raro, muitos alunos se utilizam de estratégias cognitivas e metacognitiva de aprendizagem que conduzem a esse resultado; também não se incomodam com erros ou fracassos, pois estes são encarados como inerentes ao processo de aprendizagem e sua ocorrência propicia a adoção de novas estratégias com as quais possam dar conta dos desafios.

Na meta performance-aproximação o aluno age preocupado em tirar boas notas e sente-se bem quando realiza atividades em que possa enaltecer sua inteligência. Busca agradar o professor, procurando responder aquilo que acredita que outro gostaria de ouvir; muitas vezes seleciona do discurso do professor as palavras que este utiliza sem o compromisso de entendê-las, apenas para chamar atenção para si mesmo. Quando the é perguntado sobre algo, procura responder mais rápido que os outros, mesmo que não tenha refletido sobre a pergunta. Por fim, sente-se inteligente e confiante. Orientado desta maneira, quando este aluno obtém sucesso, considera que este deriva maximamente de sua inteligência. Por outro lado, quando ocorre o fracasso não é por falta de capacidade, mas por motivos outros, como: o professor não explicou direito ou 
não se sentiu interessado pela atividade. Assim, preserva seu "status" de inteligência que é inatacável. Uma característica presente em seu comportamento é o baixo esforço, pois crê que aprender é fácil, não necessitando de muito empenho. Esta ausência de esforço, muitas vezes, atrapalha seu aprendizado quando o conteúdo exige um maior aprofundamento. Como se acha muito inteligente para aprender, acredita que basta prestar atenção à fala do professor. Não obstante, o aluno assim orientado apresenta maior persistência e esforço do que os alunos orientados a meta performance-evitação, a qual apresentaremos a seguir.

Com a meta performance-evitação, o aluno também esta preocupado com o julgamento do outro. Entretanto, em aspectos estritamente negativos, caracterizando-se pelo medo de parecer incapaz ao professor e aos colegas. Antes de começar, teme o fracasso, pois se acha incapacitado para aprender; isso favorece baixa persistência e pouco esforço. Apresenta, ainda, tendência à ansiedade o que prejudica tanto a motivação quanto o desempenho por notas. Quando questionado, mesmo sabendo a resposta, prefere calar-se com medo de errar. Em atividades em grupo, muitas vezes, prefere não emitir opinião esperando que os outros respondam por ele. Apresenta verdadeira ojeriza por provas, questionários e qualquer outro tipo de situação em que acredite que possam vir a saber sobre sua suposta incapacidade. Em algumas situações, apresenta-se alienado do processo de aprender: caso não entenda um conceito não pergunta. Em relação à responsabilidade por seu insucesso, o professor pode até ter alguma parcela de culpa, mas no final sente-se como único responsável, o que acaba por fortalecer uma auto-imagem bastante depreciativa. Os teóricos desta linha nos lembram, conforme Boruchovitch \& Bzuneck (obra citada, p. 60):

[...] que estas metas não se constituem um objetivo simples a ser atingido, mas no sentido de um esquema complexo (Dodge, Asher, e Parkhust, 1989) ou uma constelação de componentes ou mediadores cognitivos. Outros autores (Dwech e Elliot, 1988), inspirados na informática, afirmam que cada meta é uma espécie de programa mental composto por processos específicos, pensamentos, propósitos, percepções, crenças, atribuições e conceitos que levam a resultados de natureza cognitiva, afetiva e comportamental.

Devemos deixar bem claro que as metas de realização não podem ser interpretadas como leis que determinam o comportamento dos alunos de forma mecânica. As mesmas devem ser encaradas como pressuposições ou crenças que os alunos carregam sobre sua possibilidade de realizar uma tarefa escolar. Portanto, sempre 
que iniciam uma atividade estes alunos tendem a adotar estratégias de realização como as descritas aqui.Por conseguinte, podemos admitir que um aluno inicialmente orientado a meta performance-evitação ao realizar uma tarefa aonde gradativamente vá obtendo sucesso, poderá apresentar acréscimos em sua motivação, podendo até se sentir valorizado por ter concluído a tarefa. Entretanto, o mesmo aluno, caso vivencie estratégias que produzam sensações de fracasso, poderá apresentar déficits motivacionais.

Em suma, todos nós, com maior ou menor grau, no momento em que estamos diante do desafio da realização de uma tarefa criamos certas expectativas quanto à nossa capacidade de realização, pois ao longo da vida elaboramos padrões de excelência. Portanto, graças a estes padrões, todas às vezes, seja em um curso fundamental para nossa formação ou numa simples resolução de uma lista de exercícios, irrompe em nosso interior uma verdadeira contenda entre as expectativas de sucesso, ligadas a alegria e o orgulho que sentiremos por um trabalho bem realizado, e a ansiedade e medo relativos ao possível fracasso futuro (Reeve, 2006, p. 108).Isto posto, um sujeito como uma boa expectativa de auto-eficácia é capaz de controlar a ansiedade ou os sentimentos negativos diante de uma tarefa.

A auto-eficácia é um julgamento sobre si mesmo em relação às habilidades e competências que um sujeito possui para realizar uma tarefa. Sendo assim, este julgamento vincula-se principalmente a historia de sucesso ou fracasso obtido pelo sujeito em momentos anteriores. Por exemplo, um sujeito que em sua história pessoal sempre foi hábil em resolver problemas de matemática, naturalmente diante de um novo exercício se sentirá pronto para colocar em ação suas habilidades para a resolução do desafio. Pelo contrário, alguém com dúvida poderá sentir ansiedade quanto a sua capacidade, poderá ficar preso em sentimentos negativos sem apresentar um comportamento que o auxilie na realização da tarefa.

Além da historia do indivíduo, também as qualidades pessoais que um indivíduo julga possuir têm impacto em seu comportamento de realização. Os partidários da teoria da existência, que acreditam que suas qualidades são fixas e permanentes, dificilmente poderão desenvolvê-las. Por outro lado, os que apostam na teoria do desenvolvimento, acreditam que nossas habilidades podem ser melhoradas através de esforço e dedicação, mais facilmente poderão modificar sua visão. Em se tratando do esforço, os partidários 
da teoria da existência acreditam que realizar tarefas com muito esforço comprova sua pouca habilidade, ou aptidão para tarefa, pouco restando a fazer. Porém, aqueles que crêem na teoria do desenvolvimento acreditam que é exatamente o esforço a condição capaz liberar toda a potencialidade do sujeito(Reeve, obra citada).

Os constructos vistos acima parecem apontar apenas para as necessidades internas dos sujeitos. Nesse sentido, o referencial teórico ligado às metas de realização apresentam dois interessantes constructos ligados às necessidades de relacionamento interpessoal, são eles: a necessidade de afiliação e a necessidade de intimidade, as quais trataremos a seguir.

Os indivíduos com alta necessidade de afiliação são na maioria das vezes pouco populares, pois a necessidade de afiliação esta ligada ao medo de uma rejeição interpessoal (Heckhausen, apud Reeve, obra citada, p. 117). Estas pessoas se relacionam buscando evitar sentimentos dolorosos como desaprovação e solidão, portanto, muitas vezes, experimentam maior ansiedade.Por outro lado, os indivíduos com necessidade de intimidade procuram estabelecer relações "interpessoais calorosas, próximas comunicativas e com pouco espaço para a rejeição" (McAdams, 1980, 1982a, 1982b; apud Reeve, obra citada, p. 118). Portanto, a necessidade por intimidade se traduz em melhor qualidade dos relacionamentos interpessoais. Esta necessidade motiva o indivíduo para o crescimento através do enriquecimento das relações. Como bem definiu Maslow (apud Reeve, obra citada) a diferença entre os dois conceitos: "[...]a necessidade de afiliação gira em torno da "falta de amor", ao passo que a necessidade de intimidade com os outros gira em torno da "sensação de amor"."

Como resultado do mergulho no manancial representado pelos dados da pesquisa nos deparamos com relatos dos sujeitos que escapavam ao escopo cognitivo. Estes relatos estão fortemente imbricados na história do sujeito e trazem em sua maioria um excesso de significado capaz de impactar fortemente a motivação do sujeito. Muitos desses relatos estão ligados às concepções de mundo do sujeito constituindo uma espécie de metafísica capaz, talvez, de garantir a ação do sujeito diante do conflito ou do fracasso. Este condicionante representado por esta metafísica, em nosso entendimento, pareceu fazer alusão a uma possível ecologia conceitual capaz de auxiliar o sujeito a enfrentar os obstáculos. Isto nos implicou a buscar nos escritos de Piaget a ligação entre a afetividade e a lógica. 


\subsection{O Sujeito Epistemológico Piagetiano e uma possível Ecologia Conceitual.}

A bem da verdade, Piaget nunca defendeu a cognição separada da afetividade, muito pelo contrário, sua epistemologia traçou um paralelo sem precedentes ao demonstrar a indissociação entre a cognição e a afetividade. Nesse sentido, percorremos as idéias do genebrino em busca das crenças epistemológicas e metafísicas na perspectiva de contribuir para o debate em torno de uma possível ecologia conceitual capaz de sustentar a existência dos sujeitos epistemológicos aqui apresentados.

Sendo assim, a secções que se seguem procuram esclarecer em qual momento surgi para o sujeito a necessidade lógica e como esta se liga a sua subjetividade capacitando-o a superar os desafios ligados a meta-aprender, ou as sensações de fracasso presentes no MMC, ou ainda, o conflito cognitivo proposto por Piaget, a fim de produzir ao final um movimento indicando não somente um novo equilíbrio, mas um que seja majoradamente melhor, conforme postulou o pensador.

Antes de iniciarmos a discussão sobre os avanços cognitivo-afetivos desta fase é preciso levantarmos algumas características que marcam a fase precedente ( 2 a 7 anos). Do ponto de vista afetivo, a criança nutre pelos pais um respeito unilateral: mistura de amor e temor, fruto da heteronomia. As obrigações, ordens, ou regras são consideradas sagradas. A impossibilidade de coordenar o próprio pensamento com o dos outros, impede a cooperação social de fato. No tocante ao pensamento, a lógica é intuitiva, portanto, se a coisas se movem é porque tem vida resultando o animismo. Outra característica é a transdutibilidade, onde a criança superdetermina diversas variáveis, mas não consegue perceber as contradições entre elas.

Segundo Piaget, este raciocínio irreversível e fruto do pensamento egocêntrico produzindo o desequilíbrio entre os mecanismos de assimilação e acomodação, puxando o pensamento em sentidos contrários. A criança sabe que sua vontade determina seu movimento, logo no universo físico tudo que se move tem vontade própria: é o animismo, fruto da assimilação deformante. Por outro lado, quando ela percebe alguma característica externa esta é suficiente para garantir a validade de sua argumentação: "é porque é”, reponde denunciando a rigidez de seu raciocínio e a impossibilidade de coordená-lo internamente; é a transdutibilidade, resultado de uma acomodação sem assimilação. 
Assim sendo, o sujeito deverá avançar para um raciocínio mais equilibrado entre os mecanismos de assimilação e acomodação. Portanto, seu pensamento devera alcançar maior nível de simetria, afim de coordenar aspectos contraditórios possibilitando o raciocínio reversível, mais flexível. Para Piaget a interação social será responsável em garantir esta reversibilidade garantindo maior equilíbrio entre a assimilação e a acomodação à medida que as torna mais solidárias. Piaget faz coincidir estes novos valores morais à própria lógica, portanto a honestidade, a noção de justiça e a reciprocidade se constituem como um sistema racional de valores e, isto só é possível, graças à elaboração de um sistema de operações lógico-matemáticas que possibilita a criança a coordenar seu ponto de vista com o dos outros garantindo a cooperação social. O surgimento dos primeiros sentimentos morais autônomos implicará o respeito mútuo, relação afetiva mantida por indivíduos que se consideram iguais reciprocamente, muito diferente, da relação hierárquica e unilateral estabelecida com os pais na primeira infância . Portanto, a honestidade, a noção de justiça e a reciprocidade se constituem um sistema objetivo de valores pessoais observados somente quando o "eu" se subordina às leis de reciprocidade. Sendo assim, graças aos novos sentimentos morais no lugar da satisfação de um simples desejo, vê-se surgir a "vontade" a expressão máxima deste equilíbrio. No entanto, não se deve confundir a "vontade" como uma simples manifestação de energia quando o indivíduo estabelece um objetivo ou um desejo. A "vontade" estabelece uma hierarquia de valores autônomos que a criança se sente obrigada a obedecer autonomamente diante de um conflito, impedindo-a, por exemplo, de trapacear durante o jogo de bolinhas. O desejo de ganhar é grande, mas intervém a "vontade" orientada por um sentimento moral autônomo como a honestidade capaz de implicar o sujeito a observar as regras socialmente instituídas entre iguais, impedindo-o de escolher o caminho mais fácil para a consecução do objetivo.(Piaget, 2006, p. 52-6)

Do ponto de vista das relações entre cognição e afetividade, a busca pela objetividade é antes um ato de vontade autônomo, é um esforço consciente através da produção de juízos de valor, é uma avaliação realizada pela a consciência em relação a conflitos morais ou sobre os dados de uma experiência. Portanto, a criança não busca somente as variáveis capazes de justificar suas argumentações como fazia, anteriormente, seu pensamento transdutível, agora, pode operá-las reversivelmente tentado verificar se suas hipóteses são fidedignas em relação à experiência implicando-a na busca moral por um traço de "verdade" capaz de fazer justiça ao seu pensamento. 
Em suma, o advento da necessidade lógico-moral de Piaget pode-se constituir parte da Ecologia Conceitual se a considerarmos como os compromissos epistemológicos ou metafísicos que um aluno pretende observar. Obviamente, por este pensamento estar limitado apenas pela reversibilidade simples (adição, subtração ou multiplicação, divisão) esta ecologia conceitual pode ser considerada de primeira ordem. Contudo, esta necessidade lógico-moral estabelecida nesta fase será hiperdimensionada pelo advento do pensamento formal na fase vindoura.

O pensamento formal abre um leque muito maior de possibilidades e de rearranjos cognitivos. Por exemplo, considerando-se duas preposições p e q, assim como suas inversas $\sim \mathrm{p}$ e $\sim \mathrm{q}$, o raciocínio hipotético-dedutivo produzirá 16 combinações representadas por operações lógicas como a denotação condicional ou implicação (se...então), a disjunção inclusiva (ou... ou... ou os dois), a exclusão (ou...ou) e, finalmente denotação bicondicional denominada de implicação recíproca (...é condição necessária e suficiente para ...). Portanto, mesmo o sujeito não sabendo nada sobre lógica matemática pode estabelecer relações ligadas ao grupo das duas reversibilidades ou ao esquema INRC, são elas a I (Identidade), N (negação), R (recíproca) e C (correlata).

O esquema operatório formal possibilita ao adolescente levantar hipóteses, combinando diversos resultados e relacioná-los de forma lógica, mas não terminam ai seus novos poderes. Este pensamento em rede permite estabelecer proporções numéricas, trabalhar com sistemas duplos de referência, pensar em termos probabilísticos; em suma, garantir a conquista do real pelo sujeito tornando-o mais autônomo. Por outro lado, naturalmente que estas potencialidades recém descobertas produzem grandes mudanças afetivas as quais trataremos a seguir.

De um modo geral, a adolescência é vista como um período crítico representando um choque entre o fim do mundo infantil e a integração do jovem ao universo adulto. Para Piaget, este período crítico é fruto dos novos poderes produzidos pelo pensamento formal, portanto a integração à vida adulta se dará pela superação de um novo egocentrismo responsável em produzir um tripé cognitivo-afetivo, representado por uma nova relação interpessoal com o adulto, por um desejo volitivo de reformular a sociedade em que vive e, por fim, pela assunção de um programa de vida. 
O primeiro desses aspectos fundamentais é imposto pela nova constituição intrapsíquica representada pela nova forma de pensar. O jovem se põe em pé de igualdade com o adulto, fato inusitado se pensarmos nos estágios precedentes onde a criança se sentia inferior frente ao adulto e mantinha uma relação de respeito unilateral. O jovem graças a seu pensamento hipotético-dedutivo pode discutir com o adulto no mesmo nível apresentando maior liberdade e maior autonomia entre o próprio pensamento e o pensamento do outro. Sendo assim, as operações formais capacitam ao jovem verificar a veracidade das informações do seu interlocutor, mecanismo capaz de assegurar a lógica sobre o discurso garantindo-lhe maior autonomia frente o outro. Isto posto, não importa muito "quem" ou o "conteúdo do discurso", mas a possibilidade de avaliar a fidedignidade da informação através do pensamento.Portanto, graças ao pensamento formal a necessidade lógica obriga o jovem a se manter fiel quando seu pensamento é contrariado pela experiência ou na relação com o outro.Este mecanismo opera duplamente; implicando tanto uma necessidade moral de fazer justiça ao pensamento, quanto um pensamento capaz de esgotar todas as possibilidades lógicas para garantir a este julgamento de valor maior fidedignidade (Piaget, 1967, p. 189)

O hiperdimensionamento da assimilação entendida como projeção dos esquemas mentais à realidade leva o jovem à onipotência da reflexão lançando-o em uma nova barreira egocêntrica. Munido de seu poderoso pensamento hipotético-dedutivo, ele analisa todas as falhas e injustiças presentes no universo, então, estabelece uma miríade de planos teóricos mirabolantes para consertar a realidade. Logo, muitos almejarão ser cientistas famosos apresentando grandes teorias que salvarão o mundo, outros serão importantes juristas, alguns objetivarão o maior cargo da nação para acabar com a fome.

[...] Há, um egocentrismo intelectual do adolescente, comparável tanto ao do lactente que assimila o universo a sua atividade corporal. [...] Esta última forma de egocentrismo, manifesta pela crença na onipotência da reflexão, como se o mundo devesse submeter-se aos sistemas e não estes à realidade. É a idade metafísica por excelência: o eu é forte o bastante para reconstruir o Universo e suficientemente grande para incorporá-lo. (Piaget, 2006, p. 60).

Nesta fase da vida, os aspectos religiosos também são hiperdimensionados. A criança considerava seus pais como representantes divinos, entretanto agora é capaz de perceber os erros ou as falhas em seu comportamento. Não raro, o jovem se engaja em partidos políticos ou adota uma nova religião, afim de salvar a humanidade. 
Em suma, o desenvolvimento do pensamento formal estrutura uma nova realidade. Estas mudanças cognitivo-afetivas impactam aspectos epistemológicos e metafísicos do sujeito. Estes, então, podem constituir as bases de uma possível Ecologia Conceitual de segunda ordem capaz de auxiliar o aprendiz quando este passa por situações de conflito ou de fracasso com suas concepções. Afinal, o espírito garantiu maior autonomia tornando-se forte o suficiente para ser desafiado, seja por uma experiência crucial ou pela relação com o outro.

Em resumo, Piaget viu no pensamento concreto relações lógico-matemáticas simples, ou de primeira ordem e afirmou que elas engendrariam no indivíduo uma necessidade lógica de primeira ordem, que identificamos como parte de uma ecologia conceitual de primeira ordem. Analogamente, apontou as relações hipotético-dedutivas como sendo relações de segunda ordem em relação àquelase estabelecendo uma necessidade lógica também de segunda ordem, que interpretamos como constituindo assim uma ecologia conceitual de mesma potência.Ela opera duplamente, implicando tanto uma necessidade moral de fazer justiça ao pensamento, quanto um pensamento que procura esgotar todos os meios para garantir a este julgamento de valor maior fidedignidade.

Destarte, tanto a afetividade quanto o pensamento alcançam maior equilíbrio implicando-se mutuamente. A necessidade moral de segunda ordem garante $o$ manancial energético para o sujeito levantar todas as hipóteses possíveis, testá-las, manter-se fiel as suas conclusões independentemente do resultado, exigindo um sem número de argumentações para garantir a validade de seu ponto de vista. Assim sendo, este elã afetivo-cognitivo é também parte das crenças metafísicas do sujeito responsáveis por produzir uma ecologia conceitual de mesma ordem.

Pensando na sala de aula, para nós professores construtivistas quando propomos estratégias baseadas no conflito cognitivo não esperamos que os alunos mudem radicalmente suas concepções espontâneas, mas as repensem a luz de novos conhecimentos.A bem da verdade, parece nos que o esforço argumentativo, com o qual o aluno pretende sustentar uma preposição espontânea ou científica, seja condição sine qua non para permitir a evolução de seu pensamento, pois possibilita ao mesmo perceber onde se encontram suas lacunas, garantindo não só maior profundidade ao pensamento, mas sobretudo, um maior equilíbrio. Portanto, a personalidade descrita por 
Piaget, graças aos excessos megalomaníacos devido ao novo egocentrismo, produziria sempre um movimento positivo, pois o jovem se veria irremediavelmente capaz de realizar qualquer projeto. Entretanto, não é isso que se verifica, pois a nova capacidade diz respeito à possibilidade de construir teorias, portanto um jovem pouco seguro de suas capacidades intelectuais poderia olhar para o futuro com a certeza do infortúnio inexoravelmente traçado em seu desventurado destino.

[...] Quer se trate de incompreendidos e ansiosos persuadidos do fracasso, que põem em dúvida (teoricamente) o próprio valor da vida, ou de espíritos ativos persuadidos de seu gênio, o fenômeno é o mesmo, tanto na sua parte positiva como na negativa. (Piaget, 2006, p. $62)$.

Notadamente, que a última citação abre caminho para explorarmos a meta performance-evitação. Entretanto, o que dizer da meta performance-aproximação, onde o indivíduo credita o sucesso a sua capacidade intelectual? Seria agora esta crença hiper aumentada devido a constatação de seus novos poderes? Diametralmente oposto, em relação ao aluno orientado a meta aprender este se veria agora dotado de grande inteligência, o que lhe transformaria em um sujeito ligada à meta performanceaproximação.

Isto posto, vejamos como estes diversos traços teóricos desenvolvidos até aqui se combinam e ajudam-nos a entender a subjetividade dos sujeitos pesquisados. Naturalmente, que não esperamos que estas considerações teóricas sejam capazes de decifrar por completo as crenças, os compromissos epistemológicos destes sujeitos. Entretanto acreditamos ser possível co-relacionar o comportamento presente nas diferentes metas, sobretudo os referentes à meta-aprender, com os desenvolvimentos teóricos produzidos por Piaget, possibilitando responder a seguinte pergunta de pesquisa:

Como se relacionam as metas de realização: meta aprender, meta performance-evitação e meta performance-aproximação às teorias sócio-construtivistas no relato sobre a percepção motivacional de alunos do segundo grau do ensino médio que vivenciaram o conflito cognitivo ao realizarem uma atividade de ensino de física? 
Sede suas próprias luzes.

Sede seu próprio apoio.

Conservai-vos fiéis à verdade que há dentro de vós

Como sendo a única luz.

\section{O Universo da Pesquisa}

Buda.

\subsection{Caracterização da Escola}

A pesquisa foi realizada em uma escola pertencentes à rede Estadual de Ensino do Estado de São Paulo. A mesma localiza-se na periferia da zona norte da Capital, sendo considerada afastada pela Secretaria da Educação, pois os professores recebem um ganho adicional relativo à distância. O acesso é garantido por ônibus ou lotações, entretanto a maioria de seus alunos vai andando para a escola.

Esta escola possui cerca de mil e quinhentos (1500) alunos, sendo mil (1000) no período diurno e 500 no período noturno. Destes alunos 1000 estão cursando o Ensino Fundamental II, enquanto que o restante (500) cursa o Ensino Médio no período noturno.

A escola no ano de 2006 mudou-se para um novo prédio construído pela Secretária da Educação, vizinho ao antigo. Este novo prédio considerado padrão possui dezessete (17) salas de aula, uma (1) biblioteca, um (1) laboratório de ciências e um (1) laboratório de informática.

Apesar de o prédio ser novo já apresenta graves problemas de depredação do patrimônio, tais como: pichações, carteiras riscadas e quebradas, parede sujas, luminárias quebradas, as torneiras dos bebedouros foram furtadas. Os professores de Educação Artística, visando diminuir as pichações e a depredação, têm procurado pintar as paredes dos corredores com desenhos artísticos, atitude esta que vem apresentando resultados positivos.

Os alunos do noturno no tocante à disciplina apresentam os problemas corriqueiros vivenciados hoje em dia nas escolas, tais como: ficam fora da sala aula, evadem-se na unidade escolar. Suspeita-se do consumo de bebidas alcoólicas ou de drogas pesadas. Nos últimos anos, tem se avolumado os casos de ofensas ou mesmo violência física a professores ou demais funcionários da escola. Vários boletins de ocorrência têm sido lavrados denunciando o cotidiano conturbado no qual tanto alunos quanto professores estão imersos.

Trabalhamos nesta escola desde 2003, ministrando aulas de Física. No ano de 2004, prestamos o concurso, conseguindo a efetivação na escola. Atualmente, trabalhamos com uma carga horária de vinte aulas no período noturno, que tem 
facilitado à realização deste mestrado, graças também ao programa Bolsa Mestrado do Governo Estadual que tem possibilitado o conforto financeiro necessário para a realização desta dissertação.

Nesta escola, trabalhamos com alunos das três séries (primeiro, segundo e terceiro) do ensino médio, esta condição nos coloca na posição delicada e privilegiada de professor-pesquisador.

\subsection{Contexto da Pesquisa}

Acreditamos que nossa pesquisa se insere como uma pesquisa qualitativa se adotarmos a definição de Bogdan e Biklen (apud Lüdke \& André, 1986, p. 11).

- Pois, nossos dados são obtidos do ambiente natural e nos constituímos como o principal instrumento de pesquisa.

- Nossa participação como professor nos garante um contato direto e prolongado com a situação que esta sendo investigada, através de um intensivo trabalho de campo;

- Nossos dados são frutos da descrição de acontecimentos e situações (Diários de Campo); incluindo também diversas entrevistas;

- Nossa principal preocupação é com o processo e não com o produto, pois estamos interessados em entender como as metas de realização influenciam o comportamento dos alunos;

- Portanto, os significados que os diversos sujeitos da pesquisa dão aos processos em que estão inseridos, a conexão que estes estabelecem com sua própria vida, suas crenças, seus valores, suas posturas atitudinais, metodológicas constituem informações importantes para a pesquisa. Ou seja, tudoo que possibilite iluminar o dinamismo interno com o qual o sujeito sustenta ou não sua posição, qualquer que seja ela, frente a qualquer demanda externa, será considerado relevante. Por exemplo, como o aluno lida com o erro, o qual a influência de sua auto-imagem no desempenho escolar.

\subsection{Primeira Fase da Pesquisa - Caracterização do Perfil de Realização}

Como professor-pesquisador passamos para alguns alunos pré-selecionados ${ }^{3} \mathrm{o}$ questionário de Acesso as Metas de Realização(apêndice - I, p. 5) que possibilitou identificar algumas das preocupações ligadas às metas de realização capazes de orientar o comportamento dos alunos, conforme descrito no referencial teórico adotado.

\footnotetext{
${ }^{3}$ As razões estão devidamente relatadas no diário de campo pertinente a cada sujeito participante da presente pesquisa.
} 
Entretanto, este instrumento não se mostrou conclusivo; desta forma desenvolvemos e aplicamos uma entrevista denominada de Entrevista de Validação do Perfil Motivacional de Realização (apêndice I, p. 6), a fim de nos assegurarmos da caracterização do perfil motivacional de cada sujeito selecionado. Logo, o questionário de acesso às metas de realização é utilizado como "mote", como justificativa para sondarmos quais as preocupações dos sujeitos quanto as suas metas de realização. Assim sendo, nosso principal instrumento de pesquisa, nesta fase, refere-se à Entrevista de Validação do Perfil Motivacional de Realização(apêndice I, p. 6).

Devemos esclarecer que a elaboração da primeira fase é fundamental para nosso objetivo de pesquisa, pois, caso contrário, não poderíamos correlacionar o perfil de realização dos sujeitos (as metas de realização) com as reações motivacionais, após a realização da atividade aprendizagem de ensino de física.

Isto posto, nesta primeira fase, utilizamos como principal estratégia a analise dos dados obtidos pela entrevista de Validação do perfil Motivacional de Realização na perspectiva de caracterizar os perfis de realização dos sujeitos Del, Ms e M. Este procedimento contribuiu para maior "sintonia fina" entre o professor-pesquisador, o referencial teórico e aproximação destes com a realidade. Portanto, é fundamental esta fase em nosso processo de compreensão, servindo também para auxiliar a compreensão do leitor pouco habituado não só com a teoria de metas, mas, principalmente, a forma como os dados comunicam-se com o referencial teórico.

\subsection{Segunda Fase da Pesquisa - Capturar as Percepções Motivacionais.}

A segunda fase, iniciou-se com a elaboração do perfil de realização de um grupo de quatro alunos (Au, Ga, En e Des) do segundo ano do ensino médio, utilizando o questionário confeccionado com as escalas de acesso ea análise dos dados obtidos através da Entrevista de Validação ao Perfil Motivacional de Realização (apêndice I, p. 6). Cumprida esta fase crucial pertinente à caracterização do perfil de realização passamos propriamente para a etapa seguinte, na qual os mesmos sujeitos (Au, Ga, En e Des) realizaram uma atividade de ensino de Física(Apêndice-IV p.18). Esta atividade ligada à condutividade térmica contempla como estratégia de ensino o conflito sóciocognitivo ou a insatisfação no tocante às ideias prévias dos educandos como proposto pelo modelo de mudança conceitual, ou como sugerido pelo modelo sócioconstrutivista.

Imediatamente após a realização desta atividade experimental entrevistamos os sujeitos utilizando-se uma segunda instrumento: Entrevista sobre a Percepção 
Motivacional(Apêndice-II, p. 7). Este instrumento de pesquisa permitiu-nos obter os dados relativos às percepções motivacionais dos sujeitos em relação ao conflito cognitivo e a possível correlação destas com os perfis de realização dos mesmos segundo suas metas de realização.

Gostaríamos de esclarecer ainda, que poderíamos utilizar o termo "relato motivacional" no lugar de "percepção motivacional", contudo, o relato motivacional nos remete a algo mais racional, mais cognitivo, menos subjetivo. Assim sendo, em acordo como nosso principal objetivo, que é captar algo mais ligado à percepção, às sensações, aos sentimentos de foro mais íntimo, mais subjetivo do indivíduo, seja nos momentos de maior preocupação, ou mesmo, naqueles mais gratificantes se é que existiram, após o término da atividade, ainda que talvez a única possibilidade se limite a um relato. Todavia, acreditamos que o termo "percepção motivacional" defina melhor nossa intenção, na medida em que pretendemos captar paradoxalmente, por um lado, as razões que legitimam a utilização do modelo e,por outro, o "ruído de fundo" relativo às anomalias que incomodam tanto os professores quanto os pesquisadores que pretendem trabalhar com a estratégia sócio-construtivista baseada no conflito cognitivo. 


\section{Metodologia}

\subsection{Instrumentos para Caracterização do Perfil de Realização}

Nossa principal preocupação era identificar os perfis motivacionais de alunos referentes às metas de realização. Não obstante, estávamos cônscios, caso não conseguíssemos com um mínimo de credibilidade caracterizar os perfis não poderíamos continuar com a pesquisa, com os objetivos que pretendíamos.

Neste momento, o principal instrumento de pesquisa que poderia permitir o acesso às metas de realização dos alunos foi sugerido por Boruchovitch \& Bzuneck (2001, p. 67) e consiste no artigo: "The development and validation of scales assessing students' achievement goal orientations" escrito por Midgley e colaboradores,publicado em 1998 na revista: Contenporary Educational Psychology. O artigo contempla os resultados obtidos em oito anos de pesquisa na validação das escalas de acesso realizado pelo grupo de pesquisadores da Universidade de Michigan. Foram utilizadas sete diferentes amostras de estudantes do nível elementar e médio que permitiram realizar testes de consistência interna, estabilidade e validação das escalas de acesso às metas de realização dos estudantes.

O artigo apresenta um total de dezoito perguntas (Apêndice-I, p.3). Estas estão divididas em seis correspondendo à meta-aprender, seis relacionadas à meta performance-aproximação e o restante voltado à meta performance-evitação. Nós traduzimos as questões buscando obter a maior correlação possível entre as palavras utilizadas, procurando preservar seu significado. Para a comodidade do leitor apresentaremos a versão em inglês e a respectiva tradução realizada por nós.

\subsection{Questionário de Acesso às Metas de Realização}

Task Goal Orientation

A. Meta-Aprender

X1-I like school work that I'll learn from, even if I make a lot of mistakes.

1- Eu gosto de realizar tarefas na escola em que eu realmente aprenderei, mesmo que eu cometa muitos erros.

X2-An important reason why I do my school work is because I like to learn new things.

2- Uma razão importante para que eu faça tarefas na escola é porque eu gosto de aprender coisas novas. 
X3-I like school work best when it really makes me think.

3- Tarefa que eu gosto de fazer é aquela em que eu possa realmente pensar.

X4-An important reason why I do my work in school is because I want to get better at it.

4- Uma importante razão para que eu faça a tarefa na escola é porque eu sempre quero melhorar, aprender mais.

X5-I do my school work because I'm interested in it.

5- Eu faço minha tarefa na escola porque eu estou interessado nela.

X6-An important reason I do my school work is because I enjoy it.

6- Uma importante razão para que eu realize uma tarefa na escola é que eu goste dela.

\section{Ability-Approach Goal Orientation \\ B. Meta performance-aproximação}

X7-I would feel really good if I were the only one who could answer the teachers' questions in class.

7- Eu me sentiria realmente bom se eu fosse o único que respondesse as perguntas dos professores da classe.

X8-It's important to me that the other students in my classes think that I am good at my work. ${ }^{4}$

8- É importante para mim que os outros estudantes em minha classe pensem que eu sou bom nas tarefas que realizo.

X9-I want to do better than other students in my classes.

9- Eu quero fazer as tarefas melhor do que os outros estudantes da minha classe.

X10-I would feel successful in school if I did better than most of the other students.

10- Eu sentiria bem sucedido se eu melhorasse mais do que os outros estudantes.

X11-I'd like to show my teachers that I'm smarter than the other students in my classes.

11- Eu gostaria de mostrar aos meus professores que eu sou o mais esperto da classe.

\footnotetext{
${ }^{4}$ Atenção: esta questão foi excluída do estudo de Migley (et al, 1998), pois segundo os resultados desta pesquisa esta assertiva não permitida a discriminação entre a meta performance-aproximação e a meta performance-evitação.
} 
X12-Doing better than other students in school is important to me.

12- É importante para mim, que eu faça as atividades melhor do que os outros alunos.

\author{
Ability-Avoid Goal Orientation \\ C. Meta performance-evitação
}

X13-It's very important to me that I don't look stupid in my classes.

13- É muito importante que eu não seja visto como um estúpido na frente dos meus colegas.

X14-An important reason I do my school work is so that I don't embarrass myself.

14- Uma razão importante para eu faça as tarefas é para que eu não fique envergonhado.

X15-The reason I do my school work is so my teachers don't think I know less than others.

15- Eu me preocupo quando eu faço meu trabalho se os professores irão pensar que eu sou menos capaz do que os outros.

X16-The reason I do my work is so others won't think I'm dumb. 16- Uma das razões para que eu faço meu trabalho é porque não quero que pensem que eu sou burro.

X17-One reason I would not participate in class is to avoid looking stupid.

17- Uma razão que eu não participaria da aula é porque não querem que me vejam como um estúpido (a).

X18-One of my main goals is to avoid looking like I can't do my work

18- Um de meus objetivos principais é evitar que me vejam como incapaz ao realizar minhas tarefas.

Naturalmente, o conteúdo e as estruturas das perguntas trazem em seu bojo o referencial teórico que descreve as metas de realização dos estudantes. Em relação à meta-aprender é evidente o aparecimento de palavras como gostar-aprender. Já nas questões sobre a meta performance-aproximação outro binômio chamou-nos a atenção: parecer-melhor. Por fim, nas questões para a meta performance-evitação repete-se parecer-incapaz, hora substituindo-se parecer, por sentir, hora, trocando-se incapaz por burro ou estúpido. 
Todavia, o pedido para que assinalassem com um $\mathrm{X}$ apenas as questões que concordavam não permitiram a caracterização dos perfis. Alguns alunos assinalavam algumas perguntas da meta-aprender, contudo, também poderiam assinalar outras correspondendo as demais metas de realização. Diante disto, resolvemos ampliar a requisição inicial pedindo que os sujeitos, ao invés de assinalar apenas com um (X), assinalassem (C) caso concordassem com a assertiva ou (NC) caso discordassem e (CP) significando concordar parcialmente com o conteúdo das alternativas. Desta forma, procuramos obter um espectro mais amplo das preocupações que orientam as estratégias dos alunos.

Ainda sim, o instrumento não se mostrou capaz de caracterizar com segurança o perfil dos alunos, exceto para meta aprender. Entretanto, este se mostrou como um potente indicador das preocupações dos alunos no tocante as tarefas escolares. Estas preocupações foram melhor investigadas através da Entrevista de Acesso ao Perfil Motivacional analisada abaixo. Gostaríamos de salientar sobre o questionário, deste ter sido fundamental para o pesquisador iniciar a investigação, ou seja, oferecendo o mote necessário para que os entrevistados e o pesquisador iniciassem o diálogo investigativo.

Entretanto, para o leitor interessado, apresentamos os resultados e discutimos o estudo preliminar feito por pesquisadores brasileiros que tinham como objetivo validar o questionário norte-americano de acesso às metas de realização. Segundo Zenorini, os resultados diferem dos resultados da pesquisa original:

Como já referido anteriormente, os fatores aqui encontrados não coincidiram com os do estudo original, que agrupou em um fator a meta aprender e em dois fatores a meta performance, incluindo os componentes performance-aproximação e performance-evitação. No presente estudo, o agrupamento dos componentes aproximação e evitação num mesmo fator parece indicar que os alunos não perceberam diferenças entre os itens relacionados a esses componentes.[...] (Zenorini, et al, p.172).

Assim sendo, segundo nossa análise baseada no trabalho de Zenorini, os fatores que tornam o questionário incapaz de caracterizar com precisão as metas de realização são ${ }^{5}$ :

- Existem dois fatores discriminantes relativos à meta aprender e a meta performance;

\footnotetext{
${ }^{5}$ A discussão do trabalho de Zenorini encontra-se no Apêndice III - seção: Quais os Fatores que Impossibilitam o Resultado Conclusivo do Questionário de Acesso às Metas de Realização.
} 
- A escala de acesso não permite subdividir com segurança a meta performance em duas metas: meta performance-aproximação e meta performance-evitação;

- Os sujeitos pesquisados não parecem diferenciar as assertivas ligadas à meta performance-aproximação e da meta performance-evitação;

- A escala de acesso permite caracterizar com maior segurança os sujeitos orientados à meta aprender;

- Pode ocorrer dos sujeitos orientados à meta performance-aproximação citarem o esforço como estratégia de aprendizado, crença típica dos sujeitos orientados à meta aprender, sugerindo que estes constructos não são diametralmente opostos;

- Não é possível prever o comportamento de um sujeito; por exemplo, caso um sujeito concorde com todas as assertivas da meta aprender, isto não significa que não concordará com as assertivas de outras metas;

- É possível que a meta aprender e a meta performance-evitação sejam conceitos diametralmente opostos, ou seja, os alunos orientados a obter domínio não estão preocupados em evitar parecerem incapazes, portanto, tendem a não concordar com a meta performance-evitação;

- A meta aprender é um condicionante valorizado e desejado socialmente, logo, os sujeitos tendem a concordarem com as assertivas orientadas segundo esta meta.

\subsection{Entrevista de Validação do Perfil Motivacional de Realização}

Após os sujeitos de pesquisa responderem o questionário da seção anterior, são entrevistados utilizando-se as questões à seguir:

1. Você tem quantos anos?

2. Faz muito tempo que você mora no bairro?

3. Você sempre estudou nesta escola?

4. Você atualmente está trabalhando?

5. Na pergunta $n^{\circ}-1$, você assinalou que não se preocupa em cometer muitos erros, porque o importante é que você aprenda? Mas errar não é ruim? Explique.

6. Mas e se o professor lhe desse as respostas certas? 
7. Se você fosse escolher entre aprender um assunto que você nunca viu e outro que você tem alguma noção ou já ouviu falar, á qual deles você daria preferência?Explique

8. Você acha que aprender é fácil? Por quê?

9. Você acha que para aprender é necessário esforço?

10. De que forma o professor pode influenciar neste esforço?

11. Quais são as estratégias que você utiliza para aprender?(você estuda antes das provas)

12. Qual o papel do bom professor? O que é um bom professor para você?

13. O que é um bom aluno para você?

14. Quando você não aprende de quem é a culpa?

15. Você afirmou na pergunta $n^{\circ} 7$, que gosta de pensar? Como que é isto? E quando você não consegue chegar à solução, o que você sente?

16. Se você estudou para uma prova, mas na hora você se confundiu e conseguiu uma nota C. Como você se sente?

17. Você sempre tirou boas notas?

18. Quanto o professor propõe um desafio como você se sente?

19. Seus pais se preocupam com suas notas?

20. Você, alguma vez, recebeu algum castigo por ter tirado nota baixa?

21. Quantos irmãos você tem? Em relação a eles você se acha inteligente ou apresenta maior dificuldade para aprender?

22. Você já participou de algum concurso na escola? Você ganhou, perdeu? Como se sentiu?

23. Têm alunos que ao receberem as provas ficam comparando nota, o que você acha disso?

24. O professor fez uma pergunta, você tem quase certeza da resposta você arrisca e responde ou espera que alguém responda pra você?

25. O que você acha do trabalho em grupo?

26. Você tem alguma dificuldade quando trabalha em grupo? Qual?

27. O trabalho em grupo ajuda?

28. O professor pede para você resolver várias questões em grupo como o grupo se comporta?(Alguém responde depois passa as perguntas para os outros? Os alunos esperam que você explique para eles? Você costuma fazer e os outros ficam olhando? Isto não atrapalha você, onde é que você sai ganhando? 
29. Mas se você e seu amigo não souberem? Como é que fica? Explique.

30. Você esta resolvendo em grupo algumas questões de matemática e suponhamos que você não saiba fazer uma conta lá da $5^{a}$ série. O que você faz?

31. Você sabe que alguns alunos tiram barato quando os alunos respondem errado, o que você acha disso?

32. Você acha que o aluno deve repetir? Por quê??

33. Você se lembra de ter vivenciado alguma situação desagradável referente a provas e notas?

34. Você já se sentiu incapaz de realizar alguma tarefa escolar?

A entrevista parece estruturada, todavia foi utilizada como um guia. De fato, foi melhor deixar o aluno falar, incentivando-o principalmente a relatar algum caso em sua vida escolar capaz de exemplificar suas afirmações.A análise das questões da Entrevista está no apêndice.

\subsection{Metodologia - Segunda Fase}

$\mathrm{Na}$ segunda fase, os sujeitos pesquisados organizaram-se em grupo para participar de uma sequência didática de conhecimento de física que utiliza o conflito cognitivo como estratégia. Após, a realização da atividade os sujeitos foram entrevistados utilizando o instrumento abaixo com o propósito de capturarmos a percepção motivacional dos sujeitos em relação à atividade de ensino realizada.

\subsection{1- Entrevista sobre a Percepção Motivacional.}

1. O que você achou da atividade?

2. Você gostou da atividade?

3. Quais perguntas foram as mais fáceis?

4. Quais as perguntas foram as mais dificeis? (Muitos relatam o conflito).

5. Que perguntas foram mais interessantes?

6. Porque você achou estas perguntas interessantes?

7. Quais as perguntas que proporcionaram uma sensação de confusão?[Alguns alunos relatam à confusão (conflito cognitivo) que torna a pergunta interessante (pode aparecer à surpresa). Outros dizem que este fato torna a pergunta desinteressante.] 
$\checkmark$ O que motivou você a continuar tentando?[ Alguns alunos afirmam que a necessidade de entender o que esta acontecendo. Outros dizem que este fato torna a atividade desmotivante]

$\checkmark$ Mas esta sensação de confusão não é ruim, não seria mais fácil se o professor explicasse na lousa? [Muitos relatam que se explicasse não teria graça à atividade, perderia a possibilidade de desafio].

8. Em algum momento você se sentiu desafiado?

9. Em qual momento ou pergunta você se sentiu desmotivado?

10. Quando você se sentiu desmotivado o que passou pela sua cabeça?

\section{O Grupo}

11. O que diferencia esta atividade de outras disciplinas. (matemática, português, etc.)?

$\checkmark$ Você gostou de participar do grupo? Como foi sua participação?[ Alguns alunos relatam que a diferença desta atividade de outras, esta na possibilidade de atuarem em grupo, pois surge o debate].

12. Qual critério que vocês utilizam para decidir qual resposta é a verdadeira?

13. Caso você estivesse sozinho você conseguiria realizar esta atividade?

14. E se fosse um outro grupo o que você acha que aconteceria?

\section{As sensações}

15. Em algum momento, você se sentiu surpreso?

$\checkmark$ Em algum momento você sentiu que não conseguiria achar a resposta ou realizar atividade? [ Alguns relatam que a confusão provoca esta sensação, alguns continuam outros desistem].

$\checkmark$ Qual tipo de modificação que você gostaria que o professor fizesse para que você não sentisse este tipo de sensação[Alguns alunos explicam que seria o melhor o professor explicar na lousa]

16. Você acha que se o professor explicasse na lousa seria mais fácil?

$\checkmark$ Você em algum momento, vivenciou uma certa dose de tensão?[Esta tensão, muitas vezes, faz com que o aluno fique focado na atividade e esteja ligado ao conflito]

17. Qual foi sua sensação em relação ao tempo?[Alguns respondem que não perceberam o tempo passar, ficando envolvidos com a atividade]. 
18. Você vivenciou alguma sensação de satisfação ou alívio? [Alguns alunos relatam que sentiram satisfeitos com o conhecimento adquirido.Outrosrelatam uma sensação de alívio provocada pela cessação da tensão]

19. Você vivenciou alguma sensação desagradável? Esperar o sujeito responder, caso contrário exemplifique o tipo de sensação, por exemplo, sentiu-se nervoso, sentiu o coração disparar, sentiu as mãos suadas? [Alguns alunos ao perceberem a possibilidade do fracasso, entram em um processo de ansiedade e acabando por somatizar estas reações em comportamentos bem característicos como por exemplo, taquicardia, sudorese ou boca seca]

20. Qual dessas frases descreveria seu sentimento em relação à atividade?

a) Foi dificil, senti que não ia conseguir, parecia que o tempo passava rápido e ao mesmo tempo demorava, me senti desmotivado em vários momentos. Graças a Deus que acabou!

Fale-me sobre esta sensação?

b) Foi difícil, mas foi bom, fiquei tão concentrado nas discussões que nem senti o tempo passar. No final, passou a tensão e me senti alegre e realizado pelo esforço que realizei e por aquilo que eu aprendi.

Fale-me sobre esta sensação?

c) Foi fácil, ficamos com dúvidas em alguns momentos, mas logo encontramos a solução, foi tranqüilo.

Fale-me sobre esta sensação?

d) Foi dificil, fiquei confuso(a) e nervoso(a), comecei a achar que era incapaz e fui desistindo aos poucos

Fale-me sobre esta sensação?

e) Foi dificil, senti que não ia conseguir, mas conseguimos e me senti aliviando no final.

Fale-me sobre esta sensação?

f) Caso não se reconheça em nenhuma destas descrições, descreva como você se sentiu.

\section{Sobre a relevância do conhecimento}

21. Você acredita que este conhecimento serve para alguma coisa? [Alguns alunos gostam, pois explica o mundo e a relação com as coisas, outros, não conseguem 
identificar a importância do conhecimento, muitos menos, estabelecem alguma relação com o cotidiano]

22. Você recomenda que eu continue a utilizar este tipo de atividade?

23. Você faria alguma sugestão para melhorá-la? 


\section{Apresentação e Analise dos Dados}

\section{Primeira Fase - Sujeitos Del, Ms e M.}

Com o propósito de dinamizarmos a leitura deste trabalho, ao invés de apresentarmos os dados para, logo em seguida, analisá-los, procedimento comumente realizado nos trabalhos científicos, optaremos, em apresentar os dados do sujeito Del: Diário de Campo, Questionário de Acesso as Metas de Realização e a Análise do Perfil de Realização. Após, a análise deste bloco de dados e a caracterização do perfil deste sujeito, então realizaremos o mesmo procedimento para os sujeitos Ms e M respectivamente. Este procedimento fez-se necessário, pois nosso principal objetivo pertinente à primeira fase foi elaborar uma metodologia de pesquisa capaz de permitir a classificação com o máximo de segurança possível dos perfis de realização: meta aprender, meta performance-evitação e meta performance-aproximação.

Este procedimento torna-se importante para o leitor vislumbrar nosso movimento de pesquisa, ou seja, as etapas por nós empreendidas para consecução do trabalho e fundamentalmente seu amadurecimento. Não obstante, permite ao leitor investigar com profundidade as conexões entre o referencial teórico ligado às metas de realização e a realidade representada pelos dados empíricos.

\subsection{Diário de Campo, Questionário de Acesso as Metas de Realização e Resultado} da Analise da Entrevista de Acesso ao Perfil Motivacional de Realização - Del.

\subsection{Diário de Campo - A escolha dos Sujeitos de Pesquisa}

Neste momento da pesquisa, como estávamos preocupados em obter um sujeito orientado à meta aprender, começamos a observar nossos alunos com o objetivo de encontrar um sujeito que se aproximasse da descrição de um sujeito orientado a esta meta segundo o referencial teórico. Portanto, selecionamos um sujeito que parecia estar orientado a esta meta de realização: as "pistas" para este achado encontram-se descritas em nosso Diário de Campo.

Este diário é uma tentativa do professor-pesquisador-aprendiz de buscar estabelecer uma possível relação entre o que está acontecendo em sala de aula e o referencial teórico adotado. Portanto, todas as impressões, pré-conceitos do professorpesquisador-aprendiz tinham como premissa responder a seguinte pergunta: Qual dos nossos alunos parece estar orientado a meta-aprender? 
Outro termo bastante estranho, com qual devemos tecer algumas considerações, antes de continuar, é sobre o "professor-pesquisador-aprendiz". Primeiro, porque pesquisamos nossa própria prática e nossos próprios alunos. Segundo, porque basta uma olhadela rápida no referencial teórico adotado para concluir que procuramos entender a motivação do aluno frente às tarefas escolares. Portanto, quem senão o professor, em um primeiro momento, possui a capacidade de colher as primeiras impressões sobre a motivação deste ou daquele aluno, mesmo que inicialmente estas estejam baseadas em algum pré-conceito?

Por conseguinte, procurou-se estabelecer sempre a seguinte relação: as impressões captadas pelo professor possuem respaldo junto ao referencial teórico adotado pelo pesquisador-aprendiz. Assim sendo, é este movimento dinâmico que pretendemos estabelecer com o termo professor-pesquisador-aprendiz.

\subsection{Diário de Campo - Sujeito Del}

Inicialmente, acreditavamosque o aluno orientado a meta-aprender fosse popularmente conhecido como sendo um aluno "C.D.F" ${ }^{\prime 6}$. Portanto, procuravamos um aluno segundo este pré-conceito.

"O aluno Del parecia não gostar muito das minhas aulas, acredito que não as achava muito interessante. Quando lhe era proposta uma atividade em grupo não apresentava grande empenho. Em algumas ocasiões chegou a abrir uma pasta com seus desenhos de manga no meio da aula. Perguntei a ele se já tinha feito algum curso, não me lembro da resposta, mas percebi que desenha bem e disse-me que gostava de jogos e RPG. Outro dia, presenciei que ele escrevia uma relação de armas: zarabatana, arco e flecha para que seus personagens utilizassem nos jogos de RPG.

O aluno Del se mostrava bastante independente nas minhas aulas. Apresentava, muitas vezes, até um certo ar de descaso, como se a disciplina ministrada por mim fosse muito fácil e não necessitasse de uma maior atenção por sua parte. No entanto, percebi que conversava muito com o professor de matemática e parecia apresentar um real interesse por esta área de conhecimento. No momento em que apliquei a prova de matemática, tive a confirmação que o aluno era “CDF”, pois o conteúdo em questão era análise combinatória; como este é razoavelmente difícil, achei que o aluno se encaixava no perfil que eu procurava. Outro motivo é que a grande maioria dos

\footnotetext{
$6 \quad$ Este termo é utilizado para se referir pejorativamente a um aluno que suporta ficar horas e horas
} sentado estudando e por conseguinte tira ótimas notas. 
professores, independente da disciplina, se referiam a este aluno como exemplo de inteligência e esforço.

A insistência em procurar o professor de matemática durante o intervalo incomodava alguns professores:

"Nossa, ainda bem que você tem paciência, heim..."

O professor respondia:

- "Agente tem que incentivar, é raro encontrar um aluno assim..."

\subsection{Questionário de Acesso às Metas de Realização - Sujeito Del}

Apenas como recurso de visualização utilizaremos as cores dos sinais de transito. Assim sendo, os sujeitos orientados a meta aprender preocupados em obter domínio estão liberados para aprender, logo, as assertivas pertinentes a esta meta estão sinalizadas com a cor verde. Os sujeitos orientados à meta performance-aproximação mais preocupados com a performance, têm suas assertivas sinalizados com a cor amarela, ou seja, podem ter sua motivação impactada por esta preocupação impedindoos de um aprendizado mais profundo. Logo, os sujeitos preocupados em não parecer incapazes, muitas vezes, com baixa autoestima, acreditando-se possuir uma suposta incapacidade capaz de produzir déficits motivacionais, terão suas assertivas sinalizadas com a cor vermelha representando perigo para a motivação para a aprendizagem.

Portanto, se o sujeito marcou (C) para alguma assertiva ligada à meta aprender, logo, ele pontua na cor verde, caso tenha marcado (CP), ou seja, concordo parcialmente, ele recebe meio verde, não obstante, caso tenha registrado (NC), não recebera verde, não pontuando na meta aprender. Assim sendo, o mesmo raciocínio se estende para as cores amarelo e vermelho que representam respectivamente a meta performanceaproximação e a meta performance-evitação. Observação, gostaríamos de salientar que este método é utilizado aqui apenas como recurso visual, aproveitamos também para informar que a classificação final somente é conseguida com a análise dos dados obtidos com a Entrevista de Acesso ao Perfil de Realização 


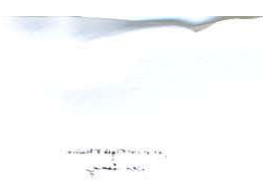

Nome: Del Aluno meta aprender idade 18 série $2^{\circ} \mathrm{C} \mathrm{n}^{\circ} .11$

Caso você concorde com as idéias abaixo as classifique colocando (C) que significa concordo, caso contrário, ou seja, se você não concordar coloque (NC) que significa não concordo. Caso você concorde parcialmente classifique as respostas como (CP) que significa concordo em algumas partes.

1- Eu gosto de realizar tarefas na escola em que eu realmente aprenderei, mesmo que eu cometa muitos erros.(c)

2- Eu me sentiria realmente bom se eu fosse o único que respondesse as perguntas dos professores da classe. (NC)

3- É muito importante que eu não seja visto como um estúpido na frente dos meus colegas.(C)

4- Uma razão importante para que eu faça tarefas na escola é porque eu gosto de aprender coisas novas.(C)

5- É importante para mim que os outros estudantes em minha classe pensem que eu sou bom nas tarefas que realizo.(CP)

6- Uma razão importante para eu faça as tarefas é para que eu não fique envergonhado.(NC)

7- Tarefa que eu gosto de fazer é aquela em que eu possa realmente pensar.(C)

8- Eu quero fazer as tarefas melhor do que os outros estudantes da minha classe. (NC)

9- Eu me preocupo quando eu faço meu trabalho se os professores irão pensar que eu sou menos capaz do que os outros. (NC)

10- Uma importante razão para que eu faça a tarefa na escola é porque eu sempre quero melhorar, aprender mais. (CP) $1 / 2$

11- Eu sentiria bem sucedido se eu aprendesse mais do que os outros estudantes.(CP)

12- Uma das razões para que eu faço meu trabalho é porque não quero que pensem que eu sou burro.(NC)

13- Eu faço minha tarefa na escola porque eu estou interessado nela.(C)

14- Eu gostaria de mostrar aos meus professores que eu sou o mais esperto da classe.(NC)

15- Uma razão que eu não participaria de uma da aula é porque não quero que me vejam como um estúpido (a).(WC)

16- Uma importante razão para que eu realize uma tarefa na escola é que eu goste dela.(C)

1.7- É importante para mim, fazer as atividades melhor do que os outros alunos. $(C P)$

18- Um de meus objetivos principais é evitar que me vejam como incapaz de realizar minhas tarefas. (NC)

Segundo, o método descrito anteriormente, o sujeito Del obteve a seguinte pontuação: 


\begin{tabular}{|l|c|c|c|}
\hline & Meta Aprender & $\begin{array}{c}\text { Meta performance- } \\
\text { aproximação }\end{array}$ & $\begin{array}{c}\text { Meta performance- } \\
\text { evitação }\end{array}$ \\
\hline Del & 5,5 & 1,5 & 1 \\
\hline
\end{tabular}

Como podemos observar o sujeito Del pontuou com cinco meio na meta aprender. Obteve um e meio na meta performance-aproximação e um ponto relativo à meta performance-evitação. Assim sendo, este sujeito parece estar orientado à meta aprender, não somente por ter obtido maior pontuação nas assertivas ligadas a esta meta, mas, principalmente, pelos poucos pontos relativos à meta performance, ;

Contudo, não é possível prever seu comportamento relativo às outras metas, justificando o fato do sujeito ter obtido nota um e meio na meta performanceaproximação, e, nota um na meta performance-evitação. $O$ fato do sujeito ter obtido nota relativamente baixa em relação à meta performance-evitação pode indicar que o sujeito orientado à meta aprender não concorda com as assertivas nas quais a principal preocupação é parecer incapaz. Por outro lado, poderíamos nos objetar dizendo que o sujeito Del responde de acordo com a valorização social do constructo meta aprender. Contudo, este sujeito poderia ter concordado com as outras metas, obtendo maior pontuação nas mesmas, o que não ocorreu.

\subsection{Resultado da Análise dos dados da Entrevista de Validação do Perfil}

\section{Motivacional de Realização do Sujeito Del.}

Nesta seção apresentaremos apenas os resultados estendidos ${ }^{7}$ da análise dos dados da Entrevista de Validação do Perfil de Realização do sujeito Del. A referida análise encontra-se detalhada no apêndice. O leitor interessado poderá recorrer à leitura do apêndice, a fim de se convencer do resultado que agora apresentamos, bem como, aprofundar-se nas conexões entre o referencial teórico e os dados empíricos.

\section{Del: "Sem guerra, não há vitória."}

O sujeito Del apresenta uma singular relação entre o "erro" cometido em situações escolares com o jogo de xadrez. Segundo sua crença, os "erros" ou os fracassos são fundamentais para o sujeito aprimorar ou aprender suas próprias táticas, seja no tabuleiro de xadrez ou na sala de aula. O sujeito acredita ainda que os "erros" e as dificuldades conferem qualidade ao aprendizado, pois caso contrário, o conhecimento

\footnotetext{
${ }^{7}$ Definimos: "resultado estendido", pois trazemos alguns trechos ou indicamos o local do mesmo na entrevista para facilitar o entendimento e o convencimento do leitor. Pois, partimos do pressuposto que talvez o leitor não tenha lido a integra da análise da entrevista.
} 
seria pouco valorizado podendo facilmente ser esquecido. Logo, esforço e dedicação estão amalgamados com o aprendizado valoroso, profundo e permanente (Apêndice, Trechos - 2, 3). Assim sendo, consideramos que este sujeito está fortemente orientado à meta aprender, pois os sujeitos assim orientados acreditam serem as dificuldades inerentes ao aprendizado fazendo-os crescer intelectualmente. Não obstante, o aprendizado conseguido com esforço e dedicação proporciona sentimentos de orgulho e realização.

Del levou aproximadamente dez anos para aprender música (Apêndice: Trechos - 5, 6); ele conta nos ainda, que no contato com um novo jogo: “...a primeira impressão é ou pára ou persiste, e eu sou uma pessoa que odeio parar no meio, quando eu começo alguma coisa eu vou até o fim, mesmo que eu quebre a cara depois."(Apêndice: Trechos - 11). Assim sendo, podemos considerar que estas vivencias permitiram ao sujeito engendrar estratégias positivas de auto-eficácia, ou seja, sua história de vida mostra que os desafios, acadêmicos ou não, devem ser enfrentados com esforço, dedicação e perseverança. Destarte, o engendramento destas estratégias de auto-eficácia repercutiram na constituição de um auto-conceito robusto no qual Del considera-se com atributos intelectuais capazes de impedí-lo de sofrer com fracassos ou decepções, pois mesmo considerando-se o melhor aluno da disciplina de matemática de sua escola - avaliação subscrita também pelos professores - o sujeito não se sentiu diminuído pelo seu pífio resultado na olimpíada de matemática (Apêndice - Trecho:12). Assim sendo, acreditamos que estas auto-avaliação resguardam Del de empreender ações desesperançadas com consequente perda do controle da situação, logo, afastandoo do conceito de desamparo.

Em relação às relações interpessoais, Del relata em alguns trechos que desconfia das atividades de aprendizagem realizadas em grupos, pois os colegas costumam aproveitarem-se de sua inteligência e de seu esforço delegando-lhe o trabalho duro(Apêndice - Trecho: 20). Contudo, no tocanteàs relações interpessoais, durante os primeiros anos escolares, Del relata um acontecimento interessante, envolvendo sua professora de português, no qual poderíamos identificar cuidado, preocupação interpessoal, calor humano e reciprocidade através da conexão emocional entre os sujeitos, preocupações que se repetem (Apêndice - Trecho: 16 , 18 (A)) no discurso dele. Portanto, acreditamos que Del aposta nas relações interpessoais com o propósito da troca de idéias, da solidariedade e do apoio mútuo. Logo, busca nas relações sentimentos de segurança e afeto, levando-nos a concluir que o sujeito estabelece suas 
relações em torno da existência do calor humano aproximando-o do conceito de necessidade de Intimidade.

Em inúmeros trechos da entrevista, Del apresenta um discurso ético-moral implicando-o com a verdade, a justiça e a honra. Este comprometimento moral e ético exige do sujeito direcionamento de energia afetiva para manter-se fiel a estes valores, confirmando o pensamento de Piaget sobre a importância da ética e da moral e sua implicação com o raciocínio hipotético-dedutivo. Assim sendo, estas crenças, estes padrões, configuram pactos metafísicos e epistemológicos que Del pretende defender ou se submeter, portanto, parece-nos que os mesmos configuram uma rede de significados constituindo uma Ecologia Conceitual capaz de sustentá-lo na busca pelo conhecimento, mesmo que esta busca seja árdua e, eventualmente, marcada por alguma sensação de fracasso ou por conflitos cognitivos.

Em suma, Del encontra-se fortemente orientado à meta aprender. Suas autoavaliações apontam a presença de uma auto-eficácia, bem como, de um auto-conceito capazes de fornecer o apoio emocional para o sujeito suportar os reveses inerentes à aprendizagem. Suas relações interpessoais são marcadas pela reciprocidade, solidariedade e segurança afetiva aproximando-o da necessidade de intimidade. Os valores como verdade, justiça podem constituir-se como pactos metafísicos e epistemológicos garantindo ao sujeito uma Ecologia Conceitual capaz, provavelmente, de suportar a sensação de fracasso ou de incerteza nos conflitos cognitivos.

\subsection{Diário de Campo, Questionário de Acesso as Metas de Realização e Resultado da Analise da Entrevista de Acesso ao Perfil de Realização - Ms}

Passaremos agora análise do sujeito MS. Devemos levar em consideração que todos os sujeitos falam, por exemplo, em esforço, todos também falam sobre o medo de fracassar. Ora, então como diferenciar um indivíduo do outro?

Isto só é possível, buscando observar o foco de realização que o sujeito revela em seu discurso. Portanto, a caracterização de um sujeito exige um conhecimento profundo das diferenças entre as metas de realização; em particular, quanto mais este sujeito se afastar da meta aprender indo em direção a uma auto-imagem negativa, mais próximo ele estará da meta performance-evitação. Assim o leitor poderá perceber a diferença entre Del e MS. 


\subsection{Diário de Campo - Sujeito Ms}

Este sujeito foi fundamental para que trilhássemos o caminho até aqui. $\mathrm{Na}$ época estavamos no início do mestrado e pretendiamos entender a reação motivacional negativa dos alunos diante do conflito cognitivo. Em uma de nossas aulas, entregamos um serie de perguntas para diagnosticar as concepções espontâneas dos alunos em relação ao calor, enquanto respondiam, nos aproximamos deste sujeito e ocorreu o seguinte diálogo:

Aproximei-me de MS e perguntei como havia chegado a uma determinada resposta que estava em seu caderno. A mesma respondeu-me, da seguinte forma:

- Ah!! Foi ele que respondeu, ele é quem sabe...

- Tudo bem, mas você não se preocupou em entender o porquê da resposta que ele chegou?

- Ah!!... Professor mas não está certo (demonstrando irritação)?, o importante é se está certo...

- Mas você precisa entender o porquê de estar certo, não basta somente copiar... Assim você não vai aprender.

Nos inquietou a situação de alienação desta aluna. Afinal, o que adianta agrupar os alunos, realizar atividades em que o mesmo vivencie o conflito cognitivo se este não apresenta nenhum interesse sobre o que está sendo ensinado.

Nos informamos junto aos outros professores sobre o comportamento dela: os mesmos relataram-nos tratar-se de uma aluna disciplinada, até um pouco tímida. Pois, copiava diligentemente toda a matéria da lousa, não questionava e não reclamava das tarefas. Entretanto, consideravam a aluna "fraca" devido suas notas, embora esta definição nos parecesse repleta de pré-conceitos, como se implicitamente dissessem: "o problema não é o comportamento, mas a falta de capacidade cognitiva”.

Esta situação foi extremamente desequilibradora. Por nosso turno, precisávamos entender porque esta aluna parecia tão alienada de sua necessidade de aprender. Por esta razão, entregamos o questionário de acesso às metas de realização e obtivemos o seguinte resultado: 
Nome: Aluna MS Meta performance-evitaçãa série $20 \mathrm{n}^{\circ}$.

Caso você concorde com as idéias abaixo as classifique colocando (C) que significa concordo, caso contrário, ou seja, se você não concordar coloque (NC) que significa não concordo. Caso você concorde parcialmente classifique as respostas como $(\mathrm{CP})$ que significa concordo em algumas partes.

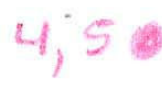

4- Eu gosto de realizar tarefas na escola em que eu realmente aprenderei, mesmo que eu cometa muitos erros.(C)

2- Eu me sentiria realmente bom se eu fosse o único que respondesse as perguntas dos professores da classe.(No)

3- É muito importante que eu não seja visto como um estúpido na frente dos meus colegas. $(C)$

4- Uma razão importante para que eu faça tarefas na escola é porque eu gosto de aprender coisas novas. $(C)$

5- É importante para mim que os outros estudantes em minha classe pensem que eu sou bom nas tarefas que realizo.(CP)

6- Uma razão importante para eu faça as tarefas é para que eu não fique envergonhado.(C)

7- Tarefa que eu gosto de fazer é aquela em que eu possa realmente pensar.(C)

8- Eu quero fazer as tarefas melhor do que os outros estudantes da minha classe. ( $N C)$

9- Eu me preocupo quando eu faço meu trabalho se os professores irão pensar que eu sou menos capaz do que os outros. ( ( P ) 0,56

10- Umà importante razão para que eu faça a tarefa na escola é porque eu sempre quero melhorar, aprender mais. (C)

11- Eu sentiria bem sucedido se eu aprendesse mais do que os outros estudantes.(NC)

12- Uma das razões para que eu faço meu trabalho é porque não quero que pensem que eu sou burro.(C)

13- Eu faço minha tarefa na escola porque eu estou interessado nela.(C)

14- Eu gostaria de mostrar aos meus professores que eu sou o mais esperto da classe.(NC)

15- Uma razão que eu não participaria de uma da aula é porque não quero que me vejam como um estúpido (a).(NC)

16- Uma importante razão para que eu realize uma tarefa na escola é que eu goste dela.(C)

17 - E importante para mim, fazer as atividades melhor do que os outros alunos. (CP)

18- Um de meus objetivos principais é evitar que me vejam como incapaz de realizar minhas tarefas.(C) 
Segundo o método de pontuação descrito anteriormente (p. 70), Ms obteve a seguinte pontuação:

\begin{tabular}{|l|c|c|c|}
\hline & Meta Aprender & $\begin{array}{c}\text { Meta performance- } \\
\text { aproximação }\end{array}$ & $\begin{array}{c}\text { Meta performance- } \\
\text { evitação }\end{array}$ \\
\hline Ms & 6,0 & 1,0 & 4,5 \\
\hline
\end{tabular}

O caso de Ms chama a atenção, pois concordou com todas as assertivas ligadas à meta aprender, entretanto, temia fortemente ser considerada incapaz por professores e colegas. Assim sendo, conforme já havíamos relatado o questionário de Acesso as Metas de Realização tornou-se inconclusivo para caracterização segura do perfil de realização.

\subsection{Resultados da Análise dos dados da Entrevista de Validação do Perfil Motivacional de Realização do Sujeito - Ms \\ "Devia ter nascido, tudo aprendido."}

Analisando o relato de Ms, encontramos a presença do esforço, contudo, resume-se a prestar atenção à fala do professor, copiar diligentemente da lousa, comportar-se disciplinarmente. Portanto, não se constitui ferramenta para o sujeito enfrentar as vicissitudes inerentes ao aprendizado, servindo apenas como justificativa para não ser confundida com um aluna preguiçosa (Apêndice - Trecho 8,9, 10 e 12, p.69). Em seu discurso, encontramos inúmeros relatos marcados por níveis altíssimos de ansiedade e angustia, relacionados a situações em que pudesse vivenciar o fracasso, pois desconfiava fortemente de possuir uma suposta incapacidade intelectual(Apêndice Trecho 19). Logo, convencida desta dificuldade, temia expor-se ao julgamento alheio, ou agia pretendendo a todo custo evitar que professores e os demais alunos tivessem ciência desta sua suposta deficiência(Apêndice - Trecho 13). Os sentimentos de medo, vergonha eram capazes de fazê-la desistir, alienando-a de um possível envolvimento ativo em seu processo de aprendizagem(Apêndice - Trecho 12, 13, 18). Nos momentos nos quais vivenciava ou pressenti o fracasso, ela direcionava sua raiva na forma de um conteúdo depreciativo contra si mesma (Apêndice - Trecho 19). Sendo assim, acreditamos que ela estava fortemente orientada à meta performance-evitação.

Ms ao longo de sua história escolar não vivenciou situações nas quais pudesse associar esforço com estratégias para solucionar os desafios, logo engendrou uma baixa 
expectativa de auto-eficácia. Assim sendo, este empobrecido senso de auto-eficácia impactava negativamente em seu auto-conceito, ou seja, não se sentia com atributos intelectuais capazes de solucionar os desafios acadêmicos. Isto posto, sem um rol de estratégias satisfatórias, desconfiando fortemente de sua capacidade cognitiva, era angustiada pela possibilidade do fracasso e por possíveis sentimentos de humilhação. Podemos admitir que seu comportamento pudesse evoluir para a perda do controle da situação, através de ações desesperadas com o consequente abandono das tarefas e a depreciação em relação a si mesma. Assim sendo, este estado de coisas aproximam Ms do conceito de desamparo. Como exemplo da perda de controle podemos citar seu comportamento desesperançado relacionado a provas e notas.

(P)o que você acha da prova, de fazer prova

(S) eu acho que não devia ter existido prova não, a gente devia ter nascido tudo aprendido deste pequeno, logo aprendido, porque é muito ruim... no dia da prova a pessoa fica bastante preocupada, ansiosa..eu fico né, eu prefiro não estudar, caso na hora a gente vê o que vai fazer na prova.(Apêndice - Trecho 20, p. ).

Em relação às relações interpessoais Ms, cita um acontecimento que marcou sua historia escolar profundamente: contrariamente ao ocorrido com Del, ao invés, do relacionamento humano girar em torno da segurança, da reciprocidade emocional, temos uma situação de tortura emocional. Durante alguns anos Ms amargou uma exposição vexatória, pois, todos em sua classe sabiam de sua incapacidade para aprender matemática. Podemos conjecturar que, paulatinamente, ela aprendeu a desconfiar dos relacionamentos interpessoais ligados à aprendizagem. Assim sendo, ela estabeleceu suas relações interpessoais girando em torno da insegurança, utilizando-se do grupo como esconderijo capaz de protegê-la do medo de um possível fracasso. Logo, Ms movimentava-se em torno da necessidade de afiliação. Isto, talvez, justifique seu comportamento em grupo captado no diário de campo. Ela protegia-se da possibilidade do erro assumindo irrefletidamente o conhecimento elaborado pelo outro.

Absolutamente, nada podemos afirmar sobre os valores ético-morais desta aluna, não por imaginarmos que ela não os tivesse, ou por acreditamos que ele não estaria comprometida com eles. Nós, apenas, não podemos pontuar que estes valores estabelecessem uma rede de significados capazes de implicá-la com seu processo de aprendizagem. Assim sendo, em relação a uma possível Ecologia Conceitual, nós não encontramos um discurso metafísico ou epistemológico capaz de constituir-se uma rede de significados poderosos auxiliando-a a suportar sentimentos de frustração ou, 
mesmo, um eventual conflito cognitivo. Pelo contrário, nos deparamos com uma autoavaliação depreciativa capaz de produzir déficits motivacionais comprometendo o movimento dela no enfrentamento das vicissitudes do conhecimento.

Em suma, Ms estava fortemente orientada à meta performance-evitação. As empobrecidas auto-avaliações de auto-eficácia e de auto-conceito não lhe permitiam proteger-se de ações desesperançadas, desembocando na perda de controle das situações de aprendizado, conforme o conceito de desamparo. Parece-nos, que as situações vexatórias contribuíram para ela estabelecer suas relações interpessoais ligadas à aprendizagem em torno de evitar a rejeição, o medo e a vergonha de um possível fracasso, aproximando-a do conceito de necessidade de afiliação. No tocante a uma possível ecologia conceitual Ms não parece ter elaborado uma rede de significados capazes de auxiliá-la a suportar os reveses inerentes ao conhecimento.

\subsection{Diário de Campo, Questionário de Acesso as Metas de Realização e Resultado da Analise da Entrevista de Acesso ao Perfil de Realização - M}

\subsection{Diário de Campo - Sujeito M}

No ano de 2004 quando ministrava aula para o primeiro colegial e ensinava conservação da quantidade de movimento, este aluno aprendeu com estrema facilidade e isto me chamou a atenção. Entretanto, à medida que os exercícios aumentaram em complexidade percebi que o mesmo começou a perder o interesse, a tal ponto, que deixou de freqüentar as aulas.

Naturalmente,não podemos interpretar o abandono como sendo resultado única e exclusivamente do aumento das dificuldades em relação ao conteúdo. Mesmo porque, este aluno apresentava problemas graves de indisciplina. Um dos mais freqüentes era a dificuldade em permanecer dentro da sala de aula; vivia nos corredores, muitas vezes, acompanhado de outros amigos, o que prejudicava o trabalho dos professores em outras salas.

Quando era questionado pelos inspetores, fazia graça e chacota. Caso o inspetor, com "jeitinho" conseguisse convencê-lo a voltar à sala, o caso estava resolvido; caso contrário, não raro partia para discussões e ofensas. Infelizmente, este comportamento tinha lhe custado caro, pois frequentava o primeiro colegial pela terceira vez. Até mesmos, entre os professores, este caso constituia-se como um divisor de 
águas. Todos o apontavam como muito inteligente, entretanto, para a maioria, este aluno: “não queria nada com nada!!”. Alguns professores, por outro lado, afirmavam que com "jeitinho", pedindo educadamente ou conversando diretamente, ele realizava as tarefas. Não raro, obtinha boas notas, confundindo os professores. O aluno era bastante popular e tinha muitos amigos. Parece-nos que rapidamente se constituiu como líder da classe e tinha acesso livre a outros grupos de alunos em outras classes.

Por nosso turno, também tínhamos a mesma impressão sobre sua inteligência. Entretanto, sua maior dificuldade estava em manter níveis de esforço conforme exigido para a realização das tarefas escolares. Um dos problemas, no trato com este aluno, aconteceu quando tentamos organizar junto aos escolares um campeonato de futebol no ano de 2006.

O aluno em questão mostrou-se bastante exigente, dava pouco espaço para a negociação. Não raro, no momento em que havia pontos de discordância, ameaçava abandonar a organização do campeonato. Parecia, muitas vezes, que ele acreditasse sermo-nos os maiores interessados em sua participação, mesmo a inscrição estando aberta a todos os alunos. Todavia, esta participação era condicionada à observância de regras discutidas em reuniões com os representantes de cada time. Para nós, a importância em um campeonato escolar organizado pelos alunos estava exatamente no estabelecimento de regras democraticamente aceitas, um limite baseado no respeito mútuo. Afinal, a sala de aula deve ser um espaço de atuação comum e, portanto, também possuir regras.

Este terceiro perfil foi o mais difícil de ser construído, poisinicialmente acreditávamos que o mesmo estivesse orientado à meta performance-evitação. Afinal, como um aluno apresentando tantas dificuldades disciplinares poderia estar orientado à meta performance-aproximação na qual o indivíduo busca parecer inteligente?

A solução veio quando percebemos a diferença entre Ms e M.A primeira preocupava-se em não parecer incapaz, evitando participar da aula ativamente. Por outro lado, $\mathrm{M}$ se achava inteligente participando da aula justamente para comprovar sua genialidade, isto ocorria até que não the fosse exigido demasiado esforço. Vejamos se analise dos dados, obtidos através dos instrumentos de pesquisa abaixo, nos permite confirmar este pré-julgamento:

\subsection{Questionário de Acesso às Metas de Realização - Sujeito M}


Nome: Aluno M perfomance-aproximaça idade série $\mathrm{h}^{\mathrm{o}}$.

Caso você concorde com as idéias abaixo as classifique colocando (C) que significa concordo, caso contrário, ou seja, se você não concordar coloque (NC) que significa não concordo. Caso você concorde parcialmente classifique as respostas como $(\mathrm{CP})$ que significa concordo em algumas partes.

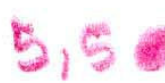

1. Eu gosto de realizar tarefas na escola em que eu realmente aprenderei, mesmöo que eu cometa muitos erros.(CP) $0,5 \mathrm{~V}$

2- Eu me sentiria realmente bom se eu fosse o único que respondesse as perguntas dos professores da classe.(Cp).

3. É muito importante que eu não seja visto como um estúpido na frente dos meus colegas.(C)

4. Uma razão importante para que eu faça tarefas na escola é porque eu gosto de aprender coisas novas. (C)

5- É importante para mim que os outros estudantes em minha classe pensem que eu sou bom nas tarefas que realizo.(C).

6- Uma razão importante para eu faça as tarefas é para que eu não fique envergonhado. (NC)

7 Tarefa que eu gosto de fazer é aquela em que eu possa realmente pensar.(CP)

8- Eu quero fazer as tarefas melhor do que os outros estudantes da minha classe. $(C P)$.

9. Eu me preocupo quando eu faço meu trabalho se os professores irão pensar que eu sou menos capaz do que os outros. (C)

10- Uma importante razão para que eu faça a tarefa na escola é porque eu sempre quero melhorar, aprender mais. (C)

11- Eu sentiria bem sucedido se eu aprendesse mais do que os outros estudantes.(CP).

12- Uma das razões para que eu faço meu trabalho é porque não quero que pensem que eu sou burro.( $\mathrm{CP}) \bullet 0,5$

13. Eu faço minha tarefa na escola porque eu estou interessado nela.(C)

14- Eu gostaria de mostrar aos meus professores que eu sou o mais esperto da classe. (CA).

15- Uma razão que eu não participaria de uma da aula é porque não quero que me vejam como um estúpido (a).(C)

16- Uma importante razão para que eu realize uma tarefa na escola é que eu goste dela.(C) $\perp v$

1.7- E importante para mim, fazer as atividades melhor do que os outros alunos. (NC)

18- Um de meus objetivos principais é evitar que me vejam como incapaz de realizar minhas tarefas.(C)

Vejamos seu questionário:foi computado erroneamente um ponto relativo à questão seis, logo a pontuação do sujeito na meta performance-evitação é de quatro e meio $(4,5)$ e não $(5,5)$ como informado acima. 
Os resultados de M são mais paradoxais ainda, quando comparados aos outros sujeitos, pois ele alcança maior pontuação em todas as metas. Assim sendo, façamos um exercício, consideremos somente duas metas, aprender e performance, conforme, quadro abaixo:

\begin{tabular}{|c|c|c|c|}
\hline Ano & Aluno & M.A. & M.P. \\
\hline \multirow{3}{*}{ 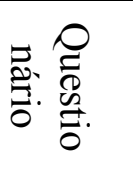 } & Del & 5,5 & 2,5 \\
\hline & $\mathrm{Ms}$ & 6 & 5,5 \\
\hline & $\mathrm{M}$ & 5 & 7,5 \\
\hline
\end{tabular}

Assim sendo, o sujeito $M$ teria obtido cinco pontos na meta aprender e sete e meio na meta performance. Caso fizéssemos o mesmo procedimento para Ms, ela pontuaria com a nota cinco e meio na meta performance, no caso do Del este apresentaria a menor pontuação, ou seja, dois e meio. Assim sendo, o resultado obtido por $\mathrm{M}$ sugere que este está muito preocupado com sua performance, contudo, não sabemos, se está preocupado em parecer inteligente ou em evitar parecer ignorante. Além disso, o sujeito concorda com as assertivas ligadas a meta-aprender, pois assim gostaria de ser. Naturalmente, também concorda com outras afirmações, revelando suas reais preocupações.

\subsection{Resultadosda Análise da Entrevista de Validação do Perfil Motivacional de} Realização do Sujeito - M

"Prefiro ser light, hehe..."

O sujeito M não estabeleceu uma relação de causa-efeito entre o aprendizado e o esforço, relação comum aos sujeitos orientados à meta aprender. Inclusive afirmou não ser adepto desta prática para a solução dos desafios da aprendizagem(Apêndice Trecho: 10, 11 e 17 p.). Por outro lado, não apresentava ansiedade ou angustia quanto ao possível fracasso escolar, pelo contrário, acreditava-se inteligente e confiante, pois, aprendia rápido qualquer conteúdo, basta que o professor explicasse bem. Isso o afastava da meta performance-evitação (Apêndice - Trecho: 16, p.).

Em seu relato, o esforço não surgiu como estratégia básica de auto-eficácia, inclusive o sujeito acreditava não possuir esta qualidade (Apêndice - Trecho: 17); por outro lado, seu sucesso era garantido por sua alta inteligência, consequentemente constituindo um inflado e ilusório auto-conceito. Podemos conjecturar que o sujeito apostava todas as suas fichas em sua inteligência, acreditando-se incapaz de sustentar 
grande parcela de esforço. Ao perceber o avolumar das dificuldades, notando que sua inteligência não podia solucionar todos os problemas, podemos admitir que seu comportamento pudesse evoluir para a perda do controle da situação, através de ações desesperadas e com o consequente abandono das tarefas, prejudicando o aprendizado mais profundo. Talvez, isto justifique o seu abandono da tarefa relatado no diário de Campo. Portanto, acreditamos que o sujeito aproximava-se do conceito de desamparo; entretanto, não porque se considerasse incapaz, mas por não conseguir manter níveis de esforço satisfatórios capazes de garantir o controle de uma situação de possível fracasso, ou que necessitasse de perseverança para ser concluída.

Durante todo o relato, $\mathrm{M}$ se mostrou bastante preocupado com o julgamento alheio. Tinha ojeriza de que seus amigos o confundissem com um aluno "C.D.F.", contudo, esforçava-se junto aos professores para que tivessem ciência de sua alta inteligência. Por outro lado, paradoxalmente, cometia atos de indisciplina para ganhar a admiração e a liderança da turma. Assim sendo, $M$ estabeleceu suas relações interpessoais buscando observar o enaltecimento de sua auto-imagem. Portanto, podemos conjecturar que o sujeito estabelecia suas relações interpessoais em busca do contato humano, da troca de vivências; contudo, estas não implicavam em uma relação baseada na segurança, no esforço solidário, ou no reconhecimento mútuo para o enfrentamento das dificuldades. Logo,afastava-o do conceito de necessidade de intimidade. Provavelmente, o sujeito estabelecia suas relações interpessoais buscando não somente proteção, mas, neste caso, o reconhecimento unilateral do outro. Por exemplo, flertava com os professores para ser reconhecido; porem, caso estes exigissem reciprocidade através do comprometimento nas atividades, abandonava a relação, pois, acreditava que a tarefa não valia o esforço. Assim sendo, este sujeito aproximava-se do conceito de necessidade de afiliação, não como proteção à frustração, mas pelo seu desejo de reconhecimento unilateral, ligando-se ao outro, não pela falta, mas pela exigência do amor incondicional, procurando nos olhos alheios o reflexo da própria vaidade.

Nada podemos afirmar sobre os valores ético-morais deste sujeito, somente, que estes valores não estabeleceram uma rede de significados capazes de implicar o sujeito em seu processo de aprendizagem. Assim sendo, em relação a sua possível Ecologia Conceitual, não encontramos um discurso metafísico ou epistemológico capaz de 
constituir-se uma rede de significados satisfatórios; pelo contrário, como o sujeito preocupava-se exageradamente com sua imagem, acreditando, graças à sua inteligência, não ser necessário manter níveis de esforço, podemos conjecturar que seria pouco provável que o mesmo sustentasse processos de conhecimento nos quais aparecessem sentimentos de fracasso ou as incertezas do conflito cognitivo, pois o sujeito podia chatear-se rapidamente, achando o assunto muito complicado e produzindo algum correspondente déficit motivacional.

Em suma, $M$ estava fortemente orientado à meta performance-aproximação a medida que pretendia parecer inteligente sem esforçar-se. A ausência de esforço como estratégia de auto-eficácia, por um lado, e o inflado auto-conceito baseado em uma ilusória super-inteligência, por outro lado, não podiam impedir o sujeito de realizar ações desesperançadas, desembocando na perda de controle das situações de aprendizado, conforme o conceito de desamparo. Preocupado, sobremaneira, com sua imagem o sujeito estabelecia sua relações interpessoais buscando a todo custo o reconhecimento unilateral alheio, aproximando-o da necessidade de afiliação. No tocante a uma possível ecologia conceitual o sujeito não parece ter elaborado uma rede de significados capazes de auxiliá-lo a suportar os reveses inerentes ao conhecimento, na medida em que acreditava não possuir o esforço, seja como qualidade a ser observada, ou como atributo a ser desenvolvido. 


\section{Avaliação da Metodologia de Acesso ao Perfil de Realização:}

\section{Del - Meta Aprender}

Acreditamos que os três instrumentos de coleta de dados estão em harmonia ao indicar Del orientado à meta aprender. O Diário de Campo, segundo as impressões ali captadas, apontava para um sujeito orientado a meta aprender, pois vários professores o consideravam inteligente e interessado, ao ponto de ser considerado um aluno "CDF". O questionário de Acesso às Metas de Realização, apesar de não estar sendo aqui utilizando como instrumento direto para o levantamento do perfil de realização, parece ter confirmando em relação ao sujeito sua orientação à meta aprender. Parece-nos que a entrevista confirmou não somente a orientação do sujeito à meta aprender, mas, talvez tenha revelado um traço de personalidade no qual o sujeito deseja ser reconhecido como alguém esforçado e dedicado principalmente nas atividades elegidas como de alto valor pelo mesmo.

\section{Ms - Meta Performance-Evitação}

Acreditamos que os três instrumentos de coleta de dados serviram para caracterização do perfil motivacional de Ms. O Diário de Campo captou uma aluna disposta a alienar seu direito de saber em nome do outro. O questionário de Acesso às Metas de Realização permitiu-nos perceber a preocupação da jovem em relação a uma possível baixa auto-estima, todavia, este instrumento também captou um sujeito fortemente orientado à meta aprender. Sendo assim, somente com a análise dos dados da entrevista de Acesso ao Perfil Motivacional de Realização pudemos não só afastar as dúvidas relativas à meta aprender, como também confirmar a orientação dela à meta performance-evitação.

\section{M - Meta Performance-Aproximação}

Acreditamos que os três instrumentos de coleta de dados serviram para o nosso propósito. ODiário de Campo,primeiro instrumento, representado pelas impressões do pesquisador-aprendiz juntamente com dos outros atores escolares revelaram um alunocom comportamento indisciplinado, mas, bastante preocupado em sustentar a imagem de um sujeito inteligente para professores e colegas, contudo, relutante ao 
empreendimento do esforço e da perseverança em relação à aprendizagem. Isso resultava em um aprendizado superficial ou no fracasso, levando-se em consideração o fato de M cursar pelo terceiro ano consecutivo o primeiro ano do ensino médio.

Por outro lado, o questionário de Acesso às Metas de Realização trouxe a luz um indivíduo bastante preocupado com sua performance, principalmente, no tocante a aspectos negativos, o que poderia indicar que o sujeito $M$ orientava-se segundoà meta performance-evitação.

Sendo assim, coube à entrevista de Acesso ao Perfil Motivacional de Realização não só afastar as sombras relativas à meta performance-evitação, como também desvelar um sujeito preocupado em parecer inteligente e bastante confiante. Contudo, o ser avesso ao esforço e à dedicação foi motivo pelo qual classificamos este sujeito como orientado à meta performance-aproximação.

O instrumento acima contribui para bem classificarmos o perfil de realização do sujeito M. Entretanto, o movimento do sujeito $\mathrm{M}$ em direção ao conceito de necessidade de afiliação no qual o sujeito pretende ser reconhecido pelo outro de forma unilateral, torna-se contundente considerando a complementaridade entre o Diário de Campo e a análise dos dados da entrevista de Acesso ao Perfil Motivacional de Realização, pois a comunidade escolar considera, a um só tempo, este sujeito como um aluno inteligente, e, paradoxalmente, indisciplinado. Logo, estes dois instrumentos complementam-se e ajudam-nos a entender os motivos de realização deste sujeito.

\subsection{Considerações Finais Sobre a Avaliação da Metodologia}

Acreditamos que os três instrumentos de coleta de dados são complementares. Assim sendo, o Diário de Campo permite uma imagem geral de como o sujeito é visto, seja pelo pesquisador-aprendiz, seja pela comunidade escolar. O questionário de Acesso às Metas de Realização permite-nos perceber as principais preocupações dos jovens em relação à aprendizagem. Estas impressões são investigadas e ampliadas na entrevista de Acesso ao Perfil Motivacional de Realização; este além de permitir aprofundarmos sobre a meta de realização, fornece-nos pistas sobre as auto-avaliações relativas à autoeficácia, bem como, ao auto-conceito permitindo-nos conjecturar como o sujeito portarse-ia diante dos inerentes reveses do conhecimento. Os conceitos de necessidade de afiliação ou de intimidade permitiram-nos intuir qual o propósito das conexões afetivas que os sujeitos visavam estabelecer nas relações interpessoais; buscavam proteger-se do fracasso, ou aliavam-se solidariamente para enfrentar os desafios. Todos estes conceitos 
ajudam-nos a compor uma de rede de significados permitindo-nos vislumbrar possíveis pactos metafísicos ou epistemológicos capazes de configurar a ecologia conceitual.

Isto posto, acreditamos, com estes instrumentos de medida, poder elaborar um mosaico motivacional relativamente seguro dos objetivos de realização dos sujeitos da pesquisa. Assim sendo, poderemos na segunda fase, captar o relato motivacional de quatro alunos, após vivenciarem o conflito cognitivo presente em uma intervenção didática.

\section{Segunda Fase da Pesquisa}

\subsection{Encontro do Grupo - Sujeitos: Au, Ga, En e Des}

Nesta segunda fase, nós precisávamos encontrar um grupo de alunos com no mínimo um aluno orientado à meta aprender e outro orientado à meta performanceevitação, pois caso contrário não poderíamos realizar a segunda fase da pesquisa com objetivo de correlacionar as metas de realização e as reações motivacionais dos sujeitos após vivenciarem o conflito cognitivo presente em uma atividade de ensino de Física. Logo, o Diário de Campo abaixo revela como encontramos o grupo e fornecemos algumas informações que achamos pertinentes sobre seus componentes.

\subsection{Diário de Campo - O Grupo}

\section{Algumas Considerações sobre o Grupo:}

O grupo foi escolhido, após percebermos que o mesmo se constituía num grupo de trabalho, principalmente por sua participação diligente na Feira de Ciência realizada na Escola, chamando a atenção dos professores. Os alunos estavam acostumados a realizarem as atividades de aprendizagem juntos, tinham em média mais de vinte e sete anos, levavam os estudos a sério, eram disciplinados e interessados, pararam de estudar devido às dificuldades e os desafios impostos pela vida. No ano anterior a pesquisa, ocorreu um episódio com a aluna Ga durante uma atividade de ensino de física, que chamou a nossa atenção. Solicitamos para o grupo, composto por Ga, En, Des e Au a realização de exercícios, que necessitavam da elaboração de simples desenhos como modelos capazes de representar a situação problema; não havia nenhuma complexidade em tais desenhos, pois eram do tipo, siga o modelo. Ga começou a reclamar que não gostava de fazer desenhos, que era aula de física, então porque fazer desenhos. Como a atividade era em grupo e nos não podíamos estar a sua disposição todo tempo, logo ela 
começou a reclamar que o professor não respondia a suas dúvidas.A partir de então, consideramos a possibilidade da aluna $\mathrm{Ga}$ estar orientada à meta performance-evitação.

No tocante a reclamação, esta não era fruto de um simples descontentamento, pois a mesma era transpassada pela ansiedade, uma ansiedade que não se justificava naquele momento exatamente pela simplicidade do exigido, assim, nem o professor, nem tão pouco os amigos a sua volta conseguiam compreender o porquê de tal impasse. Pareceu-nos tratar-se de uma reclamação fora de lugar e, sobretudo, perdida no tempo.

Outro fato, que chamou a atenção,vindo reforçar nossa concepção sobre este grupo, foi a reação à sugestão de que entrasse no grupo mais um aluno, pois acreditavamos que este novo aluno estava orientado também à meta performanceevitação. O grupo não aceitou nossa sugestão, principalmente En, referindo-se ao novo aluno da seguinte forma: “-Ah professor!!! Ele não quer nada com nada”.

O grupo foi composto por quatro alunos, que estavam orientados da seguinte forma: $\mathrm{Au}$, orientado fortemente a meta aprender, pois apresentava bastante interesse em relação à disciplina. En, orientada à meta aprender, pois realizava as atividades com esforço e dedicação suficientes. A aluna Ga,que reclamou da realização dos desenhos durante a atividade relatada acima,era aluna disciplinada e aceitou prontamente $\mathrm{o}$ convite para participar da pesquisa. Des, orientado à meta aprender, contudo bastante tímido. ${ }^{8} \mathrm{~A}$ princípio somente passamos o questionário para a En e Ga. O método confirmou nossas suspeitas iniciais, a primeira estava orientada à meta aprender e a segunda a meta performance-evitação. Desta forma, encontramos um grupo de trabalho organizado naturalmente com a configuração mínima para observar as reações motivacionais após vivenciarem o conflito cognitivo.

Entrevistamos os outros dois alunos para estabelecer seus perfis de realização somente após a atividade de Ensino de Física em que os alunos vivenciaram o conflito cognitivo. Au mostrou-se orientado à meta aprender com fortes aspectos de motivação intrinseca à ciência. Des apresentou um perfil de realização orientado à meta aprender, sentia-se tímido, contudo, confiava sobremaneira nos laços de amizade deste grupo.

\subsection{Caracterização do Perfil Motivacional de Realizado do Sujeito Au}

\footnotetext{
${ }^{8}$ Em relação a este último sujeito, foi realizada a análise referente ao perfil de realização; análise que apontou orientação à meta aprender. Contudo, em relação à percepção motivacional realizamos apenas parte da transcrição dos dados, pois houve a perda do áudio da gravação, assim sendo, concluímos uma análise parcial da percepção motivacional do sujeito Des.
} 
O Questionário de Acesso as Metas de Realização de Au e aanálise dos dados obtidos pela Entrevista de Acesso ao Perfil de Realização encontram-se no Apêndice(Segunda Fase). O leitor interessado poderá consultar toda a análise com o objetivo de dirimir eventuais dúvidas sobre o resultado do perfil de realização que apresentaremos a seguir. Contudo, antes, apresentaremos algumas poucas informações sobre Au.

$\mathrm{Na}$ época da pesquisa Au tinha vinte e oito anos de idade, casado, pai de família. Trabalhava como eletricista, tinha interesse intrínseco pela ciência e valorizava o conhecimento de forma geral. Era um aluno disciplinado, interessado, gozando de uma boa imagem junto ao seu grupo de trabalho e com os professores.

\subsection{Resultados da Análise dos dados da Entrevista de Validação do Perfil Motivacional de Realização do Sujeito Au \\ "Tudo começou por causa daquela experiência da bola, campo magnético você levanta a mão e os cabelos... Arrepia, Ai eu falei, eu quero isso!}

O sujeito em questão parecia não apresentar níveis preocupantes de ansiedade em relação ao seu sucesso escolar. Não estava preocupado com um possível julgamento negativo dos colegas ou professores, pois afirmava que gostava de situações em que podia se expor (trecho-15, 18 e 26). Não se preocupava com seu rendimento em relação às provas, pois acreditava que na ocorrência de notas baixas, bastava dedicar-se mais, ou em suas próprias palavras: "é mais motivo pra você "cafifar"”,(trecho -14). O sujeito em inúmeros trechos relacionava esforço a sucesso escolar, principal crença dos alunos orientados à meta aprender. Aliás, esforço e dedicação ultrapassavam a esfera escolar sendo ressignificados para justificar o sucesso profissional. O sujeito apresentava bastante auto-confiança achando-se inteligente, pois gostava dos desafios e respondia mesmo quando não tinha domínio sobre o assunto (trechos 12,16, 19 e 26). O trecho 14 ( onde o sujeito alega "sentir-se mal" caso obtenha uma nota baixa) não achamos relevante dentro do contexto, pois acreditamos que este sentimento tenha surjido exatamente por $\mathrm{Au}$ considerar-se esforçado e inteligente, garantindo-lhe auto-confiança. Ou seja, quando fracassava sentia-se responsável pelo infortúnio, advindo sentimentos negativos normais de alguém ao vivenciar o fracasso. Sendo assim, acreditamos que o sujeito estava fortemente orientado à meta aprender.

A bem da verdade, Au de um modo geral parecia valorizar o conhecimento, inclusive superestimando os detentores do saber: "o professor ele é um sábio". 
Destarte, parecia nutrir um interesse intrínseco pela ciência, pois além de escolher a profissão de eletricista, ele, ainda, estabelecia uma interessante relação entre ciência e religião (trecho 2, 3). O sujeito parecia procurar estabelecer uma relação íntima com o conhecimento, pois afirmava que gostava de se concentrar e ficar focado em um assunto ( trecho -7, 13), podendo até ocorrer algum insight: em suas palavras, "acende uma lampadazinha"(trecho-22).

Portanto, é provável que Au ao longo de sua história escolar tenha vivenciado inúmeras situações nas quais ao empreender esforço colheu êxito em suas ações. Logo, acreditamos que esse processo possibilitou ao sujeito desenvolver estratégias para solucionar os desafios, logo engendrou uma alta sensação de auto-eficácia. Assim sendo, este robusto senso de auto-eficácia impactava positivamente em seu autoconceito, ou seja, sentia-se com atributos intelectuais capazes de solucionar os desafios acadêmicos,principalmente, considerando o trecho no qual o sujeito relatou que mesmo não tendo certeza da resposta, não tinha dúvidas em emitir sua opinião. Isto posto, estava com um rol de estratégias satisfatórias e apostava fortemente em sua capacidade cognitiva. Podemos admitir que ao vivenciar situações de eminente fracasso o sujeito pudesse encontrar segurança em seu auto-conceito e direcionar energia na forma de esforço e concentração através da manutenção de um comportamento relacionado às suas estratégias de auto-eficácia fazendo-o empreender ações pertinentes ao controle da situação e a execução do desafio. Ao final, podiam-lhe advir sentimentos de orgulho e realização, portanto, acreditamos que o sujeito se afastasse do conceito de desamparo.

Ao longo de toda a análise, Au não relatou episódios nos quais tivesse sido alvo de exposição vexatória. Pelo contrário, parece ter tido uma boa recordação em relação aos seus professores do primário. Entretanto, houve um episódio no qual questionou publicamente a competência de uma professora em nome do conhecimento. Nas relações escolares com seus colegas, parece acreditar que os demais alunos o consideravam bastante inteligente, pois era procurado para integrar grupos devido a esta qualidade. Nesse sentido, levando-se em consideração o diário de campo do grupo temos a impressão que o sujeito parecia colocar-se na posição de líder inteligente do grupo chamando para si a responsabilidade em resolver os desafios. Portanto, acreditamos que o sujeito apostava nas relações interpessoais com o propósito de trocar ideias e pontos de vista, inclusive acreditando que aprenderia melhor nestas situações. 
Logo, buscava nas relações sentimentos de segurança e afeto, levando-nos a concluir que o sujeito estabelecia suas relações em torno da existência do calor humano aproximando-o do conceito de necessidade de intimidade.

De qualquer forma, o sujeito pode ser visto possuindo o desejo de um cientista em potencial, devido as singularidade com a qual enxergava este ramo de conhecimento, logo acreditamos que o sujeito possuisse crenças epistemológicas e metafísicas girando em torno do estabelecimento da verdade capazes de compor uma rede de significados implicando-o a buscar o conhecimento mesmo em situações de fracasso ou de conflito cognitivo.

Em suma, Au estava fortemente orientado à meta aprender;seu esforço podia até proporcionar sensações de prazer, pois apreciava situações nas quais se sentia compenetrado. As auto-avaliações de auto-eficácia e o seu auto-conceito estavam amalgamados ao esforço e a inteligência, sendo capazes de lastrear o comportamento do sujeito evitando ações ligadas à perda do controle da aprendizagem, afastando-o do conceito de desamparo. O sujeito apostava nas relações interpessoais, objetivadas pelo apoio mútuo e pelo trabalho solidário, inclusive acreditava no grupo como forma especial de organização capaz de promover maior aprendizado através das trocas de experiências e pontos de vista; logo Au aproximava-se do conceito de necessidade de intimidade. A ecologia conceitual do sujeito era especialmente robusta considerando seu interesse intrínseco em relação ao conhecimento, principalmente o da física. Este tipo de interesse podia levá-lo a constituir-se líder científico do grupo; destarte, Au podia ser capaz de suportar os reveses inerentes ao conhecimento, fossem produzidos pelo fracasso ou pela insegurança durante um conflito cognitivo.

\subsection{Caracterização do Perfil Motivacional de Realização do Sujeito Ga ${ }^{9}$}

Contudo, antes, apresentaremos algumas poucas informações sobre $\mathrm{Ga}$. $\mathrm{Na}$ época da pesquisa ela tinha vinte e setes anos de idade, era casada, mãe de família e dona de casa. Realizava as tarefas solicitadas, assim os professores a consideravam uma aluna disciplinada e interessada; o grupo acreditava que estava pronta para o trabalho. Conforme, já havíamos comentado, acreditamos que ela estava orientada à meta performance-evitação.

\footnotetext{
9 O Questionário de Acesso as Metas de Realização de Ga e a respectiva análise dos dados obtidos pela entrevista de Acesso ao Perfil de Realização encontram-se na seção (Apêndice - Segunda Fase).
} 


\subsection{Resultados da Análise dos dados da Entrevista de Validação do Perfil Motivacional de Realização do Sujeito - Ga \\ "[...] da gente errar, dos colegas rirem,bota um apelido... às vezes, muitas vezes, fui apelidada de burrinha...".}

Ga apresentava níveis altíssimos de ansiedade e angustia, cristalizados em situações em que pudesse vivenciar o fracasso, pois desconfiava fortemente de possuir uma suposta incapacidade intelectual. Destarte, temia ser considerada incapaz por professores e colegas ou expor-se ao julgamento alheio. Os sentimentos de medo,vergonha eram capazes de fazê-la desistir, alienando-a de um possível envolvimento ativo em seu processo de aprendizagem. Apesar do esforço estar presente em seu discurso, servia apenas como justificativa para não ser confundida com uma aluna indolente. Nos momentos nos quais vivenciava ou pressentia o fracasso, ela direcionava sua raiva na forma de um conteúdo depreciativo contra si mesma. Sendo assim, acreditamos que este sujeito estivesse fortemente orientado à meta performanceevitação.

Ga ao longo de sua história escolar vivenciou inúmeras situações nas quais mesmo ao empreender esforço colheu o fruto amargo do fracasso. Portanto, acreditamos que esse processo não lhe possibilitou desenvolver estratégias para solucionar os desafios, logo engendrou uma baixa expectativa de auto-eficácia. Assim sendo, este empobrecido senso de auto-eficácia impactava negativamente em seu auto-conceito, ou seja, não se sentia com atributos intelectuais capazes de solucionar os desafios acadêmicos. Isto posto, sem um rol de estratégias satisfatórias, desconfiando fortemente de sua capacidade cognitiva, angustiada pela possibilidade do fracasso e por possíveis sentimentos de humilhação, seu comportamento podia envolver a perda do controle da situação, através de ações desesperançadas, com o consequente abandono das tarefas e a depreciação em relação a si mesma. Assim sendo, este estado de coisas aproximavam Ga do conceito de desamparo.

Ao longo de toda a análise, Ga relatou diversos episódios onde aprendeu a desconfiar dos relacionamentos restritos ao cotidiano escolar. Em sua relação com os professores,ela sentiu-se inúmeras vezes rejeitada, por não ser capaz de corresponder aos padrões exigidos academicamente. Nas relações escolares com seus colegas sentiuse humilhada, ao ser considerada "burrinha”: esta situação parece ter marcado a aluna 
profundamente conforme seus relatos. Ainda estes relatos evidenciam seu sentimento de angustia quanto ao fatídico fracasso, pois estava convicta de uma suposta falha cognitiva, levando-a a acreditar de não possuir atributos com os quais pudesse ser objeto do amor alheio. De qualquer forma, independente desta falta de atributos cognitivos serem reais ou não passarem de uma ilusão, podemos conjecturar, devido ao empobrecimento atribuído às relações interpessoais em seu discurso, que Ga buscava nas relações evitar sentimentos dolorosos como a rejeição, levando-nos a concluir que seus relacionamentos eram estabelecidos em torno da falta de amor, indo ao encontro de necessidade de afiliação.

Assim sendo, em relação a uma possível Ecologia Conceitual, nós não encontramos um discurso metafísico ou epistemológico capaz de constituir-se uma rede de significados poderosos auxiliando-a a suportar sentimentos de frustração ou mesmo de um eventual conflito cognitivo. Pelo contrário, nos deparamos com uma autoavaliação depreciativa capaz de produzir déficits motivacionais comprometendo o movimento dela no enfrentamento das vicissitudes do conhecimento.

Em suma, Ga estava fortemente orientada à meta performance-evitação, acreditando possuir alguma deficiência que a impedia de aprender. As empobrecidas auto-avaliações de auto-eficácia e de seu auto-conceito não lhe permitiam proteger-se de ações desesperançadas, desembocando na perda do controle das situações de aprendizado, conforme o conceito de desamparo. Nestas situações direcionava parte de sua raiva para o autoflagelo. Parece-nos, que as situações vexatórias contribuíram para ela estabelecer suas relações interpessoais ligadas à aprendizagem em torno de evitar o medo e a vergonha por um fatídico fracasso, aproximando-a da necessidade de afiliação. No tocante a uma possível ecologia conceitual ela não parecia ter elaborado uma rede de significados capazes de auxiliá-la a suportar os reveses inerentes ao conhecimento.

\subsection{Caracterização do Perfil Motivacional de Realização do Sujeito En ${ }^{10}$}

En, há época da pesquisa,tinha trinta e um anos de idade era casada, mãe de família e dona de casa. Também parecia gostar de realizar as tarefas e era considerada pelos professores uma aluna disciplinada e interessada; parecia ser a líder organizacional do seu grupo.

\footnotetext{
${ }^{10} \mathrm{O}$ Questionário de Acesso às Metas de Realização do En e a respectiva análise dos dados obtidos pela entrevista de Acesso ao Perfil de Realização encontram-se na seção (Apêndice - Segunda Fase).
} 


\subsection{Resultados da Análise dos dados da Entrevista de Validação do Perfil}

\section{Motivacional de Realização do Sujeito - En}

\section{"[...] saber se eu to seguindo o caminho do professor, que eu estou seguindo a resposta certa...."11.}

En apresentava níveis de ansiedade ligados à possibilidade do erro ou fracasso. Ela desconfiava de sua aptidão para aprender alguns conteúdos de matemática. Nas situações em que o professor fazia perguntas para a classe, Em, mesmo sabendo a resposta, preferia não responder, pois temia errar expondo-se a zombaria alheia. Em situações ou diante de tarefas escolares em que se sentia perdida ou pressentia o fracasso experimentava sentimentos de ansiedade, raiva ou mesmo vergonha. Sendo assim, segundo estas constatações, estaríamos dispostos a classificá-lo como orientada à meta performance-evitação.

Entretanto, os níveis de ansiedade do En não eram tão altos quando comparados aos altíssimos níveis apresentado por Ga. En desconfiava de sua aptidão para aprender matemática, contudo esta desconfiança não a fazia supor ser incapaz intelectualmente. Apesar de temer a exposição pública, não agia pretendendo esconder suas falhas relativas ao domínio de algum conteúdo; pelo contrário, utilizava os erros como estratégia meta-cognitiva para melhorar seu aprendizado; logo apreciava ser avaliada, pois podia monitorar seu desenvolvimento. Em relação às emoções, se entristecia quando não conseguia realizar uma tarefa a contento, podendo até mesmo sentir raiva de si mesma. Contudo, estes sentimentos não eram fortes o suficiente para fazê-la desistir, e, nem tão pouco, estas situações a faziam desconfiar de sua capacidade. Em relação ao fracasso escolar, En acreditava que o baixo rendimento dos alunos em geral não era devido à falta de capacidade intelectual, mas, sobretudo, à falta de empenho e esforço. Sendo assim, ela escolhia os integrantes de seu grupo levando em consideração o engajamento nas tarefas escolares. Em suma, estas constatações fazem nos acreditar que este sujeito estava orientado, pelo menos em parte, à meta aprender.

Contudo, obviamente,En não estava orientado à meta aprender tão fortemente quanto $\mathrm{Au}$, convicto de que seu esforço aliado a sua inteligência lhe garantiriam o êxito. Isto posto, acreditamos queEn sofria mais com sentimentos de ansiedade em comparação com $\mathrm{Au}$, principalmente em relação aos erros, acreditando que estes

\footnotetext{
${ }^{11}$ Trecho modificado, trecho original: E: Isto me ajuda a ver se eu estou sempre errando, se eu estou fazendo alguma coisa esta indo em frente, sabe se eu to seguindo o caminho dele, não que eu estou seguindo ele, que eu estou seguindo a resposta certa (Apêndice, trecho -12, p.167)
} 
indicavam a proximidade do fracasso; contudo, provavelmente deveria apostar no esforço e na dedicação para solucionar os desafios.

Portanto, podemos conjecturar em relação à sensação de auto-eficácia desta aluna duas possibilidades: En vivenciou situações em que teve de desprender esforço para enfrentar as dificuldades inerentes ao aprendizado e obteve êxito, afinal nunca repetiu o ano. Entretanto, esta situação deve ter sido penosa, por esta razão, talvez ela desejasse possuir um grande cociente de inteligência. Destarte, este senso de autoeficácia ao mesmo tempo em que lhe permitia sentir-se capaz para aprender, paradoxalmente, também a fazia acreditar que se fosse mais inteligente do que realmente era, não necessitaria de tanto esforço para aprender. Esta sensação de autoeficácia não impactava tão negativamente o auto-conceito deEn, como no caso de Ga.No entanto, devemos considerar a possibilidade de En ao final de uma tarefa complexa na qual obteve êxito, após despender esforço e dedicação, ao invés de se sentir orgulhosa e realizada pelo caminho que trilhou, pudesse concluir: "Se eu fosse mais inteligente, não estaria passando por isto". Portanto, o auto-conceito do En girava em torno da sensação da falta, no caso, de um alto cociente de inteligência, impedindolhe de sentir maior auto-confiança; assim é razoável admitirmos que esta aluna nos momentos em que se sentisse perdida pudesse adotar um comportamento desamparado.

Por outro lado, um segunda possibilidade em relação ao senso de auto-eficácia de Em estava ligado à distância entre seu "eu” e a imagem inalcançável de um sujeito com alto coeficiente de inteligência. Esta imagem especular refletida por seus professores continua sendo implicitamente contida nos altos padrões de excelência exigidos pelo modelo tradicional de ensino. Por esta razão, em seu discurso, em vários momentos, En lamentava-se por não possuir um alto cociente de inteligência. Ora, para compensar esta distância entre o verdadeiro "eu" e a imagem projetada, ela apostava nas suas estratégias de auto-eficácia: o esforço, a dedicação e alta organização para enfrentar os desafios do conhecimento.

Neste caso, então, diferentemente do que escrevemos no parágrafo referente a primeira possibilidade, acreditamos que Em possuia estratégias de auto-eficácia permitindo-a movimentar-se em torno dos atributos que dominava, constituindo um auto-conceito sobre si mesma que lhe garantia razoável segurança para enfrentar os desafios. No mesmo sentido, somava-se a esta sensação de segurança o fato deEn ter a crença básica de que as conquistas com esforço e sacrifício são laureadas com maior valor e mérito. Desta forma, apesar não se sentir possuidora de um alto cociente de 
inteligência, Em apelava para suas estratégias de auto-eficácia baseadas no esforço, dedicação e organização como comportamentos capazes de evitar que se desesperasse, escapando da conduta típica dos sujeitos orientados ao desamparo. Isto posto, estamos mais afinados com a segunda interpretação, entretanto não podemos descartar a possibilidade da ocorrência da primeira na qual ela poderia ser capturada pelo sentimento de desamparo, caso uma tarefa escolar exigisse conhecimentos ou esforços muito aquém daqueles que ela pudesse empreender. Logo, para En deveria haver uma razoável linearidade e equilíbrio no comportamento entre aceitar o desafio e responder com esforços, dedicação e organização.

Durante a análise, En demonstrou o desejo de ser guiado de forma segura pelo ilusório caminho linear do conhecimento. Sendo assim, acreditava que o bom professor seria aquele capaz de explicar bem o conteúdo impedindo-a de se sentir perdida ou confusa; portanto tendia a vincular seu êxito a atuação do professor demonstrando certa dependência. Em seu relato, ela pareceu estabelecer relaçõespositivas com seus professores, inclusive levando-se em consideração as relações de carinho e afeto, já que nas séries iniciais as aulas eram ministradas por seus parentes. Acreditamos que seu ressentimento revelava que se fosse dotada de um alto cabedal de inteligência poderia corresponder aos altos padrões exigidos pelos professores, logo, poderia se constituir um objeto de grande estima. Assim, para compensar o nível de inteligência dentro do normal, ela adornou a si mesma com virtudes, tais como: esforço, dedicação e organização. Inclusive utilizava o esforço e a dedicação como critério para escolher os integrantes do seu grupo. Logo, como En estabelecia relações interpessoais com o propósito de se esforçar de forma solidária para realizar as tarefas escolares, acreditamos que buscasse nas relações sentimentos de segurança e afeto, levando-nos a concluir que estabelecia suas relações em torno do calor humano, aproximando-a da necessidade de Intimidade. Levando-se em consideração nosso diário de campo e o nível de dedicação, esforço e organização da aluna, temos a forte impressão de que ela se considerava um líder responsável pela organização do trabalho, distribuindo tarefas, monitorando e cuidando conjuntamente para a execução das atividades como um todo.

Em relação a uma possível ecologia conceitual,En citou que preferia lutar e enfrentar os desafios impostos pela vida a ter que desistir; acreditava que esforço e organização eram atributos de valor a serem observados e desenvolvidos, logo, as 
conquistas assim obtidas seriam capazes de produzir orgulho e satisfação. Assim sendo, parece-nos que ela estabelecia uma rede de significados capazes de sustentá-la diante de estratégias de ensino baseadas no conflito cognitivo ou na ocasião de frustrações. Entretanto,En acreditava que o bom professor seria aquele que a conduziria pelo caminho linear do conhecimento; logo, podia ocorrer que ela se sentisse perdida e desamparada durante o processo, podendo assim apresentar déficits motivacionais.

Em suma, acreditamos que a aluna estava orientada à meta aprender. Possuia como auto-conceito a crença de que não era muito inteligente, mas compensava esta condição utilizando-se como estratégias de auto-eficácia para enfrentar os desafios o esforço, a dedicação e a organização. Acreditava que o bom professor a conduzirá por um caminho seguro em direção ao conhecimento; assim, a quantidade de esforço, dedicação e organização que pretendia depreender deveria ser harmoniosa em relação ao desafio proposto pelo profissional de ensino. En estabelecia suas relações grupais levando em consideração o esforço que seus aliados poderiam empreender solidariamente para realização da tarefa, aproximando-a da necessidade de Intimidade. Em relação a sua ecologia conceitual, En parecia poder suportar os reveses do conhecimento, entretanto, havia também a possibilidade dela sentir-se perdida, apresentando déficits motivacionais.

\subsection{Caracterização do Perfil Motivacional de Realização do Sujeito Des ${ }^{12}$}

Des, há época da pesquisa tinha vinte e cinco anos de idade, era solteiro e trabalhava como limpador de vidros. O sujeito pretendiar obter o diploma para desenvolver-se profissionalmente, portanto, realizava as tarefas com interesse, contudo, considerava-se tímido e acreditava que o companheirismo com os demais membros do grupo o ajudaria a enfrentar os desafios da aprendizagem.

\subsection{Resultados da Análise dos dados da Entrevista de Validação do Perfil}

\section{Motivacional de Realização do Sujeito - Des}

\section{“[...]E: Então, (o grupo) eles é que estão me ajudando a tirar essa timidez...." "13.}

\footnotetext{
${ }^{12}$ O Questionário de Acesso às Metas de Realização do sujeito Des e a respectiva análise dos dados obtidos pela entrevista de Acesso ao Perfil de Realização encontram-se na seção (Apêndice - Segunda Fase).

${ }^{13}$ Trecho modificado, trecho original: E: Então, eles é que estão me ajudando a tirar essa timidez(Apêndice, Trecho 12)
} 
O aluno em questão parecia não apresentar níveis preocupantes de ansiedade em relação ao seu sucesso escolar. Não estava preocupado em evitar que os outros soubessem de suas falhas; pelo contrário, responsabilizava-se em tirar sua dúvidas com o professor ou com os colegas. Caso obtivesse notas baixas apostava no esforço para o êxito escolar, principal crença dos alunos orientados à meta aprender. Sendo assim, acreditamos que o sujeito estava orientado à meta aprender.

Des, de um modo geral valorizava o conhecimento, inclusive parecia querer estabelecer relações entre o conhecimento e a realidade que o cercava. Ele parecia apreciar os momentos em que a concentração podia proporcionar-lhe algum insight nas atividades em que possuia real interesse:“você já vai com corpo e alma e vai fazer”.

Portanto, é provável que Des ao longo de sua trajetória escolar tenha relacionado êxito escolar a esforço, concentração e raciocínio como principais estratégias de auto-eficácia. Assim sendo, este senso de auto-eficácia impactava positivamente em seu auto-conceito fazendo-o sentir-se com atributos intelectuais capazes de solucionar os desafios acadêmicos. Isto posto, estas auto-avaliações permitiam ao sujeito direcionar energia para a concentração e o raciocínio mantendo-o minimamente seguro e tranquilo para enfrentar os desafios ou a ameaça de iminente fracasso através da realização de ações pertinentes ao controle da situação e a execução do desafio, afastando-o do desamparo.

Em relação às relações interpessoais,Des relatou um episódio no qual sentiu-se preterido por sua professora do primário; este evento foi forte o suficiente para produzir o abandono escolar, portanto, pode ter contribuído,ao menos em parte, para sua timidez. Contudo, este evento não parecia ter produzido grandes efeitos na sua história escolar, pois após este evento nunca repetiu uma classe e sempre obteve boas menções escolares. Apesar das grandes dificuldades de acesso para estudar ele parecia lembrar-se saudosamente do envolvimento com seus colegas de classe. Assim sendo, acreditamos que Des carregasse boas recordações em relação ao seu cotidiano escolar vivido em sua infância. Durante a experiência, as intensas relações interpessoais vividas em seu grupo proporcionavam segurança e afeto capazes de blindar o aluno quanto a sentimentos de solidão, fortalecendo-o para também vencer o que acreditava ser uma falha, sua timidez. Assim sendo, acreditamos que ele tenha estabelecido suas relações, principalmente como atual grupo, em torno da existência do calor humano aproximando-o da necessidade de intimidade. 
Em suma, Des apresentava muitos indicadores da orientação à meta aprender. Suas auto-avaliações de auto-eficácia e o seu auto-conceito estavam relacionados a esforço, concentração e raciocínio, sendo capazes de garantir ao sujeito segurança e tranquilidade, afastando-o da sensação de desamparo. Des apostava nas relações interpessoais, no trabalho solidário para solucionar os problemas acadêmicos, destaque em especial para o atual grupo, pois Des acreditava que seus colegas podiam ajudá-lo a solucionar sua timidez. Assim Des aproximava-se de ser motivado pela necessidade de intimidade. Sua ecologia conceitual era razoavelmente forte para ele enfrentar as vicissitudes do conhecimento, com especial incremento relacionado aos fortes laços de amizade proporcionados por seu grupo, fazendo-o sentir-se forte o suficiente para suportar os reveses inerentes ao conhecimento, produzidos pelo fracasso ou pelo conflito cognitivo.

\subsection{Análise dos dados da Entrevista de Acesso a Percepção Motivacional: Au, Ga e En e Des.}

$\mathrm{Na}$ faseprecedente nos levantamos os perfis de realização dos sujeitos pesquisados. Eles realizaram a atividade de aprendizagem que utilizava como estratégia o conflito cognitivo. Agora, resta analisarmos os dados obtidos pela entrevista de Acesso a Percepção Motivacional dos sujeitos.

Os dados a seguir foram coletados após a realização da atividade experimental. O pesquisador buscava captar a percepção motivacional do sujeito após o término da atividade. Antes de iniciarmos a entrevista tomamos o cuidado de enfatizar para o sujeito, que o mesmo não estaria sendo avaliado, portanto, não receberia qualquer nota por sua participação. Preocupou-nos também, a possibilidade deles encararem a entrevista como uma espécie de chamada oral, o que poderia contribuir com o aumento da ansiedade. Portanto tomamos o cuidado de não os inquirir com o propósito de saber o quanto conseguiram ou não aprender. Gostaríamos também de ressaltar que não estávamos preocupados em saber se os sujeitos evoluíram ou não em suas concepções espontâneas sobre o calor. Afinal, nosso principal objetivo foi captar a impressão motivacional vivenciada pelo sujeito, após ter realizado a atividade. Agora, procuraremos estabelecer se existia alguma relação entre estas impressões e o perfil de realização do sujeito. Queríamos saber se os alunos orientados a meta aprender sentiram-se motivados, pois encararam o conflito cognitivo como um desafio capaz de 
fazê-los empreender esforço e dedicação; por outro lado, àqueles orientados à meta performance vivenciaram o conflito como uma ameaça, sentindo-se incapazes de responder ao desafio.

Devemos ter em mente, conforme análise do questionário da atividade experimental, que esta proporciona aos alunos a interação entre quatro objetos, são eles, as três colheres: metal, madeira, alumínio, de um lado, e o corpo humano sensível, de outro. A dificuldade dos alunos estava em perceber que seu corpo sensível era um objeto em constante interação com o ambiente e os demais objetos. Portanto, a inconsciência relativa às diversas trocas de energia - no caso o calor entre o corpo humano, os objetos e o ambiente - poderia confundir os sujeitos fazendo-os elaborar suas concepções espontâneas. Por exemplo, muitos alunos não sabem que a temperatura normal interna do corpo humano é de $36^{\circ} \mathrm{C}$ (Celsius), portanto o corpo tende a ceder calor para o ambiente e para os objetos em contado. Logo, se a colher traz a sensação de que é mais fria é porque o corpo humano com temperatura mais elevada está cedendo calor para o objeto que está à temperatura ambiente. Por outro lado, os alunos elaboram de forma espontânea a concepção de que a colher de metal é fria, pois ser "frio" é uma qualidade inerente, afinal trata-se de um metal. Logo, o alumínio transfere o "frio" para o corpo humano.

No mesmo sentido, outra concepção bastante arraigada é a de que os corpos ao invés de trocar energia, na forma de calor, trocam temperatura. Esta concepção espontânea surge, pois os alunos ao observarem que um corpo com maior temperatura (mais quente) quando em contado com corpo com menor temperatura (mais frio) aquele diminui sua temperatura, enquanto que a temperatura desse aumenta são levados a acreditar que os corpos trocaram a temperatura. Contudo, basta observarmos que durante a mudança de estado os corpos trocam energia, entretanto mantém a mesma temperatura.

\section{1 - Análise dos Dados da Entrevista de Acesso à Percepção Motivacional de Au}

1 - P: Bom, Au eu gostaria de saber o que você achou da atividade?

E: Boa

P: Assim que partes, você achou assim, pode ser sincero, você achou chata?

E: Não, achei interessante, interessante

2 - P: Você sabe me dizer que perguntas que provocaram mais interesse? 
E: Deixa eu vê, foi essa aqui: qual temperatura do seu corpo e qual a temperatura das colheres? Qual delas é maior? A do seu corpo ou das colheres, por quê? Essa eu achei interessante porque a gente pega as colher e muita gente acha, ah..., eu estou esquentando, apesar você está passando sua temperatura do corpo para a colher, a energia.

No início da entrevista, foi entregue para o sujeito o questionário relativo à atividade experimental para que ele recordasse quais perguntas achou interessante. $\mathrm{O}$ sujeito então começou a ler as perguntas e em seguida afirmou achar interessante o fato de as pessoas terem como concepção a crença de que o corpo humano aquece os objetos. Explicou, afirmando que este aquecimento ocorre, pois o corpo humano passava temperatura ou energia para o corpo.

O sujeito $\mathrm{Au}$, em acordo com esta concepção espontânea, misturava ao mesmo tempo a concepção espontânea e o conhecimento científico ao afirmar que o corpo estava passando temperatura ou energia para a colher. Ou seja, o conceito de temperatura não se distinguia do conceito de calor, confusão comum que, de qualquer forma, representava um avanço, pois o sujeito reconheceu que o corpo transferia algo para os objetos.

3 - P: A temperatura ou energia?

E: A energia, ta...

$\mathrm{P}: \mathrm{Ah}$, tá

E: Entendeu

P: E você tem algum outra que foi interessante também?

E: A sensação...

$\mathrm{P}:$ A questão da sensação né?

$E: \dot{E} \ldots$

Nesta pergunta, o pesquisador cedeu lugar ao professor e este pretendia saber se $\mathrm{Au}$ entendeu o conceito e voltou a questioná-lo se o que era cedido era energia ou temperatura. O sujeito pareceu responder sem muita convicção, porém a dúvida só poderia surtir efeito se o sujeito se sentisse motivado em solucioná-la.

4 - P: E alguma questão provocou confusão, deixou vocês confusos, na hora de fazer ?

E: Ah, várias porque a colher de madeira parece ser mais quente do que a de alumínio?

Deixou a gente confuso.

P: Essa pergunta é ruim

E: Não, não é que é ruim, assim porque a gente olha e achava que tá tudo a temperatura ambiente

P: Certo 
E: Só que não tem como você sabe assim, de olhando assim de fato quem esta pegando mais energia

P: Se ia acha

E: Se é a madeira

P: Ah...

E: ou alumínio, entendeu

P: Então, isso causa uma confusão, isso é interessante não

E: Interessante

Neste trecho, o pesquisador utilizou propositadamente a palavra confusão, pois o conflito cognitivo não é sentido somente como um desafio, ou seja, responder algo que não se sabe. O conflito cognitivo, neste caso, trazia para o sujeito a sensação de confusão, de que o sujeito estava perdido, pois o mesmo julgava saber algo sobre realidade, mas sua crença estava fracassando, pois ele constatava estupefato de que as colheres estavam todas à temperatura ambiente.

Ora, devemos enfatizar esta condição, pois no início da atividade os sujeitos preencheram o quadro constatando a diferença das sensações térmicas. Em seguida, logo foram questionados sobre qual o valor da temperatura das colheres, porém não sugeriram a temperatura ambiente. Para instigá-los, o professor pediu para os alunos lerem o texto de apoio (Frio...Calor...Suor) que tratava das reações do corpo com o meio ambiente. Depois da leitura, o professor colocou as seguintes perguntas:

1- Alguém esta esquentando as colheres?

2- Alguém esta esfriando as colheres?

3- As colheres estão em cima da mesa, na sala de aula e isto tudo é o que? Elas estão expostas ao que?

Alguns alunos perceberam a intenção do professor e responderam que o valor da temperatura das colheres é o mesmo valor da temperatura do meio ambiente sugerindo um valor qualitativo para a temperatura ambiente daquele dia. Em anos anteriores, ao aplicar esta atividade, apesar dos alunos concluírem desde o início que as colheres tinham a mesma temperatura, nunca alguém questionou o porquê das sensações diferentes. Eles simplesmente não reconheciam a contradição entre a afirmação inicial e a crença de que as colheres tivessem temperaturas diferentes, na medida em que produziam variadas sensações térmicas. Em particular, a colher de alumínio que produzia a sensação de estar mais fria que as demais, logo era considerada como tendo sua temperatura menor. 
Assim sendo, somente na questão 7 os alunos foram levados a entrar em contato com a contradição, portanto é natural que se sentissem confusos ou mesmo perdidos. Afinal suas concepções, construídas espontaneamente durantes anos em suas experiências cotidianas, de que um corpo que produz a sensação térmica de estar mais frio, no caso, a colher de alumínio, necessariamente, deveria estar a uma temperatura mais baixa em relação a outro corpo que proporcionasse a sensação de estar "mais quente" ou "morno" como é o caso da madeira. Entretanto, esta crença fracassava fragorosamente frente a uma simples experiência crucial bem elaborada.

Isto posto, talvez $\mathrm{Au}$ tenha concluído o primeiro passo sugerido pelo modelo de mudança conceitual, ou seja, sentir-se insatisfeito com o conhecimento prévio. No caso, esta insatisfação era percebida como confusão: Ah, várias porque a colher de madeira parece ser mais quente do que a de alumínio? Deixou a gente confuso.

Obviamente, o sujeito ou o grupo não tinham condições de resolverem este impasse sozinhos, portanto recorreram ao professor. O professor ao invés de responder diretamente, formulou as seguintes perguntas buscando a reflexão dos alunos:

1- Quando você sente frio, você perde o que para o ambiente? (questão número -2 do questionário)

2- Quando você sente calor, você ganha o que do ambiente? (questão número -3 do questionário)

3- Logo, você só perde ou ganha o que do ambiente? É possível ganhar ou perder frio?

As respostas podiam ser obtidas lendo-se o texto de apoio (Frio...Calor...Suor...) permitindo ao aluno concluir que o corpo humano troca calor ao entrar em contato com os corpos e com o ambiente a sua volta. O professor propositadamente ao por aos alunos as questões 2 e 3 pretendia monitorar o real entendimento dos alunos sobre as trocas de energia do corpo humano com o meio ambiente. Ao concluírem sobre as perdas ou ganho de calor, o professor pediu para os alunos olharem a tabela de condutividade térmica e compararem os valores do alumínio $\left(49 \times 10^{-3}\right)$ e da madeira $\left(0,02 \times 10^{-3}\right)$. Após, constatarem as diferenças, antes de qualquer explicação, o professor perguntou: O que significa condutividade? Os alunos não conseguiram responder. $\mathrm{O}$ professor então refez a pergunta em outros termos: A palavra condutividade faz lembrar o que? Vocês concordam que condutividade tem a ver com conduzir alguma coisa? Enfim, os alunos foram levados a concluir que a o termo condutividade significava a condução de algo, no caso, energia, mais precisamente o calor. Logo, o alumínio com 
coeficiente de condutividade de 49 conduzia mais efetivamente o calor quando comparado à madeira com coeficiente de condutividade de 0,02 .

Isto posto, este raciocínio podia permitir aos alunos entenderam as diferentes sensações térmicas produzidas pelas diversas colheres. Pois, apesar de estarem à mesma temperatura, a colher de alumínio "roubava" energia mais rapidamente, ou seja, conduzia mais calor quando em contato com a mão; por outro lado, a colher de madeira "roubava" menos, ou conduzia efetivamente menos calor transmitindo a sensação de que esta mais "quente" ou "morna".

Nesse sentido, Au pareceu concluir em direção ao conhecimento científico: "Só que não tem como você saber assim, de olhando assim de fato quem esta pegando mais energia". Portanto, ele transformou as diversas informações existentes na atividade em conhecimento capaz de permitir-lhe explicar os resultados anômalos, ao concluir que os corpos trocam energia de forma diferente, ou nas palavras do sujeito, "quem esta pegando mais energia”. Isto posto, temos a impressão de que o sujeito trilhou o segundo passo relativo ao Modelo de Mudança Conceitual, ou seja, o da inteligibilidade, pois devemos considerar que o conceito fez sentido para ele, pois possibilitou-lhe entender porquê as colheres mesmo estando a mesma temperatura produzem sensações térmicas diferentes.

Isto posto, talvez a explicação também podia parecer plausível, pois seus conhecimentos não foram rechaçados totalmente. Afinal suas sensações térmicas ainda podiam ser consideradas válidas, mesmo significando que um objeto que transmita a sensação de estar mais "frio" não necessariamente deve estar com temperatura mais baixa em comparação com outros objetos de materiais diferentes. De fato, corpos do mesmo material estando a temperaturas diferentes produziriam sensações térmicas diferentes e de acordo com a lógica do conhecimento prévio. Portanto, o novo conceito podia tornar-se plausível na medida em que mantinha, neste caso particular, parte das ideias do sujeito para explicar alguns fenômenos.

Antes de continuarmos, devemos ressaltar que não pretendemos nesta pesquisa estabelecer uma relação biunívoca entre o Modelo de Mudança Conceitual e as reações motivacionais dos sujeitos. Pois, estamos interessados especificamente nas reações motivacionais apresentadas pelos sujeitos, após a realização de uma atividade de ensino de física baseadas nos conceitos sócio-construtivistas.

Sendo assim, nós não podemos afirmar categoricamente que o sujeito sentiu-se em conflito, pois não sabemos sobre suas concepções previas. Entretanto, é razoável 
sabermos que o sujeito estabeleceu uma relação de significado entre aquilo que julgava saber, representado pelas suas concepções previas, e o novo conhecimento que elaborou para justificar os dados anômalos em uma experiência crucial. Ambos, conhecimentos prévios e científicos apresentavam alguma ressonância com seu perfil motivacional.

5 - P: O que você achou de aprender essas coisas assim?

E: É bom porque agora, eu sei que, por exemplo, no dia a dia, você já sabendo a teoria como aprendeu, você já sabe por que você tá sentindo frio ou calor demais entendeu agora você tem mais noção [P: hum]

E: Você tá perdendo energia pro ambiente, tá recebendo

P: Mas isso você vai usa assim na sua vida assim?

E: Acho que usa, usa sim

P: Você acaba entendendo como é que funciona né?

E: Eu acho que eu entendi direito agora, ficou bem interessante, achei bem interessante por causa disso, porque é coisas que muitas pessoas, as pessoas também não sabe e você também pode passa

P: Passa pras pessoas né?

E: Isso, porque tem muita gente que fica em dúvida também

P: Você acaba tendo um conhecimento?

E: Isso, você pode passa pra outras pessoas.

P: Isso dá uma sensação assim, como assim?

E: Ah, de aprendizado muito bom.

Nestes trechos, o sujeito considerou diversos aspectos relevantes:

1. O sujeito enxergou a possibilidade de explicar seu cotidiano;

2. Este conhecimento permitiu-lhe explicar outras situações como as sensações de frio e calor fora do contexto específico, ou seja, da atividade experimental;

3. Em nenhum momento da atividade, falou-se sobre alguma teoria específica, entretanto o sujeito parecia concluir que as diversas informações eram capazes de se constituírem em uma teoria com caráter explanatório;

Contudo, devemos olhar estes resultados com extrema cautela. Pois, em relação ao primeiro aspecto relevante, o sujeito estabeleceu apenas uma relação entre o novo conhecimento e seu cotidiano, portanto, deveríamos ter proposto a Au outras situações cotidianas para garantirmos que ele tivesse se apropriado deste conhecimento. No mesmo sentido, devemos ressaltar que o próprio texto de apoio (Frio, Calor, Suor) estabelecia relações entre a perda ou o ganho de calor produzidas nas interações com o 
meio ambiente e suas respectivas sensações térmicas, portanto, talvez o sujeito estivessse apenas repetindo a informação presente neste texto.

Entretanto, devemos também considerar que o simples fato de Au citar estas conexões estabelecendo relação explanatória com a experiência específica, pode sinalizar que este aprendizado foi minimamente significativo para o sujeito. Sendo assim, talvez o novo conceito tenha alcançado o requisito de fertilidade proposto pelo MM C, pois Au acreditava possuir agora uma teoria capaz de lhe explicar fatos de seu cotidiano diversos da experiência específica.

Em relação ao terceiro aspecto relevante, devemos considerar que em nenhum momento antes, ou durante a atividade foram discutidos aspectos teóricos capazes de elucidar a experiência crucial. Ou seja, o próprio sujeito ao se deparar com resultados anômalos produzidos por uma experiência crucial, vivenciou-os na forma do conflito cognitivo ou descritos pelo conceito de insatisfação. Sensações estas, traduzidas por Au como sentimentos de "confusão" (conforme trecho $n^{\circ} 4$ desta entrevista). Portanto, Au parecia ter assimilado-acomodado um conhecimento melhor capaz de fazê-lo entender os resultados anômalos devolvendo-o a condição de equilíbrio anterior e dirimindo sua sensação de insatisfação produzida por seus conhecimentos espontâneos.

Obviamente, que estes dados não nos permitem garantir sobre alguma mudança conceitual de fato, muito menos dizer algo sobre a profundidade desta possível mudança. Entretanto, Au olhou o processo que vivenciou avaliando as informações que recebeu para solucionar um problema específico e concluiu (grifo nosso): "você já sabendo a teoria como aprendeu, você já sabe por que você tá sentindo frio ou calor demais entendeu".Portanto, entendemos como bastante importante o fato dele acreditar possuir uma nova teoria mais robusta em detrimento do conhecimento prévio.

Sendo assim, estamos conscientes de possuirmos apenas indícios, seja de que Au alcançou um conhecimento melhor, seja de que satisfez as condiçõespropostas pelo MMC, na perspectiva de evoluir suas concepções em direção ao conhecimento científico. Por outro lado, independentemente destes processos terem-se efetivado ou não, consideramos de suma importância o fato deleter considerado a atividade experimental como sendo capaz de atender a certos aspectos presentes em suas expectativas reveladas em seu perfil motivacional, figurando como ponto alto destas expectativas o encontro com uma teoria científica.

Nesse sentido, devemos recordar que o sujeito Au adornava a ciência como um ramo de conhecimento muito especial. Au atribuiu à ciência, graças ao método 
científico, a prerrogativa em estabelecer a verdade e consequentemente de garantir a justiça dos julgamentos em detrimento, por exemplo, da religião. Sendo assim, parece razoável acreditar que ele apresentava certa tendência em aprender o novo conhecimento, principalmente se considerarmos a possibilidades deste permitir-lhe estabelecer a verdade ao entender o que realmente ocorre relativo às diversas impressões térmicas, muitas delas, contraditórias.

Portanto, se anteriormente, havia a confusão produzida pelo seu conhecimento prévio, se a realidade era turva, agora, o novo conhecimento chancelado, conforme suas concepções, de conhecimento "científico", seria capaz de lançar luzes dissipando as nuvens da confusão, permitindo o julgamento preciso, claro, límpido da natureza das sensações térmicas.

Ou seja, trata-se da ecologia conceitual de Au e seus pactos metafísicos. Para tanto, imaginemos o contrário, ou seja,que um conhecimento qualquer, diferente do conhecimento científico, fosse melhor sucedido em comparação com o científico em explicar algum fenômeno. Ora, esta possibilidade entraria em choque com os compromissos epistemológicos e metafísicos de $\mathrm{Au}$, pois afinal este acreditava que o método cientifico era capaz de garantir verdade às teorias. Logo, o novo conhecimento representaria um senão, provavelmente seria um obstáculo epistemológico de tal ordem impactando fortemente a inteligibilidade e a plausibilidade do novo conhecimento na medida em que esta novidade rechaçaria as convicções mais intimas do Au responsáveis por garantir a coesão da sua visão de mundo. Este senão, então, seria um potente desarticulador da psique do sujeito fazendo-o entrar em contato com suas concepções sobre ciência e seus pactos em torno deste ramo de conhecimento.

Antes de continuarmos, cabe uma nota sobre a possibilidade da existência de diversos níveis de conflito cognitivo e a possibilidade destes causarem impacto sobre a psique de um sujeito com consequências destrutivas em relação à motivação do sujeito. Estes níveis de conflito cognitivo devem se ligar dinâmica e estritamente à mente do sujeito (ecologia conceitual) que vão desde seus conhecimentos alternativos até sua cosmovisão. Talvez por esta razão alguns tipos de conhecimentos exijam, na maioria das vezes, um envolvimento íntimo (afetividade) do sujeito.

Isto posto, em se tratando de $\mathrm{Au}$, podemos aceitar com certa naturalidade a facilidade, ou mesmo o excesso de "boa vontade" com o qual ele aderiu ao novo 
conhecimento, pois este conhecimento carregava inerentemente a qualidade de conhecimento verdadeiro, logo, o sujeito sentiu-se "obrigado" a absorver esta verdade, portanto, aceitar e aderir à verdade científica estava em acordo com suas ideações sobre a superioridade do conhecimento científico.

Devemos também considerar a possibilidade de que esta superioridade possa ter provocado uma adesão acrítica ao novo conhecimento. Outro aspecto, que pode contribuir para este movimento,era que aderir ao novo conhecimento implicava estar afinado com o discurso do professor. Pois, durante a entrevista tivemos a nítida impressão de que $\mathrm{Au}$ parecia ter encontrado um interlocutor (professor-pesquisador) capaz de entender sua paixão pela ciência. Soma-se a esta impressão o discurso deste sujeito recuperado da entrevista de acesso ao perfil de realização sobre a figura do professor:

E: Ah... porque o professor ele é um sábio, vai passar o conhecimento dele para o aluno,... ai onde entra o aluno, respeita o professor, seguir os passos do professor, o ensinamento dele...

No mesmo sentido, ou seja, no tocante ao interesse, devemos também considerar a possibilidade de que o aluno foi capturado exatamente pela experiência ter-lhe proporcionado a elaboração de um novo conhecimento inerentemente contraditório ao senso comum. E, que a "contradição" tenha contribuído ainda mais para seduzir o interesse $\mathrm{Au}$, pois confirmava suas crenças metafísicas sobre a superioridade desta área de conhecimento em detrimento do senso comum.

Contudo, será que seu perfil motivacional harmoniza-se somente com sua tendência a aceitar o novo conhecimento? O que dizer sobre a experiência em si que lhe imprimiu a sensação de confusão? Durante a entrevista para estabelecer o perfil motivacional, houve recordação da experiência com o gerador Van der Graff, que foi considerada suficiente não só para imprimir no sujeito o desejo de aprender ciência, como também para escolher ser eletricista. Esta experiência foi impactante, nela podemos enxergar o medo da máquina desconhecida sendo transformado no deslumbre do sujeito; minutos eternos de medo e coragem antes de se tocar a bola eletrizada; formigamento ascendente pelos braços arrepiando os cabelos. Podemos imaginar sua surpresa, seu fascínio, sua curiosidade em entender como algo produzido pelo conhecimento humano poderia produzir tal efeito, despertando o desejo de se apoderar deste conhecimento. Contudo, este deslumbre, esta fascinação, este desejo produzidos 
pelo encontro com a bola eletrizada, estão longe de ser confundidos com o sentimento de confusão impressos pela experiência crucial realizada pelo sujeito.

Entretanto, devemos considerar que a experiência crucial também surpreendeu o sujeito ao contradizer o conhecimento de senso comum. Podemos também considerar que o germe da confusão também aguçou a curiosidade de Au em busca do novo conhecimento. Este novo conhecimento também demonstrou seu poder ao explicar outras situações do cotidiano confirmando a superioridade da ciência em relação aos outros conhecimentos e tornando-a objeto de grande valor. Ora, a situação, obviamente, não foi idêntica, mas trazia uma semelhança com traços do passado, que se repetiam nesta mesma e inédita experiência.A reminiscência do desejo de se descobrir algo que ao mesmo tempo assombrava e fascinava. A experiência crucial trazia um ínfimo da lembrança de seu encontro com a bola eletrizada, mas o suficiente para fazê-lo desejar e reafirmar a sua crença na relevância do novo conhecimento. Mesmo sonho, mesmo acidente que vem capturando o desejo de parte daqueles que pretendem trilhar o caminho científico ${ }^{14}$.

Voltando ao trecho da entrevista, o sujeito afirmou que poderiaexplicar às pessoas como são transmitidas as sensações de "frio" e "calor", e, como estas sensações podem ser confusas. Ora, este desejo altruísta de levar a verdade científica aos quatro cantos confirmava o alto valor atribuído por $\mathrm{Au}$ a este ramo de conhecimento. Esta vontade estava em acordo com seu perfil de realização, pois em seu discurso mostrava estar preocupado com a "verdade" e a "justiça", e, em sua cosmovisão a ciência era uma area do conhecimento que gozava destes atributos, agora ele também poderia ser um dos arautos do novo evangelho levando luz onde existissemas trevas da confusão. Portanto,este novo conhecimento tornou-se um objeto especialíssimo que podia ser confundido com a própria personalidade do sujeito que considerava a verdade e a justiça como algo de grande valor.

Não obstante, também devemos considerar a possibilidade de ao invés do nobre sentimento de altruísmo estarmos diante da auto-contemplação do Au, considerando de que saber algo de grande valor pudesse servir para distinguir as pessoas, portanto saber sobre ciência o tornaria melhor do que os demais, logo ele seria superior como também seria superior o conhecimento científico. Contudo, apesar desta possibilidade estamos

\footnotetext{
${ }^{14}$ Os dois últimos parágrafos não devem ser entendidos de forma concreta. Pois, estamos falando de aspectos imaginários, epistemológicos e metafísicos presentes no discurso do sujeito.
} 
mais afinados com a primeira possibilidade apresentada acima exatamente pelos sentimentos altruístas demonstrados na análise do perfil de realização ${ }^{15}$.

6 - P: A em relação (ao tempo), nós ficamos duas aulas e meia, depois mais duas aulas

E: Duas aulas

P: O que você achou do tempo? Você achou que o tempo demorou muito pra passar?

Como é que você sentiu o tempo?

E: Eu na minha opinião passou até rápido

P: Passou rápido

$E: \dot{E}$, porque a gente fica entretido, procurando a melhor forma de responder, a hora passa rápido

P: Passa rápido

E: Na nossa mente, passa rápido

$\mathrm{P}$ : Você não percebe a hora passar né

E: Isso

7 - P: Qual a diferença por exemplo,....qual a diferença que você assim (experimenta) entre outras matérias, ...., qual a diferença desta atividade para outras matérias, por exemplo, outros tipos de aula que você tem, você tem aulas de matemática, química qual a diferença que você vê nesse tipo de metodologia?

E: A única diferença foi mais entretenimento

P: Como assim entretenimento?

E: É mais focado né, mais um foco só, que nem essa matéria aqui foi pra saber energia, calor, foi mais focado

Antes de iniciarmos a análise, devemos deixar claro que toda a atividade necessita em média de quatro a cinco aulas de cinquenta minutos para ser efetivada, as aulas não precisam ser ininterruptas. A primeira aula é utilizada para os alunos copiarem as questões. Na segunda e terceira aulas se inicia a realização da atividade, os quinze minutos iniciais da segunda aula são necessários para o professor ordenar os grupos de alunos e explicar a realização da mesma. A quarta e quinta aulas são destinadas a correção e as respectivas explicações feitas pelo professor envolvendo as trocas de calor e suas relações com o corpo humano e o meio ambiente.

IA atividade realizada pelo grupo de Au durou além das duas aulas ininterruptas de cinquenta minutos, pois avançou sobre parte do intervalo destinado ao lanche dos alunos. Esclarecemos, ainda, não ter sido requisitado ao grupo de $\mathrm{Au}$, nem aos demais grupos de alunos a continuação da realização da atividade além do horário das duas aulas, pois a atividade seria retomada na aula seguinte. Portanto, somente aqueles desejosos de terminarem os trabalhos continuaram presentes em sala de aula, os demais se dirigiram normalmente para o pátio da escola.

\footnotetext{
${ }^{15}$ Atenção: não se trata aqui de um julgamento de valor, apenas estamos chamando atenção para aspectos presentes no discurso do sujeito capazes de fazê-lo considerar esta área do conhecimento importante.
} 
Nos oito anos em que aplicamos esta atividade, temos nos deparado com grupos de alunos que demonstravam envolverem-se ativamente na realização da tarefa. Um dos termômetros, percebidos por nós, desta condição tem sido o fato de que, mesmo após, o toque do sinal indicando o encerramento da aula, alguns grupos demonstravam o desejo de continuar realizando a atividade ou de discutirem os resultados. Portanto, o sentimento relatado pelo aluno sobre a não percepção da passagem do tempo não nos causou surpresa. Acreditamos que este fenômeno esteja ligado a níveis de motivação intrínseca do sujeito durante a realização da atividade, poisdevido ao alto nível de concentração, ele apresentava uma percepção alterada da passagem do tempo.

Este envolvimento ativo relatado pelo sujeito produzido por um alto nível de concentração está amplamente descrito pelas pesquisas que trabalham com a metodologia sócio-construtivista; acreditamos que este é um dos principais objetivos desta metodologia. Nesse sentido, uma das estratégias utilizadas para produzir este tipo de engajamento, conforme referencial teórico, é o conflito cognitivo ou alguma insatisfação, pois estes são capazes de produzir a motivação intrínseca, na medida em que o sujeito ao vivenciar uma experiência crucial em que sua lógica fracassa, se sentiria em desequilíbrio, ou insatisfeito nos termos do M. M. C. Esta condição produziria a auto-determinação necessária para o sujeito buscar o conhecimento capaz de promover o retorno à sua condição de equilíbrio anterior. Portanto, a urgência em restabelecer sua capacidade de organizar a experiência, de interpretá-la, torna-se a necessidade capaz de direcionar os esforços liberando a energia do sujeito em busca de uma equilibração de melhor qualidade e alcance. Ou, pelo menos, para promover a evolução conceitual ao satisfazer as outras três condições básicas pertinentes ao MMC.

A bem da verdade, nós não temos condições de garantir se o mecanismo cognitivo-afetivo piagetiano se efetivou ou mesmo se o sujeito trilhou algumas das condições referentes ao MMC. Entretanto, Au relatou na resposta a pergunta número quatro desta entrevista de que sentiu-se confuso, e, esta confusão coincidia com o conflito cognitivo ou com o sentimento de insatisfação relativo as ideias prévias do sujeito. Assim, não podemos corroborar se o sujeito elaborou um conhecimento efetivamente melhor ou se suas concepções evoluíram, apesar de considerarmos importante seu relato na pergunta número cinco desta entrevista, no qual, ele afirmou acreditar que os conhecimentos produzidos durante a realização da atividade solucionaram não só a atividade em "si", mas também, lhe permitiram entender alguns fenômenos do seu cotidiano. 
$\mathrm{Au}$ tinha tendência em se motivar intrinsecamente, mostrando um comportamento concentrado ao realizar as tarefas e demonstrando valorizar de um modo geral a aprendizagem, e, mais especificamente a aprendizagem de ciências. Portanto, esta é uma característica do perfil de realização deste sujeito, logo não podemos garantir que a atividade exclusivamente produziu tal fenômeno.

Contudo, podemos conjecturar que talvez tenha ocorrido uma somatória de diversas possibilidades culminando com o alto nível de adesão do sujeito a atividade. Ou seja, a atividade tornou-se interessante, pois o conflito cognitivo ou a insatisfação despertaram a necessidade de ele ir em busca ao novo conhecimento.

Entretanto, esta necessidade não é uma relação simples de causa e efeito produzida somente por um acidente singular diante da experiência crucial representada pela atividade. Talvez, esta necessidade venha a se somar as necessidades de segunda ordem. Pois, conforme já foi discutido, Au considera a ciência com um objeto de alto valor atribuindo a qualidade de justiça a este ramo de conhecimento. Ora, segundo Piaget um ato de vontade não pode ser confundido com o simples despender de energia, pois este está ligado a sentimentos morais autônomos, logo quando o sujeito vivenciou a insatisfação de seus conhecimentos, endereçou energia na forma de concentração para entender os resultados anômalos obtidos na experiência.

Por outro lado, o sujeito pode ter se sentido apto a dar conta do desafio, pois segundo à analise da entrevista do perfil de realização, concluímos que ele apresentava um auto-conceito bastante confiante sobre si mesmo acreditando ser bastante inteligente, principalmente para aprender ciências. Possivelmente, este alto conceito tenha sido robusto o suficiente para impedir que $\mathrm{Au}$ fosse atravessado por sentimentos de ansiedade diante de temas considerados difíceis, ou quando pressentisse ofracasso iminente. Alias, eledemonstrou ter certa predileção por situações desafiadoras utilizando como estratégias de auto-eficácia o esforço direcionado ao aumento do foco e da concentração. Logo, estas relações entre seu auto-conceito e suas estratégias de aprendizagem ligadas ao seu senso de auto-eficácia desenvolvidos por anos durante sua vida escolar e/ou profissional foram capazes de garantir não só a segurança necessária para realizar a atividade, como também, auxiliá-lo a conseguir êxito com as estratégias pertinentes. Nas palavras do sujeito, diante de situações desafiadoras ou diante do fracasso: "é mais motivo pra você "cafifâ" mais".

Em suma, é impossível destacar um único aspecto capaz de garantir o alto nível de comprometimento dispensado pelo sujeito ao realizar a atividade. Portanto, devemos 
considerar a influência de diversos fatores; nesse sentido, é possível que o conflito cognitivo tenha sido capaz de desequilibrar o sujeito fazendo-o direcionar suas energias em direção ao novo conhecimento. Obviamente, que este processo deve ter sido facilitado, pois o conhecimento científico era considerado como um objeto de grande valor, inclusive transferindo-lhe alguns de seus próprios valores: logo aprendê-lo significava uma questão de honra. Sem dúvida, seu auto-conceito e sua auto-eficácia garantiram a segurança e as estratégias necessárias para que o sujeito se sentisse confiante na medida em que optava por direcionar energia na forma do aumento do esforço na concentração para a realização dos desafios. Obviamente, de que parte do conjunto das ideias sobre a possibilidade de aprender de Au estavam de acordo com as crenças dos sujeitos orientados à meta aprender; no entanto, outras eram características únicas ligadas ao seu perfil.

8 - P: Porque assim, por exemplo, assim, não entendi, focada como, focada assim

E: Assim pra aprender, que nem nós ficou, bem dizer quatro aulas, só que nessas quatro aulas você tem vários tipos de respostas, entendeu, muitas de seus colegas, parceiros diferentes e a maioria se batendo na mesma, só que diferentes

P: hum, hum

E: Cada um ta na sua resposta

P: Isto gera um debate?

E: Um debate é bem melhor do que um responde só aquilo, aquilo sendo que têm várias opções também só que ninguém passa um pra outro nas outras matérias

P: Ahhh..., então você achou que essa interação do grupo e as respostas um

respondendo um e respondendo o outro é trocando as idéias (Falam juntos) é o que tornou mais interessante

$E: E$, mais interessante

$\mathrm{P}$ : a atividade

$\mathrm{Na}$ analise do trecho anterior, havíamos esclarecido que a realização da atividade pelo grupo de Au durou mais de duas aulas de cinquenta minutos. Portanto, as outras duas aulas de um total de cinco aulas referidas pelo sujeito foram destinadas à realização da correção e as respectivas explicações feitas pelo professor envolvendo as trocas de calor e suas relações com o corpo humano e o meio ambiente.

Um dos aspectos positivos sobre a realização da atividade, segundo Au foi o fato desta ter sido realizada em grupo. Esta perspectiva estava em acordo com seu relato na entrevista do perfil de realização:

Isto posto, as considerações do aluno vão ao encontro da importância do trabalho em grupo amplamente relatadas por inúmeras pesquisas que trabalham com os referenciais sócio-construtivas. Em relação ainda a este trecho, ocorreu uma 
peculiaridade que talvez possa impactar os conceitos de inteligibilidade, plausibilidade e fertilidade relativos ao MMC. Caso o sujeito realmente se concentrasse nas respostas dos outros integrantes do grupo: " muitas de seus colegas, parceiros diferentes e a maioria se batendo na mesma, só que diferentes" conforme seu relato, então, devemos considerar minimante que Au precisava direcionar a concentração para tornar inteligível a resposta do outro, mas sobretudo, ter clareza sobre seu próprio entendimento do assunto,impactando a inteligibilidade do conceito. Este movimento devia tornar mais plausível o novo conhecimento na medida em que ele se sentia obrigado a comparar as explicações fornecidas pelos sujeitos com suas próprias explicações. Em relação à última condição, ou seja, a fertilidade do novo conhecimento pode ter ocorrido devido ao surgimento de explicações ou exemplos de outros contextos, ou mesmo, o uso de metáforas, apesar destas serem raras devido ao nível de aprofundamento exigido para que um sujeito possa produzi-las.

Obviamente, que este movimento ocorreu graças às relações interpsicológicas transformando o conteúdo social exógeno em um conteúdo intrapsicológico para a reflexão do sujeito. Portanto, estes tateios realizados pelos sujeitos em torno da produção do conhecimento através da reflexão sobre as respostas dos outros sujeitos são típicas da atuação no espaço de desenvolvimento proximal, na medida em que os sujeitos dialogam tentando produzir um discurso próprio próximo do discurso científico indispensável para a solução do problema. Logo, a cognição antes distribuída entre os diversos integrantes do grupo (incluindo o professor), agora, podia ser situada dentro do sujeito como conhecimento elaborado.

Outra questão interessante, é que as reflexões sobre as respostas de outros integrantes do grupo podem contribuir para os mecanismos de assimilação e acomodação tornando-os harmoniosos à medida que o sujeito acolhe uma assertiva alheia e a compara com aquilo que produziu. Obviamente que estas podem ser conflitantes, mas de qualquer forma devem produzir melhor equilíbrio ao pensamento com enriquecimento da capacidade de argumentação do sujeito. Portanto, conforme referencial teórico, não é a realidade, ou o objeto que possa garantir um senão capaz de calibrar o julgamento entre duas proposições quaisquer, muito menos, a pressão do real para que o pensamento se constitua em uma necessidade lógica. Muito pelo contrário, é um reflexiornar-se sobre si mesmo que permitirá ao pensamento inferir se um conjunto de proposições tem maior ou menor poder de generalização conforme referencial teórico. 
9 - P: Você preferia, por exemplo assim que eu explicava na lousa, porque ai, quero dizer: "A colher de madeira parece ser mais quente do que a de alumínio", está meio confuso, poxa,

E: hum, hum

P:está meio confuso, P: não to sabendo responder isso, isso dá uma sensação assim meio ruim, você preferia assim, você passa por esse tipo de situação ou ir logo na lousa já da resposta total

E: Não é assim, aprende melhor

P: Mas porquê

E: Porque fica você responder até acertar do que você vai já explicar, sendo que na explicação às vezes já ta dando uma explicação, uma teoria, já da a pergunta, já dá uma idéia,

P: Sem ter a pergunta

E: Entendeu, você não, dando a pergunta e depois vai ali explicando tal, vai fazendo, vai interagindo é melhor

P: Hum

E: pra aprendizagem é melhor

P: Você acha que você aprende melhor

E: melhor assim

P: assim dessa forma

E: Porque oh, você deu isso aqui, que eu em casa eu tinha uns livro eu catei

P: A você foi ver os livros

E: Fui, olha aqui, olha ali, lê, tem lei de um, lei de outro e vamos, vamos, vamos e vai caçando e vai mais ou menos encaixando ai lê livro de geografia, o que é perda, ganho e vai lendo e tal, vai tendo mais noção

P: Hum, hum

E: melhor do que a pessoa só chegar e escrever, explicar lá na lousa e depois passar a pergunta

P: Hum, hum

E: Você já dando a pergunta antes a pessoa fica mais focada

$P$ : Você acha que a pessoa fica mais interessada?

E: Interessante

P: Ah, porque houve a discussão

E: Isso

Neste trecho da entrevista, tínhamos a intenção de saber se o sujeito acharia melhor se atividade fosse desenvolvida segundo o método tradicional de ensino, no qual, o professor apresenta a teoria e em seguida propõe os problemas. Au justificou acreditando que a metodologia utilizada favorecia o aprendizado. Pois, ocorreria uma maior interação com o professor à medida que o profissional dialogasse com o aluno acompanhando as dificuldades e os avanços em direção à realização da atividade.

Contudo, devemos esclarecer que em anos aplicando esta atividade este nível de interação entre professor aluno somente se instalava se os alunos estavam comprometidos na busca dos objetivos. Não raro, muitas vezes, encontramos grupos de 
alunos que não perguntavam, ou só caminhavam mediante o auxílio, ou mesmo, a insistência do professor. Alguns alunos ressentiam-se, por exemplo, quando eram aconselhados a lerem o texto de apoio para responderem algumas questões, dizendo: é muito longo! Outros reclamavam revoltados diante da recusa do professor em fornecer rapidamente a resposta correta. Obviamente, que estas situações não mais nos surpreendem, pois estas fazem parte das questões que justificam este trabalho.

Em determinado trecho, o sujeito relatou que tentou pesquisar as perguntas anteriormente em um livro de geografia. Em anos aplicando esta atividade, raramente nos deparamos com alunos que queriam responder a questões pesquisando-as fora da sala de aula. Obviamente, no caso de $\mathrm{Au}$ isto deve ter ocorrido, pois ele tinha interesse intrínseco neste ramo de conhecimento. Outra surpresa, ele ter procurado responder as questões utilizando um livro de geografia, acreditamos que isto tenha ocorrido, porque algumas perguntas $(2,3$, e 5) faziam alusão ao ambiente. Portanto, talvez o sujeito tenha entendido ambiente, como meio ambiente, conteúdo próprio da disciplina de geografia. Por outro lado, o que produziu ainda mais surpresa foi a declaração feita pelo sujeito de que obteve alguma noção, após ter consultado o livro de geografia: "caçandoe vai mais ou menos encaixando ai lê livro de geografia, o que é perda, ganho e vai lendo e tal, vai tendo mais noção". Infelizmente, não temos mais possibilidade de questionar Au sobre estas afirmações. Não obstante, também entendemos não se tratar de algo relevante; para nós fica a sensação de que o sujeito quis nos impressionar passando-nos a ideia de que é um aluno muito interessado, acima do normal. Nesse sentido, também preferimos não discutir a afirmação do sujeito de que o fato de termos entregado o questionário para a cópia contribui para motivá-lo.

10 - P: Não sei o que lá, então você acha que foi mais interessante?

E: Faz aquele grupo ai "Ah, o que você acha? Eu acho isso, e você? É isso. Ah, não eu acho isso. E agora? É vamos vê, vamos vê, vamos lá e vai debatendo até as opiniões ficarem contrárias

P: Você gosta de trabalha em grupo né?

E : Gosto

P:...Assim, então você recomenda que eu continue utilizando essa atividade?

E: Eu recomendo

P: Você acha que os alunos aprendem

E: Aprendem, os interessados aprendem [P: hum, hum] E: Pode ter certeza, por que é uma aula diferente,

P: Certo

E: né aquela típica, entendeu, rotineira

P: É isso, explica, tal o que é uma aula rotineira?

E: Rotineira é que a pessoa passa aquele texto enorme [P: Hum, hum] E: dá a explicação ai pergunta sendo que, você passou o texto, explicou, você passa a pergunta 
pessoa já tem mais noção ali, aqui não, ... você vai atrás [P: Hum] E: da resposta, você dá as perguntas e fala: "Vamos lá pessoal é isso, gosto, gosto, então vamos lá", e vai duas perguntas, beleza, ai o pessoal vai corre atrás, faz aquele grupo, entendeu, troca de ideias, informações até chegar na resposta.

O sujeito cita, como ponto que diferencia esta atividade de outras atividades realizadas em outras disciplinas, o fato de que comumente os alunos copiam o texto, e, em seguida, respondem questões baseadas no mesmo. Acreditamos que trata-se de um ponto importante em relação ao desenvolvimento da autonomia do aprendiz, pois temos a impressão de que os alunos escrevem muito pouco, ou quase nada, na medida que durante anos de escolaridade são encorajados a copiar trechos dos textos como respostas a questionários, em detrimento da própria produção. Haja vista a dificuldade encontrada pelos alunos ao terem que redigir o próprio texto; muitos pedem, insistentemente, para o professor repetir mais pausadamente a explicação para poderem copiar a resposta ao invés de produzi-la. Obviamente, que não esperamos que os alunos saiam produzindo automaticamente suas respostas de forma autônoma; entretanto, acreditamos haver algumas atividades capazes de fomentar a produção de texto, prática extremamente importante para formação de alunos mais autônomos.

Nesse sentido, acreditamos também que o trabalho em grupo pode ajudar neste processo, pois os sujeitos devem contribuir mutuamente através da troca de ideias ou discutindo qual a melhor redação nas respostas. Contudo, nada adianta se os sujeitos têm o péssimo habito de somente copiarem, enquanto apenas um se envolve verdadeiramente com as respostas. Obviamente, não temos como garantir que este grupo nunca se comportou desta maneira ou se todo o grupo sempre se comporta responsavelmente em relação a todo o conteúdo. Contudo, este grupo nesta atividade, e, em outras deu provas de que se constitui um verdadeiro grupo de trabalho.

A recomendação do sujeito para continuarmos a aplicar a atividade não nos surpreende, pois o mesmo na análise da entrevista de seu perfil de realização relatou que aprecia o trabalho em grupo e principalmente gosta da área de ciências. Isto posto, acreditamos que a atividade contemplou estas expectativas, portanto tornou-se natural sua recomendação.

11 - P: Tem que pensar...., tem que pensar mais

E: Pensa, pensa mais é legal.

P: E na hora de escrever é difícil assim, na hora de escrever tem alguma dificuldade ou vai

E: Não, você vai que a mente 
P: A mente vai

E: vai colocando as palavras, entendeu

P: Ah, certo

E: Você vai ali analisando é que sua opinião né, você tem ali o, esqueci o nome da palavra, você tá na mente ali pensativo, você vai "Ai é assim”" ai você vai escrevendo, entendeu, ai fica jóia mano, tá muito dez, eu gostei

P: Fico, fico contente.P: Você acha que alguém do grupo assim não gostou muito, teve mais, a hora se sentiu um pouco confuso assim se sentiu meio cansado, alguma coisa assim?

E: Não, meu grupo foi legal, porque um: "Ah, Não dá certo assim” ai o outro já vinha: "Não, mais e assim, assim dá mano tá errado essa ai, vamos fazer desse jeito] ai"

Neste trecho, pelo mesmo motivo com o qual encerramos análise do trecho precedente, acreditamos que o sujeito apreciou a atividade, pois esta foi ao encontro de outra de suas expectativas; neste caso, do desejo de realizar tarefas escolares em que se possa realmente pensar, de acordo com seu relato na entrevista de seu perfil de realização.

P: Obrigado, pela sua participação as duas palestras em que você, poxa, me disseram que você não ia vir hoje, chegou atrasado por causa do trabalho, muito obrigado pela sua participação, entendeu, gostei do grupo de vocês, sempre gostei do grupo de vocês, acho que vocês gostam de estudar e acho que vocês tem um futuro ai, espero que vocês não desistam de estudar

E: Não, não

P:Às vezes o professor,... é muito confuso na sala de aula e o professor não consegue fazer aquele trabalho que ele tá tentando fazer porque as vezes os alunos não...., complicam a situação, a gente tá tentando acertar né, tentando acertar, eu espero que vocês continuem na vida tentando, tentando o caminho de vocês, realizar os objetivos de vocês.Esta bom então

E: Eu achei interessante, sério mesmo

P: Então eu posso continuar

E: Pode, desse jeito pode, tranqüilo

P: Tá bom

E: Porquê foi uma coisa diferente, mano

Neste trecho final, o pesquisador inexperiente cedeu lugar ao professor e este, como não poderia ser diferente, elogiou o entrevistado e o seu grupo de trabalho, afinal não tem sido muito corriqueiro acertar uma atividade na qual os alunos sentiam-se gratificados em realizá-la. Obviamente, após anos aplicando esta atividade temos encontrado grupos como este; tem sido muito satisfatório. Por outro lado, também encontramos grupos com comportamento diametralmente opostos, fato este que também justifica nosso interesse por este trabalho de pesquisa. 
Apresentamos este trecho para que o leitor possa avaliar a possibilidade do comprometimento do pesquisador-professor com os dados de pesquisa. De qualquer forma, o caso do $\mathrm{Au}$ deve ser olhado não em sua especificidade, não em sua singularidade, mas como sendo um representante típico de alunos que alcançam altos níveis de motivação ao realizarem atividades sócio-construtivistas comumente descritas em inúmeras pesquisas da área.

12 - [O entrevistado continuou falando, então ligamos novamente o gravador] P: Eu vou voltar à pergunta, você estava fazendo porque, porque você estava preocupado mais, porque eu vou dar uma nota, não é só isso, você estava mais preocupado em ter uma nota, tirar uma nota melhor qual a sua motivação?

E: Eu na minha opinião, eu gostei por causa que eu falei pro senhor, que é só por interesse assim é

P: Uso todo dia

E: Todo, você tem isso no dia a dia o ganho que você tem de energia pro ambiente tal você sofre com ações do tempo, das climáticas tal agora você já sabe porque, com esse trabalho que você deu, é muito bom

P: Então, por isso que você achou interessante

E: Achei interessante e a maioria das aulas que nem matemática, biologia eles deviam dar mais coisas, porque muitas coisas matemática e biologia é rotineira no nosso dia, no dia-dia

P: Esta no dia-dia

E: Esta no dia-dia, no dia que você se machuca, você sabe mais ou menos o que é, você vai não que você vai se cura sozinho, você vai no medico e você já tem uma noção do que é, que nem no caso de biologia e na matemática tem muitas coisas envolvendo veículos motorizados e não motorizados que é negócio de (termo incompreensível) equilíbrio, da força, entendeu [P: Hum, hum ]E: é isso que eu acho

P: Interessante

E: Achei interessante.

P: Tá certo, obrigadão novamente.

$\mathrm{Au}$ comentou novamente sobre um dos aspectos entre aqueles que o fizeram apreciar a atividade, foi o fato de poder entender coisas relacionadas ao seu cotidiano. Esta avaliação já havia aparecido quando da pergunta número cinco desta secção. Entretanto, neste trecho $\mathrm{Au}$ afirmou que gostaria que outras disciplinas como, por exemplo, a matemática ou a biologia também desenvolvessem seus conteúdos ligados ao cotidiano. Conforme diversas pesquisas da área, muitos estudiosos tem tentado desenvolver atividades de ensino com objetivo de contemplar o cotidiano dos aprendizes, pois os sujeitos podem atribuir maior significado aos conhecimentos. 
13 - P: Você se lembra qual que você falou ou quais perguntas você achou mais interessante, você se lembra mesmo qual que foi, que você falou não, que você achou, que você achou agora, não tem problema.

E: Foi a sete....

P: Você se lembra porque você achou esta sete interessante

E: É porque, foi porque, por causa da colher se eu não me engano [P: Hum, hum] E:

Porque a madeira parece está mais quente e a alumínio

P: Parece que está mais

E: Mais fria né

P: Hum, hum P: É esta pergunta causa uma certa confusão não é isso assim

E: isso

P: você fica meio confuso é assim por acaso te dá uma certa sensação de desafio assim? E: Dá

P: Você se sente desafiado

E: Dá, dá esta sensação porque você pega assim você percebe, nós, nosso corpo percebe não essa aqui é quente, você pega aluminio já fala não esta aqui é fria (risos) não tem

P: Não tem nada a ver, ai se sente

$E: \dot{E}$

$\mathrm{P}:$ desafiado assim

Neste trecho, como o entrevistado continuava a comentar sobre a atividade, pensamos em perguntar se o sujeito viveu alguma sensação de tensão ao realizar a atividade. Portanto, novamente entregamos as perguntas para que o entrevistado se lembrasse das perguntas mais interessantes. O sujeito então relatou novamente que as questões responsáveis em causar maior sensação de confusão foram aquelas referentes ao conflito cognitivo.

14 - P: Outra coisa assim, também assim porque são várias perguntas né E: Isso

P: As perguntas vão te testando, vão ali, umas vão dizendo uma coisa outras vão dizendo outra tal, você sente assim uma certa tensão assim, uma certa tensão E: $D a ́$

P: Só que assim como é que você acha assim, como é que

E: Tenso é assim, é pra ver a resposta certa e melhor assim jeito de respondendo né com as palavras

P: Você sente uma certa tensão assim

$E:$ É, você acerta a colocação das palavras na resposta você tem vezes que você coloca uma coisa a resposta ta certa mais a combinação das palavras não tem nada

P: não tem nada (risos)

E: a ver, fica embaraçado

P: Você sente meio desafiado a fazer a ter que fazer certo, aquela coisa assim

E: É, isso

P: Mais uma coisa também assim, na hora que você termina assim de fazer o que você sente assim, na hora que você terminou a atividade assim?

E: Assim, você sente um compromisso assim, tudo certo, terminado 


\section{P: Realizado}

E: $\dot{E}$

P: Você sente assim um certo alívio assim?

E: sente

P: Parece um alívio assim Uoor (sopro) consegui,?

E: $E^{\prime}$

P: uma coisa assim de uma certa satisfação ..um um sentimento?

E: Satisfação, isso mesmo porque esse exercício que o Sr passou pra nós desse jeito foi o melhor mano pra aprende assim quebrando a cabeça foi o melhor.

P: Fica aquela coisa na cabeça, querendo, puxando?

E: Você vai no serviço, você esta fazendo .. as coisas vem martelar

P: (risos) Até no serviço, você fazia?

E: É, martela

P: Pó mas será que?

E: Teve um dia que eu sai de casa tava maior calor, meio dia pra tarde esfriou nessa situação, tá perdendo.

P: Éeee

E: Tá perdendo temperatura e vai e já vem na cabeça

P: Você já começa a explica as coisas né velho? P: Se você acha alguém você explica, não explica?

E: Explica

P: (risos) Você acaba ficando aquilo negócio na sua cabeça, te conversando, parece negócio fica conversando na sua cabeça

E: É, isso mesmo

P: Parece que tem alguém que fala olha, olha então era isso é (risos)

$E: E$, achei muito interessante mano

P: Então eu queria saber se vocês sentiam essa coisa um certo desafio, sentia aquela um pouco daquela tensão de ter visto aquela...

E: Isso

Au parece não haver sentido incômodo algum na forma do aumento da tensão. Contudo, talvez tenha sentido certa tensão ao responder a atividade, entretanto, esta tensão deve ter sido logo direcionada para o aumento da concentração necessária para se realizar alguma atividade que precisava de maior nível de atenção.

No último trecho da entrevista, o pesquisador na ânsia de captar o desequilíbrio cognitivo na forma de uma tensão generalizada, pode ter influenciado a resposta do entrevistado. Todavia, o entrevistado não reconhece uma tensão neste nível, mas, a reconhece especificamente em relação à produção do texto e a organização mental das ideias, em suas palavras: "pra aprende assim quebrando a cabeça foi o melhor". Segundo nossas experiências, no momento em que os alunos tentam organizar as ideias num texto, experimentam certa dose de tensão; neste momento, muitos reagem com as seguintes frases: "Eu sei a resposta, mas não consigo escrever", alguns pedem a 
resposta diretamente ou uma ajuda, outros levam o caderno insistentemente ou chamam o professor para ver se estão certos.

Outro aspecto interessante deste relato conforme amplamente discutido na análise de seu perfil de realização é que este sujeito apreciava ficar compenetradopensando sobre algum assunto. $\mathrm{O}$ sujeito tendo assimilado-acomodado um novo conhecimento, mesmo que parcialmente, pois ainda parecia confundir temperatura com calor, mesmo assim, o sujeito passou a aplicá-lo em seu cotidiano buscando relacionar as trocas de energia entre seu corpo e o meio ambiente e suas respectivas sensações térmicas. Conforme, seu relato presente na análise da entrevista de seu perfil de realização (pergunta n. 13), ou em suas palavras - "é tum na mente"-a atenção do sujeito foi capturada para tentar entender algum fenômeno (grifo nossos):

\subsection{2- Resultado da Análise dos Dados da Entrevista sobre a Percepção Motivacional do Sujeito Au}

Em seu relato, Au afirmou ter aprovado a atividade, pois relatou em vários trechos que gostou de realizá-la, e esta avaliação se justificava por diversas razões. Ele deixou a forte impressão de que se sentiu motivado intrinsecamente na medida em que este estado alterou sua percepção da passagem tempo; afinal, a atividade, apesar de ter durado duas aulas e meia sem intervalo, não foi considerada tediosa; pelo contrário, esta foi tão interessante ao ponto do sujeito julgar que o tempo passou rapidamente, percepção comum aos sujeitos intrinsecamente motivados. Acreditamos que esta consideração sobre a percepção alterada da passagem do tempo esteja relacionada ao nível do foco e da concentração do sujeito durante a atividade. Nesse sentido, as questões destinadas a produzir o conflito cognitivo foram consideradas "confusas", e, por isto mesmo, interessantes, pois exigiram dele o esforço na forma de atenção e concentração. Parece-nos também que este desafio pode ter sido compartilhado entre os integrantes do grupo tornando o conflito cognitivo em um conflito sócio-cognitivo, pois segundo o relato do sujeito a troca de ideias (incluindo o professor) foi fundamental para possibilitar a resolução da tarefa.

Ainda em relação ao grupo, o sujeito fez uma defesa entusiasta deste tipo de organização, passando a impressão de sentir orgulho do trabalho realizado pelos seus integrantes, inclusive, apontando esta forma de organização como um diferencial da atividade principalmente em relação às outras disciplinas. Au julgou o conhecimento relevante, não somente porque resolveu o conflito, mas, principalmente, por 
possibilitar-lhe o entendimento de situações do seu cotidiano; inclusive, acreditava-se capaz de ajudar outras pessoas a não se confundirem em relação às diversas sensações térmicas.

Esta apreciação subjetiva feita por $\mathrm{Au}$ parece indicar que a atividade foi ao encontro de algumas de suas expectativas, pois em inúmeros relatos ele passou a forte impressão de sentir-se seguro e bastante confiante ao realizar a atividade. Portanto, esta atividade parece ter se constituído um lugar propício para a atuação do sujeito na medida em que possivelmente satisfez suas crenças sobre o significado do binômio “aprender-ensinar". Provavelmente, também se aproximou dos seus pactos epistemológicos sobre como se processa a ciência fortalecendo suas crenças sobre a superioridade da ciência e contribuindo para reforçar ainda mais seu interesse intrínseco por esta área de conhecimento. Destarte, estas expectativas estavam em acordo com seu perfil de realização, sendo assim, vamos analisar mais intimamente as razões desta apreciação feita pelo sujeito e as expectativas condizentes com seu perfil de realização.

\subsection{3 - Expectativas Epistemológicas Sobre Aprender-Ensinar}

Conforme resultado final da análise do perfil de realização, concluímos que Au estava orientado à meta aprender, inclusive apreciando atividades desafiadoras nas quais pudesse realmente pensar e empreender esforços. Portanto, segundo suas crenças o aluno deve se esforçar ao máximo para aprender através de ações na direção deste objetivo. Logo, o conflito cognitivo parece ter cumprido seu papel ao desequilibrar o sujeito; este desequilíbrio foi traduzido na forma de um sentimento de confusão, ou seja, esta "confusão" constituiu-se um desafio à inteligência e às habilidades do aluno.Entretanto, este não pareceu ter vivenciado níveis preocupantes de ansiedade em relação ao êxito da tarefa.

Pelo contrário, em inúmeros trechos passou a impressão de sentir-se não somente seguro, mas bastante confortável e confiante ao realizar a atividade. Ora, esta blindagem capaz de evitar que o sujeito fosse tomado de assalto por sentimentos de ansiedade quanto ao êxito da tarefa devia estar relacionada ao seu robusto auto-conceito com o qual o sujeito se considerava bastante inteligente, principalmente, para aprender ciências. Logo, este auto-conceito aliado às estratégias ligadas ao seu senso de autoeficácia, sobretudo a estratégia de direcionar energia através do esforço no aumento da concentração, foram capazes de garantir segurança e principalmente certo nível de satisfação cognitiva, justificando sua autoconfiança. 
No mesmo sentido, a alta consideração dispensada à ciência pode ter contribuído para despertar ainda mais o interesse de Au. Podemos pressupor que o mesmo sentiu-se orgulhoso, sentimento comum vivenciado pelos sujeitos orientados à meta aprender ao empreenderem esforço e dedicação principalmente quando o grau de exigência, ao final de uma atividade, representava crescimento intelectual. Neste caso, então, temos dois motivos para que o sujeito se sentisse duplamente orgulhoso, primeiro, por este conhecimento ter sido compreendido por Au como um desafio às suas habilidades e à sua inteligência, situação propícia para o surgimento de sentimentos de auto-realização comuns àqueles orientados à meta aprender. Segundo, orgulho por ter elaborado um novo conhecimento científico, uma área de conhecimento de grande importância e "status" para o sujeito.

Segundo seu perfil de realização, Au demonstrou certas expectativas quanto ao trabalho em grupo ligadas à sua necessidade de intimidade.Isto posto, estas expectativas giravam em torno da sua participação dentro do grupo e da própria atuação do grupo para a consecução da tarefa. Quanto ao trabalho realizado pelo grupo, Au não teceu qualquer crítica em relação à atuação dos seus integrantes; pelo contrário, acreditava que todos trabalharam satisfatoriamente, defendendo com entusiasmo esta forma de organização e apontando-a como um diferencial em relação a outras disciplinas. O sujeito relatou ainda que as relações interpessoais foram importantíssimas não só para a consecução da atividade, mas, sobretudo, para a re-elaboração dos conceitos espontâneos em direção aos conceitos científicos.Provavelmente, as discussões tenham enriquecido a atividade com maior dinamismo contribuindo para que o sujeito não se sentisse entediado. Há a possibilidade também destas trocas de idéias terem reforçado a sensação de segurança do sujeito, principalmente, nas discussões com o professor, na medida em que este sinalizava que o grupo estava trilhando a direção correta.

Em relação à participação de $\mathrm{Au}$ no grupo havíamos levantado a hipótese, quando da análise de seu perfil de realização, de que ele se considerasse como líder intelectual do grupo, tomando os desafios cognitivos para si, portanto, considerando a possibilidade do conflito cognitivo ter sido vivenciado como um conflito sóciocognitivo. É provável que o sujeito tenha assumido a posição de enfrentamento do desafio diante do grupo; portanto, é razoável a hipótese de que um dos motivos do sujeito defender a organização grupal, principalmente no tocante a esta atividade, estivesse lastreada por uma positiva auto-avaliação quanto ao seu papel de líder intelectual frente ao grupo. Contribuiram para esta impressão seu entusiasmo e o fato de 
ser intrinsecamente motivado, acreditando-se inteligente o suficiente para aprender ciências. Em suma, apesar de não podermos garantir que a organização grupal produziu maior ligação entre os integrantes do grupo, pois o mesmo já trabalhava desta maneira pelo menos há um ano, podemos conjecturar que esta atividade contribui no mínimo para fortalecer os laços já existentes entre os sujeitos participantes, de acordo com as expectativas de $\mathrm{Au}$ segundo sua necessidade de intimidade.

\subsection{4 - Expectativas Epistemológicas e Metafísicas sobre a Ciência.}

No parágrafo anterior, havíamos levantado a ideia de que o sujeito havia encontrado um lugar próprio para sua atuação, um lugar onde se sentiu a vontade. Ora, em inúmeras outras seções chamamos a atenção para a possibilidade de Au ter o desejo de ser um cientista. Guardada as devidas proporções e levando-se em consideração seus relatos, podemos conjecturar que o mesmo vivenciou minimamente alguns aspectos dos procedimentos epistemológicos pertinentes à ciência. Pois, ele sentiu-se em alguns momentos motivado intrinsecamente graças ao conflito sócio-cognitivo presente em uma experiência crucial. O sujeito discutiu suas ideias junto aos seus pares, incluindo o professor, agente privilegiado na atuação na zona de desenvolvimento proximal. Au parece ter evoluído em seus conceitos, mesmo que parcialmente, em direção ao conhecimento mais robusto que o ajudava a entender aspectos de seu cotidiano. Obviamente, que todos estes aspectos foram facilitados enormemente, pois estes estavam presentes na forma de expectativas segundo seu perfil de realização. Por exemplo, o sujeito tinha a tendência a aderir ao conhecimento científico, pois acreditava que este fosse superior, pois em sua concepção este era sinônimo de verdade em detrimento do senso comum. Logo, em um só tempo, o sujeito teve expectativas epistémico-metafísicas ${ }^{16}$ contempladas, muitas delas, pré-conscientes agindo como um cenário capaz não de tornar a sala de aula um laboratório, mas no mínimo um simulacro $^{17}$, um semblante. Contudo, se também não podemos aproximar o papel do aluno com o de um investigador profissional podemos pelo menos utilizar a metáfora do

\footnotetext{
${ }^{16}$ A fusão dos substantivos epistemológico e metafísico é interessante, pois devemos considerar conforme as crenças do sujeito $\mathrm{Au}$ em relação à superioridade da ciência de que tanto aspectos epistemológicos quanto metafísicos contribuem para uma visão romanceada e fantasiosa desta área de conhecimento, portanto, os mesmos devem atuar fundidos em um nível no mínimo pré-conscientes tecendo a ecologia conceitual do sujeito.

${ }^{17}$ Simulacro é entendido como ação simulada para exercício, experiência ou simulação.
} 
"investigador novato" conforme defendido por inúmeros pesquisadores da área (Pessoa de Carvalho et al, 1999)

Isto posto, considerando as expectativas epistemológicas sobre aprender-ensinar somadas as expectativas no tocante as concepções epistémio-metafísicas de $\mathrm{Au}$ podemos considerar que estas configuram uma rede de significados, uma conjuntura ${ }^{18}$, uma Ecologia Conceitual, um bojo cognitivo-emocional, capaz de garantir não somente a subsistência dos diversos sujeitos epistemológicos: sujeito piagetiano, sujeito vygotskiano e o sujeito aprendente, mas, sobretudo, um lugar para atuação, o desenvolvimento e o vicejar destes sujeitos. No mesmo sentido, a mente do sujeito, parece sentir-se não somente confortável, mas desejando trilhar mesmo que minimamente as condições básicas do MMC: inteligibilidade, plausibilidade e fertilidade, após, o sujeito ter vivenciado a insatisfação de suas ideias em uma experiência crucial. Obviamente, não se tratando de um rechaço radical delas, mas uma evolução em direção aos conceitos científicos.

Em suma, a avaliação subjetiva de Au é típica de alguns alunos quando vivenciam o conflito cognitivo; estes aspectos motivacionais estão amplamente corroborados por inúmeras pesquisas da área apontando que esta estratégia de ensino é capaz de capturar o interesse do sujeito evolvendo-o ativamente na solução dos problemas. Para este, o conflito realiza sua função ao desequilibrá-lo, prontamente, graças ao seu perfil de realização. Ele direciona energia realizando ações com o propósito de resolver o desafio acomodando-assimilando ou evoluindo, mesmo que minimamente, o novo conhecimento, condição necessária para retornar ao equilíbrio.

Isto posto, ao final da atividade, provavelmente o sujeito a avaliou como sendo interessante e enriquecedora por dois aspectos intrínsecos: primeiro por ter sentido a necessidade durante o processo de ressignificar seus conceitos impulsionado pelo desequilíbrio; segundo por ter encontrado um objeto ou situação que lhe proporcionou ampliar seus conhecimentos ou desenvolve-los intelectualmente.

Notadamente, os pesquisadores da área classificariam este envolvimento ativo de $\mathrm{Au}$ em direção ao conhecimento, como sendo de um sujeito intrinsecamente

\footnotetext{
${ }^{18}$ A estrutura seria elaborada com os primeiros sentimentos morais autônomos do sujeito, a necessidade lógica de primeira ordem e necessidade lógica de segunda ordem como pensou Piaget. A conjuntura seriam as diversas valorizações acidentais construídas pelo sujeito durante sua história, por exemplo, o valor intrínseco dispensado a ciência ou a crença na necessidade do esforço e da dedicação para aprendizado. Logo, estrutura e conjuntura estão relacionadas não hierarquicamente como blocos que se sobrepõem, mas como um organismo vivo semelhante a uma árvore que de um lado constrói sua base com raízes fortes e do outro lança seu galhos em direção ao crescimento, ramificação e a produção de frutos.
} 
motivado. Ou ainda, um professor construtivista se sentiria bastante gratificado por ter proporcionado para seus alunos uma atividade de ensino capaz de produzir tamanho resultado.

\section{2 - Análise dos Dados da Entrevista sobre a Percepção Motivacional de Ga}

1 - P: O que você achou da atividade?

E: Difícil... boa e difícil, eu achei muito difícil porque eu não consegui entender o espírito da coisa.

P: A onde você..., pode ser sincera, alias, eu gostaria de sinceridade, entendeu, porque eu estou fazendo um trabalho, então, eu preciso vê se as pessoas gostam disso ou não, se for uma coisa muito difícil ai... né... O que você achou da atividade?

E: Ai professor na verdade, na verdade eu não gostei não, não, assim até as perguntas até então tudo bem, mas esse gráfico esse coeficiente de condutividade isso eu achei muito complicado (interrompe o pesquisador)

Ga foi classificada como orientada à meta performance-evitação por apresentar verdadeira ojeriza e temor em relação às provas e testes, conforme dados obtidos no questionário de acesso ao perfil de realização. Portanto, enfatizamos para Ga que a entrevista não era algum tipo de avaliação, pois estávamos preocupados sobre a possibilidade dela pensar que participaria de uma espécie de chamada oral, o que poderia influenciar negativamente suas respostas ou aumentar sobremaneira sua ansiedade.

Neste trecho, chama-nos a atenção a frase de que ela não entendeu o "espírito da coisa"?! O que significa esta afirmação, pois faz parte do cotidiano escolar os alunos responderem a questionários, provas e etc.Esta afirmação não nos causou grande surpresa, afinal em anos trabalhando com esta metodologia temos nos deparado com reações muito próximas a esta..." Eu achava que sabia alguma coisa, agora não sei mais de nada".

Nesse sentido, as pesquisas que utilizam o conflito cognitivo como estratégia para produzir o envolvimento ativo do sujeito, vêm captando reações muito próximas a estas, girando em torno de duas razões basicamente: fortes reações em relação à metodologia ou a dificuldade do sujeito em gerenciar internamente o conflito cognitivo.

A atividade realizada por $\mathrm{Ga}$ não se estendeu durante um grande período trabalhando com as ideais de senso comum, para depois, colocá-las em cheque através do conflito cognitivo, talvez justificando a forte reação dos sujeitos. Entretanto, a reação à metodologia foi praticamente a mesma, pois temos impressão de que Ga teria gostado de ter nos interpelado nos seguintes termos: "Não entendi o espírito da coisa?! Qual 
sua intenção, pois o senhor veio com este questionário sem explicar uma palavra. Sua intenção é provar que a gente não sabe nada?!’. Ora, devemos ter em mente o fato dos alunos corriqueiramente serem convidados a responderem questões nas quais o professor faz questionamentos para saber qual a opinião sobre algum assunto; eles respondem livremente, apresentando suas concepções sobre o assunto. No caso desta atividade, a mesma veio acompanhada de um texto de apoio, que não continha todo o tema das questões, principalmente, em relação ao conflito cognitivo.

Portanto, não nos parece que a afirmação de Ga foi produzida porque a mesma sentiu-se ameaçada por ser obrigada a responder perguntas sem nenhum embasamento teórico. Primeiro, porque ela já estava habituada a responder questões mesmo não dominando o assunto. Segundo, o texto de apoio permitia responder com certa facilidade as quatro primeiras questões garantindo razoável nível de segurança. Terceiro, o professor monitorava a evolução do grupo auxiliando-o em momentos, nos quais este não conseguia evoluir. Quarto, os sujeitos já estavam acostumados à forma de avaliação, método no qualse leva em consideração unicamente a participação do sujeito.

Isto posto, as reações acima, estão ligadas às críticas feitas em relação à metodologia. Muitas das críticas relativas à gestão do conflito cognitivo surgiram devido às crenças epistemológicas dos alunos sobre aprender-ensinar conforme discutidas em nosso referencial teórico. Estas são reforçadas pela metodologia tradicional de ensino, no qual o importante são as respostas corretas e os erros devem ser eliminados do processo. Soma-se a isto, o fato dos sujeitos estarem habituados a obter as respostas de forma fácil e rápida e, portanto, apresentarem dificuldade em suportar o desequilíbrio produzido pela estratégia. $O$ aluno então costuma reagir fortemente com o propósito de se livrar da ansiedade: “-Se o senhor já sabe, porque não dá logo a resposta!!!”. Ou ainda, o sujeito aposta em um papel passivo em relação ao aprendizado, ou no mínimo esforço: “-Ah!! Professor tem que pensar!!”, como se pensar não fosse um de seus atributos. Até mesmo, no tocante as relações interpessoais, quando o professor requisita para alguns alunos que estes consultem o colega ao seu lado, muitos reagem indignados: “O professor aqui é o Sr., não o meu colega!".

Contudo, apesar das possíveis críticas relacionadas à metodologia, Ga pareceunos focalizar as críticas em torno das dificuldades em gerenciar o conflito cognitivo. $\mathrm{O}$ problema não foi porque ela não podia aceitar a ansiedade ligada ao fracasso de seus conceitos espontâneos frente a uma experiência crucial, ou, porque tinha a preferência em obter as respostas rapidamente, pois apostava no mínimo esforço. Levantamos a 
hipótese de que a avaliação negativa feita por Ga em relação à atividade estivesse ligada ao seu perfil de realização. Pois, os sujeitos orientados segundo este perfil, tendo como representantes Ga e Ms, parecem estarem sempre hiper-vigilante quanto à possibilidade de ocorrer alguma situação na qual os outros venham a tomar conhecimento de sua suposta incapacidade cognitiva, sentindo-se humilhados por esta condição. Portanto, o desequilíbrio produzido pelo conflito cognitivo representaria uma condição insustentável, pois a ansiedade produzida seria vivenciada como um mergulho em um mar de angustia. Assim, o conflito não representou somente o fracasso das ideias de Ga, mas, para seu desespero, o conflito somou-se as inúmeras situações que pareciam confirmar para ela sua suposta incapacidade cognitiva.

2 - P: Quais as questões que têm mais complicações?

E: Quais as questões..... nove achei difícil...(O pesquisador interrompe)

$P$ : Pode pensar não tenha pressa de responder, olhas as questões com calma, não precisa ter pressa nenhuma, porque foi na quinta-feira né, na semana passada, então pode ser que tenha esquecido alguma coisa...Por exemplo, assim: Qual a temperatura do seu corpo?

E: Essa foi fácil, eu achei fácil.

$P$ : Qual a temperatura das colheres?

$E:$...

$P$ : Você achou difícil?

E: Não, achei fácil, também...

$P$ : Assim o grupo respondeu fácil esta questão?

E: Foi fácil, a gente só ficou indeciso mesmo entre a oito e a nove

$P$ : Esta daqui, quando você sente frio, você perde o que para o ambiente?

E: Calor...

$P$ : Você achou fácil ou difícil?

E: Eu achei fácil.

$P$ : E essa número seis aqui, a colher ganhou dez graus de temperatura do meu corpo?

E: Humm

$P:$ Qual que o erro?

E:A colher ganhou, a colher...eu acho que a frase inteira ta errada, né

$P$ : Mas onde?

E: Porque a colher não ganha...

$P$ : Não ganha o que?

E:Calor, aqui ta dizendo temperatura, né, não... é calor, ne?

$P$ : Isso...

E: Não é a mesma coisa, né?

$P$ :Isso

E:Humm

$P$ : Mas esta você não achou difícil?

E:Não até consegui fazer com facilidade...

Antes de iniciarmos a discussão deste trecho da entrevista, apenas como esclarecimento, gostaríamos de discutir brevemente as duas primeiras questões apenas 
para possibilitar ao leitor uma melhor avaliação sobre a situação de aprendizagem a que foram expostos os alunos e o tipo de interação promovida seja com o texto de apoio, com o grupo, ou mesmo com o professor. Assim sendo, a primeira pergunta questionava sobre a temperatura do corpo humano; esta informação encontrava-se diretamente no texto, já a questão sobre a temperatura das colheres só podia ser respondida com o auxílio do professor através da discussão onde o professor dirige o raciocínio dos alunos para que eles concluam que a colher esta a temperatura ambiente, exemplo das perguntas feita pelo professor com tal objetivo: alguém está esquentando as colheres?, ou alguém está esfriando as colheres?. Logo, se elas estão expostas dentro da sala de aula, portanto sua temperatura deve ser a da sala. Após esta discussão, os alunos chegam à conclusão que a temperatura das colheres é a do meio-ambiente sugerindo um valor aproximado para a temperatura das mesmas.

Voltando à análise do trecho, Ga declarou que não somente achou de fácil compreensão algumas questões, como também os integrantes do grupo: "Foi fácil, a gente só ficou indeciso mesmo entre a oito e a nove”. Gostaríamos de esclarecer também que as perguntas cinco e seis (discussão aprofundada na secção análise da atividade de conhecimento físico) são questões bastante complexas. Na questão número cinco a complexidade esta relacionada ao mecanismo que explica as relações entre meio ambiente, perda e ganho de calor, e as sensações térmicas. Portanto, o sujeito deve ter entendido minimamente as questões de um a quatro para poder responder esta questão. Obviamente, que o professor conduziu o raciocínio do aluno através de perguntas ${ }^{19}$ para que o aluno pudesse chegar à compreensão do mecanismo. Entretanto, como os alunos responderam em questões anteriores que quando a temperatura do ambiente abaixa, perdemos calor, logo sentimos frio e, vice-versa, quando ganhamos calor a temperatura do corpo humano se eleva e o sujeito sente a sensação térmica de calor e aciona os mecanismos de proteção descritos no texto de apoio, como, por exemplo, produzir suor para perder calor e baixar a temperatura. A questão número seis é razoavelmente difícil, pois os alunos confundem-se ao tomar como sinônimos os conceitos de temperatura e calor; esta confusão é fruto de suas concepções espontâneas. Entretanto, nossos sujeitos entenderam rapidamente esta questão, já que responderam em questões anteriores que só é possível haver troca de calor e não de temperatura, concluindo que a sensação

\footnotetext{
${ }^{19}$ As perguntas estão presentes na seção: análise da atividade experimental
} 
térmica de calor ou frio denuncia a perda ou ganho de calor, exceto em se tratando da mudança de estado, o que neste momento absolutamente não é mencionado.

Voltando ao trecho, Ga parece que entendeu o conceito, pois concorda que a frase esta errada, pois: "Calor, aqui ta dizendo temperatura, NE,. não... é calor"..Concluindo, inclusive na direção da diferença entre os conceitos de calor e temperatura, ao afirmar que estes não são a mesma coisa, finalizou, ainda este trecho afirmando ter conseguido compreender esta questão com facilidade. Há uma questão importante aqui, pois Ga conseguiu responder até a questão número seis, segundo seu relato, com certa facilidade. Ora, de um total de dez questões, logo o sujeito não deveria sentir-se tão mal, ao ponto de emitir a afirmação no trecho anterior: "eu não consegui entender o espírito da coisa.".

Aliás, gostaríamos de ressaltar que durante esta entrevista, nós não tivemos a impressão de que Ga aprendeu menos do que seus outros colegas, o que poderia justificar a avaliação negativa feita por este sujeito. Pois, a confusão em torno da diferenciação deste conceito deve ser encarada com certa naturalidade, pois não esperamos que uma única experiência seja capaz de mudar radicalmente o significado de uma concepção arraigada por anos na vida do sujeito. Nesse sentido, também Au, segundo seu relato (p. 290), também confundiu os conceitos de temperatura e de calor: "eu estou esquentando, apesar você está passando sua temperatura do corpo para a colher, a energia.". Obviamente, de que não temos como comparar se Ga aprendeu menos dos outros sujeitos, trata-se aqui apenas de uma inferência superficial e não temos o interesse em confirmá-la.

Portanto, considerando a afirmação de Ga sobre ela ter compreendido até a questão número seis da atividade, e, que em algumas destas foram respondidas com certa facilidade, inclusive as questões cinco e seis consideradas de maior complexidade. Logo, não nos parece que inicialmente Ga tenha se deparado com grandes dificuldades em entender a atividade, o que por ventura justificaria sua afirmação. Sendo assim, resta-nos acreditar sobre a avaliação negativa feita pela aluna, desta recair sobre as questões oito e nove.

Ora, a questão oito nada mais é do que a variação quantitativa da questão sete. A questão número sete é a questão referente ao próprio conflito cognitivo, esta sim carrega uma dificuldade conforme amplamente discutida na seção atividade experimental. Por outro lado, a questão oito, na verdade, funciona como um reforço na direção da compreensão, reafirmando a conclusão da questão sete valendo-se de uma informação 
quantitativa capaz de confirmar que os corpos trocam calor de forma diferente. Ou seja, se o aluno já entendeu ao responder a questão número sete de que as diferentes sensações térmicas são produzidas não porque os objetos estão a temperatura diferentes, e, sim, porque trocam calor com o corpo humano de forma diferente, devemos esperar que não seja difícil responder à questão sucessiva. Ou seja, se o metal troca calor mais efetivamente do que a madeira, logo, devemos esperar que quantitativamente o coeficiente de condutividade do alumínio seja maior do que o da madeira, indo ao encontro da avaliação qualitativa.

Isto posto, em anos aplicando esta atividade, os alunos muitos vezes têm questionado como devem responder a questão número oito, pois entendem que já solucionaram o problema na questão número sete. Isto tanto é verdade, pois ao pedirmos para os alunos compararem os diferentes valores do coeficiente de condutividade da madeira $(0,02)$ e do alumínio $(49,0)$ estas dúvidas têm sido rapidamente dirimidas, inclusive o professor ressaltando que a solução oito nada mais é do que a questão número sete acrescida dos coeficientes de condutividade. Portanto, nos estamos fortemente inclinados a concluir que a dificuldade de $\mathrm{Ga}$, bem como a avaliação negativa feita por ela,devia concentrar-se em torno do gerenciamento do conflito cognitivo.

A questão número nove refere-se ao pedido feito pelo professor para o aluno desenhar utilizando-se da imaginação sobre a direção do fluxo de calor saindo da mão do sujeito em direção a qualquer uma das colheres. Veja, se o sujeito já conclui em questões anteriores que o corpo troca calor com os objetos, parece ser razoável que o fluxo de calor se processe do corpo em direção a colher de alumínio. Isto posto, esta questão depois de toda a discussão acima não parece ser de grande dificuldade. Todavia, nos já relatamos que a aluna teve verdadeira ojeriza em realizar qualquer tipo de desenho. Portanto, a seguir vamos continuar analisando os trechos para entender quais aspectos da atividade produziram a avaliação negativa feita por ela.

3- P: E Esta pergunta aqui: Qual a relação entre o seu corpo, o ambiente, a temperatura e o ganho ou a perda de calor?

E: Vichi...essa foi dificil

$P$ : Foi difícil estabelecer estas relações?

E: IsSO...

$P:$ E esta aqui: Porque a colher de madeira, parece ser mais quente do que a de alumínio se está a mesma temperatura ambiente?

E: Esta foi dificil também

$P$ :Esta criou confusão?

E:Foi, muita confusão a gente embolou tudo. 
$P:$ O que você sentiu?

E:Como assim?

$P: O$ que você sentiu, você sentia bem, você sentia um pouco mal, porque você não estava entendendo?

E:Não eu me senti mal, porque eu achei que não tava entendendo e todo mundo tava entendendo e, as vezes, assim, é que nem no caso a sete a oito e a nove, eu achava uma coisa e o grupo achava outra,.. entendeu, eu sempre falava, não,.. eu acho que não é assim, talvez eu acho que o erro tava comigo, pode ser até que dos meus erros podia ta até certo, mas eu acho que tava errado porque o grupo todo tava dizendo que tava certo.

$P:$ Porque você achava que o seu podia estar necessariamente errado?

E: Não eu acho que..hum...não devo ter entendido direito...

$P$ : Se fosse para você fazer novamente?

E:...

$P$ : Você preferia fazer ou não fazer?

$E:$...

P: Por exemplo, se tivesse uma outra forma de explicar? Por exemplo..

E: não entendi...

$P$ : Se tivesse uma outra forma do professor explicar isso, você preferia fazer de uma outra forma?

E: acho que sim...

$P$ : O que você acha que diminui sua motivação, porque a pessoa começa motivado pra fazer alguma coisa, de repente a gente vai perdendo a motivação, você sabe me falar em que momento isso aconteceu?

E:Que nem no caso,.. foi as três perguntas que eu achei que era uma outra coisa e o grupo achou que era outra eu me senti desmotivada, desanimei porque se os três estão falando que ta certo porque eu vou achar que ta errado se.. é eu que devo ta errada, ai desanimei... até então eu tava até animada tava conseguindo tudo, mas depois...

Conforme já havíamos discutido anteriormente, a questão número cinco é bastante complexa. Pois, é necessário que o sujeito estabeleça relações entre o corpo humano, o meio ambiente, as trocas de calor e as diversas sensações térmicas. Portanto, temos a impressão de que o sujeito consegue avaliar o grau de dificuldade das questões, ou seja, as primeiras três questões são consideradas menos complexas, suas soluções encontram-se no texto de apoio, ou dependem de uma simples consulta ao professor. Obviamente, que as questões quatro e cinco exigem maior argumentação e Ga parecia estar cônscia desta diferença, portanto, é provável que ela tenha-se envolvido na busca pelas soluções, na medida em que percebeu o aumento da complexidade das questões conforme avançava na resolução da atividade.

Contudo, contrariando o que havia respondido em trechos anteriores, Ga respondeu, ao perguntarmos novamente sobre a questão número cinco, apontando o aumento da complexidade, ou a dificuldade da seguinte forma: "Vichi...essa foi difícil". Acreditamos que esta contradição em relação às afirmações anteriores tenha ocorrido 
por dois motivos; primeiro, não podemos deixar de ter em mente que estas questões foram respondidas na semana anterior, portanto ela talvez não tenha conseguido lembrar-se de seus aspectos. Pode ser que estes aspectos tenham voltado repentinamente à mente dela produzindo o tipo de expressão emitida por ela. Provavelmente, estes "flash" devem ter sido facilitados, à medida que o sujeito gradativamente podia repensar com maior tranquilidade sobre as questões.

Assim, podemos conjecturar, levando-se em consideração o perfil de realização, no qual Ga está sempre atenta às situações nas quais os seus pares possam vir a tomar conhecimento de sua suposta incapacidade para aprender, de que a questão cinco tenha acionado o alarme sinalizando sobre o aumento das dificuldades, e, consequentemente, amplificando a impressão sobre um possível fracasso iminente.

$\mathrm{Na}$ sequência, questionamos sobre a questão número sete. Infelizmente, perguntamos se ela sentiu-se confusa, portanto, há a possibilidade de termos induzido sua resposta; entretanto, Ga complementou sua afirmativa com um significado próprio: "Foi, muita confusão a gente embolou tudo.". Ora, este é o mesmo sentimento que $\mathrm{Au}$ também vivenciou, portanto, o conflito cognitivo, pareceu tornar-se um conflito sóciocognitivo, à medida que os demais integrantes comungaram do mesmo sentimento ao emitirem opinião parecida.

Entretanto, as reações de $\mathrm{Ga}$ e deAu foram diametralmente opostas; a bem da verdade, estas reações estão em acordo com seus respectivos perfis de realização. Pois, se para $\mathrm{Au}$ este sentimento de confusão foi vivenciado como um desafio que o mesmo apreciou, sentindo-se instigado a resolver, para $\mathrm{Ga}$, orientada à meta performanceevitação, pré-disposta a monitorar as situações nas quais poderia ocorrer o iminente fracasso, este sentimento tornou-se um alarme, aumentando a complexidade das questões, principalmente a número cinco. Logo, ao invés de convidá-la ao desafio e instigá-la a ação, pode ter sido a gota d' água, inundando sua psique de ansiedade, descortinando um horizonte de angustia sobre a possibilidade da consecução da tarefa: “Não, eu me senti mal, porque eu achei que não tava entendendo".

Assim, alimentado por estes pensamentos perturbadores iniciou-se o mecanismo destrutivo de motivação, impedindo a Ga de canalizar energia para aumentar a atenção, o foco e a concentração e transformando sua psique em um caos. Pois, ela não possuia um auto-conceito suficientemente robusto capaz de garantir-lhe tranquilidade para lidar com o avolumar das dificuldades. Devido ao seu baixo conceito de auto-eficácia Ga não conseguia pensar em estratégias e empreender ações capazes de mudar este estado de 
coisas. Logo, faltava pouco, para este mecanismo concluir seu ciclo levando a aluna rapidamente a produzir comportamentos e auto-avaliações capazes de contribuir para a perda do controle da situação, segundo o conceito de desamparo. Desesperada, angustiada e humilhada sentiu o exaurir de suas forças, concluindo pejorativamente que era responsável pelo fragoroso fracasso: "eu me senti desmotivada, desanimei porque se os três estão falando que ta certo porque eu vou achar que ta errado se é eu que devo ta errada”.

Assim sendo, esta situação foi vivenciada de tal forma que as relações interpessoais não a sustentaram.Relações de confiança construídas há mais de um ano, coroadas com êxito chamando a atenção não somente do pesquisador, mas, sobretudo, de outros professores que avaliaram este grupo como um grupo interessado e motivado para aprender. Estas considerações levaram-nos a concluir que se tratava de um grupo real de trabalho, porém nem mesmo as relações interpessoais que caracterizavam este grupo foram capazes de garantir segurança a $\mathrm{Ga}$, para que ela experimentasse certo nível de tranquilidade permitindo-a controlar o nível de angustia.

Ora, devemos levar em consideração que Ga vinha respondendo as questões a contento, inclusive avaliou que algumas foram de fácil compreensão. Mas de repente, ela se deparou com dificuldades e rapidamente perdeu o controle da situação. Afinal, porque não ponderou sobre a situação, pois já havia trabalhado anteriormente com o grupo?Porque não se acalmou adotando, mesmo que temporariamente, as respostas do grupo, atitude capaz, talvez, de contribuir para diminuir sua angustia, ao refletir: " $E u$ não estou entendendo tudo, mas o grupo parece que está conseguindo responder”. Mesmo porque, o professor intervinha sinalizando os avanços do grupo na direção correta. Obviamente, não estamos defendendo que Ga desistisse de entender por si mesma, adotando a reflexão alheia e desembocando no comportamento passivo do aprendiz. No entanto, entendemos como absolutamente normal o comportamento de algum sujeito em abrir mão temporariamente de seu ponto de vista. Devemos ressaltar que em nenhum momento da atividade, percebemos pelo comportamento de Ga, que ela estava vivenciando maiores dificuldades em comparação com os demais integrantes do seu grupo, pois, durante toda realização da atividade ela não nos direcionou algum questionamento mais específico, ou reclamação mais contundente. Isto tanto é verdade, que nem mesmo Au percebeu as dificuldades ou o sofrimento de Ga. Sendo assim, o fragoroso fracasso, quanto à impossibilidade das relações interpessoais de garantirem certo nível de segurança para ela, nos força a questionar se este grupo, de fato, se 
constituiu como um grupo real de trabalho. A solidariedade ou os laços de compromisso são apenas ilusões, na medida em que $\mathrm{Au}$ pareceu estar totalmente insensível ao sofrimento da colega. Como foi possível, nessa situação, Au avaliar entusiasmadamente a atuação de todos os integrantes, fazendo-nos acreditar que a atividade experimental havia contribuído para reafirmar os laços de confiança entre os integrantes do grupo? Ou, ainda, o desequilíbrio cognitivo foi tão intenso ao ponto de abalar estes laços de confiança de Ga em relação ao grupo?

Antes de continuarmos, vamos considerar as expectativas de Ga em relação ao grupo conforme análise do perfil de realização.Levantamos a hipótese de que Ga tenha estabelecido suas relações interpessoais segundo a necessidade de afiliação. Portanto, podemos considerar a possibilidade de estar presente em seu comportamento a preocupação em observar se os seus colegas a estavam rejeitando. Será que, implicitamente, Ga deixou transparecer certa decepção, certo incomodo, certa frustração na relação com os demais integrantes do grupo, na medida em que eles pareciam não considerar a opinião dela? Será que Ga já havia vivenciado relações interpessoais parecidas com o desconforto vivido na experiência, reminiscências de emoções que teimavam em se repetir? Alguns trechos da entrevista do perfil de realização parecem corroborar esta impressão e nos levaram a classificá-la com o perfil de realização orientado a necessidade de afiliação. Estes trechos revelam que ela foi motivo de chacota sentindo-se humilhada por ter sido considerada "burrinha" por seus colegas. Em certa ocasião, também em uma atividade em grupo, relata ter sentido muito raiva, inclusive do professor, por ser a única a não conseguir responder as perguntas. Em outra situação, sentiu-se diminuída supondo o sentimento envaidecido de um colega ao obter sucesso, enquanto, ela experimentou o fracasso.

Ora, a atividade experimental também parece ter produzido as mesmas sensações, pois Ga afirma: Não eu me senti mal, exatamente, por não conseguir responder as perguntas, enquanto, seus colegas pareciam obter sucesso: desanimei porque se os três estão falando que ta certo. Sucesso reforçado pelo professor, pois este indicava que o grupo trabalhava a contento. Logo, restou-lhe apenas concluir sobre aquilo que vem se repetindo durante anos: [...] eu acho que o erro tava comigo.

Acreditando-se de alguma forma rejeitada, Ga avançou rapidamente comportando-se como se experimentasse falta de amor, conforme o conceito de necessidade de afiliação. Logo, preferiu não incomodar demais os outros integrantes do seu grupo; melhor calar-se, pois não era digna de mais atenção, acreditando possuir uma 
falha que a incapacitava para aprender. Portanto do que adiantariam os esforços explicativos alheios. "[...] entendeu, eu sempre falava, não eu acho que não é assim, talvez eu acho que o erro tava comigo".

Isto posto, talvez este estado de coisas justifique a insensibilidade atribuída a $\mathrm{Au}$ por não ter percebido o sofrimento de $\mathrm{Ga}$, pois logo ao intuir que os colegas pareciam não considerar seu ponto de vista, ela procurou se passar despercebida. Soma-se a esta possibilidade, o fato dos sujeitos orientados à meta performance-evitação serem especialistas em comportamentos capazes de evitar que os outros venham a saber sobre suas dificuldades de aprendizagem, justificando a ignorância dos demais sujeitos a sua volta em relação ao seu sofrimento.

Aliás, talvez Ga tenha sentido o desejo de romper com o grupo, levando-se em consideração a possibilidade desta ter sentido raiva devido à situação de sofrimento a que foi exposta. Entretanto, talvez não o tenha feito, exatamente, por saber da consideração dos sujeitos a sua volta, na medida em que gozava da confiança, principalmente de En, que a considerava esforçada. Portanto, talvez Ga não tenha agido propriamente em relação a este grupo, mas a todas as situações do passado nas quais experimentou sentimentos próximos ao vividos durante a atividade experimental. Obviamente, que é impossível corroborar estas conjecturas, entretanto, é razoável considerá-las como possibilidades.

Ainda em relação aos sentimentos de rejeição e frustração amalgamados à possível raiva talvez sentida por ela, parece-nos também provável deste sentimento ter respingado tanto em relação à atividade quanto à figura do professor. Pois, o motivo essencial que nos levou a suspeitar da orientação à meta performance-evitação de Ga foi sua forte reação em relação à confecção de um simples desenho requisitado pelo professor, conforme relatado no diário de campo. Portanto, a frase do início desta entrevista: "eu não consegui entender o espírito da coisa.”, tenha cumprido duas funções, a primeira descarregar parte da raiva: raiva sentida em relação à atividade, pois esta parecia ter confirmado sua suposta incapacidade intelectual. Também raiva em relação ao grupo, pois seus parceiros a abandonaram ao ousar aprenderem enquanto solitariamente falava sozinha: desenlace afetivo conforme outras relações interpessoais do passado. Raiva em relação ao professor, o orquestrador de uma espécie de "arapuca" experimental, na qual, ela foi capturada em uma espiral descendente de sensações e sentimentos autopunitivos repetindo-se eternamente na sua vida escolar. Portanto, descarregada, parte da energia, faltava apenas cumprir a segunda função, ou seja, o 
desagravo, ao deixar muito bem claro e o mais direto possível através desta frase inquisitória: "eu não consegui entender o espírito da coisa.".

4 - P: Mas foi mais negativo ai, então foi...

E: Isso foi no caso das perguntas, eu achei que eu tava certa, mas depois os três acharam que tava certo, ai eu falei, então ta certo, é porque eu tava errada...

$P$ : Isso representa o que pra você?

$E: \ldots$

$P:$ Que representação isto tem pra você?

E: como assim...

$P:$ Assim o que você acha quando você passa por estas coisas assim?

E: Eu acho que eu sou menos inteligente, do que as pessoas que estão ali, tenho mais dificuldade... que mais, as vezes, eu pergunto várias vezes e ainda continuo sem entende, com dificuldades pra entende...

$P$ : Então, mas os meninos também perguntavam para mim varias vezes a mesma coisa?

E: Isso o senhor., perguntava..que nem no caso, varias vezes foi perguntado e o senhor respondeu, até então, essas três ai, eu não entendi, o senhor explicou, explicou, explicou e não entrou.

No trecho antecedente, levantamos as expectativas negativas de Ga no tocante às relações interpessoais. Sendo assim, deveríamos repetir este mesmo procedimento em relação ao conflito cognitivo, entretanto, sobre este item, o que dizer, a não ser de que o mesmo não se efetivou. Ou melhor, este foi vivenciado parcialmente até o momento em que ela experimentou o sentimento de confusão produzido pelas suas concepções espontâneas frente à experiência crucial.

Assim sendo, a partir deste sentimento de confusão, melindrada pelo desequilíbrio cognitivo, Ga não foi capaz de obstar e canalizar energia destinando-a à resolução do problema. Ora, este aumento de tensão psíquica garantiria a energia necessária traduzida no esforço dirigido para o aumento da atenção, foco e concentração capazes de contribuir para a assimilação-acomodação de um novo conhecimento, aprimorando as estruturas de pensamento e satisfazendo o mecanismo de equilibração majorante. Contudo, este aumento não deveria produzir mais desconforto, pelo contrário, até produziria prazer na medida em que a energia fluísse livremente através das ações mentais do sujeito conforme este percebe estar evoluindo.

Por outro lado, no caso de $\mathrm{Ga}$, provavelmente o desconforto psíquico tenha produzido um curto-circuito, com consequente desvio de energia para o mecanismo disruptivo de motivação. Ou seja, a energia obstada pela confusão e pela dúvida foi direcionada, não para a resolução do desafio, mas para comportamentos de menor potencial, considerando a ideia de que estes comportamentos são de menor potencial 
exatamente por estarem cristalizados nas atitudes do sujeito e ligados às conhecidas expectativas negativas do mesmo, traduzidas em reações desesperançadas, autoavaliações pejorativas com o consequente exaurir de suas forças.

Portanto, acreditamos não ter faltado capacidade cognitiva, principalmente, porque Ga vinha obtendo sucesso. Todavia, houve um excesso de energia direcionada para angustia produzindo pensamentos destrutivos, impedindo-a de se acalmar, condição capaz de contribuir com suas tentativas de compreender o novo conhecimento. Portanto, é provável que este excesso de angustia justifique sua impossibilidade para aprender. Portanto, o conflito cognitivo não é o responsável em produzir as reações deletérias vivenciadas pelo sujeito ao realizar a atividade de aprendizagem, mesmo porque, estas já estavam cristalizadas em seu íntimo, construídas por anos de fracasso escolar constituindo a ecologia conceitual do sujeito relativo às suas possibilidades para aprender.

Ainda em relação ao conflito cognitivo, quando da análise de $\mathrm{Au}$, chamamos a atenção sobre a possibilidade do desequilíbrio trazer em seu cerne minimamente a lembrança da surpresa e o deslumbramento sentidos no seu encontro com a bola magnética. Não obstante, nos ocorre à mesma impressão, em relação à Ga, ou seja, o desequilíbrio também traz reminiscências do passado, obviamente, lembranças dolorosas. Repetem-se as mesmas sensações capazes de levá-la aos sentimentos de outrora. A solidão de quem se considera rejeitado e a frustração, pois mais uma vez, a realidade confirma a incapacidade para aprender: "Eu acho que eu sou menos inteligente, do que as pessoas que estão ali[...]".

Isto posto, inacreditavelmente, $\mathrm{Au}$ e $\mathrm{Ga}$ são lados opostos de uma mesma moeda, um o avesso do outro. Pois, a mesma realidade que produziu um, também gestou o outro. Conquanto, um parece ser representante da providência divina, abençoado com toda a inteligência e força de vontade, acreditando-se infalível, certo do sucesso, não havendo conhecimento que não pudesse absorver utilizando-se de ferramentas básicas como esforço e dedicação. O outro, amadrinhado por um anjo tordo, desgraçadamente presenteado por uma suposta falha cognitiva, vaga pelo mundo exaurido de suas forças, havendo sempre um conhecimento impossível de ser aprendido a despeito dos seus hercúleos esforços. Portanto, tanto um quanto outro, encontram na realidade, na cultura ou imaginariamente razões para comprovar, seja a certeza do sucesso, ou o fragoroso fracasso. 
Em relação a MMC Ga trilhou somente o primeiro passo, ou seja, a insatisfação dos conceitos frente à experiência crucial. Portanto, não há o que dizer sobre os passos referentes à inteligibilidade, plausibilidade ou fertilidade. Pois, o alto nível de angustia experimentado por ela a impossibilitou de compreender minimamente o novo conhecimento, tamanho o seu desespero. Logo, pesquisadores da área poderão responsabilizar a estratégia por produzir déficits motivacionais, ou, observarão surpresos de que o sujeito nada aprendeu.

Isto posto, em nosso referencial teórico trouxemos diversos exemplos das críticas e das reflexões sobre a crise motivacional supostamente produzida pelo conflito cognitivo, ou pela condição de insatisfação. A primeira reação a este problema foi a perda da condição prévia do conceito de insatisfação ou do conflito cognitivo. Muitos pensadores saíram em defesa do conflito cognitivo, advertindo ao professor sobre o devido cuidado no manejo da estratégia, afim de evitar a possibilidade de o conflito significar para o aluno o fracasso total de suas ideias prévias produzindo desde a recusa total do novo conhecimento, ou uma defesa radical do conhecimento espontâneo por parte do aprendiz em detrimento do conhecimento científico (Gil-Perez, 1999)

Isto posto, parece-nos que esta recomendação em se tratando do caso do sujeito $\mathrm{Ga}$, provavelmente surta pouco ou nenhum efeito. Pois, ela era hiper-vigilante em relação às situações nas quais experimentasse sentimentos de dúvida, ou, mesmo confusão, decorrentes de situações de aprendizagem nas quais percebesse que não estaria aprendendo como consequência de sua suposta incapacidade cognitiva. Portanto, por mais que haja esmero do professor no gerenciamento do conflito, pode ser pouco provável que Ga não se sentisse desesperada ao experimentar o sentimento de confusão produzido pelo conflito cognitivo, pois esta é a natureza desta estratégia, ou seja, a nova lógica contraria, mesmo minimamente, a lógica anterior, advindo sentimentos de confusão ou dúvida.

Assim sendo, imaginemos por hipótese de que a insatisfação ou o conflito sejam deixados para o final da estratégia de ensino. Portanto, o professor inicia a atividade apresentando o novo conhecimento investindo na compreensão junto aos alunos. Aplica-o em situações de sucesso e fornecendo exemplos diversos contribuindo para a robustez e a frutificação do conhecimento científico. Após algumas aulas, o professor apresenta uma situação cotidiana, na qual, os conhecimentos prévios e o científico 
concorram para resolução do problema, portando, produzindo certo nível de confusão ou dúvida. Provavelmente, $\mathrm{Ga}$, se sentiria tão incomodada quanto se sentiu durante esta atividade, exatamente, pelo monitoramento e pelo desespero em relação às situações nas quais era acometido por sentimentos de confusão ou dúvida. Pois, esta era sua condição de entrada quando da realização de alguma atividade escolar independente se esta se baseia ou não no conflito cognitivo. Portanto, caso se tratasse de uma atividade de ensino tradicional, no momento em que experimentasse a dúvida, parece natural, conforme seu perfil de realização e as evidências vistas até aqui, de que Ga iniciasse o mecanismo disruptivo levando-a ao desespero e a perda de controle da situação.

5 - P:Então veja bem, o aluno.... me perguntou na ultima questão se o corpo é um bom termômetro, então não foi só você que não entendeu ?

E:Sei lá, as vezes eu acho que é só comigo...

$P: A i$ quando acontece essas coisas você....E se você tivesse sozinha?

E: Seu eu tivesse sozinha?

$P:$ Se não tivesse o grupo, por exemplo?

E: Eu acho que não tinha conseguido responde a metade...

$P$ : Por quê?

E: Porque ... eu sozinha, eu não consigo...

$P$ : Mas porque você não consegue ou porque você perde a motivação antes, ou as duas coisas?

E: As duas coisas...

Este trecho é relativo a erro cometido por $\mathrm{Au}$, pois este havia concluído na pergunta número dez de que o corpo humano é um bom instrumento de medida de temperatura. Ora, toda a atividade experimental foi construída sobe a confusão produzida pelas diferentes sensações térmicas sentidas pelo corpo humano que pareciam indicar diferentes temperaturas para colheres de diferentes materiais. Portanto, a conclusão obvia seria de que o corpo humano não permitiria a leitura confiável da temperatura, já que todas colheres estavam à mesma temperatura. Isto posto, responder, ao final da atividade, de que o corpo humano é um bom instrumento de medida passa a impressão de que o sujeito aprendeu muito pouco ao realizar a atividade. Logo, questionamos junto a Ga porque ela sentiu-se tão mal durante a realização da atividade, pois não somente ela sentiu-se confusa ou em dúvida, mas o próprio Au também sentiuse confuso e cometeu erros durante a atividade, inclusive este grave erro. Em seguida, Ga justificou suas reações atribuindo a si mesmo as sensações de desespero: "Sei lá, as vezes eu acho que é só comigo..." 
A bem da verdade, a pergunta talvez fosse esta: "Porque você reagiu com tamanho desespero em relação a confusão, aos erros e as dúvidas? Veja o sujeito $\mathrm{Au}$, ele também cometeu erros e mesmo assim, não se sentiu tão mal quanto você?" Ora, diante deste tipo de comparação inquisitória somente poderíamos produzir a resposta na qual ela concluiria possuir uma suposta falha pessoal. Isto posto, a mesma impressão também foi produzida durante a análise do perfil de realização de Ga em que pareceu esforçar-se para não passar a imagem de aluna indolente, cansada de justificar aos outros porque não aprendia.Isto posto, temos uma forte impressão que inadvertidamente, também colocamos a aluna em uma condição forçando-a a concluir sobre àquilo já cristalizado em seu íntimo, ou seja, a crença de possuir alguma falha fazendo-a diferente dos outros. Portanto, cansada de procurar razões do seu sofrimento quando comparado aos outros, ela rapidamente desembocou em uma avaliação autoflagelante. Talvez fosse impossível outra auto-avaliação a não ser esta, pois afinal foram anos de fracasso escolar engendrando junto ao sujeito a crença em sua suposta incapacidade intelectual.

Ainda levando-se em consideração a análise do perfil de realização da aluna chamamos a atenção para a existência de um fictício instrumento de tortura no qual ela poderia se imolar castigando-se pelos seus fracassos. Caso ela tenha percebido a comparação entre os sujeitos realizada durante a entrevista, esta tenha contribuído para aumentar ainda mais os sentimentos humilhantes com os quais ela já foi outrora exposta. Entretanto, não temos como corroborar estas conjecturas deixando-as para a avaliação do leitor.

Contudo, apesar da hipótese acima, devemos levantar outra, pois temos a impressão de que a própria Ga parece estar se comparando pejorativamente em relação aos outros integrantes do grupo ao afirmar ter sido o único membro do grupo incapaz de conseguir compreender, consequência fruto da crença em suas impróprias capacidades. Isto posto, os mecanismos de tortura estão internalizados dentro dela sujeito sendo iniciados a partir da mínima percepção do sucesso alheio, enquanto ela colherá o fracasso. Assim sendo, isto diminui nossa responsabilidade no acionamento deste mecanismo, contudo, manteríamos nossa contribuição para os sentimentos de humilhação considerando que Ga percebeu a inadvertida comparação entre os sujeitos realizada pelo professor pesquisador.

Antes de continuarmos, gostaríamos de ressaltar um "insigth" no aprofundamento na compreensão de dois conceitos utilizados para entender os objetivos 
com os quais os sujeitos estabelecem suas relações interpessoais. No caso de $\mathrm{Au}$, concluímos que o sujeito estabeleceu suas relações interpessoais em torno do calor humano, da existência do amor; isto posto, este acreditava que as relações humanas podiam proporcionar segurança, companheirismo, compreensão. Pois bem, temos a impressão que foi exatamente isto o que sentiu $\mathrm{Au}$ em relação ao seu grupo. Estes sentimentos devem ter ocorrido não somente porque o sujeito obteve sucesso ao final da atividade, pois ele também sentiu-se confuso, inclusive cometeu erros percebidos pelos outros integrantes do grupo. Ou seja, não somente o sucesso foi dividido pelo grupo, mas também os sentimentos de frustração, logo superá-los contribuiu para reafirmar os elos de amizade dentro do grupo; portanto, as frustrações, os prazeres e os desprazeres deveriam fazer parte da própria vivência não se podendo culpabilizar alguém pelo fracasso ou festejar um único integrante pelo sucesso.

Contudo, o mesmo não pode ser dito em relação à necessidade de afiliação, no qual os sujeitos estabelecem seus vínculos afetivos buscando evitar a rejeição, o abandono ou o fracasso. Ora, estes sujeitos buscam nas relações interpessoais diminuírem as possibilidades de sofrerem com as vicissitudes, com os reveses presentes nas situações as quais o sujeito está normalmente exposto. Logo, quando lhe ocorre o fracasso, o sujeito olha ao seu redor culpando os outros, independente, se estes teriam condições de evitar ou não o acontecido.

Isto posto, talvez o conceito de necessidade de afiliação ajude-nos a compreender as afirmativas feitas por Ga direcionadas ao professor: "eu não consegui entender o espírito da coisa.", ou, relacionadas ao grupo: "o grupo achou que era outra, eu me senti desmotivada, desanimei porque se os três estão falando que ta certo". Como se o sujeito indignado acusasse os outros, dizendo: "eu me afiliei a vocês, confiei em vocês, então como puderam permitir o meu fracasso, porque não me protegeram, porque não cuidaram de mim”.

Portanto, os sujeitos pretendem escapar a rejeição, rejeitando ao perceber a possibilidade de serem rejeitados. Neste caso, Ga rejeitava o grupo e o professor exatamente por estes não terem sido capazes de impedir a ocorrência do seu fracasso. Logo, acreditando-se despossuída de poder para enfrentar as instabilidades ou os desafios das situações cotidianas, também retirou o poder alheio ao concluir: "Não adianta insistir, pois sou incapaz para aprender". Pois, de uma só vez, indubitavelmente, apontava o fracasso da ajuda do incautos que por ventura tivessem em mente socorrê-lo, mantendo a postura de vítima orgulhosa de sua ignóbil situação. 
Voltando a análise do trecho, não nos causa estranheza o fato de Ga acreditar-se incapaz para solucionar os desafios propostos pela atividade caso tivesse de resolvê-la contando apenas com suas próprias capacidades. A bem da verdade, é muito provável, que dificilmente algum aluno conseguisse resolver esta atividade somente com a ajuda do professor ou do texto de apoio, caso dispensasse, ou não se valesse das importantíssimas discussões com seus pares. Obviamente, Ga apostou na certeza do fracasso, ao concluir que se não conseguiu compreender com o auxílio do grupo, situação na qual valeria a máxima popular de que "várias cabeças pensam melhor do que uma", logo, sozinha poderia fazer muito pouco, ou quase nada para a obtenção do sucesso. Contudo, deve-se ressaltar a facilidade com a qual Ga chegou a este veredicto sobre sua responsabilidade quanto ao fracasso na resolução da atividade. Ora, esta avaliação esta diretamente em acordo com seu perfil de realização no qual atribuia a si mesmo uma suposta incapacidade para aprender.

A forte reação de $\mathrm{Ga}$, assim como as reações de $\mathrm{Au}$, devem ser vistosnão como casos singulares, mas a luz de inúmeras constatações em pesquisas da área apontando as dificuldades dos aprendizes em gerenciar o conflito e a consequente improdutividade das discussões em grupo, colocando em "cheque" este importante cânone do modelo sócio-construtivista.

Assim, conforme analisado em trechos anteriores desta mesma sessão sobre o fracasso das relações interpessoais ao falharem do ponto de vista motivacional, não é garantida nenhuma segurança para que o sujeito se sinta minimamente tranquilo para a resolução do desafio. Desta forma, o mecanismo de desenvolvimento proposto por Vygotski não pode se efetivar na medida em que a mente do sujeito foi invadida por pensamentos angustiantes quanto a sua possibilidade de resolver a tarefa.

Logo, a alta ansiedade vivida por Ga traduzido na forma de um fluxo caótico e excessivo de pensamentos e ideias pejorativas contras si mesmo, impediu-o de cotejar o ponto de vista alheio, portanto, com a mente inundada, esta não foi capaz de absorver o novo conhecimento. Pois, apesar de o grupo, com a ajuda do professor, parecer avançar em direção a resolução do desafio, Ga não concentrou seus esforços no domínio dos pontos explicativos deste novo conhecimento. Podemos, então, conjecturar que Ga tinha sua concentração desviada por preocupações excessivas sobre a possibilidade de consecução da tarefa fruto de sua crença em uma suposta incapacidade para aprender e 
pelo autoflagelo através de avaliações pejorativas. Logo, os sujeitos mais capazes representados, seja pelo professor, seja pelos seus colegas que pareciam conseguir resolver o desafio, não conseguiram atuar na zona de desenvolvimento proximal de Ga, trabalho intrapsíquico essencial para dinamizar a efetivação do conhecimento potencialjunto ao sujeito.

No mesmo sentindo da conclusão em relação ao conflito cognitivo, também as relações interpessoais não podem ser responsabilizadas pela improdutividade das discussões realizadas em sala de aula. Pois, aqui estavam em jogo, pelo menos, em relação a Ga, seu perfil de realização impedindo-a de efetivar os mecanismos destinados à evolução do pensamento. Não porque estes não funcionavam conforme predito pela teoria, masporque Ga possuia um perfil de realização propício à rápida involução para o desespero e a consequente perda do controle, impedindo-a de aprender.

Antes de encerrarmos, gostaríamos de discutir sobre o desconforto emocional produzido pelo contado com o sofrimento de Ga. Em muitos momentos, seja na entrevista do perfil de realização, mas principalmente na presente entrevista analisada, sentimo-nos como se estivéssemos fazendo o sujeito Ga sofrer. $\mathrm{Na}$ entrevista, referente ao perfil de realização, no momento em que pedimos para ela lembrar-se de situações tão humilhantes, contribuíamos para o seu sofrimento, parecíamos "cutucar" sua ferida. Por outro lado, na entrevista agora analisada, sentimo-nos por vezes torturadores, pois além de produzir a atividade de ensino, viemos agora a contemplar seu sofrimento, inquirindo-a sobre porque não se motivou a aprender, onde pelos menos teórica e experimentalmente, outros se motivavam nesta direção. Experimentamos um misto de indignação e surpresa: indignação, pois pretendíamos obter como resultado o aumento do interesse da aluna; surpresa, por produzirmos exatamente o contrário. Afinal, como professores sócio-construtivistas, estávamos interessados em proporcionar uma situação de aprendizagem capaz de entusiasmar os participantes, marcar suas histórias educacionais enaltecendo a importância do conhecimento científico. Ora, sentimento e desejo vivenciados também por nós na condição de alunos durante nossa própria história no contato com a ciência, sentimentos e condicionamentos também capturados em outras pesquisas da área (Barolli;Valadares;Villani,2007)

Assim sendo, creditamos este desconforto emocional a nossa formação, nossa pouca experiência no contato com este tipo de sentimentos, pois como profissionais 
licenciados em Física não fomos preparados para as inquietantes emoções emergidas neste trabalho. Portanto, foi causa de inquietação e consternação em determinados momentos da entrevista sentirmos responsáveis em produzir os sentimentos tão deletérios vivenciados por Ga. Talvez esta razão tenha produzido uma grande diferença na quantidade e na qualidade do relato de Au, quando comparado ao de Ga, pois em determinado momento insistir demasiadamente na investigação através de perguntas parecia fazer sofrer ainda mais esta aluna. Nestes momentos, passava em nossa mente o desejo de terminar o mais rápido possível, afim de interromper tal constrangimento. Obviamente, que suas dores emocionais foram produzidas exatamente pelo presente fracasso, contudo, talvez este fracasso também veio a confirmar junto à aluna sua suposta incapacidade cognitiva, aumentando ainda mais seu desconforto.

Em resumo, a diferença entre o relato de Ga e os de En e Au pode ter sido provocada ou influenciada pelo desejo de rapidamente terminar a seção de tortura por parte do professor-pesquisador, somado ao desconforto emocional vivenciado por Ga ao relembrar e refletir sobre as razões que a levaram a avaliar a experiência de aprendizagem como uma vivência de fracasso.

\subsection{1 - Resultado da Análise dos Dados da Entrevista de Acesso a Percepção Motivacional de Ga}

Em seu relato, Ga deixou clara sua desaprovação, demonstrada através de certa animosidade ao afirmar não ter entendido qual o propósito da atividade de aprendizagem. Este possível rancor estava ligado aos fortes sentimentos de angustia vivenciados durante a realização da mesma. Estes sentimentos iniciaram-se com o aumento gradativo da complexidade da tarefa, amplificando-se, sobremaneira, quando Ga experimentou o sentimento de confusão produzido pelo conflito sócio-cognitivo. Confusa, advieram sentimentos de desespero aliados a julgamentos auto-depreciativos levando-a à perda do controle emocional e cognitivo da situação impedindo-a de cotejar e se beneficiar das explicações dos outros integrantes do grupo, ou mesmo, das intervenções do professor.

Em relação ao grupo, a dificuldade em gerenciar o desequilíbrio cognitivo foi vivenciada de tal maneira a impossibilitar os laços afetivos de garantirem segurança, e, consequente tranquilidade ao sujeito. Pode-se conjecturar, também, o afrouxamento ou o desgaste dos elos responsáveis em garantir a harmonia grupal, pois, Ga sentiu-se 
desprestigiada em relação ao grupo, ao acreditar que os outros integrantes não levaram em consideração sua opinião. Destarte, soma-se a isto, a impressão de ter sofrido com o abandono, pois se sentiu perdida e confusa como se nada estivesse entendendo. Segundo sua avaliação, este desamparo não foi causado somente pelos seus colegas, mas também pelo professor, pois o grupo continuou com a resolução do desafio apoiado nas intervenções realizadas pelo profissional a despeito das reivindicações aflitas feitas por ela. Assim sendo, acreditava-se menosprezada pelos seus pares, humilhada e desesperançada por se acreditar como único integrante do grupo incapaz de conseguir compreender o novo conhecimento; logo, este conjunto de sentimentos e autoavaliações acabaram por contribuir para desmotivá-la ainda mais, com consequente exaurir de suas forças creditando somente a si a responsabilidade pelo fracasso.

Ao final da atividade, Ga conclui que o fragoroso fracasso desta experiência, somava-se a uma infinidade de outros presentes em sua história escolar corroborando, sem sombra de dúvidas, a sua suposta incapacidade para aprender. Esta avaliação autodepreciativa a fez concluir prontamente de que seria incapaz de terminar ao menos a metade da atividade, caso estivesse sozinha, conclusão que a impedia de salvaguardar algum resquício de auto-estima.

Portanto, esta mesma atividade de aprendizagem pareceu para $\mathrm{Au}$ ter se constituído um lugar propício para a sua atuação, permitindo-o liberar prontamente suas energias em direção ao conhecimento, pois possivelmente contemplou suas crenças em relação ao significado do binômio "aprender-ensinar". Infelizmente, temos a forte impressão, considerando todo o processo, inclusive as entrevistas, destes terem sido capazes de sujeitar Ga a uma espécie de maquinação psíquica de tortura constituída por sentimentos deletérios como a humilhação, a vergonha e o medo do julgamento alheio mediante o fracasso. Obviamente, que Ga não desejava vivenciar estes sentimentos, muitos menos, apostava no fracasso quando do início da atividade, entretanto, estes condicionamentos estavam amalgamados à sua história escolar, compondo um rol de expectativas negativas quanto ao binômio aprender-ensinar em acordo com seu perfil de realização.

\subsection{2 - Expectativas Epistemológicas Sobre Aprender-Ensinar}

Conforme resultado final da análise do perfil de realização concluímos que Ga estava orientado à meta performance-evitação, acreditando-se incapaz para aprender. Os sujeitos orientados a esta meta desconfiam fortemente de suas possibilidades de enfrentar os desafios acadêmicos mesmo valendo-se do esforço ou da dedicação.Ga 
durante os anos nos quais frequentou os bancos escolares apesar de ter se esforçado na direção do conhecimento, não elaborou um rol de estratégias satisfatórias com as quais pudesse dar conta dos desafios acadêmicos, amargurando, então, inúmeras e contundentes situações de fracasso conforme relatado e analisado na seção supra citada.

Portanto, com um auto-conceito pejorativo e com comportamento e atitudes deficientes no tocante as suas estratégias de auto-eficácia, Ga não conseguiu blindar sua psique de uma avalanche de preocupações quanto sua capacidade de responder aos desafios escolares. Este condicionante complicou ainda mais quando advieram os sentimentos de confusão produzidos pelo desequilíbrio cognitivo, logo, não conseguiu experimentar o mínimo de segurança capaz de lhe garantir a tranquilidade necessária para o gerenciamento e a solução do conflito sócio-cognitivo.

Nesse sentido, podemos admitir que seu comportamento durante a atividade de aprendizagem evoluiu rapidamente para a perda do controle da situação, através de ações desesperançadas, com o consequente abandono emocional e cognitivo de tentar compreender o novo conceito, recaindo no ciclo vicioso do direcionamento de parte de sua raiva na forma de um conteúdo depreciativo contra si mesmo em acordo com a situação de desamparo.

Como resultado da análise do perfil de realização do sujeito Ga chegamos a conclusão de que ela aprendeu a desconfiar dos relacionamentos restritos ao cotidiano escolar. Pois, em sua relação com os professores, sentiu-se inúmeras vezes rejeitada, pois não foi capaz de corresponder aos padrões exigidos academicamente. Nas relações escolares com seus colegas sentiu-se humilhada, ao ser considerada "burrinha", sendo que estas situações a marcaram profundamente. Portanto, acreditamos que ela buscava nas relações evitar sentimentos dolorosos como a rejeição, levando-nos a concluir que seus relacionamentos eram estabelecidos em torno da falta de amor indo ao encontro de sua necessidade de afiliação.

Contudo, como Ga fazia parte de um real grupo de trabalho, acreditávamos na possibilidade destas relações interpessoais garantirem a segurança necessária para que pudesse gerenciar o conflito sócio-cognitivo. Entretanto, ela reagiu de tal maneira em relação ao desequilíbrio que não somente os laços afetivos não foram capazes de garantir segurança e tranquilidade, mas também parte de sua raiva parece ter sido direcionada aos integrantes do grupo, pois se sentiu abandonada pelo grupo, confusa e perdida sem alguém para socorrê-la. Parte desta raiva, também, deve ter sido direcionada a figura do professor, pois se sentiu decepcionada com o profissional, pois 
este não conseguiu solucionar suas dúvidas. Ela pode ter sentido raiva ao sentir-se desprestigiada, pois o grupo continuou com a resolução do desafio apoiado nas intervenções do professor, enquanto ela continuava sem obter o conhecimento.

Assim sendo, sentindo-se menosprezada pelos seus pares, humilhada e desesperançada por se acreditar como único integrante do grupo incapaz de conseguir compreender o novo conhecimento, este estado de sentimentos e auto-avaliações a aproximaram da necessidade de afiliação na qual o sujeito parece cobrar de seus pares algum tipo de proteção ilusória contra os sentimentos de desamparo, rejeição e frustração produzidos pelo fracasso. Mesmo que os sujeitos ao seu redor não fossem diretamente responsáveis, ou, por simplesmente ignorarem a ocorrência de tais sentimentos.

Obviamente, em se tratando do caso de Ga diferentemente do realizado para $\mathrm{Au}$ não temos como discutir sobre suas expectativas epistemo-metafísicas relativas à ciência pelo simples fato destas expectativas não terem surgido durante a entrevista de análise do seu perfil motivacional.

\section{3 - Análise dos Dados da Entrevista de Acesso a Percepção Motivacional de En}

1 - P: Deixa eu começar aqui, pronto, é...O que você achou da atividade?

E: Eu gostei, gostei muito

P: Assim mais é, o que você achou mais interessante assim, por exemplo, que você tem idéia?

E: Olha, o que eu gostei mesmo foi a gente trabalhar em grupo pra debate porque foi muito legal.

P: É, qual a diferença por exemplo de uma atividade como esta aqui e as atividades que você tem em outras aulas, por exemplo, que pontos que você apontaria as diferenças? E: Eu acho que essa daí, a gente pôde, é assim oh, assim esse trabalho que a gente tá fazendo a gente pode ta discutindo com outros, com os meninos né, a gente vai e discuti, teve muitas coisas, eu falava que era uma coisa e eles achavam que eram outra dai a pouco juntava o que eu tava pensando com que ele tava pensando e dava certo ..e as outras matérias não a gente não pode tá debatendo a não ser que a gente mesmo se junte e faça isso.

En concordou com $\mathrm{Au}$, demonstrando também certo entusiasmo ao afirmar que a atividade é bastante interessante, exatamente, pelo fato desta fomentar o trabalho em grupo tendo como pontos altos o debate e a troca de ideias. Nesse sentido, quando da análise deAu, levantamos também a hipótese de as discussões terem enriquecido a atividade com maior dinamismo contribuindo para que ele não se sentisse entediado, 
impressão também reafirmada pela En, principalmente considerando que a atividade durou mais do que duas aulas de cinquenta minutos ininterruptamente.

Durante a análise do perfil de realização de $\mathrm{Au}$, chamamos a atenção do leitor para um possível "insight" relativo ao aprofundamento do real significado do "envolvimento ativo do sujeito", como significando o revolver dinâmico das estruturas de pensamento animadas energeticamente pelo desejo em aprender o novo. Ora, quando En relata: "a gente pode ta discutindo com outros, com os meninos né, a gente vai e discuti, ,"

Podemos perceber o dinamismo da situação produzida por uma possível discussão acalorada sobre o tema. Entretanto, talvez não seja somente o dinamismo relativo a uma possível discussão animada, talvez esteja presente no relato deEn o movimento de seu pensamento: "teve muitas coisas, eu falava que era uma coisa e eles achavam que era outra". Em seguida, os sujeitos produziam a síntese entre as duas assertivas: "juntava o que eu tava pensando com que ele tava pensando e dava certo". Obviamente, que para garantir que estes trechos representam o revolver das estruturas cognitivas de En, deveríamos tê-la arguido procurando saber quais os trechos foram responsáveis em produzir a divergência de ideias para, logo depois, concluir em torno do consenso. De qualquer forma, apesar de não conseguirmos corroborar o movimento cognitivo dela, fica registrado o impacto deste possível movimento. Afinal é razoável considerarmos que En tenha experimentado algum tipo de dinamismo cognitivo, na medida em que considerava o fenômeno digno de nota sendo um dos pontos altos da atividade.

Ainda em relação a este trecho, devemos considerar que En vivenciou pelo menos minimamente certo nível de concentração, pois manteve-se atenta o suficiente não somente para perceber as diferenças entre sua opinião e as afirmativas dos colegas, mas, principalmente, para produzir uma síntese capaz de solucionar alguma das questões. Devemos ressaltar que este nível de concentração talvez não seja o mesmo nível de motivação intrínseca vivida por $\mathrm{Au}$, entretanto, devemos pensar em algum nível de concentração quando se resolve um questionário no qual as respostas estão diretamente no texto, e num nível maior ainda quando se está diante de pontos de vista contraditórios, obrigando o sujeito a monitorar quais são os aspectos concordantes ou dissonantes capazes de produzir a recusa, a aceitação, ou a síntese de afirmativas como foi caso. 
Em razão da análise do perfil de realização de En, levantamos a possibilidade de ela apresentar níveis consideráveis de ansiedade ligados à possibilidade do fracasso. Ela também demonstrou certo temor, na medida em que optou por não responder as perguntas ao invés de correr o risco de ser alvo da exposição publica caso cometesse algum erro. En também declarou preferir abrir mão de seu ponto de vista, mesmo naqueles momentos nos quais teria razão, pois pretendia evitar o embate demasiado, chamando-nos a atenção sobre duas possibilidades, a primeira: de que ela não se sentia segura o suficiente para defender o seu ponto de vista, a segunda: de que ela buscava um comportamento mais conciliador.

Contudo, independente, destas possibilidades En pareceu ter se sentido bastante segura ao realizar a atividade considerando que necessitou de certa coragem ao expor seu ponto de vista. Por outro lado, não se sentiu ameaçada com a opinião alheia e estava tranquila de tal modo a compreender a síntese entre seu pensamento e o pensamento alheio, atitude bem diferente quando comparados com a reação de Ga.

Assim sendo, nos parece que a segurança durante a realização da atividade resultava dos laços de amizade, confiança e liberdade existentes entre os integrantes deste grupo, pois estes estavam juntos há mais de um ano, organização conduzida pela própriaEn ao utilizar como critério de escolha e permanência no grupo o engajamento e a dedicação dos integrantes na realização das tarefas. Isto posto, talvez justifique a defesa e o entusiasmo por parte de En em relação ao fomento ao trabalho em grupo muito próximos das razões levantadas por Au ao indicar que a organização grupal foi o ponto alto e o diferencial desta atividade quando comparados com outras disciplinas.

2 - P: Em que pergunta você acredita que gerou este tipo de ...discussão

E: (interrompe) Confusão

P: Controvérsia.

E: Foi a sete, essa oito que é..., tem a ver com a sete

$P$ : hum

E: A dez, que a gente debateu muito este assunto e a temperatura do corpo, que a gente ficou debatendo muito, que achava que não era a temperatura, outros achavam que era, outros achavam que era o calor, outros achavam que não era.

En reconheceu que as questões sete e oito foram responsáveis em produzir maior discussão entre os integrantes do grupo. No mesmo sentido a questão número dez que procurava saber se o corpo humano é um bom instrumento de medida de temperatura também causou discussão dentro do grupo. Acreditamos, que esta última questão tenha 
produzido certa controvérsia, ou, mesmo debate, pois Au errou ao concluir na direção de que o corpo humano é um bom instrumento de medida de temperatura.

De qualquer forma, o sujeito avalia que as questões sete e oito produziram maior nível de confusão, corroborando a tese de que conflito cognitivo tornou-se um conflito sócio-cognitivo, pois não só En, mas, também, $\mathrm{Au}$ e $\mathrm{Ga}$ sentiram-se confusos ao entrarem em contado com as perguntas destinadas a produzirem o desequilíbrio.

Isto posto, o desequilíbrio também foi significado na forma do sentimento de confusão, todavia, a reação de En frente ao desequilíbrio foi bastante diferente quando comparado com a reação produzida por Ga. En parece ter se sentido segura e tranquila quanto à possibilidade de responder ao desafio, pois havia a possibilidade delaevoluir para o descontrole da situação segundo o conceito de desamparo conforme avaliamos durante a análise de seu perfil de realização. Nesta seção, também concluímos que ela tinha predileção por situações de aprendizado nas quais espera ser conduzida em direção ao conhecimento de forma segura pelo professor. Portanto, havia o receio de En responsabilizar o professor, pois os sentimentos de confusão vivenciados por ela foram produzidos pela atividade de ensino orquestrada pelo profissional de ensino. Logo, havia a possibilidade de En direcionar sua frustração, ou mesmo raiva, à figura do professor caso se sentisse perdida, assim como fez Ga. Contudo, En não nos parece ter vivenciado níveis preocupantes de ansiedade, pelo contrário, ocorre-nos a impressão de ela ter se sentido bastante à vontade nos momentos em que o grupo realizou discussões com o propósito de resolver o desafio. No entanto, devemos também lembrar sua crença sobre como deve ocorrer o aprendizado: caminho seguro e linear em direção ao conhecimento.

\footnotetext{
P: Porque estava escrito

E: Foi muito legal

P: Porque estava escrito no texto

E: No texto é... Mas esta aqui, foi a mais a oito com a sete né que é uma resposta dentro da outra

P: Certo, é uma resposta, na verdade é a mesma pergunta só que aqui eu quero que você responda só

E: de um jeito é

P: em uma concepção... P: E aqui eu quero que você relacione com a tabela científica

$\mathrm{E}: e^{e}, e ́ .$.

P: entendeu

E: dai a gente ficou muito (som de estalar os dedos)
} 
P: Aqui é uma resposta que eu posso te dizer mais quantitativa. é qualitativa, porque você só vai fala, vai conta o conceito ..e aqui ela mais é quantitativa, porque aqui você vai apresenta um número, por exemplo, alumínio é 0,49

$E: \dot{E}$

P: e a madeira é 0,02 , então ele conduz melhor, dá a sensação de frio

E: De frio ou calor, quero dizer rouba a temperatura do nosso corpo, da nossa mão né

O sujeito ainda confundiu os conceitos de calor e temperatura, fato considerado natural, afinal são conceitos arraigados e de difícil diferenciação. Entretanto, o sujeito compreendeu o mecanismo envolvido na produção das diferentes sensações térmicas ao afirmar que as colheres "roubam" de forma diferente, obviamente, neste caso, trata-se do calor e não da temperatura. Ela demonstrou que realmente se envolveu com a resolução destas questões, pois avaliou que a resposta oito estava embutida dentro da sete diferenciando-as apenas pelo cociente de condutividade térmica.

Assim sendo, podemos considerar que Endeve ter alcançado, pelo menos, uma compreensão mínima da atividade. Esta compreensão deve ter produzido certo nível de satisfação cognitiva, pois no primeiro momento sentiu-se confusa devido ao desequilíbrio. Portanto, incomodada pelo aumento da tensão, animada pela dúvida, ela atuou conjuntamente com os integrantes de seu grupo em direção a compreensão do novo conhecimento, mesmo, talvez, não resultando em um profundo entendimento. Podemos conjecturar desta aprendizagem ter sido o suficiente para devolver a aluna à sua condição de equilíbrio anterior, com a consequente diminuição do nível de tensão psíquica, podendo ter produzido certo nível de satisfação intelectual.

De outra maneira, também devemos levar consideração que ela estava orientada à meta aprender, sendo que os sujeitos assim orientados estão predispostos a apreciarem atividades nas quais o grau de exigência são capazes de proporcionar crescimento intelectual e consequente orgulho após empreenderem esforço e dedicação na solução dos desafios. Nesse sentido, como resultado da análise do perfil de realização de En concluímos sobre a necessidade de haver certa linearidade e equilíbrio representado pelo desafio de um lado, bem como, os esforços, a dedicação e a organização por outro. $\mathrm{Na}$ análise do perfil de realização, En afirmou gostar de realizar tarefas nas quais existisse certo nível de concentração, todavia este não deveria passar de certo limite. Portanto, esforço psíquico traduzido na forma de concentração deveria conduzirà obtenção do êxito diminuindo a possibilidade do sujeito sentir-se frustrado por ter 
passado por um processo no qual o alto nível de esforço despendido, renda-lhe um fruto de nenhuma ou pouca qualidade.

Portanto, podemos conjecturar que a atividade constitui-se um desafio às habilidades e à inteligência de Em e ela sentiu-se à altura de responder a estas exigências. Logo, podemos considerar que o nível de esforço despendido por ela, traduzido num aumento da concentração, e os níveis de ansiedade, quanto ao enfrentamento do desafio, e os sentimentos de confusão produzidos pelo conflito cognitivo foram bem gerenciados por En.

Pois, também como resultado da análise do perfil de realização de En havíamos concluído que ela experimentava certo paradoxo relativo ao seu senso de auto-eficácia, pois ao mesmo tempo em que lhe permitia sentir-se capaz para aprender, contraditoriamente, também a fazia acreditar que se fosse mais inteligente do que realmente era, não necessitaria de tamanho esforço para aprender. Logo, ao final de uma tarefa complexa na qual obteve êxito, após despender esforço e dedicação, ao invés, de se sentir orgulhosa e realizada pelo caminho que trilhou, podia concluir: "Se eu fosse mais inteligente, não estaria passando por isto".

Portanto, o auto-conceito de En girava em torno da sensação da falta, no caso, de um alto cociente de inteligência, impedindo-lhe de sentir maior auto-confiança. Contudo, para compensar esta distância entre o verdadeiro "eu” e a imagem idealizada e projetada de alguém com alto coeficiente de inteligência, ela apostou em estratégias de auto-eficácia, tais como: o esforço, a dedicação e alta organização para enfrentar os desafios do conhecimento. Portanto, podemos conjecturar que a atividade de ensino harmonizou-se quanto aos seus conceitos de auto-eficácia, ao exigir-lhe esforço e dedicação na resolução do desafio; sua organização também foi testada, pois afinal o grupo por ela organizado obteve êxito. Em relação, ao seu auto-conceito pode-se conjecturarque, caso tenha passado por sua mente alguma dúvida intelectual, seja sobre algum conceito, ou mesmo, sobre a possibilidade da consecução do desafio, esta dúvida deve ter sido diluída ao ser distribuída pelos demais integrantes do grupo. Portanto, En experimentou na medida certa alguma dose de desafio e certo medo relativo ao sucesso, empreendeu algum esforço e dedicação, todos distribuídos e modulados pelas relações interpessoais, e desfrutou segurança, tranqüilidade e certo desenvolvimento cognitivo. Ao final, concluiu: "E: Foi muito legal”. 
P: É P: Aqui você falou pra mim sobre a questão da temperatura

E: A temperatura

P: A questão oito, a sete e a oito que houve um debate é, por exemplo, logo na primeira questão você já criou uma certa

E: Uma certa confusão

P: Isto não é uma coisa ruim

E: Não, eu não acho porque desde o início a gente começou a debater e já vê que já vai procurar uma solução pra aquele problema

P:Então, mas você não vai se sentir desmotivada, porque eu não to entendendo faze

E: Não, em momento algum, acho que ninguém do grupo ficou assim

$\mathrm{P}$ : Mas isso não incomodou por exemplo, assim não to entendendo isso

E: Não

P: não to conseguindo faze

E: Não, não incomodou não.

Este trecho da entrevista confirma nossa hipótese de que o conflito cognitivo foi vivenciado pelo grupo como um conflito sócio-cognitivo, pois $\mathrm{Au}$ e Ga também sentiram-se confusos nas questões pertinentes a produzirem o desequilíbrio. En relata ainda que apesar de ter se sentido confusa, não se sentiu incomodada, portanto, podemos considerar que ela não sofreu com altos níveis de ansiedade. Também temos a impressão deela ter vivenciado otimamente o desequilíbrio cognitivo, assim sendo, podemos considerar que En talvez tenha minimamente elaborado certo conhecimento que a devolveu a condição de equilíbrio anterior. Obviamente, que nem todo desequilíbrio produz uma equilibração majorante, contudo devemos considerar a possibilidade de ter havido, no mínimo, uma equilibração compensatória capaz de satisfazer pelo menos algum critério do sujeito.

Logo, considerando que En vivenciou o conflito sócio-cognitivo, e, que este desequilíbrio foi resolvido graças às interações em grupo ou com o professor podemos cotejar duas possibilidades: a primeira, o desafio não esteve muito distante da zona de desenvolvimento proximal de En. A segunda, de que as discussões com o professor (ator privilegiado na atuação do espaço de desenvolvimento proximal), ou, mesmo, a troca de idéias e a interação com os outros integrantes do grupo serviram para internalizar algum conhecimento antes exógeno, fazendo com que ao final da atividade ela a avaliasse como sendo enriquecedora. Contudo, mesmo que este enriquecimento resuma-se à descoberta da dúvida, pois, sabemos o quão raro são os momentos nos quais os alunos evoluem em seus conhecimentos ao ponto de produzirem algum questionamento, isso representaria um avanço na aprendizagem. Principalmente, se esta dúvida é capaz de envolver o sujeito libertando suas ações em direção a uma nova 
compreensão, trata-se de um passo em direção à autonomia, independente se esta evolução é atitudinal, metodológica ou conceitual.

Isto posto, é preciso ter ideia do que está em jogo aqui, pois, caso En tenha realmente se envolvido com o conhecimento, podemos cotejar o dinamismo em torno da solução do problema: a leitura da pergunta, o entendimento do desafio, a dúvida sobre qual procedimento tomar, a leitura do texto em busca de uma resposta, a emissão das ideias, a discussão e avaliação desta ideia por parte do grupo, o descarte daquelas consideradas impróprias, e, finalmente a redação da resposta em comum acordo com o entendimento coletivo(incluindo o professor). Pode-se também conjecturar sobre a precisão da informação, pois quando o grupo não conseguiu evoluir em alguma questão e buscou a ajuda do professor, este forneceu uma informação considerada interessante exatamente por responder uma demanda, uma lacuna na cadeia de raciocínio do próprio grupo ou do sujeito. Esta situação é muito diferente de quando o professor discursa, pois muitas vezes são palavras perdidas no vento, não sendo capazes de produzir nenhum nível reflexão.

Assim sendo, talvez pelo dinamismo de toda a situação, En tenha estado alheia à aflição sentida por Ga. Obviamente, soma-se a esta possível razão, a intenção deliberada desta em passar despercebida, evitando aos outros de tomarem ciência de suas dificuldades. Esta constatação reforça nossa impressão sobre $\mathrm{Ga}$ ter se sentido abandonada exatamente pelo simples fato de seu sofrimento não ter sido percebido por nenhum integrante do grupo, ou, mesmo pelo professor.

P: É, sua percepção sobre o tempo como é que foi?

E: Hum?

P: Nós ficamos duas aulas

E: Olha eu gostei e até achei que a gente se ficasse um pouquinho mais dava pra gente ter respondido as outras três que faltaram né, mas foi

P: Mas você achou muito cansativo o tempo

E: Não, não achei não

P: Mas se acha que o tempo, como é que o tempo passo, quando você ta fazendo uma coisa muito, meio chata

E: Não, foi uma coisa tão boa que eu até comentei, pela primeira vez a aula passou tão rápida que a gente nem percebeu E: Que nem a gente passou a primeira aula, o intervalo e a segunda no caso

P: Não, a segunda

E: a terceira

P: na terceira e no intervalo

E: É o intervalo ainda e já tava entrando na

P: outra aula 
E: na outra aula e a gente não percebeu isso, foi direto, foi no pique ali que se deixasse a gente ia até e nem percebia que o tempo estava correndo foi uma coisa boa, foi construtiva.

$\mathrm{P}: E ́$, então você achou por exemplo, foi uma atividade boa de se faze?

E: Foi uma atividade boa de se faze

A título de comparação, podemos lembrar o comentário de Au também sobre a sua percepção em relação à passagem do tempo: os discursos do En e do Au são praticamente idênticos, como se o discurso de um completasse o discurso da outra. Nos trechos a seguir, ambos versam sobre o dinamismo da atividade de aprendizagem respectivamente: [foi uma coisa tão boa que eu até comentei, pela primeira vez a aula passou tão rápida que a gente nem percebeu], [Na nossa mente, passa rápido]. $\mathrm{O} \mathrm{Au}$ pareceu explicar a frase do En como se dissesse: "Não que o tempo tenha passado rápido realmente, esta foi a percepção da nossa mente”. Assim sendo, os sujeitos aludiam à existência de um fluxo, obviamente, não sabemos se este fluxo se referia somente às ideias, ou mesmo, as atitudes, ou provavelmente a um misto com o propósito de solucionar o desafio. Em outro momento, En pareceu exemplificar os argumento de Au relativos ao controverso papel da concentração : [É mais focado né, mais um foco só, que nem essa matéria ],[foi direto, foi no pique ali que se deixasse a gente ia até e nem percebia que o tempo estava correndo]. Pois, com o aumento do foco e da concentração, ao invés de experimentar a sensação de algo estático, paradoxalmente, nos deparamos com maior dinamismo, como se o aumento da concentração promovesse o fluxo de ideias.

Destarte, estas explicações estão em acordo com o comportamento de um sujeito motivado intrinsecamente, pois os sujeitos assim autodeterminados apresentam alta concentração, por isso perdem a noção do tempo, logo, aquilo que não se relaciona com atividade não é capaz de desviar sua atenção. Portanto, estamos diante de um mecanismo no qual o sujeito obsta e direciona energia para o esforço na forma de concentração, mantendo o foco, animando o pensamento, dinamizando o raciocínio com o propósito da produção de uma resposta para solucionar o desafio. Assim sendo, é pouco provável de que ansiedade ou as emoções negativas produzidas por eventuais dúvidas quanto à possibilidade de êxito tenham conseguido algum lugar propício para vicejar na mente da aluna. Desta forma motivada, En apesar de sentir-se confusa, frustrada diante do fracasso de seus conhecimentos espontâneos, contudo, sentiu-se 
ainda mais instigada a continuar tentando; ao final avaliou: [foi uma coisa boa, foi construtiva.]

Ainda sobre estes trechos, não nos poderia passar despercebido exatamente o fato destes sujeitos produzirem relatos quase idênticos. Poderiamos objetar, dizendo que suas avaliações foram próximas, pois partilharam da mesma experiência. Contudo, estamos aqui chamando a atenção, para um outro patamar de percepção diferente daquele quando distintos sujeitos emitem um parecer técnico ou mesmo subjetivo sobre determinada coisa, pois devemos considerar que os mesmos se preparam para captar o observado, mesmo assim, ainda podem divergir. Contudo, no presente caso, ao passarem por uma situação no qual pretendiam a resolução do problema, ou seja, o objetivo principal era responderem ao desafio e não monitorarem suas emoções durante a atividade de aprendizagem, eles emitiram avaliações muito próximas em relação aos aspectos emocionais vivenciados durante a realização da atividade.

Logo, isto nos leva a conjecturar de que as relações interpsicológicas foram capazes de produzir uma espécie de sintonia intrapsicologica com a mesma impressão em sujeitos distintos sobre tais aspectos emocionais. Este fenômeno é bastante conhecido da psicologia, no qual sujeitos sintonizam-se e se harmonizam quando expostos a situações nas quais estão presentes as emoções tais como: a alegria, a tristeza ou medo, afinal é condição básica da humanidade o reconhecimento semiótico das emoções. Neste caso, provavelmente estes dois sujeitos comungaram do desejo em resolver o desafio, da concentração, de algum medo relativo à possibilidade do fracasso. Principalmente, quando do sentimento de confusão, devem ter experimentado a satisfação por alguma evolução e a alegria verdadeira produzida pela impressão de se ter realizado um trabalho significativo; obviamente não é possível mensurar as emoções, às quais os sujeitos foram expostos, todavia, tristeza ou raiva, provavelmente não advieram.

Isto posto, podemos talvez, então, entender porque En e Au não perceberam o sofrimento de Ga; ora estes estavam em outra sintonia, modulados pela concentração, exigindo que a atenção fosse toda empregada na resolução do problema. Não obstante, também podemos entender porque Ga não conseguiu entrar na mesma freqüência dos demais sujeitos, exatamente, por não ter conseguido manter o mesmo nível de tensão psíquica na forma de concentração, provavelmente, sofrendo interferência produzida por pensamentos deletérios relativos à possibilidade do êxito da tarefa. 
Conforme visto até o momento, estes trechos reforçam em nós a impressão sobre En, assim como $\mathrm{Au}$, destes terem experimentado uma atividade de aprendizagem capaz de produzir certo nível de entusiasmo, fenômeno relativamente raro quando comparado com outras situações de aprendizado existentes no cotidiano escolar. Isto posto, acreditamos que um professor sócio-construtivista sentir-se-ia gratificado não só por ter presenciado tal demonstração, mas principalmente, por acreditar-se responsável em fomentar tal nível de engajamento. Logo, ficaria convicto de que o conflito sóciocognitivo cumpriu o seu papel em produzir junto aos sujeitos os níveis de interesse e de satisfação cognitivas. Contudo, talvez, devido a contundência destes relatos, porventura, este professor sócio-construtivista poderia acabar negligenciando os fortes sentimentos sofridos por Ga considerando-os como um acidente de percurso, ou como fruto da idiossincrasia da mesma, ou, justificando internamente de que é impossível desenvolver uma atividade capaz de agradar a todos. Logo, este procedimento dificultaria ao profissional de ensino de atuar na direção de tentar entender e porventura intervir com o objetivo de auxiliar os sujeitos orientados conforme Ga.

P: Que outras coisas você acha que foi interessante, assim, por exemplo, você falou que foi a discussão, foi esses momentos aqui de E: É o grupo é ele, todo mundo, a gente ficou, sabe: a gente se uniu mesmo, se preocupou com isso pra responder, tanto é que o Áu na, ontem ele ia faltar por causa do (termo incompreensivel), foi um grupo, então isso ai incentiva a gente a fazer, isso é muito gostoso a gente trabalhar com um grupo assim, porque ele falou assim (termo incompreensível) anteontem ele falou assim, não eu não venho, amanhã por causa do trabalho, não você tem que vim, o professor quer você aqui, talvez não vou falar provavelmente independente por causa do trabalho, tudo isso incentiva pra caramba P: Hum, hum, eu tenho que entrevistar ele ainda, não posso deixar de entrevistar ele? E: É, isso incentiva, nossa eu gosto de trabalhar em grupo assim, mas em grupo que, que rende.

Neste trecho, En reafirmou sua opinião ao apontar o trabalho em grupo como ponto principal da atividade, deixando claro sua predileção por este tipo de organização: “nossa eu gosto de trabalhar em grupo [...]”, opinião em acordo com a análise de seu perfil de realização. Entretanto, devemos questionar se somente o tipo de organização foi responsável em produzir o entusiasmo presente no discurso dela, pois afinal ela já trabalhou desta forma anteriormente, logo, não havia nada de ineditismo em tal procedimento. Isto posto, então o que poderia ter causado tal entusiasmo? Este pode ter sido produzido se considerarmos que a atividade de ensino contribuiu para o grupo fortalecer os laços de amizade: “[...] a gente se uniu mesmo [..]”. Todavia, esta hipótese 
ainda não nos parece ser capaz de justificar o entusiasmo da En, pois a mesma já trabalhava há mais de um ano com este grupo e vivenciou outros momentos nos quais obteve grande sucesso: por exemplo, ao participar da feira de ciências da escola ela vivenciou momentos também capazes de fortalecer os elos de amizade.

Assim sendo, acreditamos que o entusiasmo dispensado por En em relação à atividade referia-se, obviamente, ao fato desta atividade ter fomentado as relações interpessoais fortalecendo os laços de amizade entre os integrantes do grupo, conforme as expectativas dela. Entretanto, este entusiasmo também deve ter sido fruto do conflito sócio-cognitivo, pois o desequilíbrio foi traduzido coletivamente pelo sentimento de confusão; este sentimento deve ter produzido alguma dúvida na forma de certo receio quanto à possibilidade de consecução da tarefa. Logo, melindrados os sujeitos liberaram energia para o aumento da concentração e de ações com o propósito de resolver o desafio. Obviamente, En deve ter sentido em seu íntimo que o conhecimento elaborado resolveu alguma demanda interna, e, exatamente, por esta razão ela considerou a atividade de ensino muito envolvente: em suas palavras: "foi no pique ali... que se deixasse a gente ia até e nem percebia que o tempo estava correndo... foi uma coisa boa, foi construtiva.".

Assim sendo, acreditamos que a atividade de aprendizagem fomenta este tipo de engajamento nos sujeitos com perfis de realização orientados a meta aprender, pois esta possui três momentos marcantes e distintos. No primeiro momento, o aprendiz é convidado a trabalhar com suas concepções espontâneas, fazendo-o sentir-se confiante de que solucionará a tarefa. Em seguida, o sujeito percebe que suas concepções fracassam devido ao conflito cognitivo;assim, a atividade evolui de uma simples tarefa, para repentinamente tornar-se um desafio. Ao final, o sujeito graças às relações interpessoais (incluindo o professor) assimila um novo conhecimento capaz de devolvêlo a condição de equilíbrio anterior, solucionando o desafio. Ora, de um só golpe, o sujeito sente-se confiante, depois, confuso e preocupado com a possibilidade da realização do desafio, ao final, conclui entusiasmado de ter participado de uma atividade de ensino que devido ao seu grau de dificuldade possibilitou-lhe crescimento intelectualmente. Portanto, o dinamismo ligado as diferentes emoções experimentadas durante a atividade de aprendizagem estava em consonância, obviamente, com os perfis de realização de alguns sujeitos capazes de suportar as diferentes e, muitas vezes, contraditórias emoções vividas durante o processo de aprendizagem. 
P: E agora, você sentiu que alguém ficou assim horas de confusões assim você sentiu que alguém tipo ficou meio incomodado?

E: Não

P: Em algum momento?

E: Não, ninguém

P: Tá muito confuso isso?

E: Não, não tem, ninguém do grupo ficou assim indeciso é inibido em momento algum

P: mesmo nos momentos de maior confusão

E: Mesmo nos momentos de maior confusão estava todo mundo ali querendo acha uma solução.

Neste trecho, En novamente afirmou não ter percebido nada do comportamento de que algum integrante do grupo que estivesse aflito durante a realização da atividade. Au também não percebeu o sofrimento de Ga, entretanto o relato de En é especialmente oportuno, pois acreditamos que ela se preocupava com a organização, com o desempenho e com o bem estar dos demais integrantes do grupo, sendo sensível e solidáriacom as dificuldades alheias. Ora, isto não significa que $\mathrm{Au}$ fosse insensível, mas ele parece ter direcionado sua atenção a aspectos e preocupações mais racionais, ligadas ao conhecimento, conquanto, En parece ter-se preocupado em garantir um clima organizacional agradável com o propósito de favorecer a realização de um trabalho a contento, inclusive evitando embates desnecessários.

Logo, apesar dos sujeitos orientados à meta performance-evitação serem exímios em executar ações ou comportamentos com o objetivo de evitarem aos outros tomarem ciência de suas dificuldades, como foi no caso de $\mathrm{Ga}$, eles produzem talvez a insensibilidade dos outros integrantes do grupo. Assim sendo, a constatação da insensibilidade de En em relação ao sofrimento de Ga, reforça-nos a idéia de que ela e $\mathrm{Au}$ estavam em outra sintonia, modulados pela tensão psíquica traduzidas em um comportamento concentrado com o propósito da resolução do desafio, ou, nas palavras de En: "Mesmo nos momentos de maior confusão estava todo mundo ali querendo achar uma solução." Portanto, esta sintonia, esta mesma frequência impediu que En entrasse em ressonância com os sentimentos destrutivos e as dificuldades aflitivas sentidas por Ga.

P: É, bom sobre isso já tá, era isso que estava interessado em saber, deixa eu ver se tem mais alguma coisa por exemplo, então é, se você fosse, se você fosse colocar os pontos seria não sei de repente assim: $\mathrm{O}$ trabalho em grupo

E: trabalho em grupo 
P: né,

E: isso

P: Ééé, a dificuldade nas questões assim, a dificuldade das questões também... seria uma coisa motivadora ou desmotivadora?

E: Olha é motivadora porque a gente tem aquele motivo de tá pensando, de ta tentando procura uma solução, ...incentiva a gente, isso deixa a gente com mais curiosidade

P: Você acha que a atividade desperta a curiosidade?

E: Desperta a curiosidade

Neste trecho, En deixou claro que a atividade foi interessante por fomentar o trabalho em grupo. Em seguida, apesar de sugerirmos que as questões seriam motivadoras, ela ofereceu uma interpretação totalmente sua, afirmando que a atividade era motivadora, pois era capaz de despertar a curiosidade: "deixa a gente com mais curiosidade". Curiosidade, capaz de convidar a reflexão, ao raciocínio: "é motivadora porque a gente tem aquele motivo de tá pensando, de ta tentando procurar uma

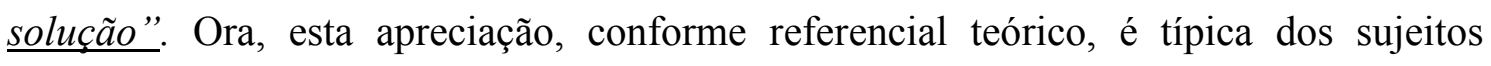
orientados a meta aprender, pois estes tem predileção por tarefas escolares desafiadoras nas quais possam realmente pensar.

P: Que perguntas, que pergunta você acha que tem mais essa característica assim de despertar a curiosidade?

E: De despertar a curiosidade é essa mesmo que eu jamais pensava que fosse o nosso corpo, o calor, pra medir a temperatura, não é né, nesse caso...

P: Ou seja, que há...

E: Que o nosso corpo é....

$\mathrm{P:}$ Não consegue medir a temperatura

E: Não consegue medi a temperatura [P: hum,hum] E: que a gente, que o nosso corpo ele mostra que tá quente, mas ele não pode medir

P: Certo

E: Eu acho isso muito legal, que era uma coisa que a gente desconhecia

Neste trecho, En citou novamente a questão número dez; esta questão causou realmente certa confusão, pois em outros trechos desta análise a mesma já havia produzido alguma polêmica. Temos a impressão de que os sujeitos de um modo geral têm como concepção espontânea a crença que o corpo consegue realmente mensurar a temperatura, afinal toda mãe mede a temperatura do filho colocando a mão em sua testa. Soma-se a este fato, a dificuldade natural dos aprendizes em entender o conceito científico desta grandeza. 
P: Hum, hum e a questão da colher de alumínio ter a mesma temperatura que as outras

E: interessante também

P: Não, desculpa a colher de alumínio ter uma sensação, mais fria

E: mais fria que a madeira é interessante também

P: Mas elas tendo a mesma

E: temperatura né eu achei interessante isso também

$\mathrm{P}$ : Mas isso não criou uma confusão lá na hora

E: Criou uma confusão, mas é..., porque a gente pega na colher a gente vê que a colher estar super gelada e a madeira tá quente [P: hum, hum] E:Lógico que a gente vai logo de cara, fala assim: "a colher é mais fria, a colher ta mais gelada, a colher é mais isso, $e$, na verdade, não é, né, é a mesma coisa [P: hum,hum] E: Na mesma temperatura da madeira que qualquer outra coisa, eu achei isso muito interessante também [P: Hum, hum.]

Neste último trecho, En traduziu o conflito cognitivo no sentimento de confusão, pois apesar das diversas sensações térmicas, todas as colheres estavam à mesma temperatura. Obviamente, o que tornava esta informação um conhecimento interessante era exatamente a possibilidade deste contrariar a lógica espontânea, conforme as palavras de En: [...] E:Lógico que a gente vai logo de cara, fala assim: "a colher é mais fria, a colher ta mais gelada, a colher é mais isso, e, na verdade, não é, né, é a mesma coisa" [...].

Novamente, En corroborou a ideia de que o fluxo contraditório de ideias tornava o conhecimento interessante, pois em um primeiro momento a contrariedade amedrontava-a com a possibilidade de fazê-la experimentar o fracasso ou tomar consciência da existência de alguma lacuna em seu raciocínio. Obviamente, esta dúvida, foi percebida primeiramente de forma racional, afinal ela devia estar cônscia de que suas concepções fracassavam, mesmo que este fracasso fosse denunciado pelo outro. Entretanto, este acontecimento, ainda não garantia por parte de En seu engajamento na busca de uma nova compreensão, pois ela podia escolher negligenciar o conflito. Destarte, esta negligência podia ocorrer por inúmeras razões desde as banais como a falta de tempo ou mesmo o simples desinteresse. Contudo, caso ela desejasse envolverse afetivamente (energia), ou seja, emocionalmente com o objetivo de alcançar a compreensão de um novo conhecimento, ela devia estar predisposta à possibilidade de ser acometida por emoções deletérias, pois poderia sofrer com dúvidas desde a possibilidade do êxito até sua própria capacidade. Portanto, ela deve ter recorrido às suas experiências de auto-eficácia somadas ao seu auto-conceito capazes de garantir certo nível de segurança e tranquilidade. Este processo deve ter ocorrido de forma mais rápida e menos conflitiva possível, pois, caso contrário, ela poderia ter permanecido 
presa ou ter desperdiçado energia em uma rede de pensamentos negativos impossibilitando-a de agir. Sendo assim, a superação deste momento conflituoso só pode ter ocorrido com o advento de um novo conhecimento capaz não só de explicar os resultados do passado, mas também solucionar o desafio presente. Portanto, afetividade e racionalidade caminharam juntas amalgamadas não se podendo diferenciar uma da outra, não se podendo precisar se foi o fluxo do raciocínio responsável em produzir a emoção ou se foi à própria emoção capaz de intensificar o raciocínio. Logo, devemos ressaltar neste caso, sobre aquilo capaz de ter tornado este conhecimento interessante para o Em; talvez não se tenha restringido somente aos aspectos racionais envolvidos, talvez os aspectos emocionais, mesmo contraditórios, como por exemplo, o medo, tenham contribuído com igual importância para avaliação de que todo o processo tenha se constituído uma experiência interessante.

\subsection{1- Resultado da Análise dos Dados da Entrevista sobre a Percepção Motivacional de En}

Antes de iniciarmos a presente seção, gostaríamos de produzir uma pequena modificação, pois ao invés de discorrermos única exclusivamente sobre a percepção motivacional do En, optaremos em traçar uma aproximação entre as razões com as quais En e Au avaliam positivamente a realização da atividade. Assim o fazemos, pois acreditamos que atividade de ensino proporcionou uma vivencia capaz de produzir em sujeitos distintos discursos muitos próximos, portanto En e $\mathrm{Au}$ sintonizaram-se emocional e cognitivamente em torno de sentimentos comuns a ambos.

Em seu relato,En afirma ter aprovado a atividade, pois em vários trechos declarou todo seu apreço por realizá-la, avaliação subjetiva justificada por diversas razões. Uma destas razões foi utilizada por Au, também para justificar sua avaliação positiva no tocante a realização da atividade, sinalizando sobre a possibilidade de ambos os alunos, em vários momentos, terem se sentido altamente engajados, na medida em que foram alteradas suas percepções sobre a passagem do tempo, consideração típica dos sujeitos motivados intrinsecamente. Nesse sentido, En e Au devido ao interesse, e, muitas vezes, graças à curiosidade perderam a noção da passagem do tempo, acreditando que o mesmo passou rapidamente, apesar da atividade ter durado duas aulas e meia, ininterruptamente.Esta atividade não foi considerada tediosa;pelo contrário, ambos os sujeitos atribuíram, como causa para explicar o fenômeno relativo à alteração 
da passagem do tempo, o alto nível de esforço direcionado ao aumento do foco e da concentração durante a atividade.

Em se tratando ainda das razões, com as quais ambos os sujeitos avaliaram positivamente a atividade, estas referem-se às questões destinadas a produzirem o conflito cognitivo, consideradas confusas, e, por isto mesmo capazes de despertar o interesse, bem como, a curiosidade. Logo, isso corrobora a hipótese de que o desequilíbrio foi compartilhado entre os integrantes do grupo tornando o conflitocognitivo em um conflito sócio-cognitivo, pois segundo o relato deles a troca de ideias (incluindo o professor) foi fundamental para possibilitar a resolução da tarefa.

Portanto, a atividade tornou-se um desafio às habilidades e à inteligência de En havendo harmonia entre o exigido e a quantidade de esforço e entrega ofertado pelo pronto engajamento em direção à produção de um novo conhecimento capaz de devolvê-la ao equilíbrio anterior. Ao final, En sentiu-se orgulhosa por ter participado de um processo de aprendizagem no qual o esforço e o engajamento foi traduzido em crescimento intelectual.

Ainda em relação às relações interpessoais, os sujeitos concordaram de que a organização grupal foi o grande diferencial desta atividade quando comparada com as de outras disciplinas, ambos fazendo uma defesa entusiasta deste tipo de organização. Segundo En a possibilidade da troca de ideias e opiniões foram condições propícias para animar todo processo dinamizando a sinergia entre os integrantes do grupo fazendo-a sentir-se realizada pela maneira com a qual o grupo portou-se diante da solução do desafio.

Esta apreciação subjetiva feita pela aluna, muita próxima daquela produzida por $\mathrm{Au}$, parece indicar que ambos sentiram-se seguros e bastante confiantes ao realizar a atividade, como se a atividade fosse ao encontro de algumas de suas expectativas. Portanto, a atividade também parece ter se constituído um lugar propício para a atuação de En, assim como foi para $\mathrm{Au}$, na medida em que possivelmente satisfez algumas de suas crenças sobre o significado do binômio "aprender-ensinar". Não porventura, estas expectativas estão em acordo com seu perfil de realização, sendo assim, vamos aproximar mais intimamente as razões desta apreciação feita por En e as expectativas condizentes com seu perfil de realização.

\subsection{2 - Expectativas Epistemológicas Sobre Aprender-Ensinar de En.}

Em, em razão da análise de seu perfil de realização, apresentou níveis consideráveis de ansiedade ligados à possibilidade do erro ou fracasso. Ela também 
demonstrou desconfiar de sua aptidão para aprender alguns conteúdos de matemática. Nas situações escolares de possível exposição pública, En mesmo sabendo a resposta, preferia não responder, pois temia errar expondo-se a gozação alheia. Em situações ou diante de tarefas, nos quais se sentia perdida ou previa o fracasso surgiam sentimentos de ansiedade, raiva ou mesmo vergonha direcionados para o próprio eu. Sendo assim, segundo estas constatações, estávamos predispostos a classificá-la como orientada à meta performance-evitação.

Entretanto, nesta mesma análise percebemos que os níveis de ansiedade de En não eram tão altos quando comparados aos altíssimos níveis apresentados por Ga ou por Ms, ambos, fortemente orientados meta performance evitação. Nesse sentido, En apesar de desconfiar de sua aptidão para aprender matemática, contudo esta desconfiança não a fazia supor ser incapaz intelectualmente. Apesar de temer a exposição pública, ela não agia pretendendo esconder suas falhas relativas ao domínio de algum conteúdo, pelo contrário, utilizava os erros como estratégia meta-cognitiva para melhorar seu aprendizado, logo ela apreciava ser avaliada, pois podia monitorar seu desenvolvimento. Em relação às emoções, ela se entristecia quando não conseguia realizar uma tarefa a contento, podendo até mesmo sentir raiva de si mesma; contudo, estes sentimentos não eram fortes o suficiente para fazê-la desistir, e nem tão pouco estas situações a faziam desconfiar de sua capacidade. Em relação ao fracasso escolar En acreditava que o baixo rendimento dos alunos em geral não era devido à falta de capacidade intelectual, mas, sobretudo, à falta de empenho e esforço. Sendo assim, ele escolheu os integrantes de seu grupo levando em consideração o engajamento nas tarefas escolares. Em suma, estas constatações fizeram nos classificar este sujeito como orientado à meta aprender.

Contudo, obviamente,En não estava orientado à meta aprender tão fortemente quanto $\mathrm{Au}$, convicto de que seu esforço aliado a sua inteligência lhe garantiam o êxito, e, de que os erros e fracassos eram bem vindos como desafios capazes de promover o desenvolvimento intelectual. Isto posto, En estava predisposta a sofrer mais com sentimentos de ansiedade em comparação com $\mathrm{Au}$, principalmente em relação aos erros, pois acreditava que estes indicavam a proximidade do fracasso, porem apostava no esforço e na dedicação para solucionar os desafios. Logo, parece-nos que En estava mais sujeito as condições sócio-cognitivas e emocionais envolvidas durante o aprendizado de algum conceito ou da realização de alguma tarefa escolar. Assim sendo, ela não parecia estar no domínio total de suas capacidades para aprender, dividindo sua responsabilidade entre a dedicação e o esforço pessoal e entre a segurança emocional e 
o importante desenvolvimento intelectual proporcionado pelo trabalho em grupo. Principalmente, confiava na atuação do professor, pois segundo suas convicções o bom professor era aquele capaz de conduzi-la pelo caminho seguro do aprendizado.

Porquanto, também concluímos que as constatações acima são fruto de certo paradoxo relativo ao seu senso de auto-eficácia, pois ao mesmo tempo em que lhe permitia sentir-se capaz para aprender, contraditoriamente também a fazia acreditar que, caso fosse muito mais inteligente, não necessitaria de tamanho esforço para aprender. Logo, ao final de uma tarefa complexa na qual obtivesse êxito, após despender esforço e dedicação, ao invés, de se sentir orgulhosa e realizada pelo caminho que trilhou, poderia concluir: "Se eu fosse mais inteligente, não estaria passando por isto".

Portanto, o auto-conceito do En girava em torno da sensação da falta, no caso, de um alto cociente de inteligência, impedindo-lhe de sentir maior auto-confiança. Contudo, para compensar esta distância entre o verdadeiro "eu" e a imagem idealizada e projetada como a de alguém com alto coeficiente de inteligência, ela apostava em estratégias de auto-eficácia, tais como: o esforço, a dedicação e alta organização para enfrentar os desafios do conhecimento, como exemplo, citamos a alta consideração dispensada ao trabalho em grupo refletindo a crença de En de que este tipo de organização poderia potencializar suas chances de aprendizado.

Isto posto, considerando o nível de engajamento de En durante a realização da atividade, podemos considerar que a atividade de ensino harmonizou-se quanto aos conceitos de auto-eficácia dela, pois a atividade exigiu-lhe algum nível de esforço e dedicação, testou sua capacidade de organização: afinal o grupo organizado por ela obteve êxito. Em relação ao seu auto-conceito, mesmo que En tenha sofrido com alguma dificuldade capaz de ameaçar sua autoconfiança, seja sobre algum conceito, ou mesmo, sobre a possibilidade da consecução do desafio, esta dúvida, muito provavelmente, deve ter sido diluída ou mesmo distribuída pelos demais integrantes do grupo. Portanto, En experimentou na medida certa alguma dose de desafio, certo medo relativo ao sucesso; não obstante, engajou-se com esforço e dedicação. Todos esses sentimentos foram distribuídos e modulados pelas relações interpessoais, logo, ela desfrutou de segurança, tranquilidade e certo desenvolvimento cognitivo conforme as expectativas presentes em seu perfil de realização.

Ainda em relação ao seu perfil de realização, temíamos que En ao sentir-se perdida ou confusa, sentimentos realmente vivenciados produzidos graças ao conflito sócio-cognitivo,fossem capazes de desequilibrá-la a tal ponto de precipitá-la em um mar 
de angustia fazendo-a produzir avaliações típicas do sujeitos orientados à meta performance-evitação ou involuir rapidamente para comportamentos segundo a situação de desamparo. Contudo, contrariamente aos nossos temores, os sentimentos de confusão produzidos pelo conflito sócio-cognitivo foram interpretados como sendo interessantes ou curiosos fazendo com que ela se motivasse intrinsecamente ao ponto de fazê-la perder a noção do tempo. Logo, após solucionar o desafio En sentiu-se orgulhosa e satisfeita intelectualmente na medida em que seus esforços e empenho foram gratificados com crescimento intelectual; consideração típica dos sujeitos orientados a meta aprender e pertinente ao seu perfil de realização.

Em relação ao trabalho em grupo, havíamos concluído que En preferia este tipo de organização não somente por que, para ela, um maior número de "cabeças" pensavam melhor do que apenas uma. A razão desta predileção não se referia somente a segurança e a tranqüilidade ao se dividir coletivamente as responsabilidades pelo êxito de uma tarefa, mas, principalmente, dirimia o sofrimento causado por um possível fracasso, e, a possível constatação de não se sentir capaz de aprender. Contudo, contrariamente também a esta possibilidade, En sentiu-se orgulhosa não somente pelo trabalho realizado pelos integrantes do grupo, mas também pela troca de ideias e discussões: estas não só dinamizaram a elaboração do novo conhecimento como também animaram a realização da atividade de aprendizagem, fazendo com queela apontasse esta forma de organização como sendo o principal diferencial desta atividade.Isso contribuiu para reforçar, ainda mais, sua crença no poder deste tipo de organização como potencializadora de aspectos cognitivos e emocionais importantíssimos para aprendizagem.

Ainda em relação ao grupo, havíamos concluído que En estabeleceu relações interpessoais com o propósito de se esforçar de forma solidária para realizar as tarefas escolares, buscando nas relações sentimentos de segurança e afeto, levando-nos a concluir que ela visava promover a existência do calor humano aproximando-a da necessidade de Intimidade. Levando-se em consideração nosso diário de campo apontando para o nível de dedicação, esforço e organização dela, temos a forte impressão de que En se considerava um líder responsável pela organização do trabalho distribuindo tarefas, monitorando e cuidando conjuntamente da execução das atividades como um todo. Logo,e a atividade de aprendizagem serviu para reforçar ainda mais os laços de amizade dos sujeitos, principalmente, levando-se em consideração que En e Au experimentaram a mesma sorte de sentimentos tais como confusão produzida pelo 
conflito cognitivo, sinergia ao empreenderem esforços conjuntos para resolução do desafio, e, finalmente, orgulho e satisfação afetiva e cognitiva pelo trabalho que realizaram com consequente elaboração de um novo conhecimento.

Isto posto, outra dúvida referia-se ao fato de En acreditar que o bom professor é aquele capaz de conduzir os alunos linearmente até o aprendizado; havia a possibilidade da confusão produzida pelo conflito fazer com que ela direcionasse algum tipo de frustração para o professor, pois, afinal, este foi o responsável em arquitetar a experiência crucial com o propósito de produzir o fracasso de suas ideias. Logo, considerando o alto nível de valorização dispensada à atividade por En, podemos conjecturar que ela considerou positivas as intervenções do professor nos momentos nos quais o grupo não conseguiu solucionar alguma questão ou resolver algum impasse. Nesse sentido, se não podemos garantir que o papel do profissional de ensino foi valorizado, pelo menos, podemos garantir que ele se manteve incólume.

Em suma, acreditamos que En considerou a atividade de aprendizagem um lugar propício para sua atuação segundo suas expectativas de ensino-aprendizagem. Houve harmonia entre o exigido e aquilo que poderia ter sido ofertado pelo mesmo. Ao final, ela sentiu-se bastantes gratificada pela experiência de aprendizado que vivenciou, consideração comum partilhada por inúmeros sujeitos, captadas em inúmeras pesquisas da área baseadas nos aportes teóricos sócio-construtivistas.

Obviamente, em se tratando do caso de En, assim como fizemos para Ga, não temos como discutir sobre suas expectativas epistemio-metafísicas relativas à ciência pelo simples fato destas expectativas não terem surgido durante a entrevista de análise do seu perfil motivacional.

\section{4 -Análise dos Dados da Entrevista sobre a Percepção Motivacional de Des}

1-P: Assim é...eu estou mais interessado assim em sabe, o que você achou da atividade assim?

E: Atividade, não, eu gostei

P: Que partes que você acho, que perguntas você achou assim interessante assim?

E: Ah, todas eu gostei né, mas...

A apreciação de Des aproxima-se das avaliações feitas por Au e En ao defender com entusiasmo a realização da atividade, ao afirmar que gostou de todo o processo.

2-P: Então, mas se relaciona a interesse 
$E: e ́$

P: desperto interesse? P: Pode olha com calma

E: Ah, a da primeira qual é a temperatura do meu, do seu corpo

P: A letra a

E: A pergunta quatro eu não sabia

P: Você achou

E: Eu achei interessante

P: Tem mais

E: Eu não sabia

Des achou interessante as perguntas inicias relativas à temperatura corporal; provavelmente, considerou a informação de trinta e seis graus relevante. Não podemos deixar de esquecer, conforme análise em seu perfil de realização, que o mesmo aprecia utilizar o conhecimento para entender a realidade a sua volta, portanto, talvez o conhecimento do valor da temperatura, e, principalmente o esclarecimento dos mecanismos fisiológicos responsáveis em manter a temperatura estável do corpo humano,descritos no texto de apoio, tenham despertado a curiosidade dele.

Des afirma que não sabia responder a questão número quatro, entretanto, não parece ter ficado muito preocupado, inclusive, achou esta pergunta interessante. Portanto, podemos conjecturar que ele não sofreu com ansiedade excessiva, pelo contrário parece que manteve-se bastante tranquilo.Esta tranquilidade pode ser atribuída, ou, porque acreditava que poderia dar conta do desafio ou contar como apoio fornecido pelo grupo, ou ainda que o professor solucionaria as eventuais dificuldades. Não podemos deixar de considerar o fato deste aluno apostar sobremaneira nas relações interpessoais.

3-P: Tem mais alguma outra que você achou legal

E: Da colher também

P: A número oito

E: E a número sete

P: Número sete

E: Isso

P: Porque você achou interessante

E: Não porque eu achava que a colher e tal a de madeira ... achava diferente né

P: Mas aqui a colher de alumínio era mais fria mesmo

E: Mais, fria isto

$\mathrm{P}:$ que a temperatura menor

$E: \dot{E}$ 
Des parece ter reconhecido o conflito cognitivo, pois acreditava que as colheres possuíam temperaturas diferentes exatamente por transmitir sensações diferentes ao toque. Contudo, não nos parece ter sentido um aumento da tensão psíquica, ou seja, talvez não tenha sentido verdadeiramente o conflito cognitivo, portanto, a questão número sete tornou-se mais uma questão entre as demais. Nós temos a impressão, contudo não temos como sustentá-la, de que o sujeito talvez não tenha vivenciado o desequilíbrio, seja, por ter a certeza de que o grupo a resolveria, portanto, não sentiu-se admoestado pelo conflito.

Isto posto, nós temos esta impressão, pois em anos aplicando esta sequência didática nos deparamos com inúmeras reações frente ao conflito; muitos reagem fortemente, seja engajando-se em sua solução, ou fugindo desesperadamente reclamando da metodologia e do professor. Contudo, também nos deparamos com aqueles que passam pela atividade de forma tênue. Um dos principais motivos desta situação ocorre quando os sujeitos rapidamente encontram a solução do problema, quase esbarram nela, sem ter percebido completamente as dificuldades envolvidas. Outras vezes, o forte desejo em explicar pressionava para os alunos a“curto-circuitar" o processo e procurar atalhos para a solução, como a resposta do professor ou de colegas, deixando que o esforço se limitasse a verificar se esta era compatível, evitando dessa forma experimentar os aspectos dramáticos do conflito. Acreditamos que estas duas possibilidades não se aplicaram aos sujeitos $\mathrm{Au}$, En e Ga deste grupo, pois eles vivenciaram o conflito cognitivo profundamente. No entanto, parece-nos que Des não sentiu-se desequilibrado pelo conflito exatamente por confiar que o grupo solucionaria o desafio, portanto, manteve-se tranquilo e seguro. No entanto, isso não parece ter prejudicado completamente a aprendizagem de Des, pois as informações e o conhecimento assimilados foram relevantes e relativamente profundos, quando ele se esforçou para elaborar a resolução do desafio. Principalmente, comparando com sequencias didáticas nas quais o conhecimento é retirado diretamente de um texto.

P: do que a de madeira P: Éee....

E: Também gostei porque também pó, eu já estudei esta matéria de Física, mas nunca estudei assim

P: Então

E: Bem diferente

P: Então, assim qual a diferença que você achou, o que que é diferente?

E: Porque que na época quando eu estudava, quando eu era pequeno, faz tempo que eu estudei

P: fala alto (Havia alguns alunos fazendo trabalho de educação artística)

E: Faz uns quatro cinco anos que eu parei de estuda 
P: certo

E: um espaço muito grande que eu pulei, eu senti ai parei, depois eu voltei agora

P: Hum, hum

E: Na época que eu estudei era..., a professora não explicava assim, só passava o nome

P: Eu também não expliquei (risos)

E: Não, explicou, escreveu. é você passou texto aqui, mas quando a gente tava falando você tava dando uma ajuda

P: Uma instrução

E: É, mas lá onde eu estudei, não passava o conteúdo na lousa e acabou, entendeu

Des mostra-se empolgado em relação à metodologia de ensino comparando-a com as do passado. Não podemos deixar de esquecer, que o sujeito em sua infância sentiu-se preterido e reagiu fortemente a esta situação. Portanto, poderia ocorrer de Des sentir-se novamente preterido, pois a atenção do professor foi distribuída pelo grupo sendo direcionada mais para Au e En, por eles endereçaram maior número de perguntas. Contudo, Des enalteceu a atuação do professor exatamente pelo tratamento atencioso ao compará-lo com outros professores, mesmo este não tendo explicado a matéria anteriormente, portanto, se suas palavras expressarem efetivamente seus sentimentos, ele deve acreditar que seu professor dispensou atenção necessária para responder suas dúvidas. Indubitavelmente, esta avaliação estava em acordo com as expectativas de Des relativas à atuação de um bom professor, pois conforme análise do seu perfil de realização ele acreditava que a função principal de um professor era ajudar o aluno a solucionar suas dúvidas. Portanto, talvez o comportamento do profissional de ensino tenha cumprido este papel sendo então motivo de enaltecimento por parte de Des. Por nosso turno, nós não lembramos que ele tenha nos direcionado alguma pergunta, pelo contrário, nós perguntávamos tanto para Ga como para ele se estavam entendendo ou tinham maiores dificuldades.

4-P: Que pergunta te deixou mais confuso? Você sentiu confusão também?

E: Verdade mesmo, eu acho que foi a nove, foi a nove

P: A sete também não? P: Qual te deixou mais confuso

E: A nove e a....seis

$\mathrm{P}:$ A seis também deixou

$E: \dot{E}$

P: Por causa da...

O sujeito afirmou que a pergunta número nove criou confusão: isso causa-nos estranheza, pois esta pergunta era relativamente simples na medida em que os sujeitos nas questões de um a seis são levados a concluir: primeiro, o corpo troca calor com o ambiente, segundo, o corpo perde calor para um objeto, logo tem-se a sensação de frio. Assim sendo, só pode ocorrer um fluxo de calor da mão em direção a colher. Contudo, 
não dispomos mais deste arquivo, portanto, não podemos conjecturar sobre qualquer possibilidade capaz de justificar o sentimento de confusão de Des.

\subsection{1 - Resultado da Análise dos Dados da Entrevista sobre a Percepção Motivacional de Des}

Infelizmente, houve a perda do arquivo, portanto, não podemos nos aprofundar nos motivos que levaram Des a ter avaliado positivamente a atividade de ensino. Contudo, podemos afirmar que o mesmo não sofreu excessivamente com a ansiedade, pelo contrário parece ter se sentido bastante tranquilo. Existe a possibilidade dele não ter vivenciado o conflito cognitivo, portanto, a questão número sete, destinada a produzir o desequilíbrio, pode ter sido alvo do mesmo tratamento ordinário das outras questões. De qualquer forma, o sujeito afirmou ter apreciado todas as questões achandoas interessantes. Parece-nos que a grande confiança dispensada pelo sujeito em relação ao êxito do grupo, impediu que Des se sentisse desequilibrado pelo conflito, ou seja, envolveu-se com a atividade, absorveu o conhecimento que era produzido pelo grupo, contudo, delegou para $\mathrm{Au}$, líder científico, e para En, líder organizacional, o enfrentamento do desafio. Devemos ter profundo cuidado com esta conclusão, exatamente devido à falta dos dados que poderiam confirmá-la, e, principalmente pelo fato do sujeito ser tímido, deixando-nos na dúvida quanto ao real envolvimento do sujeito em relação a tarefa.

\subsection{2 - Expectativas Epistemológicas Sobre Aprender-Ensinar}

Conforme resultado final da análise do perfil de realização, concluímos queDes estava orientado à meta aprender relacionando êxito escolar a esforço, concentração e raciocínio como principais estratégias de auto-eficácia.Assim sendo, temos a impressão que a atividade de ensino proporcionou a Des uma experiência de raciocínio e compreensão fazendo-o avaliar positivamente a atividade de ensino.Segundo seu perfil de realização, Des estabeleceu fortes relações de confiança em relação ao trabalho em grupo. Portanto, talvez esta exacerbada confiança tenha contribuído para não ter vivenciado o conflito cognitivo, à medida que pode ter delegado aos outros sujeitos do grupo a efetiva resolução do desafio. De qualquer forma, a atividade contribuiu para ela reafirmar os laços de amizade sentindo-se realizado pelo trabalho que realizou em acordo com suas expectativas relativas à necessidade de intimidade.

Ainda em relação às relações interpessoais, Des enfatizou em diversos trechos

que a principal qualidade de um professor é a possibilidade deste ajudar o aluno a 
resolver suas dúvidas. Por outro lado, devemos levar em consideração que na infância o mesmo reagiu fortemente ao sentir-se preterido por sua professora. Assim sendo, havia o risco dele sentir-se preterido exatamente pelo fato do professor ter dispensado mais atenção para $\mathrm{Au}$ e En. Contudo, Des enalteceu a atuação do professor exatamente pelo tratamento atencioso, portanto, talvez o comportamento do profissional de ensino tenha se aproximado das expectativas do aluno quanto ao papel do professor.

\subsection{3 - Expectativas Epistemológicas e Metafísicas sobre a Ciência.}

Segundo o resultado final da análise do perfil de realização, Des parecia querer estabelecer relações entre o conhecimento e a realidade que o cercava. Assim sendo, as informações e os conhecimentos que assimilou sobre os mecanismos físiológicos capazes de manter a temperatura do corpo em um valor próximo de trinta e seis graus, tenham sido consideradas relevantes e despertado a curiosidade dele. Portanto, os conhecimentos elaborados podem ter atendido a suas expectativas epistemológicas ao ajudá-lo a entender seu cotidiano. 


\section{Considerações Finais}

Neste trabalho, levantamos o perfil de realização de sete sujeitos de pesquisa;em relação aos quatro últimos estabelecemos correlações entre a reação motivacional destes sujeitos (correlação parcial para Des) frente a uma atividade de ensino baseada no conflito cognitivo como estratégia para produzir maiores níveis de engajamento em direção ao conhecimento. Para tanto, aprofundamo-nos em algumas ideias sócioconstrutivistas, trouxemos a baila o referencial teórico oriundo da psicologia da educação representado pelas metas de realização, conceitos motivacionais diversos como auto-eficácia, auto-conceito ligado à constituição intrapsíquica. Desamparo, necessidade de intimidade ou filiação nos auxiliaram para entender aspectos ligados aos laços intersubjetivos. Conceitos todos que se entrecruzaram para estabelecer uma rede de significados, uma colcha de retalhos conceituais capazes de abarcar o impossível, dar conta da ecologia conceitual do sujeito, ou seja, a própria psique.

Obviamente, que falhamos, afinal estávamos diante do infinito, nos aproximamos mais de desvelar as crenças que implicavam em um comportamento mais de uns do que de outros, como $\mathrm{Del} \mathrm{e} \mathrm{Au}$, pois as crenças deles praticamente os obrigavam a um comportamento. Contudo, o que dizer de En e Des ambos orientados à meta aprender?Uma ressentia-se por não possuir uma alta capacidade cognitiva, o outro, afirmava ser tímido, acreditando que o seu atual grupo teria cuidado desta ferida.

Isto posto, é possível estabelecer uma linha mestre capaz de ligar todos os sujeitos, ou seja, um lugar comum de onde todos falavam, de onde todos referendavam suas histórias, algo que se repetia indistintamente no discurso do sujeito, acidentes da infância.

\subsection{Considerações Gerais Sobre os Sujeitos da Pesquisa}

Iniciemos primeiro com Del e $\mathrm{Au}$ fortemente orientados à meta aprender. Del relatou um evento impactante em sua história escolar referindo-se a sua professora. Ela separou-o dos demais alunos, exigiu exercícios extras, e ele respondeu reciprocamente ao cuidado empreendendo maior esforço e dedicação. Este evento contribuiu não somente para o sujeito amalgamar esforço e dedicação a aprendizagem, mas, sobretudo, fez o sujeito desejar repetir esta forma de envolvimento afetivo na forma de laços mais profundos com seus professores. Este acontecimento marcante ajuda-nos a entender o 
comportamento do sujeito relatado no diário de campo onde ele busca insistentemente conversar com o professor de matemática, a ponto de chamar a atenção de outros professores. Isto força-nos uma pergunta, será que o sujeito, apesar de possuir uma ecologia conceitual robusta, se envolveria na resolução do conflito cognitivo? Afinal, não gozamos da mesma consideração do seu professor de matemática, na medida em que não estabelecemos com Del os laços capazes de exigir dele o esforço e a perseverança.

Por seu lado, Au deparou-se com o assombros o encontro com a bola magnética em sua infância sendo capaz de despertar seu interesse para ciência, experiência proporcionada porsua professora do pré-primário. Não obstante, no presente, a atividade de ensino de física parece ter se aproximado da experiência infantil ao produzir sentimentos de confusão e surpresa relacionados ao conflito cognitivo. Durante a entrevista de acesso ao perfil de realização, tivemos a nítida impressão de que $\mathrm{Au}$ via em nós um interlocutor capaz de compreender seu amor pela ciência. Assim sendo, $\mathrm{Au}$, bem como Del parecem ter buscado no presente a repetição de vivências e acontecimentos do passado. A experiência de Física no presente era semblante do encontro com a bola magnética e o professor-pesquisador confundia-se com o reflexo da professora do pré-primário. No mesmo sentido, o professor de matemática de Del que o tratou de forma diferente dos outros alunos, era semblante da professora de português que um dia o separou da turma e exigiu-lhes exercícios extras. Ms e Ga vivenciaram situações vexatórias proporcionadas pelos professores ou por seus colegas de classe que engendraram no íntimo destes sujeitos a certeza em sua suposta incapacidade para aprender. Ambos eram hiper-vigilantes durante qualquer situação de possível fracasso escolar, razão pela qual Ms desconfiou de nosso convite para sua participação na pesquisa. Razão que justifica o desagravo feito por Ga relatado no diário de campo no momento de nossa requisição de uma tarefa escolar. Ecos do passado que reverberaram no presente.

M buscava o reconhecimento tanto dos professores ao esforçar-se em parecer inteligente, quanto à aprovação de seus colegas através de atos de indisciplina. Durante a análise dos dados do seu perfil de realização, não encontramos nenhum evento capaz de justificar este comportamento, entretanto, este vinha se repetindo ao custo de inúmeras reprovações no ensino médio.En orientada à meta aprender, contudo, ressentida por não possuir um alto cabedal de inteligência, esperava ser conduzida ao conhecimento pela mão de um professor que não a deixaria sentir-se perdida, 
significação que só pode ter sido elaborada em sua infância. Des acreditando-se tímido, relatou ter sido preterido pela professora no primário, e, agora, anos depois, enxergava em nossa a atuação, uma grande atenção que certamente não dispensamos ao mesmo. Como se o sujeito monitorasse nosso comportamento, comparando-o com a professora do primário que o preteriu. Assim sendo, a motivação deste aluno, apesar dos diversos recursos teóricos utilizados para entendê-la, parece estar ligada geneticamente a atuação do professor, exatamente por esta atuação ser imaginária, pois por mais verdadeira que esta tenha sido, não deveria continuar produzindo comportamentos tão repetitivos. Parece-nos que Des nos revelou esta verdade em relação à importância dos afetos direcionados aos professores das séries iniciais e o impacto na vida futura dos aprendizes.

(A): Mas se for para mesmo pra pensa todos os alunos são dependentes do professor, porque tanto que, dizem que, os primeiros professores mais importantes, são os da primeira a quarta série, se você pega um professor que te explique melhor em uma área, provavelmente os alunos vão gostar mais daquela área, se você pega um professor que não te explique bem, você vai chega no primeiro, segundo, terceiro, aquela área você não vai consegui entender, porque quando a gente está em formação $o$ primeiro professor é o que mais conta. Os primeiros professores, porque se você di primeira série, de segunda teve uma má impressão de uma matéria, mais pra frente você vai manter aquela impressão,[...].

\subsection{Outras Considerações Finais}

Em nosso trabalho contemplamos basicamente quatro grandes, permitam-nos mais uma metáfora, "planetas" teóricos: a Epistemologia Piagetiana, o sócioconstrutivismo presente no Ensino de Ciências, as Metas de Realização e o Modelo de Mudança Conceitual. Abordamos também alguns aspectos do desenvolvimento do indivíduo segundo Vygotsky, entretanto não nos aprofundamos neste vasto território, pois não nos sentimos a vontade para discutir mais seriamente os constructos elaborados por este pensador; sendo assim, acreditamos que mergulhamos com mais propriedade apenas nos mundos acima referidos. Em seus movimentos orbitais, estes mundos se aproximam, entretanto, em outros momentos também se afastam, por exemplo: o conflito cognitivo piagetiano é capaz de motivar os alunos intrinsecamente. Ora, o modo de pensar e as reações afetivas de um aluno orientado a meta-aprender é muito próximo de alguém assim motivado. Por outro lado, as considerações ligadas à meta 
performance-evitação estão bastante distante dos constructos sócio-construtivistas; afinal este é um território estritamente ligado ao mundo das Metas de Realização, porém este pode se constituir como atributo pertinente a ecologia conceitual de um sujeito.

Isto posto, para dar ordem ao possível caos, como em todo sistema solar, existe um astro massivo responsável em iluminar, garantir coesão e manter seus respectivos planetas em sua órbita, no nosso casso, o astro rei: a Motivação. Sendo assim, iremos percorrer pelos diversos "mundos" apontando os possíveis resultados que foram iluminados e vieram à tona graças ao poder gravitacional deste nosso astro rei. Começaremos, então, pelo Ensino de Ciência e a Motivação, pois este foi o motivo pelo qual iniciamos nossa viagem.

\subsection{Ensino de Ciência e a Motivação.}

O Ensino de Ciências ligado às teorias sócio-construtivistas aponta diversas estratégias (problemas abertos, perguntas desencadeadoras, etc.) para ensinar seus conceitos. Neste trabalho, nos refletimos basicamente sobre dois elementos: o conflito cognitivo e a "insatisfação". Independentemente de suas origens teóricas e suas especificidades, ambos pretendem envolver intrinsecamente o aluno.

Sendo assim, por nosso turno, pretendemos defender a ideia de que os alunos orientados a meta aprender são capazes, graças a sua ecologia conceitual, de se envolverem mantendo níveis de esforço e perseverança. Estes condicionantes são suficientes para dar conta do desafio envolvido, não só no ato de aprender de um modo geral, mas, sobretudo, no tocante as metodologias que se utilizam do conflito e da insatisfação.Para tanto, devemos lembrar, pois este se encontra desenvolvido em nosso referencial teórico, que um sujeito intrinsecamente motivado está auto-determinado para a realização da atividade, ele busca prazer, alegria e uma satisfação inerente em realizar a atividade. Portanto, um sujeito que joga xadrez exclusivamente com o único objetivo de se divertir encontra-se dentro desta situação. Contudo, em sala de aula, a situação descrita acima praticamente não existe como condição de entrada, pois o ambiente é extrinsecamente controlado, ou seja: os caminhos a serem seguidos necessitam do aval não só do professor, mas também dos membros do grupo do qual o indivíduo faz parte. Isto sem falar do desejo do sujeito de realizar ou não a tarefa. Ora, isto significa ser impossível ao ensino de ciências motivarem os alunos intrinsecamente? 
Estamos apenas chamando a atenção em relação ao conceito de motivação intrínseca proposto pelo ensino de ciência, que nos parece diferente da motivação intrínseca que chamamos de primitiva e que foi descrita acima. Expliquemos algumas das diferenças.A motivação primitiva se refere a um sujeito disposto a realizar a tarefa como condição de entrada e que em seguida vai vivenciar o conflito cognitivo ou a insatisfação em relação as suas ideias. Naturalmente, o desequilíbrio experimentado pode ser capaz de envolver o sujeito intrinsecamente ao ponto deste sentir orgulho, satisfação e alegria ao final da tarefa. Todavia, esta condição não é uma situação natural ou de fácil acontecimento na sala de aula de ciências, haja vista, os relatos sobre déficits motivacionais produzidos pelas várias estratégias.Muitas vezes, acredita-se implicitamente, até um pouco ingenuamente, que uma atividade bem elaborada, contendo um bom conflito cognitivo ou uma boa experiência crucial é por si só capaz de envolver os alunos ativamente, como se a mesma pudesse anular as motivações pessoais construídas durantes anos pelos sujeitos.

Notadamente, não estamos negando as inúmeras pesquisas da área feitas durante anos demonstrando os profundos conhecimentos elaborados pelos sujeitos durante a realização das estratégias. $\mathrm{Na}$ verdade, estamos apenas concordando com os pesquisadores Gunstone (1992) e Pintrich (et al, 1993) que apontam não serem somente as concepções espontâneas capazes de impactar o processo de aprender os novos conceitos, mas sobretudo, as concepções sobre ensino-aprendizagem elaboradas pelos alunos em anos de "que-fazeres" escolares. Estas concepções sobre aprender-ensinar, chamadas de motivações "epistêmicas dos estudantes", podem se constituir verdadeiras barreiras ao processo, inclusive inviabilizando-o.

No mesmo sentido, graças a estes novos condicionantes, vieram à tona uma avalanche de críticas ao Modelo de Mudança Conceitual, tendo como alvo o conflito ou a "insatisfação" e esta acabou por perder seu caráter de condição prévia. Portanto, a estrutura lógica do modelo foi atacada em seu cerne, pois é bastante razoável, se pretendemos mudar uma crença espontânea, começarmos colocando-a em cheque através de uma experiência crucial. Todavia, vários pesquisadores saíram em defesa do conflito, chamando atenção que ele deve ser utilizado somente em determinadas condições. Por seu turno, Mortimer (1995) apontou como simplistas as pesquisas que responsabilizavam o conflito cognitivo pela improdutividade das discussões em grupo, 
ou pior, creditavam ao processo a reafirmação do senso-comum em detrimento do conhecimento cientifico.

Isto posto, em nosso referencial teórico colocamos em cheque a existência dos dois sujeitos epistemológicos piagetiano e vygotskiano, pois pareceu nos pouco provável sua existência natural no cotidiano, exatamente pela dificuldade dos alunos conviverem com os conflitos. Por conseguinte, também ficamos temerosos pela implicação teórica entre o conflito cognitivo e sua relação com o conceito de equilibração majorante, idéia cerne ligada ao desenvolvimento do indivíduo. Por outro lado, relativo à interação social, o que dizer do conceito de zona de desenvolvimento proximal, onde um aluno mais capaz pode ajudar a internalizar no outro um conhecimento ainda potencial através das discussões e da interação em grupo? Será que os sujeitos em seu cotidiano não se interpelam mutuamente na defesa de seus interesses em comum? Em nossa opinião, a sala de aula é um lugar especial, capaz de engendrar para os alunos uma epistemologia própria, diferente, ao menos em parte, da que caracteriza os dois sujeitos epistemológicos ligados a teoria sócio-construtivista. Acreditamos, que o "locus operandi" destes sujeitos epistemológicos está distante da sala de aula, ou seja, sua existência livre, seu desenvolvimento, a naturalidade de seu aparecimento ocorrem com mais propriedade nos laboratórios científicos ou no cotidiano social.Ora, naturalmente esta epistemologia tem sido abordada pelos teóricos da área: o próprio conceito de ecologia conceitual do modelo trata exatamente dos conhecimentos, compromissos epistemológicos e as crenças metafísicas: todo este conjunto diz respeito ao foro íntimo do indivíduo, capaz de impactar tanto a "inteligibilidade", ou seja, a compreensão do novo conceito, como sua "plausibilidade", a possibilidade deste ser aceito.

Isto posto, com o propósito de diminuir ainda mais nosso foco na busca de tecer melhores explicações encetaremos a temática levantada nos parágrafos precedentes, por dois flancos,o primeiro: correlacionando a teoria de metas de realização e o conflito cognitivo, por outro lado, as metas de realização e suas implicações com o modelo de mudança conceitual, mas mantendo como eixo central a motivação. 


\subsection{Conflito Cognitivo: Herói ou Vilão das Estratégias de Ensino Sócio- Construtivistas?}

A partir da decada de 1970, o programa sócio-construtivista evoluiue passou por um período de pelo menos vinte anos de grande sucesso, pela enormidade de dados referentes às concepções espontâneas dos sujeitos. Encontram receptividade a partir do surgimento de um modelo para promover a mudança conceitual indicando o possível amadurecimento em torno de uma proposta de aprendizagem com pelo menos algumas premissas básicas, por exemplo: deve-se promover o envolvimento ativo do aprendiz, as ideias prévias dos estudantes devem ser levadas em consideração, pois influenciam o processo de aprendizagem, portanto, estas ideias devem ser fruto de discussões com o apoio do professor.

O ensino de ciências se apoderou da imagem projetada por estes sujeitos epistemológicos, seja a ofertada pelas concepções piagetianas ou aquela produzida pelo Modelo de Mudança Conceitual, ou ainda, pelo ideias vygostkianas. Destarte, estas concepções seduziram e fascinaram tanto professores quanto pesquisadores da área. Os professores enxergaram-no como o arauto de um novo dia, em seu bojo, alvorecia a promessa de uma escola mais democrática, capturados pela esperança de conseguir a adesão do aprendiz sem se utilizar de nenhum tipo de motivação extrínseca.

Portanto, não seria necessário qualquer tipo de discurso autoritário, coação ou intimidação, muito menos, o uso costumeiro de algum subterfúgio como por exemplo: "apelar para notas" para conseguir o envolvimento do aluno. Pois, como num sonho todos estes estariam fora da sala de aula. Afinal, o próprio sujeito motivado intrinsecamente atuaria como protagonista em direção ao conhecimento, única via capaz de devolvê-lo a condição de equilíbrio anterior ou de dirimir sua sensação de insatisfação. Aliás, muitos daqueles que optam por carreiras científicas, relatam em algum momento terem vivenciado um profundo prazer ao estabelecerem uma relação autodeterminada com o conhecimento, portanto o desejo subjetivo de se reproduzir esta mesma marca é legítima e autoriza o movimento dos professores que se consideram sócio-construtivistas.

Por seu turno, os pesquisadores estavam diante de um verdadeiro banquete de possibilidades. Primeiro, o planejamento de um bom conflito garantia uma porta de 
acesso à mente do sujeito e, mais ainda, uma possibilidade de desenvolvê-la. Por outro lado, do ponto de vista metodológico, um conflito produzido por uma experiência crucial bem orquestrada poderia minimizar a preocupação com a miríade de variáveis envolvidas no processo.

Todo este movimento pareciam indicar um consenso dentro da comunidade cientifica, os mais otimistas acreditavam que o programa evoluíra e dava sinais de inaugurar uma fase pré-paradigmática. Entretanto,

\begin{abstract}
Antes que pudesse evoluir para um paradigma, o construtivismo começou a dar sinais de esgotamento. [...] O segundo sinal, bem mais evidente que o primeiro, é o número razoável de artigos na literatura criticando aspectos filosóficos, psicológicos e pedagógicos do construtivismo. Solomon (1994) fala em Raise and fall of constructivism e atesta a falta de uma mensagem para um futuro entre construtivistas numa conferência tradicional do movimento. Osborne (1994), por seu turno, se diz Beyond Constructivism ao constatar a falta de uma base filosófica mais coerente para o movimento. Nesse aspecto, ele reforça a crítica de Matthews (1992), para quem o construtivismo não conseguiu se divorciar completamente do empirismo. Suchting (1992) critica as bases filosóficas do "construtivismo radical" de Glasersfeld (1989). Essas críticas, apesar de se avolumarem nos últimos anos, já estavam presentes num artigo do número especial do International Journal of Science Education, de 1989, que marcou uma espécie de celebração do movimento no seu ápice. (Mortimer, 1996, p.24).
\end{abstract}

Não obstante, apesar de apresentarmos na citação acima as críticas referentes à base filosófica do sócio-construtivismo, contudo, estas não serão alvo de nossa reflexão. Pois, nosso foco principal se circunscreve a discutir a problemática motivacional concernente à utilização do conflito sócio-cognitivo como mecanismo utilizado para promover um maior engajamento do sujeito frente ao desafio de aprender ciências. Logo, as críticas de cunho filosófico são arroladas aqui apenas para o leitor tomar ciência do momento de reflexão vivido pela pesquisa em ensino ciências baseada nesta estratégia.

Em nossa jornada tratando-se especificamente do corte motivacional que realizamos, apresentamos os contundentes e paradoxais resultados anômalos. Pois, em décadas de pesquisas relativas ao ensino de ciências sócio-construtivista que utilizam o conflito cognitivo como "centelha" responsável em garantir o engajamento dos alunos na resolução do desafio, ao final da atividade, eles reelaboravam os conhecimentos prévios evoluindo-os em direção a conhecimentos majoradamente melhores. Por outro 
lado, quase como uma afronta, surgiram resultados desconcertantes, pois a mesma estratégia, ao invés de contribuir para evolução dos conceitos, estava produzindo exatamente o contrário, a reafirmação dos conceitos espontâneos. Contudo, ainda mais, ameaçadoras, foram as pesquisas responsabilizando o conflito como potente desarticulador da motivação dos aprendizes; surgiram os déficits motivacionais. Isto posto, a teoria de metas de realização, segundo nosso entendimento, pode ser articulada junto ao ensino de ciências ajudando-nos a entender as diversas reações motivacionais captadas por anos de pesquisa da área. Pois, no momento no qual o indivíduo participa de atividades de ensino capitaneadas pelo conflito cognitivo ou pela insatisfação de suas idéias, este reage segundo sua meta de realização.

Contudo, antes de relacionarmos as metas de realização; meta aprender, meta performance-evitação e meta performance-aproximação às teorias sócio-construtivistas para entender o relato sobre a percepção motivacional de alunos que vivenciaram o conflito cognitivo ao realizarem a atividade de ensino de física nesta pesquisa. Devemos salientar, graças ao empate desta teoria com os dados empíricos, que esta necessitou ser ampliada, adotando-se conceitos ligados ao interior do sujeito como: auto-eficácia, autoconceito e desamparo. Por outro lado, mas no mesmo sentido, outro vetor surgiu, forçando o referencial teórico a dar conta da realidade, conceitos ligados as interações sócias, tais como: necessidade de intimidade e necessidade de afiliação tornaram-se obrigatórios.Deste intenso movimento, vemos surgir uma teoria híbrida, mistura conceitual capaz de podermos elaborar o perfil de realização dos sujeitos pesquisados; esta proto-teorização é candidata a postular padrões ligados às crenças epistemológicas e metafísicas, ou, a entender e estabelecer comportamentos metodológicos ou atitudinais dos alunos ao vivenciarem o conflito cognitivo. Em suma, esta aproximação teórica pode nos ajudar a compreender e a teorizar aspectos da Ecologia Conceitual, conceito caro e importantíssimo para o ensino de ciências, entretanto, esta conceituação não será possível neste momento, logo, retornemos ao nosso propósito de correlacionas a reações as motivacionais as metas de realização.

Assim sendo, os sujeitos Au e En, ambos orientados à meta aprender sentiramse motivados durante a atividade realizada nesta pesquisa, pois esta permitiu-lhes vivenciar o conflito cognitivo, como um desafio a ser superado. Portanto, torna-se natural que os sujeitos sintam-se orgulhosos e realizados ao final da atividade enaltecendo-a. Esta situação parece ter sido relatada no artigo de Villani et al(2007)ao 
analisaremos o caso da professora $\mathrm{Ma}^{20}$ que pretendia ensinar conceitos newtonianos dentro da perspectiva sócio-construtivista para alunos do segundo ano do ensino médio, pois ao desenrolar do planejamento pedagógico formaram-se três grandes grupos:

[...] um primeiro grupo, mais participante, que, ao identificar conflitos cognitivos entre o conhecimento de senso comum e as noções científicas, então apreendidas, procurava utilizar analogias para resolver os impasses, fazia afirmações seguras e cuidava em garantir coerência entre elas; sobretudo, dificilmente abandonava um problema sem propor algum caminho ou solução. [...] [A] professora organizou uma sessão de entrevistas com os alunos da sala, na qual apresentava a eles alguns experimentos que poderiam gerar conflito cognitivo. Com satisfação, percebeu que vários alunos fizeram um grande investimento para tentar resolver as situações apresentadas, abandonar o apelo à memorização e propor sugestões até bastante criativas para os impasses decorrentes das tentativas de solucionar os problemas. Esses alunos se surpreenderam com o próprio desempenho, que parecia nunca ter ocorrido anteriormente. (Barolli; Valadares; Villani, 2007).

Apresentado este resultado, voltemos a conjecturar sobre a possibilidade da teoria de metas de realização descrever as reações motivacionais. Podemos imaginar, agora tratando-se de um sujeito orientado à meta performance-aproximação preocupado em parecer inteligente para o professor, como o caso do sujeito M. Destarte, este utilize como estratégia para impressioná-lo a repetição de suas palavras sem refleti-las ou fora de contexto. Este comportamento, por um lado, garante para o sujeito a admiração do professor, por outro, permite um envolvimento superficial com atividade, "curtocircuitando" a possibilidade do sujeito se engajar na resolução do conflito cognitivo. Este comportamento também foi relatado na pesquisa citada acima, referente a participação de um dos grupos:

[...] um terceiro grupo, constituído pela maioria dos estudantes, oscilava entre a aceitação e a recusa de desafios; percebia-se, ainda que esse grupo preocupava-se em agradar a professora oferecendo respostas que refletiam expressões e palavras utilizadas por ela, mas que nem sempre eram compatíveis com o contexto do problema. (Barolli; Valadares; Villani, 2007).

Podemos ainda admitir que os sujeitos orientado à meta performanceaproximação sintam-se motivados enquanto conseguem dar conta superficialmente das perguntas do professor, ou, enquanto conseguem aparentemente solucionar o desafio proposto. Todavia, à medida que suas soluções não estão de acordo com o esperado, ou ainda, caso a tarefa aumente gradativamente sua dificuldade, exigindo-lhe maior empenho e esforço, talvez se sintam incomodados e comecem a suspeitar de suas

20 Este artigo interpreta os resultados utilizando-se o referencial teórico psicanalítico. Portanto, não é feita nenhuma alusão ao referencial ligado às metas de realização. 
capacidades. Ao final da atividade, estes podem avaliar negativamente esta estratégia de ensino achando-a tediosa ou enfadonha, pois não conseguiram realizar seu principal objetivo, ou seja, a de analtecer sua suposta elevada capacidade cognitiva.

Por outro lado, um sujeito orientado à meta performance-evitação que suspeita fortemente de sua capacidade cognitiva. E, exatamente, por isto, tem como preocupação básica não parecer incapaz para professores e colegas independente da atividade a ser realizada ou da metodologia. Podemos admitir que ao iniciar a atividade este adote como estratégia principal: passar despercebido, não reconhecendo o conflito. Consequentemente, um dos resultados relatados na pesquisa acima também pareceu não reconhecer os conflitos, uma vez que o "[...] segundo grupo que fornecia respostas rápidas baseadas no senso comum e que parecia não perceber eventuais conflitos cognitivos, dando indicações de não ter incorporado quase nada do novo conhecimento" (Barolli; Valadares; Villani, 2007).

Imaginemos, ainda, os sentimentos de angustia e ansiedade que estes sujeitos estarão expostos ao perceberem que seus conhecimentos de senso comum fracassam diante de uma experiencial crucial bem orquestrada. Ora, devemos considerar que seu comportamento de evitação se justifica pelo fato do sujeito não pretender entrar em contato com as inconsistências de seu pensamento, pois, caso contrário, a sensação de fracasso viria a confirmar junto a ele sua suposta incapacidade cognitiva.

Agindo desta forma, podemos conjecturar que o conceito de zona desenvolvimento proximal vygotskiano está ameaçado. Pois, como um sujeito mais capaz poderá atuar junto ao outro se este tem como principal objetivo evitar que venham a perceber as falhas de seu pensamento? Como poderá verbalizar ao máximo suas idéias através de uma discussão se desconfia de sua inteligência e teme ser julgado pejorativamente pelo outro? Logo, como o professor ou o sujeito mais capaz ajudarão o sujeito orientado a meta performance-evitação a internalizar processos psicológicos superiores se este está preocupado em passar despercebido por todo o processo? Podemos concluir que não é de se espantar que as discussões em sala de aula tenham resultado num custo-benefício desfavorável como apontou Mortmer (1996).

Ao final, o sujeito poderá reagir fortemente em relação à atividade, e, esta reação seria captada. E, por fim, interpretada pelas diferentes pesquisas da área que 
utilizam o conflito ou a insatisfação como estratégia para promover o ativo envolvimento do aprendiz, como tendo provocado justamente o contrario, ou seja, o déficit motivacional.

Sendo assim, podemos considerar que o conflito cognitivo não é o responsável direto em produzir tais déficits, por dois motivos. Primeiro, o conflito cognitivo não foi responsável em internalizar junto ao sujeito qualquer tipo de orientação de realização, muito menos, uma auto-imagem depreciativa como é caso da meta performanceevitação. Neste sentido, não devemos deixar de considerar de que apesar do sucesso das idéias sócio-construtivistas são raros os momentos em que os alunos têm contato efetivamente com esta metodologia de ensino.

Segundo motivo, o surgimento destes déficits motivacionais não devem ser exclusivos da estratégia sócio-construtivista, afinal o sujeito de antemão está convicto de sua suposta incapacidade cognitiva. Portanto, é muito provável, que em atividades escolares tradicionais, principalmente quando estas começam a aumentar em dificuldade, o sujeito orientado à meta performance-evitação também apresente tais déficits motivacionais. Entretanto, estes déficits devem passar despercebidos, pois os sujeitos orientados a esta meta procuram esconder possíveis dificuldades inclusive as motivacionais.

Por outro lado, as pesquisas em ensino de ciências captam estes déficits motivacionais, muitas vezes, evidenciando-os com tonalidades mais fortes: primeiro por utilizarem como estratégia explorar exatamente as inconsistências do pensamento do sujeito, logo em se tratando de um sujeito orientado a meta performance-evitação é provável que sua reação seja negativa em relação à atividade. O segundo motivo é trivial pelo fato destas estratégias serem alvo de investigação, os seus resultados são evidenciados. Soma-se a isto, a condição destes déficits motivacionais serem considerados dados anômalos, afinal a estratégia buscava o envolvimento ativo do sujeito. Portanto, estes resultados são alvos de acaloradas discussões dentro da comunidade científica.

Desta forma, estamos convencidos que as atividades baseadas no conflito sóciocognitivo estão sendo responsabilizadas erroneamente pelos déficits motivacionais. A bem da verdade, o aluno passa anos lidando no ambiente escolar com uma metodologia 
baseada em uma epistemologia tradicional de ensino. Sendo assim, podemos supor que com o tempo, esta epistemologia produziu junto ao sujeito não só uma orientação de realização, mas também a forma de como o sujeito aprende determinando seu possível relacionamento com o conhecimento. No tocante a esta possível epistemologia descrita por Pintrich, Marx e Boyle (1993), citações apresentadas anteriormente, e, repetidas aqui para economia do leitor:

[...] As motivações epistémicas dos estudantes orientam de forma geral os objetivos de aprendizagem fornecendo um mecanismo para explicar como e porque podem conduzir a uma maior atividade cognitiva.

Neste mesmo caminho, escreveu Gunstone (1992):

[...] O fato mais significativo que contribui para o problema é que estudantes têm uma visão extremamente transmissiva de aprendizado e ensino, uma visão muito passiva do papel que devem realizar nesses processos. Mais ainda, esta visão epistemológica é muito consistente com algumas visões sobre aprender e ensinar. Isto é, a única importância em aprender física se resume a não mais do que obter a "resposta correta". Portanto, sustentar argumentos, explorar perspectivas alternativas, conectar com outros conceitos são dispensados, essas ações mentais podem ser muito significativas ao professor. Certamente um professor construtivista colocaria um valor elevado em tais coisas.

Neste modelo de ensino o professor é o principal ator, portando a atuação do aluno é relegada à atuação do outro que sabe. Sendo assim, aquele deve acatar todas as indicações e determinações para que possa absorver o conteúdo ofertado devendo principalmente prestar atenção, repetindo inúmeras vezes o raciocínio do mestre. O erro representa fracasso e deve ser evitado ao máximo. Naturalmente, procura-se repetir o mais próximo possível o discurso da autoridade, não importando uma possível consequência: se faz sentido ou não. Logo, por qual motivo, então, um aluno entraria em um debate para defender suas idéias se acredita que o professor é o detentor do conhecimento, por qual motivo não esperar a resposta pronta ao final da tarefa? Melhor ainda, se esta resposta acarretar a diminuição da ansiedade e da angustia daquele que desconfia de sua capacidade cognitiva como é o caso dos alunos orientados à meta performance-evitação.

A partir do entendimento de todos os fatos expostos, podemos concluir que o conflito sócio-cognitivo não é herói nem vilão, ele apenas possibilita ao aluno entrar em contato de forma mais sensível com os seus objetivos de realização e a auto-imagem que este comportamento de realização carrega. Seja obter competência, através de 
esforço e dedicação ao solucionar o conflito; seja o de impressionar professores ou colegas, às custas de um envolvimento efetivo capaz engajá-lo na tarefa, ou ainda, evitar parecer incapaz, não reconhecendo os conflitos cognitivos.

A partir do ponto de vista piagetiano, parece-nos que o conflito cognitivo além de levar o aluno à tomada de consciência de suas ações e das imagens da essência do objeto. Destarte, o conflito também funciona analogamente como um catalisador que acelera o contado do aluno com seu perfil motivacional de realização. Um catalisador não faz parte dos reagentes, tampouco compõe os produtos finais da reação saindo intacto. Isto também se verifica, pois em qualquer outra atividade em que o aluno possa vivenciar o fracasso de suas concepções novamente o conflito estará presente, notadamente um conflito mais abstrato, caso este tenha anteriormente acomodado um novo saber sobre o objeto.

Portanto, a realidade se encarregará de oferecer vez ou outra um senão, cabendo ou não ao aluno recorrer a sua auto-imagem, bem como a sua sensação de autoeficácia $^{21}$ para solucionar o presente desafio. O que talvez possibilitará a tão sonhada equilibração majorante. Para nós este mecanismo complexo entre o interno e o externo representa o moto-contínuo piagetiano capaz de fornecer um manancial energético infinito para aluno a voltar a sua condição de equilíbrio, conforme citação.

[...] Essa busca, que constitui o princípio da acomodação e assimilação, como a primeira manifestação de um dualismo entre o desejo e satisfação, portanto entre o valor (psique) e o real, entre a totalidade que se completa e a totalidade incompleta, dualismo que reaparecerá em todos os planos da atividade futura e cuja redução será tentada ao longo de toda a evolução mental, embora esteja destinado a acentuar-se incessantemente. (Piaget, 1970, p. 48).

Portanto, o conflito ou a sensação de insatisfação apenas desvela, faz emergir e lança uma luz sobre o comportamento de realização que está consumado no íntimo do aluno, inclusive sendo conscientemente admitido por ele, conforme os relatos dos sujeitos capturados nesta pesquisa. Acreditamos serem as metas de realização, os frutos produzidos pela metodologia tradicional de ensino sendo responsáveis em produzir tais resultados motivacionais, pois esta é a principal estratégia de ensino praticada em

21 A auto-eficácia é um julgamento sobre si mesmo em relação às habilidades e competências que um sujeito possui para realizar uma tarefa, portanto este julgamento pode ajudá-lo a controlar a ansiedade ou os sentimentos negativos relacionados a consecução da tarefa. 
nossas escolas, vejamos o relato de Kami (1995) uma relevante pesquisadora da área construtivista.

[...] Os professores usam de recompensa e punição também no domínio intelectual para que as crianças dêem respostas "corretas". Um exemplo dessa prática é o uso das folhas de exercícios. Na aritmética do $1^{\circ}$ grau, se a criança escreve " $4+4=\underline{7}$ ", a maioria dos professores assinala esta resposta como errada. $\mathrm{O}$ resultado deste tipo de ensino pode ser visto quando percorremos uma classe de $1^{\circ}$ grau enquanto as crianças estão fazendo as lições e paramos para perguntar a uma dada criança como ela obteve aquela resposta. Elas tipicamente reagem agarrando suas borrachas, mesmo quando a resposta é perfeitamente correta! Já no $1^{\circ}$ grau, muitas aprendem a desconfiar de seu próprio raciocínio. Crianças que são assim desencorajadas a pensar crítica e autonomamente construirão menos conhecimentos que aquelas que são confiantes e pensam sozinhas (Kami, 1995, p. 91).

Sendo assim, a metodologia tradicional de ensino conseguiu, após anos de prática escolar, construir no íntimo de cada sujeito um objetivo de realização: meta aprender, performance-aproximação ou performance-evitação. E, em se tratando de alguns sujeitos, levando em consideração a citação acima, este objetivo de realização surge como déficit motivacional, ou seja, a meta performance-evitação.

Neste sentido, este comportamento de realização é capaz de impossibilitar o acionamento do mecanismo de equilibração majorante, afinal é pouco provável que um aluno possa desenvolver as estruturas de seu pensamento se desconfia fortemente de seu raciocínio. Como poderá o aluno assimilar as suas estruturas de pensamento aos objetos ou as situações de aprendizagem, se acredita de antemão que estas fracassarão? Esta condição resulta na suposta crença da insegurança de seu próprio raciocínio. Como poderá acomodar as suas estruturas de pensamento: o elemento novo, as diferenças, as lacunas, as anomalias presentes nas imagens dos objetos ou nas situações de aprendizagem se estas lhe são potencialmente ameaçadoras? Logo, parecem confirmar sua suposta incapacidade cognitiva, o que por fim, dificultaria ao sujeito aprendente construir seus conhecimentos da maneira como pensou Piaget.

Assim sendo, é pertinente notarmos que a Teoria de Metas de Realização permite-nos emitir um "salvo-conduto",22 relativo aos diversos e anômalos resultados obtidos nas últimas quatro décadas pelas pesquisas ligadas à metodologia sócioconstrutivista que utilizam o conflito cognitivo ou a insatisfação como estratégia, principalmente aquelas relativas ao ensino de ciência. Este "salvo-conduto" é

22 Aqui, o termo "salvo-conduto" refere-se à extrapolação proposital, mas necessária que acreditamos abordar a partir de uma analogia que emprestamos das relações jurídicas a fim de permitir uma maior compreensão das situações abordadas. 
necessário, pois nas discussões acadêmicas sobre os resultados anômalos toda sorte de argumentos são trazidos à baila para defender ou atacar a utilização desta estratégia de ensino. Alguns alegam que o conflito motiva os sujeitos, outros que este mesmo conflito, produz exatamente o contrário, ou seja, déficits motivacionais. Os construtivistas mais aguerridos alegariam que pode ter havido alguma falha na efetivação do conflito, ou na elaboração da experiência crucial, esta não deve ter sido contundente o suficiente para instalar o desequilíbrio junto aos sujeitos, o que inviabilizou o processo de equilibração majorante. Os vigotskianos mais combativos apontariam falhas relativas ao gerenciamento das interações interpessoais, justificativa responsável em impossibilitar que as discussões em grupo pudessem surtir efeito na zona de desenvolvimento proximal.

Neste aspecto a idéia de um "salvo-conduto" poderia garantir a veracidade e a pertinência na descrição do comportamento de alguns alunos quando vivenciam o conflito cognitivo, pois este os intriga sendo capaz de envolvê-los ativamente na solução dos problemas. Para estes, o conflito realiza sua função, desequilibrando-os. Este desequilíbrio é capaz de fazer com que os sujeitos liberem energia. Esta é prontamente transformada em ação direcionada para a acomodação ou evolução dos conhecimentos, condição necessária para retornarem ao equilíbrio.

Isto posto, ao final da atividade, provavelmente os sujeitos a avaliem como sendo interessante e enriquecedora por dois aspectos intrínsecos: primeiro por terem sentido a necessidade durante o processo de ressignificar seus conceitos impulsionados pelo desequilíbrio, segundo por terem encontrado um objeto ou situação que proporcionou-lhes ampliar seus conhecimentos, conforme Piaget (1977):

[...] a necessidade traduz-se, por outro lado, na forma de $<<$ interesse $>>$, e isto em dois aspectos indissociáveis: por um lado, o interesse é uma relação entre as necessidades do sujeito e os caracteres do objeto, que se torna $<<$ interessante $>>$ na medida em que satisfaz as necessidades, por outro lado, o interesse como dizia Claparède, é um dinamogeneizador que liberta as energias do sujeito e o anima a acção na direção do objeto. (Piaget, 1977, p. 103)

Notadamente, os pesquisadores da área classificariam este envolvimento ativo do sujeito em direção ao conhecimento, como sendo de um sujeito intrinsecamente motivado. Ou ainda, um professor construtivista se sentiria bastante gratificado por ter 
proporcionado para seus alunos uma atividade de ensino capaz de produzir tamanho resultado.

Não obstante, outro "salvo-conduto" seria emitido descrevendo o comportamento dos sujeitos orientados à meta performance-aproximação, mais preocupados em conseguir uma boa nota do que investigar as inconsistências de seu pensamento, já que seu principal objetivo é impressionar tanto professores quanto colegas. Destarte, isto justifique um alto envolvimento no início da tarefa, pois o sujeito acredita que obterá facilmente uma boa nota, afinal julga-se muito inteligente. Todavia, com o passar do tempo e o aprofundamento do exigido para a realização da tarefa, somadas com as possíveis sensações de fracasso isto provoque uma queda gradativa no interesse culminando com um baixo envolvimento ao final da tarefa e um sentimento de embotamento em relação à mesma.

Por fim, as pesquisas que prematuramente apontaram as estratégias baseadas no conflito cognitivo como responsáveis em produzir déficits motivacionais conforme bem argumentou Mortimer (1996). Muito provavelmente, não tenham levado em consideração que os sujeitos entram em sala de aula com um objetivo específico de realização. Notadamente, um outro "salvo-conduto" garantiria a razoabilidade de que alguém orientado à meta performance-evitação apresente déficits motivacionais ao vivenciar uma situação de fracasso. Contudo, estes déficits estão ligados à história pregressa do sujeito e não propriamente ao conflito cognitivo:

[...] Quanto às emoções, as crianças não nascem com sentimentos de orgulho ou de vergonha, visto que estas não são emoções inatas. Em vez disso, o orgulho surge a partir de uma história do desenvolvimento de episódios de sucesso culminado na proficiência; e a vergonha surge a partir de uma história no desenvolvimento com episódios de fracasso culminado no ridículo (Stipek, 1983 apud Reeve, 2006, p. 108).

Em suma, parece-nos que nem os críticos mais ácidos, tampouco os defensores mais fervorosos poderiam prever a existência de tais operantes em sala de aula. Com efeito, talvez a máxima shakespereana pode servir de grande valia: "Há mais coisas no céu e na terra, [...] do que sonha a tua filosofia". Parafraseando, poderíamos muito bem escrever: "Há muito mais objetivos de realização dentro de uma sala aula, do que poderiam imaginar tanto os céticos, quanto os defensores mais ortodoxos da metodologia sócio-construtivista”. 
Assim sendo, nos parece que a Teoria de Metas de Realização pode ser um alento promissor ao trabalho dos professores, pois estes podem evitar serem tomados de surpresa por reações motivacionais adversas apresentadas pelos alunos ao entrarem em contato com o conflito cognitivo. Exatamente, pelo fato destas reações serem descritas e previstas pela teoria de metas de realização. Os professores podem utilizar o conflito para produzir níveis de engajamento em seus alunos orientados à meta aprender, pois estes apreciam estes momentos de auto-determinação.

Em relação, aos alunos orientados à meta performance-aproximação os professores podem atuar junto a estes sujeitos auxiliando-os a sustentarem níveis de maior engajamento, orientando-os a empreenderem maior esforço na busca da elaboração de conhecimentos mais profundos, restabelecendo harmonia entre $\mathrm{o}$ conhecimento exigido e a quantidade de esforço a ser ofertado.

Em relação as reações motivacionais relativas a meta performanceaproximação, estas reações podem ser alvo da reflexão dos professores na perspectiva de uma atuação junto ao aluno para ajudá-lo nos momentos nos quais sinta-se desesperançado. Acredito, que um vínculo afetivo próximo baseado na confiança, segurança, respeito ao desafio mútuo de ensinar-aprender, possa ajudar os alunos orientados à meta performance-evitação a paulatinamente evoluírem em direção a resignificação de suas estratégias de auto-eficácia, com consequentes impactos positivos em seu auto-conceito, com o objetivo do resgate da autonomia e fundamentalmente de sua auto-estima tão miserável, produto de uma cultura meritocrática. Mesmo, sabendo o quão difícil significa gerenciar espaços com um número muito grande de alunos, imersos em uma cultura competitiva, fazendo-os desconfiar das intenções de ajuda tanto dos professores quanto de um colega mais capaz, muitas vezes, o aluno sente-se ofendido, dizendo: quem ensina é o professor! Recusando-se a solucionar suas dúvidas com outro aluno. Ainda assim, apostamos que o professor consciencioso das diversas metas de realização poderá traçar estratégias, ou, pelo menos intuir qual o objetivo de realização de seus alunos, atuando na perspectiva de desenvolvê-las ou mudá-las.

No tocante ao programa de pesquisa sócio-construtivista de ensino de ciências, os pesquisadores interessados poderão desenvolver ainda mais às metas de realização com a perspectiva de desenvolver possíveis perfis para se caminhar na direção do entendimento da Ecologia Conceitual do aprendiz. Outra, questão de suma importância 
é o esclarecimentos que os dados anômalos captadas em anos de pesquisa, nada mais são, do que os reflexos de uma cultura de ensino, que em anos de que-fazeres escolares internalizaram no íntimo dos indivíduos objetivos de realização diversos.

Portanto, encerrado as conexões entre as reações motivacionais mediante o conflito cognitivo e as metas de realização. No capítulo a seguir, iremos traças aproximações entre o Modelo de Mudança Conceitual e as Metas de Realização e seus possíveis impactos na aprendizagem.

\subsection{O MMC e as Metas de Realização.}

\subsection{O MMC e a Meta-Aprender}

Conforme escrito acima, o conflito cognitivo ou a insatisfação buscam através de uma experiência crucial desequilibrar o sujeito envolvendo-o intrinsecamente na busca do novo conhecimento. Isto posto, uma das principais características de um aluno orientado à meta aprender é que seu comportamento além de estar muito próximo de aluno intrinsecamente motivado, também predispõe o sujeito a experimentar de forma mais natural este tipo de auto-determinação. Podemos conjecturar que no momento em que o sujeito perceber o fracasso de suas concepções este possa suportar não somente a ameaça a sua auto-imagem, pois internalizou em sua estrutura cognitiva o esforço como chave que abre o arcabouço fechado do conhecimento. Em nosso trabalho, para Del esta crença não era somente uma ferramenta, mas se constituiu um comportamento idealizado sendo considerado como de alto valor.

Piaget aponta o poder da vontade em torno dos valores que a criança pretende observar. Já na adolescência, estes canalizadores energéticos representados pelos valores são ampliados, tornando-se uma necessidade moral responsável em garantir o fluxo energético permitindo ao sujeito levantar todas as hipóteses possíveis, testá-las, manter-se fiel as suas conclusões, mesmo que estas lhe sejam contrárias, pois deseja fazer justiça ao seu pensamento diante da realidade. Parece-nos, quanto mais próximo do seu senso-comum, quanto mais próximo o novo conhecimento se referir aquilo que o sujeito carrega, mais este vai tentar buscar voltar ao equilíbrio. Afinal, o sujeito tendo o seu mundo negado, graças ao novo egocentrismo adolescente, buscará reconquistá-lo. Del mesmo sentindo raiva em um determinado jogo não desistiu, não desanimou, pelo 
contrário este sentimento agiu como canalizador energético implicando-o significativamente cada vez mais na busca por assimilar e acomodar as novas regras.

E o que ganhou com isto? Ora, o sujeito reforçou seu conceito de auto-eficácia, pois conseguiu dominar as novas regras do jogo, manteve sua auto-imagem intacta: como alguém que busca enfrentar os desafios com esforço e dedicação. Naturalmente, poderíamos objetar que Del gosta destas atividades, portanto seria natural seu maior envolvimento. Todavia, os sujeitos orientados à meta aprender independente de gostarem ou não da disciplina buscam nos desafios escolares a possibilidade de crescerem intelectualmente.

Voltando aos compromissos epistemológicos, Del segundo nossa análise parece ter sido capturado pelo "ideal do eu" projetado em seu relacionamento com sua professora. Sendo assim, talvez isto tenha sido capaz de internalizar o esforço e a dedicação como um traço de sua personalidade. Portanto, toda vez que cumprir estes pré-requisitos durante a realização de uma tarefa, ele se aproxima desta auto-imagem projetada, fazendo-o se sentir satisfeito e orgulhoso. Naturalmente, nem todo aluno orientado a meta aprender, conforme nos adverte o referencial teórico, tem como traço de personalidade o "esforço". Todavia, mesmo como condição periférica estes sujeitos ao realizarem uma atividade procuram o uso desta estratégia como uma forma de fazerem jus aos conhecimentos que serão adquiridos. Talvez então, a principal razão para seu comportamento não se resuma somente a cumprir as obrigações escolares, ou cumprir as ordens do professor. Podemos admitir, como principal justificativa, a busca pelo sentimento de orgulho e satisfação.

Parece-nos ainda que estes sentimentos surjam, porque os sujeitos mantiveramse fieis aos seus compromissos epistemológicos. Portanto, o orgulho e a satisfação representa a obtenção de certa cota de prazer, mesmo reservado apenas ao final do processo. Pois, segundo referencial teórico, os sujeitos ao receberem um feedback negativo investem ainda mais energia ou mudam suas estratégias para dar conta dos desafios e, ao final da tarefa, sentem-se satisfeitos e orgulhosos por terem perseverado.

Isto posto, podemos admitir que os sujeitos buscam esta forma auto-determinada de agir afim de obterem algum prazer ligados as estes sentimentos de auto-realização. Assim, podemos concluir que o aluno orientado a meta aprender mesmo quando não 
está motivado intrinsecamente, todavia se aproxima dos comportamentos que o caracterizam. Sendo assim, é exatamente esta forma de agir que a condição de "inteligibilidade" do Modelo de Mudança Conceitual supõe. O sujeito após vivenciar o conflito ou a insatisfação se auto-determina buscando voltar à sua condição anterior de compreensão. Para tanto, concentra-se nas imprecisões de sua estrutura conceitual comparando-a com o novo conhecimento; quanto maior for o foco, quanto maior a atenção em direção a obtenção do novo conhecimento, maior será a profundidade e a inteligibilidades deste, pois se sentira envolvido e comprometido com a solução do desafio.

Podemos também admitir que a condição de "plausibilidade" também é afetada, pois quanto mais o sujeito se esforça em utilizar a estratégia metacognitiva de comparar seu conceito espontâneo ao novo conceito, mais acaba por tornar este último plausível, pois estabelece profundas conexões entre os dois conhecimentos, percebendo onde falha sua concepção e onde o novo conhecimento resolve o desafio.

Naturalmente, se este novo conceito além de resolver o desafio proposto pela experiência crucial, ganhar em valor heurístico sendo "fértil" em responder a novos problemas que sua antiga concepção não era capaz de explicar, então talvez o sujeito produza uma evolução em suas concepção espontâneas em direção aos conhecimentos científicos de acordo com o Modelo de Mudança Conceitual, cumprindo as quatro condições lógicas. Ao final o sujeito, se sentirá satisfeito e orgulhoso por ter conseguido resolver o desafio.

Isto posto, observemos agora como a ecologia conceitual é a base que permitirá ao sujeito alinhavar todos os pontos do Modelo de Mudança Conceitual construindo uma trama capaz de fornecer coesão, estabilidade e expansão ao novo conceito. Para tanto, devemos admitir como principal instrumento epistemológico utilizado pelo sujeito o "esforço": é com esta "pinça" que pretende inquirir a realidade. Portanto, o conflito ou a insatisfação funcionam como catalisadores otimizando a necessidade de esforço e atenção, pois a sensação de fracasso aparece como um desafio às habilidades do sujeito. Destarte, acreditamos que estamos diante de um mecanismo "adaptador de motivação". Por ventura, seus compromissos são colocados a prova, seus valores como justiça e honestidade obrigam-no a canalizar uma grande reserva de energia para compreensão da realidade que se apresenta. O sujeito olha para a trama representada 
pelo seus conceitos, compara esta trama com o conceito científico e percebe suas falhas, com a "pinça" representada pelo esforço, perseverança e atenção desfaz os nós e, os liga ao novo conceito, neste processo este ganha em "inteligibilidade". Logicamente, a nova trama não é somente mais estética, mas também evolui em maior coesão e estabilidade do que sua antecessora.

Todavia, o sujeito ainda não esta satisfeito, pois seu sentimentos de honestidade e justiça exigem-lhe por a prova este novo "bordado-conceito", é necessário conferir harmonia entre a nova concepção e a realidade, a psique exige uma base logico-moral, a fim de garantir reciprocidade entre o novo conceito e a realidade. Portanto a trama ganha em "plausibilidade" na medida em que melhor explica os dados anômalos, fazendo justiça ao pensamento antes obliterado. Cabe ressaltar, não é a base empírica que permite ao sujeito internalizar o novo conceito, é um reflexionar-se sobre si mesmo, é antes de tudo um julgamento de valor que veio se especializando ao longo da historia do sujeito.

Agora a trama já pronta deve provar todo seu valor áureo, deve mostrar todo seu caráter potencializador, frutificando na forma de explicações de outras situações. A trama-conceito se desprende das condições reais criadas pela experiência crucial, está pronta então para permitir ao sujeito entender novas situações impossíveis de serem entendidas com a trama anterior.Sendo assim, acreditamos que a ecologia conceitual do sujeito orientado à meta aprender que internalizou "esforço" como principal ferramenta de atuação, amalgamou a esta forma de agir, sentimentos ético-morais capazes de obrigá-lo a ir à busca do novo conhecimento para reconquistar seu equilíbrio. Pois, neste processo seu espírito deve estar disposto a enxergar as fraquezas de suas concepções, ou seja, suas inconsistências.

Portanto, o sujeito não deve apresentar nem ansiedade, muito menos emoções negativas, capazes de desviar-lhe a atenção ou produzir-lhe déficits motivacionais. Contudo, só é possível vivenciar esta situação graças a um auto-conceito, a uma autoimagem bem formada, capaz de suportar certo risco, sempre presente no aprendizado dos conteúdos escolares, condição somente possível àqueles que possuem "esforço" como principal estratégia ligada à auto-eficácia. Afinal, Del preferia "quebrar a cara" do que desistir; esta indulgência em relação a auto-imagem só é possível para aqueles espíritos seguros de que seu esforço e perseverança poderão curar-lhes as feridas. 
Não obstante, tratamos acima apenas da ecologia conceitual referente à relação íntima que o sujeito estabelece com o conhecimento. Todavia o aprendizado dos conteúdos escolares não se resume apenas à atuação individual, pois a metodologia sócio-construtivista aposta no trabalho em grupo como importante forma de aprender. Vejamos agora quais traços ligados atuação coletiva permitem ao sujeito reforçar sua ecologia conceitual. Naturalmente, em se tratando dos conteúdos escolares, não podemos deixar de ter em mente, que o conhecimento, de um modo geral, possui regras e estas são socialmente construídas devendo ser internalizadas pelos sujeitos. $\mathrm{O}$ conceito de "inteligibilidade" trata exatamente da internalização do conhecimento. Isto posto, o aluno orientado a meta aprender apresenta em seus relacionamentos interpessoais certa "necessidade de intimidade", levando os sujeitos a estabelecerem relações mais recíprocas baseadas na busca pelo entendimento mútuo.

Diante do conflito cognitivo, podemos admitir que o sujeito fortaleça suas relações de amizade, afinal deverá se juntar de forma solidária para a solução dos desafios; para tanto, deverá estabelecer certa proximidade emocional com os demais parceiros e o professor. Deverá também demonstrar calor humano e preocupação interpessoal não passando por cima dos outros se suas ideias obtiverem êxito.Buscará um diálogo recíproco e mais honesto demonstrando suas dificuldades e as lacunas de seu pensamento, já que sua principal preocupação não é parecer inteligente a professores e colegas. É provável que a preocupação interpessoal exija deste sujeito um vínculo ético envolvendo-o afetivamente com o outro, sendo assim, isto talvez facilite e garanta a atuação na zona de desenvolvimento proximal conforme pensou Vygotsky, conceito tão caro as metodologias sócio-construtivistas.

Segundo Piaget, honestidade, desejo por justiça e, graças aos constructos ligados as metas de realização, a "necessidade de cuidado" são capazes de se constituírem valores conscientes, garantindo ao sujeito recursos energéticos para sua efetivação, troca e desenvolvimento e estabelecendo uma relação mais equilibrada no relacionamento do indivíduo com seus pares.Naturalmente, que ancoramos estes desenvolvimentos a uma auto-imagem e a um auto-conceito bem construído, pois o indivíduo busca a solução dos desafios e não desvia sua atenção e seu esforço para objetivos diferentes da realização da tarefa. A ansiedade e angustia de um possível fracasso não são vivenciados, pois todos os sujeitos do grupo se envolvem mutuamente para a 
consecução da tarefa; mesmo advindo um mal resultado, o fracasso não é individualizado, sendo dividido pelo grupo.

Por nosso turno, não acreditamos que o grupo represente um utópico lugar de bondade onde todos os sentimentos são positivos, livres de conflitos, alias a vantagem está exatamente na possibilidade destes virem à tona com maior facilidade. Sendo assim, parece-nos mais razoável admitir que o enfrentamento dos desafios em grupo, pode aumentar os laços interpessoais. Portanto, graças a esta necessidade humana, representada pela necessidade de intimidade, os sujeitos poderão se sentir mais seguros, onde cada um possa se enxergar na imagem fornecida pelo outro, assim seus integrantes podem perceber suas dificuldades, falhas, inabilidades, podendo até explorá-las ou desenvolve-las. Por outro lado, também poderão enxergar seus pontos positivos, suas qualidades construindo uma auto-imagem mais equilibrada, capaz de auxiliar os sujeitos em seu fundamental processo de individuação.

Com o intuito de explicitar melhor as conexões entre a meta aprender e o Modelo de Mudança Conceitual, bem como seus possíveis efeitos, elaboramos a tabela abaixo. A mesma pode ser utilizada por pesquisadores para melhor monitorar a possível conexão entre os diferentes constructos teóricos. Por exemplo, o sujeito utilizando como ferramenta básica o esforço para enfrentar os desafios da aprendizagem poderá lidar com a insatisfação sugerida pelo modelo. Esta condição poderá impactar positivamente a "inteligibilidade", pois o esforço traduzindo em forma de concentração poderá facilitar na compreensão do novo conceito.

Para entender a tabela que se segue, devemos co-relacionar a linha com a coluna. Por exemplo, na primeira linha o aluno orientado à meta aprender interessado em obter domínio, quanto se sente "insatisfeito" devido o fracasso de suas concepções espontâneas, este apresenta maior possibilidades de agir como descrito: $O$ sujeito sentese realmente intrigado e confuso com o fracasso de suas ideias, o fracasso torna-se um desafio as suas habilidades. Logo, interessado em solucionar o desafio este tenderá a produzir desenvolvimentos na inteligibilidade do conceito, conforme a primeira linha segunda coluna. Assim sendo, este raciocínio deve ser expandido para as outras colunas da tabela. Não obstante, o mesmo deve ser feito para o restante da tabela. A segunda coluna foi desenvolvida levando-se em consideração as relações que o sujeito orientado a meta-aprender pode estabelecer com o grupo. Por fim, a última linha refere-se ao 
impacto na motivação. Obviamente, trata-se aqui apenas de uma extrapolação teórica, pouco provável que na realidade poderíamos confirmar tal "script" da forma como desenvolvemos.

\begin{tabular}{|c|c|c|c|c|}
\hline M..M. C. & Insatisfação & Inteligibilidade & Plausibilidade & Fertilidade \\
\hline $\begin{array}{c}\text { Obter } \\
\text { Domínio }\end{array}$ & $\begin{array}{l}\text { O sujeito sente-se } \\
\text { realmente intrigado } \\
\text { e confuso com o } \\
\text { fracasso de suas } \\
\text { idéias, o fracasso } \\
\text { torna-se um desafio } \\
\text { as suas habilidades. }\end{array}$ & $\begin{array}{l}\text { Comprometido com } \\
\text { a solução do } \\
\text { desafio, } \\
\text { concentradoem } \\
\text { monitorar as } \\
\text { imprecisões de sua } \\
\text { estrutura conceitual } \\
\text { comparando-a com } \\
\text { acientífica; } \\
\text { (Impactando na } \\
\text { profundidade e } \\
\text { Inteligibilidade do } \\
\text { novo conhecimento) }\end{array}$ & $\begin{array}{c}\text { Ao comparar } \\
\text { os } \\
\text { conceitos,assi } \\
\text { mila e } \\
\text { acomoda } \\
\text { profundas } \\
\text { conexões entre } \\
\text { os dois } \\
\text { conhecimentos. } \\
\text { (As falhas em } \\
\text { sua concepção, } \\
\text { reforçam o } \\
\text { conceito } \\
\text { científico } \\
\text { tornando-o } \\
\text { mais } \\
\text { plausível). }\end{array}$ & $\begin{array}{l}\text { Caso o novo } \\
\text { conceito } \\
\text { adquira valor } \\
\text { heurístico } \\
\text { sendo "fértil" } \\
\text { respondendo } \\
\text { a novos } \\
\text { problemas. O } \\
\text { sujeito talvez } \\
\text { evolua suas } \\
\text { concepções } \\
\text { em direção ao } \\
\text { novo } \\
\text { conhecimento } \\
\text { (ciclo } \\
\text { virtuoso) }\end{array}$ \\
\hline $\begin{array}{c}\text { Alia-se } \\
\text { Solidaria } \\
\text { mente ao } \\
\text { grupo de } \\
\text { colegas e } \\
\text { ao } \\
\text { Professor } \\
\text { (semblante } \\
\text { de um } \\
\text { grupo de } \\
\text { Pesquisa) }\end{array}$ & $\begin{array}{l}\text { O sujeito em } \\
\text { conflito busca aliar- } \\
\text { se solidariamente } \\
\text { ao grupo } \\
\text { pretendendo voltar } \\
\text { à condição de } \\
\text { equilíbrio anterior }\end{array}$ & $\begin{array}{l}\text { O sujeito buscará } \\
\text { um diálogo } \\
\text { recíproco e honesto } \\
\text { demonstrando suas } \\
\text { dificuldades. Este } \\
\text { processo } \\
\text { possibilitará vinculo } \\
\text { afetivo aos diversos } \\
\text { atores facilitando a } \\
\text { possível atuação na } \\
\text { zona de } \\
\text { desenvolvimento } \\
\text { proximal. Quanto } \\
\text { mais ricas as } \\
\text { discussões maior o } \\
\text { impacto na } \\
\text { Inteligibilidade. }\end{array}$ & $\begin{array}{l}\text { A resolução do } \\
\text { desafio, } \\
\text { somados a } \\
\text { anuência do } \\
\text { professor, } \\
\text { conjuntamente } \\
\text { com os colegas } \\
\text { do grupo } \\
\text { garantirão } \\
\text { maior } \\
\text { plausibilidade } \\
\text { ao } \\
\text { conhecimento, } \\
\text { pois este } \\
\text { tornou-se } \\
\text { interpsicológic } \\
\text { o }\end{array}$ & $\begin{array}{c}\text { O valor } \\
\text { heurístico é } \\
\text { assimilado- } \\
\text { acomodado } \\
\text { junto ao } \\
\text { grupo de } \\
\text { pesquisa. A } \\
\text { Fertilidade é } \\
\text { compartilhada } \\
\text { coletivamente } \\
\text { (Ciclo } \\
\text { virtuoso, } \\
\text { retro-alimenta } \\
\text { a } \\
\text { Inteligibilidad } \\
\text { e a } \\
\text { Plausibilidade }\end{array}$ \\
\hline $\begin{array}{c}\text { Ações } \\
\text { Próximas }\end{array}$ & $\begin{array}{l}\text { O conflito funciona } \\
\text { como catalisador } \\
\text { otimizando a } \\
\text { necessidade de }\end{array}$ & $\begin{array}{l}\text { O sujeito traduz } \\
\text { esforço na forma de } \\
\text { concentração, maior } \\
\text { foco e atenção em }\end{array}$ & $\begin{array}{l}\text { O sujeito se } \\
\text { mantém } \\
\text { perseverante } \\
\text { tentando }\end{array}$ & $\begin{array}{l}\text { Ao explicar } \\
\text { outras } \\
\text { situações o } \\
\text { sujeito sente- }\end{array}$ \\
\hline
\end{tabular}




\begin{tabular}{|c|c|c|c|c|}
\hline $\begin{array}{c}\text { de um } \\
\text { Sujeito } \\
\text { intrinseca } \\
\text { mente } \\
\text { Motivado }\end{array}$ & $\begin{array}{c}\text { esforço e } \\
\text { concentração. } \\
\text { (Mecanismo } \\
\text { “adaptador de } \\
\text { motivação") }\end{array}$ & $\begin{array}{c}\text { direção a obtenção } \\
\text { do novo } \\
\text { conhecimento. } \\
\text { (Impactanto a } \\
\text { Inteligibilidade e a } \\
\text { profundidade ) }\end{array}$ & $\begin{array}{l}\text { conectar o } \\
\text { novo } \\
\text { conhecimento } \\
\text { a realidade, } \\
\text { tornado o } \\
\text { conhecimento } \\
\text { mais plausível }\end{array}$ & $\begin{array}{c}\text { se } \\
\text { compensado } \\
\text { pelo esforço e } \\
\text { a } \\
\text { perseverança } \\
\text { exigidos pelo } \\
\text { processo. }\end{array}$ \\
\hline
\end{tabular}

Isto posto, terminadas as conexões entre a meta aprender e o MMC, passemos agora as possíveis relações entre o modelo e a meta performance-aproximação apontando os possíveis impactos provocados por esta orientação.

\subsection{O MMC e a Meta Performance-Aproximação.}

O sujeito orientado à meta performance aproximaçãono início da atividade devese sentir seguro, pois considera-se inteligente e confiante. Entretanto, ao vivenciar o conflito ou a insatisfação poderá desenvolver duas diferentes reações. Caso ainda acredite poder dar conta do desafio, continua na atividade, pois será uma oportunidade para demonstrar para professores e colegas sua alta capacidade intelectual. Todavia, é bastante provável que demonstre certo desanimo no momento em que percebe sua maior dificuldade, talvez até demonstre um comportamento irritadiço criticando a atividade, a metodologia ou a pessoa do professor. Diante da exigência de maior esforço para a compreensão de algum conceito, pode apelar: "Professor, porque o senhor não fornece logo as respostas, o senhor já sabe”.

Conforme os dados analisados, este sujeito na ânsia de parecer inteligente para professores e colegas procura rapidamente responder as perguntas feitas pelo professor, mesmo sem ter refletido. Não raro, adota palavras presentes no discurso daquele, somente para agradá-lo, sem ter um conhecimento claro de seus significados.

Antes de continuarmos, vejamos as profundas coincidências entre 0 comportamento ligado a esta meta e alguns resultados obtidos pelas pesquisas baseadas no MMC e suas reações motivacionais:

- “Quer agradar o professor” (Villani, 1999);

- "Busca obter notas boas" (Pintrich et al, 1993);

- "Identificar-se com uma figura famosa" (Pintrich et al, 1993); 
- “Pretende ser reconhecido pelos colegas” (Pintrich et al, 1993);

- “-Ah!! Professor tem que pensar!!”(Baird et al apud Villani,2001).

Os alunos orientados a esta meta gostam de pensar, mas na situação restrita ligada a sua principal qualidade: "Eu tenho um raciocínio rápido, pego as coisas com facilidade", ficar pensando profundamente sobre um tema talvez se torne rapidamente algo enfadonho. Afastadas estas pequenas dúvidas, vamos tentar entender estas reações produzidas pelo Modelo de Mudança Conceitual.Naturalmente, o alvo de uma experiência crucial são as concepções espontâneas que o sujeito carrega. Todavia, estas constituem o universo conceitual com o qual o sujeito explica o mundo, define a forma como atua e se insere dentro dele. Sendo assim, a insatisfação ou o fracasso não atinge somente estas concepções como queriam racionalmente seus idealizadores: parte deste fracasso acaba por respingar tanto na auto-imagem quanto na auto-eficácia do indivíduo. Um sujeito orientado à meta aprender que desenvolveu sua auto-imagem e seu auto-eficácia em torno do esforço, tenderá a procurar a nova compreensão para reparar sua auto-imagem; pelo contrário, um sujeito orientado a meta performanceaproximação terá dificuldade em se envolver intrinsecamente na tarefa, após vivenciar o conflito cognitivo ou a insatisfação de suas ideias. Esta dificuldade ocorre por dois motivos principais: primeiro, porque sua principal ferramenta epistemológica - a inteligência -com a qual o sujeito pretende inquirir a realidade é negada. Destarte, o sujeito aposta em sua grande inteligência para apreendê-la, aliás, seus próprios conceitos espontâneos são frutos da atuação desta ferramenta. O segundo motivo se refere a sua auto-imagem, pois, no momento em que estas concepções, resultado desta alta inteligência, são colocados em xeque, cai sobre ela um desafio perturbador. Portanto, o conflito ameaça não só as concepções, mas principalmente a forma como o sujeito lida com o mundo e mais intimamente com sua alto-imagem.

Destituído de seu poder, resta ao sujeito escapar buscando um bode expiatório para justificar seu fracasso, a fim de preservar seu "status" de inteligência. Portanto, ao invés de buscar canalizar sua energia, direcionando-a para o aumento não só da sua cota de esforço, mas principalmente ajustando seu foco na forma de mais atenção,o sujeito contraria este fluxo natural e se concentra em responsabilizar a atividadeao professor, ou simplesmente perde o interesse. 
Notadamente, interessado em cumprir apenas o primeiro quesito concernente à "insatisfação" proposto pelo Modelo de Mudança Conceitual, o sujeito acaba comprometendo toda estrutura. Comecemos então a argumentar neste sentido, iniciando pelo conceito de "inteligibilidade", pois o sujeito não pode se concentrar nas imprecisões de suas estruturas conceituais. Ora, enxergá-las é admitir e lidar com erro não só em relação ao conteúdo espontâneo de suas concepções, mas, sobretudo, lidar com uma dúvida sobre sua auto-imagem que lhe é insuportável. Isto posto, preocupado em salvaguardar o próprio "eu", não poderá se aprofundar no novo conceito e sua aproximação se dará de forma superficial. Tenderá a saltar algumas partes do processo, buscando rapidamente a resposta para reparar-lhe a imagem e provar sua alta capacidade intelectual. Portanto, este comportamento pode produzir uma "miscelânea", um híbrido entre os dois conceitos, onde o sujeito não consegue nem fazer evoluir a concepção anterior, nem tão pouco aproximar-se do conceito científico, impactando fortemente na "inteligibilidade" do resultado.

Por mais improvável que possa parecer, a"plausibilidade" pode se produzir rapidamente junto ao sujeito, pois sua ecologia conceitual não lhe obriga a estabelecer um compromisso epistemológico com o conhecimento, o que lhe exigiria não só confirmar o novo conceito conectando-o a realidade, mas também, obrigá-lo a monitorar o resultado. Por outro lado, sua ecologia conceitual o atrapalha sobremaneira, pois como pretende agradar o professor, concorda com ele rapidamente, sem perseverar o suficiente para refletir com profundidade sobre o assunto. Pior ainda, se adotar a estratégia bastante funcional, principalmente para quem quer parecer inteligente, de repetir sem entender as bonitas palavras presentes no discurso do mestre.

Portanto, a "plausibilidade" é quase imediata; afinal, pondera: para que ficar perdendo tempo e energia testando conceitos para os quais o professor já sabe a resposta; melhor é prestar a atenção em seu discurso para captar a importante mensagem, repeti - lá com zelo e cuidado, garantindo assim dois objetivos: primeiro conquistar a admiração dos professores e colegas, segundo, obter uma boa nota de participação.

Apesar do temeroso quadro acima, o pior ainda esta por vir, reservado ao conceito de fertilidade. Imaginemos que o professor, tendo percebido que uma boa parte dos alunos responderam com facilidade suas perguntas, inclusive utilizando termos 
específicos da área, resolva propor uma espécie de teste, contendo diversos exemplos das situações relacionadas ao conceito para os sujeitos proficuamente testarem a fertilidade do mesmo. Agora, de repente, tomado de assalto, o hibrido produzido anteriormente esta livre para produzir toda sorte de devastação na forma de repostas "ad-hoc". Nos exemplos próximos ao conceito espontâneo, este então reina absoluto, mostra toda sua força e pujança: surgi então uma miscelânea de termos do senso comum fundidos ou próximos dos termos científicos; ao final, a argumentação comprova a existência dos dois espécimes. Não obstante, este resultado não previsto e distante do Modelo de Mudança Conceitual, ainda assim, estaria de acordo com a meta de realização do indivíduo orientado a meta performance-aproximação, pois este buscou apenas parecer inteligente. Sendo assim, não se envolveu com o conhecimento, não realizando as quatro condições do modelo, impossibilitando-o de enxergar a contradição em suas respostas. Talvez, esta forma de agir explique os resultado obtidos por pesquisadores da área, apontando a pouca eficiência do modelo.

Naturalmente, diante de um resultado tão desastroso, isto talvez leve o responsável pelo processo a colocar em cheque o modelo ou a própria atuação. Imaginemos a seguinte situação: o tenaz professor com dedicação e zelo tentou elaborar uma estratégia para que os alunos refletissem sobre suas concepções espontâneas, através de uma experiência crucial. Julgando fazer o melhor, pois acreditava estar trabalhando em nome da motivação dos estudantes, ainda se esforçou em tentar atender os incessantes apelos dos sujeitos alvoroçados pelas sensações de fracasso. Condição esta, que o obrigou a retornar repetidas vezes aos grupos, na tentativa de dirimir as principais dúvidas, respondendo quase sempre as mesmas perguntas. Como se ainda não bastasse tamanho o esforço, foi levianamente apontado pelos colegas, devido ao burburinho em sua sala, como um professor "condescendente" com a indisciplina. Ao final, olha estupefato o resultado, e se pergunta: “Onde foi que eu errei!".

Podemos também imaginar qual será a reação dos alunos na semana seguinte, quando da entrega do resultado do teste, em coro: "Tá vendo o Sr. não explicou direito!!”, “O Sr. vem com estas experiências malucas, que a gente não entende nada!!”, “E agora e o vestibular” "E as provas, só perdemos tempo”. Podem parecer exageradas, ou até absurdas estas reações, mas o artigo escrito por Villani et al. (obra 
citada , p. 9) relatando o caso da professora Ma, se aproxima desta condição. Nos mesmos nos deparamos com essa situação.

Em se tratando do gerenciamento da sala de aula, Pintrich et al., (1993, p.178) criticam a transposição direta da epistemologia utilizada no laboratório para a sala de aula chamando justamente a atenção para a possibilidade das metas de professores e alunos constituírem verdadeira barreiras ao processo, pois estas são muito diferentes daquelas dos cientistas. Naturalmente, para um professor sócio-construtivista é exatamente a proposição desta nova relação com o conhecimento que o impulsiona a utilizar novas metodologias, mesmo diante do aumento de certos problemas de gerenciamento. Todavia, no tocante as metas dos alunos, predispostos já a uma epistemologia tradicional de ensino, estes estejam, por exemplo, muito mais preocupados com o conteúdo obrigatório para as provas, do que ficar discutindo sobre suas concepções espontâneas.

[...] Ao mesmo tempo, a mudança das estruturas da sala de aula cria demandas adicionais no sistema de gerenciamento da sala de aula. Por exemplo, métodos de pesquisa e descoberta, que são sugeridos como possíveis formas para ensinar a mudança conceitual, através de tarefas autenticas (por exemplo, experiências reais da ciência), podem diminuir o papel de autoridade do professor, e frequentemente mudam como os estudantes serão avaliados, criando muitos problemas de gerenciamento." ${ }^{23}$

Com o intuito de explicitar melhor as conexões entre a meta performanceaproximação e o Modelo de Mudança Conceitual, bem como seus possíveis efeitos, elaboramos a tabela abaixo. A mesma pode ser utilizada por pesquisadores para melhor monitorar a possível conexão entre os diferentes constructos teóricos, exemplo: o sujeito buscando parecer inteligente, portanto, pode aprender os conceitos superficialmente. Esta condição, além de impactar a "inteligibilidade" também produz estragos quanto fertilidade, pois o "Frankstein-conceitual" pode-se adaptar a qualquer situação.

\footnotetext{
${ }^{23}$ Tradução do autor; texto original: "At the same time, the changing of these classroom structures creates additional demands on the classroom management system. For example, discovery and inquiry methods, which are suggested as potential ways to teach for conceptual change, often use authentic tasks ( e. g., real science experiments), decrease the role of the teacher's authority, and change how students are evaluated, yet they create many management problems".
} 
Para entender a tabela que se segue, devemos co-relacionar a linha com a coluna, como sugerido na tabela anterior no caso da meta apreender. Obviamente, repete-se aqui a advertência anterior, pois, trata-se apenas de uma extrapolação teórica, sendo pouco provável que na realidade possamos confirmar em todos os detalhes tal "script" da forma como desenvolvemos.

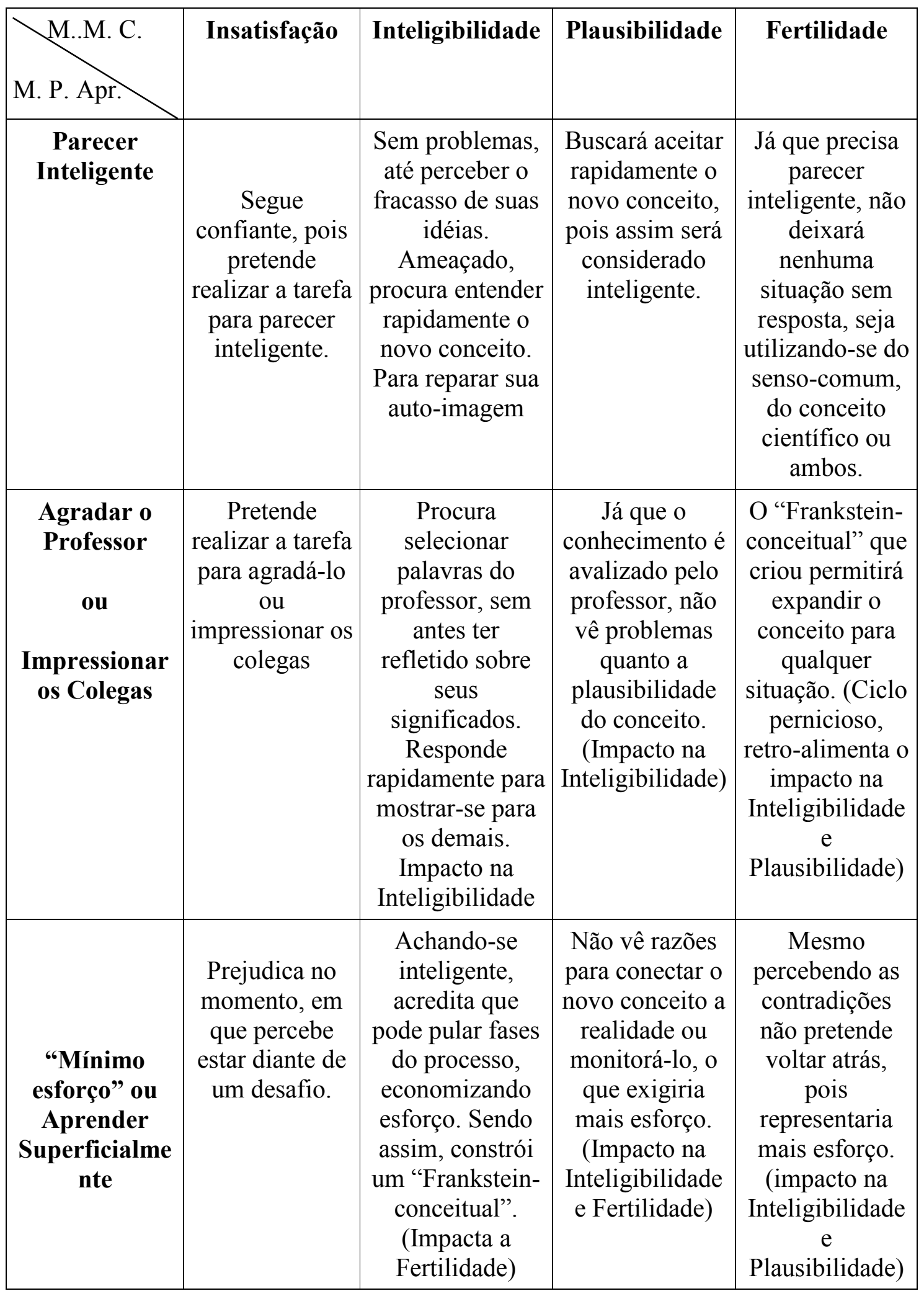


Em nossa análise dos dados fornecidos pelo sujeito $\mathrm{M}$ afirmamos que o mesmo poderia fazer parte do seguinte grupo da professora Ma citado há pouco:

[...] Finalmente, um terceiro grupo, constituído pela maioria dos estudantes, que oscilava entre a utilização da linguagem científica e a de senso-comum, bem como entre a aceitação e a recusa de desafios; percebia-se, ainda, que esse grupo preocupava-se em agradar a professora oferecendo respostas que refletiam expressões e palavras utilizadas por ela, mas que nem sempre eram compatíveis com o contexto do problema."

Este trecho afirma que este comportamento foi apresentado pela maioria dos estudantes. Isto então, seria um indicativo que a maioria dos estudantes estão orientados a meta performance-aproximação, buscando parecer inteligentes. Absolutamente, não é este o caso: em nossa interpretação o comportamento dos alunos da professora Ma pode ser explicado pelo choque entre as duas epistemologias: a tradicional versus a revolucionária, proposta pelo modelo de Mudança Conceitual.Pois, ambos estabelecem estratégias e metodologias que trazem em seu bojo a forma como os alunos aprendem.De um lado, o MMC preconiza um sujeito mais ativo, mais responsável pelo seu aprendizado, o que implicaria ao professor uma postura de mediador do processo; por outro lado, o modelo tradicional coloca o professor no centro deste, pois é ele quem ensina, acabando por relegar ao aluno uma posição mais passiva. Sendo assim, aquele deve acatar todas as indicações e determinações para que possa absorver o conteúdo ofertado; deve principalmente prestar atenção, repetindo inúmeras vezes o raciocínio do mestre. O erro representafracasso; logo, deve ser evitado ao máximo. Natural, então procurar repetir o mais próximo possível o discurso da autoridade.

Portanto, os sujeitos passaram anos a fio tentando se sustentar e atuar em uma estrutura social já estabelecida, estrutura esta centrada na figura do professor, onde o seu discurso é revestido de imenso valor, por conseguinte, os alunos constroem uma epistemologia baseada no medo do erro, no mínimo esforço, resultando na dependência do julgamento e da anuência do professor.O medo do erro é o resultado de intermináveis questionários e provas sempre com o objetivo de apontar uma falha: assim esta deve ser corrigida, todavia esta também pode ser ocultada. Naturalmente, então é melhor repetir sempre o conteúdo correto proferido pelo professor. Destarte, isto redunda em uma economia do esforço, pois para que se esforçar, se ao final o mesmo fornecerá as respostas, afinal esta é a razão de seu ofício: “ofertar o conhecimento". 
Isto posto, acreditamos ser pouco verossímil que a maioria dos alunos estejam interessados em parecer inteligentes. Todavia, podemos conjecturar, pois foram anos de treino nesta metodologia, que uma boa parte dos alunos procuram agir de acordo com a epistemologia tradicional observando os seguintes objetivos: medo do erro, mínimo esforço e a dependência do professor.

Apenas para explorar as diferenças, um aluno "dependente do professor" a cada passo espera a anuência do mesmo. Por outro lado, um aluno orientado a meta performance-aproximação interessado em agradar o professor, também espera sua anuência, mas sobretudo seu objetivo é obter a admiração do outro em relação a sua alta sagacidade e inteligência. De qualquer forma, este comportamento também garantiria os resultados existentes na tabela acima.

Naturalmente, as afirmações feitas nos parágrafos acima, inclusive a construção da tabela não são frutos diretos de nossa pesquisa, mas constituem-se apenas em reflexões sobre os possíveis desdobramentos de um aluno orientado a meta performance-aproximação.Antes de encerrarmos, gostaríamos de esclarecer que não nos sentimos a vontade para tecer comentários sobre os conceitos de necessidade de intimidade ou necessidade de afiliação dos sujeitos assim orientados, pois, apesar, de termos feitos algumas considerações a respeito do comportamento de $\mathrm{M}$ em relação a professores e seus colegas de grupo, não temos informações mais detalhadas sobre sua atuação. Todavia, este sujeito, segundo nosso entendimento, parece ser adepto da teoria da existência, pois segundo nossa análise o mesmo admite não possuir "esforço". E o mais grave, este talvez acredite como uma suposição básica que o esforço não possa vir a ser desenvolvido como uma forma de auto-conhecimento. Sendo assim, terminadas as conexões entre a meta performance-aproximação e o MMC, passemos agora as possíveis relações entre o modelo e a meta performance-evitação e os possíveis impactos provocados por esta orientação.

\subsection{O MMC e a Meta Performance-Evitação.}

As pesquisas ligadas ao MMC captaram as seguintes reações dos alunos frente à insatisfação em relação a suas idéias. (Chinn \& Brewer, apud Villani \& Cabral, 1997, p. 4); 
- Fica perplexo e guarda a dúvida;

- Muitas vezes, o aluno ignora o fracasso;

- Tenta minimizar os efeitos do insucesso;

- Interpreta o acontecimento como singular;

- Arranja explicações ad-hoc.

Como podemos perceber, os indivíduos assim orientados buscam evitar serem vistos como "burros". Sendo assim, evitam a todo custo demonstrar aos outros sua suposta incapacidade, assim este comportamento captado nas pesquisas da área parece comprometer a primeira e principal condição do MMC. Notadamente, este impacto se refere à condição de entrada do sujeito, pois este apresenta grande dificuldade em lidar com a insatisfação de suas ideias. A experiência crucial tem como alvo o senso comum que o sujeito carrega. Este conhecimentoexplica e determina a forma como os sujeitos podem atuar em seu mundo; também, a sensação de fracasso não se limita somente ao conhecimento de senso-comum, mas atingeos conceitos de auto-imagem e a autoeficácia do indivíduo.

Um aluno orientado à meta aprender vivencia o conflito como um desafio, portanto, fica intrigado e quer descobrir o que acontece. Já, um aluno orientado à meta performance-aproximação inicia o processo, todavia, quando percebe o fracasso de suas ideias, sente sua imagem ameaçada; logo, curto-circuita o caminho, pretendendo adquirir o novo conceito de forma superficial, construindo um "Frankstein-conceitual". Parece-nos então, que o sujeito orientado à meta performance-evitação ou não inicia o processo ou tenta salvaguardar o senso-comum como último ato de desespero.

Em relação a este possível comportamento voltemos ao caso da professora Ma, citado anteriormente, sobre formação de um outro grupo de alunos:

[...] Um segundo grupo que fornecia respostas rápidas baseadas no senso comum e que parecia não perceber eventuais conflitos cognitivos, dando a indicação de não ter incorporado quase nada do novo conhecimento (Villani et al,obra citada , p. 9).

Isto posto, vamos tentar agora cruzar o referencial teórico ligado a meta performance-evitação, com as reações motivacionais captadas pelas diversas pesquisas acima, veremos o quanto esta orientação pode estar impactando o MMC. 
O sujeito percebe parcialmente o fracasso de suas ideias, isto lhe é extremamente angustiante, pois esta situação vem a reforçar a impressão de sua suposta incapacidade cognitiva. Conforme análise de dados, Ms não demonstrou possuir nenhuma estratégia de auto-eficácia capaz de fornecer um suporte adequado para enfrentar a situação. $\mathrm{O}$ sujeito tem seu mundo negado e invadido pela dúvida na forma de ansiedade e angustia. Estes sentimentos negativos dificultam ou mesmo paralisam seu movimento, pior não lhe permitem encarar o problema, causando talvez as seguintes reações motivacionais captadas pelas pesquisas, como ficar perplexo e guardar a dúvida, ignorar o fracasso ou minimizar os efeitos do insucesso.

Este estado de perplexidade, mais parecendo uma cegueira momentânea só pode ser compensado agarrando-se a única possibilidade de atuação: o sujeito ameaçado procura salvaguardar seu mundo, buscando preservar seu conhecimento de sensocomum.Naturalmente, isto ameaça o segundo passo do modelo referente à inteligibilidade, por dois motivos: primeiro, o sujeito não pretende estabelecer profundas conexões com o novo conceito, pois não pode compará-los, enquanto esta condição seria insuportável. Não porque sua inteligência sejanegada naquele momento, conforme os sujeitos orientados a meta performance-aproximação, mas, sobretudo, por confirmar sua suposta incapacidade radical, pois este passou anos desenvolvendo e acreditando em conhecimentos que agora deverão ser percebidos como insuficientes.

Desesperados, pois este julgamento também se refere à sua auto-imagem, os alunos orientados à meta performance-evitação preferem não olhar para as inconsistências de seu pensamento, pois enxergá-las seria confirmar uma falha angustiante relacionada ao próprio “eu”. Sem saída, buscam valorizar e salvaguardar a única coisa que lhes resta: o senso-comum. Sendo assim, podem utilizar como estratégia propor explicações "ad hoc" como,por exemplo: "o termômetro está quebrado", quando estiverem diante de um resultado anômalo. Os sujeitos sabem de antemão da impossibilidade de aprenderem os novos conceitos, pois tem certeza do fracasso internalizado em anos de sofrimento escolar, confirmado por provas, questionários, notas e etc.

Contudo, diferentemente dos sujeitos orientados à meta performanceaproximação, estes não buscam um responsável para aliviar-lhes, pois já tem a certeza do veredicto, a culpa recai sobre si mesmos, já que se acreditam incapazes para 
aprender. O professor, a atividade, estes não são responsáveis, apenas desvelam aquilo que é impossível esconder: "sua falta de inteligência". Invadido por estas preocupações, o sujeito não é capaz de direcionar sua reserva energética para resolver o desafio na forma de mais atenção ou esforço. O que talvez impactasse positivamente na inteligibilidade do conceito. Por outro lado, este fica preso em um ciclo angustiante de preocupação, ansiedade e finalmente fracasso.

Isto posto, aplausibilidade do novo conhecimento simplesmente não se realiza, já que não cumpriu o passo referente a inteligibilidade. O sujeito ou não entendeu ou incorporou muito pouco do novo conceito. Sendo assim, como poderá se sentir seguro em defender ou tentar conectar o novo conceito à realidade?Ele até pode vir a repetir algumas palavras do professor, pode até se permitir estabelecer algumas conjecturas, mas basta sentir-se ameaçado para voltar a se agarrar ao senso-comum. Sua ecologia conceitual, dominada pelos sentimentos de fracasso, medo, vergonha, ansiedade e angustia não lhe permite acessar nenhuma ferramenta epistemológica capaz de socorrerlhe. Sem opção e sem possuir uma sensação de "auto-eficácia" suficientemente forte ecapaz de prover-lhe a calma necessária para testar os novos conceitos, nada lhe permite esmiuçar a realidade em busca de uma explicação plausível para dar conta do experimento. O sujeito está também sem uma ecologia conceitual, capaz de exigir-lhe comprometimento epistemológico e obrigá-lo a monitorar o resultado, e sem uma autoeficácia capaz de garantir-lhe qualquer ilusão quanto ao sucesso da tarefa, como, por exemplo, o "esforço" no caso da meta aprender ou a "inteligência" na meta performance-aproximação. Doravante, o sujeito encontra-se abandonado a própria sorte inundado pela dúvida.

Portanto, resta agora,à condição de fertilidade confirmar o inevitável: o professor obterá como resultado, nada mais, nada menos do que a reafirmação do sensocomum. Pois, já que o sujeito procura não parecer incapaz, não deixará nenhuma das perguntas sem resposta, fazendo uso de seu conhecimento de senso-comum passando a impressão de reforçá-lo. Por conseguinte, isto poderá ser interpretado por parte do professor como uma alienação do aluno em relação ao conhecimento. Pois, não podemos esquecer que Ms, conforme analise dos dados, nestes momentos, procurava entregar a atividade apenas para mostrar que tentou realizá-la não se importando com as possíveis falhas. 
Em suma, agindo desta maneira, podemos admitir que o sujeito não se envolveu com o processo, pois a todo custo buscou evitar perceber as lacunas existentes em seu pensamento. Depois, angustiado em relação ao possível fracasso não se envolveu com o novo conhecimento por acreditar não ter capacidade intelectual para incorporá-lo. Deveras, também não procurou tornar o conhecimento plausível, pois não o entendeu com profundidade, não se sentindo seguro para defendê-lo em relação à realidade. Por fim, para não parecer incapaz preservou o senso-comum acreditando poder dar conta dos possíveis questionamentos feitos pelo professor.

No parágrafo anterior, colocamos em cheque a atuação do sujeito: ele está convicto de sua suposta incapacidade cognitiva, logo, não atua ou não se envolve, pois teme que venham confirmar esta condição. Podemos conjecturar que em grupo, no momento em que apareçam as primeiras dificuldades com suas ideias, ele não as apresentará, pois não pretende ser visto como incapaz. Quando inquirido sobre suas dúvidas, pode passar a impressão de estar compreendendo, mas apenas para se livrar da angustiante sensação de dúvida em relação a sua estrutura de pensamento. Durante as discussões, prefere calar-se esperando que os mais capazes elaborem a resposta correta. Poderia até defender seu conhecimento de senso-comum, mas isto lhe é impossível, pois seria obrigado a enxergar as falhas em sua estrutura. Portanto, é melhor esperar a correção feita pelo professor no final da atividade.

Com o intuito de explicitar melhor as conexões entre à meta performanceevitação e o Modelo de Mudança Conceitual, bem como seus possíveis efeitos, também elaboramos a tabela abaixo.

Para entender a tabela que se segue, analogamente aos casos anteriores, devemos co-relacionar a linha com a coluna. Obviamente, repete-se aqui a advertência anterior, pois, trata-se apenas de uma extrapolação teórica, sendo pouco provável que na realidade possamos confirmar em todos os detalhes tal "script" da forma como desenvolvemos. Todavia, podemos ressaltar que agindo de maneira semelhante ao descrito na tabela, o aproveitamento dasituação de desenvolvimento proximal de Vygotsky estaria ameaçado. 


\begin{tabular}{|c|c|c|c|c|}
\hline M...M. C. & Insatisfação & Inteligibilidade & Plausibilidade & Fertilidade \\
\hline $\begin{array}{c}\text { Acha-se } \\
\text { Incapaz para } \\
\text { aprender }\end{array}$ & $\begin{array}{c}\text { Não admite } \\
\text { colocar em } \\
\text { cheque seus } \\
\text { conceitos } \\
\text { espontâneos, } \\
\text { pois confirmaria } \\
\text { sua } \\
\text { incapacidade. } \\
\text { Portanto, ignora } \\
\text { o fracasso de } \\
\text { suas idéias. } \\
\text { Pode utilizar-se } \\
\text { de explicações } \\
\text { "ad-hoc". }\end{array}$ & $\begin{array}{c}\text { Não aceita } \\
\text { comparar seus } \\
\text { conceitos com os } \\
\text { científicos, pois } \\
\text { está convicto que } \\
\text { não poderá } \\
\text { entendê-los. } \\
\text { Desesperado, } \\
\text { agarra-se ao senso- } \\
\text { comum. (Impacta a } \\
\text { Plausibilidade e a } \\
\text { Fertilidade) }\end{array}$ & $\begin{array}{c}\text { Como não } \\
\text { entendeu, não } \\
\text { busca tornar o } \\
\text { novo conceito } \\
\text { plausível. Não o } \\
\text { conecta com a } \\
\text { realidade. } \\
\text { Resta-lhe } \\
\text { apenas } \\
\text { conservar o } \\
\text { conhecimento } \\
\text { espontâneo. }\end{array}$ & $\begin{array}{l}\text { Já que precisa } \\
\text { evitar parecer } \\
\text { incapaz, não } \\
\text { deixará } \\
\text { nenhuma } \\
\text { situação sem } \\
\text { resposta, } \\
\text { utilizando-se do } \\
\text { senso-comum. }\end{array}$ \\
\hline $\begin{array}{l}\text { Não que ser } \\
\text { visto como } \\
\text { incapaz para } \\
\text { professores e } \\
\text { colegas. }\end{array}$ & $\begin{array}{l}\text { Como não quer } \\
\text { ser visto como } \\
\text { incapaz não } \\
\text { demonstra para } \\
\text { professores e } \\
\text { colegas as } \\
\text { dificuldades ou } \\
\text { o fracasso de } \\
\text { suas idéias. }\end{array}$ & $\begin{array}{c}\text { Sente-se } \\
\text { desamparado e } \\
\text { perdido escuta a } \\
\text { todos perplexo. } \\
\text { Parece concordar, } \\
\text { mas no fundo, } \\
\text { pouco ou nada esta } \\
\text { entendendo, quer } \\
\text { apenas acabar com } \\
\text { o sofrimento. } \\
\text { (Impacto na } \\
\text { Plausibilidade e } \\
\text { Fertilidade }\end{array}$ & $\begin{array}{l}\text { O sujeito pouco } \\
\text { entendeu, } \\
\text { portanto não } \\
\text { esta preocupado } \\
\text { em provar a } \\
\text { plausibilidade } \\
\text { do novo } \\
\text { conceito para } \\
\text { professores e } \\
\text { colegas. }\end{array}$ & \begin{tabular}{|c} 
Utilizará o \\
senso-comum \\
parecendo não \\
haver \\
incorporado \\
nada do novo \\
conceito. \\
(Ciclo \\
pernicioso, \\
retro-alimenta o \\
impacto na \\
Inteligibilidade \\
e \\
Plausibilidade)
\end{tabular} \\
\hline $\begin{array}{l}\text { "Baixo } \\
\text { Envolvimento, } \\
\text { Baixo Esforço" }\end{array}$ & $\begin{array}{c}\text { Como não } \\
\text { suporta lidar } \\
\text { com o fracasso } \\
\text { de suas idéias, } \\
\text { não se envolve. } \\
\text { Procura realizar } \\
\text { a atividade } \\
\text { apenas para } \\
\text { cumprir a } \\
\text { obrigação. } \\
\text { (Mecanismo } \\
\text { Disruptivo de } \\
\text { Motivação) }\end{array}$ & $\begin{array}{c}\text { O sujeito fica } \\
\text { preso em um ciclo } \\
\text { angustiante de } \\
\text { preocupações } \\
\text { relativas ao medo } \\
\text { do fracasso. } \\
\text { Logo,o sujeito não } \\
\text { é capaz de } \\
\text { direcionar sua } \\
\text { reserva energética } \\
\text { para resolver o } \\
\text { desafio na forma } \\
\text { de mais atenção e } \\
\text { esforço .(Impacta a } \\
\text { Plausibilidade e a } \\
\text { Fertilidade). }\end{array}$ & $\begin{array}{l}\text { Não vê razões } \\
\text { para se } \\
\text { esforçar, } \\
\text { conectando o } \\
\text { novo conceito a } \\
\text { realidade ou } \\
\text { monitorando-o, } \\
\text { já que pouco } \\
\text { entendeu. } \\
\text { (Ciclo } \\
\text { pernicioso, } \\
\text { retro-alimenta o } \\
\text { impacto na } \\
\text { Inteligibilidade) }\end{array}$ & \begin{tabular}{|} 
Não esta \\
preocupado \\
com as \\
possíveis falhas \\
em seu \\
pensamento. \\
Contudo, pelo \\
menos \\
esforçou-se o \\
suficiente para \\
cumprir a \\
tarefa proposta.
\end{tabular} \\
\hline
\end{tabular}


De fato, como um sujeito mais capaz poderá atuar junto ao outro se este tem como principal objetivo evitar que venham a perceber as inconsistências de seu pensamento? Como poderá internalizar os conhecimentos socialmente construídos, se os toma como potencialmente ameaçadores em relação a sua auto-imagem? Como poderá se envolver em discussão com o outro se desconfia de sua inteligência e teme ser julgado pejorativamente pelo outro?

Nas considerações feitas em seções acima, apresentamos as ferramentas epistemológicas de cada meta de realização: os sujeitos orientados a meta aprender têm como ferramenta o "esforço" com o qual pretendem inquirir e atuar junto à realidade, quando seu mundo é negado estes liberam energia para modificar-se, para tentar entendê-lo ou até mudá-lo. Contudo, os sujeitos orientados a meta performanceaproximação tem como pedra angular a crença em sua alta inteligência; quando recebem um "não", este não causa grande incômodo, a não ser que ameace a sua principal ferramenta de atuação. Diametralmente oposta, chama-nos a atenção em relação à meta performance-evitação a falta de uma ferramenta epistemológica. Parece-nos que estes sujeitos carecem de "potentia", parece que não foram inflados com uma sensação de poder suficientes para acreditar serem capazes de mudar a si mesmos, ou o mundo a sua volta.

Em nosso referencial teórico, aproximamos a função do professor a da mãe: tanto aquele, quanto esta são responsáveis em guiar, proteger e construir um mundo seguro onde seus filhos-alunos possam viver e atuar com certa autonomia. Del encontrou em sua história de vida, uma professora atuando no papel de uma "mãe de fora suficientemente boa". Ela não negou a realidade, mostrou-lhe suas falhas, o separou dos demais filhos-alunos e apesar da possível exposição, ela garantiu um caminho seguro através do esforço e da dedicação para que ele pudesse melhorar. No caso de $\mathrm{M}$, não sabemos de algum acontecimento potencialmente relevante, somente que este procurava impressionar tanto a professores quanto a seus colegas. Todavia, Ms não teve a mesma sorte que Del, pois esta encontrou um professor atuando num papel de "mãe de fora ogro", uma mãe fria que não enxergou, não percebeu o profundo sofrimento que causava semana após semana a exposição pública do fracasso de seus filhos-alunos. A professora de Del com o olhar, com sua atuação próxima, parece ter projetado um "ideal do eu" com o qual o sujeito podia se espelhar, ajustando sua auto- 
imagem através do esforço e da perseverança constituindo-se como marcas de sua personalidade. Naturalmente, que o cotidiano ofereceu uma miríade de situações para que este reforçasse este condicionamento. Por outro lado, podemos conjecturar que o professor-ogro de Ms ofereceu um "ideal do eu" infinitamente distante, uma imagem tão alta, que o sujeito não conseguiu alcançar. Pior, contribui para que este internalizasse uma imagem torta de si, como um anjo caído, com uma falha impossível de ser remediada. Pensando em fazer o melhor, o professor buscava introduzir em cada um, uma cópia de si mesmo, uma imagem verossímil. Talvez, pensasse enquanto elaborava os exercícios da semana seguinte: "Eu só exijo dos meus alunos, aquilo que exigiria de mim mesmo". Todavia, parte dos sujeitos abandonados e desamparados não tinham condições de modificar a realidade melhorando a si mesmos, nutrindo-se do saber do mestre. E assim, Ms foi paulatinamente perdendo o controle da situação, internalizando a certeza da incapacidade, a angustia, o medo e finalmente o doloroso fracasso.

Devemos esclarecer que o referencial teórico ligado às metas de realização recomenda que seus constructos não podem ser confundidos com a personalidade dos indivíduos. Portanto, estes apenas determinam as condições de entrada dos indivíduos relativas aos objetivos que estes pretendem cumprir. Sendo assim, todas as considerações feitas acima inclusive às tabelas, não passam de conjecturas de possíveis acontecimentos. Nesse sentido, estas considerações devem ser vistas com cautela e não podem constituir juízos de valor dos sujeitos pesquisados. Pois, apenas captamos uma fotografia momentânea das preocupações destes em relação às tarefas escolares. Nesse sentido, temos a nítida impressão que não tratamos propriamente dos sujeitos, apenas construímos figuras emblemáticas. Sendo assim, ao olhar para a realidade será possível encontrar alguns sujeitos muito próximos, quase fidedignos a estas caricaturas, todavia outros muito distantes. 


\section{Bibliografia:}

AGUIARJÚNIOR,O.G.Mudanças conceituais (oucognitivas) na educação em ciências: revisão crítica e novas direções para a pesquisa. Ensaio. Pesquisa em Educação em Ciências,v.3,n.1,p.1-20,2001.

Abib, M. L. V dos S. A construção de Conhecimentos sobre Ensino na Formação Inicial do Professor de Física: “...agora, nós já temos as perguntas.” São Paulo: USP, tese de doutorado, 1996, 300p

Arantes, V. A (org). Afetividade na escola: alternativas teóricas e práticas. São Paulo: Editorial Summus, 2003, v. 1, 240 p.

Barolli, E. Valadares, J. M. Villani,A. Explicitando Uma Metodologia de Pesquisa: A Experiência de uma Professora de Física. Ciência\&Educação,V.13,n.2, 2007Disponívelem:http://dx.doi.org/10.1590/S151673132007000200008 Acesso08dejan.de2012.

Boruchovitch, E. Bzuneck, J. A. A Motivação do Aluno: contribuição da psicologia contemporânea / organizadores - Petrópolis, RJ: Vozes, 2001.

Cabral, T.C.B Tese de doutorado- FE-USP, 1998

Freire, P. Pedagogia do Oprimido, 17ª ed. Rio de Janeiro, Paz e Terra, 1987.

Freitas, D. Villani, A. Formação de professores de ciências: um desafio sem limites.. Investigações em Ensino de Ciências (Online), Porto Alegre, v. 7, n.3, p. 25-37, 2002.

Garmier, C. Bednarz, N. Ulanovskaya, I. (organizadores): Após Vygotsky e Piaget: Perspectivas Social e Construtivista Escolas Russa e Ocidental - Porto Alegre - Artes Médicas - 1996

Gil Perez, D. et al. ¿Puede Hablarse de Consenso Constructivista en la Educacion Científica?- Ensenaza de Las Ciências, 1999, 17 (13), 503-512

Gunstone, R. F. : 'Constructivism and metacognition: Theoretical issue and classroom studies', In Duit, R; Coldberg, F.; Niedderer, H (eds.) Research in Physics Learning: Theoretical Issues and Empirical Studies. IPN. Kiel (d) pp. 176-187. 1992.

Inhelder, I\& Piaget, J.Da Lógica da Criança à Lógica do Adolescente -São Paulo: Pioneira, 1976.

Kamii, C. :Desvendendo a Aritmética: Implicações da Teoria de Piaget-Campinas, SP: Papírus, 1995.

Mortimer, E. F. Construtivismo, Mudança Conceitual e Ensino de Ciências: para onde vamos? In: Investigação em Ensino de Ciências. Porto Alegre: UFRGS, vol.1, n.1 abr. 1996, capturado de http://www.if.ufrgs.br/public/ensino em 02/2006. 
Oliveira, M. K. de: Vygotsky: Aprendizado e Desenvolvimento um Processo SócioHistórico - São Paulo: Scipione, 1993

Palangana, I C. Desenvolvimento e aprendizagem em Piaget e Vygotsky: (a relevância do social) - São Paulo: Sumus, 2001 - 3ed.

Pessoa de Carvalho, A. M. et al.¿Tiene Sentido Seguir Disntinguiendo entre Aprendizaje de Conceptos, Resolucións de Problemas de Lápis y Papel e Realización de Práticas de Laboratorio?- Ensenaza de Las Ciências, 1999, 17 (2), 311-320.

Pessoa de Carvalho, A. M. et al. ¿Puede Hablarse de Consenso Contructivista en la Educacion Científica?- Ensenaza de Las Ciências, 1999, 17 (3), 503-512.

Pessoa de Carvalho, A. M.: Ensino de Ciências e Epistemologia Genética -Viver Mente \& Cérebro - Coleção Memória da Psicologia, n.1: Jean Piaget - p. 50 a 57 - São Paulo: Segmento Duetto, 2005.

Piaget, J.: O Desenvolvimento do Pensamento: Equilibração das Estruturas Cognitivas - Lisboa, Publicação Dom Quixote, 1977.

Piaget, J. Seis Estudos de Psicologia- Rio de Janeiro: Forense Universitária, 2006 ed. 24.

Piaget, J e Inhelder, B. A Psicologia da Criança- Rio de Janeiro: Difel, 2006 ed. 2.

Piaget, J. O Nascimento da Inteligência na Criança - Rio de Janeiro: Zahar Editores, 1970.

Piaget, J. A epistemologia genética -São Paulo: Abril Cultural (Coleção Os Pensadores), 1983 ed. 2.

Piaget, J. A Formação do Símbolo na Criança Editora- Rio de Janeiro: LTC, 1990 ed. 3.

Piaget, J. O Juizo Moral na Criança-São Paulo: Summus, 1994.

Piaget, J. O Raciocínio da Criança-Rio de Janeiro: Record, 1967.

Pintrich, P. R.; Marx, R W \& Boyle, R. A. : 1993, Beyond Cold Conceptual Change: The role of Motivational Beliefs and Classroom Contextual Factors in the Process of Conceptual Change, Review of Educational Research 63 (2): 167-199.

Posner, G. J. Strike, K. A. Hewson, P. W.Gertzog, W. A. (1982). Accommodation of a Scientific Conception: Toward a Theory of Conceptual Change. Science Education, v. 66, n2: 211-227.

Reeve, J.: Motivação e Emoção / Johnmarshall Reeve; - Rio de Janeiro: LTC, 2006. 
Silva, E. L.: Aspectos Motivacionais em Operação nas Aulas de Física do Ensino Médio, nas Escolas Estaduais de São Paulo - Dissertação Mestrado - USP: São Paulo, 2004.

Souza, L. S e Pessoa de Carvalho, A. M. Ensino de Ciências e a Formação da Autonomia Moral- V Encontro Nacional de Pesquisa em Educação em Ciências: $V$ Enpec, 2005.

Villani, A ; Barolli, E. Valadares, J. M. Franzoni, M. Guridi, V. M. Ferreira, D B. Contribuições da Psicanálise para uma Metodologia de Pesquisa em Educação em Ciências. In: Flávia Maria Teixeira dos Santos; Ileana Maria Greca. (Org.). A Pesquisa em Ensino de Ciências no Brasil e suas Metodologias. Porto Alegre: UNIJUI, 2006, v. 1, p. 323-390.

Villani, A. Cabral, T. C. B.. Mudança Conceitual, Subjetividade e Psicanálise. Investigações em Ensino de Ciencias, Porto Alegre, v. 2, n.1, p. 43-61, 1997.

Villani, A.O Professor de Ciências é Como um Analista? Ensaio - Pesquisa em Educação em Ciências Volume 01 / Número 1 - setembro de 1999.

Villani, A. Filosofia da Ciência e Ensino de Ciências: Uma Analogia?. Ciência e Educação (UNESP), UNESP - Bauru (S.P.), v. 7, n.2, p. 98-110, 2001.

Villani, A.. Filosofia da ciência, Ensino de ciências e Psicanálise. Amazônia (Banco da Amazônia), Belém -Pará, v. 1, n.1 e 2, p. 63-72, 2005.

Vygotski, L. S. A Formação social da Mente: o Desenvolvimento dos processos psicológicos superiores- São Paulo - Martins Fontes, 1998 - 6 ed.

White, R. T. Condiciones Para Um Aprendizaje de calidad en la enseñanza de las Ciências. Reflexiones a Partir Del Proyecto Peel. Enseñanza de Las Ciências, 1999, 17 (1), 3-15

Zenorini R. P. C. Santos, A. A. A. Bueno, J.M.H. Escala de Avaliação das Metas de Realização: estudo preliminar de validação. Aval. psicol., Porto Alegre,v. 2, n. 2, dez. 2003Disponível

em $<$ http://pepsic.bvsalud.org/scielo.php?script=sci_arttext\&pid=S167704712003000200007\&lng=pt\&nrm=iso > . acessos em 10 fev. 2013. 


\section{Apêndices}

Apêndice - I: Instrumentos de Pesquisa Primeira Fase

Questionário de acesso às Metas de Realização............................................................

Tradução do Questionário (Primeira Versão)..............................................................

Questionário de Acesso às Metas de Realização (Versão Final).................................5

Entrevista de Validação do Perfil Motivacional de Realização....................................6

Análise da Entrevista de Validação do Perfil Motivacional de Realização................. 7

Apêndice - II: Instrumentos de Pesquisa Segunda Fase

Entrevista sobre a Percepção Motivacional............................................................13

Apêndice - III

Quais Fatores que Impossibilitam o Resultado Conclusivo do Questionário de Acesso às Metas de Realização

Apêndice - IV

Apresentação da Atividade Experimental para ser Realizada pelo Grupo 24

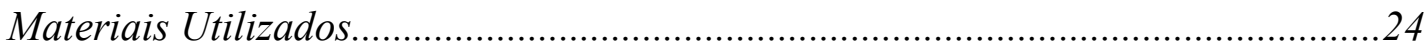

Atividade Experimental: Colheres de plástico, madeira e metal..............................24

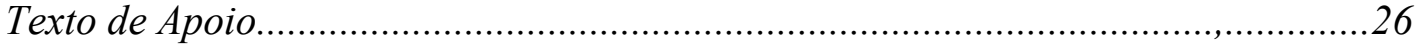

Descrição e Pequena Análise da Atividade Experimental .....................................27 Apêndice - $V$

Entrevistas Primeira Fase - Perfil de Realização: Sujeito Del, Ms e M

Análise dos dados da Entrevista de Validação do Perfil Motivacional de Realização do Sujeito Del.

Análise dos dados da Entrevista de Validação do Perfil Motivacional de Realização

do Sujeito Ms.

Análise dos dados da Entrevista de Validação do Perfil Motivacional de Realização do Sujeito M.

Apêndice - VI

Questionários, Entrevistas - Segunda Fase-Perfil de Realização: Sujeito Au, Ga, En e Des

Questionário de Acesso às Metas de Realização do Sujeito

Au.

Análise dos dados da Entrevista de Validação do Perfil Motivacional de Realização do Sujeito Au. 
Questionário de Acesso às Metas de Realização do Sujeito Ga.

Análise dos dados da Entrevista de Validação do Perfil Motivacional de Realização do Sujeito Ga

138

Questionário de Acesso às Metas de Realização do Sujeito En. .154

Análise dos dados da Entrevista de Validação do Perfil Motivacional de Realização do Sujeito En. .155

Questionário de Acesso às Metas de Realização do Sujeito Des. 186 Análise dos dados da Entrevista de Validação do Perfil Motivacional de Realização do Sujeito Des. 187 Resumo da Análise da Entrevista de Validação do Perfil Motivacional de Realização do Sujeito Des. 187

Dados da Entrevista de Validação do Perfil Motivacional de Realização do Sujeito Des. 
Apêndice - I

\section{Instrumentos de Pesquisa Primeira Fase}

Questionário de Acesso às Metas de Realização

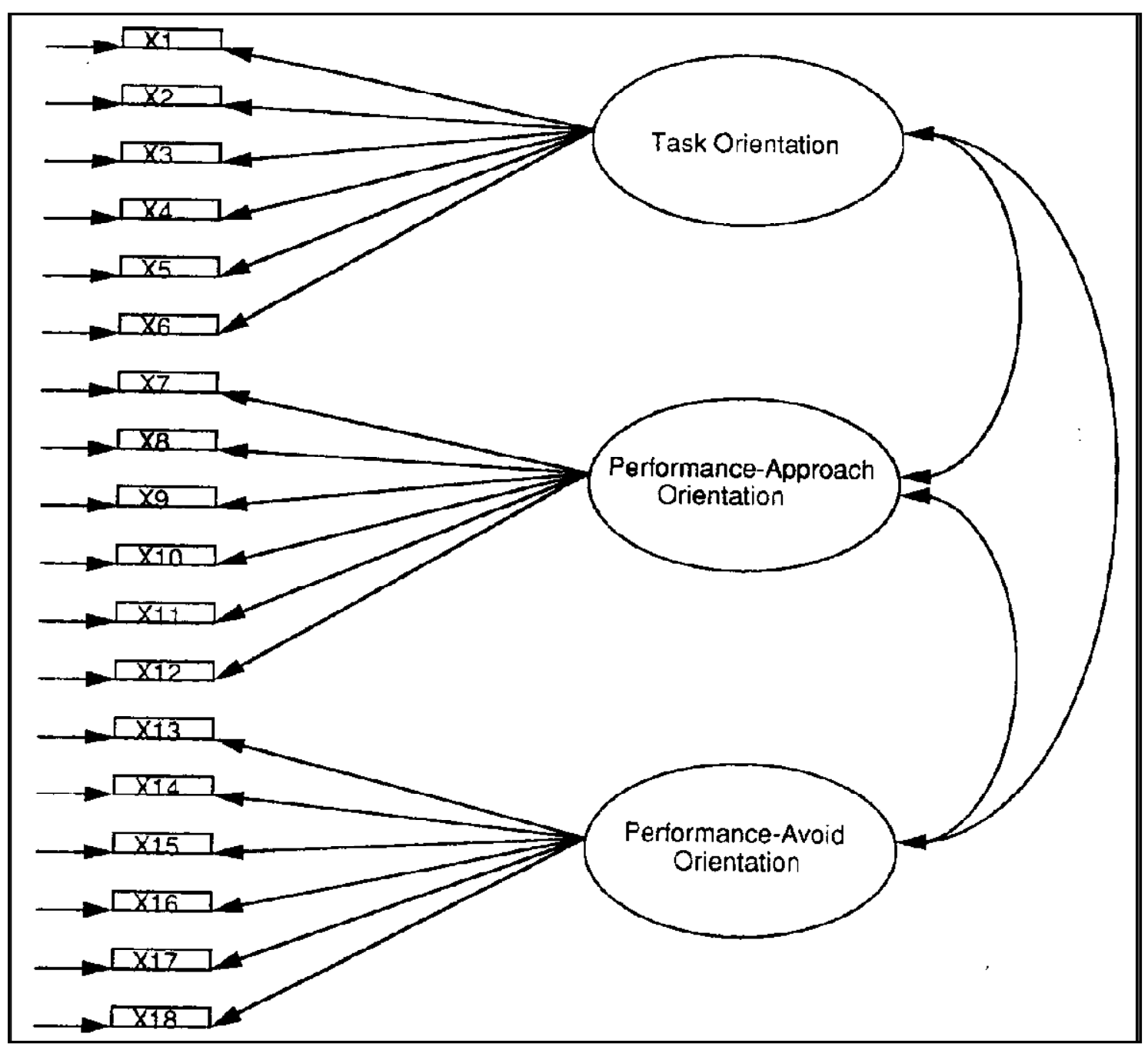

Goal Orientation Scales

\section{Task Goal Orientation}

XI-I like school work that I'll learn from, even if I make a lot of mistakes.

X2-An important reason why I do my school work is because I like to learn new things.

X3-I like school work best when it really makes me think.

X4-An important reason why I do my work in school is because I want to get better at it.

X5-I do my school work because I'm interested in it.

X6-An important reason I do my school work is because I enjoy it. 
X7-I would feel really good if I were the only one who could answer the teachers' questions in class.

X8-It's important to me that the other students in my classes think that I am good at my work. 3

X9-I want to do better than other students in my classes.

X10-I would feel successful in school if I did better than most of the other students.

X11-I'd like to show my teachers that I'm smarter than the other students in my classes.

X12-Doing better than other students in school is important to me.

\section{Ability-Avoid Goal Orientation}

X13-It's very important to me that I don't look stupid in my classes. X14-An important reason I do my school work is so that I don't embarrass myself.

X15-The reason I do my school work is so my teachers don't think I know less than others.

X16-The reason I do my work is so others won't think I'm dumb.

X17-One reason I would not participate in class is to avoid looking stupid.

X18-One of my main goals is to avoid looking like I can't do my work.

Tradução do Questionário

(Primeira Versão)

Nome: idade série $n^{o}$

Responda as perguntas, assinalando com um $X$.

1- Eu gosto de realizar tarefas na escola em que eu realmente aprenderei, mesmo que eu cometa muitos erros. ( )

2- Eu me sentiria realmente bom se eu fosse o único que respondesse as perguntas dos professores da classe. ( )

3- É muito importante que eu não seja visto como um estúpido na frente dos meus colegas. ( )

4- Uma razão importante para que eu faça tarefas na escola é porque eu gosto de aprender coisas novas.( )

5- E importante para mim que os outros estudantes em minha classe pensem que eu sou bom nas tarefas que realizo.( )

6- Uma razão importante para eu faça as tarefas é para que eu não fique envergonhado.( )

7- Tarefa que eu gosto de fazer é aquela em que eu possa realmente pensar.( )

8- Eu quero fazer as tarefas melhor do que os outros estudantes da minha classe. ( )

9- Eu me preocupo quando eu faço meu trabalho se os professores irão pensar que eu sou menos capaz do que os outros. ( )

10- Uma importante razão para que eu faça a tarefa na escola é porque eu sempre quero melhorar, aprender mais. ( )

11- Eu sentiria bem sucedido se eu aprendesse mais do que os outros estudantes.() 
12- Uma das razões para que eu faça meu trabalho é porque não quero que pensem que eu sou burro.( )

13- Eu faço minha tarefa na escola porque eu estou interessado nela.( )

14- Eu gostaria de mostrar aos meus professores que eu sou o mais esperto da classe.( )

15- Uma razão que eu não participaria de uma da aula é porque não quero que me vejam como um estúpido(a).( )

16- Uma importante razão para que eu realize uma tarefa na escola é que eu goste dela.( )

17- É importante para mim, fazer as atividades melhor do que os outros alunos. ()

18- Um de meus objetivos principais é evitar que me vejam como incapaz de realizar minhas tarefas.( )

\section{Questionário de Acesso às Metas de Realização (Versão Final)}

Nome: idade série $n^{o}$.

Caso você concorde com as ideias abaixo as classifique colocando (C) que significa concordo, caso contrário, ou seja, se você não concordar coloque (NC) que significa não concordo. Caso você concorde parcialmente classifique as respostas como (CP) que significa concordo em algumas partes.

1- Eu gosto de realizar tarefas na escola em que eu realmente aprenderei, mesmo que eu cometa muitos erros. ( )

2- Eu me sentiria realmente bom se eu fosse o único que respondesse as perguntas dos professores da classe. ( )

3- É muito importante que eu não seja visto como um estúpido na frente dos meus colegas. ( )

4- Uma razão importante para que eu faça tarefas na escola é porque eu gosto de aprender coisas novas.( )

5- E importante para mim que os outros estudantes em minha classe pensem que eu sou bom nas tarefas que realizo.( )

6- Uma razão importante para eu faça as tarefas é para que eu não fique envergonhado.( )

7- Tarefa que eu gosto de fazer é aquela em que eu possa realmente pensar.( )

8- Eu quero fazer as tarefas melhor do que os outros estudantes da minha classe. ( )

9- Eu me preocupo quando eu faço meu trabalho se os professores irão pensar que eu sou menos capaz do que os outros. ( )

10- Uma importante razão para que eu faça a tarefa na escola é porque eu sempre quero melhorar, aprender mais. ( )

11- Eu sentiria bem sucedido se eu aprendesse mais do que os outros estudantes.()

12- Uma das razões para que eu faça meu trabalho é porque não quero que pensem que eu sou burro.( )

13- Eu faço minha tarefa na escola porque eu estou interessado nela.( )

14- Eu gostaria de mostrar aos meus professores que eu sou o mais esperto da classe.( )

15- Uma razão que eu não participaria de uma da aula é porque não quero que me vejam como um estúpido(a).( ) 
16- Uma importante razão para que eu realize uma tarefa na escola é que eu goste dela.( )

17- É importante para mim, fazer as atividades melhor do que os outros alunos. ()

18- Um de meus objetivos principais é evitar que me vejam como incapaz de realizar minhas tarefas.( )

\section{Entrevista de Validação do Perfil Motivacional de Realização}

1 - Você tem quantos anos?

2- $\quad$ Faz muito tempo que você mora no bairro?

3- $\quad$ Você sempre estudou nesta escola?

4- Você atualmente está trabalhando?

5- $\quad$ Na pergunta $n^{\circ}-1$, você assinalou que não se preocupa em cometer muitos erros, porque o importante é que você aprenda? Mas errar não é ruim? Explique.

6- Mas e se o professor lhe desse as respostas certas?

7- $\quad$ Se você fosse escolher entre aprender um assunto que você nunca viu e um outro que você tem alguma noção ou já ouviu falar, qual deles você daria preferência? Explique.

8- $\quad$ Você acha que aprender é fácil? Por quê?

9- $\quad$ Você acha que para aprender é necessário esforço?

10- De que forma o professor pode influenciar neste esforço?

11- Quais são as estratégias que você utiliza para aprender?(você estuda antes das provas - perguntas nesse sentido)

12- Qual o papel do bom professor? O que é um bom professor para você?

13- O que é um bom aluno para você?

14- Quando você não aprende, de quem é a culpa?

15- Você afirmou, na pergunta $n^{\circ}$. 7, que gosta de pensar? Como que é isto? E quando você não consegue chegar à solução o que você sente?

16- Se você estudou para uma prova, mas na hora você se confundiu e conseguiu uma nota $C$. Como você se sente?

17- Você sempre tirou boas notas?

18- Quando o professor propõe um desafio como você se sente?

19- Seus pais se preocupam com suas notas?

20- Você, alguma vez, recebeu algum castigo por ter tirado nota baixa?

21- Quantos irmãos você tem? Em relação a eles você se acha inteligente ou o que apresenta maior dificuldade para aprender?

22- Você já participou de algum concurso na escola? Você ganhou, perdeu? Como se sentiu?

23- $\quad$ Tem alunos que ao receberem as provas ficam comparando nota, o que você acha disso?

24- O professor fez uma pergunta, você tem quase certeza da resposta você arrisca e responde ou espera que alguém responda pra você?

25- $\quad$ O que você acha do trabalho em grupo?

26- Você tem alguma dificuldade quando trabalha em grupo? Qual?

27- O trabalho em grupo ajuda?

28- O professor pede para você resolver várias questões em grupo como o grupo se comporta? 
Um responde depois passa as perguntas para os outros/Os alunos esperam que você explique para eles/Você costuma fazer e os outros ficam olhando. Isto não atrapalha você, onde é que você sai ganhando.

29- Mas e se você e seu amigo não souberem? Como é que fica? Explique.

30- Você está resolvendo em grupo algumas questões de matemática e suponhamos que você não saiba fazer uma conta lá da $5^{a}$. série. O que você faz?

31- Você sabe que alguns alunos tiram barato quando os alunos respondem errado, o que você acha disso?

32- Você acha que o aluno deve repetir? Por quê?

33- Você se lembra de ter vivenciado alguma situação desagradável referente a provas e notas?

Você já se sentiu incapaz de realizar alguma tarefa escolar?

\section{Análise da Entrevista de Validação do Perfil Motivacional de Realização}

As primeiras quatro questões têm o propósito de iniciar o diálogo, buscando dirimir alguma possível preocupação do aluno. Alguns alunos ficam preocupados se terão que responder perguntas difíceis. $\mathrm{O}$ entrevistador poderá alongar ao máximo possível esta fase caso tenha percebido uma certa ansiedade por parte do entrevistado.

1. Você tem quantos anos?

2. Faz muito tempo que você mora no bairro?

3. Você sempre estudou nesta escola?

4. Você atualmente está trabalhando?

Com a quinta questão busca-se entender como o aluno interpreta o erro. Independentemente da meta de orientação, muitos concordam com esta afirmativa, afinal, é senso comum que aprendemos com nossos erros. Entretanto, este quesito é um dos pressupostos básicos estabelecidos para a meta-aprender. A sexta pergunta visa aprofundar sobre a resposta anterior, pois é sabido, que muitos alunos preferem receber as repostas prontas do professor.

5. Na pergunta $n^{\circ}-1$, você assinalou que não se preocupa em cometer muitos erros, porque o importante é que você aprenda? Mas errar não é ruim? Explique.

6. Mas e se o professor lhe desse as respostas certas? 
A próxima contempla a meta aprender, pois os alunos assim orientados buscam progredir sempre, dominando mais conteúdos com inovação e criatividade. Por outro lado, deve ser motivo de preocupação para o aluno orientado à meta performanceevitação, afinal, o novo pode trazer consigo a possibilidade do erro, reafirmando a sensação de incapacidade. Desta maneira resgata-se a pergunta número 5 só que em outro contexto.

7. Se você fosse escolher entre aprender um assunto que você nunca viu e um outro que você tem alguma noção ou já ouviu falar, qual deles você daria preferência?Explique.

A oitava questão nos remete a duas respostas possíveis: “-Sim, eu acredito que aprender é fácil", ligada à meta performance-aproximação. Ou, “-Não, é necessário muito esforço e dedicação": referente meta-aprender ou meta performance-evitação. Provavelmente, o aluno na meta performance-evitação ao citar a palavra esforço, coloca maior ênfase na dificuldade, pois conforme referencial teórico, o aluno assim orientado tem dificuldades de aprendizagem não por falta de esforço, mas por acreditar não ser possuidor de capacidade intelectual. Poderá ocorrer ainda, de o indivíduo relatar a seguinte variação: "Depende da disciplina, algumas eu aprendo fácil, outras com maior dificuldade”; o pesquisador poderá então se estender investigando o porquê desta percepção.

\section{Você acha que aprender é fácil? Por quê?}

Caso o aluno, não tenha se referido ao esforço na questão anterior, o entrevistador, na questão 9, faz a relação entre aprendizagem e esforço. Já na questão 10, entra em cena o papel do professor e a possibilidade que este tem de motivar os alunos a se esforçarem para aprender. No tocante à motivação para aprender, Silva (2004 p. 185) em sua dissertação chega à seguinte conclusão: "Os alunos consideram o professor como um elemento muito importante e o único responsável por sua motivação...".

9. Você acha que para aprender é necessário esforço?

10. De que forma o professor pode influenciar neste esforço? 
Na próxima pergunta estamos interessados em saber se os alunos utilizam-se de alguma estratégia para aprender, também um dos pressupostos ligados à meta-aprender.

11. Quais são as estratégias que você utiliza para aprender? (você estuda antes das provas - perguntas nesse sentido)

Ao perguntamos ao aluno sobre o que significa ser um bom professor estávamos interessados em saber se a principal função do professor é tornar descomplicado o processo de aprender. Mas não no sentido de mostrar o caminho, de orientá-lo durante o processo, mas sim, no sentido do mínimo esforço, ou seja: o professor só é bom caso eu aprenda com facilidade. Por outro lado, estamos também preocupados com o quanto o discente se sente responsável por seu aprendizado, ou se isto pode provocar grande ansiedade. Em Silva (obra citada, p. 185) encontramos: "Seu discurso raramente atribui a si mesmo esta responsabilidade ou possibilidade, num procedimento que talvez seja mesmo inconsciente, de transferir para o outro a responsabilidade ou a culpa.".

Baird nos adverte que alguns alunos se ressentem diante da exigência de terem de pensar. Os alunos tendem a preferir a resposta correta e pronta do professor.

\section{Qual o papel do bom professor? O que é um bom professor para você?}

13. O que é um bom aluno para você?

14. Quando você não aprende de quem é a culpa?

Baird (apud Villani, **) nos adverte que alguns alunos se ressentem diante da exigência de terem de pensar. Os alunos tendem a preferir a resposta correta e pronta do professor.

15. Você afirmou, na pergunta $n^{\circ} 7$, que gosta de pensar? Como que é isto? E quando você não consegue chegar à solução o que você sente?

A décima sexta e décima sétima perguntas procuram saber o quanto os alunos estão preocupados com notas. Ou seja, se tiram ótimas notas podem ser considerados inteligentes, caso contrário, notas ruins, significam baixa capacidade intelectual. Dependendo da resposta, o entrevistador pode perguntar como o aluno se sente em 
relação às provas ou questionários. Não podemos deixar de ter em mente que provas sempre trazem consigo a possibilidade do fracasso, pois parte-se do pressuposto de que trazem um conteúdo já desenvolvido pelo professor, devendo agora o aluno demonstrar sua compreensão, que será comprovada por uma bela nota, ou não.

16. Se você estudou para uma prova, mas na hora você se confundiu e conseguiu uma nota C. Como você se sente?

17. Você sempre tirou boas notas?

A décima oitava se refere ao desafio proposto pelo professor. E o objetivo deste é bastante diferente do da prova, pois caso o aprendiz não o resolva, não há problemas, pois o professor sabe que poucos conseguirão. Portanto, não haverá motivos para uma nota baixa, como seria o caso de uma prova, onde os conteúdos foram previamente discutidos. Sendo assim, o aluno que resolvê-lo terá garantido no mínimo um punhado de elogios e o respeito da classe.

18. Quando o professor propõe um desafio como você se sente?

Nas próximas duas perguntas, estamos interessados em saber como anda a autoimagem em relação à família, se já passou por cobranças, qual o peso dessas cobranças e o quanto se preocupa com o julgamento feito pelos pais.

19. Seus pais se preocupam com suas notas?

20. Você, alguma vez, recebeu algum castigo por ter tirado nota baixa?

21. Quantos irmãos você tem? Em relação a eles você se acha inteligente ou o que apresenta maior dificuldade para aprender?

$\mathrm{Na}$ vigésima segunda pergunta, procuramos captar se o aluno já viveu alguma situação de sucesso ou sensação de fracasso considerada importante em sua vida escolar.

22. Você já participou de algum concurso na escola? Você ganhou, perdeu? Como se sentiu? 
Sondamos nesta pergunta, outro aspecto da vida escolar do indivíduo e a preocupação em relação a sua auto-imagem perante outros alunos. $\mathrm{O}$ aluno é quem procura impressionar os outros, ou é motivo de piada. Segundo, Pintrich et al (1993, p. 173):

[...] Os estudantes possuem diversas metas além de aprender tais como: fazer amigos, encontrar um namorado ou namorada, ou impressionar seus pares - o que pode produzir um curto-circuito em um engajamento ${ }^{1}$.

23. Tem alunos que ao receberem as provas ficam comparando nota, o que você acha disso?

Na vigésima quarta, procuramos captar como o aluno se sente em relação à sua autoconfiança ou possibilidade de auto-realização. Possivelmente, o aluno orientado à meta-aprender diante desta situação sinta-se confiante em emitir sua opinião. Por outro lado, o aluno orientado à meta performance-evitação procure esperar que outro aluno responda para não colocar em risco sua auto-imagem. Já o aluno na meta performanceaproximação procure responder o mais rápido possível, demonstrando assim, possuir um raciocínio rápido, o que comprovaria para os seus pares e professores a sua vasta capacidade intelectual.

24. O professor fez uma pergunta, você tem quase certeza da resposta, você arrisca e responde ou espera que alguém responda para você?

O trabalho em grupo é uma estratégia muito importante para o ensino de ciências. Portanto, é importante saber qual a visão que os alunos têm sobre esta importante metodologia de aprendizagem. Nesse sentido, a $25^{\mathrm{a}}$ pergunta é bastante aberta para que o sujeito possa responder livremente sobre o trabalho em grupo.

25. O que você acha do trabalho em grupo?

\footnotetext{
${ }^{1}$ Tradução do autor: Texto original: "Students may have many social goals in classroom context besides learning - such as, making friend, finding a boy-friend or girlfriend, or impressing their peers (see Wentzel, 1991) - which can short circuit any in-depth intellectual engagement."
} 
O pesquisador deve ter em mente que o trabalho em grupo levanta questões paradoxais, por exemplo: para muitos, é um lugar em que as responsabilidades e as tarefas serão divididas, para outros, pode ser uma oportunidade de menos trabalho delegando as tarefas mais complexas aos alunos mais capazes. Para alguns, pode ser o lugar propício para o desenvolvimento de pontos de vista contrários; embora, alguma parcela prefira o sólido conhecimento do professor ao invés de ficar debatendo longas questões com seus pares. Sendo assim, as questões $26^{\text {a }}$ até $30^{\mathrm{a}}$ têm o propósito de contemplar essas possíveis conjecturas. Já as questões seguintes $(31,32)$ buscam sondar se o aluno possui autoconfiança suficiente para tirar uma dúvida que todos julgariam como sendo fácil.

26. O que você acha do trabalho em grupo?

27. Você tem alguma dificuldade quando trabalha em grupo? Qual?

28. O trabalho em grupo ajuda?

29. O professor pede para você resolver várias questões em grupo como o grupo se comporta?

30. Um responde depois passa as perguntas para os outros/ Os alunos esperam que você explique para eles/ Você costuma fazer e os outros ficam olhando. Isto não atrapalha você, onde é que você sai ganhando?

31. Mas e se você e seu amigo não souberem? Como é que fica? Explique.

32. Você está resolvendo em grupo algumas questões de matemática e suponhamos que você não saiba fazer uma conta lá da $5^{\underline{a}}$ série. O que você faz?

Novamente, em relação à auto-imagem, só que agora ligada à possibilidade de ser motivo de chacota no momento em que emite sua opinião. Naturalmente, que esta pergunta procura encetar a vergonha e está ligada ao sentimento característico dos sujeitos orientandos à meta performance-evitação.

33. Você sabe que alguns alunos tiram barato quando os alunos respondem errado o que você acha disso?

A pergunta a seguir recupera novamente a questão do esforço. Pois os alunos orientados à meta aprender costumam relacionar sucesso escolar a esforço, portanto, aqueles que não aprendem são vistos como preguiçosos, ou que, no mínimo, não se 
dedicam para aprender. Por esta razão, acreditam que o aluno que não se esforça não tem o direito de ser aprovado, desta forma, criticam a situação atual de ensino por considerarem que os alunos são aprovados automaticamente.

34. Você acha que o aluno deve repetir? Por quê?

Por fim, as duas últimas perguntas procuram esclarecer se o aluno vivenciou, em sua vida escolar, alguma experiência que tenha deixado marcas negativas em sua autoimagem.

35. Você se lembra de ter vivenciado alguma situação desagradável referente a provas e notas?

36. Você já se sentiu incapaz de realizar alguma tarefa escolar?

\section{Apêndice - II: Instrumentos de Pesquisa Segunda Fase}

\section{Entrevista sobre a Percepção Motivacional.}

1. O que você achou da atividade?

2. Você gostou da atividade?

3. Quais perguntas foram as mais fáceis?

4. Quais as perguntas foram as mais difíceis?

$\checkmark$ Muitos relatam o conflito.

5. Que perguntas foram mais interessantes?

6. Porque você achou estas perguntas interessantes?

7. Quais as perguntas que proporcionaram uma sensação de confusão?

$\checkmark$ Alguns alunos relatam que a confusão (conflito cognitivo) é que torna a pergunta interessante (pode aparecer a surpresa). Outros dizem que este fato torna a pergunta desinteressante.

8. O que motivou você a continuar tentando?

$\checkmark$ Alguns alunos afirmam que a necessidade de entender o que está acontecendo. O que podemos entender como sendo a necessidade de voltar ao equilíbrio, outros dizem que este fato torna a atividade desmotivante. 
9. Mas esta sensação de confusão não é ruim, não seria mais fácil se o professor explicasse na lousa?

$\checkmark$ Muitos relatam que se explicasse não teria graça a atividade, perderia a possibilidade de desafio.

10. Em algum momento você se sentiu desafiado?

11. Em qual momento ou pergunta você se sentiu desmotivado?

12. Quando você se sentiu desmotivado o que passou pela sua cabeça?

\section{O Grupo}

13. O que diferencia esta atividade de outras disciplinas. (matemática, português, etc.)?

14. Você gostou de participar do grupo? Como foi sua participação?

$\checkmark$ Alguns alunos relatam que a diferença entre atividade e outras está na possibilidade de atuarem em grupo, pois surge o debate.

15. Qual critério que vocês utilizam para decidir qual resposta é a verdadeira?

16. Caso você estivesse sozinho você conseguiria realizar esta atividade?

17. E se fosse um outro grupo, o que você acha que aconteceria?

\section{As sensações}

18. Em algum momento, você se sentiu surpreso?

19. Em algum momento você sentiu que não conseguiria achar a resposta ou realizar atividade?

$\checkmark$ Alguns relatam que a confusão provoca esta sensação, alguns continuam outros desistem.

20. Qual tipo de modificação que você gostaria que o professor fizesse para que você não sentisse este tipo de sensação?

$\checkmark$ Alguns alunos explicam que seria melhor o professor explicar na lousa.

21. Você acha que se o professor explicasse na lousa seria mais fácil?

22. Você em algum momento, vivenciou uma certa dose de tensão?

$\checkmark$ Esta tensão, muitas vezes, faz com que o aluno fique focado na atividade e esteja ligado ao conflito.

23. Qual foi sua sensação em relação ao tempo?

$\checkmark$ Alguns respondem que não perceberam o tempo passar, ficando envolvidos com a atividade.

24. Você vivenciou alguma sensação de satisfação ou alívio? 
$\checkmark$ Alguns alunos relatam que se sentiram satisfeitos com o conhecimento adquirido.Outros relatam uma sensação de alívio provocada pela cessação da tensão.

25. Você vivenciou alguma sensação desagradável? Esperar o sujeito responder, caso contrário exemplifique o tipo de sensação, por exemplo, sentiu-se nervoso, sentiu o coração disparar, sentiu as mãos suadas?

$\checkmark$ Alguns alunos, ao perceberem a possibilidade do fracasso, entram em um processo de ansiedade e acabando por somatizar estas reações em comportamentos bem característicos como, por exemplo, taquicardia, sudorese ou boca seca.

26. Qual dessas frases descreveria seu sentimento em relação à atividade?

a) Foi difícil, senti que não ia conseguir, parecia que o tempo passava rápido e ao mesmo tempo demorava, me senti desmotivado em vários momentos. Graças a Deus que acabou!

Fale-me sobre esta sensação?

b) Foi difícil, mas foi bom, fiquei tão concentrado nas discussões que nem senti o tempo passar. No final, passou a tensão e me senti alegre e realizado pelo esforço que realizei e por aquilo que eu aprendi.

Fale-me sobre esta sensação.

c) Foi fácil, ficamos com dúvidas em alguns momentos, mas logo encontramos a solução, foi tranquilo.

Fale-me sobre esta sensação.

d) Foi difícil, fiquei confuso(a) e nervoso(a), comecei a achar que era incapaz e fui desistindo aos poucos

Fale-me sobre esta sensação.

e) Foi difícil, senti que não ia conseguir, mas conseguimos e me senti aliviando no final.

Fale-me sobre esta sensação.

f) Caso não se reconheça em nenhuma destas descrições, descreva como você se sentiu.

\section{Sobre a relevância do conhecimento}

27. Você acredita que este conhecimento serve para alguma coisa? 
$\checkmark$ Alguns alunos gostam, pois explica o mundo e a relação com as coisas, outros não conseguem identificar a importância do conhecimento, muito menos, estabelecem alguma relação com o cotidiano.

28. Você recomenda que eu continue a utilizar este tipo de atividade?

29. Você faria alguma sugestão para melhorá-la?

Apêndice - III

Quais Fatores que Impossibilitam o Resultado Conclusivo do Questionário de Acesso às Metas de Realização.

O artigo: "Escala de Avaliação das Metas de Realização: estudo preliminar de validação” escrito por Zenorini e colaboradores foi publicado em 2003. O artigo tem como objetivo validar o questionário de acesso às metas de realização desenvolvido por Midgley (1998) e utilizado nesta pesquisa. Neste estudo, participaram 189 alunos, regularmente matriculados em diversos cursos de uma universidade particular do interior do Estado de São Paulo. O maior número de sujeitos concentrou-se na faixa de 18 a 25 anos. Do total de sujeitos, 34,5\% eram do gênero masculino e 65,5\% do gênero feminino.

Infelizmente, somente encontramos este estudo quando já havíamos realizado toda nossa coleta de dados. Este fato impossibilitou a utilização do questionário testado pelos pesquisadores. Todavia, apenas como comparativo, apresentaremos as assertivas utilizadas no estudo de Zenorini e as utilizadas nesta presente pesquisa respectivamente.

\section{A. MetaAprender}

2.Gosto dos trabalhos escolares com os quais eu aprendo algo, mesmo que cometa um bocado de erros. ${ }^{2}$

1- Eu gosto de realizar tarefas na escola em que eu realmente aprenderei, mesmo que eu cometa muitos erros.

4.Uma razão importante pela qual eu faço as tarefas escolares é porque eu gosto de aprender coisas novas.

2- Uma razão importante para que eu faça tarefas na escola é porque eu gosto de aprender coisas novas.

5.Eu gosto mais das tarefas quando elas me fazem pensar.

\footnotetext{
${ }^{2}$ Para efeito de comparação, apresentaremos as assertivas de Zenorini fora de ordem numérica. Logo, o número dois representa a segunda assertiva no questionário daquele pesquisador.
} 
3- Tarefa que eu gosto de fazer é aquela em que eu possa realmente pensar.

8.Uma importante razão pela qual eu estudo pra valer é porque eu quero aumentar meus conhecimentos.

4- Uma importante razão para que eu faça a tarefa na escola é porque eu sempre quero melhorar, aprender mais.

13.Faço minhas tarefas escolares porque estou interessado nelas.

5- Eu faço minha tarefa na escola porque eu estou interessado nela.

14.Uma razão pela qual eu faço minhas tarefas escolares é que eu gosto delas. 6- Uma importante razão para que eu realize uma tarefa na escola é que eu goste dela.

Como podemos facilmente perceber, o significado das assertivas é praticamente o mesmo, exceto pelo fato de as assertivas de Zenorini estarem muito melhor escritas, logo estas devem melhorar a compreensão dos sujeitos pesquisados. Todavia, não acreditamos que este fato produza algum efeito essencial no tocante à classificação do perfil de realização.

\section{B. Meta performance-aproximação}

3.Eu me sentiria bem se eu fosse o único que pudesse responder às perguntas do professor em classe.

7- Eu me sentiria realmente bom se eu fosse o único que respondesse as perguntas dos professores da classe.

18. Obviamente, o estudo de Zenorini exclui a assertiva número oito, conforme prescrição dos pesquisados americanos.

8- É importante para mim que os outros estudantes em minha classe pensem que eu sou bom nas tarefas que realizo.

6.Na minha turma, eu quero sair melhor que todos os demais.

9- Eu quero fazer melhor as tarefas do que os outros estudantes da minha classe.

10.Sucesso na escola, para mim, é fazer as coisas melhor que a maioria da classe.

10- Eu sentiria bem sucedido se eu melhorasse mais do que os outros estudantes.

15. Gostaria de mostrar aos meus professores que eu sou mais inteligente do que os outros. 
11- Eu gostaria de mostrar aos meus professores que eu sou o mais esperto da classe.

12.É muito importante, para mim, fazer as tarefas melhor que os colegas.

12- É importante para mim, que eu faça as atividades melhor do que os outros alunos.

Em se tratando das assertivas pertinentes à meta performance-aproximação, também constata-se a semelhança entre os significados dos questionários de Zenorini e o utilizado na presente pesquisa. Obviamente, o estudo descartou a assertiva número oito em conformidade com o estudo realizado por Midgley (1998).

\section{Meta performance-evitação}

1. É muito importante para mim que eu não apareça como burro na minha classe.

13- É muito importante que eu não seja visto como um estúpido na frente dos meus colegas.

7.Uma razão pela qual eu estudo é que eu não quero passar vexame.

14- Uma razão importante para eu faça as tarefas é para que eu não fique envergonhado.

11.A razão pela qual me dedico às tarefas escolares é para que os professores não fiquem pensando que eu sei menos que os outros.

15- Eu me preocupo quando eu faço meu trabalho se os professores irão pensar que eu sou menos capaz do que os outros.

16.Procuro sair-me bem nas tarefas escolares para que os outros não fiquem pensando que eu sou burro.

16- Uma das razões para que eu faço meu trabalho é porque não quero que pensem que eu sou burro.

9.Uma razão pela qual eu participo da aula é evitar parecer ignorante.

17- Uma razão que eu não participaria da aula é porque não querem que me vejam como um estúpido (a).

17.Um dos meus principais objetivos é nunca dar a impressão de que eu não consigo dar conta da tarefa.

18- Um de meus objetivos principais é evitar que me vejam como incapaz ao realizar minhas tarefas. 
No tocante à meta performance-evitação, os significados são obviamente os mesmos. Os adjetivos contundentes: estúpido, burro e incapaz estão presentes, salvo a questão número sete na qual Zenorini traz a expressão "vexame", enquanto, em nosso questionário, encontramos a palavra "envergonhado". Assim sendo, nossa tradução está muito próxima da tradução feita por Zenorini, logo não acreditamos que este fato contribuiu para o resultado inconclusivo apresentado pelo questionário.

Outra semelhança entre os questionários refere-se à requisição feita aos participantes da pesquisa de Zenorini, pois as questões foram elaboradas e pontuadas segundo a escala Likert, envolvendo quatro opções de resposta: concordo plenamente (4 pontos), concordo (3 pontos), discordo (2 pontos), discordo plenamente (1 ponto). Nosso questionário orientava aos participantes assinalarem: (C) caso concordassem com a assertiva ou (NC) caso discordassem e (CP) significando concordar parcialmente com o conteúdo das alternativas. Nós também utilizamos o recurso da pontuação, caso o sujeito assinalasse (C) recebia um ponto; (CP), meio ponto, $(\mathrm{NC})$, não pontuava. Obviamente, esta pontuação não tem nenhum valor estatístico, contudo, permite, ao final, percebermos o quanto o sujeito aproximou-se ou afastou-se de uma meta de realização de forma comparativa. Exemplo, o sujeito poderia obter nota máxima, ou seja, seis, na meta aprender e nota três na meta performance-aproximação. Ora, isto provavelmente revela que o sujeito poderia estar orientado à meta aprender, mas preocupa-se em parecer inteligente. De qualquer forma, as assertivas assinaladas poderiam ser objeto de arguição durante a Entrevista de Acesso ao Perfil de Realização, o que dificilmente aconteceria caso o sujeito assinalasse somente com um (X).

Isto posto, realizado este exercício comparativo, vamos agora apresentar as razões capazes de justificar porque o questionário não possibilita resultados conclusivos.

O estudo de Zenorini apresentou resultados muito próximos aos realizados por outros pesquisadores em outras pesquisas relativas à discriminação entre a meta aprender e a meta performance. Entretanto, não foi possível obter os mesmos resultados relativos à meta performance capazes de assegurar a subdivisão em meta performanceaproximação e meta performance-evitação conforme a pesquisa original (Migley et al, 1998).

Os dois fatores obtidos correspondem exatamente às duas dimensões das metas de realização, a que inclui metas baseadas no desempenho (denominada meta performance) e a que engloba as metas baseadas no 
próprio interesse pela tarefa (denominada meta aprender)[...] (Zenorini, et al, p.170).

Neste estudo o agrupamento dos itens do fator 1, correspondentes à meta performance, não evidenciou os componentes aproximação e evitação como fatores isolados, tal como no estudo de Midgley e cols. (1998). Os itens agrupados no fator 2 corresponderam ao que os autores identificaram como meta aprender. No entanto, estes resultados assemelham-se aos obtidos nas pesquisas iniciais da Teoria de Metas de Realização (Dweck \& Elliott, 1983; Maehr \& Midgley, 1991; Ames, 1992; Anderman \& Maehr, 1994). (Zenorini, et al, p.170).

Segundo o estudo de Zenorini, os resultados indicam que os sujeitos pesquisados parecem não perceber as diferenças entre a meta performance aproximação e a meta performance-evitação, impossibilitando, assim sua discriminação.

Como já referido anteriormente, os fatores aqui encontrados não coincidiram com os do estudo original, que agrupou em um fator a meta aprender e em dois fatores a meta performance, incluindo os componentes performance-aproximação e performance-evitação. No presente estudo, o agrupamento dos componentes aproximação e evitação num mesmo fator parece indicar que os alunos não perceberam diferenças entre os itens relacionados a esses componentes.[...] (Zenorini, et al, p.172).

À guisa de exemplo ${ }^{3}$, a condição acima poderia ser representada da seguinte maneira, um aluno orientado à meta performance-aproximação concorda com a assertiva número 11 do nosso questionário (ou a questão 15 de Zenorini): Eu gostaria de mostrar aos meus professores que eu sou o mais esperto da classe. Contudo, também concorda com a assertiva típica dos sujeitos orientados à meta performanceevitação (assertiva - 13 de nossa pesquisa, ou a assertiva - 1 de Zenorini): 13- É muito importante que eu não seja visto como um estúpido na frente dos meus colegas. Afinal, aquele extremamente preocupado em parecer muito inteligente para os outros, também deve se preocupar exasperadamente em não parecer incapaz para professores ou colegas, pois incorreria na impensável falha em seu alto nível de inteligência.

Ora, o inverso também deve ocorrer, ou seja, um aluno orientado à meta performance-evitação concordaria com a questão número um, preocupado em não parecer "burro" para professores e colegas, entretanto, desejaria fortemente, como em um sonho, provar para todos ser o mais inteligente, concordando então com a questão número quinze.

\footnotetext{
${ }^{3}$ Atenção este exemplo não se encontra no trabalho de Zenorini.
} 
Ainda sim, poderiam nos questionar a respeito do fato de um aluno orientado à meta aprender, de que este também não gostaria de ser visto como estúpido na frente de professores ou colegas, assim sendo, poderia concordar com esta assertiva. Ou ainda, talvez desejasse ser considerado o mais esperto da classe, afinal esforça-se para aprender. Contudo, os resultados de inúmeras pesquisas demonstram que os alunos orientados à meta aprender têm como principal objetivo obter domínio em relação aos conteúdos, portanto não se preocupam tanto com seu desempenho. Isto posto, poderíamos pensar que a meta aprender e a meta performance seriam diametralmente opostas de um mesmo conceito. Contudo, segundo o trabalho de Zenorini, não é possível corroborar esta conclusão. Isto ocorre, exatamente, pois alunos muito preocupados em obter boas notas, como são aqueles orientados à meta performanceaproximação, muitas vezes, discursam em nome do esforço.

\begin{abstract}
Além disso, poderia se supor que os dois conceitos (meta aprender e meta performance) representassem dois polos de um mesmo construto, isto é, que as metas de realização pudessem variar desde um extremo, relacionado à meta performance, até outro, relacionado à meta aprender. Se esse pressuposto fosse válido, a correlação entre as escalas teria que ser significativa e negativa, fato que não ocorreu. (Zenorini, et al, p.171).
\end{abstract}

Vale ressaltar que só os estudos mais recentes dessa teoria apontam a existência desses dois componentes (aproximação e evitação) em indivíduos com orientação à meta performance (Bouffard \& colaboradores, 1995; Elliot \& Harackiewicz, 1996; Skaalvik, 1997; Urdam, 1997), identificando que o esforço, a perseverança e o uso de estratégias de aprendizagem, frequentemente associados à orientação à meta aprender, podem aparecer em certos casos também associados à meta performance-aproximação. (Zenorini, et al, p.170).

Não obstante, os resultados obtidos por Zenorini não garantem a previsibilidade, ou seja, um sujeito que concordou com todas as assertivas da meta aprender, por exemplo, não necessariamente negaria as assertivas ligas à meta performance, pois não ocorreu correlação significativa e negativa entre as escalas de realização:

[...] O coeficiente de correlação de Pearson entre as duas escalas foi de $0,08(\mathrm{p}<0,30)$, indicando que as escalas são ortogonais e que diversas combinações de pontuações altas e baixas são possíveis entre elas. Assim sendo, pode-se dizer que a pontuação de um sujeito em uma das escalas não pode prever a pontuação do mesmo sujeito na outra escala (Zenorini, et al, p.171). 
Segundo o estudo de Zenorini, uma das principais razões capazes de fazer com que sujeitos orientados à meta performance-aproximação ou meta performance-evitação assinalem as assertivas pertinentes à meta aprender é o quanto este constructo é valorizado socialmente. Isto posto, os sujeitos passaram anos nos bancos escolares ouvindo seus professores correlacionarem aprendizado acadêmico com esforço e dedicação, logo diante de um questionário concordam com aquilo que não possuem, mas desejariam ardentemente.

A média da escala de meta aprender apresentou-se bastante alta em relação ao intervalo possível ( 1 a 4), enquanto que a média da escala de meta performance situou-se um pouco abaixo do ponto médio da escala. Este resultado pode ser atribuído ao fato dos itens da escala de meta aprender serem mais suscetíveis à desejabilidade social do que os itens da escala de meta performance. Os desvios padrões, que foram muito parecidos em ambas as escalas, indicam que houve boa variabilidade dos sujeitos em relação à média, podendo-se supor que a escala conseguiu captar essa variabilidade (Zenorini, et al, p.171).

Outro resultado interessante é que os alunos orientados à meta aprender, preocupados em desenvolver suas habilidades e capacidade parecem não concordar com as assertivas dos sujeitos orientados à meta performance-evitação; preocupados em evitar parecem ignorantes, indicando sobre a possibilidade destes constructos serem diametralmente opostos.

Buscando maior entendimento sobre os dados obtidos, procurou-se analisar os índices de correlação existentes entre as duas dimensões da meta performance com a aprender. Os coeficientes obtidos foram $\mathrm{r}=-$ 0,01 entre a meta performance-aproximação com a meta aprender $(\mathrm{p}=0,88)$ e $\mathrm{r}=-0,15$ com a meta performance-evitação $(\mathrm{p}=0,04)$. Estes dados indicam que a meta performance-aproximação e a meta aprender não se correlacionam, confirmando o resultado anteriormente obtido. No entanto, a meta performance-evitação correlacionou-se negativa e significativamente com a meta aprender, isto é, os sujeitos que disseram estar mais motivados a aprender, também disseram estar menos motivados a evitar parecer como mau aluno, e vice-versa. É possível que aprender e evitar sejam polos opostos de um mesmo construto (Zenorini, et al, p.172).

Ao final, como não poderia ser diferente, os pesquisadores solicitam à comunidade científica maiores estudos, com uma amostra mais abrangente, levantando a possibilidade de as diferenças culturais terem influenciado o estudo, produzindo, então, resultados diferentes do trabalho americano original (Migley, 1998).

Levando-se em conta que os estudos realizados envolvendo a Teoria de Metas de Realização são estrangeiros, não se pode deixar de considerar as possíveis diferenças culturais e os fatores inerentes ao 
contexto educativo. Embora o instrumento tenha apresentado um índice de precisão que indica alta consistência interna, os resultados indicam a necessidade de pesquisas com maior número de sujeitos de diferentes instituições, de maneira que se possa aperfeiçoá-lo, $[\ldots]$ (Zenorini, et al, p.172).

Em suma, apresentaremos resumidamente as razões arroladas acima, que impossibilitam a escala de acesso às metas de realização tornarem-se um instrumento conclusivo quanto à motivação do aluno:

- Existem dois fatores discriminantes relativos à meta aprender e à meta performance;

- A escala de acesso não permite subdividir com segurança a meta performance em duas metas: meta performance-aproximação e meta performance-evitação;

- Os sujeitos pesquisados não parecem diferenciar as assertivas ligadas à meta performance-aproximação da meta performance-evitação;

- A escala de acesso permite caracterizar com maior segurança os sujeitos orientados à meta aprender;

- Pode ocorrer que sujeitos orientados à meta performance-aproximação citem o esforço como estratégia de aprendizado, típico dos sujeitos orientados à meta aprender, sugerindo que estes constructos não são diametralmente opostos;

- Não é possível prever o comportamento de um sujeito, por exemplo, caso ele concorde com todas as assertivas da meta aprender; isto não significa que não concordará com as assertivas de outras metas;

- É possível que a meta aprender e a meta performance-evitação sejam conceitos diametralmente opostos, ou seja, os alunos orientados a obter domínio não estão preocupados em evitar parecerem incapazes, portanto tendem a obter poucos pontos na meta performance-evitação;

- A meta aprender é um condicionante valorizado e desejado socialmente, logo, os sujeitos tendem a concordar com as assertivas orientadas segundo esta meta.

Isto posto, acreditamos ter apresentado as razões que impossibilitam este instrumento de tornar-se uma ferramenta capaz de captar com precisão a motivação do aluno. Logo, nem nossa tradução, tampouco a inclusão indevida da assertiva número 
oito (8- É importante para mim que os outros estudantes em minha classe pensem que eu sou bom nas tarefas que realizo.) são responsáveis em produzir tal fenômeno. Contudo, a escala de acesso mostrou-se de valor extremado ao fornecer o mote necessário para podermos arguir junto aos sujeitos pesquisados. Não obstante, acreditamos que os resultados inconclusivos acima são fruto do desenvolvimento de um ferramental conceitual e metodológico extremamente complexo, logo, as atuais vicissitudes dão provas da envergadura de tal empreendimento.

\section{Apendice - IV}

\section{Apresentação da Atividade Experimental para ser Realizada pelo Grupo}

\section{Materiais Utilizados}

Foram entregues ao grupo três colheres: uma de metal, uma de madeira e outra de plástico. Também receberam uma folha contendo a atividade experimental para serrespondida pelo grupo.Disponibilizamos, também, o texto de apoio intitulado: Frio...Calor...Suor.

\section{Atividade Experimental}

Colheres de plástico, madeira e metal.

Examine as colheres e responda preenchendo o quadro.

\begin{tabular}{|c|c|c|}
\hline Colheres & Quente & Frio \\
\hline Metal x Madeira & & \\
\hline Metal x Plástico & & \\
\hline Madeira x Plástico & & \\
\hline
\end{tabular}

Perguntas:

1- Qual a temperatura do seu corpo?Qual a temperatura das colheres? Qual delas é maior, a do seu corpo ou das colheres? Por quê? (leia o texto: Frio, Calor e Suor)

2- Quando você sente frio, você perde o que para o ambiente?

3- Quando você sente calor, você ganha o que do ambiente?

4- Qual a relação entre temperatura e as sensações de quente e frio?

5- Qual a relação entre seu corpo, o ambiente, a temperatura e o ganho e a perda de calor?

6- Onde está o erro na frase a seguir: A colher ganhou $10^{\circ} \mathrm{C}$ de temperatura do meu corpo.

7- Por que a colher de madeira parece ser mais quente do que a de alumínio se está à mesma temperatura ambiente?

8- Responda a questão $\mathrm{n}^{\mathrm{o}} 7$ levando em consideração os coeficientes de condutividade do alumínio e da madeira. 
9- Qual é a direção do fluxo de calor entre sua mão e a colher? Faça um desenho.

10- O seu corpo é um bom instrumento de medida de temperatura?

\begin{tabular}{|c|c|c|}
\hline \multirow{2}{*}{$\begin{array}{l}\text { Substâncias } \\
\text { aço }\end{array}$} & \multicolumn{2}{|c|}{$\begin{array}{c}\text { Coeficiente de condutividade } \\
\text { térmica } \\
\text { (cal/s.cm. }{ }^{\circ} \mathrm{C}\left[20^{\circ} \mathrm{C}\right] \text { ) }\end{array}$} \\
\hline & 11,00 & $\times 10^{-3}$ \\
\hline água & 0,15 & $\times 10^{-3}$ \\
\hline alumínio & 49,00 & $\times 10^{-3}$ \\
\hline amianto & 0,02 & $\times 10^{-3}$ \\
\hline antimônio & 55,00 & $\times 10^{-3}$ \\
\hline ar & 0,006 & $\times 10^{-3}$ \\
\hline bismuto & 2,00 & $\times 10^{-3}$ \\
\hline cerâmica & 0,11 & $\times 10^{-3}$ \\
\hline chumbo & 8,30 & $\times 10^{-3}$ \\
\hline cobre & 92,00 & $\times 10^{-3}$ \\
\hline concreto & 0,2 & $\times 10^{-3}$ \\
\hline cortiça & 0,04 & $\times 10^{-3}$ \\
\hline ferro & 16,00 & $\times 10^{-3}$ \\
\hline fibra de vidro & 0,0075 & $\times 10^{-3}$ \\
\hline gelo $\left(\right.$ a $0^{\circ} \mathrm{C}$ ) & 0,22 & $\times 10^{-3}$ \\
\hline latão & 26,00 & $\times 10^{-3}$ \\
\hline madeira & 0,02 & $\times 10^{-3}$ \\
\hline mercúrio & 1,97 & $\times 10^{-3}$ \\
\hline ouro & 70,00 & $\times 10^{-3}$ \\
\hline poliestireno & 0,0075 & $\times 10^{-3}$ \\
\hline prata & 97,00 & $\times 10^{-3}$ \\
\hline tijolo & 0,3 & $\times 10^{-3}$ \\
\hline vidro & 0,25 & $\times 10^{-3}$ \\
\hline
\end{tabular}




\section{FRIO ... CALOR ... SUOR ...*Texto de Apoio}

Bem, vejamos: O frio

De início, devemos lembrar que o ser humano é um animal homeotérmico, ou seja, existe uma estreita faixa de temperaturas - que fica ao redor $\operatorname{dos} 36,1^{\circ} \mathrm{C}-$ dentro da qual

Por que sentimos frio ou calor?

Por que ficamos todo arrepiados e trememos de frio?

Quais são os mecanismos que geram, em nós, o suor e qual a sua função?

E a febre?

nosso

corpo

consegue

funcionar

adequada-

mente,

regulando

as funções

de nossas

células; fora desta faixa, problemas graves podem ocorrer e até mesmo ocasionar a morte. Para evitar que nossa temperatura corporal saia fora dessa estreita faixa, nosso organismo criou mecanismos de defesa.

Quando o ambiente está frio, e começamos a perder calor para ele, são acionados, de início, os horripiladores, pequeninos músculos que ficam na raiz de cada pelo que temos espalhados pelo corpo. Esse acionamento causa de imediato o conhecido arrepio, uma onda de trepidação muscular pelo corpo todo. A tremedeira, que logo depois se estende a outros músculos, é nossa primeira proteção, pois tremer é um processo mecânico para gerar calor.

Além disso, os pelos eriçados colaboram na retenção de uma camada de ar junto à pele e, como o ar é um bom isolante térmico, eis nosso primeiro agasalho natural. Quanto mais pelo, mais ar é aprisionado e tanto melhor será esse agasalho natural. Nas aves, tal agasalho é constituído pelas penas.

Outra proteção natural do corpo é o embolar; fechamos as mãos, cruzamos os braços, encolhemos as pernas e curvamos o corpo - tudo isso para diminuir a superfície externa exposta quanto menor a superfície exposta, menor será a área pela qual o calor pode escapar para o ambiente.

Está percebendo porque, no frio, o gato dorme todo enrolado, os bois se juntam ao máximo e você se encolhe todo sob os cobertores?

O segredo é diminuir a superfície exposta!!

O calor - E quando sentimos calor?

Aí inverte tudo: agora é a vez do nosso corpo receber calor do ambiente que está mais quente do que nós próprios. Que fazer para remediar este acréscimo exagerado de calor que recebemos do ambiente? Ora, devemos dar um jeito de jogar calor para fora do corpo. Lá vem nossa proteção: o sangue intensifica sua técnica de fluir e passa a irrigar partes mais próxima da pele

- é aquele vermelhão que começamos a ver e sentir na pele - como a camada protetora do sangue diminui (pois está mais próximo da epiderme), o calor pode mais facilmente se transferir dele para a superfície da pele e escapar para o ambiente.

O suor- Se isso ainda não é suficiente, lá vem mais proteção: entram em ação as glândulas sudoríparas. São glândulas em forma de tubos que se abrem na superfície da pele formando os poros - elas expelem o suor - e esse, ao evaporar retira mais calor da própria pele, esfriando-a.

Então: Sentir frio é perder calor exageradamente. Sentir calor é receber calor exageradamente. Sempre é o calor que vai do lugar mais quente para outro mais frio. Frio não é coisa que entra ou coisa que sai - frio é uma sensação ocasionada por perda de calor! - não "ondas de frio", há massas de ar frio que passam por nós e que retiram calor de nossos corpos... e temos a sensação de frio!

A febre - Mesmo sendo animais homeotérmicos, há situações em que nosso organismo precisa de uma temperatura maior que a normal para seu bom desempenho e isso ocorre, por exemplo, quando somos atacados por micro-organismos - vírus e bactérias - e nossas defesas internas (glóbulos brancos e seu exército) precisam lutar contra eles para nos defender. Acontece que essas defesas são realizadas à custa de reações químicas, cuja eficiência aumenta com o aumento da velocidade com que se processam estas reações, e o aumento da temperatura ajuda neste processo. Para ajudar os glóbulos no combate a essa invasão de micro-organismos nosso organismo decide, nesta situação de guerra, aumentar a temperatura corporal bem acima dos $36,1^{\circ} \mathrm{C}$. Está instalada a febre - não é ela uma doença em si, mas a consequência de uma luta que está sendo travada em nosso benefício - não é um problema, pelo contrário, é até um benefício, pois nos mostra que estamos equipados com mecanismos adequados de defesa. Pior seria se não tivéssemos febre! Aí os micro-organismos acabariam conosco num piscar de olhos. O problema aparece quando nosso organismo, em desespero de causa, continua a aumentar a temperatura corporal; às vezes, para além dos $40^{\circ} \mathrm{C}$ : ai o bicho pega! A temperatura passa a ser um problema seríssimo, pois aniquila nossas enzimas e nossas células podendo, mesmo, ocasionar a morte. Antes de chegar a tal situação, devemos fazer algo para baixar a temperatura. É aí que entram os medicamentos para controlar a febre, e não para acabar com ela... e conosco!*Prof.Luiz Ferraz Netto, site www.feiradeciências.com.br 


\section{Descrição e Pequena Análise da Atividade Experimental}

Atenção, como é fundamental provocarmos o conflito sócio-cognitivo, apresentaremos atividade e realizaremos uma pequena análise da atividade experimental.

Colheres de plástico, madeira e metal.

Examine as colheres e responda preenchendo o quadro.

\begin{tabular}{|c|c|c|}
\hline Colheres & Quente & Frio \\
\hline Metal x Madeira & & \\
\hline Metal x Plástico & & \\
\hline Madeira x Plástico & & \\
\hline
\end{tabular}

Nesta primeira parte da atividade, os alunos agrupados têm a chance de entrar em contado com suas concepções espontâneas, de trazer à consciência aquilo que pensam sobre as sensações de quente e frio. Este momento possibilita uma possível reflexão do indivíduo sobre esses conceitos.

$\mathrm{Na}$ verdade, ocorre a interação entre quatro objetos: a colher de madeira, a de alumínio e a de plástico. O quarto objeto, o aluno não tem como percebê-lo, pois é ele próprio. Um dos motivos pelo qual o aluno constrói este conceito espontâneo é que não se percebe trocando calor com o meio e com os objetos a sua volta. Desautels \& Larochelle (apud Aguiar, obra citada, p. 4) defendem a ideia de que "as crianças acreditam que as sensações dão acesso imediato à compreensão... Essas convicções ontológicas e epistemológicas constituem a base da física ingênua e, para elas, deve ser dirigida à atenção nas atividades de ensino."

O corpo humano, quando troca calor com o meio, provoca as diferentes sensações de quente e frio, avisando-nos da queda da temperatura, quando perdemos calor, ou do aumento da temperatura, quando ganhamos calor. Os outros corpos trocam calor com maior ou menor rapidez: o alumínio, por ser um metal, perde ou ganha calor mais rapidamente do que a madeira ou o plástico, conforme a tabela de condutividade térmica, e é esta característica a responsável pelo indivíduo acreditar que este é mais frio do que, por exemplo, a madeira. 
1. Qual a temperatura do seu corpo?Qual a temperatura das colheres? Qual delas é maior, a do seu corpo ou das colheres? Por quê? (leia o texto: Frio, Calor e Suor).

A primeira pergunta pretende que o aluno perceba que possui uma temperatura corporal e sua condição evolutiva garante a manutenção desta temperatura em torno de $36^{\circ} \mathrm{C}$, informação esta contida no texto de apoio (Segunda Fase Anexo-II).

Em seguida os alunos perguntam como devem medir a temperatura dos objetos. Devolvemos a pergunta questionando-os: como os objetos não produzem calor e estão expostos ao ambiente, então qual temperatura devem possuir? Alguns não conseguem responder mesmo lendo o texto, mas, depois de muita discussão dentro do grupo, chegam à resposta "temperatura ambiente", inclusive inferindo o valor.

2. Quando você sente frio, você perde o que para o ambiente?

3. Quando você sente calor, você ganha o que do ambiente?

Essas perguntas pretendem que o aluno se reconheça como um corpo que troca calor com o meio. Os alunos confundem calor com temperatura, ou seja, acreditam que quando sentem frio é porque perderam temperatura, quando sentem calor é porque ganharam temperatura.Outra confusão diz respeito à relação causal existente entre calor, temperatura e o fenômeno sensações, por exemplo: quando se perde calor para o meio, a temperatura tende a cair, logo sentimos frio, por outro lado, quando se ganha calor do meio, a temperatura do corpo tende a subir e sentimos calor, informações estas contidas no texto de apoio(Segunda Fase - Anexo I-b).

4. Qual a relação entre seu corpo, o ambiente, a temperatura e o ganho e a perda de calor?

5. Onde está o erro na frase a seguir: A colher ganhou $10^{\circ} \mathrm{C}$ de temperatura do meu corpo.

Os alunos que conseguiram perceber a relação do corpo com os objetos conseguem facilmente responder estas questões, os que não conseguiram perceber as conexões internas entre os objetos e o fenômeno não conseguem nem entender a própria pergunta. Nesse momento ou recorrem a nossa ajuda ou à do colega.

6. Por que a colher de madeira parece ser mais quente do que a de alumínio se está à mesma temperatura ambiente?

Esta pergunta é fundamental, pois possui um conflito sócio-cognitivo, afinal a maioria dos alunos acredita que a madeira é mais quente do que o alumínio. É neste 
momento, em que se espera um maior envolvimento do aluno com a atividade, pois esperamos que fique intrigado em tentar entender porque percebe um corpo frio e um corpo quente mesmo estando ambos à mesma temperatura. $\mathrm{O}$ aluno só consegue responder se realizou uma síntese causal entre calor, temperatura e as diferentes respostas sensoriais que seu corpo apresenta diante da perda ou ganho de calor.

7. Responda a questão anterior levando em consideração os coeficientes de condutividade do alumínio e da madeira.

8. Qual é a direção do fluxo de calor entre sua mão e a colher? Faça um desenho.

A sétima pergunta é idêntica à anterior, entretanto remete à percepção da tabela; até então os alunos não a tinham percebido e neste momento esperamos que trabalhem com o conceito percebendo que os corpos trocam calor com velocidades diferentes e isto provoca a sensação de quente e frio em objetos que estão à mesma temperatura. Esperamos também que o aluno interprete quantitativamente o coeficiente de condutividade, informação capaz de fazê-lo se certificar que em relação à madeira o alumínio conduz calor mais efetivamente do que a madeira e por essa razão parece ser mais frio.

A oitava questão é mais um momento de síntese caso o aluno não tenha entendido como os corpos trocam calor. O fluxo de calor se processa do corpo mais quente para o mais frio, e, esta é a primeira lei da termodinâmica, conceito que será melhor trabalhado no futuro.

\section{O seu corpo é um bom instrumento de medida de temperatura?}

Naturalmente, o corpo é um instrumento razoável, afinal a mãe percebe a temperatura do filho utilizando o tato, todavia não é um instrumento preciso. Buscamos também uma reformulação epistemológica, afinal o conflito sócio-cognitivo, conforme já dito anteriormente, nasce pelo fato de os alunos atribuírem seu conhecimento às percepções sensoriais; não pretendemos transformar o conhecimento advindo das sensações como sendo errôneo, mas que deve ser confrontado com a realidade. 
Apêndice - V

Entrevistas Primeira Fase - Perfil de Realização: Sujeito Del, Ms e M

\section{Análise dos dados da Entrevista de Validação do Perfil Motivacional de Realização do Sujeito Del}

Analisaremos agora os dados obtidos com o instrumento: Entrevista de Acesso ao Perfil Motivacional de Realização. Vejamos se é possível estabelecer alguma congruência entre as impressões obtidas no diário de campo, no questionário e nos novos dados advindos desta entrevista, procurando sempre: quais são os pontos em acordo, os pontos discordantes e quais novos aspectos podem ser revelados.

O Símbolo $(\mathrm{P})$ e $(\mathrm{S})$ significam respectivamente fala do pesquisador e fala do sujeito, os números colocados no início de cada parágrafo revelam sua ordem dentro da entrevista, para que leitor interessado o encontre com maior facilidade:

Antes de iniciarmos a análise, devemos entender que não existe um aluno totalmente orientado a alguma meta, ou seja, não devemos procurar na realidade uma cópia empírica do referencial teórico adotado. Por exemplo, um aluno da meta performance-evitação pode relatar que não tem medo de errar, pois acredita que aprender envolve certo risco, todavia ele pode sentir calafrios diante das provas prejudicando sobremaneira seu desempenho.

Ou por outro lado, poderemos ter um sujeito ligado à meta aprender que tem medo de errar, pois não quer se sentir envergonhado na frente de colegas. No entanto, este mesmo sujeito adora provas e notas, pois pode comparar onde errou e saber o quanto chegou de um ótimo rendimento. Sendo assim, de modo geral, os sujeitos sempre carregam algo de outra meta, afinal quem gostaria de parecer burro para professores e colegas. Estas variações estão de acordo com o referencial teórico adotado; apenas à guisa de esclarecimento, escrevemos:

[...] Em suma, todos nós, com maior ou menor grau, no momento em que estamos diante do desafio da realização de uma tarefa criamos certas expectativas quanto à nossa capacidade de realização, pois ao longo da vida elaboramos padrões de excelência. Portanto, a estes padrões, todas as vezes, seja em um curso fundamental para nossa formação, ou simples resolução de uma lista de exercícios irrompe em nosso interior uma verdadeira contenda entre as expectativas de sucesso ligadas a alegria e o orgulho que sentiremos por um trabalho 
bem realizado, ou por outro lado, somos castigados pela ansiedade e medo relativos ao possível fracasso futuro (Reeve, 2006, p. 108).

Além do mais, qualquer informação só é transformada em dado, como resultado de nossa incursão no manancial representado pela entrevista, caso as justificativas sejam ricas em significados estabelecendo alguma possível conexão com o referencial teórico adotado.

Este procedimento repete em pequena escala o mesmo adotado para triangular os dados, em que buscamos não uma comprovação tácita de um perfil, mas sim, o que podemos chamar de uma comprovação conseguida através de aproximações-sucessivas. Para tanto, os diversos instrumentos de coleta de dados devem ser capazes de compor não um quadro realista, não uma cópia precisa da realidade, mas um mosaico, multicolorido que nos permite circunscrever e contemplar quais as principais preocupações de tal sujeito diante das tarefas escolares. E, sobretudo, se estas são capazes de aproximá-lo ou afastá-lo de um possível comportamento ligado a uma determinada meta. Neste sentido, estamos particularmente interessados no conjunto de justificativas e na interpretação destes conteúdos à luz do referencial teórico capaz de possibilitar o engendrar de uma rede de significados que possam sustentar uma possível caracterização.

O sujeito é convidado a discorrer porque concorda com a assertiva: "Eu gosto de realizar tarefas na escola em que eu realmente aprenderei, mesmo que eu cometa muitos erros", contida no questionário:

2-(P): Então, mas qual a sensação, mas se as pessoas cometem muitos erros, isto não dá uma sensação desagradável.

(Del): Dá mais, tem que supera né, erra é humano, nem sempre a gente acerta.

(P): Então não seria mais simples se o professor desse a resposta certa (Del): Não, e como é que eu ia aprender...

3-(P):Então, assim... mas, e... a função do professor, não é assim que...que você ...qual a função do professor, então.

(A) Ensina.

(P): O que, que é então ensina..., mas errar, errar...? 
(A): errar acontece é como se fosse um tabuleiro de xadrez, como que eu vou aprende a usar as peças se você deixa eu ganhar, como é que eu vou criar minhas táticas se eu ganho sem dificuldade, sem dificuldade não há vitória, sem guerra não há vitória.

A resposta: "Dá mais, tem que supera né, erra é humano, nem sempre a gente acerta". Muito pouco, ou nada pode ser dito neste trecho, pois a maioria dos alunos, independentemente da meta de realização, creem que errar faz parte do aprendizado. Por outro lado, nos chama a atenção a justificativa inusitada interpolada pelo sujeito para relacionar: jogo de xadrez,erro e aprendizado, "errar acontece é como se fosse um tabuleiro de xadrez".

Neste sentido, jogar xadrez exige do sujeito o desenvolvimento de novas táticas, na medida em que este se depara com jogadores mais astutos, ou experientes. A derrota no tabuleiro é vivenciada como um erro, uma falha existente em sua tática, denunciada pelo rei morto. Portanto, é o erro que obriga o sujeito a desenvolver uma nova tática de ataque ou uma nova estratégia de defesa capaz de elevá-lo de derrotado a vitorioso.

Para o sujeito, o "erro" é um conceito, é uma ideia, é um símbolo que permite ao sujeito transpô-lo e operá-lo em outro lugar, ou seja, nas situações de aprendizado. Destarte, é esta operação que permite a analogia entre o jogo de xadrez e o aprendizado, possuindo como elo de ligação o conceito de "erro".

Podemos então inferir que o "erro" talvez faça parte do intrincado processo de aprender para este sujeito, talvez represente o esforço de aprender através do método de tentativa e erro, mas não um método cego em que se experimenta a esmo, mas uma tentativa de se entender onde está a falha. Em sala de aula, pode ser que ao perceber o "erro" em seu raciocínio talvez também procure o lugar da falha. Ou ainda, esta situação seja a "pedra" no meio do caminho capaz de obstar o pensamento linear, obrigando-o a um raciocínio mais elaborado através do desenvolvimento de um novo conceito ou de uma nova tática, capaz de dar conta do obstáculo, seja na sala de aula, seja no tabuleiro de xadrez: "como é que eu vou criar minhas táticas se eu ganho sem dificuldade".

Isto posto, consideramos que o trecho: “criar minhas táticas"significa o desenvolvimento de novas estratégias. Podemos então admitir que o sujeito se aproxima da meta aprender, pois conforme referencial teórico, o aluno assim orientado acredita serem os "erros e fracassos inerentes ao processo de aprendizagem, propiciando a adoção de novas estratégias com as quais se possa dar conta dos desafios".

O indivíduo reconhece no trecho: "como é que eu vou criar minhas táticas se eu ganho sem dificuldade"que, no cadinho da alma, o desenvolvimento está amalgamado 
ao esforço. E este possível reconhecimento nos remete à outra característica ligada à meta aprender: "a de que os desafios acadêmicos que, por seu grau de exigência, são capazes de proporcionar o desenvolvimento intelectual". Soando quase como um axioma: diretamente proporcional ao desenvolvimento almejado, será a cota de dificuldade ou do desafio a ser vencido.

Considerando-se a conexão, entre os trechos: "se eu ganho sem dificuldade" e o trecho "sem dificuldade não há vitória, sem guerra não há vitória" podemos conjecturar, para além dos dados, que o indivíduo parece atribuir um valor intrínseco ao processo de aprender. Sendo assim, não basta apenas aprender, não basta apenas conseguir uma nota, pois é preciso fazer jus a esta conquista sendo necessário enfrentar as dificuldades inerentes ao processo. Pois, vencendo-se assim, conforme referencial teórico ligado à meta aprender: o êxito conseguido após esforço dá origem a sentimentos de orgulho e realização.

Mas qual seria o júbilo a ser conquistado? Será que o prêmio por esta vitória pode ser um aprendizado significativo ${ }^{4}$ : seja de uma tática de jogo, seja um conteúdo escolar? O sujeito nos alerta: "como que eu vou aprender a usar as peças se você deixa eu ganhar" é preciso haver um desafio a ser superado, um obstáculo a ser transposto, é possível haver uma conexão entre o obstáculo e o conflito cognitivo de Piaget, será que o jogo é uma atividade propícia para o aparecimento do sujeito cognoscente piagetiano?

Voltemos à analise utilizando os referenciais ligados às metas de realização, no trecho: "sem dificuldade não há vitória, sem guerra não há vitória." Existe aqui algo sobre a crença de auto-eficácia e sobre a auto-imagem deste sujeito: as palavras guerra e vitória, conforme visto acima, trazem inerentemente o significado de "dificuldade"; podemos conjecturar que o indivíduo a priori acredite ser possuidor de atributos, de qualidades que lhe possibilitem enfrentar os desafios configurando uma sensação de auto-eficácia positiva.

No tocante à auto-imagem, estas palavras nos remetem a algo de heroico, afinal quem voluntariamente optaria pela guerra? Quem viveria em busca da vitória senão o herói? Um aspecto interessante envolvido em um jogo é o desejo pela batalha, pelo combate: o bom soldado não é aquele que tem como objetivo a vitória, mas sim, aquele

\footnotetext{
${ }^{4}$ Chamamos de aprendizagem significativa a aprendizagem de algum conhecimento que possibilite uma evolução seja conceitual, metodológica, seja atitudinal do sujeito. Dependendo do nível de desenvolvimento de uma nova tática de xadrez por parte do sujeito, pode ser que este desenvolvimento responda a uma ou a estas três condições.
} 
que é apaixonado pela batalha, pois é ali que pode mostrar o seu valor, a sua técnica, a sua destreza, a sua força.

Este desejo de enfrentar desafios já havia aparecido no diário de campo, pois este aluno gosta de jogos, conforme ali relatado, inclusive em uma de nossas aulas ele estava escrevendo uma relação de armas: zarabatana, arco e flecha para que seus personagens utilizassem nos jogos de RPG. Particularmente, nesses jogos os indivíduos encarnam personagens, muitos inclusive se vestindo como magos, bruxos, guerreiros, etc.

Esta necessidade por desafios é bem característica do adolescente, segundo Piaget;devido às novas capacidades cognitivas, o sujeito é capaz de estabelecer grandes planos teóricos, graças à “onipotência da reflexão"levando-o a um novo egocentrismo, um egocentrismo megalomaníaco. Talvez, então, o jogo RPG interesse ao sujeito por dois motivos: o primeiro, por permitir que o sujeito trabalhe exclusivamente com seu pensamento simbólico, elaborando diferentes teorias na forma de jogos, afinal suas novas capacidades cognitivas abrem espaço para estas construções. E é exatamente aí que está uma das principais características do RPG: a liberdade dos jogadores de elaborarem uma miríade de histórias. Muitas vezes, uma partida dura semanas, tamanhas são as possibilidades.

O segundo motivo se refere à questão afetiva, pois nesse jogo o jovem pode dar asas a seu ego inflado, podendo encarnar o papel do herói, possuidor de armas fantásticas, testar seu espírito aventureiro, colocar a prova - mesmo de forma imaginária - seu caráter quando tiver que escolher entre o caminho mais fácil, e aquele mais árduo e, por isso mesmo, mais nobre. Este jogo pode representar um ensaio das agruras que estão por vir na idade adulta.

Parece-nos que há uma diferença entre a meta performance-aproximação e a meta aprender. Os que as adotam se acham superconfiantes, acreditam demasiadamente em sua auto-eficácia, pois ambos apostam em sua inteligência, possuem também uma inflada auto-imagem. Todavia, diferem por um único e nevrálgico ponto: o esforço.

Continuando a análise da entrevista, vejamos o próximo trecho:

5-(P): Você tava falando que... esta coisa de erra e tal que você não se incomoda com isto e aquele negócio que você falou, se você for jogar xadrez e tiver as respostas e aí não tem graça

(A):É... 
(P) Porque e aí como é que você vai aprender sobre sua própria prática $(\mathrm{P})$ : você acha que aprender é fácil

(A): Não..., não, não é, eu tenho dez anos de música, comecei faze com ...eu ia faze 9 anos quando eu comecei, no início foi muito difícil, mas hoje pra mim, é mais fácil, nada é fácil e se fosse não ia te graça.

6-(P): Então precisa, você acha que tem de ter um esforço, necessário um esforço como é que é isso?

(A) Sim tem que te um esforço, porque se não houver um esforço, a pessoa não dá crédito, não da valor, tudo o que é fácil a pessoa, o ser humano não dá crédito, isto é mal para o ser humano.

Novamente, o indivíduo reconhece que aprender é difícil, mas não que a dificuldade revele sua incapacidade para aprender. Pelo contrário, é exatamente neste lugar, no conflito, na lacuna, na pedra no meio do caminho, onde se encontra a graça do aprendizado, pois é o enfrentamento da dificuldade que lhe possibilita atribuir valor. Sendo assim, basta que algum conhecimento o desafie para que este seja considerado valioso, confirmando a ideia de que o indivíduo atribui valor intrínseco ao aprendizado. Talvez pense o sujeito: "se isto está sendo ensinado é porque deve ter algum valor, mesmo que inicialmente não o reconheça, portanto devo tentar aprendê-lo".

Portanto, enfrentar as dificuldades, aceitar o desafio e transpor os obstáculos melhora o indivíduo, é uma crença que está de acordo com a meta aprender e os desafios acadêmicos, pois são capazes de proporcionar o desenvolvimento intelectual, graças ao seu grau de exigência.

Por exemplo, no caso do aprendizado de música, o indivíduo, além de lidar com a dificuldade inerente ao instrumento, tal como obrigar a mão a realizar movimentos pouco naturais para se encaixar nas cordas de um violão com o propósito de emitir uma determinada nota musical, também terá de repetir uma enfadonha e contínua série de diversos exercícios. Portanto, para poder tocar, o sujeito deverá se render às especificidades do instrumento, exigindo-lhe certo disciplinamento.

No entanto, acreditamos que o substantivo "disciplina" não seja a palavra mais apropriada, pois estabelece uma relação de heteronomia, algo fora do próprio indivíduo. Provavelmente, se levarmos em consideração que o desejo de tocar violão apareça primeiro socialmente, como é o caso de nosso aprendiz de música, depois este desejo possa vir a se tornar intrapsicológico, talvez devêssemos substituir este substantivo, por outro mais completo, representado pela palavra perseverança, que nos remete à 
autodisciplina, pois a conquista do instrumento exige treino, exige prática, exige horas de estudo.

Ainda assim, precisamos de mais outro, pois se perseverança nos traz a sensação de tempo, de duração, devemos então procurar um para indicar a forma de como se deve proceder a ação, ou o esforço em direção ao saber. E, se estamos falando em movimento, acreditamos que tenacidade é este outro termo, pois está ligado ao empenho que o sujeito deve ter para realizar seu desejo.

Isto posto, talvez justifique o conteúdo da seguinte crença ligada à meta aprender: os alunos assim orientados acreditam que devem enfrentar os desafios acadêmicos com esforço e perseverança.

A teoria das metas entende que o esforço é uma ferramenta para que o indivíduo possa liberar seu potencial e sua habilidade, portanto é fundamental entendermos quais as conexões que o indivíduo faz relativo à ideia de esforço.

Voltando ao trecho: “...nada é fácil e se fosse não ia te graça.”, temos a impressão que o indivíduo tem certa preleção pela dificuldade, será que resolver algo difícil possui algo de prazeroso? Vejamos o que Vygotski (1998, p. 130) nos revela sobre o prazer paradoxal existente no brinquedo(grifo nosso) :

[...], no brinquedo, a criança segue o caminho do menor esforço- ela faz o que mais gosta de fazer, porque o brinquedo está unido ao prazer - e, ao mesmo tempo, aprende a seguir os caminhos mais difíceis, subordinando-se às regras e, por conseguinte, renunciando ao que ela quer, uma vez que a sujeição a regras e a renúncia à ação impulsiva constitui o caminho para o prazer no brinquedo.

Continuamente a situação de brinquedo exige que a criança aja contra o impulso imediato. A cada passo a criança vê-se frente a um conflito entre as regras do jogo e o que ela faria se pudesse, de repente, agir espontaneamente. [...] $\mathrm{O}$ maior autocontrole da criança ocorre na situação de brinquedo. Ela mostra o máximo de força de vontade quando renuncia a uma atração imediata do jogo[...] Comumente, uma criança experiência subordinação a regras ao renunciar a algo que quer, mas aqui, a subordinação a uma regra e a renúncia de agir sob impulsos imediatos são os meios de obter prazer máximo.

Devemos esclarecer que a primeira linha quase nos confunde, pois afirma que a criança segue o caminho do menor esforço. Ora, isto ocorre, pois o esforço está ligado ao prazer: logo, o esforço não é esforço algum. Para percebermos isto, basta observar o comportamento das crianças: caso a mãe peça para a criança varrer o chão, já começa a 
reclamação, o pequeno sai batendo o pé diante da tarefa. Mas no brinquedo não, elas ficam horas brincando, não podemos esquecer que o brinquedo nasce de uma necessidade que a criança precisa satisfazer. E é exatamente a urgência em satisfazer esta necessidade que impulsiona o infante.

Por isto, no embate entre uma necessidade física, por exemplo: comer, em detrimento do prazeroso brinquedo, não raro elas se esquecem da primeira. Portanto, a diferença entre a tarefa exigida pela mãe e o brinquedo não está relacionada a maior ou menor esforço, mas fundamentalmente, a que esta atividade é escolhida pelo próprio indivíduo. Portanto, submeter-se às regras é fonte de prazer, nesse sentido, Vygotski (obra citada, 131) cita Piaget: [...]. Tal regra é uma regra interna, uma regra de autocontenção e autodeterminação, como diz Piaget, e não uma regra que a criança obedece à semelhança de uma lei física.

Voltemos à análise do trecho: [...] sim tem que te um esforço, porque se não houver um esforço, a pessoa não dá crédito, não dá valor, tudo o que é fácil a pessoa, o ser humano não dá crédito, isto é mal para o ser humano., está no contexto do que melhora o ser humano. Apesar de o indivíduo se referir a algo geral quando cita o termo humanidade, não podemos deixar de conjecturar que este está dizendo algo sobre o seu próprio "eu", sobre aquilo que julga ser importante para a melhora de si mesmo. Notadamente, para este indivíduo, êxito após esforço e dedicação é uma de suas crenças mais profundas, pois isto o torna melhor. Mas, porque a necessidade de nos fazermos melhor? Porque não nos contentamos em ser somente? O que em nós denuncia esta incompletude?

Será que os teóricos adotados nos dariam pistas para entender o que melhora o ser humano? Piaget constrói seu conceito de equilibração majorante levando em consideração as ideias sobre a evolução das espécies de Charles Darwin, em que é preciso se adaptar ao ambiente para sobreviver, promovendo ao longo do tempo a seleção de características mais aptas do indivíduo, portanto, melhorando a espécie.

Para aquele pensador, as estruturas cognitivas evoluem graças à interação com o meio, pois é fundamental para o indivíduo voltar à situação de equilíbrio, quando o pensamento não dá conta da realidade, processo este que desenvolve o intelecto. Será que este mecanismo filogenético de desenvolvimento de alguma forma se torna social, impactando ontogeneticamente a vida de cada representante da espécie?

Já para Vygotski, fiel às ideias Marxistas, o caminho é inverso: nosso meio não é amorfo, nós nos relacionamos com um ambiente humano, um ambiente social datado 
historicamente. Portanto, o sujeito sente a necessidade de melhorar como indivíduo, pois este é um imperativo social. Este imperativo social se apresenta a cada indivíduo nas relações interpessoais e graças à linguagem que estes imperativos se tornam necessidades intrapsicológicas.

Portanto, o que é social se torna biológico, exemplo: se para nosso desenvolvimento filogenético é necessária a organização social, então ontogeneticamente cada indivíduo da espécie sentirá o impulso relativo à participação social. Naturalmente, todo este processo está ligado às relações interpessoais e aos acidentes derivados desta interação, o que por fim acabará por constituir a subjetividade do indivíduo.

Voltemos à análise da entrevista:

7-(P): De que forma o professor pode influenciar neste esforço, o que você acha que o professor pode fazer, porque, o professor pode chegar, bom eu vou dá uma boa aula, ele chega lá, ele explica tudo, explica tudo, não tem esforço nenhum, esse professor é um bom professor?

(A): De um certo ponto de vista, pros relaxados sim, mas pra quem que aprende não, porque a resposta dada, a pessoa ela aprende por algum tempo e depois esquece, a resposta conquistada, a pessoa aprende e se quiser ela vai saber por toda vida.

Este sujeito parece apresentar uma posição mais independente em relação à atuação do professor, pois não espera que o professor forneça todas as respostas. Vejamos, ele pretende "conquistar a resposta"; segundo nosso referencial teórico, graças ao pensamento formal o adolescente é capaz de discutir em pé de igualdade com o adulto demonstrando certa autonomia entre o próprio pensamento e o do outro, diferentemente da criança que se sente inferior diante do adulto.

Novamente, apresenta certa dose de "egocentrismo adolescente" ao se referir aos demais como sendo "relaxados". O sujeito se sente melhor que os outros devido não só às suas novas capacidades intelectuais, mas, sobretudo, ao esforço que dedicará para obter a resposta. Novamente, a cognição e a afetividade serão usadas para a conquista das respostas.

Esta pergunta versa sobre os dois principais entraves para as propostas sócioconstrutivistas, o primeiro diz respeito à posição passiva do aluno perante $o$ aprendizado, conforme já apresentado na secção análise da entrevista, "Seu discurso raramente atribui a si mesmo esta responsabilidade ou possibilidade, num 
procedimento que talvez seja mesmo inconsciente, de transferir para o outro a responsabilidade ou a culpa."

O segundo entrave se refere, aliás, como a maioria das coisas, ao seu oposto complementar representado pelo desejo do professor de tudo explicar. Villani (et al, 2006) apresenta neste artigo o caso da professora Ma que pretendia ensinar conceitos de Mecânica. Esta utilizou a proposta sócio-construtivista como metodologia, no início, um começo promissor, mas durante o processo, um grande número de alunos se rebelou contra a proposta, segundo os pesquisadores as grandes dificuldades se relacionavam à relação professor-aluno:

"a posição que o professor ocupa para seu aluno é verdadeiramente daquele que sabe; o aluno atribui isso a ele. Entretanto, o fato de ocupar um lugar a que se atribui, por antecipação, um saber, não livra o professor da ambivalência do amor; é bom que isto esteja claro. Quantos professores não caem nessa armadilha do desejo de saber e acabam por pedir que sejam sempre reconhecidos como bons, belos, caridosos, desprendidos, e tantas outras palavras que o amor cristão permite engendrar para sua realização? Por essa via, eles se afastam da possibilidade de sustentar a transmissão, não realizam outra função a não ser a da sedução, já que acreditam ser, eles próprios, o verdadeiro objeto de amor de seus alunos.

No artigo há pouco citado, Villani trata também da dificuldade dos alunos de se responsabilizarem pela própria aprendizagem já que sua entrada na situação escolar é marcada pelo mínimo esforço. Isto ocorre, pois inconscientemente o aluno crê ser o professor o responsável em dar conta de todas as dificuldades, desta forma as possibilidades de real envolvimento com o conhecimento podem ser afetadas fortemente.

Isto posto, estes alunos, frente aos desafios e dificuldades inerentes envolvidos em um aprendizado significativo, apresentam um espírito dependente. Eles exigem do professor a cada passo sua aprovação, como um desejo inconsciente de evitar a todo custo a angustiante possibilidade do erro.

Nesse sentido, é natural pensarmos que dois dos principais cânones básicos das metodologias sócio-construtivistas estão ameaçados: o primeiro, relacionado à participação ativa do aluno em seu processo de aprendizado. Segundo o genebrino o envolvimento do sujeito pode ser conseguido promovendo o conflito cognitivo no momento em que o aluno percebe que suas crenças não dão conta da realidade. Ora, o desequilíbrio pode se apresentar como algo angustiante, pois nasce do desacordo com a experiência sendo sentido pelo aluno como uma possibilidade de erro. E, 
paradoxalmente, é este desequilíbrio que impulsiona o indivíduo a ir em busca do novo conhecimento para voltar à sua condição anterior de equilíbrio, naturalmente majoradamente melhor.

Sendo assim, esta condição exige do aluno um espírito forte, ou pelo menos um espírito mais confiante, diferente daquele que espera a todo o momento a aprovação do mestre. Absolutamente, não pretendemos responsabilizar somente o aluno por esta prática. Afinal, como foi dito acima, também o professor, mesmo de forma inconsciente, tem alimentado esta crença junto à criança.

No que se refere aos conceitos vygotskianos, a principal ameaça se refere à zona desenvolvimento proximal e à atuação do sujeito mais capaz. Nesse modelo de evolução do pensamento, o indivíduo deve verbalizar ao máximo suas ideias junto aos outros sujeitos. Desta forma, o conhecimento externo poderá ser internalizado através das relações interpessoais; podemos supor até que quanto mais valiosas forem essas discussões, tanto mais provável que o indivíduo internalize novas e mais elaboradas formas de pensamento.

Entretanto, por que o aluno irá trabalhar com suas concepções espontâneas se $a$ priori julga seu pensamento como errado? Logo, não é melhor esperar a correção do professor e assim evitar os erros e a angústia inerentes deste processo? Nesse sentido, qual vantagem há em defender seus pontos de vista em grupo, por que pelejar com o outro sobre as questões se o professor já detém a resposta. Porque não esperar confortavelmente o conhecimento seguro vindo do professor, no final das contas, basta que copie o raciocínio alheio e o repita na hora da avaliação.

Quanto ao espírito, temos a impressão de um espírito esvaziado, o indivíduo está ausente, o único referencial válido é o do outro, o outro é um ser total, o indivíduo só participa do mundo do conhecimento se atado ao outro. Parece-nos que alguns professores e uma porção de alunos estão de mãos dadas envolvidos em uma dança ilusória que busca a todo custo escapar das angústias, tensões e conflitos envolvidos nas situações de aprendizado significativo.

Antes de continuarmos, é preciso chamar a atenção, pois da forma que escrevemos o parágrafo anterior parece que não existe possibilidade de um comportamento autônomo por parte do aluno. Em momento algum estamos defendendo esta ideia, estamos apenas querendo chamar a atenção sobre a possibilidade destes condicionantes inconscientes estarem agindo dentro das salas de aula a despeito tanto de professores quanto dos alunos. 
$\mathrm{O}$ artigo sobre a professora Ma relata-nos ainda o surgimento de três grupos: o primeiro, mais participante, identificava os conflitos cognitivos buscando resolver os impasses através de afirmações seguras e dificilmente abandonava um problema sem propor algum caminho ou solução. Um segundo grupo pareceu não perceber os conflitos, indicando não haver incorporado o novo conhecimento. Um terceiro grupo, constituído pela maioria, oscilava entre o conhecimento de senso comum e o científico e entre a recusa e a aceitação de desafios. "[...] percebia-se, ainda, que esse grupo preocupava-se em agradar a professora oferecendo respostas que refletiam expressões e palavras utilizadas por ela, mas que nem sempre eram compativeis com o contexto do problema."

Em relação ao referencial teórico adotado neste trabalho, podemos colocar algumas perguntas: Será que o comportamento do primeiro grupo se aproxima de alguma forma ao referencial teórico que descreve as formas de agir dos alunos orientados à meta aprender? Será que estes alunos em sua história escolar de alguma forma romperam com estes condicionamentos inconscientes, portanto, tornando-se mais autônomos em relação ao seu processo de aprendizagem?

No mesmo sentido, será o comportamento do segundo grupo próximo dos comportamentos descritos aqui relativos à meta performance-evitação, no tocante à dificuldade em reconhecer e vivenciar o desacordo de suas ideias? Por outro lado, os integrantes do grupo que agem preocupados em agradar à professora estabelecem alguma relação com a meta performance-aproximação? Seria possível uma aproximação entre referenciais teóricos tão distantes? Absolutamente, não temos condições de responder essas perguntas, entretanto, parece-nos razoável interpô-las.

Voltando ao nosso sujeito, não podemos garantir a hipótese de que este indivíduo superou estes determinantes inconscientes, todavia acreditamos que, para que ocorra o aprendizado significativo, o indivíduo deve se envolver com o conhecimento de forma mais autônoma do que a discutida até aqui.

Nesse sentido, recuperamos o seguinte fragmento da análise realizada no primeiro trecho desta entrevista em que levantamos a seguinte questão: Mas qual seria o júbilo a ser conquistado? Será que o prêmio por esta vitória pode ser um aprendizado significativo: seja de uma tática de jogo, seja um conteúdo escolar? Será que o trecho a seguir é uma possível resposta? De um certo ponto de vista, pros relaxados sim, mas pra quem aprende não, porque a resposta dada, a pessoa ela aprende por algum tempo 
e depois esquece, a reposta conquistada, a pessoa aprende e se quiser ela vai saber por toda vida.

Nós acreditamos que neste trecho o aluno confirma que a resposta assim obtida, ou seja, o aprendizado de uma tática de xadrez ou um conhecimento escolar se torna um conhecimento significativo, que nas próprias palavras do sujeito: "irá permanecer por toda a vida", se e somente se, conquistado após esforço e dedicação e que esta crença deve exigir por parte do indivíduo maior responsabilidade por seu aprendizado.

Isso tanto é verdade, que novamente aparece um juízo de valor, relativo ao trecho: De um certo ponto de vista, pros relaxados sim, mas pra quem aprende não. Naturalmente, este sujeito não gostaria de se ver como um relaxado, portanto, talvez este sentimento contribua com seu envolvimento na realização das tarefas. Será que o indivíduo que se responsabiliza mais pelo seu aprendizado apresenta uma menor tendência a culpar inconscientemente o outro pelas suas dificuldades? Chamamos a atenção para o caso já discutido na análise do trecho da pesquisa de Silva, o sujeito também ali, de certa maneira, pune os alunos que só querem brincar em sala de aula.

Desta forma, podemos conjecturar que o indivíduo se sinta merecedor do conhecimento adquirido, pois esforçou-se em obtê-lo, isto provavelmente deve também contribuir para sua auto-imagem, afinal provou seu valor enfrentando os desafios com determinação e perseverança sentindo-se bem com o êxito obtido.No mesmo sentido, esta condição deve levá-lo a fortalecer sua sensação de auto-eficácia na medida em que sua atuação o possibilita desenvolver novas habilidades e competências. Permitam-nos o seguinte corolário: auto-imagem positiva, sinônimo de alta estima, por outro lado, auto-imagem negativa significa baixa estima, ambas construídas tão mais próximas ou mais afastadas do real graças aos poderes ou fraquezas elaborados pelo senso de autoeficácia do sujeito.

Dito isto, e buscando melhorar as perguntas acima, podemos conjecturar: Será que o conhecimento obtido após esforço e dedicação ajudam os alunos a superarem os determinantes ligados inconscientemente a culpabilizar o outro?

Será que o êxito constado, após esforço e dedicação, leva o sujeito a construir uma auto-imagem positiva o suficiente para poder suportar suas próprias dificuldades sem culpar o outro por um possível fracasso?

Será que aquele que possui uma crença positiva no tocante a sua auto-eficácia, além de se responsabilizar mais por seu aprendizado, já que acredita ser possuidor de 
habilidades e competências que lhe permitem realizar determinadas tarefas, também acaba adotando um comportamento mais autônomo?

Antes de finalizarmos a análise deste trecho, devemos esclarecer o conteúdo presente no quarto parágrafo acima, pois este pode transmitir ao leitor a falsa ideia de que a aprendizagem significativa se resume a um conhecimento que "dure por toda a vida”, bastando que seja obtido após esforço e dedicação.

Todos nós sabemos a quantidade de conhecimento descontextualizado e inútil que somos obrigados a decorar para depois repetir. Exigência que não pode ser cumprida sem grande parcela de esforço e dedicação. Entretanto, em nosso caso, acreditamos que a elaboração de uma nova tática de jogo, dependendo da condição lógica do sujeito, exija por parte deste uma evolução conceitual, metodológica ou atitudinal capaz talvez de se constituírem em novos esquemas de ação por parte do indivíduo.

Continuando a análise da entrevista, no trecho a seguir, o sujeito responde a seguinte pergunta: Tarefa que eu gosto de fazer é aquela em que eu possa realmente pensar?

11-(P)Você afirmou aqui na pergunta 7 que gosta de pensar, quando você não consegue chegar à solução, você gosta de pensar, gosta pensa tal, quando você não chega à solução, que se sente?

(A)Tipo...eu posso dá um exemplo do jogo (P):humhumm (A)Eu tava fazendo aquele jogo chamado Sudoco, que é um jogo japonês de número, eu de início, eu achei, tipo ele bem chatinho, bem complicado e passei bastante raiva nos primeiros que eu fiz, mas na forma que eu fui me esforçando e pegando mais a ideia do jogo, foi me facilitando, assim como todo mundo, tem uma dificuldade, a primeira impressão é ou para ou persiste, e eu sou uma pessoa que odeio parar no meio, quando eu começo alguma coisa eu vou até ofim, mesmo que eu quebre a cara depois.

Neste trecho novamente aparece o envolvimento com o jogo. Entretanto, a primeira impressão do sujeito é que este é desagradável: “eu achei, tipo ele bem chatinho, bem complicado e passei bastante raiva nos primeiros que eu fiz, mas na forma que eu fui me esforçando e pegando mais a ideia do jogo foi me facilitando [...]." Acreditamos que o indivíduo retoma a discussão sobre se é fácil ou não aprender, só que em um outro contexto, anteriormente no trecho 6 da entrevista apareceram os seguintes: no início foi muito difícil, mas hoje pra mim, é mais fácil, nada é fácil e se 
fosse não ia te graça[...] (A) sim tem que te um esforço, porque se não houver um esforço, a pessoa não dá crédito, não dá valor, tudo o que é fácil a pessoa, o ser humano não dá crédito, isto é mal para o ser humano.

Na primeira aparição, o indivíduo afirmou que o conhecimento não ia ter graça se fosse fácil e que o esforço era importante para que ele fosse reconhecido como algo de valor. Já na segunda, aparecem as possíveis emoções paradoxais envolvidas quando o indivíduo pretende aprender algo novo e talvez mais complicado: chatinho, bem complicado e passei bastante raiva nos primeiros que eu fiz[...]. Não estamos afirmando serem estas emoções positivas, ou que o aprendizado de qualquer conhecimento deveria provocar este tipo de reação, mas talvez seja natural o aparecimento destes sentimentos contraditórios na maioria das vezes em que nos deparamos com situações onde não estamos totalmente preparados.

A fim de eliminarmos estas situações, nós professores ingenuamente estamos sempre preocupados em evitar que os alunos, ao entrarem em contato com o conhecimento, vivenciem sensações desagradáveis, pois acreditamos que assim se manterão motivados a continuarão a realizar as tarefas. Nesse sentido, recuperamos de nosso referencial teórico o seguinte trecho:

[...] Além disso, algumas professoras acreditam que para se ter alunos motivados é suficiente criar um clima emocional positivo em classe, o que se consegue simplesmente sendo uma pessoa agradável, atenciosa, toda desvelo e carinho. Sem diminuir a importância dessas qualidades positivas, deve se ter presente que os alunos precisam ser motivados para tarefas significativas, desafiadoras, mesmo que sejam árduas, não prazerosas, exigentes e sob cobrança externa".

De alguma forma, este nosso comportamento de proteção falseia a realidade, apesar de estar de acordo com nossas necessidades de evitar a todo custo os sentimentos angustiantes referentes à possibilidade do erro. Voltando ao nosso sujeito, é provável que o sentimento de chatice tenha sido sentido pelo indivíduo por não conseguir entender as regras do jogo ou de alguma forma por não conseguir dominá-las.

Não podemos esquecer, segundo Vygotski, conforme já escrito acima, que o indivíduo obtém máximo prazer no jogo quando se auto-subordina às regras existentes, pois a tensão surge entre manter-se preso às regras ou a possibilidade de agir espontaneamente. Portanto, nos jogos mais complexos, as regras são imutáveis: logo, os momentos de maior prazer serão aqueles em que, dominando as regras com astúcia e criatividade, o indivíduo consiga vencer o jogo. 
Naturalmente, que deve haver obtenção de prazer quando se joga com um indivíduo mais capaz, pois quanto mais valoroso o adversário, mais difíceis e mais elaboradas serão as táticas que o outro será obrigado a desenvolver. Não obstante, perceba também que durante todo o jogo a tensão entre vencer e ser vencido só chega ao fim com o término da partida, consequentemente maior será a sensação de prazer, principalmente se esta vier acompanhada da vitória.

Após a descrição dos possíveis motivos relacionados à chatice do jogo, tomemos o sentimento de raiva. Segundo os referenciais teóricos ligados à motivação, a raiva surge quando as formas como as pessoas pensam são desrespeitadas, ou a essência da raiva “[...] é a crença de que a situação não é o que deveria ser, ou seja: nem a restrição, nem a interferência ou a crítica são legítimas (De Rivera apud Reeve, obra citada, p. 198).

Portanto, esta é uma emoção negativa, devendo ser evitada, mas muitas vezes, apresenta aspectos positivos, pois é capaz de canalizar energia para - nas palavras do próprio autor - "o vigor, a força, e a persistência para transformarmos o mundo ao nosso redor naquilo que ele deveria ser." (Reeve, obra citada, p. 199).

Ora, segundo Piaget, as novas capacidades cognitivas levam o adolescente a uma nova barreira egocêntrica, sendo assim este olha para o mundo na perspectiva de mudálo segundo seus esquemas teóricos. Portanto, podemos conjecturar que este desejo juvenil de mudanças irá encontrar resistências no meio social em que vive e nas diversas formas de "não".

Isto é bastante razoável, pois muitas vezes nos referimos aos adolescentes como se estivessem sempre prontos em apontar os erros do mundo. Portanto, o número de situações em que podem vivenciar esta emoção deve ser relativamente maior quando comparado com pessoas mais maduras, pois estas ou já estão conformadas com a forma como o mundo se apresenta. Ou preocupam-se em mudar as situações que realmente estão sob seu alcance, ou responsabilidade, o que nos parece uma posição mais equilibrada.

Isto posto, como o sentimento da raiva nasce do desacordo entre aquilo que acreditamos ou desejamos e a realidade e, portanto, de alguma forma temos nossas expectativas frustradas sentindo-nos ofendidos por algum fator externo. De modo geral, o sentimento de raiva deve produzir uma tensão sobre o corpo e o aparelho psíquico, esta tensão impulsiona o indivíduo a resolver a situação. Ora, talvez seja por esta razão que a raiva pode ser algo positivo, capaz de despertar processos criativos por parte do 
sujeito. Podemos admitir que, solucionada a situação, haverá uma diminuição de tensão com consequente sensação de prazer advindo do enfrentamento do desafio.

Talvez o conflito cognitivo de Piaget se aproxime desta condição, pois este nasce do desacordo entre a experiência e a lógica do indivíduo. Este desequilíbrio, nas próprias palavras do pensador: “[...] obrigam um sujeito a ultrapassar o seu estado atual e procurar seja o que for em direções novas... " (grifo nosso) (Piaget, 1977, p. 23).

Entretanto, o sentimento é outro. No caso piagetiano, o sentimento estaria ligado ao advento da dúvida em relação ao conhecimento que se tinha anteriormente. Portanto, podemos conjecturar que a dúvida de um modo geral faz parte do ato de descoberta, ela é fruto da diferença entre nossa lógica e os resultados obtidos; nesse sentido, então não é a experiência que possibilita o contato com nossas inconsistências de pensamento. A bem da verdade, é a dúvida que suspende a habitual certeza permitindo rever algum processo considerado corriqueiro.

Cabe a nós uma pergunta: será que a dúvida provocada pelo conflito cognitivo também é vivenciada pelo organismo como uma tensão que impulsiona o sujeito em direção ao novo e, no momento em que esta inconsistência do pensamento é resolvida também se produz algum sentimento de prazer ligado à diminuição de tensão? E seria este prazer o mesmo relatado pelas pessoas quando afirmam que gostam de aprender?

De qualquer forma, é fundamental a participação ativa do sujeito através da descoberta da dúvida, para que o mecanismo ligado à equilibração majorante tenha início. Imaginemos quão difícil para este mecanismo iniciar este movimento caso alguém busque a todo custo evitar qualquer sentimento desagradável produzido pelo seu próprio pensamento.

Notadamente, é por essas razões que a participação ativa do sujeito não pode se referir única e exclusivamente à questão cognitiva. É provável, a despeito do encaminhamento demasiadamente lógico, que o envolvimento ativo do aprendiz também se refira a uma relação mais íntima do sujeito com o conhecimento, portanto sentimentos contraditórios e momentaneamente desagradáveis possam naturalmente advir quando estamos envolvidos no ato de aprender.

Dito isto, não estamos afirmando que o desequilíbrio produza um sentimento de raiva, entretanto parece-nos natural supor que um indivíduo que passou a vida toda acreditando que o cobertor o aquece, sinta-se de alguma forma logrado, caso em uma aula de Física perceba o fracasso desta crença por esta não dar conta da experiência. Talvez não apareça apenas um sentimento de dúvida, porventura, sinta raiva por essa 
condição. Nesse sentido, provavelmente isto justifique o que ouvimos antes de entrar em sala de aula: - Já vem esse professor com as experiências dele, eu achava que sabia alguma coisa agora eu não sei mais de nada!!

Ora, o conflito cognitivo é de alguma forma uma ofensa moral. Pois, a experiência crucial coloca em cheque o conhecimento que o sujeito construiu. Não podemos esquecer que o jovem, graças às novas capacidades cognitivas, coloca-se em pé de igualdade com o adulto. Portanto, do ponto de vista egocêntrico, não deve ser muito confortável ver seus conhecimentos construídos em anos de experiências espontâneas serem rechaçados. Talvez se instale na cabeça do sujeito uma peleja entre os novos conteúdos e os antigos.

Por outro lado, esta mesma condição talvez possa representar a necessidade moral de segunda ordem, conforme referencial teórico. Ou seja, esta situação talvez forneça o elã afetivo-cognitivo, exigindo que o sujeito envolva todo o seu pensamento formal para voltar à condição anterior de equilíbrio. Talvez um equilíbrio melhor, mais de acordo com a adaptação "do real ao eu" ao invés do "eu ao real" conforme previu o genebrino.

Voltemos à análise e tentemos entender como se relacionam as sensações de chatice e raiva. Primeiro aceitemos a explicação que a chatice do jogo possa estar ligada, no início, ao fato deque o sujeito entra em contato com as primeiras dificuldades impostas pelas novas regras. Portanto, podemos conjecturar que: "é chato porque é difícil, é chato porque eu não consigo, é chato porque eu achei que iria ser fácil e não está sendo": logo, esta situação produzirá um sentimento de raiva, pois as expectativas não estão sendo satisfeitas.

Desta forma, a ofensa possui um alvo e se dirige para o interior do sujeito, mais precisamente para o ego. Esta parece depor contrariamente à sensação de auto-estima construída em experiências passadas que faziam-no acreditar ser possuidor de atributos necessários para transpor este desafio. Consequentemente, a crença em sua auto-eficácia também está ameaçada, afinal toda a habilidade e competência desenvolvidas em anos de prática não o estão ajudando a vencer os desafios impostos por este novo jogo.

Resumindo, em termos motivacionais, podemos colocar da seguinte forma, o sujeito deseja apreender o objeto tanto cognitiva quanto afetivamente envolvendo-se ativamente neste processo, portanto, sua ação é autodeterminada: logo intrínseca. Para tanto, deve entrar em contato com a essência do objeto; este relacionamento não se dá de forma direta, mas na forma de regras, neste caso, elaboradas socialmente por outros 
indivíduos. O sujeito, então, utiliza de todas as suas competências e habilidades adquiridas para lidar com o novo desafio.

Entretanto, a lógica que usa representada em seus esquemas de ação não the permitem dominar o objeto. Nosso herói ${ }^{5}$ sente seu espírito enfraquecido, advém a raiva, a sensação de fracasso o acompanha. Entretanto, ao invés de desistir abandonando o campo de batalha ou culpar o outro inconscientemente, elegendo um "bode" para lhe expiar toda a vergonha, isto não lhe é possível, mesmo porque, outro não há, existe somente o objeto estranho e o ego em perigo.

Munido das únicas armas de que dispõe nosso guerreiro reage, através do seguinte relato: [...] mas na forma que eu fui me esforçando e pegando mais a ideia do jogo foi me facilitando [...]. Novamente aparece o esforço, os alunos orientados à meta aprender sempre citam este elemento, este até parece uma chave mágica que abrirá o arcabouço hermeticamente fechado do conhecimento.

Pura ilusão, quem de nós não passou noites estudando para uma prova e ao final, não ficamos arrasados e envergonhados, com notas tão aquém de nossos hercúleos esforços. Entretanto, não sendo esta, quais outras armas dispomos para enfrentar quaisquer desafios que não seja o esforço e, até mesmo, certa cota de sacrifício naquelas áreas que se relacionam profundamente com nossas almas?

Conforme já discutido em outros momentos: será que este desejo pelo esforço e até mesmo pelo sacrifício não está inconscientemente ligado de alguma forma a condicionamentos culturais representados pelo herói que se auto oferece em sacrifício como último ato em sua evolução espiritual?

Esta crença metafísica estaria ligada à ecologia conceitual do sujeito fazendo-o continuar mesmo diante de certo sacrifício? Nós não sabemos e nem podemos concluir nada a este respeito. Gostaríamos de salientar que estamos apenas tentando entender possíveis determinantes que podem estar contribuindo para a subjetividade do indivíduo e, que porventura podem estar impactando em sua motivação.

Voltemos ao trecho, observemos a conexão entre "na forma que fui me esforçando e pegando mais a ideia do jogo foi me facilitando”, ou seja, no momento em que se vai dominando mais as regras do jogo, podemos supor que maior quantidade de prazer se vai obtendo. Quem de nós ao realizar uma atividade que prematuramente

\footnotetext{
${ }^{5}$ A palavra "herói” não representa nenhum julgamento de valor em relação ao sujeito. Significa apenas um recurso estilístico.
} 
tínhamos julgado como sendo chata, ao seu término não se sentiu surpreendido achando-a prazerosa?

Nesse sentido, cabe uma pequena reflexão, quantas vezes ao propormos uma atividade para nossos alunos, estes já começam a reclamar sem antes, ao menos, terem tido tempo para entrar em contato com ela. Naturalmente, não estamos afirmando de um modo geral que o indivíduo não possui a priori atributos para julgar se uma atividade será interessante ou não. Afinal, o próprio Piaget nos recomenda, conforme referencial teórico, que quanto mais próximo estivermos dos interesses dos alunos, produzidos por suas necessidades, mais podemos esperar de seu rendimento. Entretanto, sabemos que devido ao grande número de interesses em sala de aula fica um pouco difícil acertar o alvo, o que é interessante para uns, desinteressa a outros.

Outra questão é que não podemos deixar de reconhecer que todo o conhecimento, até mesmo o senso comum, se coloca na forma de regras; quanto mais complexas forem estas regras, mais complexo será o conhecimento. Ora resolver uma equação matemática é antes de tudo obedecer às regras necessárias para sua solução. Torna-se então complicado ensinar para alguém que não deseje lidar com o desconhecido, afinal as regras são externas, sendo socialmente construídas, necessitando por parte do indivíduo certo esforço.

Nesse sentido, o sujeito conclui: [...] assim como todo mundo, tem uma dificuldade, a primeira impressão é ou para ou persiste, e eu sou uma pessoa que odeio parar no meio, quando eu começo alguma coisa eu vou até o fim, mesmo que eu quebre a cara depois..." o novo conhecimento se apresenta na forma de um desafio que deve ser transposto. E na medida em que se vai obtendo sucesso, após esforço e dedicação, muito provável, que o indivíduo ressignifique sua experiência como sendo enriquecedora. Principalmente, se esta possibilitou o desenvolvimento de novas habilidades e competências, ampliando tanto seus sentimentos de auto-estima como de sua auto-eficácia, antes, ameaçados.

Sendo assim, talvez o indivíduo no final do processo acredite que o jogo é difícil, até chato, mas aprendeu muito com ele e, apesar da raiva pode mostrar todo o seu valor, pois não desistiu.

Ainda sobre este trecho, o egocentrismo piagetiano aparece fortemente: [...] assim como todo mundo, tem uma dificuldade, a primeira impressão é ou para ou persiste, e eu sou uma pessoa que odeio parar no meio, quando eu começo alguma coisa eu vou até o fim, mesmo que eu quebre a cara depois.[...] . Há um desejo em se 
testar, em colocar o ego à prova, mesmo se tratando de um simples jogo. Como se nesta fase da vida tudo fosse pessoal. Ora, poderíamos escrever o trecho acima da seguinte forma: "eu não sou igual a todos, eu sou diferente, enquanto os outros desistem, eu continuo". Conforme Piaget previu, é puro "egocentrismo consciente", capaz de embotar o espírito com certo ar "indolente".

Antes de encerrarmos, cabe-nos mais uma pequena reflexão. Parece-nos que o novo traz algo de desagradável no trecho: "mesmo que eu quebre a cara depois." Vejamos, há uma ameaça: “quebrar a cara” Será que existe um "eu” inventado por nós que está sempre obrigado a obter sucesso? Afinal, pode acontecer de não sermos capazes de lidarmos com a nova situação, portanto, qual o problema se fracassarmos? Haverá um espelho surreal que nos denunciará a cara quebrada? Será que todo novo conhecimento carrega em seu cerne esta ameaça velada e que, por conseguinte, sempre revivemos esta ansiedade de despedaçamento?

Segundo Piaget, a metafísica própria do adolescente nesta fase produz paixões megalomaníacas fazendo com que o jovem se lance na vida procurando reformar toda a sociedade. O genebrino deixa claro que parte da cura deste egocentrismo cabe à integração do jovem na sociedade através da escolha de uma profissão. Sendo assim, com tantos sonhos mirabolantes, é natural que o jovem espere em algum momento: “quebrar a cara” e, segundo o pensador, será através da atuação em uma profissão que o jovem poderá aproximar mais objetivamente seu poder de ação a seu desejo de mudança.

Gostaríamos de salientar, que consideramos este dado como sendo anômalo em relação aos dois principais arcabouços teóricos deste trabalho. Em primeiro lugar, referente à meta aprender, pois o sujeito orientado por esta meta crê que os desafios acadêmicos podem fazê-lo crescer intelectualmente. Não obstante, então, porque o sentimento de raiva?

Já no que se refere ao nosso principal e mais importante referencial teórico ligado aos conceitos piagetianos, pareceu-nos potencialmente ameaçador. Pois, imprimiu em nós a sensação que o genebrino havia proposto como caminho para evolução do sujeito um caminho insuportável ligado às sensações desagradáveis produzidas pelo conflito cognitivo. Ora: quem em sã consciência pode viver em uma gangorra emocional: pois ora estamos em equilíbrio, instantes após poderemos nos desequilibrar? Podendo, até em alguns casos, sentirmos emoções negativas como a raiva, ou mesmo angústia. 
A insurgência deste dado anômalo foi o fator dinamogeinador, pois exigiu-nos o comprometimento moral nos obrigando a enveredarmos para o aprofundamento teórico deste pensador. E ali contemplamos o nascer da necessidade lógica, representando o manancial energético infindável, capaz de impulsionar o sujeito a utilizar todos os meios lógicos em busca da objetividade.

Voltemos à análise, no trecho a seguir:

12-(P): Você já estudou para uma prova, mas na hora você se confundiu e conseguiu uma nota $\mathrm{C}$, como você se sente.

(A): Eu não me sinto tão mal assim, como... parece que deram a resposta do...das olimpíada de Matemática, falaram que eu fui, eu ainda não vi, ainda não tenho certeza, mas falaram que eu fui um dos que tiraram a menor nota de matemática, sendo que eu sou o melhor aluno da es..., da minha sala de matemática, tipo na hora dá até uma sensação ruim, mas..hé..se eu vacilei foi por falta de atenção ou, ou alguma coisa, mas... eи não...eu não vou me martirizar, não vou me.... me achando um lixo, isso, aquilo, por causa de uma nota, porque ela não é única da... ela não é a primeira da minha vida e não é a única, eu só tenho que aprende mais e me esforçar um pouco melhor.

É interessante notar que perguntamos ao jovem como se sente quando recebe uma nota média, pois pretendíamos auferir o quanto está interessado em obter notas altas, após empreender esforço. Entretanto, ele muda o foco da pergunta, pois responde sobre esforço e fracasso.

No trecho: das olimpíada de Matemática, falaram que eu fui, eu ainda não vi, ainda não tenho certeza, mas falaram que eu fui um dos que tiraram a menor nota de matemática, sendo que eu sou o melhor aluno da es, da minha sala de matemática, o aluno comete um ato-falho, no momento em que interrompe a frase, dizendo que se considera o melhor aluno da escola. Entretanto, segundo a maioria dos professores ele não é somente o melhor aluno de sua classe, mas um dos melhores da escola. Qualquer concurso e seu nome é logo citado.

Sendo assim, apesar do fracasso, sua auto-estima continua intacta. Naturalmente, que o auto-conceito com o qual construiu sua personalidade durante anos de sucesso escolar blinda seu "eu" não permitindo que o sujeito sofra com o fracasso obtido: mas... eu não...eu não vou me martiriza, não vou me...fica... me achando um lixo, isso, aquilo, 
por causa de uma nota, porque ela não é única da... ela não é a primeira da minha vida e não é a única,.

A olimpíada de Matemática é um concurso que visa selecionar os alunos mais capazes nesta disciplina. Sendo assim, este sujeito deveria se sentir bastante chateado, pois a prova não comprovou seus anos de estudo, nem tampouco foi capaz de tornar pública sua fama de aluno inteligente. Ao invés de se autodepreciar, questionando sua auto-eficácia, ele a manteve inalterada, pois novamente cita a fórmula mágica para abrir o arcabouço hermeticamente fechado do conhecimento (grifado): "eu só tenho que aprende mais e me esforçar um pouco melhor ".

Podemos também supor, graças ao novo egocentrismo adolescente, que este foi capaz de inflar todos os constituintes de sua auto-imagem. Pois, segundo Piaget, os julgamentos que fazemos de nós mesmos são resultado das interações reais a nossa volta, mas também são resultado de nossa imaginação. Destarte, já que o adolescente "reedita o egocentrismo infantil devido à onipotência de sua reflexão", é bastante razoável admitirmos que seu auto-conceito, sua auto-eficácia estejam superavaliados fazendo o espírito acreditar poder realizar qualquer tarefa, ou aprender qualquer conceito bastando apenas dedicação e esforço.

Continuando com a análise, temos:

(P): Você sempre tirou notas boas?

(A): Razoáveis...não boas, eu até...

(P): Mas a nota preocupa você, se preocupa, isto te preocupa às vezes

(A): Se eu gosto da matéria e gosto do professor me preocupa, mas se eu não gosto da matéria e não ligo pro professor... não.

Este trecho está distante do comportamento do aluno ligado à meta-aprender, pois os alunos assim orientados independentemente da disciplina ou do professor esforçam-se para aprender.

Entretanto, como este sujeito nunca foi reprovado, tem boas notas e é considerado pela maioria dos professores como sendo inteligente e esforçado. Temos duas possibilidades: a primeira é descartar este trecho, pois um único dado anômalo não é capaz de refutar toda a análise. Ou a segunda, por absurdo, considerar que este aluno gosta de todas as matérias e de todos os professores, sendo esta hipótese bastante improvável; logo, ficaremos com a primeira descartando este dado, ou como consagrado no jargão corrente dos laboratórios científicos, diante do surgimento de um ponto que não pode ser predito pela teoria: "este é um ponto fora da reta". 
Todavia, antes de descartamos totalmente, Villani (2005) relata o seguinte caso (Referencial Teórico). Repetimos aqui para evitar que o leitor seja obrigado a retornar.

[...] Ann, pelo contrário, era uma aluna esforçada e inteligente, que conseguia se sair bem na disciplina de Química, apesar de afirmar detestá-la. Seu desempenho aponta claramente para uma diferença entre conhecer e envolver-se..., ela recusou-se envolver com o conhecimento proposto pelo professor, apesar de revelar que seu desejo implícito estava bastante próximo do desejo do saber."

Poderíamos, então, interpretar o conteúdo desta fala admitindo que nas disciplinas em que o aluno não deposita grande valor, ou mesmo por desgostar da metodologia, ou do professor, ele não apresente o desejo de envolver-se, mas talvez mantenha sua capacidade de conhecer, sustentando seu desejo de saber. Sendo assim, então este trecho poderia ser tratado pelo referencial teórico ligado à meta-aprender. De qualquer modo, esta interpretação está distante do referido dado, sendo assim deixamos a cargo do leitor descartá-lo ou considerar como uma interpretação fora dos dados.

13-(P):Quando o professor propõe um desafio, por exemplo, um problema como você se sente?

(A): Quando eu proponho um desafio..., um problema

(P): Quando o professor, o professor propõe um desafio, um problema pra resolve como é que você se sente? (A)depende como o professor me apresento isto, se ele me apresento e eu senti no ar dele, um tom de desafio que ele... desconfia da mi...

(P):Oi...

(A):Ele desconfia da minha capacidade, ele acha que eu não tenho capacidade

(P)Não ele apresentou pra classe (A) Hum...Há...se eu tipo olha o desafio e olha assim eu vê que eu gosto mesmo, eu vo di frente...

(P): Tá então, tudo bem, voltando então àquela pergunta, aquilo que você estava falando e se ele tiver desafiando sua capacidade?

(A): Se ele me desafiou minha capacidade, mesmo que seja numa área ruim, eu vou me esforçar ao máximo, pra pode prova... que eu, que eu só, que eu, que eu valo, pelos meus esforços, mesmo que seja uma área ruim, se eu tira uma nota ruim, que dize que ... ou eu não me esforcei o suficiente ou aquela área realmente eu não, eu não sou adequado aquela área. 
Novamente, segundo o referencial teórico adotado, o esforço e a dedicação são ferramentas com as quais o indivíduo pretende enfrentar os desafios acadêmicos, que pelo seu grau de dificuldade são capazes de fazê-lo crescer intelectualmente. Nesse sentido, o desejo por aprender coisas difíceis são significados como de grande valor.

Neste trecho, também o egocentrismo adolescente reaparece: "mesmo que seja numa área ruim, eu vou me esforçar ao máximo, pra pode prova... que eu, que eu só, que eu, que eu valo, pelos meus esforços,". Ora, este parece confirmar nossa impressão de que o sujeito, devido ao novo egocentrismo, tem seu sentimento de auto-eficácia e sua auto-imagem inflados. Doravante, o "eu", dotado de um grande espírito, motivado pela nova vida que se agita, faz com que qualquer desafio ganhe ares de grandes realizações.

Destarte, muitas vezes, temos a impressão, no trato com adolescente, que no momento em que este ouve um "não", ou algum objeto, ou melhor, quando um símbolo captura sua intenção, afinal não nos relacionamos diretamente com os objetos, mas com seus representantes: os símbolos. E estes se mostram arredios a sua compreensão, aí aparece a fagulha aguçando-lhe o interesse.

No referencial teórico, afirmamos que ao iniciarmos uma tarefa é natural o aparecimento de pensamentos referentes tanto ao prazer advindo pelo sucesso, quanto certa angústia por um possível fracasso, condição claramente presente neste trecho: “mesmo que seja uma área ruim, se eu tira uma nota ruim, que dize que ... ou eu não me esforcei o suficiente ou aquela área realmente eu não, eu não sou adequado aquela área." Todavia, novamente o sujeito cita o esforço como remédio para desfazer a angústia. Nesse sentido, vejamos o conceito de auto-eficácia em ação, pois o sujeito recorre ao passado, e avalia sobre sua possibilidade de realizar alguma tarefa, e conclui: o esforço é a única e possível resposta.

16-(P):Você tem alguma, você gosta, o que você acha do trabalho em grupo? 17-(A) Ôooo...eu não vou critica, mas eu também não vou elogia, porque o grupo, o trabalho em grupo, vale muito do grupo e também das pessoas tanto internas quando externas do grupo...eu quando era mais novo gostava muito de faze trabalho em grupo porque eu me sentia mais à vontade, me sentia bem, porque é modo de você ter mais comunicação com alguém, mas por problemas externos do grupo que uma vez eu tive, que não tinha nada a ver com ninguém do grupo, era uma pessoa completamente externa, o meu pensamento no grupo... mudou bastante i...alguns assuntos de grupos. 
(P): Mas assim você tem... você trabalha, você participa de vários jogos, né nesses projetos assim?

(A): Sim?...

(P): E tudo é em grupo?

(A): Hum, hum (concordando)

(P): Então...?

(A): Mas aqui, mas nesse ponto, eu, eu muitas vezes dou a cara a tapa, eu arrisco pra vê o que acontece, se dê um resultado bom eu prossigo, se dê um resultado mau, mas as minhas convicções permanecerem eu continuo.

Este aluno como já foi relatado joga RPG e participa de grupos de jogadores. $\mathrm{Na}$ feira cultural da escola, montou uma sala para divulgar este jogo, convidou inclusive alunos de outras escolas para realizarem as partidas. Portanto, pareceu-nos que o jovem dá bastante importância aos relacionamentos pessoais, mesmo carregando certa possibilidade de frustração: "Mas aqui, mas nesse ponto, eu, eu muitas vezes dou a cara a tapa, eu arrisco pra vê o que acontece, se dê um resultado bom eu prossigo, se dê um resultado mau, mas as minhas convicções permanecerem eu continuo. Naturalmente, a imagem dos pais, nesta fase da vida, perde certo valor, enquanto que o relacionamento com os amigos torna-se deveras importante.

Não obstante, nos chama a atenção a expressão: “dou a cara a tapa” se referindo à possibilidade de fracasso nas relações pessoais. Na pergunta onze, aparece uma expressão parecida: "mesmo que eu quebre a cara depois" relacionada ao possível fracasso representado pelo conhecimento. $\mathrm{O}$ primeiro discurso se refere às relações interpessoais. Já na pergunta onze, o discurso aponta para as relações com o conhecimento. Sendo assim, parece-nos que de forma geral o sujeito fala sobre suas relações objetais, ou seja, a forma como pretende se relacionar com a realidade. Talvez este sujeito tenha uma grande necessidade de se envolver intimamente com a realidade assumindo os riscos deste envolvimento, conforme este trecho: "eu arrisco pra vê o que acontece, se dê um resultado bom eu prossigo, se dê um resultado mau, mas as minhas convicções permanecerem eu continuo".

Isto posto, parece que na adolescência surgem necessidades tanto afetivas quanto cognitivas, talvez representando maior simetria, maior reciprocidade, maior equilíbrio entre essas duas funções. O jovem quer se relacionar socialmente, mas também quer aprender sobre o mundo, ou resumindo: deseja conhecer. Nesta fase, parece renascer o desejo pela vida e para experimentá-la. Acreditamos que esta nova condição está 
contemplada em nosso referencial teórico sobre o adolescente piagetiano, mas vejamos a citação, confirmando, pelo menos para nós, estas inferências:

[...] $\mathrm{Na}$ verdade, apesar das aparências, as conquistas próprias da adolescência asseguram ao pensamento e à afetividade um equilíbrio superior ao que existia na segunda infância. Os adolescentes têm seus poderes multiplicados; estes poderes inicialmente, perturbam a afetividade e o pensamento, mas depois, os fortalecem.(Piaget, 2006, p. 58)

Em nosso referencial teórico, os sujeitos ligados à meta aprender podem buscar relacionamentos interpessoais baseados na solidariedade à medida que pretendem enfrentar os desafios acadêmicos com esforço e perseverança, portanto, têm a tendência de estabelecerem laços de amizade em torno do trabalho solidário, este desejo foi definido como “necessidade de intimidade".Naturalmente, esta interpretação está além do que se pode inferir diretamente dos dados, todavia em outro trecho desta entrevista retornaremos a este ponto.

18-(P)Você acha que o trabalho em grupo ajuda?

(A): Ajuda... sim, ajuda

(P): No que que ajuda...no que se acha que é legal trabalho em grupo, quando o professor propõe o trabalho em grupo se acha que vai ganha, quando você tá realizando trabalho em grupo?

(A): Óoo...eu acho que em questão de grupo, não é tipo só em trabalhos, os professores tem que pensa muito, né, sobre o trabalho em grupo, porque tem que pensa, porque são seres humanos diferentes, pensamentos diferentes e humores completamente diferentes e tem que analisa quem vai faze parte do grupo, tanto que eu acho muito interessante, quando o professor separa os grupos, não há,deixa vai ai e forme os grupos e pronto, porque quando é assim sempre vai te aquela panelinha, então não tem graça, e como uma época que eu estudava aqui no Pedro tinha um professor que eu achava muito interessante e eu estudei também no Marechal Rondon e eu acho,tinha um professor que eu achava muito interessante, tanto das duas escolas, que nos jogos, nos esportes, não tinha o negócio de ele dá a bola pros alunos, óoo, vai joga, ele que parava os grupos, ele se fazia tudo, porque ele sabia que... se deixasse, há.. toma bola vai começa a joga, tem as panelinhas os que jogam vão joga, os que não jogam vão ficar de canto, ou então os que querem joga, mas não sabem, vão fica de canto, porque eu mesmo, eu 
não sou um aluno esportista eu sou um aluno mais... tecno-dinâmico, eu gosto mais de diversões psicológicas, eu gosto mais de coisas assim, só que pelo profe, eu tive um professor que me incentivo tanto a faze esporte que eu acabei gostando em uma época, que ele não deixava os alunos separa os grupos, ele ia lá, você pra cá, você pra lá, você pra cá e todo mundo vai joga, não importa e se um briga com outro, os dois saem.

O sujeito demonstra não ter grande desejo por esportes até se define como um aluno "tecno-dinâmico" se sentindo atraído por diversões psicológicas. Talvez, os motivos para esta afirmação se relacionem ao alto valor que este indivíduo atribui aos jogos e a estudar. Praticar esportes é uma atividade em que o sujeito não se sai bem, pois não é escolhido pelo grupo dos bons jogadores ou, parafraseando suas palavras, excluído da "panelinha" reservada aos melhores.

Entretanto, quando o professor não deixou que os alunos mais habilidosos excluíssem os de menor capacidade, o sujeito não só referendou a atuação do professor, mas também passou a se interessar por sua prática. Parece-nos então que o sujeito mesmo diante de uma atividade onde possui baixo desempenho, esta condição não impede de realizá-la, podendo até alcançar algum nível de satisfação: "que eu acabei gostando em uma época”.

Nesse sentido, poderíamos conjecturar que talvez a "necessidade de intimidade" motivou o sujeito a se envolver com esporte? Pois o sujeito percebeu o empenho que o professor despendeu para que viesse a praticá-lo. Sendo assim, será que este respondeu reciprocamente ao comportamento do professor, sentindo-se responsável em fazer jus à preocupação daquele, o que o obrigou a dedicar-se mais?Afinal, segundo o referencial teórico, os sujeitos com esta necessidade tendem a dar valor ao compromisso com os outros. Notadamente, esta inferência está longe dos dados e deve ser tratada com cautela.

Piaget também relata quando do surgimento da segunda infância, que os sentimentos ganham certa lógica devido às relações de primeira ordem, pois estas são responsáveis em tornar o pensamento mais simétrico e recíproco. Portanto, talvez o sujeito tenha percebido o interesse do professor em ensiná-lo sobre a importância dos esportes: logo, reciprocamente, sentiu-se implicado em pagar com a mesma moeda dedicando certo interesse e esforço, até o momento em que a própria atividade pode capturar parte do seu desejo e investimento: "que me incentivou tanto a faze esporte que eu acabei gostando em uma época" 
Parece-nos que esta é a principal função do mestre: demonstrar um interesse sobre sua disciplina, enriquecê-la de um tal valor, temperá-la com um sabor capaz de seduzir o paladar do outro, até que o próprio conhecimento ou atividade complete esta tarefa.

18 (A) - (P): E no ensino o que se acha que no estudo o trabalho em grupo proporciona? (A): Proporciona a mesma coisa do esporte, raiva, discussão, alegria, companheirismo, fortalecimento de pessoa, amizade.

Novamente, o mesmo desejo em se relacionar com a vida e com tudo o que dela faz parte: "raiva, discussão, alegria, companheirismo, fortalecimento da pessoa, amizade". Chama-nos a atenção, o trecho : "fortalecimento da pessoa" é uma pena que no momento desta entrevista, não havíamos tomado conta do conceito da "necessidade de intimidade". Pois, caso o tivéssemos, então teríamos inquirido o sujeito sobre o significado desta afirmação. Conforme já escrevemos, os sujeitos respondem a esta necessidade acreditando que seu crescimento passa através do enriquecimento das relações, ou conforme a citação:

[...] o desejo, ou necessidade social de intimidade, surge a partir do desejo de cuidado e preocupação interpessoal, calor humano e compromisso com outros, conectividade emocional, diálogo recíproco, ser compatível com o outro e de amor (McAdams apud Reeve, obra citada, p. 118).

Continuação da pergunta anterior(18):

(P)Mas em relação, e ao pensamento?

(A) Ao pensamento, isso já é uma coisa mais complicada, porque dependendo da atividade você pode gerar conflito, você nunca pode dá uma atividade que gere conflitos como religiosos, conflitos, ou então conflitos que...

(P)(interrompe a fala do aluno) Não, por exemplo, assim, você pensa uma coisa, outra pessoa pensa outra,...

(A): Sim.

(P): Entendeu, então vocês vão ter uma discussão?

(A): Sim... mas discussão é uma coisa saudável...deve, uma sociedade que não existe discussão 
(P): (interrompe o aluno)Eu sei mas, o que acha que vai sair de ganho pra você dessa discussão, porque se a pessoa se incomoda com a sua mesma opinião...

(A): Ai há uma aliança, mas aquela que discuti há um conflito é isso que você que sabe, é isso que você que sabe

(P): Não, não precisa do conflito, mas tipo

(A): (aluno interrompe) Mas há o conflito de ideias

(P): Isso, de ideias...Humm...

(A): Ai eu paro pra ouvi, há ideia sempre é ouvi o outro lado, nunca apresenta apenas o seu lado, o meu lado tá certo, o meu lado e fim de papo, nunca deve se feito assim, mesmo que o lado da outra pessoa estiver errado você deve ouvir e prestar atenção que é o mais importante.

(P):Mesmo porque a gente não sabe se o lado da pessoa tá errado realmente, não é verdade?

(A): Hum,hum...

(P): Que às vezes, por exemplo, você tá aprendendo alguma coisa de ciências, por exemplo, você acredita em uma coisa a pessoa acredita em outra

(A): Sim,como

(P): (professor interrompe)Aí vai haver uma discussão, aí depois vocês vão lê pra sabe quem tá certo

(A): É...é mas é claro que também tem assuntos que não há ponto pacífico, como evolução e criação, os evolucionistas nunca vão bate de acordo com os criacionistas (P): Não isso...isso...

(A): São assuntos que se colocarem em pauta entre um grupo (P)(professor interrompe)Mas você não acredita que um desenvolve o pensamento do outro (A) Sim, (P): Porque um vai tenta atacar o outro e vai... aí o cara vai ter que melhora o argumento dele

(A): Ai é que eu vejo o erro, não deve haver um ataque e sim uma apresentação de fatos, como no julgamento não se deve atacar o outro e sim se apresentar os fatos fortes, assim deve ser feito, você não deve ataca, háaa ele fez isto, ele fez isto, ele, eu to certo, ele não, dá, dá..., tem que apresenta ó, tem isso, isso, isso, isso o que que você tem? Tenho isso, isso, isso, isso, compara e chega num ponto certo num ponto de concordância. 
Neste trecho da entrevista, as intensas interrupções demonstram claramente que o pesquisador deixou seu posto para se envolver na defesa da importância da discussão ou do conflito para o desenvolvimento do conhecimento:

Ainda sim, o aluno acaba revelando sua preocupação com o outro no trecho:“(A) Aí é que eu vejo o erro, não deve haver um ataque e sim uma apresentação de fatos, como no julgamento não se deve atacar o outro...”. Talvez, esta preocupação interpessoal esteja relacionada com o conceito de necessidade de intimidade.

Nesse sentido, em um trecho mais acima, o sujeito também parece demonstrar esta preocupação, só que agora refere-se à necessidade de ouvir e respeitar a opinião alheia, o que reforça nossa impressão sobre o conceito acima:

No fragmento a seguir, temos:

20-(P) O professor pede para vocês resolverem várias questões em grupo como você se se comporta, não, como o grupo se comporta, você tem assim, participado dos grupos, como é que se acha que tem se comportado.

(A)Hoje em dia, geralmente quando os grupos são formados, principalmente quando o professor dá direito aos alunos formarem, geralmente são um dois que fazem e o resto observa, enquanto aqueles dois preparam tudo e fazem o resto fica de canto o que fizer tá feito se tive errado tá errado se tive certo tá certo e pouco importa.

Esta situação é uma ameaça a um dos cânones básicos da metodologia sócioconstrutivista. Pois a metodologia defende que os alunos trabalhem em grupo, podendo, assim, trocar ideias e proposições livremente, confrontando-as com seus parceiros aprendendo a respeitar as posições contrárias. Neste espaço privilegiado, este pode participar ativamente na colaboração, discussão e principalmente através da reflexão. Portanto, o grupo é capaz de desenvolver capacidades: conceituais, metodológicas e atitudinais, explicitamente um dos grandes sonhos desta metodologia.

Outra ameaça, também diretamente ligada ao escrito acima, refere-se ao conceito de zona de desenvolvimento proximal, em que, graças à interação social, um aluno mais capaz pode atuar no desenvolvimento das capacidades cognitivas dos demais. Naturalmente, este aluno mais capaz, mesmo já dominando o conceito, no momento em que se esforça para comunicá-lo ao outro, clareia as próprias ideias, fazendo que o conceito ganhe em inteligibilidade, plausibilidade e fertilidade conforme sugere o Modelo de Mudança Conceitual.

No referencial teórico, apresentamos a crítica de Mortimer em relação ao conflito cognitivo: a improdutividade das discussões em grupo seria devida à 
dificuldade dos aprendizes de lidarem com o desequilíbrio de suas ideias ligadas ao senso comum. Talvez esta improdutividade não se deva ao conflito, mas à forma como os alunos encaram a participação em grupo, neste caso, utilizando-se principalmente a estratégia do "mínimo esforço".

Nesta mesma seção do referencial teórico, relatamos as pesquisas de Gunstone ligadas às motivações epistêmicas sobre aprender-ensinar capazes de orientar e impactar a forma como os alunos irão cumprir os objetivos e as tarefas escolares. Talvez "o mínimo esforço" se traduza na metodologia com a qual alguns alunos pretendem atuar em grupo delegando a responsabilidade pelo seu aprendizado aos alunos mais capazes. Comportamento até natural, se levarmos em consideração que uma das suposições básicas desses alunos se refira à crença prejudicial de que para aprender Física seja necessária uma elevada capacidade cognitiva.

Sendo assim, também seria natural um professor sócio-construtivista creditar o fracasso à sequência didática, sem ter em mente que as condições de entrada dos alunos talvez tenham sido determinantes para o mal resultado do processo.

Entretanto, poderiam objetar que as propostas sócio-construtivistas buscam envolver os alunos através de perguntas instigadoras ou utilizando como estratégia os problemas abertos. Porém os alunos construíram suas crenças epistêmicas durante anos de práticas escolares. Será que estas podem ser modificadas, somente com a atuação apenas nos últimos três anos do ensino, correspondendo ao período regular e obrigatório para ensino de Física? Diversas pesquisas relatam o sucesso das novas propostas constatando um maior envolvimento dos alunos. Contudo outras demonstram seus limites.

21- (P) Porque que você acha que eles não participam (A) Falta de interesse $e$ necessidade de se dá bem em cima dos outros, o ser humano tem uma... tem um gênio muito forte em querer se dá bem em querer te lucro com pouco esforço ele quer, ele quer levantar um prédio, sem mover um dedo, este é o problema, então aqueles, mais... mais capacitados fazem e os menos capacitados, não é nem... menos capacitados, aqueles que têm menos interesse se escoram.....se achando que ainda estão fazendo a coisa certa, sem eles para pra se toca, que por ele não tá se esforçando não estão aprendendo

Na pergunta número 6, sobre o esforço, o sujeito respondeu:(A) sim tem que te um esforço, porque se não houver um esforço, a pessoa não dá crédito, não dá valor, 
tudo o que é fácil a pessoa, o ser humano não dá crédito, isto é mal para o ser humano. Naquele trecho concluímos que esforço e dedicação é uma das crenças mais profundas deste sujeito. Parece-nos ser o esforço e dedicação as ferramentas básicas para o sujeito melhorar a "si" mesmo. Ou melhor, o "eu" que este sujeito pretende projetar traz como características principais estes condicionamentos, como se ele dissesse ao se olhar: “Como eu sou esforçado" este é meu principal valor. Ora, como resultado de suas experiências este assimilou como auto-conceito a importância de empreender esforço. Nesse sentido, para que algo seja interessante, basta responder a esta estrutura conceitual de si mesmo.

Novamente, o sujeito apresenta a fórmula para reformular a humanidade, curando-a do mal do "mínimo esforço": gênio muito forte em querer se dá bem em querer te lucro com pouco esforço ele quer, ele quer levantar um prédio, sem mover um dedo”. O sujeito olha para a sociedade e não se furta a estabelecer uma teoria para modificá-la, próprio do egocentrismo adolescente.

22 (P)Você acha por exemplo, que, por assim pra você ir bem nas matérias, tal não sei o que, é os alunos, é as vezes se aproximam de você, no grupo, por exemplo, você acha, que esperam que você responda? (A) Sim...sim...(P)Depois copia? (A)Sim...acontece muito isso comigo em questão de provas e avaliações, quando eu faço uma coisa ele vê qual a resposta, qual a resposta, eu nunca peguei resposta, eu nunca peguei cola, mas sempre quando alguém vem pega eu falava pega, porque eu acho um negócio, você tem que vale seu esforço, a nota que você tirar é relativa e a seu esforço, se você pega uma resposta de alguém, a nota não é sua, aquele esforço não é seu, quer dize você pegou alguma coisa que não é sua em um certo ponto de vista é roubo.

Conforme relatamos no referencial teórico, Piaget atribuiu à lógica concreta a formação dos novos valores morais presentes na segunda infância (6 aos 12 anos): logo, a necessidade de ser honesto e o conceito de justiça se constituem um sistema racional de valores pessoais. E a lógica formal permite ao adolescente extrair a essência do conceito permitindo aplicá-lo em outras situações de sua vida. Sendo assim, não estamos mais diante de um comportamento apenas moral, ligado à norma, mas diante de um conceito ético que o sujeito pretende observar independentemente da situação concreta, conforme o trecho: "a nota que você tirar é relativa e a seu esforço, se você pega uma resposta de alguém, a nota não é sua, aquele esforço não é seu, quer dize você pegou alguma coisa que não é sua em um certo ponto de vista é roubo." 
Sendo assim, talvez por traz das crenças ligadas à meta-aprender, como por exemplo: estes alunos têm a convicção ou crença de que os resultados positivos nas tarefas derivam maximamente de esforço ou o êxito constatado após esforço dá origem a sentimento de orgulho e realização. Talvez, o germe primitivo destas crenças se refira às construções relativas à honestidade e à justiça, pois agindo assim o sujeito está cumprindo em plano inconsciente suas necessidades morais construídas na segunda infância ampliadas na adolescência.

21-(P)Por exemplo, assim...então num certo sentido trabalhar em grupo pra você é ruim (A) Sim (P)Porque pessoal, só suga (A) Sim, sim...mas aí vai do assunto como foi apresentado, ai eu volto nesta...nesta questão, se o professor apresentar o assunto de um modo mais interessante, de um jeito ou de outro os alunos vão se empolgar mais se ele apresenta um assunto mais enjoativo, de um modo mais chato, os alunos não vão se esforça, mas também tem aqueles que mesmo que se apresenta o melhor assunto possível, do melhor jeito possível ainda vão se escora sem faze nada.(P) É...né.

O sujeito acredita que a forma como o professor apresenta o conteúdo pode motivar ou não os alunos a se envolverem nas tarefas. Entretanto, logo depois, apresenta a ideia de que alguns alunos, independentemente da forma que for apresentado o conteúdo, estes não irão se comprometer. Este fatalismo está presente tanto no discurso dos professores, quanto dos alunos. Por nosso turno, pretendemos entender quais as concepções que produzem este comportamento.

Os próximos trechos estão deslocados da sequência da entrevista. São referentes às perguntas oito, nove e dez. Nós havíamos descartado estes dados, pois entendíamos tratar-se apenas de reclamações sobre a atuação do professor. Todavia, após aprofundamento teórico, talvez possamos tecer certa análise.

8- (P):Você afirmou na pergunta 7...antes, qual o papel de um bom professor, que você acha que é um bom professor pra você, na sua visão, professor que você gosta, eu aprendo com este professor

(A): É um incentivo, uma dedicação ao aluno... é mostrar que ele gosta do aluno, mesmo que ele não goste, mas tipo mostra, porque muitas vezes eu já catei professores que não me mostraram que eu tinha matéria que eu gostava, mas pelo professor, mostra um desinteresse em mim, pra mim pouco me importava aquela matéria e sim que já teve matéria que eu odiava, que eu não me dava bem e por ver um insistência do 
professor eu acabava me esforçando, então o professor tem...ele tem que querer ensina o aluno, que senão pra que ele quer...pra que que ele quer se professor

Vejamos este trecho, o aluno apresenta um discurso focado na atuação do professor e a relação que este deve manter com o sujeito. Pode-se perceber que o aluno deseja ser objeto do interesse do professor: podemos interpretar este fragmento significando que o sujeito deseja uma atenção quase infantil, o que estaria próximo do conceito referente à "necessidade de afiliação". Ou por outro lado, conforme questão número dezoito o "interesse do professor" foi capaz se sensibilizar o sujeito ao ponto que, de forma recíproca, este se sentiu obrigado a também demonstrar interesse. Talvez os trechos abaixo possam afastar definitivamente estas dúvidas.

9-(P): (pesquisador interrompe) Mas olha só, como é que você vai saber por exemplo, um assunto novo, aquilo a priori, num primeiro momento, é uma coisa chata $(A)$ $H U M \ldots$.. (P):aquilo não sei o que... o professor talvez não tenha conseguido mostrar aquilo de uma forma que se torne interessante, porque talvez não seja tão interessante, mas é uma ferramenta, com o domínio dela você vê uma certa... uma certa utilidade, porque ela desenvolve o seu pensamento, tal não sei o que, se o professor não pode te obrigar, você nesse caminho, entendeu, como é que você vai saber, se o professor não consegue passar esta motivação logo de início, que você deve fazer ou não, e aí você não vai com a cara do professor, por exemplo(A) Aí no caso $(\mathrm{P})$ : Você não fica um pouco dependente do professor, no caso?

(A): Mas se for para mesmo pra pensa todos os alunos são dependentes do professor, porque tanto que, dizem que, os primeiros professores mais importantes, são os da primeira à quarta série, se você pega um professor que te explique melhor em uma área, provavelmente os alunos vão gosta mais daquela área, se você pega um professor que não te explique bem, você vai chega no primeiro, segundo, terceiro, aquela área você não vai consegui entender, porque quando a gente tá em formação o primeiro professor é o que mais conta, os primeiros professores, porque se você di primeira série, de segunda tive uma má impressão de uma matéria mais pra frente você vai mante aquela impressão, como eu e minha irmã somos completamente diferentes em questão de matéria eu tive bons professores que me ensinaram matemática de primeira e quarta série e ela teve ótimos professores que ensinaram português, ela odeia matemática e eu odeio português, não tem ninguém que possa mudar a minha ideia se eu cato uma boa professora de português eu me esforço e consigo tira umas notas acima da minha média normal, mas eu não gosto de português. 
Para Piaget, o(a) professor(a) é visto pela criança como um adulto que goza de uma posição especial, sendo assim, o pequeno lhe endereçará toda a energia em forma de interesse através da observância das regras e pelo zelo em realizar as tarefas que este lhe exigir. Naturalmente, então, estes podem influenciar nos interesses futuros do infante:

O sujeito veementemente afirma "odiar" português, pois teve péssimos professores, inclusive o mesmo motivo justificaria também a "raiva" da irmã pela matemática. Todavia, qual ou quais características teria uma "boa" professora? Ou ainda, o que teriam feito os professores de matemática para despertar o interesse do sujeito por esta disciplina? Será que eles foram bonzinhos com o aluno, distribuindo estrelinhas no seu caderno? Será que esta seria uma prova cabal da fraqueza de espírito deste sujeito, no tocante à dependência do professor? Vejamos o que nos revelam os próximos trechos:

10-(P)Teve professores que conseguiram faze isso (A):Humm. (P)Teve professores que conseguiram faze isso com você... (A) que conseguiram me ajuda em matérias dificultadas ...(P)É que você (A):Sim...Sim...eu não vou menti na terceira série e tive uma professora, eu tinha um tipo, minha letra não era feia, eu tinha muita dificuldade em português e era meio relaxado, na questão de português, nunca fui de matemática, mas sim de português, a professora me colocou de canto da sala, não isolado, mas na frente dela, e assim, fora da lição normal que ela dava, ela me dava lições extras tentando faze eu me esforçar mais e mostrava pra mim que eu valia a pena pra ela, eu não era apenas mais um aluno de mais um ano, eu não era mais um que tava passando ali da sala de quarenta, eu era um, assim como o outro era ele, uma coisa certa, o professor não pode ver a sala como quarenta alunos, ele tem que vê cada aluno, como um aluno, não é porque ele tem dois mil alunos, ele dá aulas em não sei quantas escolas, fica não sei quantas horas fazendo aula, que ele tem que leva tudo a ferro e fogo ou então leva todos os alunos como lixo ou não presta, tem que leva cada aluno como seu ideal, porque cada aluno tem sua ideia e seu pensamento.

Em nosso referencial teórico, também escrevemos que a criança espera ser conduzida pelo letramento das séries iniciais por uma mão segura a lhe amparar nos momentos difíceis, da mesma maneira que a mãe, quando lhe ensinou os primeiros passos, evitando-lhe os acidentes. Ora, a principal qualidade desta professora foi exatamente estabelecer este relacionamento interpessoal com o sujeito. 
Todavia, este relacionamento não foi estabelecido por uma professora que pretendia ser toda "boazinha". Pelo contrário, primeiro ela colocou o aluno próximo dela, depois exigiu-lhe esforço: "e assim, fora da lição normal que ela dava, ela me dava lições extras tentando faze eu me esforçar mais”. O sujeito poderia ter interpretado esta atitude como significando ser incapaz para aprender, pois recebeu tratamento especial exatamente pela sua incapacidade.

Entretanto, este interpretou a atitude da professora como uma demonstração de cuidado, conforme trecho: "mostrava pra mim que eu valia a pena pra ela, eu não era apenas mais um aluno de mais um ano,". Neste acontecimento, provavelmente, o sujeito tenha internalizado em seu "eu" a necessidade de esforço como estratégia para melhorar a "si" próprio, pois relatou que estas circunstâncias ajudaram-no a superar suas dificuldades.

Na maioria das vezes, quando perguntamos para pessoas porque gostam de uma disciplina, elas costumam apresentar as seguintes razões: a primeira é porque gostam, a segunda; julgam ter maior facilidade. Não sabemos se é pelo fato de gostarem que acabam por adquirir maior compreensão. Ou, pelo contrário, exatamente por obterem resultados melhores, sobre os demais, é que passam a gostar.

Naturalmente, para este sujeito, o aprendizado de matemática não deve ser algo muito difícil, pois deve ter percebido que possui maior habilidade nesta disciplina. Todavia, independentemente de seu interesse intrínseco, a professora deve em algum momento ter contribuído para reforçar a crença do aluno relativa a esforço, pois em algum momento, ela the exigiu maior cota de esforço, e porque não dizer sacrifício diante deconteúdos de maior complexidade.

Talvez, os alunos da meta aprender vivenciem estas situações nas diversas disciplinas que lhes interessam. Mas, sobretudo, a construção da crença de que o esforço é a chave mágica que abre o arcabouço hermeticamente fechado do conhecimento deve ter sido construída principalmente naquelas disciplinas em que o sujeito declara ter maior dificuldade, contribuindo para elaborar as seguintes crenças:

- Estes alunos têm a convicção ou crença de que os resultados positivos nas tarefas derivam maximamente de esforço, que é um fator interno e sob seu controle;

- Por isso, enfrentam os desafios acadêmicos que, por seu grau de exigência, são vistos como capazes de fazê-los crescer intelectualmente; 
Perguntamos na análise do primeiro trecho desta entrevista o que o sujeito pretendia conquistar, qual seria seu prêmio, após esforço e dedicação? Será que este trecho é a resposta: "mostrava pra mim que eu valia a pena pra ela, eu não era apenas mais um aluno de mais um ano, eu não era mais um que tava passando ali da sala de quarenta...” Será que o prêmio a ser conquistado é o respeito e o carinho da professora? Ela não o veria mais como um relaxado? Ela concluiria que este é bom aluno, pois é dedicado e esforçado?

Será então que o "ideal do eu" projetado pela professora foi internalizado pelo aluno através do esforço e dedicação, neste momento, em que a atuação adulta junto à criança é tão poderosa?

[...] Piaget lembra a abordagem de Baldwin sobre a origem dos diferentes sentimentos morais nas relações interindividuais. Para esse autor, a consciência do "eu" procede da consciência de uma semelhança entre os gestos do outro, próximo, e do próprio corpo, o que é confirmado pelo comportamento da imitação. Relações desse tipo levam à formação do "eu ideal" que ultrapassa o "eu individual". Esse "eu ideal" possui as mesmas características do superego descrito por Freud e explica a obediência. Piaget considera a explicação de Baldwin insuficiente, pois, ainda que esclareça a gênese da obediência, não explica o sentimento de obrigação que vem junto com ela (Arantes et al, 2003, p. 63).

Podemos conjecturar que ao final da atividade tanto a professora quanto o sujeito se sentiram orgulhosos e realizados por terem ultrapassado seus limites. Será que esta situação seria capaz de justificar a seguinte crença relativa à meta aprender:

- O êxito constatado após esforço dá origem a sentimento de orgulho e realização.

Analisando ainda a situação social, poderíamos identificar cuidado, preocupação interpessoal, calor humano, afinal a professora colocou o menino junto a sua mesa. Temos, também, compromisso, pois passou-lhe exercícios extras, conectou-se emocionalmente ao menino, pois deve ter-lhe percebido os momentos de maior dificuldade. Podemos supor a existência de um diálogo compatível com as atividades e tarefas a serem realizadas. É provável ter havido compatibilidade, reciprocidade entre o esforço exigido pela professora e a parcela de interesse e dedicação do menino. Ora, estes condicionamentos, nada mais são do que a definição do conceito de " necessidade de intimidade" que gira em torno da sensação de amor. 
Entretanto, ainda falta tornar esta necessidade de envolvimento pessoal um valor. Cabe então, ao pensamento do genebrino nos auxiliar, o sujeito relatou que este acontecimento se deu na terceira série, ou seja, por volta dos nove anos; segundo Piaget, é na segunda infância que os sentimentos ganham certa lógica devido às relações de primeira ordem responsáveis em tornar o pensamento mais simétrico e recíproco.

Portanto, talvez o sujeito tenha reconhecido na relação com a professora um sentimento baseado na honestidade, pois este tinha uma dificuldade real referente à disciplina. Percebeu também ser justo por parte da professora exigir-lhe maior esforço para superá-las. E quando obteve sucesso percebeu recíproca e simetricamente fazer jus ao valor que a professora lhe atribui, após ter se implicado significativamente em realizar a tarefas com esforço e perseverança.

Isto posto, conceitos como: honestidade, sentimento de justiça, e agora, "necessidade de cuidado" constituir-se-ão em um sistema racional de valores pessoais e, portanto, por si só capazes de motivar o sujeito a despender energia para sua busca, manutenção e troca nas relações interpessoais de uma forma mais consciente, ou como queria o pensador na citação abaixo:

[...] Nunca há uma ação puramente intelectual (sentimentos múltiplos intervêm, por exemplo: na solução de um problema matemático, interesses, valores, impressão de harmonia, etc.), assim como também não há atos que sejam puramente afetivos (o amor supõe compreensão). Sempre e em todo lugar, nas condutas relacionadas tanto a objetos como a pessoas, os dois elementos intervêm, porque se implicam um com o outro. (Piaget, 2006, p. 37)

\section{Análise dos dados da Entrevista de Validação do Perfil Motivacional de Realização do Sujeito Ms}

Analisaremos agora os dados obtidos com o instrumento: Entrevista de Acesso ao Perfil Motivacional de Realização. Antes de iniciarmos propriamente a análise, gostaríamos de observar ao leitor nesta primeira fase que estamos principalmente interessados em construir uma metodologia capaz de possibilitar a caracterização do perfil de realização do presente sujeito. Para tanto, é necessário percepção da diferença de significados entre a meta aprender e a meta performance-evitação. Esta percepção é enormemente aumentada quando se compara o discurso produzido pelo sujeito Del e o presente discurso produzido pela aluna Ms. Isto posto, vamos a análise: 
8-(P): Você respondeu na pergunta 10 que sempre quer aprender mais... e melhor né...(A): $E_{\text {... }}$

(P):Você acha que aprender é fácil...

(A): Não.

(P):Pra aprender tem que ter o que, o que é necessário pra aprender? (A): Eu acho que é prestar atenção, participar, entender...eu acho né...

(P): Mas pera aí, mas entender depende de quem?

(A): De mim...

(P):Você fala assim prestar atenção.(A):Prestar atenção na aula, né professor, o que o professor explica.

Diferentemente de um sujeito orientado à meta aprender, este não apresenta em seu discurso as estratégias básicas como esforço e perseverança, resumindo-se apenas a "prestar atenção". Sabemos que prestar atenção é uma das condições mínimas para aprender qualquer assunto, entretanto esta não é uma estratégia capaz de garantir um melhor resultado quando os conteúdos se tornam mais complexos. Não obstante, os alunos orientados à meta aprender costumam mencionar a seguinte crença:

- Estes alunos têm a convicção ou crença de que os resultados positivos nas tarefas derivam maximamente de esforço, que é um fator interno e sob seu controle.

9-(P):O que que é um bom aluno?

(A):Um bom aluno... Não é só vir pra aula para ficar na sala de aula sentado, é pra aprender, participar.(P): Participar como?(A):Participar da aula professor tanto faz (aluna responde com impaciência)(P):Mas o que é participar da aula?Por exemplo, assim se o professor ta lá na frente explicando qual a participação do aluno?(A):prestar atenção, bastante atenção $(\mathrm{P})$ :e qual que a outra, que mais que o aluno participa.. como, mais no que...que ele participa (A):Ah professor eu não sei, eu não sei responder.(P)Não assim qual os outros tipos de participação que se acha que o aluno tem que ter...(A) Respeitar o professor, na hora que o professor tiver explicando, ficar quieto, não ficar falando conversando, entendeu, senão atrapalha os outros, que quer aprender(falou junto com a pergunta do professor(P):Mas basta isto prestar atenção. (A):Não... não basta não. 
O sujeito afirma que para aprender é preciso participar: "Não é só vir pra aula para ficar na sala de aula sentado, é pra aprender, participar”. Entretanto, a aluna não consegue apontar como esta participação pode ocorrer, resumindo-se a "prestar atenção ao professor". Contudo, após insistência do pesquisador, o sujeito concordou que não basta somente prestar atenção para aprender,conforme trecho: “(A):Não... não basta não. ”Mas, também não apresentou nenhuma estratégia que incluísse esforço e perseverança.

Será que o sujeito acredita ser o professor(a) o único responsável pelo seu aprendizado? Sendo assim, resta-lhe apenas prestar atenção ao discurso do professor. É difícil concluir algo neste sentido, pois o ensino tradicional incentiva estas posturas; nesta metodologia o professor é o detentor do conhecimento restando ao aluno ouvi-lo com atenção para entender o conteúdo.

Todavia, chama a atenção o sujeito não incluir em seu repertório como estratégia de aprendizagem o esforço e a dedicação. Não podemos deixar de ter em mente que "prestar atenção à fala do professor" não requer tanto esforço cognitivo quando comparados, por exemplo, à realização de exercícios. Portanto, talvez o sujeito busque realizar esta estratégia para facilitar-lhe em um momento ulterior quando deverá realizar exercícios propostos pelo professor para fixação do conteúdo. Sendo assim, este comportamento é natural para qualquer aluno interessado em aprender.

Por outro lado, estaria tal estratégia encobrindo a seguinte avaliação sobre si mesmo: "Preciso prestar bastante atenção, pois caso não entenda o que o professor ensina, como sou incapaz, não terei outro momento para aprender". Naturalmente, que não podemos sustentar esta assertiva somente com o dado acima. Sendo assim, podemos apenas auferir que o sujeito enfatiza como principal estratégia de aprendizagem "prestar atenção à fala do professor(a)".

10-(P): O que que é um bom professor?...(A)Um bom professor é aquele que ensina, ajuda você quando você tem dificuldade de responder alguma coisa, você vai lá e pergunta e ele ensina, entendeu pra mim isto é um professo bom..., não basta ser só professor também né, amigo também né(P): Hum...(A): O professor não basta ser só professor, amigo também....(P) Então o que ele tem que fazer para ser um bom..(A):Ser bom...(P):O que que tem que fazer pra ser bom professor...qual é a função... o papel do professor? (A): Explicar bem, pra gente entender!!! 
Notadamente, para qualquer aluno, um bom professor é aquele que explica bem. Esta é uma das principais crenças que os alunos carregam sobre o significado de aprender-ensinar. Entretanto, segundo Gunstone, (obra citada), muitos alunos possuem uma visão extremamente passiva em relação ao seu envolvimento com o conhecimento, delegando ao professor toda a responsabilidade pelo processo.

Acreditamos que o trecho: “(A)Um bom professor é aquele que ensina, ajuda você quando você tem dificuldade de responder alguma coisa, você vai lá e pergunta e ele ensina, entendeu pra mim isto é um professo bom..., não basta ser só professor também né, amigo também né”, juntamente com o fragmento: “(A): Explicar bem, pra gente entender!!!” reafirmam nossas conclusões acima no tocante à principal estratégia de aprendizagem deste sujeito se resumir à "prestar atenção à fala do professor".

Portanto, se "O bom professor explica bem e eu aprendo" esta condição colocaria o professor como principal agente responsável pelo aprendizado do sujeito. Isto posto, podemos desdobrar duas vertentes possíveis capazes de impactar tanto o esforço quanto a perseverança do sujeito: primeiro, "Eu prefiro esperar a explicação do professor, assim terei certeza da resposta, isto economiza aborrecimento com os possíveis erros e principalmente na quantidade de esforço". Segundo, "Como sou incapaz para aprender, sou dependente da explicação do professor”. Ambos desembocando no "mínimo esforço", naturalmente que por caminhos diferentes, um ligado à meta performance-aproximação e outro ligado à meta performance-evitação, conforme referencial teórico.

Isto posto, devemos ressaltar que estas conjecturas só podem ser levadas em consideração quando o sujeito aponta como principal estratégia de aprendizagem “prestar atenção à fala do professor”. E não cita em seu discurso o esforço e perseverança para solucionar as eventuais dificuldades inerentes ao processo, como fazem os alunos orientados à meta aprender. Não obstante, se o sujeito houvesse feito esta conexão não haveria razão para levantarmos tais hipóteses.

Em relação ao trecho: “amigo também”devemos esclarecer que os alunos orientados à meta aprender também apontam como qualidade do professor o bom relacionamento interpessoal. Entretanto, esta necessidade de interação social estaria ligada ao conceito de "Necessidade de Intimidade" ou ao conceito de "Necessidade de Afiliação"? Sendo que este último se refere à "falta de amor" e o primeiro à "existência de amor" nas relações entre os sujeitos. Naturalmente, com apenas o dado acima não podemos sustentar nenhuma destas assertivas. 
12-(P): Você falou para mim que o bom professor é aquele que explica bem $(A): E_{\text {... }}$ (P): Não é isso?(A):É ele vai lá na frente ensina, ajuda você a responder(P)Mas e se agente não aprende com a explicação dele? Às vezes (A): Não aprende, oxe faze o que, a gente não pode fazer nada...explicar, entender...(P)Então mas que outras coisas na sala de aula que o professor pode fazer pra aluno aprender...(P): Explicar você já falou uma (A): Hum...hum...(P):O que se acha a mais, além que pode acontecer na sala de aula pra gente aprender mais (A): Ficar mais à vontade (P): Como assim...(A): Pra participar da aula... (P): Mas participar de que aula, como assim, participar da aula, o que você fala participar da aula (A): Às vezes assim o professor faz uma pergunta, aí ele vê, bota lá no quadro, aí se tá certo ou errado ele vai e pergunta aí se aquela pessoa tem capacidade de responder, vai e responde.

O trecho: “(A): Não aprende, oxe faze o que, a gente não pode fazer nada...explicar, entender..." pode significar simplesmente que o sujeito tem consciência de que alguns conteúdos podem ser assimilados, outros apresentarão maior dificuldade, ou não serão compreendidos o que de forma alguma permite considerarmos este trecho ligado à meta performance-evitação.

Todavia, caso a principal estratégia do sujeito seja apenas prestar atenção à fala do mestre: logo, quando o professor não conseguir tornar claro o conteúdo este parece não reagir: (A): Não aprende, oxe faze o que, a gente não pode fazer nada...explicar, entender... Ora, o sujeito não cita alguma estratégia capaz de solucionar o problema, ele parece simplesmente aceitar o fatalismo desta condição. Talvez, este de alguma forma não se sinta responsável pelo processo de aprendizagem atribuindo inerentemente o fracasso a "si” ou ao outro. Afinal, talvez pense: “o professor é o responsável pelo ensino, se ele não consegue explicar direito, fazer o que".

Com efeito, não devemos esquecer que os alunos orientados à meta-aprender mencionam esforço como uma de suas ferramentas para enfrentar os desafios. Graças a esta forma de agir, apresentam bons resultados em diversas disciplinas, independentemente se gostam ou não do professor. Ou melhor, os desafios acadêmicos são bem vistos, pois possibilitam aos sujeitos crescerem intelectualmente. Logo, aceitar passivamente a incompreensão de algum conteúdo não é um comportamento típico de alguém orientado à meta-aprender.

Nesse sentido, será que o fatalismo aceito pelo sujeito de forma passiva se refira à crença ligada à meta performance-evitação, em que o aluno acredita não possuir 
capacidade intelectual necessária para dar conta dos desafios? Naturalmente, não podemos com este dado justificar esta interpretação.

Todavia, devemos enfatizar, além da ausência de alguma estratégia para solucionar uma possível dificuldade ligada à aprendizagem, o fato de que o sujeito parece não se importar muito quando não consegue aprender os conteúdos.

13-(P)Você respondeu na pergunta número 1 que pra aprender você não se incomoda de cometer muitos erros (A): não... (P):Se não se incomoda com isso (A)tsu..tsu...tsu...(balançou a cabeça, concordando não haver problema) (P): Você acha que não tem problema (A) Não (P):Mas errar não é ruim.(A):É, mas todo mundo erra (P): mas quando você erra o que acontece, o que você sente quando você erra $(A): A h$ fico preocupada... quando eu erro, quando eu faço e às vezes vou mostrar para o professor se não tiver certo... eu prefiro não mostrar, deixo lá, aí no caderno(P) E aí se erra fica chato(A)Ai se erra fica chato, mesmo assim todo mundo erra(P) Mas então porque você se incomoda.(A) Ah porque eu me incomodo professor...você não se incomoda...Em erra também(P)Ah...(A)Ah... não tem essa não tá...risos..(P):risos....

Deveríamos anular a primeira alternativa do questionário de Acesso às Metas de Realização, pois a aluna apesar de afirmar não se importar com os erros naquele questionário, agora revela sentir angústia: "Ah fico preocupada..., quando eu erro, quando eu faço e às vezes vou mostrar para o professor se não tiver certo". Destarte, preocupa-se sobremaneira com o julgamento do outro, e o pior, este é capaz de paralisar sua ação: "eu prefiro não mostrar, deixo lá, aí no caderno".

Isto posto, o comportamento do sujeito é típico do aluno orientado à meta performance-evitação. Como estamos interessados em triangular os dados, acreditamos que estes trechos justificam as alternativas que este sujeito assinalou no questionário de Acesso às Metas de Realização:

- 6- Uma razão importante para que eu faça as tarefas é para que eu não fique envergonhado.

- 9- Eu me preocupo quando eu faço meu trabalho se os professores irão pensar que eu sou menos capaz do que os outros.

- 12- Uma das razões para que eu faça meu trabalho é porque não quero que pensem que eu sou burro. 
- 18- Um de meus objetivos principais é evitar que me vejam como incapaz ao realizar minhas tarefas.

Devemos ressaltar que o comportamento típico de um aluno orientado à metaaprender se refere à crença de que os erros e fracassos são encarados como inerentes ao processo de aprendizagem, propiciando a adoção de novas estratégias com as quais se possa dar conta dos desafios, portanto o comportamento: "eu prefiro não mostrar, deixo lá, aí no caderno" afasta este sujeito desta meta.

Acreditamos também que este dado implicitamente confirma nossas suspeitas quanto à principal estratégia de aprendizagem desde sujeito resumir-se a "prestar atenção à fala professor". Pois, como não pretende solucionar as dificuldades no momento em que está realizando a atividade, logo: podemos conjecturar que ele espera o final da atividade para obter as respostas certas do professor. Ora, este momento deveria ser utilizado pelo sujeito para solucionar dúvidas relativas a alguma pergunta mais complexa ou para confirmar e internalizar mais substancialmente os conteúdos, ou obter uma visão mais global de toda a atividade através da explanação final do professor. Muitos sujeitos maximizam sua possibilidade de aprendizagem adotando como estratégia comparar suas respostas com a do professor.

Isto posto, a explicação final do professor não deveria ser utilizada como principal momento de aprendizagem. A bem da verdade, poderíamos admitir que o sujeito faltou à atividade ou não a realizou por completo, pois a abandonou em seu principal momento: "eu prefiro não mostrar, deixo lá, aí no caderno”, comparecendo apenas ao seu final, quando o professor realiza a correção.

Sendo assim, podemos imaginar que neste momento em que o sujeito se encontra sozinho, longe dos olhares do professor e dos demais colegas, enquanto copia da lousa as respostas corretas, ele evita vivenciar duas situações consideradas inaceitáveis pelos alunos orientados à meta performance-evitação: a primeira, ser julgado como incapaz por professores e colegas e, a segunda, escapar aos sentimento de angústia e ansiedade ligados à possibilidade de fracasso:“Ah fico preocupada..., quando eu erro, quando eu faço e às vezes vou mostrar para o professor se não tiver certo”.

Sem sombra de dúvidas, esta forma de agir também denuncia o não comprometimento deste sujeito com seu processo de aprendizagem, já que não pretende esclarecer suas próprias dúvidas ou resolver suas dificuldades. Todavia, esta falta de comprometimento não significa que o sujeito está indiferente ou não pretende se 
responsabilizar pelo seu processo de aprendizado, esta alienação ocorre, pois o sujeito acredita não possuir atributos cognitivos capazes de fazê-lo se responsabilizar por seu processo de aprendizagem.

Outro agravante se refere à construção do conhecimento, pois como poderá internalizar os conhecimentos produzidos socialmente à medida que adota como estratégia esconder seus erros de professores ou dos colegas? Como estes poderão the ajudar a transpor os obstáculos comuns ao processo?

Porquanto, podemos ainda avaliar o possível impacto deste comportamento, caso este sujeito venha a participar de sequências didáticas baseadas na metodologia sócioconstrutivistas, pois estas possuem como principal mecanismo de aprendizagem a reflexão, principalmente no tocante às inconsistências do pensamento do sujeito. Notadamente, estas estratégias primam muito mais pela qualidade do processo, do que pelos resultados finais.

Destarte, não podemos deixar de considerar que por mais que um professor se esforce em desenvolver estratégias de ensino, estas não terão um bom resultado se uma parcela dos alunos pretende não se envolver com seus próprios erros. Estes podem, ao final, aprender muito pouco ou quase nada.

Cabe ressaltar, que este comportamento alienado também tem sido captado em pesquisas em outros países. O projeto PEEL, realizado por professores australianos, tinha como objetivo ensinar aos alunos processos metacognitivos. Eles encontraram como principal dificuldade $o$ fato de parte dos alunos não apresentarem comportamentos básicos ligados ao envolvimento no processo de aprendizagem, como por exemplo,"perguntar, quando não entendem". Ao final, preocupados com os resultados, desenvolveram vinte e cinco boas posturas relativas à aprendizagem; selecionamos algumas possivelmente ausentes no comportamento de nosso sujeito:

1- Avisam ao professor quando não entendem;

2-Perguntam ao professor porque não entendem;

3-Diz ao professor o que é que não entendem;

19-Trata de descobrir debilidades de sua própria compreensão. Comprovando a consistência de suas explicações através de diversas situações;

16-(P): É...quando o professor propõe um desafio, desafio assim, um problema pra você resolver, vai ter um problema $(A)$ (aluna interrompe) eu tento resolver do meu jeito $(\mathrm{P})$ : 
Mas o que você sente (A): eu fico preocupada, ansiosa, ansiosa (P): porquê? $(A)$ : porque eu tenho que responder certo...do jeito que o professor mandou(P): mas e se você não responder certo $(A): a h$...eu entrego assim mesmo $(\mathrm{P})$ : você fica chateada $(A)$ : fico mas eu tentei, pelo menos eu tentei responder né...

Diante do desafio, sensações de angústia tomam de assalto o sujeito: "eu fico preocupada, ansiosa, ansiosa". Ao invés de se concentrar na tarefa, preocupa-se com o resultado futuro: "porque eu tenho que responder certo..." Mas qual a razão deste medo, onde se encontra a ameaça? Quem lhe apontará os erros, o fracasso? "do jeito que o professor mandou”. Talvez por traz deste comportamento estejam as seguintes crenças ligadas à meta performance-evitação presentes no Questionário de Acesso às Metas de Realização:

- Eu me preocupo quando eu faço meu trabalho se os professores irão pensar que eu sou menos capaz do que os outros.

- Uma das razões para que eu faça meu trabalho é porque não quero que pensem que eu sou burro.

- Um de meus objetivos principais é evitar que me vejam como incapaz ao realizar minhas tarefas.

Segundo nosso referencial teórico, diante do desafio representado pela realização de uma tarefa, vivemos expectativas quanto ao sucesso por um trabalho bem feito ou somos castigados pela ansiedade e medo relativos a um possível fracasso. Estas sensações surgem, pois, ao longo da vida, elaboramos padrões de excelência. Nesta situação não é o sujeito quem determinou o padrão a ser alcançado, pois a atividade deve ser realizada segundo os padrões do outro: “do jeito que o professor mandou”.

Naturalmente, este sujeito não nasceu com este medo relativo às tarefas, foi desenvolvendo ao longo de sua vida escolar, vejamos a citação abaixo. O trecho foi retirado de um artigo onde a autora discutiu a autonomia segundo a perspectiva piagetiana. A pesquisadora critica tanto a punição quanto a recompensa relativas aos erros ou acertos cometidos pelas crianças nas séries iniciais:

[...] Os professores usam de recompensa e punição também no domínio intelectual para que as crianças deem respostas "corretas". Um exemplo dessa prática é o uso das folhas de exercícios. $\mathrm{Na}$ aritmética do $1^{\circ}$ grau, se a criança escreve " $4+4=\underline{7}$ ", a maioria dos professores assinala esta resposta como errada. $\mathrm{O}$ resultado deste tipo de ensino pode ser visto quando percorremos uma classe de $1^{\underline{0}}$ grau enquanto as crianças estão fazendo as lições e paramos para perguntar a uma dada criança como ela obteve aquela resposta. Elas tipicamente reagem agarrando suas borrachas, mesmo quando a resposta é 
perfeitamente correta! Já no $1^{\circ}$ grau, muitas aprendem a desconfiar de seu próprio raciocínio. Crianças que são assim desencorajadas a pensar crítica e autonomamente construirão menos conhecimentos que aquelas que são confiantes e pensam sozinhas.(Kami, 2001, p. 91).

O ensino tradicional é centrado na figura do professor, este é o detentor do saber, logo, o aprendizado tem como principal meta a repetição pelo aluno daquilo que ensinou o mestre. Portanto, caso a criança não consiga repetir as respostas corretas, esta acaba sendo punida através do "sublinhar" a tinta vermelha de todos os seus erros. Este processo se repete indefinidamente durante a vida escolar do sujeito.

17-(P):O professor faz uma pergunta... você tem quase certeza da resposta, você arrisca e responde, ou espera que alguém $\operatorname{responda}(A) E u(\mathrm{P})$ o professor perguntou... lá na sala, todo mundo na sala (A): eu espero alguém responder por mim...risos (P): Porque mulher.... (A)porque... porque sim...risos (P)porque você tem medo de errar $(A) E$ porque eu tenho medo de errar...eu posso te a pergunta certa mas mesmo assim eu não falo, fico com vergonha.

Para este sujeito, expor-se diante dos amigos, do professor: impossível. Melhor é alguém responder: "eu espero alguém responder por mim...risos". Agindo assim, espera que alguém possa tomar o seu lugar, está sempre pronta para alienar o seu direito: "eu posso te a pergunta certa mas mesmo assim eu não falo”. Ora, esta mesma alienação não é uma variante do comportamento em grupo, capturado em nosso diário de campo?Afinal, também ali, o sujeito manteve-se calado e adotou irrefletidamente o discurso do outro. Será - conforme citação na análise do dado anterior - que ele aprendeu a desconfiar do próprio raciocínio? Por esta razão, de antemão teme o erro: " $E$ ' porque eu tenho medo de errar..."

Isto posto, talvez a possibilidade do erro faça brotar em seu coração o medo do vexame: "fico com vergonha." Este sentimento deve ter sido construído no íntimo do sujeito, ou por ter vivido ou presenciado situações em que ele, ou algum colega tenha sido vítima de alguma situação vexatória na qual o erro deve ter produzido risos por parte dos professores e colegas.Esta reação emocional à exposição pública está presente nas seguintes assertivas, ligadas à meta performance-evitação:

- Uma razão importante para que eu faça as tarefas é para que eu não fique envergonhado; 
- Uma das razões para que eu faça meu trabalho é porque não quero que pensem que eu sou burro.

Será que os anos de erros devidamente corrigidos, os meses subsequentes de conceitos "E" e "D" foram capazes não só de denunciar-lhe os fracassos escolares relativos ao conteúdo, mas, sobretudo, de provar-lhe não possuir capacidade intelectual? Sendo assim, no fundo ele possa pensar: "para que estudar, para que me envolver, afinal não tenho capacidade"?

Isto posto, podemos conjecturar - conforme citação na análise do dado anterior que com o passar dos anos, estes condicionantes foram paulatinamente fazendo com que este sujeito fosse construindo menos conhecimentos em relação aos demais alunos, pois não se envolveu com os conceitos de forma autônoma e crítica. Sendo assim, este estado de coisas nos permitiria entender o julgamento preconcebido dos professores presente em nosso Diário de Campo sobre a capacidade cognitiva deste sujeito: "Ele é fraco". Notadamente, estas conjecturas são interpretações que não podem ser confirmadas por estes dados.

18-(P)Você sabe que alguns alunos tiram barato quando a gente dá uma resposta errada o que você acha disso(A) eu acho errado, fica dando risada dos outros $(\mathrm{P})$ você acha que isso atrapalha $(A)$ :atrapalha bastante $(\mathrm{P})$ de que forma isto atrapalha, porque ...o que a pessoa sente quando o pessoal começa há...(A)fica com medo né... eu acho né professor.

Naturalmente, até mesmo um sujeito ligado à meta-aprender não gostaria de ser motivo de chacota para os outros. Entretanto, este sujeito já demonstrou ficar paralisado diante de tais situações conforme análise acima. Obviamente, a palavra vergonha não apareceu neste trecho, mas podemos postular implicitamente que o medo do sujeito está ligado à possibilidade de se sentir humilhado diante dos colegas.

Sendo assim, o sujeito apresenta sempre as mesmas razões para justificar estes comportamentos, os binômios: ansiedade-medo, erro-medo e medo-vergonha acompanham-no. Parece estar sempre alerta, hiper-vigilante quanto à possibilidade de ocorrer alguma situação na qual os outros sujeitos venham a tomar conhecimento de sua suposta incapacidade cognitiva: logo, sentindo vergonha de "si" mesmo.

Nesse sentido, apenas para estabelecermos melhor as diferenças entre as metas: Os alunos orientados à meta aprender relacionam erro-esforço ou desafio-esforço aos 
binômios erro-orgulho ou desafio-orgulho, pois os sujeitos, ao realizarem uma tarefa que lhes exigiu esforço e dedicação, sentem-se orgulhosos e realizados, após obterem êxito. Em contrapartida, chama-nos a atenção os sentimentos negativos referentes à ansiedade ou angústia ligados aos erros e às tarefas desafiadoras.

Este trecho da entrevista trata da relação com o outro; no limite, esta deve ser aniquiladora. Pois, como este indivíduo poderá ser sujeito? Como poderá defender seus pontos de vista em uma discussão em grupo? Como lutará para defender seus conceitos quando estes forem atacados? Não, talvez seja melhor repetir, colocar na própria boca as palavras do outro como se fossem suas.

Destarte, este seria então um comportamento mais seguro. Para que arriscar errar? É mais fácil repetir o seguro conhecimento elaborado pelo outro. Talvez uma das assertivas ligadas à meta performance-evitação deveria ser: os alunos preferem se envolver em atividades com pouca possibilidade de erro.

19-(P): E esse negócio de ficar comparando nota na hora que tira...por exemplo o aluno tirou 10...aí tem o aluno que tirou A...com o aluno que tirou $\mathrm{D}$ eles ficam comparando o que você acha...(A) ah!, como eu sou burro nem respondi igualzinho, errei(P) Ah..meu Deus (risos) (A) risos ...(A)não é assim... não professor (P) Hã... (A)não é assim não é ???(P): então mas é ...

Nosso modelo atual de ensino baseado na Meritocracia arrumou um jeito de separar os mais capazes dos incapazes ou, biblicamente falando, separar o joio do trigo. Existe no cotidiano escolar uma miríade de situações em que o sujeito possa contemplar sua incapacidade: “ah!, como eu sou burro nem respondi igualzinho, errei”. Todos os dias o sujeito está diante de um espelho surreal, um espelho simbólico, em que se pode ir construindo uma imagem depreciativa de si mesmo.

Voltando à análise, esta suposta incapacidade sentida pelo sujeito pode ser fruto também do "egocentrismo adolescente". Pois, em nosso referencial teórico, graças à “onipotência da reflexão", o púbere é capaz de elaborar novas teorias. Sendo assim, um espírito convencido de seu infortúnio, ao invés de teorias megalomaníacas de sucesso projetaria o fracasso como inexorável em seu destino.

Isto posto, seria razoável admitirmos, em relação ao seu auto-conceito ou em relação ao seu sentimento de eficácia, estes estarem "hipoavaliados", levando o sujeito, de antemão, a se acreditar incapaz de realizar tarefas desafiadoras. $\mathrm{O}$ indivíduo quando 
percebe que a situação começa a lhe escapar do controle começa a se desesperar depreciando-se a "si" próprio, conforme citação:

[...] Quando o fracasso se mostra em toda a sua fealdade, as pessoas orientadas para o desamparo podem começar a dizer coisas do tipo: "Não dou para esse tipo de coisa" ou "Acho que não sou muito inteligente". Em outras palavras, elas denigrem suas capacidades e mesmo seu valor próprio (Diener \& Dweck 1978 apud Reeve, obra citada, 2006)

20-(P)Então gente quer saber se Às vezes a prova, o provão faz isso...(P)A prova é uma coisa ruim...você acha assim...(A) oi.. .(P)o que você acha da prova, de fazer $\operatorname{prova}(A)$ eu acho que não divia ter existido prova não, a gente divia ter nascido tudo aprendido deste pequeno, logo aprendido, poque é muito ruim... no dia da prova a pessoa fica bastante preocupada, ansiosa... eu fico né, eu prefiro não estuda, caso na hora a gente vê o que vaifazer na prova(P)Porque você fica assim (A) porque sim professor...quase todo mundo tem isso $(\mathrm{P})$ mas estuda fica ruim...num fica $(A) E$...(P)não sei parece que daí tem sempre uma prova que vai ...se pode irmal...(A):É...

O sujeito apresenta verdadeira ojeriza por provas, novamente sentimentos de preocupação e ansiedade invadem-no. Espera apenas a concretização do fracasso, deixemos, pois: “na hora a gente vê o que vai fazer na prova”. Não há estratégia capaz de prevenir-lhe o desastre, talvez estudar seria o remédio, mas conclui: "eu prefiro não estuda" Este procedimento não compõe seu rol de estratégias, afinal o problema é sua suposta falta de capacidade, sendo assim, basta aceitar o ciclo angustiante de preocupação, ansiedade e, finalmente fracasso, uma fórmula perfeita resultando sempre no líquido e certo sofrimento.

Conforme hipótese na análise da pergunta dezoito, as provas vão internalizando no indivíduo a crença irremediável de sua incapacidade. Será que estes condicionantes externos não agem como uma morsa, pressionando o sujeito para dentro de si, empurrando consciente adentro suas falhas e seus fracassos, até que um dia, o sujeito cansado abandona o posto que é seu por direito, alienando-o em nome do outro?

Isto posto, esta falta de envolvimento afetivo-cognitivo em relação a processo de aprendizagem remete-nos ao conceito de "Desamparo", pois os indivíduos assim orientados não conseguem melhorar seus esforços ou não procuram mudar suas estratégias, como se estas não estivessem sob seu controle. Como se o sujeito estivesse alienado do controle da situação. 
21-(P):Você falou pra mim, uma vez... de você responder na lousa, desde quando você fez isso e aonde?(A)lá no nordeste( $\mathrm{P})$ e como é que era(A)eu estudava na quinta série sexta até a sétima $(\mathrm{P})$ Como é que era que o professor fazia $(A)$ Ah, o professor ia $e$ chamava de um e um pra ir no quadro responder ... mas eu ia, ia me matando pra não ir, mas eu tinha que ir né, fazer o que (P)porque você não gostava de $\operatorname{ir}(A)$ Ah, porque ninguém gosta de ser chamado na frente de todo mundo pra responder e se saiu errado (P)quando saía errado o que acontecia (A): acontecia que a professora vai lá e vai corrigir tá errado... (palavra que não foi entendida) ...corrigido (P):É ruim isto(A): $E$ bastante ruim.

No caso do aluno Del, a professora separou-o dos demais, colocando-o ao seu lado, pois este merecia maiores cuidados. Entretanto, MS não teve a mesma sorte, o professor manteve a distância, se aproximando principalmente para corrigir-lhe os erros: “professora vai lá e vai corrigir, tá errado...". Este professor, sem perceber, também deve ter separado os alunos em dois grupos, com o tempo, todos já sabiam quem iria se dar bem, quem conseguiria resolver os exercícios. De outro lado, sabidamente quem iria fazer "feio" lá na frente, quem seria humilhado:"...ser chamado na frente de todo mundo pra responder e se saiu errado".

Contudo, a professora que orientou Del foi toda "boazinha"? Não, não foi, pelo contrário, mostrou-lhe os erros, exigindo-lhe mais esforço: "e assim, fora da lição normal que ela dava, ela me dava lições extras tentado faze eu me esforçar mais". Destarte, ela entregou-lhe "o esforço" a chave mágica que abre o arcabouço hermeticamente fechado do conhecimento. O professor de MS, ao contrário, ele a corrigia na frente de todo mundo. Não tardou, veio a certeza da incapacidade intelectual, por fim, o sofrimento: “mas eu ia, ia me matando pra não ir", confirmado teoricamente na citação abaixo:

[...] Quanto às emoções, as crianças não nascem com sentimentos de orgulho ou de vergonha, visto que estas não são emoções inatas. Em vez disso, o orgulho surge a partir de uma história do desenvolvimento de episódios de sucesso culminado na proficiência; e a vergonha surge a partir de uma história no desenvolvimento com episódios de fracasso culminado no ridículo (Stipek, 1983 apud Reeve, obra citada, p. 108 ).

Isto posto, o ciclo está efetivado: certeza do fracasso, medo, vergonha e sofrimento na forma de ansiedade e angústia. Basta agora, que qualquer outra disciplina 
se aproxime desta situação, funcionando como um motor de arranque capaz de acionar este moto-contínuo de desprazer ligado ao aprender. Talvez esta situação, naturalmente, reforçada por outras, deve ter servido para o sujeito internalizar as seguintes crenças relacionadas à meta performance-evitação:

- Preocupa-se com o julgamento alheio, pois se acha incapaz;

- Tem medo de parecer "burro" ao professor e aos colegas;

- Antes de começar, teme o fracasso, pois se acha incapaz;

- Parece alienado do processo de aprender: “-Para que eu vou perguntar, afinal eu não vou entender mesmo.";

Por outro lado, no caso do aluno Del, provavelmente, este tenha internalizado em seu "eu" a necessidade de esforço como estratégia para melhorar a "si" próprio. Logo, aumentando a crença em sua auto-eficácia. Entretanto, para a aluna Ms esta situação análoga serviu para orientá-la a uma motivação segundo o conceito de "Desamparo", sempre pronta a perder o controle sobre a situação e a questionar o seu auto-conceito.

Em relação ao conceito de "ideal do eu”, o professor de Ms também projetou um ideal. Pois, toda vez que os alunos mais capazes iam à lousa e resolviam o problema, provavelmente ele os elogiava dando-lhes boas notas. Entretanto, para nossa entrevistada, esta recebia pelo esforço: "está errado, você precisa melhorar”. Apenas, para confirmar o veredicto, talvez recebesse uma menção abaixo da média. Este "ideal do eu", impossível de ser alcançado, pois o professor não pareceu, segundo o relato do sujeito, ter demonstrado nenhuma estratégia para que esta desse conta de suas dificuldades. Sendo assim, acabou internalizando paulatinamente a certeza de sua incapacidade.

Podemos conjecturar, sobre esta relação interpessoal, o quanto um escapou ao olhar do outro? O quanto o professor deve ter preenchido o coração do pequeno com medo e humilhação. Ou o quanto este estar "distante", "esta inconsciência do "outro" engendrou na consciência de nosso sujeito o conceito de Desamparo, pois assim abandonado este não conseguiu estabelecer estratégias para controlar a situação. Notadamente, o professor não foi capaz de ensiná-lo a desenvolver estas estratégias, diferentemente do caso do aluno Del, sobrando apenas o descontrole da situação e o gosto amargo do fracasso e da humilhação: 
[...] Suas emoções rapidamente tornam-se negativas, e elas começam a lidar com o crescimento da ansiedade e da sua dúvida de modo inusitado, como quando passam a agir de maneira tola, ou tentam mudar a tarefa, ou suas regras (Diener \& Dweck, 1978). Se não acreditam em si, o moral negativo e adoção de estratégias imaturas são sinais da presença de desamparo, seu indício típico é a maneira rápida e enfática com que o indivíduo desiste da tarefa (Dweck, 1999, apud Reeve, obra citada, 153).

Analisando ainda a situação social, poderíamos classificar esta situação pela "falta": faltou preocupação interpessoal, faltou calor humano. As reais dificuldades do sujeito estiveram sempre distantes, faltou compromisso em entendê-las, não houve uma conexão emocional, pois o professor não percebeu o sofrimento do sujeito. O diálogo existiu, mas foi apenas para corrigir-lhe o erro. Naturalmente, esta é a definição do conceito de " necessidade de afiliação" que gira em torno da sensação de "falta de amor", conforme referencial teórico. Notadamente, esta inferência está longe dos dados, diferentemente da necessidade de intimidade do aluno Del, que, ao nosso ver, foi confirmada paulatinamente ao longo dos dados.

Esta "necessidade de afiliação talvez seja confirmada pelo comportamento em grupo obtido em nosso Diário de Campo. Pois os indivíduos com esta necessidade social de relação interpessoal buscam nos relacionamentos o apoio emocional para lidarem com situações capazes de produzir medo. Sendo assim, o grupo seria um meio propício para o sujeito se esconder, evitando uma avaliação individualizada, dividindo o ônus de um possível fracasso e recebendo ajuda para enfrentar a situação, conforme citação acima. Todavia, esta interpretação carece de mais dados para ser sustentada.

$\mathrm{Na}$ análise de Del, levantamos a hipótese de que suas necessidades de envolvimento pessoal se tornaram um valor. Afinal, segundo o pensamento do genebrino, na segunda infância, surgem os primeiros sentimentos ligados à lógica de primeira potência, responsáveis em tornar o pensamento mais simétrico e recíproco. Nesse sentido, concluímos também que os valores ali elaborados exigirão do sujeito o desprendimento de energia para a sua manutenção. Pois eles talvez permitam ao sujeito ir em busca de sua auto-imagem projetada. Entretanto, para o caso do sujeito MS, cabe uma pergunta preocupante, para onde se dirige seu manancial energético?

Continuemos a analise: 


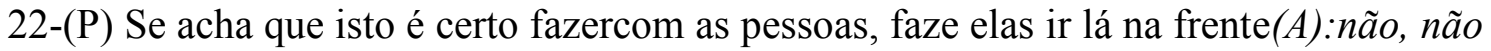
é certo não... de jeito nenhum não é .... (P)Pelo menos assim...o professor quer que você vai na lousa, você não gosta de ir, às vezes a gente erra e aí a gente fica chateado, você acha o que o professor devia fazer pra gente não ficar chateado assim, você acha que o professor devia fazer alguma coisa $(A)$ : Não professor acho que não, se ele chamo pra ir se é obrigação de todo mundo ir tem que ir né (P): É mas não é ruim $(A) E$ É ruim é ruim, mas a gente tem que ir, ou vai, ou tira nota ruim $(\mathrm{P})$ tirar nota é uma coisa ruim $(A) E$... muito ruim ...

Em nosso referencial teórico, com a ajuda da psicologia piagetiana, elaboramos a personalidade egocêntrica do adolescente. Nesta nova fase, o sujeito se sente em pé de igualdade com o adulto, pronto para reformular a sociedade e lutar em nome destas reformas. Portanto, justificando um comportamento desobediente ou teimoso, caso o sujeito não fosse devidamente convencido das razões para fazer ou deixar de fazer alguma coisa.

Percebemos que o sujeito, neste trecho, desaprova a atitude do professor: “(A):não, não é certo não...de jeito nenhum não é....” Entretanto, sente a obrigação de cumprir este ritual de fracasso e sofrimento: “(A): Não professor acho que não, se ele chamo pra ir se é obrigação de todo mundo ir tem que ir né”. Naturalmente, caminha coercitivamente: “(A) É ruim é ruim, mas a gente tem que ir, ou vai, ou tira nota ruim”.

Todavia, não percebemos nenhum sentimento de raiva relativo à ação daquele professor. O sujeito não fica indignado com os acontecimentos que o implicaram em uma auto-estima tão depreciativa. Páginas acima, discutimos sobre a "raiva" ser um importante potencializador, quando devidamente canalizada, permitindo ao sujeito superar algum obstáculo. Talvez, para o sujeito, estes condicionantes sociais são tão comuns e "normais" que dispensam qualquer possibilidade de indignação. Ou, por outro lado, conclua: muitos alunos aprendem neste sistema, portanto o culpado sou eu, ou pior, talvez eu realmente não sirva para estudar.

23-[...](P):Mas assim... o que que tem responder umas perguntas...(A)nada...eu achava que o professor ia dar alguma nota eu acho, ou ia me chamava pra dar alguma coisa, na escola ai(P):Trabalhar na escola $(A)$ Não na aula né...pra apresentar alguma coisa, entendeu, falar sobre aquele, que a gente foi lá no laboratório(P): Humm...(A):Pensei que o professor ia botar eu pra responde... eu não vou responde(P):Porque você achou 
que eu devia perguntar pras meninas e não pra você...(A)Aquela aluna lá...que senta lá na frente, ou então pra meninas aquelas que senta lá no fundo lá (P): Mas porque você acha que eu devia perguntar pra ela e não pra você(P): porque assim, não é tudo aluno(A):É... (P):Mas porque você acha que você não é (A)(aluna interrompe)Não... é a primeira vez que alguém chama pra fazer alguma coisa assim(P):não mais assim, você não sabia, mas você já não queria $(A) E$ por isso mesmo, eu já sabia que não ia ser $\operatorname{bom}(\mathrm{P})$ Você achou que as perguntas iam... eu ia dar nota alguma coisa assim $(A)$ : achei ...aí a menina falou vai responde...eu mandei ela vê (P)E na hora que você viu as perguntas, você achou o que $(A)$ : achei fácil(P): Porque(P):Você ficou com medo ou perdeu o medo(A): Levei pra casa e fiquei matutando...responde a pergunta dele ou não responde.....o responde $(\mathrm{P})$ : Porque você acha que tem algum problema, eu queria entender isto, porque... (A): (aluna interrompe) porque eu sou esquisita.

$\mathrm{Eu}$ questionei o sujeito, porque de início havia se negado a responder o questionário ligado às metas de realização. $\mathrm{O}$ sujeito ficou intrigado em entender porque somente ela: "Não... é a primeira vez que alguém chama pra fazer alguma coisa assim”. Antes mesmo de responder o questionário: “É por isso mesmo, eu já sabia que não ia ser". Todavia, no momento em que percebeu a facilidade das questões, respondeu, mas ainda com dúvidas. Sobre o motivo de sua recusa inicial, concluiu: "porque eu sou esquisita”.

Qualquer questionário, qualquer situação em que os outros venham a perceber sua suposta incapacidade o sujeito inicia o ciclo de preocupação e angústia: "Levei pra casa e fiquei matutando..., responde a pergunta dele ou não responde..., o responde. "Surgem, novamente, preocupações quanto ao possível resultado e à possibilidade de que alguém venha a saber sobre sua suposta incapacidade: "nada...eu achava que o professor ia dar alguma nota eu acho, ou ia me chamava pra dar alguma coisa, na escola ai”

Continuando a análise, temos:

(P)O professor quer saber, assim, por exemplo, se eu gosto de fazer estudar não precisa cometer erros, tudo bem é uma pergunta, que tem esta pergunta, não é uma pergunta assim é qual os países da Ásia eu não sei o que, sei lá, não é uma pergunta assim, di di... uma pergunta do que você gosta, porque você se sentiu assim (A)Porque eu não me sinto à vontade, entendeu... se fosse outra pessoa também, ia faze do mesmo jeito que eu... chega assim do nada...(P):Eu to tentando entende qual foi o seu medo, ficou com medo do que(A):Fiquei com medo do professor me chama pra pergunta 
aquele trabalho que o senhor fez lá do laboratório, eu acho que o senhor ia pedi pra eu fala, eu não ia responder não (P):riso...risos...(A)eu não ia mesmo nada professor, já tinha chamado eu não ia não (P)Mas se você soubesse da matéria, por exemplo, entendeu, você estudou, aprendeu a matéria tal, você não apresentaria (A)não...só se tivesse alguém, mais eu. algum colega, participando também, na hora, aí eu responderia...

Diante da possibilidade de apresentar algum trabalho para o grupo, mesmo dominando o conteúdo, o sujeito se sente incapaz de apresentá-lo para a classe: “não...só se tivesse alguém”. Só apresentaria se contasse com a participação de um colega: "algum colega, participando também”.

Conforme referencial teórico, os indivíduos motivados pela necessidade de afiliação costumam procurar a companhia de outras pessoas para se sentirem fortalecidos emocionalmente. Entretanto, não podemos descartar a hipótese de o indivíduo ser tímido, procurando fugir destas situações. Por outro lado, não podemos esquecer que o indivíduo, conforme análise acima, apresenta um histórico em que se sentiu humilhado.

\section{Análise dos dados da Entrevista de Validação do Perfil Motivacional de Realização do Sujeito M}

Os dados a seguir foram obtidos graças à entrevista de Acesso ao Perfil de Realização. Vamos à análise:

1-(P): Você escreveu aqui eu gosto de realizar tarefas na escola em que eu realmente aprenderei, mesmo que eu cometa muitos erros, porque que você colocou que você concorda parcialmente?(A)Ah, porque..., depende da tarefa (P) Não mais assim, assim, o que se acha, assim, a gente tenta faze alguma coisa, aí não dá certo (A) Eu não gosto de aprender com muito erro (P) É ruim, errar é uma coisa (A) Não errar é certo, mas com muito erro, também não prrufs...

Os sujeitos orientados à meta-aprender também podem declarar que não gostam de aprender cometendo muitos erros. Entretanto, não é este o problema, pois os alunos com este perfil consideram os erros como oportunidades para verificarem onde se encontra a inconsistência do seu pensamento.

Sendo assim, aprender com erros é uma estratégia metacognitiva, pois permite ao sujeito monitorar seu processo de pensamento. Naturalmente, este processo possui 
duas implicações, primeira: o sujeito percebe suas limitações exigindo um auto-conceito positivo. Segunda, este processo requer maior esforço, pois o sujeito precisa reconstruir seu caminho para entender onde ocorreu a falha.

Processo bem diferente quando respondemos um questionário e acertamos todas as questões. É por isso que o esforço é uma suposição básica implicitamente contida nesta meta, ligado aos erros. Este núcleo está ausente neste dado; outra questão, qual é quantidade de erro razoável que este sujeito está disposto a suportar. Não podemos esquecer que esta meta prevê que os reveses motivam o sujeito a continuar tentando. Naturalmente, este dado não permite concluir se o sujeito está orientado para alguma meta, entretanto o binômio erro-esforço não foi encontrado.

2-(P):Você colocou aqui eu me sentiria realmente bom se eu fosse o único que respondesse as perguntas do professor da classe, concorda parcialmente: (A): Concorda parcialmente, porque não é muito legal se o único e concordo um pouco porque você tá aprendendo. (P): Então, mas significa o que?...(P): Assim... o que que se ... o que te ti daria que...que sensação que te daria assim se você tivesse nesta situação?(A): $E$ que meus amigos não tá aprendendo, não taria adiantando nada o professor..., alguma coisa tá errando, né ... só eu aprendo.

O sujeito concorda parcialmente com esta assertiva, pois ele seria o único a obter sucesso em detrimento dos demais. Uma postura muito próxima de um sujeito orientado à meta aprender. Continuemos a análise.

3-(P) Hummm...É importante para mim que os outros estudantes da minha classe pensem que eu sou bom nas tarefas que realizo.... você falou que concorda, o que que significa isso, assim, o que, que (A):Ah, é legal né, pessoal vê que você não é burro, pelo o que eu zoo pessoal vê que eu não sou idiota, eu zoo porque...(P): Mas se acha assim que às vezes quando pessoal não sabe as coisas aí, pessoal acha que a pessoa é burra, assim.. (A): E que só sabe zoa.........

Em nosso Diário de Campo, relatamos os elogiosos comentários dos professores relativos à alta inteligente deste sujeito. Entretanto, quanto ao seu interesse, declaram: “ele não quer nada com nada". Parece que o sujeito, de alguma forma, está ciente deste juízo de valor: "pelo o que eu zoo pessoal vê que eu não sou idiota,. O sujeito demonstra estar preocupado com o julgamento dos professores e colegas: "pessoal vê 
que você não é burro." Talvez, seja por esta razão que o sujeito concordou plenamente com cinco das assertivas relacionadas à meta performance-evitação:

3- É muito importante que eu não seja visto como um estúpido na frente dos meus colegas.

9- Eu me preocupo quando eu faço meu trabalho se os professores irão pensar que eu sou menos capaz do que os outros.

12- Uma das razões para que eu faça meu trabalho é porque não quero que pensem que eu sou burro.

15- Uma razão que eu não participaria da aula é porque não querem que me vejam como um estúpido (a).

18- Um de meus objetivos principais é evitar que me vejam como incapaz ao realizar minhas tarefas.

Sendo assim, seria razoável concluirmos, como fizemos com Ms, que este sujeito também está orientado à meta performance-evitação, pois preocupa-se em não parecer "burro" ou "idiota" para professores e colegas. Apesar do binômio medovergonha estar presente, a conexão com os binômio medo-ansiedade culminando com sofrimento está ausente na fala do sujeito. Todavia, não podemos concluir somente com este dado que o sujeito não os sinta em tais momentos.

Não obstante, podemos conjecturar ainda que naqueles momentos em que o sujeito venha a sentir ansiedade e angústia diante do fracasso culminando com sofrimento, este simplesmente interrompa o ciclo pernicioso. Sendo assim, ao invés de se culpar, busca um bode expiatório a fim de preservar sua auto-imagem de um julgamento depreciativo. Transferindo a responsabilidade pelo fracasso para: "o professor", "a atividade", ou ainda, credite à falta de sucesso simplesmente porque não se sentiu interessado. Contudo, esta conjectura não pode ser sustentada somente por este dado.

Voltando a análise, gostaríamos de salientar nossa não satisfação em classificar o perfil motivacional deste sujeito como orientado à meta performance-evitação. Pois se faz mister demonstrarmos a tênue diferença entre os conceitos ligados à meta performance-evitação e à meta performance-aproximação; veremos não ser por acaso que ambos carregam a mesma raiz (performance).

4-(P) Uma razão importante para que eu faça as tarefas e para que eu não fique envergonhado, você colocou não concordo (A) Porque não tem nada a ver...hum 
(P)Mas e se você não fizer, as tarefas (A) Como assim se eu não fize (P) Por exemplo assim, o professor propõe uma coisa pra faze, aí você não faz, pessoal da classe faz você não faz, como é que você se sente por exemplo, isto já aconteceu alguma vez, assim. (A) Já, mas eu sempre pego, eu sempre faço (P): Mas se você fica sem faze nada o que acha que vão pensa de você (A) Que não que nada da vida...

Na pergunta três, o sujeito relatou: "pelo o que eu zoo pessoal vê que eu não sou idiota,", interpretamos este trecho como um possível indicativo de o sujeito estar consciente sobre o julgamento negativo que parte dos professores fazem sobre seu comportamento. Neste trecho, novamente o sujeito volta a apresentar esta preocupação: "Que não que nada da vida...”.

Os alunos orientados à meta-aprender relatam que o êxito constatado após esforço dá origem a sentimentos de orgulho e realização. No caso específico do aluno Del, temos a impressão que o "esforço e a dedicação" constituem suas ferramentas básicas para o sujeito melhorar a "si" mesmo. Ou melhor, o "eu" que este sujeito pretende projetar traz como características principais estes condicionamentos, como se ele dissesse ao se olhar: "Como eu sou esforçado, este é meu principal valor". Naturalmente, este sujeito busca ser reconhecido por estas qualidades. Sendo assim, à medida que vai obtendo sucesso, ele reafirma para "si" mesmo estes condicionantes.

No caso da aluna Ms, esta pretende evitar que professores e colegas tomem conhecimento de sua suposta incapacidade intelectual, sendo assim, procura se "esconder" de situações nas quais os outros possam vir a confirmar esta sua crença. Por outro lado, quanto mais passa por estas situações, mais reforça seu comportamento de evitação. Isto posto, percebemos que em ambos os casos existe uma conexão linear entre a crença e o comportamento dos sujeitos.

Entretanto, no caso do aluno $\mathrm{M}$, esta conexão não é tão linear. Pois, tem consciência do julgamento depreciativo que os professores fazem de seu comportamento. Ele se descreve como um aluno que gosta de "zoar". Sendo assim, uma relação mais linear, seria procurar modificar este comportamento para que automaticamente fosse considerado um aluno inteligente, se esta for sua real preocupação. Desta forma, este seria até um caminho mais fácil, pois estaria apenas confirmando o julgamento positivo que os professores fazem da sua inteligência.

Todavia, cabe-nos uma pergunta: será que o sujeito $\mathrm{M}$ obtém algum ganho com este comportamento? O sujeito Del com seu comportamento sente orgulho e realização, 
mas é considerado um aluno "CDF". Já, o sujeito Ms, com seu comportamento,pretende escapar de ansiedade, humilhação e sofrimento. Não obstante, a impressão imediata é negativa, pois M cursa pela terceira vez o primeiro ano colegial. Todavia, este sujeito, conforme "Diário de Campo", é um líder. Portanto, seria esta necessidade social tão representativa a ponto dominar seu comportamento, produzindo indiretamentesua reprovação?

Ou por outro lado, mais simples seria supor como hipótese que "estudar" não se constitui uma atividade de valor para este indivíduo. Contudo, então porque é necessário parecer inteligente? Não seria mais fácil apresentar o mínimo esforço, se não gosta de estudar, necessário para passar de ano? Assim poderia se dedicar a outras atividades mais interessantes. Pois é o terceiro ano consecutivo na mesma série.

Poderíamos também conjecturar outra hipótese: o aluno está orientado à meta performance-evitação, portanto, cônscio de sua suposta incapacidade cognitiva. Logo, está revoltado com esta condição, indo à escola somente para, segundo suas palavras, “zoar". Condição pouco provável, pois conforme já foi dito, a maioria dos professores o veem como um aluno inteligente. Naturalmente, as inferências feitas nos três últimos parágrafos, estão muito distantes do presente dado.

5-(P):Você tem medo que o pessoal pense que você é CDF?

(A) Ah não curto muito não (P)Você acha que seria uma imagem ruim, assim...tipo assim...(A)pessoal não respeita, infelizmente não respeita não, mais é te o respeito de todos, dos professores e dos alunos.

Segundo o questionário deste sujeito, este está fortemente preocupado com sua auto-imagem. Nesta pergunta, o sujeito relata que não gostaria de ser visto como um aluno "CDF", pois esta imagem está ligada socialmente a um comportamento pouco popular, onde o indivíduo é considerado inteligente e exageradamente esforçado. Portanto, o que para alguns poderia ser considerado até um elogio, no cotidiano escolar deste aluno, esta imagem, é vista como um desvalor: "pessoal não respeita, infelizmente não respeita não, mais é te o respeito de todos, dos professores e dos alunos."

Não há nenhum problema no fato de o aluno não querer se identificar com esta imagem, afinal natural um jovem procurar fugir deste rótulo. Todavia, os alunos ligados à meta performance-aproximação têm interesse em parecer inteligentes, preocupando-se em tirar boas notas. Este interesse acaba inerentemente se aproximando do 
comportamento do aluno orientado à meta aprender, ou de um aluno "CDF", pois estes também parecem inteligentes e também acabam conseguindo boas notas.

Entretanto, o que diferencia estas metas é que o aluno orientado à meta aprender acredita que o "esforço" é a estratégia básica para conseguir este objetivo. Por outro lado, os alunos orientados à meta performance-aproximação creem que este objetivo é alcançado pela sua enorme inteligência. Sendo assim, será que o sujeito temendo ser rotulado como um sujeito "CDF", pois é identificado pelos professores como sendo inteligente, procura compensar apresentando um comportamento indisciplinado?

Isto posto, este comportamento iria lhe garantir seu "status" de inteligência e preservaria sua popular condição de líder. Naturalmente, este dado não permite tal inferência.

6-(P)Você...eu me sentiria bem sucedido se eu aprendesse mais do que os outros estudantes? (A)Ah....porque ia vale a pena, né (P) Você gosta de tira uma nota legal $(A)$ gosto...uma coisa que eu não gosto, que o professor fica tirando, fica tirando, eu não... eu não confia no aluno, pra mim já... eu não curto isto daí......

O sujeito gosta de tirar boas notas: "Ah....porque ia vale a pena, né”. Os alunos orientados à meta aprender também gostam de tirar boas notas, entretanto, o orgulho e a satisfação estão ligados ao esforço e à dedicação envolvidos na realização de uma tarefa. Não obstante, um aluno orientado à meta performance-aproximação interessa-se por boas notas a fim de provar para professores e colegas sua superioridade intelectual. Este dado não permite concluirmos nenhuma interpretação neste sentido.

7-(P) Quando o professor propõe um desafio, pra classe, um desafio, um problema pra ser resolvido, uma coisa que, entendeu, o que você acha (A):Acho da hora, ainda mais quando eu respondo, que nem os negócio lá das figurinhas lá, foi eu que descobri (P): (aluno começa a batucar na mesa) Então mas se você não responde, se acha não, assim quando você responde o que se acha que... que que se sente assim, porque que é bom responder quando o professor pergunta, o que que cê sente (A) Ah pelo menos eu mostro pro pessoal que não to (Inaudivel) ...eu sei o bagulho.

O sujeito, ao contrário de alguém orientado à meta performance-evitação, acha "da hora". Principalmente se é ele quem responde, afinal pode demonstrar sua boa 
performance. Esta atividade, “das figurinhas", referida pelo sujeito é uma sequência didática do ano anterior, com o objetivo de ensinar a conservação da quantidade de movimento. Ele se envolveu até que os exercícios, em aulas subsequentes, ganharam em complexidade exigindo maior esforço e dedicação.

O sujeito abandonou as aulas, conforme relatado em nosso Diário de Campo,ao invés de demonstrar algum constrangimento, como faria alguém ligado à meta aprender, já que abandonou sem enfrentar os desafios. Ou, como alguém orientado à meta performance-evitação que busca fugir de qualquer desafio, com medo de parecer incapaz. Nosso sujeito, pelo contrário, não perde a oportunidade de chamar a atenção para a sua inteligência: “que nem os negócio lá das figurinhas lá, foi eu que descobri”.

No último trecho, ele reafirma sua preocupação com o julgamento de professores e colegas sobre sua imagem: "Ah pelo menos eu mostro pro pessoal". Notadamente, esta preocupação se relaciona a parecer inteligente: "eu sei o bagulho." Portanto, segundo o referencial teórico ligado à meta performance-aproximação, os sujeitos assim orientados caracterizam-se por:

1. Preocupar-se com o julgamento alheio;

2. Seu principal interesse está em parecer inteligente;

3. Adoram agradar o professor;

4. Buscam ser vistos como inteligentes, tanto por professores quanto por seus colegas;

Isto posto, estas são as principais diferenças de um aluno orientado à meta performance-aproximação, pois conforme acima demonstrado, este procura a todo momento confirmar para os demais sua alta capacidade. Por outro lado, a principal característica do comportamento de aluno orientado à meta performance-evitação é evitar a todo custo situações em que possam vir a tomar ciência de sua suposta incapacidade.

8- (P) Assim você gosta assim, por exemplo assim de mostrar pros professores que se manja dá, das coisas assim e tal (A):Lógico, ainda mais no meu caso que maloqueiro só gosta de aloprar (P) risos....(A)Ai eu falo pros amigos, que...(P) Você gosta também porque aícê cria uma imagem assim, que se é um cara que (A) Lógico (P)que tem consciência, tal, (A) Humhum (P) cê bagunça mas você na hora de estudar, estuda (P) 
essa é a imagem que você gostaria de $\operatorname{criar}(A)$ Lógico $(\mathrm{P})$ Você bagunça, mais $(A)$ Separa as coisas...

Infelizmente, o sujeito demonstra novamente ter consciência sobre a ideia que os professores e seus colegas fazem de seu comportamento; apesar da ironia declara: "Lógico, ainda mais no meu caso que maloqueiro só gosta de aloprar". O sujeito esclarece que procura parecer inteligente como uma estratégia compensatória para aliviar seu comportamento indisciplinando, como se ele quisesse provar: "Eu sou bagunceiro, mas sou inteligente e estudo na hora certa". Sendo assim, o sujeito aproxima-se de um aluno orientado à meta performance-aproximação nos seguintes termos:

1. Preocupa-se com o julgamento alheio;

2. Seu principal interesse está em parecer inteligente;

3. Adora agradar o professor;

4. Busca ser visto como inteligente, tanto por professores quanto por seus colegas;

Acreditamos que este trecho confirma parcialmente as hipóteses levantadas sobre os possíveis condicionantes sociais que determinam o comportamento do indivíduo, apresentados na pergunta cinco desta entrevista. Voltemos, então, aos aspectos ali levantados, para tentar entender quais pressupostos são revelados, na presente frase: "Lógico, ainda mais no meu caso que maloqueiro só gosta de aloprar".

Esta frase parece confirmar a seguinte conjectura: o sujeito apresenta um comportamento indisciplinado, portanto busca parecer inteligente. Por outro lado, caso invertêssemos a premissa, teríamos: o sujeito por ser considerado inteligente por professores e colegas teme ser rotulado como um sujeito "CDF", logo, procura compensar apresentando um comportamento contrário. Ou ainda, o sujeito é afetado por ambos os condicionantes.

Isto posto, levando-se em consideração a conclusão retirada do questionário de Acesso às Metas de Realização: que este sujeito está fortemente preocupado com o julgamento alheio, podemos supor os possíveis condicionantes desta relação com o outro, isto é, relativo às diversas relações interpessoais. Sendo assim, parece-nos haver duas principais pressões agindo sobre o comportamento deste sujeito: a primeira, ligada aos valores dos pais, naturalmente representados pelos apelos dos professores 
pressionando este rapaz para que apresente um bom comportamento e naturalmente consiga boas notas, pois é considerado inteligente. Entretanto, consegue cumprir parcialmente esta exigência, esforçando-se em parecer inteligente.

Por outro lado, o segundo condicionante social relaciona-se ao seu grupo de amigos, ele naturalmente é seu líder. Todavia, como em qualquer grupo, para sustentar sua condição de líder, é natural ter de realizar proezas consideradas de valor pelo grupo. Ora, dificilmente um aluno considerado "CDF" ou "bonzinho" conseguiria fazer parte deste grupo, muito menos, exercer tamanha função. Não podemos deixar de ter em mente que o comportamento típico do adolescente é justamente se afastar do seio familiar, direcionando sua energia para os novos relacionamentos presentes em seu grupo.

Sendo assim, talvez o sujeito queira garantir seu livre trânsito entre estes dois mundos: o primeiro representado pelos valores dos pais, portanto, esforçando-se em parecer inteligente para professores. Por outro lado, também observa os requisitos básicos para manter sua condição de liderança através de um comportamento indisciplinado. Desse modo, parece-nos que "eu" do sujeito está no meio de um cabo de guerra em que os grupos sociais disputam ferozmente pelo seu envolvimento. Conjecturemos um exemplo desta possível cooptação: a professora zelosa e preocupada diz: "Você é um rapaz tão inteligente!! Porque você faz isto...", carregando no ar de tristeza. Por outro lado, seu melhor amigo: "Caramba!!! Você teve coragem", notadamente entusiasmado.

Estas hipóteses, apesar de não serem verificadas diretamente, afastam possíveis considerações pejorativas quanto a possível idoneidade dos sujeitos desta pesquisa, pois temíamos que o leitor concluísse ao final, que este trabalho procura separar os alunos "bonzinhos" de comportamentos esforçados, dos alunos "mauzinhos", de comportamentos indisciplinados. Preferimos acreditar que o sujeito é responsável, mas também é vítima destes poderosos condicionantes sociais, sem talvez estar totalmente consciente desta situação. Todavia, independentemente de qualquer rótulo, ou justificativa, temos um jovem que não consegue se desembaraçar, já há três anos consecutivos, da primeira série do ensino médio. E nós sociedade: professores, amigos e família, infelizmente, não estamos conseguindo ajudá-lo na superação deste obstáculo.

9-(P) Ta... O professor fez uma pergunta, você tem quase certeza da resposta você arrisca e responde ou espera que alguém responda pra você? 
(A) Eu respondo...(P)Porquê? (A)Porque se eu tenho quase certeza, às vezes quando eu não tenho certeza eu respondo (P) E se você tiver errado? (A) O professor vai fala (P)Então, você não acha, que o professor, sei lá de repente pó, o cara tá, você não pensa assim (A) Não... ele perguntou.. não perguntou?, perguntou quem sabe, eu respondi.

Neste trecho, o sujeito define a diferença entre as metas. Não é concebível este comportamento em um aluno orientado à meta performance-evitação, pois foge diante de qualquer tipo de exposição. Entretanto, para um aluno orientado à meta performanceaproximação, a mesma situação é um prato cheio "Porque se eu tenho quase certeza, às vezes quando eu não tenho certeza eu respondo”. Continuando a comparação, um aluno orientado à meta performance-evitação foge, pois teme a humilhação. Por outro lado, este "eu" certo de sua inteligência está livre de qualquer possibilidade de autodepreciação.

Páginas acima, citamos o caso da professora Ma,: "percebia-se, ainda, que esse grupo preocupava-se em agradar a professora oferecendo respostas que refletiam expressões e palavras utilizadas por ela, mas que nem sempre eram compativeis com o contexto do problema.". Ora, parece que o sujeito M está sempre pronto a impressionar a professora, talvez também possa fazer parte deste grupo.

Este tipo de comportamento vem sendo captado em diversas pesquisas ligadas ao Modelo de Mudança Conceitual, conforme apresentamos em nosso referencial teórico, obrigando os teóricos a expandir o conceito de "fertilidade" para englobar outros aspectos motivacionais dos alunos, como por exemplo: querer obter boas notas, ou agradar o professor, ou ser reconhecido pelos colegas, ou se identificar com uma figura famosa, etc.

10-(P) Então, voltando, se você tivesse, por exemplo, assim, você ia te...você tivesse uma....o professor fosse dá, passa um trabalho pra você faze, como se fica quando você recebe um trabalho pra você faze (A) Ah eu não curto muito não óo... faze trabalho em casa (P) Porquê?(A)Ah se sempre deixa pra depois, se vai vê ta em cima da hora e já num dá (P) Se acha assim, que por exemplo, assim entre o professor explica uma coisa e você aprender e você tem que faze um trabalho pra aprende, você prefere o que? (A) Explicar e aprende (P) E... (A) Depois de aprende faz um trabalho, mais dá hora (P) Heee...apresenta trabalho, você gosta de apresenta trabalho na escola (A) $T s u$, 
tsu...trabalho eu gosto de faze entrega na hora, deixa pra depois...minhas notas eu tiro tudo assim...

Novamente, a diferença entre os dois construtos é tácita, um sujeito orientado à meta performance-evitação procura prestar atenção, pois sabe de sua incapacidade e se não aprender com o professor, então, o fracasso será líquido e certo. Não obstante, o aluno da meta performance-aproximação devido a sua alta performance cognitiva prefere apenas prestar atenção, pois está acima da média, não necessitando realizar trabalhos em casa que exigem maior esforço, todavia esta dedicação é necessária para construir conhecimentos mais profundos.

11-(P)Agora assim.... faze trabalho, assim você não curti (A) Depende do trabalho (P)Se você tem que, se você tem que faze pesquisa, pega caderno (A) Não... curto não, não é comigo não (P) Você gosta de pega, assim, você gosta mais que o professor explica, aí você aprende. (A) É aprendo, depois se vê se você não aprendeu, se faz um trabalho em cima disso (aluno fala uma palavra inaudivel) às vezes o professor pega uma revista fala ó, lê em firma aí se fica ali na sala, mais pro aluno levar pra casa e depois entrega...

O sujeito neste parágrafo reafirma a ideia do mínimo esforço, ligada à realização de uma suposta pesquisa ou trabalho: "Não... curto não, não é comigo não". Caso ele não venha a aprender, prefere que o professor faça um trabalho para ser realizado na própria sala de aula: "lê em firma ai se fica ali na sala, mais pro aluno levar pra casa e depois entrega...”. Talvez, este trecho confirme nossa impressão relatada em nosso diário de campo relativo ao abandono da aula quando os conteúdos ganharam em complexidade, talvez tenha pensado: "Ah, isto já tá ficando chato".

13-(P)Você já viu alguma vez o professor tirar barato dos alunos que não acertam as perguntas, que ele faz, se já viu isso. (A) Já.. 14-(P) Tem aluno que fica comparando nota, se já fez isso, já? (A) principalmente(termo muito dificil de entender), com CDF, eles pensa que é maior pá ai chega no fim da média lá eu to com nota melhor que eles, dai ele...é maior pá.

Neste trecho podemos perceber que o sujeito pretende sair-se melhor do que os alunos considerados "CDF" em provas. Parece que implicitamente existe um clima 
competitivo: "eles pensa que é maior pá ai chega no fim da média lá eu to com nota melhor que eles,". Em nosso referencial teórico, chamamos a atenção para a falta de solidariedade entre os alunos devido ao clima competitivo.

15-(P) $\mathrm{O}$ que você acha mais importante, assim, não que às vezes assim, tirar nota e não aprender, mais se acha que, o que que é, não que você vai ter que tirar nota mais não vai aprender, mas entre tirar uma boa nota e aprender, mas ficar com uma nota razoável, o que que você prefere? (A) Prefere tirar um A e não aprender e tirar um $C$ e aprender (P) É. (A): Tirar um $C$ e aprender (P) Mas e ah... e se você precisar de nota depois? (A) Se eu to tirando um C dificilmente.

Este é o quesito que mais afasta este sujeito de um aluno tipicamente orientado à meta performance-aproximação,pois os sujeitos orientados à meta performanceaproximação buscam tirar boas notas para enaltecer sua inteligência. $O$ sujeito $M$ até apresenta certo interesse em tirar boas notas, conforme ficou demonstrado na pergunta anterior, pois ele tem o objetivo de superar os alunos "CDF". Todavia, este não é o foco de sua preocupação, para ele,o enaltecimento de sua inteligência é estratégia básica para compensar sua imagem de aluno indisciplinado. Ou seja, apesar de não se esforçar, não realizar os trabalhos para serem feitos em casa, não assistir ou bagunçar nas aulas, tudo seria compensado pelo reconhecimento dos professores e de seus colegas de sua alta capacidade cognitiva.

16-(P)Você acha que aprende é fácil?

(A) Há...há eu levo tempo... mas aprendo as coisa rápido (P)Você aprende as coisa rápido (A)Se o professor explica, pode ser o que for $(\mathrm{P})$ Você acha que é fácil, assim, entre, você acha que se tem mais esforço ou você acha que aprende mais rápido ( $A)$ Não tem que ter mais atenção, né (P) Porque daí você, não assim, que dizer que você ouviu, você não é do tipo que assim, estuda pra prova, você estuda pra prova, assim (A)Não...não estudo pra prova (P)Você faz a prova sem estuda (A)Acho assim na prova não é importante se há nota, importante se responder a coisa certa, você aprendeu alguma coisa (P) Então, mas então pra você estuda não é difícil (A) Bom nota é consequência.

Novamente, o sujeito se acredita inteligente: "mas aprendo as coisa rápido", principal característica de um aluno orientado à meta performance-aproximação. Ora, um aluno orientado à meta aprender também se acredita inteligente e também deixa 
transparecer certo ar superior, entretanto, esta inteligência e sua autoconfiança só podem ser confirmadas através de dedicação e esforço.

O sujeito afirma simplesmente não estudar: "Não...não estudo pra prova”. Será que este aluno acredita que estudar é uma estratégia dos alunos que não possuem muita inteligência? Por outro lado, os alunos orientados à meta performance-evitação, porventura também não estudam para as provas, pois têm certeza do fracasso, afinal provas só têm o propósito de confirmar sua pouca capacidade intelectual. Será então que M não estuda, pois tem certeza de sua inteligência e esta é uma condição necessária e suficiente para seu sucesso?

O sujeito se refere ao aprendizado de algum conteúdo, como se este fosse um objeto: “...importante se responder a coisa certa, você aprendeu alguma coisa”. Sendo assim, o sujeito foi ou não presenteado no passado, se aprendeu, foi graças ao seu "montante de inteligência" que lhe possibilitou tal feito. Caso contrário, não pode fazer nada, não se sente responsável, pois não acredita no esforço como estratégia básica para garantir-lhe o aprendizado, conforme o trecho: "Não...não estudo pra prova".

Ora, também o sujeito orientado à meta performance-evitação é adepto da teoria da "existência", entretanto, em seus aspectos estritamente negativos, acredita que seu "montante de inteligência" está mais para um saldo devedor. Sendo assim, natural também não estudar para provas, afinal: porque se esforçar, se já tem certeza do resultado.

Razoável também supormos que o sujeito $\mathrm{M}$ credite o fracasso à conta do professor, pois este não foi capaz de lhe transmitir o conteúdo, afinal detém alto padrão de inteligência. Pois, se não se sente responsável pelo seu aprendizado, quem será pelo seu fracasso? Poderiam nos objetar que o fracasso deu-se graças à atividade, todavia o responsável em elaborá-la é o professor, logo o caminho do "mínimo esforço" leva à escolha de um bode expiatório. Talvez esta condição, além do componente indisciplinar, também contribua para levar o sujeito a ter atrito com os professores. Naturalmente, esta interpretação não pode ser referendada diretamente dos dados.

17-(P) Então, mas, se acha desse pessoal que fica, que nem o pessoal estuda e tal e não sei o que e se esforça e tal, que se acha assim? (A) Eu queria ter essa vontade, mas eu não tenho mano...bem que eu queria... tipo faze os bagunho direto e reto se maior obcecado... pó (P) Mais aí você ia ter que se CDF (A) Então (P) Mais aí entre se CDF e 
você prefere o que? (A)Prefiro se light, hée... ali ó...sabe dividi né meu, que alopra vamo alopra bem aloprado que aprende vamo aprende legal...

Pronto, neste trecho o sujeito revela de forma veemente sua orientação a meta performance-aproximação: “Eu queria ter essa vontade, mas eu não tenho mano”. Pois, no tocante ao esforço este afirma não possuir esta qualidade, se bem que gostaria: "Eu queria ter essa vontade, mas eu não tenho mano...bem que eu queria”. Para o sujeito o esforço é uma qualidade que se tem ou não, exatamente a mesma crença dos partidários da teoria da existência.

Sendo assim, como este sujeito não pretende dedicar esforço nas tarefas que realiza, logo poderá apresentar dificuldade em apreender conhecimentos mais complexos. Ou aprenderá, em sua maioria, de forma superficial.

O sujeito $\mathrm{M}$ relaciona esforço a um comportamento: "mas eu não tenho mano...bem que eu queria... tipo faze os bagulho direto e reto se maior obcecado... pó”." Ora, no contexto de sua afirmação, uma pessoa obcecada é aquela que não mede esforços em direção aos seus objetivos. Confirma esta interpretação, pois contrariamente se define como: "Prefiro se light, hée..." Desta forma, M esta revelando a forma como pretende se relacionar com o objeto do conhecimento.

Não podemos deixar de ter em mente a forma como o sujeito orientado à meta aprender se relaciona com o objeto de conhecimento. Este relacionamento se dá através de esforço e dedicação, pressupostos capazes de fazê-los melhorar ou crescer intelectualmente. Portanto, no espelho surreal da auto-imagem, o sujeito se enxerga incompleto, não todo perfeito, necessitando então projetar-se melhor. Esta condição também impacta nas relações interpessoais ao seu redor, pois busca através de relações recíprocas pautadas no compromisso mútuo uma forma de crescimento, conforme determina o conceito de necessidade de intimidade.

Todavia, o sujeito $\mathrm{M}$ constrói todo o seu valor em cima de sua alta capacidade cognitiva. Poderíamos então supor que a alta inteligência é seu objeto de valor? Seria esta condição suficiente para produzir certa sensação de completude? Portanto, assim completo, o sujeito tende a estabelecer relações mais superficiais? O que, por fim, dificultaria à eleição de um objeto de valor à altura de seu investimento energético? $\mathrm{O}$ que implicaria em um comportamento que apresentasse esforço e dedicação? Ou talvez, os objetos escolares ainda não foram capazes de implicar-lhe? Naturalmente, os dados não nos permitem responder tais questões. 
Não tomemos estas reflexões como um fatalismo ligado ao futuro do sujeito, afinal a escola e seus conteúdos representam apenas uma fase no processo de individuação. Talvez, seu objeto de identificação não esteja encerrado dentro das paredes escolares.

Apêndice - VI

Questionários, Entrevistas - Segunda Fase - Perfil de Realização: Sujeito Au, Ga, En e Des

Questionário de Acesso às Metas de Realização do Sujeito Au 
Nome: AU idade 28 séried

Caso você concorde com as idéias abaixo as classifique colocando (C) que significa concordo, caso contrário, ou seja, se você não concordar coloque (NC) que significa não concordo. Caso você concorde parcialmente classifique $\mathrm{a}^{\sim \cdots \cdots n n+}$ s como $(\mathrm{CP})$ que significa concordo em algumas partes.

$$
\text { Ap.6/4.Pis } 1 / \text { Eve } 1
$$

1- Eu gosto de realizar tarefas na escola em que eu realmente aprenderei, mesmo que eu cometa muitos erros.(C)

2- Eu me sentiria realmente bom se eu fosse o único que respondesse as perguntas dos professores da classe. (NC)

3- É muito importante que eu não seja visto como um estúpido na frente dos meus colegas.( $C$ )

4- Uma razão importante para que eu faça tarefas na escola é porque eu gosto de aprender coisas novas.(C)

5- É importante para mim que os outros estudantes em minha classe pensem que eu sou bom nas tarefas que realizo.(C)

6- Uma razão importante para eu faça as tarefas é para que eu não fique envergonhado.( $\mathrm{NC}$ )

7- Tarefa que eu gosto de fazer é aquela em que eu possa realmente pensar.(C)

8- Eu quero fazer as tarefas melhor do que os outros estudantes da minha classe. (nC)

9- Eu me preocupo quando eu faço meu trabalho se os professores irão pensar que eu sou menos capaz do que os outros. (NO

10- Uma importante razão para que eu faça a tarefa na escola é porque eu sempre quero melhorar, aprender mais. (C)

11- Eu sentiria bem sucedido se eu aprendesse mais do que os outros estudantes. ( $\mathrm{CO}$ )

12- Uma das razões para que eu faço meu trabalho é porque não quero que pensem que eu sou burro.(NC)

13- Eu faço minha tarefa na escola porque eu estou interessado nela.(C)

14- Eu gostaria de mostrar aos meus professores que eu sou o mais esperto da classe.(NC)

15- Uma razão que eu não participaria de uma da aula é porque não quero que me vejam como um estúpido (a).(NC)

16- Uma importante razão para que eu realize uma tarefa na escola é que eu goste dela.(C)

17- E importante para mim, fazer as atividades melhor do que os outros alunos. (NC)

18- Um de meus objetivos principais é evitar que me vejam como incapaz de realizar minhas tarefas.(C) 


\section{Análise dos Dados da Entrevista de Validação do Perfil Motivacional de Realização do Sujeito Au}

\section{Entrevistas - Primeira Fase}

1 - P: Têm quantos anos?

E: vinte nove

P: Vinte nove

$\mathrm{P}:$ Você sempre estudou aqui?

E: Oi...?

P: Você sempre estudou aqui:

E: Não eu morava no Guarujá

P: Ah!! Você morava no Guarujá

P: Você estudou até que série lá?

E: Lá eu estudei até...terminei a oitava, comecei o primeiro, não terminei lá, vim embora P:Mas ai você ficou sem estuda?

E: Fiquei dez anos longe da escola.

P: Porquê?

E: Não consegui vaga aqui não.

P: Ah!! E aí você ficou sem estuda este período

E: Fiquei sem estuda

P: Mas você veio mora pra cá.

E: Vim mora pra cá, aí eu fiquei sem estuda.

2- P: Faz quanto tempo você mora aqui no bairro, já?

E: Aqui que eu conheço essa região aqui vai faze seis anos

P: Seis anos...P: É você está trabalhando, né

E: oi?

P: Ta trabalhando?

E: To...

P: Trabalha no que?

E: Sou eletricista

P: Bom, se você é eletricista então você gosta de ciências, então

E: Gosto

P: Porque você acha que você gosta de ciências, o que ti..??

E: Ah...pesquisas, conhecer várias inúmeras coisas, corpo humano, processos...eu gosto de ciências por causa disso, tem muitas coisas que eu gosto de ver, vejo na televisão, tento faze em casa também..., junto uma coisa com outra.

O pesquisador pergunta ao sujeito sobre sua profissão, entretanto ao invés de ouvi-lo falar sobre seu trabalho, o que seria um encadeamento lógico do discurso, o pesquisador infelizmente devido a sua inexperiência curto-circuita o processo perguntando se o sujeito gosta de ciências. Entretanto, este erro pode ter sido interessante, afinal podemos conjecturar: por que o sujeito não voltou a falar sobre seu ofício? Afinal, ele poderia ter explicado o que faz cotidianamente enfatizando os desafios que enfrenta estabelecendo alguma relação com sua auto-eficácia, ou, chamar a 
atenção para a importância do seu trabalho técnico para a empresa. Será que o abandono revela um pouco mais sobre suas motivações?

Devemos ter em mente que o sujeito é um homem de 28 anos, trabalhador, pai de família que volta à sala de aula para completar seus estudos em um curso noturno. Sendo assim, deveríamos esperar que o seu discurso estabelecesse relações mais concretas entre a ciência e o seu ofício. Todavia, seu discurso apresenta um caráter um tanto quanto geral e abstrato, se considerarmos o trecho em que o sujeito se interessa por "pesquisas", pois parece aludir a pesquisas em geral, principalmente, tomando-se a continuação de seu discurso: “conhecer várias inúmeras coisas”. Sendo assim, o sujeito então parece valorizar o conhecimento em si, e esta valorização parece ser independente da área, pois também tem interesse sobre o "corpo humano". Obviamente, talvez este interesse seja pelo próprio corpo, o que é absolutamente normal.

Entretanto, esta guinada para a área biológica surpreende, pois seu interlocutor é seu professor de física e estávamos falando sobre a ciência dentro do contexto de seu ofício de eletricista. Portanto, chama-nos a atenção sobre este trecho, pois parece quebrar a sequência lógica do discurso, afinal qual a relação entre ciência, seu trabalho de eletricista e o "corpo humano". Por outro lado, o discurso volta ao seu encadeamento lógico se considerarmos o "corpo humano" como exemplificação do trecho antecedente: "conhecer várias inúmeras coisas".

De qualquer forma, estes trechos parecem demonstrar que o sujeito valoriza o conhecimento científico em si. Todavia, devemos considerar por hipótese, que este interesse seja relativo à cultura em geral e não propriamente à ciência, o que já seria bastante interessante, caso este sujeito se mostre orientado à meta aprender, pois os sujeitos assim orientados costumam apresentar níveis de esforço satisfatório mesmo em áreas que não são de seu total interesse.

Sendo assim, não devemos deixar de ter em mente que, além de pretendermos caracterizar a orientação do sujeito em relação às metas de realização, também procuramos saber se este sujeito tem interesse intrínseco pela área de ciências. Desta forma, poderíamos admitir para além dos dados, neste caso, que a ciência pode gozar junto ao sujeito de um "status" maior como corpo de conhecimento específico em relação à cultura geral.

Isto posto, considerando que o sujeito inicia suas justificativas afirmando seu gosto por ciências devido às "pesquisas" e encerra falando sobre "processos". Então, talvez, poderíamos inferir implicitamente, que o sujeito valoriza as possibilidades que a 
ciência pode oferecer como metodologia, principalmente se levarmos em consideração seu interesse por "pesquisas" e "processos"? Assim sendo, graças a estes aspectos abstratos presentes em seu discurso, poderíamos admitir, também para além dos dados, que para este sujeito o método científico garante alguma "verdade" ao discurso e por essa razão o ramo de conhecimento seria capaz de desvendar os mistérios da natureza, e, exatamente por isto, a ciência gozaria então de "status" elevado? Obviamente, estas suposições são muito distantes dos dados necessitando serem corroboradas por dados futuros.

Voltando à análise, o trecho "tem muitas coisas que eu gosto de ver, vejo na televisão, tento faze em casa também..., junto uma coisa com outra.", parece revelar como o sujeito pretende se relacionar com o conhecimento, afinal ele afirma que ao ver algo sobre ciência, tenta fazer em casa. Talvez, ele construa algum objeto para seu uso de forma técnica, juntando partes, sem estabelecer relações com a teoria. Ou, conforme suas palavras, talvez junte uma "coisa com outra", ou seja, estabelecendo relações entre a teoria e a prática. De qualquer forma, não nos parece muito comum alguém assistir a algo sobre ciências e, depois, tentar "fazer em casa", se não considerarmos que o sujeito possui um razoável interesse pela ciência. Será que este trecho revela que o sujeito possui desejo intrínseco em se envolver com o conhecimento? Obviamente, que estas ilações necessitam ser confirmadas.

Ainda sobre estes fragmentos, podemos perceber certo ar jovial em: "tem muitas coisas que eu gosto de ver, vejo na televisão, tento faze em casa também..., junto uma coisa com outra.", existe algo quase lúdico nestes trechos, fazendo-nos lembrar da análise da entrevista retirada de Silva (2004). Naquela análise (p. 97), o sujeito também voltava de um longo tempo fora da sala de aula e declarou sua curiosidade afirmando que gostaria de aprender através de "dinâmicas", por exemplo, medindo a sala de aula, etc. Nós concluímos que o comportamento deste sujeito poderia aproximá-lo de alguém orientado à meta aprender, pois parece ser razoável que alguém “curioso" assume maior risco de errar, logo, necessitando de um auto-conceito mais robusto, do que alguém orientado à meta performance-evitação que sofre pelo medo do fracasso. Sendo assim, também este sujeito pode estar orientado à meta aprender, principalmente se considerarmos que seu ofício de eletricista exija-lhe certa dose de confiança ao se deparar com os desafios envolvidos em sua área técnica. Portanto, pode ser até natural que o sujeito, ao ver algo sobre ciência, sinta-se apto a realizá-lo em casa, afinal seus anos de experiência devem refletir em sua sensação de auto-eficácia. 
Antes de irmos para o próximo trecho, gostaríamos de levantar uma hipótese sobre o possível motivo pelo qual o sujeito não falou sobre seu trabalho. Nós tivemos a impressão de que ele não enfatizou aspectos de seu trabalho, pois pretendia exatamente falar sobre seu desejo pelas ciências, pois encontrou um interlocutor capaz de entendêlo. Afinal, sendo seu professor de física, portanto talvez ele tenha considerado que também temos um desejo intrínseco pela ciência. Sendo assim, falar sobre seu trabalho seria pueril, diante do que significa a "ciência", portanto o sujeito pode ter nos considerado como alguém capaz de "saber" sobre o profundo significado com o qual considera a ciência. Isto posto, vejamos se os próximos trechos são capazes de confirmar esta hipótese.

P: Desde quando você gosta de ciências

E: de ciências?

P: Desde quando...

E: Desde pequenininho

P: O que que te chamava atenção, assim...em relação...assim a ciência é um corpo de conhecimento né, o que te chamava assim, o que você queria resolver quando era criança, o que que chamava sua atenção

E: era a questão... tudo começou por causa daquela experiência da bola, campo magnético você levanta a mão e os cabelos ...

P: Ah.....

E: Começo dali;

P: E aonde aconteceu isto, quando foi

E: Foi no Guarujá, no tempo do prezinho.

P: Ah, é...

E: eu tinha seis anos

P: Aíi você colocou a mão lá

E: Aí os cabelo arrepiou...

P: Aí você?

E: Ai eu falei, eu quero isso!

P: Aí foi por isso que você escolheu eletricidade então porque você achou o fenômeno, assim uma coisa?

E: A professora ai do prezinho, ai fui para a escola primeiro de maio aí lá fiquei sabendo mais das coisas aprendendo é muito legal...

O sujeito afirma que gosta de ciências desde criança, seu interesse foi despertado pelo toque em uma bola magnética: "tudo começou por causa daquela experiência da bola, campo magnético". Imaginemos o impacto produzido por tal experiência em uma criança de seis anos, pois segundo Piaget, nesta fase da vida, tanto a acomodação quanto a assimilação estão subordinadas aos desejos sendo capazes de deformar a realidade ao seu bel prazer, esta é a idade própria da fantasia e da imaginação. 
[...] Os exemplos são abundantes: jogos de boneca, brincar de comidinha. É fácil dar-se conta de que estes jogos simbólicos constituem uma atividade real do pensamento, embora essencialmente egocêntrica, ou melhor, duplamente egocêntrica. Sua função consiste em satisfazer o eu por meio de uma transformação do real em função dos desejos[...]. Em suma: o jogo simbólico não é um esforço de submissão do sujeito ao real, mas, ao contrário, uma assimilação deformada da realidade ao eu(Piaget, 2006, p.28).

Isto posto, será possível admitir que este deslumbre: "Aí os cabelo arrepiou..." foi capaz de lançar a ciência ao alto adornando-a como algo fantástico a ponto de transformá-la em seu objeto de maior valor capturando o desejo do sujeito: “Ai eu falei eu quero isso!'”? Este tipo de deslumbramento, muitas vezes, é bastante comum entre aqueles que escolhem a carreira científica. Sendo assim, estes trechos parecem confirmar, sem sombra de dúvida, que o sujeito está intrinsecamente orientado a aprender ciência, principalmente se considerarmos o trecho onde o sujeito afirma: "tudo começou por causa daquela experiência da bola", ou seja, esta experiência foi forte o suficiente para o sujeito escolher sua profissão de eletricista.

Em suma, estes trechos reforçam a impressão do pesquisador sobre a pretensão do sujeito em dialogar sobre o profundo valor depositado na ciência para seu interlocutor, portanto, podemos conjecturar que o entrevistado julgou seu interlocutor como alguém capaz de entender este valor, portando a entrevista pode ter sido o lugar em que sujeitos desconhecidos puderam se encontrar para "falar" sobre algo do mesmo interesse. Contudo, também devemos considerar a possibilidade do inverso, ou seja, talvez o próprio pesquisador tenha encontrado alguém para comungar do mesmo objeto de valor.

De qualquer forma, estes trechos parecem delinear a possível Ecologia Conceitual do sujeito, pois este parece supervalorizar a ciência. Em nosso referencial teórico (p. 35), escrevemos que Piaget fazia confundir o surgimento dos sentimentos morais, tais como: a reciprocidade, a honestidade e o senso de justiça para a elaboração por parte da criança das quatro operações lógico-matemáticas. Para o pensador, um dos principais sentimentos morais é o conceito de justiça, sentimento lógico-moral capaz de garantir não só maior reciprocidade ao pensamento, mas, sobretudo, produzir o engajamento afetivo-cognitivo exigindo ao sujeito a necessidade de fazer justiça ao seu pensamento. Destarte, este engendrar foi denominado de Ecologia Conceitual de Primeira Ordem ligado às quatro operações matemáticas. Obviamente, estes trechos não são capazes de revelar nada sobre as concepções morais deste sujeito em sua infância. 
Todavia, podemos admitir a possibilidade, mesmo remota, do imbricar deste sistema racional de valores, levando-se em consideração o alto valor atribuído à ciência por parte desse sujeito. Sendo assim, vejamos se os próximos trechos são capazes de nos fornecer pistas sobre as possíveis qualidades com as quais o sujeito adorna este ramo do conhecimento.

3- P: É...Ciência e religião?

E: Não se bate

P: Porquê?

E: Porque religião é mais você crê, ciência não, ciência é teoria e prática..., ciência é calculou o resultado vai ser aquele, religião não, religião bate com um, cada um tem um formato na sua mente daquilo, a ciência não você calculou até chega naquele resultado é dali você quebra qualquer crença, qualquer algo que você esteja pesquisando assim: Num dá certo, num da certo, você fez o cálculo, chegou num resultado é aquilo ai quebra a crença, foi isto que me interesso, difícil as duas relacionarem...

P: Então mais você....acredita em Deus

E: Acredito em Deus

P: Então quem é que é mais verdadeiro, ou não existe isto assim

E: Não existe... Deus (P: interrompe)

$\mathrm{P}$ : Mas ai a ciência?

E: A ciência ela só mostra, através de pesquisa, estudos, o que... que faz, por exemplo, aqui vai nascer uma flor, vai mostra o processo que vai nascer esta flor o como né...porque na crença tudo né... P(interrompe)

P: Porque Deus quis né?!..

E:Tudo Maravilha, tudo Deus que (risos)...

P: Então a ciência ela só vai mostra estes processos só?

E: Isso...

P:Mas quem fez aquilo então, quem produziu aquilo então necessariamente, quem foi em sua concepção, a vida vem de onde em sua concepção, assim?

E: A gente pensa em Deus

P: Aí você acredita, acha que Deus é que...

E: Em Deus

Nestes trechos, acreditamos ter capturado não só o valor, mas também as qualidades atribuídas à ciência pelo sujeito: "Porque religião é mais você crê, ciência não, ciência é teoria e prática..., ciência é calculou o resultado vai ser aquele”. Pois, a ciência em sua visão, ao aliar teoria e prática, é capaz de desvelar a "verdade", ou seja, a ciência graças a sua metodologia pode provar suas afirmações: "ciência é calculou o resultado vai ser aquele”. Por outro lado, a religião são crenças onde cada um acredita na sua verdade: "religião bate com um, cada um tem um formato na sua mente daquilo", contudo, a "ciência" se faz pela apreciação minuciosa, o crivo da "verdade"; mais poderosa do que qualquer crença: "a ciência não você calculou até chega naquele 
resultado é dali você quebra qualquer crença", qualquer algo que você esteja pesquisando assim:" Ora, este poderoso método interpretado pelo sujeito como, “ciência é teoria e prática...," tomou o lugar do mito religioso sendo considerada dogmática:Num dá certo, num da certo, você fez o cálculo, chegou num resultado é aquilo ai quebra a crença, foi isto que me interesso, dificil as duas relacionarem...

Continuado a análise, apesar de no último trecho ciência e religião não se relacionarem, elas não estão absolutamente em conflito, pois o pobre discurso religioso não pode fazer frente ao discurso científico, pois aquele justifica as coisas do mundo, por um princípio em si mesmo, ou seja, o princípio divino: "Tudo Maravilha, tudo Deus que (risos)..." Por outro lado, a ciência é o arauto da verdade, capaz de decifrar, de desvelar os processos pelos quais o criador produziu a realidade: "A ciência ela só mostra, através de pesquisa, estudos, o que... que faz, por exemplo, aqui vai nascer uma flor, vai mostra o processo que vai nascer esta flor o como né...porque na crença tudo né..." Antes de encerrarmos este trecho, a forma como escrevemos pode ter causado a falsa impressão de ironizarmos a fala do sujeito considerando-o ingênuo. Muito pelo contrário, gostaríamos de afirmar nossa solidariedade, pois também, em nossa juventude, acreditávamos na ciência, de forma também dogmática, como o único método capaz de desvendar o mecanismo por traz da realidade. Não obstante, a única diferença entre a minha visão e a do sujeito pesquisado era a não necessidade da existência de uma entidade divina para justificar a realidade.

$\mathrm{Na}$ análise do trecho antecedente, fizemos alusão à Ecologia Conceitual de Primeira Ordem, pois chamamos a atenção para a possibilidade de o sujeito ter amalgamado ao seu conceito sobre "ciência" sentimentos lógico-morais, sobretudo, o sentimento representado pela noção de justiça. Ainda, sobre aqueles trechos, também consideramos a ciência como objeto de grande valor para o sujeito, pois ele declara: " $A i$ eu falei, eu quero isso!".

Isto posto, nos trechos analisados, a ciência não somente é a ideação de um objeto de grande valor, mas também é chancelada pelo sujeito como ramo do conhecimento capaz de eleger a "verdade", por exemplo, caso duas afirmações conflitantes exijam para si o lugar de descrever a realidade. Então, será este ramo de conhecimento não só capaz de julgá-lo, mas o único capaz de elevá-la de uma simples crença ao sinônimo de verdade, mesmo sendo este processo um falseacionismo ingênuo: "você fez o cálculo, chegou num resultado é aquilo ai quebra a crença". Sendo assim, estamos interessados em saber se esta visão de ciência onde "valor", 
"verdade" e "justiça" aparecem amalgamados sendo poderosos o suficiente para implicar, para exigir, para assujeitar lógica e moralmente o indivíduo conforme descrito abaixo:

[...] o indivíduo adota determinada regra, a título de hipótese, para ver se, aplicando-a, ele chega à satisfação moral e, sobretudo, se ele é capaz de permanecer fiel a si próprio e de evitar as contradições. Com efeito, nas questões de definições ou de escolha de premissas, os critérios da contradição e da fecundidade não são exteriores, mas internos ou morais. Resolve-se a questão somente por uma série de raciocínios efetuados visando constatar, não o que se passará na realidade (como é o caso do decorrer da simples experiência mental"), mas em que estado de satisfação ou de insatisfação se achará a vontade que dirige o pensamento (Piaget, 1967, p. 189).

Todavia, nestes trechos se os examinarmos mais detidamente será que poderíamos inferir algo sobre a Ecologia Conceitual de Segunda Ordem, ou seja, os valores estariam elevados à segunda potência conforme descritos em nosso referencial teórico? Vejamos se as premissas levantadas pelo sujeito para garantir verdade lógica à ciência podem ser analisadas à luz do grupo das duas reversibilidades, são elas a I (identidade), N (negação), R (recíproca) e C (Correlata) demonstrando que o sujeito alcançou o pensamento hipotético-dedutivo. Analisemos sua primeira hipótese, ou seja, a teoria (p) implica em um resultado empírico (q), estabelecendo uma relação unívoca, $\operatorname{logo}, \mathrm{p} \rightarrow \mathrm{q}$. Para testar esta hipótese, devemos propor sua inversa ou negação $(\mathrm{p} . \sim \mathrm{q})$, ou seja, os resultados não estão de acordo com a teoria, então a teoria não é teoria científica, pode se tratar de apenas uma crença, pois não se aplica à realidade, ora, é o próprio falseacionismo ingênuo, pois se a realidade não é capaz de confirmar a teoria, então, ela emite um sonoro não quando os fatos refutam a teoria, nas palavras do sujeito: "ciência é: calculou o resultado vai ser aquele".

Por outro lado, poderíamos resolver o problema de forma simétrica, ou seja, se existe um resultado empírico (q) este implica em uma teoria (p) para descrevê-lo, ou seja, $(q \rightarrow p)$. Para verificá-la, devemos observar sua inversa, ou seja, ( p pq) uma falsa teoria é capaz de descrever os fatos, talvez um pré-conceito produzido apenas para se ajustar aos dados, neste ponto, então a lógica falha, pois não existe um critério interno capaz de impedir uma falha teórica. Todavia, o sujeito parece eleger uma outra condição para salvaguardar a ciência: "A ciência ela só mostra, através de pesquisa, estudos, o que... que faz, por exemplo, aqui vai nascer uma flor, vai mostra o processo que vai nascer esta flor.'Em trechos antecedentes, o sujeito já havia mencionado seu interesse 
por processos, enfatizando a importância destes para a ciência, então, seriam os processos capazes de garantir validade científica as afirmativas? Ou ainda, seria demais supormos sobre a visão deste sujeito, que para uma assertiva ser considerada científica, esta assertiva além de se subordinar ao teste de "teoria" e "prática", também deve se submeter ao critério de coerência interna, então, por esta razão, o sujeito cita em seu discurso a importância em saber sobre os processos científicos?

Obviamente, serem estes dados inconclusos nesta direção, afinal deveríamos ter interpelado junto ao sujeito com o objetivo de clarificar quais os significados e as relações estabelecidas entre "teoria-prática" e o peso da importância dos "processos" para ciências em sua visão. Este cuidado científico faz-se necessário para dirimir qualquer dúvida quanto à validade de nossas hipóteses, pois devemos considerar a possibilidade de os "processos" aparecerem em seu discurso apenas como uma justificativa justaposta à "teoria" e "prática", ou seja, os "processos" figurariam apenas como um adendo, uma qualidade a mais. Por outro lado, caso os "processos" fossem um critério de exclusão, como são os critérios de "teoria" e "prática, então a visão do sujeito sobre ciência não seria mais de um falseacionista ingênuo, sua visão seria mais refinada, seria então classificada de acordo com o falseacionismo metodológico. Sendo assim, a teoria (p) e os dados empíricos (q) implicar-se-iam mutuamente aos "processos" científicos $(\Theta)$. Ao final do desenvolvimento lógico - por economia não o apresentaremos - teríamos a seguinte relação lógica: $(p \cap q) \leftrightarrow(\Theta)$.

Isto posto, parece termos falhado ao submeter o discurso do sujeito à análise lógica representada pelo esquema INRC; caso conseguíssemos este feito, poderíamos admitir, sobre o sujeito, que mesmo não sabendo nada sobre lógica, este alcançou o raciocínio hipotético-dedutivo, pelo menos, em relação a sua visão sobre ciência. Todavia, este esforço não nos parece de todo perdido, pois a visão do sujeito sobre ciência, pelo menos para nós, não pode ser classificada como uma visão simplista, portanto este nível de refinamento deve ter exigido por parte do sujeito uma considerável reflexão, confirmando não só seu interesse por ciência, mas aludindo a possibilidade de o sujeito ser adepto a certos níveis de raciocínio reflexivo. Vejamos se estas impressões serão confirmadas no desenrolar da análise.

4 - P: Em relação assim você gosta de explicar as coisas né, você gosta da ciência para explicar as coisas, voltando a sala de aula, né, aqui na pergunta, aliás, deixa eu pega as perguntas aqui......., na pergunta número 1, você colocou aqui, eu gosto de realizar tarefas na escola que eu realmente aprenderei, mesmo que eu cometa muitos erros. 
E: Isso

P: Porquê?

E: Porque se você ali tá tentando, você ta tentando faze as coisas, você tá, o professor vai explica a matéria, passa as perguntas, você vai tenta faze o que, vai tenta com aquele conhecimento que o professor passo pro aluno tenta faze, num importa se você vai errar... se você acertar de primeira bom, agora você faz erra um palavrinha, ou erra um número qualquer coisa não tem aquela importância, o medo de errar, porque você ta aprendendo e se você tem dúvida, conversa com professor, ele vai de explicar é isso que a pessoa tem que tenta faze...

P: Hum...hum...Mas você não acha que seria mais fácil se o professor desse todas as respostas certas, assim?

E: Não, fica errado porque mesma coisa você só vai copia, você não vai aprende, você não vai trabalhar a mente, você tem que trabalha sua mente seu pensamento, o jeito de ver uma... uma opinião sua de fazer um exercício

No primeiro trecho, no qual questionamos o sujeito sobre se tem medo de errar, ele não demonstra níveis consideráveis de ansiedade, pois a possibilidade do erro não tem muita importância, conforme suas palavras: "num importa se você vai errar... se você acertar de primeira bom, agora você faz erra um palavrinha, ou erra um número qualquer coisa não tem aquela importância, ”.Por outro lado, o seu discurso faz menção importância de se tentar fazer: "Porque se você ali tá tentando, você ta tentando faze as coisas[...].[...] vai tenta com aquele conhecimento que o professor passo pro aluno tenta faze, num importa se você vai errar..." . Também parece não se incomodar em perguntar para o professor quando se está com dúvidas, afinal: "você ta aprendendo e se você tem dúvida, conversa com professor, ele vai de explicar é isso que a pessoa tem que tenta faze... "Sendo assim, parece haver certa naturalidade quando da ocorrência de erros, já que o sujeito está aprendendo.

Isto posto, os trechos acima se não confirmam que o sujeito está orientado à meta aprender, pelo menos, afastam-no da meta performance-evitação, pois além do sujeito não apresentar níveis altos de ansiedade relativos à possibilidade de errar, também parece não se incomodar em perguntar para o professor. Devemos lembrar que os sujeitos orientados à meta performance-evitação muitas vezes não perguntam a fim 
de evitar serem considerados incapazes pelos professores. No tocante à meta performance-aproximação, não é possível fazer nenhuma conjectura.

No segundo trecho, estávamos interessados em saber se o sujeito poderia considerar um método mais seguro receber as respostas prontas do professor, pois assim diminuiria a possibilidade do erro. O sujeito não concorda com este método e enfatiza: "fica errado porque mesma coisa você só vai copia, você não vai aprende, você não vai trabalhar a mente, você tem que trabalha sua mente seu pensamento". Na análise da sessão anterior, tínhamos chamado a atenção, pois parecia que o sujeito apreciava certa dose de reflexão, este trecho vai ao encontro desta hipótese, pois o sujeito afirma que é necessário "trabalhar a mente"; devemos ressaltar que esta será uma preocupação recorrente do sujeito. Devemos lembrar também, que o sujeito Del enfatizava a importância de desenvolver o pensamento comparando o aprendizado ao jogo de xadrez questionando-nos como poderia desenvolver suas táticas se recebesse o conhecimento pronto. Sendo assim, este trecho parece aproximar o sujeito da meta aprender, pois os sujeitos assim orientados valorizam a possibilidade de desenvolver sua capacidade de raciocínio. Contudo, devemos considerar que também os sujeitos das outras metas valorizam o desenvolvimento do pensamento. Não obstante, o que difere os sujeitos orientados à meta aprender é que este desenvolvimento é empreendido com esforço e dedicação. Vejamos, nos próximos trechos, como o sujeito estabelece as relações entre aprendizado, esforço e dedicação.

5 - P: Então mais olha só, por exemplo, não seria mais prático e mais rápido, por exemplo: O professor vem passa um questionário, já dá logo a resposta, não seria, depois é só o aluno estudar para a prova, não seria mais prático, assim

E:Não, ai fica tipo robótico, vai fica tipo robótico, não é bom...

P: Você acha que o aluno tem (Entrevistado interrompe)

E:Porque você vai fica...como se fala..., é preguiça ai qualquer coisa que você vai fazer fora da sala de aula, resolve uma questão fora, trabalho tudo o que for, você não vai por sua mente para trabalhar de tanto preguiçoso que você é, vai vê tudo difícil, e na verdade não é nada dificil, você tem que passar a pergunta, claro você vai passar resposta explicando na hora da correção tal, porque isso, porque aquilo, tem que ser assim, se você passar a pergunta e já a resposta não adianta, ai o cara vai estudar, estudar, estudar o que, ele só vai lê, lê, lê, lê... não errado

O pesquisador insiste na possibilidade de se facilitar o processo de aprendizagem fornecendo as respostas prontas. O sujeito afirma que aprender iria se tornar um processo "robótico". Podemos entender este trecho, levando-se em consideração o trecho antecedente em que o sujeito enfatizou a importância em se desenvolver o 
pensamento, sendo assim, entregar as respostas prontas não possibilita que o aluno desenvolva seu raciocínio, e, o pior, o sujeito pode ficar preguiçoso segundo o sujeito, o que no futuro, poderia atrapalhar seu desenvolvimento profissional: "resolve uma questão fora, trabalho tudo o que for, você não vai por sua mente para trabalhar de tanto preguiçoso que você é, vai vê tudo dificil, e na verdade não é nada difícil’”.

Devemos chamar a atenção, pois este sujeito talvez não goste de ser julgado preguiçoso, por isto considera importante "por sua mente para trabalhar". No mesmo sentido, outros sujeitos analisados neste também fazem juízo de valor ao relacionarem esforço e aprendizado, pois os sujeitos orientados à meta aprender sentem-se orgulhosos ao perceberem que aprenderam, após dedicação e esforço.

P: Hum...hum...(concordando) P:Por exemplo: se você fosse escolher aprender um assunto novo, que você nunca viu e um outro que você tem alguma noção ou já ouviu falar, qual deles você daria preferência?

E: ah... o novo

P: Você prefere o novo?

E: $O$ novo

P: Mas o novo não é mais difícil:

E: Não...é um desafio a ser compreendido, não é difícil, nada é difícil, tudo é questão de você querer aprende, conhecimento, isso é muito importante para nós, conhecimento, embora, assim a pessoa fala: -Ah mais vou aprender isso hoje, mas nunca viu, não é porque você nunca viu que você vai fica assustado com a matéria ou você passou tipo um questionário, você nunca viu aquela palavra, ai que entra o aluno, você tem que procura sabe e você mesmo, você pesquisa: você tem uma pergunta assim, vou pesquisa, pesquisa você vai achar a resposta...ou curta, longa não interessa, tem vez que pode ser uma opinião sua e você tá ali se matando lendo um livro aqui ali e nada disso é uma opinião própria em cima daquela pergunta por isso que é bom ter conhecimento.

O sujeito está orientado à meta aprender, pois além de valorizar o conhecimento este é um desafio a ser superado: "Não...é um desafio a ser compreendido, não é difícil, nada é difícil, tudo é questão de você querer aprende, conhecimento, isso é muito importante para nós, conhecimento”. O sujeito também aposta no esforço, como chave para abrir a caixa hermeticamente fechada do conhecimento: "vou pesquisa, pesquisa você vai achar a resposta...ou curta, longa não interessa”, não importa se para tal feito, tenha que se submeter a certo sacrifício: "você tá ali se matando lendo um livro”. Destarte, o importante é conquistar, é desenvolver sua opinião, valorizando o 
conhecimento que se conquistou: "nada disso é uma opinião própria em cima daquela pergunta por isso que é bom ter conhecimento".

6- P: Para você aprender é fácil?

E: Não, nada assim aprender é fácil, você vai aprender se você se dedicar, claro tem umas perguntas que você vê, trabalha, você tem conhecimento, já ouviu fala e tudo é fácil, ai só porque tem uma palavra em uma pergunta muito difícil, a pessoa já acha uma coisa do outro mundo e não tem nada a ver, vai ver que nem dicionário, você põe umas palavras do dicionário, que a pessoa nunca viu, acha que é difícil, olha no dicionário: - Pó é isso meu, caramba...entendeu!

Neste trecho, o sujeito novamente reafirma sua convicção de que para aprender é necessário dedicação. Destarte, elabora a metáfora da pesquisa no dicionário para exemplificar esta relação quando se está diante de conteúdos difíceis de serem aprendidos. Pois, nestes momentos, o importante é não se desesperar: "a pessoa já acha uma coisa do outro mundo e não tem nada a ver", então, ele compara esta situação com a condição de se procurar o significado de uma palavra no dicionário: "você põe umas palavras do dicionário, que a pessoa nunca viu, acha que é difícil, olha no dicionário”. E, aquilo que parecia um "bicho de sete cabeças", torna-se surpreendentemente simples: “-Pó é isso meu, caramba...”.

Isto posto, este trecho apesar de simples tem muito a revelar não só sobre o autoconceito, mas também sobre a sensação de auto-eficácia e as relações que o sujeito estabelece entre esforço, dedicação e aprendizado. Pois, em relação ao seu autoconceito, devemos considerar que o sujeito é bastante confiante, pois diante de temas difíceis ao invés de ser atravessado por sentimento de ansiedade este se mantém seguro. Ora, de onde vem esta sensação de segurança? Esta sensação de segurança vem de seu conceito de auto-eficácia, ou seja, podemos supor que durante seus anos de aprendizado deve ter vivido situações de desconfiança em relação à possibilidade de aprender, deve ter sentido ansiedade e desconforto. Sendo assim, podemos conjecturar que superou estas situações através de esforço e dedicação, ou seja, o enfretamento destas situações ensinou-lhe que não adianta se desesperar gastando em vão sua energia, o melhor é manter o controle aplicando a energia para o enfrentamento das situações, por isso no trecho anterior o sujeito enfatiza: "você pesquisa: você tem uma pergunta assim, vou pesquisa, pesquisa você vai achar a resposta...".

Por conseguinte, esta forma de agir, além de garantir o controle da ansiedade, mantém o sujeito focado na consecução do objetivo garantindo-lhe maior possibilidade 
de êxito. O saber adquirido, após o enfretamento destas situações incide sobre o sujeito de duas maneiras, por um lado, infla seu auto-conceito fazendo-o acreditar que poderá dar conta dos desafios, por outro lado, reforçam sua auto-eficácia, pois este sabe como deve proceder para enfrentar os desafios, estes procedimentos incluem esforço e dedicação capazes de garantir o aprendizado.

7- P: É então para aprender, o que você falou para aprender?

E: Vontade de conhece...

P: Vontade de saber?

E: Vontade de sabe, conhece mais...

P: Então você acha que é precisa de esforço, então?!

E: Tem que ter esforço

P: Esforço, de que parte, mais do professor ou mais do aluno?

E: Mais do aluno... porque o professor, que nem você fala:-Eu já sei, você passa, você explica, só que você não vai pega na mão do aluno ou fica no ouvido direto pra ele faze a lição, a pessoa tem que quere e se você quer você consegue; é bem melhor do que a pessoa fica só palpitando, palpitando, e você coloca só a resposta da pessoa

P: Hum...Hum...

E: Você tem que coloca através da sua mente, por isso que tem várias opiniões, vários tipos de respostas, tem vez que uma resposta que ta certo a outra ta diferente, mas se você lê ta igual

P: Hum...Hum...

E: Ou seja, as duas tão certa, entendeu porque fica várias opiniões em uma mesma questão e pode ta certa ou errada um pouco, mas pode ta certa também, por isso que o aluno tem que querer aprende.

P: Hum...Hum...

O sujeito neste trecho afirma que o aluno para aprender necessita ter vontade para conhecer, convicção bastante natural partindo de um sujeito que considera a ciência como um objeto de grande valor. Devemos lembrar pois, segundo Piaget, que a vontade não é uma simples manifestação de energia, a vontade é um princípio regulador capaz de exigir do sujeito sua fidelidade naquilo que considera importante. Para este sujeito, devido ao "status" atribuído à ciência, sua vontade é endereçada à obtenção do conhecimento, portanto, estamos diante de um ato de vontade, sendo assim, não significa apenas despender energia, mas ao contrário, torna-se um poderoso regulador provavelmente implicado em valores morais.

Assim sendo, também é razoável a crença deste sujeito de que o aluno para aprender deve se envolver com o conhecimento produzindo sua própria resposta, exemplo de seu ato de vontade: "Você tem que coloca através da sua mente". Obviamente, que as respostas não serão idênticas, mas elas deverão concordar em sua 
essência: "tem vez que uma resposta que ta certo a outra ta diferente, mas se você lê ta igual". O sujeito então deve desenvolver autonomia para produzir sua própria resposta. Por conseguinte, o sujeito sente-se responsável com o próprio processo de aprendizado, portanto esta crença está de acordo com a meta aprender, pois os sujeitos acreditam que o êxito escolar depende de condições internas como esforço e empenho, e, a não observância destas regras eletivas faz com que o sujeito sinta-se em débito consigo mesmo.

8- P: E...então você acha que pra aprende...se acha assim que o professor pode influenciar neste esforço?

E: Pode

P: O que o professor faz que você acha que pode influencia neste esforço?

E: Ah...orientação na sala de aula, explica que nem tem coisa na matemática que você nunca fez, claro ai o professor vai e dá um toque, começa assim que é a fórmula, você vai agilizando, é que nem aprende a anda de bicicleta, você faz a primeira, a segunda é fácil, a terceira é fácil e vai embora, isso é o que o professor faz que é o certo a pessoa não consegue faze mais do que isto, na minha opinião.

Neste trecho, apesar de o sujeito afirmar que o professor pode influir no esforço do aluno, sua atuação é limitada. O professor explica e orienta, então, o aluno tenta repetir o que o professor fez: "o professor vai e dá um toque, começa assim que é a fórmula, você vai agilizando". Por fim, é o aluno mesmo que deve ir tentando, repetindo, aquilo que o professor fez, da mesma forma quando se aprende a andar de bicicleta, tenta uma vez, cai, vai, tentando até conseguir andar por si próprio. Novamente, o sujeito acredita que o aluno deve se responsabilizar pelo conhecimento, pois caso o aluno não se responsabilize, o professor não conseguirá muita coisa: “isso é o que o professor faz que é o certo a pessoa não consegue faze mais do que isto, na minha opinião." Este tipo de conclusão é típico dos alunos orientados à meta aprender, pois mesmo quando não conseguem aprender com a explicação do professor, não desistem mantendo o esforço para aprender.

9- P: Você utiliza de alguma estratégia pra você aprende, alguma coisa que você faz pra você aprende, alguma estratégia?

E: Eu faço, ai se eu, pra mim grava assim eu faço de novo a mesma, copio a pergunta e faço de novo.

P: Na hora que você faz de novo... o que você tá pensando, na hora que você tá fazendo, você fez uma vez, você faz a segunda o que você tá procurando, o que você faz no sentido de novo, o que você acha que tá fazendo 
E: É pra a memorização mais, você faz, faz de novo, memorização, embora, já química e matemática eu faço assim tem conta em matemática que você faz de um jeito ai faz uma conta, faz outra, faz outra, beleza, embora quando você faz a segunda, o que você faz aqui subtraiu, multiplico, você aqui já pode ir direto, você não usa subtraiu, multiplico, você pode, por exemplo,vai entra a divisão, você vai direto na divisão e chega na mesma resposta

P:Hum...hum...

E: fica mais rápido.

P: Certo, hum...Hum....P:fica mais fácil?

E: igual química, química tem vez que põe falen(inaudível) não sei o que, não sei o que, baba, mesma coisa, você junta aqui, mais aqui, mais aqui, você chega aqui no final, ao invés de você fazer todo aquele processo grande, então você diminui, já põe direto, fica mais fácil, este faze de novo, que as pessoas, todos os professores, falam "Faz os exercícios em casa" é pra isso, é você trabalha sua mente, pra não fica só naquele negócio... tipo robô mano, porque tem vez que você faz uma conta de matemática "desse tamanho" aí se a pessoa não tenta, todas "desse tamanho" não, você vai treinando, treinando, você já faz conta de cabeça, você não precisa marcar mais aquilo, só põe o resultado, pula aqui, vai ali e é a mesma coisa de você fazer a conta grande... entendeu, isto é trabalha a mente, você tenta, você sua, chega no extremo, tem vez que você não faz nem conta só põe a resposta.

P: (risos) Porque você já tá...

E: Éeee...

O sujeito no primeiro trecho utiliza como estratégia a metacognitiva repetir os exercícios; ele parece repetir diversas vezes não só para memorizar as contas, pois em um determinado momento, devido ao processo indutivo, o sujeito abstrai as operações e não precisa realizar todas as contas, podendo saltar para o resultado direto: "você aqui já pode ir direto”. Por outro lado, parece também se interessar em obter os resultados por processos diferentes: "multiplico, você pode, por exemplo,vai entra a divisão, você vai direto na divisão e chega na mesma resposta”. Poderíamos concluir que o interesse neste processo é torná-lo mais rápido conforme sua afirmação: "fica mais rápido", porém o próximo trecho demonstra que esta não é sua principal preocupação.

O principal interesse do sujeito é desenvolver o seu raciocínio, por isso é que aceita as recomendações dos professores: "Faz os exercícios em casa" é pra isso, é você trabalha sua mente". Novamente, o sujeito repete sua vontade em desenvolver seu raciocínio, utilizando-se de esforço, dedicação e até mesmo à custa de certo sacrifício: "isto é trabalha a mente, você tenta, você suar, chega no extremo". Pois, ao final o sujeito dominará os processos, então, não irá mais precisar de fazer todas as contas: "tem vez que você não faz nem conta, só põe a resposta”.

Em secções anteriores, havíamos levantado a hipótese de o sujeito ter predileção por níveis maiores de abstração, novamente neste trecho não só demonstra este desejo, 
mas parece justificá-lo se considerarmos a hipótese de que talvez acredite que a alta concentração seja capaz de potencializar seu raciocínio. Conforme já foi discutido aqui, um sujeito intrinsecamente motivado perde a noção do tempo, pois se encontra em um alto nível de concentração, obviamente que não podemos admitir que este sujeito esteja sempre motivado desta maneira, todavia talvez busque situações em que possa experimentar esse nível de entrega. Pois devemos considerar que esta forma de agir está ligada às sensações de prazer que não serão discutidas neste momento. Todavia, já havíamos encontrado este prazer paradoxal em outra análise (Vygotski 1998, p. 130).

10 - P:É...Qual o papel do bom professor, o que é o bom professor pra você?

E: Ah...o bom professor, Ah...o professor pra mim sempre é bom

P: Ham??

E:O professor pra mim sempre é bom.

P:Você acha que o professor sempre é o...

E: Sempre é bom, todos meu.

P: Então você... E: (Interrompe)

E: Porque é assim, quem faz o professor é o aluno e não o aluno faz o professor, faz o aluno é sempre o contrário: é o aluno que faz o professor, porque tem aluno que não estuda e acha o professor ruim e porque os que estudam nunca falam nada, só falam: "é bom", "é bom", "é bom", "é bom”, entendeu, é o aluno meu, não tem professor ruim todos os professores são bons e que tem uns que explicam de um jeito, outros explicam de outros, mas todos são bons, não tem esse negócio: "um explica melhor", "outro explica melhor", todos explicam bem, o problema está nos alunos é que tem uns interessados em aprende e outros só vai pra bagunça meu, aí não adianta.

Neste trecho, o sujeito acredita que todos os professores são bons, isto soa um pouco estranho, afinal este sujeito nunca teve a experiência de não gostar de algum professor? O sujeito justifica esta crença, pois segundo ele: "é o aluno que faz o professor", na medida em que os alunos que estudam, dificilmente reclamam de seus professores, logo estes não são ruins, por outro lado: "porque tem aluno que não estuda e acha o professor ruim.". Contudo, apesar da opinião exagerada, acreditamos que os sujeitos orientados à meta aprender tendem a se esforçar para aprender ao invés de responsabilizarem seus professores; obviamente que estes sujeitos também produzem juízos de valor em relação aos seus professores, e a maioria deles não devem ser positivos. Talvez o sujeito esteja apoiando-se em seu método de aprendizagem baseado em esforço e dedicação para afirmar que mesmo diante de um professor considerado "ruim" este seria competente para aprender, pois aposta nestas ferramentas suficientemente poderosas capazes de garantir-lhe êxito. 
11 - P: O que é um bom aluno pra você, acho que até você já me respondeu? O que é um bom aluno pra você?

E: Ah...ser atencioso na sala de aula, presta atenção no mestre que é o professor, porque o professor ele é um sábio, vai passa o conhecimento dele para o aluno, ai onde entra o aluno, respeita o professor, seguir os passos do professor, o ensinamento dele... P: E aí?

E:Beleza meu.

Neste trecho, fica claro porque o sujeito não se sente à vontade para emitir juízos de valor em relação aos professores, afinal: “o professor ele é um sábio”. Este sujeito parece não considerar somente a ciência de forma mítica, mas parece santificar o ofício dos professores como os legítimos representantes terrenos do dogma científico. Isto posto, para realizarmos a reflexão a seguir, gostaríamos de recuperar o seguinte fragmento da entrevista: E: A ciência ela só mostra, através de pesquisa, estudos, o que... que faz, por exemplo, aqui vai nascer uma flor, vai mostra o processo que vai nascer esta flor o como né...porque na crença tudo né...

Em um interessante artigo, Villani (2005) elabora e categoriza as formas de como os cientistas podem aderir ao paradigma, qual é o seu estilo e sua atitude diante de possíveis mudanças. Segundo o autor, os sujeitos podem aderir em relação ao paradigma de forma normal apostando na teoria vigente, ou revolucionária caso sentissem o desejo de mudança, nos momentos em que a norma sofresse algum declínio. Em relação ao estilo, esta adesão ocorre de acordo com o desvelamento caso o sujeito pretenda apostar em aspectos intuitivos, ou pela construção, caso queira desenvolver ou aprimorar aspectos da teoria vigente. No tocante à atitude, esta poderia ser dogmática ou crítica. Portanto, um sujeito pode apresentar uma adesão revolucionária a algum conhecimento tendo como estilo o desvelamento, caso este novo conhecimento se aproxime da visão de mundo fosse por ele intuída. Por outro lado, sua atitude poderia ser dogmática ao acreditar que o novo conhecimento é uma verdade incontestável.

Sendo assim, o sujeito Au talvez possa, em relação ao paradigma, apresentar uma adesão normal, pois confia na ciência e nos detentores do saber. Entretanto, seu estilo talvez fosse de desvelamento devido ao desejo não só de um relacionamento íntimo com o conhecimento, mas, sobretudo, o de desvelar os mistérios da natureza por ele intuídos. Por outro lado, sua atitude seria dogmática no sentido de aceitar a ciência como uma verdade. Sendo assim, esta impressão advém de seu relato de que quem criou a vida foi Deus, mas é a ciência quem revela o processo, através das experiências e dos cálculos (trecho3). Obviamente, estas são somente conjecturas. 
12 - P: Quando você não aprende de quem é a culpa?

E: Não tem como não aprende.

P: Não, mas se caso acontece fazer o que, às vezes a gente não consegue.

E: Tem vez que não entra na cabeça, mas porque falta aquela pitada a mais, aquela voizinha, só...

P: Então quando às vezes acontece isso, o que...que...?

E:Acho que o aluno que deixou escapa alguma coisa.

$\mathrm{P}:$ Você acha que ele não...

E: É... porque tem vez que o professor explica, explica, explica e nada, explica, explica e o cara nada, nada, e o professor, que nem você falou uma vez, fala uma bobagem, tal outra, aí o cara pegou aquilo, pronto, ali já, faz tudo...(risos)

O sujeito relata ser impossível não aprender alguma coisa, novamente responsabiliza o aluno, pois se este não aprendeu, provavelmente porque deixou passar alguma coisa. O sujeito parece ter experimentado situações em que vivenciou algum tipo de insight: "Tem vez que não entra na cabeça, mas porque falta aquela pitada a mais, aquela voizinha, só... [...] fala uma bobagem, tal outra, aí o cara pegou aquilo, pronto, ali já, faz tudo”.Assim sendo, devemos considerar que apesar de o sujeito referir-se genericamente a qualquer aluno, também fala um pouco sobre si mesmo, então podemos admitir que o sujeito além de confiar muito no próprio "eu", também, deposita alta confiança no professor. Consequentemente, talvez seja por esta razão que o sujeito não parece ficar muito preocupado quando não aprende, esta segurança pode estar ancorada em sua autoconfiança baseada em seu esforço e dedicação, conforme já havíamos analisado, ou pode advir da confiança que deposita em seu relacionamento com o professor. No mesmo sentido, é bastante provável que todos estes condicionantes operem conjuntamente para garantir ao sujeito esta sensação de conforto relativo a possíveis fracassos escolares.

Não obstante, podemos também propor um movimento inverso, talvez este possibilite entendermos o sentimento atribuído pelo sujeito à possibilidade de fracassar, pode ser que o sujeito sinta-se bastante confiante, pois acata a orientação do professor sem muitas objeções, quando se sente com maior dificuldade realiza pesquisas, procurando sanar as dúvidas, todo seu movimento é marcado por esforço e dedicação. Logo, deve concluir: "caso não aprenda é porque ninguém aprenderia”, afinal fez tudo que o mestre mandou e utilizou todas as ferramentas de que conhece para aprender.

No mesmo sentido, ele também deve intuir que os educadores, além de valorizar o conteúdo aprendido, também consideram de alto valor a percepção sobre a dedicação 
e o esforço despendidos pelos alunos em relação às disciplinas ministradas por eles. Em relação a este sujeito, dificilmente um professor iria lhe dar notas baixas, pois na visão dos educadores desta escola, este sujeito é visto como um aluno dedicado e esforçado. Consequentemente, durante a reunião do conselho de classe, quando se discute o desempenho dos alunos, caso este obtivesse uma menção negativa, o professor seria alvo da pressão coletiva traduzida no seguinte comentário queixoso: "Nossa!!, mas ele é um aluno tão bom?! Obviamente, não vemos neste procedimento nenhuma falha ética, pelo contrário, enfatizamos a sensibilidade dos educadores que consideram de alto valor o desejo de saber dos educandos; isto significa, caso o sujeito não esteja indo muito bem ou tenha fracassado no aprendizado de um conteúdo, que este necessariamente não será avaliado com menções negativas, pois pode-se honestamente considerar os esforços empreendidos pelo sujeito. Voltemos à análise do próximo trecho.

13 - P:Você afirmou aqui na pergunta número 7 aqui que tarefa que eu gosto de fazer e a tarefa é aquela que eu possa realmente pensar. Porquê?

E:Porque você fica fixo a mente.

$\mathrm{P}:$ Como assim fixo a mente?

E: Assim você fica concentrado demais, você concentra mais.

P: Você acha legal este caso?

E: Acho, você fica mais focado, eu gosto quando você fica assim focado e um negócio que chama você, você não faz a lição aqui, você vai trabalhar e tá no serviço, quando pensa que não: "é tum na mente" ai você: "Caramba como que faz" e pra você vai faze qualquer outra coisa ela tá lá meu (risos).

P: O negócio fica te perseguindo?

E: Fica... aí você, aí onde entra você, você vai não, eu vou faze, aí vai estuda aqui, vê ali, pergunta pra outros: vou vê, vai e vê até faze mano, (risos) fica doidinho.

P: Você fica ali alucinado?

E:(fala junto com o pesquisador) É...é uma coisa que ...nossa fica focado é muito bom..

Conforme já havíamos relatado em seções anteriores, este sujeito gosta de ficar compenetrado refletindo sobre algum assunto; às vezes, é tomado de assalto pelo tema que parece persegui-lo: "você vai trabalhar e tá no serviço, quando pensa que não: "é tum na mente" aí você: "Caramba como que faz" e pra você vai faze qualquer outra coisa ela tá lá meu (risos)." O sujeito se entrega de tal maneira que parece obcecado pelo assunto: "vai e vê até faze mano, (risos) fica doidinho". Este estado de espírito é fonte de prazer, pois afirma gostar de ficar concentrado: "nossa fica focado é muito bom”.

Isto posto, podemos conjecturar de que forma o sujeito obtém prazer por este processo, devemos admitir que de início o sujeito tenha algum interesse pelo 
conhecimento ou problema a ser resolvido, assim sendo, ele canaliza energia na forma de atenção para sua solução; esta tensão psíquica é aumentada conforme o sujeito vai obtendo pequenos sucessos. Ou talvez ocorra justamente o contrário, pode ser que o aumento da dificuldade exige-lhe maior dispêndio de energia sobrecarregando tanto o corpo quanto o aparelho psíquico. Para alguns, este processo deve ser desconfortável, entretanto para este indivíduo, devido ao aumento do foco e da máxima concentração, o sujeito sinta-se absorvido pela atividade não percebendo nenhuma sensação desconfortável; é possível que esta concentração alcance tal nível ao ponto de o sujeito perder a sensação da passagem do tempo, pois nada pode obstar seu caminho para a obtenção da solução do problema.

O sujeito parece direcionar quantidades de energia para o aparelho psíquico na forma de vigor, força e persistência, aumentando o foco e a concentração: ao mesmo tempo que nada escapa ao seu exame, todo o resto não lhe pode chamar a atenção. De repente, quando o sujeito encontra a solução para o problema, sente de súbito o descarregar da tensão psíquica, produzindo por um lado satisfação prazerosa graças ao relaxamento da tensão, e, por outro lado, orgulho moral por ter sido perseverante o suficiente para solucionar o problema ou por elaborar o conhecimento. Construímos esta alegoria levando em consideração a ideia de desequilíbrio cognitivo, tensão e volta ao equilíbrio conforme pensou Piaget.

Desde já, cabe aqui uma pergunta antecipadora: qual será a reação deste sujeito ao vivenciar o conflito cognitivo proposto em nossa atividade de ensino? Ela será capaz de desencadear o mesmo nível de engajamento apreciado pelo sujeito? Não obstante, no tocante às metas de realização, parece óbvio que este sujeito não só está orientado à meta aprender, na medida em que obtém prazer ao aprender, mas exatamente por isto, ou seja, devido ao prazer, ele possa facilmente se motivar intrinsecamente.

14 - P: Você estudou para uma prova, mas na hora você se confundiu e conseguiu uma nota $\mathrm{C}$, como você se sente?

E: Ah...... como se sente, mal não é, sente mal, só sente que...na hora ali.

P: Você fico meio...

E: dá um...troca ali, tem que você responde, que nem o ano passado (risos) a A era a D e aí você já viu (risos), o ano passado fiz uma troca danada, mano, era uma, era outra(risos).

P:Mas assim você não se sente mal, assim ?

E: não, não, não de jeito nenhum...

15 - P: Assim você sempre tirou notas boas? 
E: Não, não, assim quando em tava começando é dificil a gente tira sempre notas boas, a gente faz tudo pra não tira, mas acontece e isso aí também não, quando você tira notas ruins não quer dizer que você não se esforçou em aprende nem nada, não tem nada a ver, é ali você ah...oh...ah tirei vermelha, tudo bem, a próxima é mais motivo pra você "cafifa" mais (risos) e mostra na próxima (risos).

P: Se esforça mais...

E: Isssso...se esforça mais e mostra na próxima (risos) aí tá vendo.

P: Tá pensando o que, não é...

E: Éeee....

O fracasso escolar não é ofensivo ao ponto de fazê-lo desconfiar de sua capacidade cognitiva. O sujeito apresenta sua fórmula mágica para solucionar os possíveis problemas de aprendizado: “cafifa” mais”, ou seja, deve-se proceder com maior nível de concentração, estratégia além de prazerosa, garante maior foco e atenção, maximizando as possíveis operações ou procedimentos para a consecução do objetivo. Isto posto, este sujeito está orientado à meta aprender, pois o sujeito em razão dos fracassos escolares ao invés de se depreciar, adota como estratégia esforço e dedicação, entendidos, neste caso, como maior concentração.

16 - P:Quando o professor propõe um desafio como você se sente?

E: Ah eu me sinto (P: interrompe)

P: Professor chega na sala e fala assim: "Pessoal tenho um desafio para vocês responderem aqui" como é que você se sente nesta hora?

E: Ah...eu me sinto, vontade se eu tiver conhecimento responde na bucha, responde certinho, professor fala é isso aí...

P: (risos) Mas você não fica preocupado, assim: "Pô"...

E: Não

P: a gente fica assim "não vou conseguiii..., já fica não vou consegui” não passa assim pela sua cabeça.

E: Não

P: Você acha que cê, vai tentá

E: Vou tentá fazer, agora se vai sai certo ou errado, aí sempre depois

P: Mas se vai...?

E: Mais eu quero faze pra ver se vai dá

Conforme havíamos concluído em trechos anteriores, sobre o fato deste sujeito considerar-se bastante confiante, implicitamente também parece acreditar-se bastante inteligente: "vontade se eu tiver conhecimento responde na bucha”. Também parece querer obter a admiração do mestre: "professor fala é isso aí...”. Portanto, esta autoconfiança, quase soando como soberba, faz lembrar o caso do sujeito $\mathrm{M}$ orientado à meta performance-aproximação. Este é um exemplo tácito da sintonia fina do modelo, 
pois tanto os alunos orientados à meta aprender, quanto os alunos orientados à meta performance-aproximação desejam o reconhecimento do professores. Entretanto, a diferença é que os primeiros consideram-se inteligentes, mas apostam seu êxito principalmente graças aos seus esforços e à sua dedicação. Por outro lado, os alunos orientados à meta performance-aproximação, por considerarem-se superinteligentes, acreditam que não é necessário empreender esforço e dedicação para aprender.

17 - P: É quando você era garoto assim seus pais se preocupavam com suas notas assim E: Preocupavam, tinha vez que eu tirava muita nota vermelha no terceiro que eu tava terceiro ano.

P:Terceira série

E:Terceira série

P: Lá do

E: Lá do tempo do colegial

P: Não...

E:Não...

$\mathrm{P}:$ Quando você era meninão

E: Isso, meninão, menino, quando eu era meninão aquela es(inaudivel) ficava com vermelha meu pai ficava preocupado.

P: Ficava preocupado?

$E: E_{\text {... }}$

P: Ele chegou a bate em você, já assim?

E: Não, nunca bateu não, ele falava: "Tá vendo, estuda menino tem que estuda"

P: Já deixou de castigo, já não?

E: Não, não deixava não.

P: Você achava que seus pais achavam que você era um aluno bom ou um aluno assim mais complicado?

E: Se achava bom?

P: Achava que você era bom aluno. P:Você têm mais irmãos?

E: Não, sou filho único

P: Você é filho único

Neste trecho, o sujeito não demonstra ter sofrido nenhuma exposição vexatória em relação aos seus fracassos escolares em sua infância, também não demonstra ansiedade quanto ao julgamento dos pais, nem tampouco foi vítima de alguma violência, percebia, no máximo, a preocupação dos pais em relação às notas baixas: "ficava com vermelha meu pai ficava preocupado". Assim sendo, em seu discurso não estão presentes queixas capazes de aproximá-lo de um sujeito orientado à meta performance-evitação.

18 - P: Tem aluno que quando recebe as provas ficam comparando nota o que você acha disso? 
E: Ah...eu acho assim, compara nota é besteira, agora vê assim a resposta, vamos vê " Oh esta é a resposta certa? É, mas a minha, a sua tá errada porque a sua falto isso, aí eu acho legal, interessante

P: hum...hum...P: Aí você vai...?

E:Vai analisa porque a sua também tá certa porque a dele tá errada, por causa de uma letra ou uma palavrinha que faltou tal tá errado, por causa de uma palavra.

P: Certo

E: Aí você vai compara, aí eu acho legal, agora compara nota e...

$P$ : Besteira E: não adianta

19 - P: Porque tem gente que fica assim um cara tiro A o outro tiro D, ai fica?

E: (interrompe) aí não adianta não, tem que vê a resposta do cara, tem vez que o cara tira um A o outro tira um $B, o$ B tiro, tiro menos ali porque faltou essa letrinha aqui que o cara tiro A e aí... E: Hum...hum...E: ai é fácil, "Pó, mas por causa da letrinha", "É, e agora", "agora nos vamos ter que estuda, pra não esquecer a letrinha é fácil"

P: (risos) Então você acha que se você fizer isto, então a pessoa que tá comparando, você acha positivo assim porque, porque?

E:Positivo só pra correção assim, não das notas.

P: Então, mas assim, você acredita que o cara que faz ele tá aprendendo mais, ele vai tá aprendendo mais, porque ele vai tá é....sabendo onde ele erro alguma coisa assim

E: O aluno sim

P: Hum...hum... P: Se ele compara

E:Sim

P: Se ele fize esta comparação?

E: Sim, quem fize esta comparação nesse ponto de vista, sim

P: Hum...hum...

E: Agora tem muita gente que só compara por compara, aí não adianta.

Antes de discutirmos propriamente este trecho, vamos conjecturar sobre os possíveis comportamentos de cada meta. Um sujeito orientado à meta performanceevitação poderíamos admitir, caso recebesse uma menção negativa, que este talvez prefira esconder a prova de seu insucesso não comentando com os amigos seus possíveis erros ou falhas, afinal este procedimento contribuiria para confirmar sua suposta incapacidade para os demais. Este é exatamente o comportamento de Ms classificada como orientada à meta performance-evitação analisada neste trabalho, pois além de odiar provas e notas, não se preocupa em saber onde errou. Por outro lado, um sujeito orientado à meta performance-aproximação caso obtivesse uma excelente menção, este seria seu grande momento em que poderia mostrar a todos sua exacerbada capacidade intelectual. $\mathrm{O}$ sujeito $\mathrm{M}$, orientado à meta performance-aproximação, apresenta uma variante deste comportamento, pois mesmo não estudando, não fazendo os trabalhos, não se esforçando, poderia mostrar aos demais, principalmente indo à 
desforra em relação aos "CDFs", pois também obteve boas notas, corroborando sua enaltecida inteligência.

Contudo, um aluno orientado à meta aprender também ficaria orgulhoso das boas notas que tirou, estas seriam a prova de sua inteligência, mas principalmente o reconhecimento de seus esforços. Por outro lado, caso obtivesse uma menção negativa,ele procederia com uma atitude metacognitiva, ou seja, compararia suas respostas erradas com as respostas certas para ter ciência de suas falhas, comportamento exatamente descrito pelo sujeito: “É, mas a minha, a sua tá errada porque a sua falto isso, ai eu acho legal, interessante". Assim sendo, este sujeito está orientado à meta aprender, pois os erros e fracassos transformam-se em estratégias metacognitivas à medida que permitem ao sujeito tomar ciência das inconsistências de seu pensamento, na possibilidade de desenvolvê-las.

P: Éee....o professor fez uma pergunta, você tem quase certeza da resposta, você arrisca e responde ou espera que alguém responda pra você?

E: Eu arrisco

P: Você arrisca?

E: Eu arrisco, eu não tenho medo de erra

P: Você não tem medo erra?

E:Não, não, falei aí se tiver certo (termo incompreensível) se tiver errado, tudo bem, vamos ver a certa agora.

P: Hum...

E:Tem que, a pessoa tem que se incentivar a si mesmo!

P: Certo

E: Porque o que você aprende na escola fica pra você pro resto da vida e você não tem medo do mundo lá fora, porque tem muita, setor de serviço.

Conforme outros trechos, o sujeito mostra-se bastante autoconfiante, pois afirma não ter medo de se expor, acredita que deve incentivar a si mesmo, por isto não tem medo de se arriscar. No último trecho, temos a impressão de que o sujeito refere-se não somente aos conhecimentos disciplinares em si, mas parece fazer alusão ao conhecimento significativo, pois este, em sua concepção irá "fica pra você pro resto da vida”. Talvez, esta frase contenha implicitamente sua preocupação em desenvolver suas capacidades cognitivas, nos aspectos conceituais, metodológicos ou atitudinais. Pois estes poderão ser utilizados em outros setores de sua vida, como o campo profissional.

Isto posto, estes pressupostos parecem ir ao encontro das crenças do sujeito Del orientado à meta aprender que acreditava que um conhecimento adquirido com esforço e dedicação será útil para o resto da vida: "a reposta conquistada, a pessoa aprende e se 
quise ela vai saber por toda vida". Nestes trechos, discutimos sobre a possibilidade de aspectos inconscientes impactarem negativamente a autonomia dos sujeitos, fomentados pelas leituras de: Silva (2004), (Villani et al, 1998,), (Pintrich et al, obra citada,) e (Gunstone,obra citada,). Assim sendo, como frutos dessas discussões, produzimos as seguintes perguntas:

Será que o conhecimento obtido após esforço e dedicação ajudam os alunos a superarem os determinantes ligados inconscientemente a culpabilizar o outro? Será que o êxito constado, após esforço e dedicação, leve o sujeito a construir uma auto-imagem positiva o suficiente para poder suportar suas próprias dificuldades sem culpar o outro por um possível fracasso? Será que aquele possuidor de crenças positivas no tocante a sua auto-eficácia, além de se responsabilizar mais por seu aprendizado, pois suas experiências foram capazes de enriquecê-los com habilidades e competências que lhe permitem realizar determinadas tarefas? Esta condição também acabe por levar o sujeito a um comportamento mais autônomo?

Assim sendo, será que este sujeito também construiu seu estofo afetivocognitivo de maneira muito similar ao do sujeito Del? E, exatamente por isto, seus discursos, muitas vezes, apresentam certas ressonâncias?Desse modo, poderíamos supor a existência de um conteúdo social oculto com determinantes tais capazes de laçá-los socialmente fazendo-os compartilhar dos mesmos significados. Portanto, este caldo cultural do qual o sujeito emerge foi interpretado e nomeado pela psicologia de metas de realização como as crenças de alguém orientado à meta aprender? Vejamos, pois nos próximos trechos o sujeito da continuidade ao trecho anterior discorrendo sobre sua posição em relação ao seu trabalho, em que poderemos constatar quais são seus significados atribuídos à palavra autonomia.

P: Certo

E: Que eu presto serviço tudo, tem muitas pessoas que vai fazer prova, já fica com medo nem viu as perguntas sabe o que é e já tá com medo.

P: É, é verdade...

$E: E ́$ não adianta meu, não adianta a pessoa vai lá, não pode ter medo, é que nem aquele negócio, você é correto, é não tem aquele palavra talvez ou é sim ou não, cabo, agora tem gente que, eu vejo, coloca talvez, talvez, talvez, não adianta você responde um questionário pra tantas perguntas pra talvez [P: (risos),] não adianta meu, é sim ou não e a maioria dos empresários que eu conheço é tudo assim, eles mesmo falam: "Eu não gosto de pessoas que põe talvez, porque esta é uma pessoa duvidosa, tá com dúvida de si mesmo, eu gosto de pessoa que mesmo que não tem muito estudo, que chega e seja espontânea, é sim e não, sim e não, porque: porque é o jeito mas fácil da pessoa cresce dentro de uma empresa, não tem medo do desafio, você vai lá põe o desafio, "você vai 
(bate na mesa) fica no lugar do fulano hoje, ai você (bate na mesa) mostra pra que veio é sua oportunidade, vai lá tu, tu, e aquele lá vai pra outro setor, mais acima e você entrou no lugar dele, cresceu um pouquinho é isso que a pessoa tem que ver... Muito bem...

O sujeito justifica porque não tem medo de se arriscar, pois acredita que este comportamento é valorizado em sua profissão. Interpõe uma questão moral para exemplificar seu posicionamento: "é que nem aquele negócio, você é correto, é não tem aquele palavra talvez ou é sim ou não”.O sujeito conforme já havíamos constatado é autoconfiante e este juízo sobre si mesmo impacta em sua autonomia, mesmo sabendo que não possui um nível educacional elevado não se intimida diante dos desafios que a vida lhe oferece. Ora, este não é o mesmo posicionamento autônomo apresentado pelo sujeito Del diante dos desafios: "a primeira impressão é ou para ou persiste, e eu sou uma pessoa que odeio parar no meio, quando eu começo alguma coisa eu vou até o fim, mesmo que eu quebre a cara depois."

Isto posto, acreditamos que estes sujeitos encontram-se ligados pelos mesmos determinantes sociais, este determinantes foram capazes de engendrar suas posições em relação àquilo que acreditam que lhes dizem respeito. Por nosso turno, podemos enxergar nestes determinantes aspectos de suas Ecologias Conceituais, ou seja, estes são os pactos metafísicos que estes sujeitos pretendem observar em uma determinada situação. Ou poderíamos falar que estes valores, muito deles morais, são potentes reguladores de energia obrigando os sujeitos a manterem-se fiéis mesmo quando seria mais fácil, por exemplo, mudar de opinião ou optar por cortar o caminho quando este se mostra árduo, estes valores estariam de acordo com a psicologia ético-moral piagetiana. Ou ainda, que suas crenças os aproximam dos sujeitos orientados à meta aprender, por acreditarem que o esforço e a dedicação são as ferramentas básicas utilizadas para resolverem os desafios.

Contudo, independentemente desta ou daquela classificação teórica, o importante é que estes sujeitos, graças as suas vivências, a despeito dos possíveis acidentes de percurso, construíram uma auto-imagem referendada por uma sensação de auto-eficácia nascida por suas experiências de êxito. Destarte, estes auto-conceitos são robustos o suficiente para permitir-lhes sonharem, ou mesmo, alçarem voos mais audazes demonstrando não só sua autonomia, mas o desejo da confirmação pela realidade de seus espíritos corajosos. 
20 - P: Éee...o que você acha do trabalho em grupo?

E: Muito importante, em vários aspectos, porque as pessoas se unem mais.

[P: Hum...Hum...] E:São várias cabeças ali entendeu, trabalham ali, várias opiniões diferentes é que a resposta mais certa ali, positiva, pra todo mundo coloca ali, na ponta do lápis, mais concentração, mais apoio um do outro, tem vez que um sabe, tem medo de fala, o outro vai lá: "(trecho inaudivel, o entrevistado fala muito baixo) pa, pa, li, já," o outro fala, fala, ai chega naquele resultado final [P: Hum...hum] E: Isso é bom pro grupo, porque se um tá em dúvida, o outro também já sabe, mas não tem certeza, o outro mais o menos, ai se junta meu.

P: Aí?

E: Aí sai uma resposta ali que... [P: (interrompe)]

O sujeito levanta diversos pontos positivos relacionados ao trabalho em grupo: a união, o fomento à diversidade de ideias e opiniões e a solidariedade quando um dos integrantes apresenta alguma dificuldade seja com o próprio conteúdo, ou relativo ao medo da exposição. Estes argumentos em defesa do trabalho em grupo, muitas vezes, ocorrem de forma natural, e, devemos deixar claro que o grupo deste sujeito realmente se constitui um verdadeiro grupo de trabalho conforme relato em nosso diário de campo. Todavia, sabemos que formar grupos que realmente trabalham não é uma tarefa simples ou mesmo natural; vejamos se os próximos trechos revelam se o sujeito já participou de grupos inoperantes.

21 - P: O grupo que cê tá é um grupo bom de trabalho, vocês já trabalham um tempo juntos, tal, mas, assim você já participou de grupo que ninguém queria saber de nada, só você?

E: Ah...o ano passado (risos)

P: O ano passado (risos) e aí como é que fazia

E: Aí....(risos), um fica esperando resposta (risos), só de um (risos), você fica ali pensando, e os caras nem pra pensa, mano.

P: Os caras não tão nem aí

E:Nem aí... ai fica difícil

P: Fica só pra um

E: Fica só pra um, pra um, fica caramba e não, fica acelerando né, depressa: "E ai meu rápido, professor vai pega o trabalho, vamos lá, vamos lá", eu fico, "Calma”, nem um nem outro.

P: Além dos caras não faze nada...

E: ainda fica apressando o outro ainda que quer faze, ai não adianta meu

P: Você acha que é mais fácil se encontra um grupo de trabalho mesmo que faz as coisas, ou um grupo que ninguém que faze nada e só que deixa pra um?

E: Ah...um grupo que ninguém que nada é mais fácil

P: de encontra (risos)?

E: Porque aquele ali, já vê ali, aquele cara sabe, aí vup

P: Os caras já vão pra cima do cara?!

E: vai pra cima ali: "E aqui, e aqui, tá formado, tá formado (risos)

P: Você não tem nem pra onde fugi(risos)! 
E: não tenho, ainda mais eu que sento no fundão ali (risos, o entrevistado fala rindo) só si quebra a parede e.....(o entrevistado ri junto, trecho inteligivel).

P: Ai....ai !

E: É fogo meu filho .....

O sujeito agora apresenta um único argumento capaz de inviabilizar o trabalho em grupo: os sujeitos se organizam em nome do mínimo esforço, ou melhor, apostam na maioria das vezes, no esforço de um único integrante, os outros reservam-se apenas ao trabalho de copiar as respostas. Em outro trecho, o sujeito demonstra ter sido quase forçado a participar de um grupo, devemos considerar a veracidade deste fato, pois seus colegas devem considerá-lo como um sujeito que realiza as atividades escolares com esforço e dedicação, logo sua permanência no grupo deve significar certeza de boas notas.

Isto posto, em outras secções já havíamos discutido sobre como este problema relativo às organizações grupais podem dificultar a efetivação de um dos conceitos mais caros à teoria de Vygotski. Pois, como um sujeito mais capaz, poderá contribuir junto à zona de desenvolvimento proximal dos outros sujeitos ajudando-os a internalizar formas superiores de pensamento, uma vez que, segundo este construto, o diálogo é o mediador na relação interpessoal, portanto mecanismo estruturante capaz de transmitir os significados culturais. Assim sendo, neste caso, o diálogo, ou não existe, por não estar endereçado ao problema, ou ocupa apenas a função de burlar o próprio processo, à medida que os colegas a sua volta estão mais interessados ou em terminar a atividade rapidamente ou sem a mínima disposição intrapsíquica em relação à tarefa.

No mesmo sentido, caso se tratasse do conflito cognitivo, o processo poderia até se efetivar, mas não estaríamos mais falando de um conflito sócio-cognitivo; à medida que os significados sociais não seriam compartilhados entre os membros do grupo. Portanto, haveria o empobrecimento de todo o processo, afinal os sujeitos não verbalizariam ao máximo suas concepções espontâneas; talvez este sujeito afeito a níveis maiores de concentração poderia ao final ter evoluído suas concepções, enquanto que para a maioria do grupo poucos efeitos seriam produzidos.

22 - P: Por exemplo: você tá em grupo né se você e seu amigo não souberem, como é que fica, você tá em grupo ali, vocês não conseguem responder, como é que fica? E: Aí se não sabe, pede a opinião do professor [P:Hum...hum] E: Pede opinião 
P: É por exemplo assim, você tá resolvendo em grupo uma questão, várias questões que o professor passou, aí tem um pergunta lá da quinta série, você é o único que não sabe, entendeu, você faltou, não foi naquela aula na quinta série.

E: Sei

P:Você não consegui aprende na época, tá lá aquela continha, o que cê faz, você pergunta pros seus colegas, ou você faz de conta que...

E: Não, tem que pergunta pros colegas

P: Você não vai fica com vergonha assim dos caras acha: "Pó o cara é maior inteligente, mas?

E: Não, porque é assim coisas que vai passando, mesmo você tenha grava, você memoriza no cérebro, guardado, a questão e você lembra ali, naquele momento, porque tem uns que lembra de coisas no momento, mas já não é aquela mesma resposta, já é outra, assim vai variando, você pode até lembra, mas ai você vai fica pensando, pensando, tem vez que você não consegue naquela aula, pode consegui na próxima, você vai lembra, tal, "a questão é assim”, aí você acha mais a lampadazinha, né, acende a lampadazinha aí você "não assim", ai sim, mas na hora assim, no momento em que a coisa tá fervendo ali aí você tem que pedi opinião mesmo

P: Você pergunta pra quem?

E:Pergunta ih!!

P: Você não vai fica sentindo assim com vergonha?

E: Não, não, não

P: Você não tem esse problema?

E: Eu não tenho esse problema não.

O interesse principal nesta pergunta era sondar sobre a possibilidade de o sujeito ter preocupações ligadas à meta performance-evitação, pois é provável que um sujeito orientado a esta meta tenha receio em perguntar para os demais colegas caso não soubesse de algum conteúdo considerado de conhecimento obrigatório pela sua simplicidade. Obviamente, tratando-se de um sujeito que gosta de "cafifa", naturalmente que ele vai ficar pensando sobre o assunto em busca de um insight, ou, em suas palavras, até: "acende a lampadazinha". Caso não tenha muito tempo, então, "em que a coisa tá fervendo ali aí você tem que pedi opinião mesmo”. Portanto, o sujeito não está preocupado em demonstrar suas falhas, este comportamento o afasta das preocupações típicas dos sujeitos orientados à meta performance-evitação.

23 - P:Você sabe que tem alguns alunos que ficam tirando barato quando o pessoal responde uma resposta, quando o pessoal responde errado, o que você acha disso assim? Você acha que isso atrapalha os alunos tal?

E: Atrapalha os outros alunos que que aprende

P: Porque? P: Porque você acha que atrapalha, quando um fica tirando barato do outro?

E: Ah, porque é assim se você tira o barato só naquele momento ali e ali morreu, tudo bem, mesmo que na hora do intervalo continue, tudo bem, ai é outra coisa, agora a partir do momento, que o professor, que nem aí, tiro o barato ali, ai o professor vai 
explicar aí não consegue explicar porque os caras estão fazendo barulho, ai é dureza meu, ai atrapalha.

P: Aí atrapalha a aula, né.

E:Atrapalha a aula, entendeu, agora aquele momento ali, ai tudo bem, mas tem que se assim, começo morreu ali, que o professor tá dando aula, tá dentro da classe, agora na hora do intervalo, depois aí pode continua né meu, numa boa, porque isso ai tudo mundo tira mesmo (risos).

$\mathrm{P}$ : isto não tem jeito $\mathrm{E}$ : Isto não tem jeito (risos)

E: Todo mundo brinca, mano

P: É todo mundo...

E: Entendeu

P: Isto faz parte

E: faz parte mesmo

E: Agora só não pode na hora que o professor tá explicando, porque o Sr. os outros professores que explica as coisas e não consegue por causa de meia dúzia, dois, três, aí P:Tá na bagunça né ?!

E: É dureza e ai é difícil para quem que aprende porque você tá concentrado ali, mesmo que você as outras pessoas tá conversando ou fazendo barulho, você tá li, tá concentrado no que o professor tá falando, você tá memorizando o que o professor tá falando, cê tá esquecendo: esqueceu as outras vozes, tá só na voz do professor, mas só que eles atrapalham até os outros e você mesmo que tá ali concentrado.

P: Hum...hum...

E:Porque no momento de raciocínio seu, se uma pessoa, você tá ali raciocinando, uma pessoa fala um " $a$ ", desconcentra você e agora aquela palavra que se ia fala, já não fala mais.

P: Já num...aí tira você.

E: Já tira você... tiro e até você volta meu...

24 - P: Não, mas. Assim a pergunta que eu te fiz assim não é em relação à disciplina, mas por exemplo assim, o professor faz uma pergunta, aí o aluno responde e responde errado, aí os alunos começam a tira um barato?

E: (entrevistado interrompe): Pro aluno?

$\mathrm{P}$ : Entendeu, mas isso assim, claro que fica ruim pra disciplina da sala

E: Isso

P:Mas pro aluno que eles tão tirando barato

E: Não... isso aí não atrapalha não

P: Cê acha que..

E: Não, tira barato não.

Nestas perguntas, estamos interessados em captar o incômodo do sujeito quando percebe que um colega é ridicularizado por ter respondido algo de errado, muitos se sentem condoídos pela exposição alheia independentemente da orientação de realização. Contudo, os alunos orientados à meta performance-evitação costumam reclamar desta situação e alguns reportam ter passado por este tipo de constrangimento.

O sujeito, em questão acredita não haver problemas na ocorrência destas situações vexatórias, acha até normal, isto pode demonstrar, ou que o sujeito não passou 
por este tipo de situação, ou realmente não se incomoda em ser motivo de gozação alheia, afinal pelo menos tentou responder, ou o pior, ele também acha muita graça nestas situações. Contudo, em trechos anteriores, o sujeito afirma que quando o professor pergunta: "se eu tiver conhecimento responde na bucha". Sendo assim, podemos inferir, já que o sujeito não tem medo de se arriscar, que ele não se incomoda quando erra, mesmo se os colegas rirem, pois pelo menos em seu entendimento ele tentou responder.

Antes de finalizar a análise deste trecho, gostaríamos de salientar nossa impressão que o sujeito parecia estar mais interessado em falar sobre a indisciplina escolar. Pois este se incomoda com o barulho dos demais colegas quando está concentrado na fala do professor, inclusive seu nível de concentração é tamanho que esquece outras vozes: “esqueceu as outras vozes, tá só na voz do professor". Esta queixa é veemente e bastante comum quando os sujeitos estão preocupados em aprender.

25 - P: Você nunca passou por uma coisa chata na escola, uma situação chata assim, por exemplo, professor, sei lá ti deu uma nota vermelha, você se sentiu injustiçado.

E: Não eu já passei assim, eu discuti com a professora de química na sétima série P: Porquê?

E:Porque ela, é as respostas né.

P: Você deu uma resposta...

E: Não esta resposta tá errada.

P: Hum...

E: Levantei da carteira peguei o giz e coloquei o CM e o três da fórmula, "não, mais assim é cálculo", eu falei, "não se você colocar aqui o, que fórmula é”, e eu com o livro na mão(risos), e ela, "não, num pode", aí nós discutimos, veio a diretora, nossa, maior confusão danada.

P: Mas eu tava E(interrompe):

E: Aí depois, já o sangue frio duas partes, eu fui lá pedi desculpas pra ela, ela tá bom, tá bom.

P:Não tá certo realmente é uma confusão.

E: É uma confusão brava!

Nesta pergunta, estávamos interessados em sondar junto ao sujeito se vivenciou situações possíveis de serem cotejadas pela meta performance-evitação, portanto questionamos se o sujeito havia passado por alguma situação vexatória ao receber alguma menção negativa, ou se sentiu injustiçado por algum tratamento. Ora, o sujeito demonstra não só o nível de sua autoconfiança, afinal levantar no meio da aula para 
corrigir a professora com o livro na mão é quase uma inversão da pergunta, ou seja, o sujeito fez o professor passar por situação de exposição negativa.

26 - P: Mas assim você nunca se sentiu, assim, por exemplo, por exemplo, se sentiu assim burro assim?

E: Não...

P: Você nunca passou por uma situação assim...

E: burro não

P:A professora, pó chamou você na lousa e você não sabia responder aquilo aí você ficou com vergonha de seus amigos, dos seus colegas, você nunca sentiu, isto assim,

E: Não, eu acho bom quando eu vou na frente.

P: Você num?

E: Acho legal, acho muito legal!

P: Porque

E: Começo na quinta série, porque na quinta série todo o trabalho de geografia tinha que se em grupo e cada um do grupo vai fala de um território brasileiro ou internacional que nós fazia né, ia lá desenhava um mapa na cartolina tal, você lê essa parte do livro, o outro lê essa, o outro le essa e gravando não é mole, porque chega lá na frente e fala, o cara de da o mapa, pega a anteninha e fala aqui é isso, aqui aconteceu isso, foi assim, puta mano, quinta série, eu me encantei quando eu fiz isso aí mano

P: Você gostava

E: Gostei mano, gostei mano

P: Você gostava por causa da parte de explica

E: Não a parte de você explica, e mesmo quando você errava, as pessoas, lá há (inaudivel), ela chegava e falava, "não ai tá faltando um negócio, e aquela cidadezinha com aquele vulcão não sei o que", ai nós, "é isso professora", "então aqui nesse lugar aconteceu isso", (risos) é muito legal, eu acho muito interessante esta parte.

Neste trecho, perguntamos diretamente se o entrevistado já se sentiu incapaz para aprender ou se já foi julgado desta maneira por professores ou colegas, preocupação básica dos sujeitos orientados à meta performance-evitação. O sujeito além de relatar não ter sido alvo deste tipo de consideração, ainda afirma que gosta de se expor relatando uma experiência em que a professora o corrigiu na frente de todos: "não aí ta faltando um negócio, e aquela cidadezinha com aquele vulcão" [...] (risos) é muito legal, eu acho muito interessante esta parte". Ainda sobre sua exposição, alega que achou muito interessante a possibilidade de ter explicado para a classe um conteúdo de geografia: "pega a anteninha e fala aqui é isso, aqui aconteceu isso, foi assim, puta mano, quinta série, eu me encantei quando eu fiz isso aí mano”.

Devemos chamar a atenção de que o conteúdo era o de geografia e não necessariamente o de ciências no qual o sujeito parece estar intrinsecamente motivado, notem, pois, novamente o sujeito demonstra envolvimento com a tarefa.Esta experiência 
deve ter sido realmente marcante, pois o sujeito se recorda de um evento do passado com requintes de detalhes: "[...] desenhava um mapa na cartolina," lembra da distribuição das tarefas: [...] "você lê essa parte do livro, o outro lê essa", inclusive das dificuldades, [...] o outro lê essa e gravando não é mole[...].Isto posto, este sujeito além de demonstrar o desejo de se envolver com os conhecimentos elegidos por ele como grande valor, como por exemplo, o saber científico, este também nutre interesse pelo conhecimento de uma forma geral, aproximando-o dos sujeitos orientados à meta aprender.

Devemos ressaltar que este trecho vai ao encontro do trecho 23 , em que concluímos que o sujeito não se incomodava, caso cometesse algum erro, sendo vítima das risadas dos colegas; levantamos a hipótese sobre esta ausência de incômodo estar ligada à constatação de que o sujeito não tem medo de se arriscar, sendo assim, a possível falha seria encarada como um resultado natural e representaria a oportunidade para ser corrigida.

Antes de terminarmos a análise deste trecho, gostaríamos de relatar uma impressão contida nos meandros do discurso do sujeito. Pois, em diversos trechos temos a impressão ao seu relato de certo movimento psíquico quando fala de seu envolvimento com o conhecimento, pois as palavras: "cafifa”(trecho15), “concentração, fica assim focado(trecho13)", "é tum na mente(trecho13)", "calcula de formas diferentes(trecho9)", "ficar raciocinando (trecho23)", "são várias cabeças ali entendeu(trecho20)", "vamos ter que estuda(trecho 19)”. Apesar destas palavras remeterem à ideia de algo estático, por exemplo, "concentração", vem a nossa mente a imagem de um fenômeno estático, parado, todavia, na boca do sujeito, paradoxalmente, temos a impressão de algo acelerado, de um movimento psíquico dinâmico de alta energia (afetivo). Sendo assim, acreditamos que durante a análise dos trechos da entrevista deste sujeito temos a impressão de ter nos ocorrido um insight, pois a percepção deste movimento repetido em seu discurso nos ajudou a entender a real dimensão do conceito, tão caro ao ensino de ciências, ou seja, o real significado do envolvimento ativo do sujeito, para nós, o seu significado mais profundo. Agora, é o revolver dinâmico das estruturas de pensamento animadas energeticamente, obviamente, que não se trata de algo material, mas um movimento abstrato como bem pensou Piaget. 
27- P: Agora deixa eu te fazer uma outra pergunta, quando você era garoto assim, logo assim, a primeira série, o prezinho né.

E: Isso

$\mathrm{P}$ : O que que representava a professora pra você? Você consegue se lembra, mais ou menos, o que ela representava pra você?

E: Eu achava....eu achava bem legal.

P:O que que representava pra você, se você compara a professora com alguma coisa você compararia a professora com o que, você nunca viu a professora na verdade é a primeira vez, que se ia

E: A Primeira vez, foi no prezinho na primeira série, onde eu conheci a tia Maria foi no prezinho, ali eu soube assim um prof...uma pessoa mais uma tia, considerava uma tia

E: Tia assim, um parente E: tia assim, tia como você chama quando é pequeno, uma conhecida, um negócio novo, todo dia chegava a hora de tarde, "ai mãe tá na hora ir pra tia lá, faze a lição com a tia, aprende”, eu achava legal, essa parte

$\mathrm{P}$ : Você tinha uma relação de carinho?

E:Carinho, carinho

P: Na verdade esta pessoa, é uma pessoa desconhecida?

E: É desconhecida

P: Você nunca viu?

E: Eu nunca tinha visto

P:Se você passasse no parque e olhasse "eu não vou com esta mulher não

E: Isso

P: eu não sei quem ela é"

E: No primeiro dia, eu ainda queria, chorei, queria ir pra casa, ficava no portão e tudo, aí no terceiro e no quarto eu fui ficando dentro da sala de aula, aí fui conhecendo as pessoas

P: Então você acha, como uma tia, assim...um parente...

E: Um parente...

A razão desta pergunta se justifica, pois acreditamos que a professora é o representante da "mãe de fora", "a mãe de esfera privada", ocupando uma posição de destaque na infância, à medida que é significada pela família como alguém gozando de um status muito importante. Isto posto, o sujeito relata que considerava a professora como uma tia, como um parente, em análises futuras veremos como a experiência com uma professora insensível pode aproximar o sujeito da meta performance-evitação. 


\section{Questionário de Acesso às Metas de Realização do Sujeito Ga}

Nome: Ga

idade $2 f$ série

Caso você concorde com as idéias abaixo as classifique colocando (C) que significa concordo, caso contrário, ou seja, se você não concordar coloque (NC) que significa não concordo. Caso você concorde parcialmente classifique as respostas como (CP) que significa concordo em algumas partes.

\section{$60,5 \quad 3$}

1- Eu gosto de realizar tarefas na escola em que eu realmente aprenderei, mesmo que eu cometa muitos erros.(C) $\bullet \perp$

2- Eu me sentiria realmente bom se eu fosse o único que respondesse as perguntas dos professores da classe. (n)

3- É muito importante que eu não seja visto como um estúpido na frente dos meus colegas.(C) i

4- Uma razão importante para que eu faça tarefas na escola é porque eu gosto de aprender coisas novas.(C) 1

5- É importante para mim que os outros estudantes em minha classe pensem que eu sou bom nas tarefas que realizo.(CP)

6- Uma razão importante para eu faça as tarefas é para que eu não fique envergonhado.( $\mathrm{NC})$

7- Tarefa que eu gosto de fazer é aquela em que eu possa realmente pensar.(C) 1

8- Eu quero fazer as tarefas melhor do que os outros estudantes da minha classe. (NC)

9- Eu me preocupo quando eu faço meu trabalho se os professores irão pensar que eu sou menos capaz do que os outros. (c) 1

10- Uma importante razão para que eu faça a tarefa na escola é porque eu sempre quero melhorar, aprender mais. (c) $\downarrow$

11- Eu sentiria bem sucedido se eu aprendesse mais do que os outros estudantes.(NC)

12- Uma das razões para que eu faço meu trabalho é porque não quero que pensem que eu sou burro.(NC)

13- Eu faço minha tarefa na escola porque eu estou interessado nela.(C)

14- Eu gostaria de mostrar aos meus professores que eu sou o mais esperto da classe. (WC)

15- Uma razão que eu não participaria de uma da aula é porque não quero que me vejam como um estúpido (a).(Nc)

16- Uma importante razão para que eu realize uma tarefa na escola é que eu goste dela.(C) 1

17- E importante para mim, fazer as atividades melhor do que os outros alunos. (NC)

18- Um de meus objetivos principais é evitar que me vejam como incapaz de realizar minhas tarefas.(C) $\rfloor$ 


\section{Análise dos dados da Entrevista de Validação do Perfil Motivacional de Realização do Sujeito Ga}

O símbolo $P$ significa fala do pesquisador, $E$ significa fala do entrevistado. Trechos em sequência estão separados apenas por um parágrafo simples, enquanto que os trechos não sequenciais estão separados por um traço.

1- P:Você estudou para uma prova, mas na hora você se confundiu e conseguiu uma nota C. Como você se sente?

E: Mal, muito mal porque eu me esforcei para conseguir.

P: Prova é uma coisa ruim?

E: É é uma coisa ruim.

$\mathrm{P}: \mathrm{O}$ que você sente quando você terá fazer uma prova?

E:Uma sensação que eu sempre vou me dar mal, sempre vou me dar mal que eu não aprendi direito, uma vez até o professor não me explicou, fico nervosa muito, entendeu, fico muito nervosa, muito nervosa mesmo e a maioria das vezes dá o branco.

Perguntamos ao sujeito como ele se sente ao tirar uma menção mediana representada por uma nota "C", apenas para compararmos, caso se tratasse de uma escala de um a dez, o aluno teria auferido a nota cinco. Assim sendo, chama-nos a atenção a forma veemente como o sujeito afirma sentir-se tão mau em relação a uma nota que de maneira nenhuma representa o fracasso. Ora, também os sujeitos orientados à meta aprender não se sentem satisfeitos quando obtêm esta menção, na medida em que esta não reflete seus esforços. Entretanto, estes sujeitos não apresentam uma reação tão negativa ao obterem uma menção classificando-os dentro da média, a máxima conclusão: é a de que deveriam ter se dedicado mais, ou na próxima oportunidade, empreenderão ainda mais esforço. Pois é exatamente a falta desta crença que afasta este sujeito daqueles orientados à meta aprender.

Ainda neste sentido, ou seja, da possibilidade ou não de o sujeito estar se afastando da meta aprender, o trecho: "Mal, muito mal porque eu me esforcei para conseguir", ocorre-nos a impressão de o sujeito utilizar a palavra esforço para justificar o seu pesar, como se dissesse: “- Eu sofro, porque me esforço e mesmo assim fracasso.” Ou seja, será que o sujeito está convicto que mesmo se esforçando não obterá êxito? Todavia, caso seja confirmada esta impressão, torna-se razoável, então, o pesar exacerbado do sujeito, afinal sofre, pois, independentemente de seu empenho, tem a certeza de nunca conseguir um êxito memorável. Obviamente, esta impressão é bastante prematura, necessitando de outros dados para ser corroborada. 
O sujeito Ga apresenta significados muito próximos do sujeito Ms orientado à meta performance-evitação.Comparativamente, ambos os sujeitos são causticamente tomados por sentimentos de ansiedade e angústia, vejamos o sujeito Ga: "Uma sensação que eu sempre vou me dar mal, [...] fico nervosa muito, entendeu, fico muito nervosa, muito nervosa”.

Sendo assim, esta sensação de angústia parece produzir reações aparentemente diferentes, pois Ms adota a estratégia de não estudar, ou seja, este comportamento deve diminuir-lhe a ansiedade, afinal não entra em contato com suas possíveis dificuldades, garantindo-lhe um menor nível de ansiedade permitindo-lhe fazer a prova, isto talvez a impeça de entrar em pânico escapando da repentina perda de memória (dar branco). Por outro lado, caso consideremos o primeiro trecho da entrevista em que Ga declara sentirse mal, pois se esforça e mesmo assim tira notas medianas, talvez seja exatamente por isto, ou seja, ao estudar, entrando em contato com suas reais dificuldades, que ela vivencia o terror da possibilidade do fracasso, então, no momento da prova, segundo suas palavras: "maioria das vezes dá o branco".

Obviamente, também os sujeitos orientados à meta aprender, após estudarem sentindo-se demasiadamente pressionados, também podem ocorrer-lhes a perda repentina da memória no momento das provas. Entretanto, o que chama a atenção, nos dois casos,é a certeza que o sujeito tem do fracasso. No caso de Ms, sua certeza é explicitamente revelada pelo desejo da inexistência das provas: "eu acho que não devia ter existido prova não, a gente devia ter nascido tudo aprendido deste pequeno”. No caso de Ga, esta certeza é implícita, na medida em que as provas são sinônimo de pesar, logo devemos considerar a possibilidade de esta desejar o fim das provas, como remédio para aplacar seu sofrimento: "Uma sensação que eu sempre vou me dar mal, sempre vou me dar mal que eu não aprendi direito".

Isto posto, apenas como comparativo analisemos as possíveis estratégias de realização das duas metas aqui discutidas. Os sujeitos orientados à meta aprender. também devem ficar ansiosos com a possibilidade da chegada das provas; entendemos aqui ansiedade como um excesso de energia psíquica acumulada e obstada na forma de preocupações, neste caso, relacionadas à possibilidade do fracasso ou êxito diante de exames ou provas.

Assim sendo, os sujeitos orientados à meta aprender, ao invés de se afogarem em um mar de ansiedade, utilizam como estratégia para fugir a essa condição sua crença básica, ou seja, esforçam-se para obstar e direcionar energia na forma de ações, no caso, 
aumentando a concentração capaz de possibilitar ao sujeito dominar o possível caos mental e impedindo ou controlando o surgimento de pensamentos negativos capazes de fazê-los desviar a atenção. Consequentemente, a ansiedade, o desconforto psíquico, ou é minimizado, ou não é sentido, pois o excesso de energia é transformado em maior foco e concentração permitindo, por um lado, dar conta do desafio, por outro, este direcionamento e o fluir da tensão durante o processo deve contribuir com maior sensação de conforto, ou até mesmo, de prazer psíquico. Podemos considerar que estamos diante de mecanismo de adaptação motivacional.

Contudo, caso o sujeito perceba que não está obtendo êxito, mesmo assim é razoável que consiga maior controle da ansiedade na medida em que direcionou este excesso de energia com o propósito de solucionar suas dúvidas e dificuldades, portanto diminuída a tensão psíquica é provável que também encontre de maneira mais consistente a solução para os problemas decorrentes do próprio processo. Obviamente, não se trata de uma estratégia infalível, primeiro, porque esta não existe e segundo, porque mesmo os alunos orientados à meta aprender reclamam também de sofrer de perda repentina de memória (“deu branco"), todavia esta forma de agir pode possibilitar maior êxito, principalmente se comparada à meta performance-evitação a qual descreveremos a seguir.

Antes de discutirmos propriamente o comportamento dos sujeitos orientados à meta performance-evitação, devemos definir como consideramos aqui a angústia. Em nosso entender, esta difere da ansiedade, pois a angústia é fruto do temor ou medo cristalizados no interior do sujeito, sendo considerados por ele como predestinados a acontecer. Em nosso caso, esta crença se refere ao fato que independentemente dos esforços, devido a sua suposta incapacidade cognitiva, os sujeitos orientados à meta performance-evitação estão predestinados ao fracasso. Portanto, neste caso, os sujeitos também percebem o avolumar da ansiedade com advir das provas e exames, entretanto, diferentemente dos sujeitos orientados à meta aprender, este excesso de energia não encontra o direcionamento e a possível descarga desta tensão. O sujeito, angustiando pela certeza do iminente fracasso, tem sua psique invadida e tomada por pensamentos aterradores: "Você não conseguirá", "Você não é capaz”, Estes pensamentos perturbadores tornam sua mente um caos, impedindo-o de canalizar energia para aumentar a atenção, o foco e a concentração, pois apesar de esforçar-se, tem muita dificuldade em manter a concentração; a todo momento sente-se ameaçado pelo fracasso, à medida que percebe suas dificuldades. Conclui, então, confirmando 
exatamente sua suposta incapacidade cognitiva. Isto posto, se no caso de a meta aprender estamos diante de um mecanismo adaptador de motivação, neste caso estamos diante do contrário, ou seja, de um mecanismo "disruptivo" de motivação desembocando em comportamentos e autoavaliações que contribuem para a perda de controle da situação:

[...] Dotado de uma orientação motivacional desamparada, o indivíduo responde ao fracasso desistindo da tarefa, agindo como se a situação estivesse fora do seu controle (Dweck, 1975; Dweck \& Repucci, 1973 apud Reeve, obra citada, p.153).

Nesse sentido, é razoável entendermos a motivação de Ms em preferir não estudar para as provas, afinal é melhor esperar para ver o que acontece, do que mergulhar antecipadamente em um mar de ansiedade. Imaginemos, então, o sofrimento de Ga no momento da prova, ela se esforça procurando se concentrar, mas a angústia traduzida na forma de um excesso de preocupação deve ser tamanha sendo capaz de impedir-lhe a ação do pensamento, possivelmente de duas maneiras: o excesso de energia psíquica é direcionada para a concentração. Por exemplo impedindo que o sujeito saia da primeira questão; ele não consegue responder, muito menos, abandonála; usa freneticamente a borracha, pois escreve algo e em seguida apaga, afinal desconfia que está errado. De outra maneira, este excesso de energia poderia acelerar o pensamento do sujeito, a psique ficar tão acelerada que não consegue se concentrar em nenhuma questão: ele lê a primeira pergunta, depois lê a segunda, lê a prova inteira, mas não sabe por onde começar. Em ambos os casos, o sujeito relatará perda de memória repentina ("deu branco").

Obviamente,não estamos utilizando de nenhum referencial teórico neurofisiológico para sustentar as possíveis conjecturas e a relação entre ansiedade, angústia e seus possíveis efeitos no aparelho psíquico. Contudo, basta que o leitor verifique se em algum momento de sua vida vivenciou situações correspondentes às descritas aqui. Sendo assim, esperamos apenas, a despeito de qualquer confirmação teórica destas conjecturas, a possibilidade de nossos leitores se sensibilizarem da razoabilidade destes condicionantes.

2- P: O que você acha dos alunos que ficam comparando nota? Exemplo, um aluno tirou A e fica desmerecendo o outro que tirou E. O que você acha disso?

E: Isto é péssimo isto, não é nada bom!! 
P: Alguma vez já fizeram isto com você?

E: Ah já... é péssimo, é triste, você acha que você não presta pra nada, você tá ali... se num...

Apenas como comparativo, quando perguntamos para Ms, orientada à meta performance-evitação, esta respondeu (trecho 19, p.167):(P) E esse negócio de ficar comparando nota [...] o que você acha...(A) ah!, como eu sou burro nem respondi igualzinho, errei(P) Ah...meu Deus (risos) (A) risos [...]. Nesta ocasião, discutimos a possibilidade de o sistema escolar estar baseado na meritocracia separando os sujeitos segundo sua performance: de um lado encontram-se aqueles que obterão sucesso, do outro, uma grande quantidade de indivíduos irão paulatinamente se sentindo fracassados e diminuídos.

No trecho antecedente, levantamos a hipótese da existência de um mecanismo disruptivo capaz de produzir déficits motivacionais. Pois bem, este mecanismo está diretamente ligado ao senso de auto-eficácia do sujeito, ou seja, como podemos perceber, conforme a análise da seção anterior, o sujeito, angustiado pela certeza do fracasso, não consegue escapar aos pensamentos negativos, logo não é capaz de desenvolver ou perseverar em ações capazes de lhe possibilitar situações exitosas. Isto posto, podemos conjecturar que durante a vivência escolar destes sujeitos estes vivenciaram um número maior de fracassos, em comparação às situações em que obtiveram êxitos, com o passar do tempo, paulatinamente, avaliaram como ineficazes suas estratégias de auto-eficácia para responder aos desafios escolares.

Obviamente, também com o passar do tempo, e a repetição destas situações, e a certeza de estratégias de auto-eficácia ineficazes, estas acabaram por engendrar uma auto-imagem ou um auto-conceito pejorativo. Logo, o ataque a si mesmo: "você acha que você não presta pra nada" é a consequência de um meio social, em que a todo momento, o sujeito pode contemplar o seu fracasso através de provas e notas. Isto posto, este comportamento é descrito pelo conceito de desamparo, já apresentado na análise de Ms:

3 - P: O professor faz uma pergunta você tem quase certeza da resposta, você arrisca e responde ou espera que alguém responda para você?

E: Espero que alguém responda...

P: Por quê?

E: Eu fico com vergonha, de eu tá errada.

P: Mas e se você estiver errada, o que você acha que vai acontecer?

E: Não sei acho que o professor vai falar esta menina não tá aprendendo nada, não adianta vir pra escola, não consegue mais aprende... (risos) 
Antes de iniciarmos a análise deste trecho, é preciso deixar bem claro que ninguém gostaria de ser motivo de risos por parte de professores e colegas, caso respondesse algo de errado em sala de aula. Contudo, devemos ressaltar que os sujeitos Del e $\mathrm{Au}$, ambos orientados à meta aprender não se incomodam com esta possibilidade, bem como, o sujeito $\mathrm{M}$ orientado à meta performance-aproximação. Pois, além de não sofrerem com esta possível condição, parecem ainda apreciá-las, afinal no primeiro caso dos sujeitos orientados à meta aprender podem mostrar o que sabem, já no segundo, este pode mostrar sua superioridade intelectual. Ora, provavelmente, assim o fazem por terem vivido um maior número de situações nas quais obtiveram êxito quando comparado às situações em que obtiveram fracasso, de qualquer forma, demonstram possuir uma auto-imagem inflada o suficiente para suportarem a possibilidade de se exporem ao ridículo, saindo ilesos, pois caso provoquem o riso alheio, concluem: "Pelo menos, eu tentei".

Assim, devemos considerar esta ojeriza à exposição pública como sintoma de um sujeito orientado à meta performance-evitação, se e somente se, este medo vem acompanhado de um auto-conceito pejorativo sobre si mesmo, por exemplo, o sujeito se considera inapto para aprender. Portanto, este cuidado metodológico se faz necessário para escaparmos dos casos de indivíduos com excesso de timidez. Dito isto, o caso do sujeito Ga parece descartar a hipótese de se tratar de excesso de timidez: "Não sei acho que o professor vai falar esta menina não tá aprendendo nada, não adianta vir pra escola, não consegue mais aprende... (risos)". Pois, segundo este fragmento, ela teme o julgamento pejorativo por parte do professores, contudo, este julgamento é a mesma depreciação que aflige sobre si mesma, conforme trecho anterior: “Ah já... é péssimo, é triste, você acha que você não presta pra nada, você tá ali.. .se num...”. Desta forma, este sujeito está orientado à meta performance-evitação, pois teme situações em que possa se sentir humilhado devido a sua suposta incapacidade intelectual, crença em acordo com as assertivas abaixo referente a esta meta:

- Uma razão pela qual eu não participo da aula é evitar parecer ignorante;

- É muito importante para mim que eu não apareça como burro na minha classe.

4 - P: Em grupo quando você não consegue obter a resposta, o que você sente? 


\section{E:Eu fico com raiva, com raiva danada...}

P: Porque você fica com raiva?

E: Fico com raiva porque eu acho que eu to ali, to fazendo um esforço danado pra aprende e não consegui, mesmo tando em grupo porque eu acho que cinco seis cabeça pensam melhor, mesmo a gente cada um tendo sua opinião a gente estudando cada caso e eu não consegui!! eu acho que eu fico com muita raiva!!! Com muita raiva, eu fico com raiva da professora (risos).

No trecho1, referente à análise deste sujeito, apresentamos a forma como entendemos a ansiedade, consideramos esta como um excesso de energia acumulada e obstada na forma de preocupações sobre a possibilidade do êxito ou fracasso. Também, estabelecemos, segundo nosso entendimento, o significado da angústia como certeza fatídica de que o pior acontecerá, pois os sujeitos orientados à meta performanceevitação creem que fracassarão, pois estão convictos de não possuírem atributos cognitivos à altura dos conhecimentos exigidos. Consideramos também a possibilidade de a angústia tornar-se um mecanismo disruptivo de motivação, pois o sujeito tem sua psique invadida por pensamentos negativos, impedindo-o de direcionar toda a sua atenção na forma de concentração para a solução do problema.

Pois bem, agora estamos diante de outro sentimento: a raiva, este também nos remete ao excesso de energia, entretanto, analogamente ao calor, a raiva é energia em trânsito, devendo ser direcionada ao ataque ou a ação. Ora, a angústia também é um excesso de energia, entretanto, é energia cristalizada, represada, obstada pela certeza do fracasso, impedindo o livre fluir da energia através da descarga emocional direcionada à ação. Sendo assim, teria a psique encontrado uma maneira de descarregar este excesso de energia obstado pela angústia, utilizando a via do sentimento da raiva?

Nesse sentido, podemos conjecturar a possibilidade de a raiva descarregar a energia através da ação, através do ataque dirigido a si mesmo, portanto, se durante a realização da tarefa o sujeito angustiado tem pensamentos negativos em relação ao sucesso, por exemplo, "eu não conseguirei”, o sentimento de raiva transforma a psique em um caldeirão, em que esta carga emocional é utilizada com "fervor" para amalgamar a certeza do fracasso presente na angústia com atributos pejorativos com os quais o sujeito pode se autoafligir, concluindo: "não consegui, porque sou burro(a)". 
Por outro lado, todo este excesso de energia pode encontrar outro alvo para ser direcionado, ou seja, a figura do professor ou os colegas a sua volta. Dessa forma, relatamos em nosso diário de campo sobre o fato deste sujeito ter ficado extremamente irritado quando lhe pedimos para realizar simples desenhos com o propósito de representarem o exercício em questão. Esta irritação gratuita e desproporcional, pois os desenhos eram de fácil execução, foi o acontecimento que nos fez intuir que o sujeito poderia estar orientado à meta performance-evitação. Sendo assim, diante do relato do sujeito no qual cita sentir raiva do professor nestas situações, acreditamos também ter sido alvo deste sentimento "[...]Com muita raiva, eu fico com raiva da professora(risos).

Ainda sobre este trecho, provavelmente o sujeito sente raiva, pois conforme seu relato: "[...] mesmo a gente cada um tendo sua opinião a gente estudando cada caso e eu não consegui!!",ou seja,como pode não aprender se todos a sua volta estão conseguindo. Obviamente, deve sentir raiva de si mesmo, pois esta situação vai ao encontro de sua crença, ou seja, confirma indelevelmente sua suposta fragilidade intelectual. Toda a situação funciona como um espelho refletindo os possíveis julgamentos no olhar alheio, fazendo-a contemplar seu fracasso sentindo-se, então, diminuída e humilhada.

5 - P: Imagine você está em grupo e tem uma questão lá da quinta série considerada fácil, mas você esqueceu, ou não aprendeu o que você faz?

E: Eu procuro ajuda, dos colegas, dos alunos, do professor primeiro, aí no caso se eu já fui uma, duas vezes falar com o professor, já nem vou mais, eu fico com vergonha aí eu procuro os colegas, a gente tenta, aí eu fico com uma vergonha, eu tento fazer, tento, tento várias vezes, até um dia que o professor cansa... fala oh.

P: Você falou que sente vergonha, assim...?

E:Eu fico com vergonha.

P:Por quê?

E:Porque eu to ali estudei tanto e sempre quis, sempre tive vontade de aprende e nunca consegui na quinta série é uma coisa que é muito difícil de você vê agora.

Neste trecho, novamente o sujeito se esforça, utiliza-se da estratégia de buscar ajuda tanto do professor, quanto dos colegas. Entretanto, apesar de todo o esforço, quando não desiste após inúmeras tentativas, acredita que o próprio professor desistirá. Desamparada, sente-se humilhada e exaurida pelos esforços infrutíferos, em 
consequência, desconfia de sua capacidade cognitiva que a impede de aprender, conforme descrito pelo conceito de desamparo. Estudar, então, constitui-se um suplício, um castigo, comparado ao mito de Sísifo: condenado a empurrar uma rocha ladeira acima e vê-la eternamente despencar, tornando inúteis seus esforços. Analogamente, Ga tem esperança de poder aprender, esforça-se, desespera-se e colhe fruto amargo do derradeiro fracasso.

Neste trecho, o sujeito deixa transparecer o julgamento de sua autoeficácia, ou seja, ele relata uma sequência de ações metacognitivas em direção ao domínio da situação; tenta várias vezes, ou procura ajuda dos professores ou colegas. Entretanto, estas ações metacognitivas falham, o esforço vão redunda em fracasso. Obviamente, com o passar do tempo e a repetição destas situações, o sujeito engendra em seu íntimo uma desconfiança sobre seu senso de auto-eficácia. Atrelado aos seus sentimentos de vergonha,estes acabarão por contribuir para uma avaliação depreciativa de seu autoconceito. Não tarda, esta avaliação negativa relativa tanto ao seu auto-conceito quanto a sua auto-eficácia levará o sujeito a desesperar-se diante de tais situações precipitando-o para o descontrole, a rápida exaustão das forças, aproximando-o do comportamento típico daqueles que atuam segundo o conceito de desamparo.

Contudo, qual é o propósito de seu esforço? Pois admitimos a possibilidade de este sujeito estar convicto de sua suposta fragilidade cognitiva. Então, porque continua se esforçando? Ora, porque não age como Ms que prefere não estudar, ou seja, para que se esforçar? Conforme já havíamos relatado no trecho1,nossa impressão de que o sujeito Ga utiliza o esforço para justificar seu fracasso, como se dissesse implicitamente: "não é falta de esforço, é porque eu não consigo aprender", no mesmo sentido, temos a intuição de que a insistência do sujeito em enfatizar o quanto se esforça parece revelar que ele não pretende passar a imagem de indolente. Assim, teríamos a frase: "não é preguiça, não é falta de esforço, é porque não consigo aprender".

Devemos considerar esta possibilidade, por dois motivos, primeiro talvez seja importante para este sujeito não ser considerado preguiçoso, ou seja, aceitaria com maior naturalidade uma suposta fragilidade cognitiva, pois não pode fazer nada para solucionar uma falha estrutural. Por outro lado, escaparia à falha moral de ser considerado preguiçoso, pois esta pode ser corrigida mudando-se os hábitos. Contudo, também devemos levar em consideração que ao longo dos anos o sujeito ouviu sempre a mesma receita para melhorar seu desempenho escolar: "porque você não estuda mais", "se você se esforçar um pouco mais, aprenderá". Sendo assim, cansada dos insistentes 
conselhos, arremata: "sempre tive vontade de aprende e nunca consegui", ou seja, não é falta de vontade, não é falta de interesse, não é falta esforço. Logo, a única conclusão que chegou para explicar sua condição foi acreditar não possuir suficiente capacidade intelectual .

Devemos ressaltar sobre o objetivo desta pergunta, pois pretendíamos sondar junto ao sujeito como reagiria caso não soubesse um conteúdo considerado de fácil compreensão e que fora ensinado no passado, passível de ser esquecido. Ora, esta situação é bastante normal, afinal ninguém é obrigado a saber de conceitos embotados pelo tempo. Nesse sentido, os sujeitos $\mathrm{Del}$ e $\mathrm{Au}$, ambos orientados à meta aprender não se sentiram afetados negativamente caso vivenciassem esta situação. Por outro lado, Ga parece realmente ter vivido esta situação, tamanho é o desconforto presente em seu discurso, assim sendo, parece que esforço, fracasso e vergonha são intrínsecos e amalgamados a sua história escolar.

P: (retomando a pergunta) Veja bem, a gente aprende um monte de coisa, algumas coisas a gente aprende mais, outras aprende menos aí, às vezes, você faltou na aula ou esqueceu, não aprendeu...

E: Então, deixa eu te conta, aconteceu comigo assim eu to tendo aula de matemática, caiu vezes tabuada, eu não sei nada, nada tabuada, a professora vai perguntando, vai perguntando, eu não respondo eu fico morrendo de vergonha, eu faço de conta que eu sei, o que acontece, ai depois, eu vou tentando, que nem eu to fazendo várias vezes, nossa muitas vezes (entrevistador interrompe)

P:Quando você passa por este tipo de situação, o que você sente?

E: Eu fico com vergonha, me sinto... incapaz de aprender, entendeu e às vezes eu fico pensando eu tenho de desistir, que aquilo não é pra mim. Porque eu não consegui aprende tal e agora também eu não to conseguindo ai eu fico desanimada, mui...(entrevistador interrompe)

Este relato é muito próximo do relato do sujeito Ms (p.188), pois este era chamado para realizar os cálculos na lousa, sentindo-se humilhado quando da correção feita pelo professor. Neste caso, acreditamos que a suposta professora realizava chamada oral sobre tabuada; imaginemos a ansiedade e o desespero do sujeito Ga. Nas vezes em que acerta, alívio, quando erra: humilhação, vergonha, aflição. No caso do sujeito Ms, quando tinha que ir para lousa (grifo nosso): “[...] mas eu ia, ia me matando 
pra não ir, [...]". Da mesma forma, o sujeito Ga sofre: "eu não respondo eu fico morrendo de vergonha", veja: os sujeitos estão sob a tortura do possível julgamento alheio sentindo-se destruídos por estas situações consideradas opressoras. Sendo assim, para minimizar tal sofrimento, Ga utiliza-se do faz de conta: "eu faço de conta que eu sei, " para evitar que os outros venham, a saber, sobre seus erros que denunciariam aos quatro ventos sua suposta inadmissível fragilidade cognitiva.

No segundo trecho do relato, temos mais um exemplo do mecanismo disruptivo, pois o sujeito sente-se envergonhado, desonrado diante da impossibilidade de poder provar a si mesmo e aos outros que pode aprender. Portanto, ao invés de o sujeito dirigir energia para realizar ações com o propósito de dominar a situação, ocorre-lhe justamente o oposto, pois sua psique é inundada pela dúvida e pela certeza do fracasso, logo, conclui (grifo nosso): "[...] e às vezes eu fico pensando eu tenho de desistir, que aquilo não é pra mim." Ora, desesperado o sujeito perde o controle da situação caminhando a passos largos em direção ao desamparo, sobrevindo a sensação disruptiva do exaurir de suas forças (grifo nosso): "não to conseguindo aí eu fico desanimada".

6 - P: Se você fosse se definir, você se definiria como uma pessoa inteligente, uma pessoa que aprende, mas precisa de esforço ou uma pessoa que tem dificuldade?

E: Uma pessoa que tem dificuldade.

7 - P: Em relação ao seu primário, o que mais te deixava chateada no primário?

E:Que nem esse caso das crianças, da gente erra, dos colegas rirem, fica zoando, bota um apelido às vezes, muitas vezes fui apelidada de burrinha... entendeu...

P:Isto já aconteceu?

E: Já...

Obviamente, levando-se em consideração o desenvolvido até este momento, é natural que o sujeito Ga tenha elaborado seu auto-conceito admitindo-se como um indivíduo com grandes dificuldades para aprender: "Uma pessoa que tem dificuldade". Obviamente, este auto-conceito é amparado por um baixo senso de auto-eficácia, na medida em que ao longo desta análise o sujeito ressaltou em seu discurso situações nas quais, mesmo tendo se esforçado, obteve fracasso, sentindo-se angustiado e humilhado. Portanto, ao invés de uma boa expectativa de auto-eficácia capaz de impactar positivamente em seu auto-conceito este parece ter desenvolvido a orientação motivacional para o desamparo, pois observamos que o sujeito desaprova suas capacidades, pois tem certeza do fracasso futuro, muitas vezes, perdendo a esperança. 
Isto posto, em relação às emoções ligadas à possibilidade de aprender sabidamente, o sujeito as desenvolveu nos relacionamentos ligados à sua história escolar, pois, por absurdo, seríamos forçados a acreditar que estes sentimentos seriam inatos. Sendo assim, os sentimentos de vergonha foram produzidos por situações de fracasso que resultaram na sensação do ridículo.

Isto posto, em nosso referencial teórico também apresentamos conceitos referentes à necessidade de intimidade ligada à sensação de amor como algo presente nos relacionamentos ou a necessidade de afiliação girando em torno da ausência deste sentimento nas relações interpessoais. Neste sentido, também chamamos a atenção para o "status" ocupado pela professora comparando-a com a mãe, afinal esta deve conduzir com mão segura os primeiros passos do filho, aquela analogamente deve cuidar para um letramento confiante e seguro. Consequentemente, conforme relato do sujeito Ga devido ao seu sofrimento e à humilhação afligidos podemos admitir a possibilidade deste sujeito desconfiar dos relacionamentos que estabelece de acordo com o conceito de necessidade de afiliação. Esta desconfiança em relação à possibilidade de ser amado, além de ter sido produzida pela baixa qualidade dos relacionamentos que estabeleceu, também deve ter sido alimentada, exatamente, por acreditar não possuir capacidade cognitiva. Diante desta possível falta, talvez o sujeito não possa se considerar um objeto capaz de admiração, logo, do amor do outro, talvez nem em relação a si mesma. Principalmente, naqueles momentos, trecho 4, nos quais o sujeito direciona toda sua raiva ao próprio "eu". Obviamente, esta inferência necessita de dados para ser corroborada.

Antes de finalizarmos a análise deste trecho, devemos chamar a atenção sobre o relacionamento deste sujeito com o outro. Afinal, nos conhecemos, sabemos quem somos graças à imagem ofertada pelo outro, esta imagem não é transferida diretamente pela palavra, por exemplo, quando alguém diz que você é assim ou é assado. Absolutamente, não, esta imagem nos é enviada de forma cifrada, embutida na qualidade de nossos relacionamentos, cristalizada nos gestos, escondida nas entrelinhas das palavras trocadas, mesmo com tantos rapapés civilizados, pode parecer, às vezes, ser difícil ter ideia do que pensam sobre nós. Todavia, em nosso íntimo temos a certeza dos contornos desta imagem refletida pelo outro. Sendo assim, parece-nos que a imagem ofertada pelo outro e internalizada por este sujeito foi: "muitas vezes fui apelidada de burrinha..." 
P:Você se lembra em que situação que foi?

E: Foi no caso que a professora me fez a pergunta.

P:Você se lembra da pergunta?

E: Não, agora não me lembro mais, entendeu, foi assim também é justo naquela época que a gente tinha que faze, era a matéria, era inglês que a gente tinha que um fala pro outro (entrevistado interrompe, pois inglês não é ensinado no primário).

P: Mas inglês não é...

E:Não eu digo assim, que hoje em dia é parecido...

P: Ah!! Você esta dizendo que era parecido...

E: Isso que o professor chama a gente lá e a gente tinha que fala um pro outro, entendeu ai quando eu errei o outro aluno acertou, ele ficou nas nuvens se achando o máximo, enquanto eu fiquei lá embaixo, lá embaixo, bem lá embaixo, que eu fiquei com muita vergonha, depois desse dia pra cá eu nunca mais consegui responde, entendeu, ..., às vezes, eu to com a resposta na ponta da língua, eu tenho certeza absoluta que ela tá certa, mas eu não falo, eu falo pra uma pessoa que tá na minha frente, pra uma pessoa que tá atrás, fala que tá certo, mas eu não falo...

Em trechos anteriores, chamamos a atenção para a possibilidade de o sujeito sentir-se torturado pelo julgamento alheio. Pois, neste trecho parece que o sujeito descreve o funcionamento deste "aparelho" de tortura. Este "instrumento" de tortura psíquica parece agir de duas maneiras: primeiro parece empurrar o sujeito garganta adentro, impedindo-o de se expandir, pois devemos considerar a potência da fala como uma das formas de expandirmos nossos horizontes estabelecendo relacionamentos com o outro: “depois desse dia pra cá eu nunca mais consegui responde”. Assim sendo, o sujeito parece demonstrar estar consciente do poder que lhe foi tirado por esta experiência, na medida em que atribuiu sentimentos exatamente contrários ao colega que participava do teste e obteve sucesso: "[...] aí quando eu errei o outro aluno acertou, ele ficou nas nuvens se achando o máximo". Ainda sobre esta forma de tortura, temos a intuição de tratar-se de um peso insustentável sobre os ombros, achatando o sujeito, capaz de fazer o corpo curvar-se, rebaixando o sujeito e finalmente prostrando-o: "enquanto eu fiquei lá embaixo, lá embaixo, bem lá embaixo, que eu fiquei com muita vergonha, ". 
Isto posto, este trecho estabelece uma relação entre admiração e humilhação. Ora, talvez o sujeito pretendesse ser considerado o máximo, entretanto experimentou o gosto amargo da desilusão na relação com o professor sentindo-se ofendido. Nesse sentido, as vivências relatadas por este sujeito estão repletas de situações onde o sujeito colhe como fruto de suas relações, seja com o conhecimento, ou propriamente com os atores - professores e alunos - a sua volta, sensações de desconfiança sobre sua capacidade cognitiva e sofrimento na forma de humilhação. Consequentemente, conforme hipótese levantada no trecho anterior, existe a possibilidade deste sujeito não considerar-se como alguém passível de ser amado exatamente por acreditar possuir uma falha estrutural que o impede de aprender. Em decorrência, podemos admitir que este sujeito está orientado segundo o conceito de necessidade de afiliação girando em torno da falta de amor, na medida em que não pode ser amado, pois não possui atributos capazes de serem admirados por outrem. Pois bem, esta admiração parece ter sido direcionada para outro lugar em detrimento do próprio sujeito através do sentimento de humilhação.

8 - P:Imagina só, saindo da sala de aula, situação de trabalho, exemplo: seu chefe pede alguma coisa que você terá que fazer, desenvolver como é que fica?

E:Eu vou tenta faze, mais só que assim é um sufoco danado, vai ser um sufoco muito grande, entendeu, vai ser um sufoco muito grande eu vou ficar com muito medo, nervosa..., entendeu e é assim eu acho que eu tano nervosa com medo, com vergonha eu acho que só sai errado (entrevistador interrompe).

Este relato do sujeito Ga é bastante contundente, entretanto, está de acordo com as inúmeras situações vivenciadas pelo sujeito, nas quais, mesmo após aplicar esforço e dedicar-se, colheu como fruto o amargo fracasso. Notadamente, estes fracassos serviram para fortalecer sua convicção na certeza de uma possível incapacidade cognitiva, logo é natural esperarmos que esta fatídica certeza produza estragos também em outras áreas. Este trecho talvez sirva para aproximar ainda mais o sujeito do conceito de necessidade afiliação, pois o sujeito poderia considerar a hipótese de que poderia aprender com os demais colegas de trabalho, ou seja, ele investiria no relacionamento pessoal para enfrentar os desafios com o seguinte pensamento: "os outros conseguiram, então com ajuda eu também posso conseguir". Entretanto, este procedimento talvez seja pouco provável levando-se em consideração seus relatos sobre os relacionamentos com a autoridade representada pela figura do professor, ou em relação aos seus possíveis colegas de trabalho, representando as relações com os demais alunos. Obviamente, não 
estamos aqui sentenciando o sujeito ao fracasso, todavia, devemos considerar que o próprio sujeito em seu discurso não elabora uma forma de escapar a estes condicionantes.

P:Você acha que você acaba aprendendo menos?

E:Isso, eu acho que eu aprendo menos

$\mathrm{P}$ : Então isso foi uma coisa que marcou na sua vida?

E:Isso marcou

P: Coisas que você vai levar da escola, que seriam...negativas, vamos dizer assim.

E: IsSO...

P: Você acha que o professor tem como ajudar você a superar esta situação ou você acha que é complicado?

E: Eu acho que é complicado, porque isso é... sentimento da gente né... é uma coisa que a gente tem isso, entendeu, não é outra pessoa ou professor que vai tirar isso, entendeu, tudo bem que ele possa explicar, várias vezes, ensinar, se esforçar ao máximo, mas chega lá na hora...

P: Mas, por exemplo, se você tivesse que passar por estas sensações é uma coisa que você preferia não passar?

E: Isso eu preferia não passar

P: Ou seja, participar em atividades em que você pode incorrer no erro, se sentir envergonhado, ou perceber que você não consegue saber é uma coisa que você prefere... E: Eu prefiro, fica no meio, faço de tudo pra corre.

Este trecho nos força uma pergunta: será que este sujeito aprende menos? Será que realmente possui alguma falha cognitiva? Obviamente não, entretanto, devemos considerar a possibilidade de este sujeito aprender menos exatamente pelo fato dele desconfiar de sua capacidade cognitiva, à medida que foi desencorajado a raciocinar de forma autônoma, não se sentindo confiante em defender seu ponto de vista. Isto posto, é razoável admitirmos que não se sinta confiante em projetar suas estruturas em direção ao objeto tentando assimilá-lo, pois pode se deparar com alguma forma de conflito, talvez este poderia produzir alguma acomodação melhor do que a estrutura de seu pensamento antecedente. Entretanto, é provável, já que está convicto de sua suposta incapacidade cognitiva, que talvez vivencie este conflito segundo o conceito de desamparo; desesperando-se pela certeza do fracasso, evita entrar em contato com as lacunas de seu pensamento, sempre pronto a descartar seu raciocínio sem a mínima apreciação, preferindo o seguro conhecimento produzido pelo outro. Sendo assim, enfatizamos sobre a possibilidade real do sujeito aprender menos, mas não por uma falha cognitiva, mas pelo simples fato desta fatídica certeza impedir-lhe a plena liberação de energia do sujeito em direção ao saber. 
Continuando a análise, em relação a um possível auxílio do professor para ajudálo a mudar o conceito sobre si mesmo, perguntamos: Ora, como poderia este sujeito acreditar que o investimento na relação com o professor poderia ajudá-lo? Afinal, foram anos de ansiedade e medo relativo ao possível fracasso, foram inúmeras situações em que o sujeito não conseguiu alcançar os padrões de excelência exigidos. Pois bem, quem elaborou ou projetou estes padrões de excelência a serem alcançados senão o professor? Portanto, é razoável que o sujeito desconfie daquele que o puniu sublinhando todos os seus erros minuciosamente, pois ao longo de sua vida escolar, foram uma miríade de testes, provas e finalmente notas que confirmaram em seu íntimo a inaptidão para aprender. Então, como agora, este relacionamento marcado, por um lado, pela cobrança, pelo outro, no mínimo, pela insensibilidade poderia tornar-se uma relação de confiança e segurança, própria do conceito de intimidade onde os sujeitos movem-se em torno da sensação de amor.

9 - P: Porque que você acha que você tem mais medo para aprender do que os outros? E:Eu acho que eu tenho muito mais medo do que as outras pessoas, muito mais medo de errar, eu acho que tenho muito mais do que todos que eu já vi até hoje, medo pra tudo, eu acho que eu tenho mais, entendeu, nunca ninguém tem mais que eu, sempre sou eu...

Com esta pergunta esperávamos ouvir da boca do sujeito a seguinte resposta em relação ao seu medo para aprender: "Eu tenho mais medo, porque me acho burra". Entretanto, captamos o medo pelo medo, o medo como fim em si mesmo, apenas medo. Todavia, medo do quê? Medo do fracasso; medo da nota; medo do julgamento; medo da humilhação; medo da prova; medo de ser débil; medo da maldade, na forma do riso alheio. Talvez, seja exatamente isto: o simples terror de vir a ser sujeito. 


\section{Questionário de Acesso às Metas de Realização do Sujeito En}

Nome: En idade $3 \perp$ série $^{c}$

Caso você concorde com as idéias abaixo as classifique colocando (C) que significa concordo, caso contrário, ou seja, se você não concordar coloque (NC) que significa não concordo. Caso você concorde parcialmente classifique as respostas como (CP) que significa concordo em algumas partes.

$$
\text { AP } 5 \text { P. A } 1 \text { P.E } 2
$$

1- Eu gosto de realiza na escola em que eu realmente aprenderei, mesmo que eu cometa muitos erros.(NC)

2- Eu me sentiria realmente bom se eu fosse o único que respondesse as perguntas dos professores da classe.(CP) $\oplus, 5$

3- É muito importante que eu não seja visto como um estúpido na frente dos meus colegas.(NC)

4- Uma razão importante para que eu faça tarefas na escola é porque eu gosto de aprender coisas novas.( ( ) $\perp$

5- É importante para mim que os outros estudantes em minha classe pensem que eu sou bom nas tarefas que realizo.( $\mathrm{NC}$ )

6- Uma razão importante para eu faça as tarefas é para que eu não fique envergonhado.(c) 1

7- Tarefa que eu gosto de fazer é aquela em que eu possa realmente pensar.(c) 1

8- Eu quero fazer as tarefas melhor do que os outros estudantes da minha classe. (NC)

9- Eu me preocupo quando eu faço meu trabalho se os professores irão pensar que eu sou menos capaz do que os outros. (NC)

10- Uma importante razão para que eu faça a tarefa na escola é porque eu sempre quero melhorar, aprender mais. (c) 1

11- Eu sentiria bem sucedido se eu aprendesse mais do que os outros estudantes.(NC)

12- Uma das razões para que eu faço meu trabalho é porque não quero que pensem que eu sou burro.(NC)

13- Eu faço minha tarefa na escola porque eu estou interessado nela.(C) $\perp$

14- Eu gostaria de mostrar aos meus professores que eu sou o mais esperto da classe.(c)

15- Uma razão que eu não participaria de uma da aula é porque não quero que me vejam como um estúpido (a).( $(\mathrm{c})$

16- Uma importante razão para que eu realize uma tarefa na escola é que eu goste dela.(c) 1

17- E importante para mim, fazer as atividades melhor do que os outros alunos. (Nc)

18- Um de meus objetivos principais é evitar que me vejam como incapaz de realizar minhas tarefas.(c) 1 


\section{Análise dos dados da Entrevista de Validação do Perfil Motivacional de Realização do Sujeito En}

Os trechos em sequência estão separados apenas por um parágrafo simples, enquanto que os trechos não sequenciais estão separados por um traço.

1 - P: Então mais ai você estudou até os, até que idade?

E: Estudei até os vinte um

$\mathrm{P}:$ Até os vinte e um?

E:Ai parei fui embora pra aqui aí não estudei mais

P: Então você reprovou?

E: Não, nunca reprovei

P: Mas se você estudou até os vinte anos já tinha terminado?

E:Porque eu estudei, quando eu comecei a estuda foi muito tarde eu comecei a estuda P: Ah...

E: Aí parei, aí voltei a estuda e tornei a para de novo, aí quando eu comecei a estuda a quinta série, ai eu estudei a quinta, sexta, sétima e comecei a oitava, aí vim embora pra aqui, porque eu sou da Bahia [P: Hum...] E: Aí eu vim embora pra aqui, aí fiquei sem estuda, trabalhava né, ai fiquei sem estuda, quando foi o outro ano eu comecei, aí o ano passado eu vim pra aqui, ai eu continuei na oitava né.

O sujeito En tem 31 anos de idade e voltou a estudar após dez anos. O fato mais importante neste trecho é que o sujeito não foi reprovado nas séries iniciais, sendo assim, podemos admitir minimamente que, mesmo que tenha vivenciado dificuldades de aprendizagem, estas não resultaram em fracasso, representado pela reprovação. Obviamente, este fato não afasta nem aproxima o sujeito de qualquer meta, pois poderíamos ser levados a acreditar que o sujeito se aproxima da meta aprender, afinal não sentiu o gosto amargo do fracasso. Entretanto, seu êxito poderia representar justamente o contrário, ou seja, esforçou-se tanto, ao ponto de se imaginar com alguma dificuldade para aprender, aproximando-o, então, da meta performance-evitação.

2 - P: Quando você parou nas primeiras séries, você parou em que série, você parou porque?

E: Bom, eu parei porque todas as vezes em que eu comecei a estuda alguém me seguia aí eu ficava com medo, com medo, de ir pra escola sozinha, ai eu fiquei com medo ai eu peguei e sai da escola, as três vezes aconteceu, aí quando foi o ano passado, foi que uma amiga minha começou a estuda ai eu continuei, mas não por falta de vontade eu sempre tive vontade, mas cada vez que eu ia sempre tinha alguém no caminho querendo atrapalhar e eu (trecho inaudivel).

P: Até quando você era criança

E: Não, quando eu era criança não, eu era criança eu comecei a estuda eu já.. já grande.

P: Quantos anos? 


\section{E: Eu morava na roça \\ P: Há...complicado né \\ E: $\dot{E}$.}

Neste relato, o sujeito nos conta sobre as dificuldades inerentes à permanência na escola fora dos grandes centros urbanos, pois morava na roça no Estado da Bahia. Isto posto, para nossa pesquisa, o trecho mais importante refere-se ao fato de o sujeito enfatizar que não deixou de estudar por falta de "vontade", mas por motivos de força maior. Esta ênfase pode revelar alguma crença do sujeito, talvez ele acredite que quem desiste de estudar ou é por ser preguiçoso ou por falta de interesse, portanto, em seu caso, não se trata de nenhuma das duas hipóteses, pois afirma que sempre teve vontade. Por outro lado, podemos considerar que o sujeito não gostaria que o entrevistador, ou seja, seu professor julgasse que havia parado de estudar por ser preguiçosa, ou por falta de interesse. De qualquer forma, independentemente dessas duas hipóteses, o sujeito não gostaria de ser considerado indolente ou desinteressado.

3 - P: Aqui na pergunta número um, você falou que se preocupa em aprender e se cometer muitos erros, você colocou "Não concordo"?

E: Eu não concordo

P: Porque?

E: Ah... professor eu queria, sabe quando eu quero, eu quero aprende sabe o que eu to fazendo, não eu tá fazendo e errando

P: Mas e se erra?

E: Porque a maioria das vezes, você faz e erra, faz e erra

P: Mas entendeu e se você erra? P: O que que tem?

E: Tenta de novo(risos), é o que eu tenho feito (risos)...Errando e tentando de novo

O sujeito demonstra incômodo ao cometer erros ao realizar uma tarefa escolar, portanto, condição que o afasta da meta aprender, pois os sujeitos orientados a esta meta acreditam que os erros ou fracassos são inerentes ao processo de aprendizagem. Ora, esta crença é bastante importante, pois se liga nevralgicamente ao esforço, afinal os sujeitos orientados a esta meta, ao perceberem os erros empreendem ainda maior esforço, muitas vezes, acabam por mudar suas estratégias.

Sendo assim, nos deveríamos considerar que o sujeito aproxima-se da meta performance-evitação, entretanto chama-nos a atenção o fato de o sujeito não apresentar ansiedade ou mesmo angústia como é o caso do sujeito Ms orientado à meta performance-evitação (p. 160). 
Isto posto, talvez devêssemos considerar a hipótese de o sujeito acreditar na existência de um ilusório caminho seguro em direção ao conhecimento, ou talvez o sujeito tenha considerado o erro como perda de tempo? Pois, pretende "eu quero aprende sabe o que eu to fazendo, não eu ta fazendo e errando". Obviamente, este caminho seguro protege o sujeito da angústia do possível fracasso em relação ao processo, sendo assim, acreditamos que este trecho aproxima o sujeito da meta performance-evitação.

4 - P: Veja bem, você prefere aprender uma coisa que você já tem alguma ideia ou uma coisa nova?

E: Uma coisa nova

P: Mas se você aprende uma coisa nova, você não acha que você pode comete mais erros, do que aquilo que você já sabe, porque aquilo que você já sabe?!

E: Há mais aquilo que eu já sei, eu já sei, eu não cometo erros.

P: Não tem nem muita graça

E: $E^{\prime}$

P: Não adianta e você não vai comete nenhum erro.

E: Num vou te erro, mas o outro eu vou correr o risco de errar, mas eu vou te aquela dúvida, né

P: Então mais ai erra ou não, então como é que fica o erro aí?

E: Fica complicado

P: Você acha que, o que traz de ruim o erro?

E: Eu não gosto mesmo de erra sabe, eu gosto de faze tudo certinho

P: Você gosta de fazer as coisas

E: Certinha, tudo na metragem(trecho confuso), pra não te erro, pra não me arrepende depois.

O sujeito afirma que gostaria de aprender coisas novas, mas esta situação o incomoda, pois traz o risco inerente da possibilidade do erro. Em seu discurso, não existe relação entre o binômio erro-esforço, próprio dos sujeitos orientados à meta aprender. Por outro lado, nos chama a atenção não estarem presentes em seu discurso sentimentos de angústia ou ansiedade típicos dos sujeitos orientados à meta performance-evitação.

Contudo, este sujeito reafirma nossa impressão de que ilusoriamente acredita que poderia aprender sem correr o risco de errar: "Certinha, tudo na metragem(trecho confuso), pra não te erro, pra não me arrepende depois”. Será que este sujeito acredita que o professor pode ensiná-lo como num passe de mágica, conduzindo-a por um caminho seguro em direção ao conhecimento, constituindo-se um pacto inconsciente a fim de evitar sentimentos angustiantes? No mesmo sentido, este desejo inconsciente 
poderia constituir-se em uma crença epistemológica baseada em uma metodologia extremamente transmissiva em relação a seu papel como aprendiz? Pois bem, se assim o for obviamente não podemos aproximar este sujeito da meta aprender, nem tampouco poderia ser classificado como alguém orientado à meta performance-evitação. Esta hipótese justificaria a não existência de sentimentos angustiantes em seu discurso, na medida em que não está convencido de uma suposta inabilidade cognitiva. Todavia, quaisquer destas hipóteses necessitam ser corroboradas por outros dados.

5 - P: Você colocou assim, você se sentiria realmente bom se fosse o único que respondesse as perguntas do professor da classe, como assim?

E: Eu só, eu morro de vergonha, o professor pergunta ele está lá e eu to daqui pra responde, eu gostaria de se mais assim aberta, sabe tipo o professor pergunta e eu te a resposta pra fala, às vezes eu tenho a resposta e tenho a vergonha pra fala.

P: Você tem vergonha porque?

E: De responde errado, de erra.

P: Mas se você erra o que que pode acontece

E: A minha vergonha é de vaiarem [P: Hum...] E: Esse é meu medo.

Antes de iniciarmos a análise, é preciso deixar bem claro que ninguém gostaria de ser motivo de risos por parte de professores e colegas, caso respondesse algo de errado em sala de aula. Contudo, devemos ressaltar que os sujeitos Del e Au, ambos orientados à meta aprender e o sujeito $\mathrm{M}$ orientado à meta performance-aproximação parecem não se incomodar, pois se arriscam sem se preocuparem. No primeiro caso, os sujeitos orientados à meta aprender podem mostrar o quanto sabem, fruto de muito esforço. No segundo caso, este pode mostrar sua suposta superioridade intelectual. Ora, acreditamos que assim o fazem por terem vivido um maior número de situações onde obtiveram êxito em relação a uma possível humilhação, de qualquer forma, demonstram possuir um auto-conceito robusto o suficiente para suportarem a possibilidade de se exporem ao ridículo.

Isto posto, devemos considerar este temor à exposição pública como sintoma de alguém orientado à meta performance-evitação, se e somente se, este medo vem acompanhado de um auto-conceito pejorativo sobre si mesmo, por exemplo, o sujeito se considera incapaz para aprender. Portanto, este cuidado metodológico se faz necessário para escaparmos dos casos de indivíduos que sofrem do excesso de timidez. Talvez seja o caso deste sujeito, pois afirma que gostaria de responder abertamente em sala de aula, todavia, teme ser motivo do riso alheio. 
Contudo, acreditamos que este sujeito se aproxima da meta performanceevitação, pois teme situações em que possa ocorrer sua exposição pública. Entretanto, ainda não estamos convictos de que ele desconfia de sua capacidade intelectual, hipótese que necessita de novos dados para ser corroborada.

6- P: É... então, por exemplo, você está falando sobre a questão do erro

E: Do erro

P: Mas e se o professor desse as respostas certas, não seria melhor?

E: Seria bom ele dar as respostas certas, só que é bom a gente às vezes quebra a cabeça um pouquinho pra vê se pega mais rápido o assunto, sabe

P: Hum... Hum....Então você preferia qual dessas duas estratégias, que nem você colocou aqui por exemplo: tarefa que eu gosto de fazer é aquela que eu realmente possa pensar?

E: Certo, eu gosto, eu gosto de faze assim uma coisa que eu to sozinha quieta, sabe pra eu pega aquilo ali, eu começa e termina

$\mathrm{P}:$ Hum, mas por exemplo, do outro lado o professor chega e dá as respostas né, explica e a explicação dele dá as respostas

E: Por exemplo, o professor vai lá dá aquela, deu aquela explicação então naquilo ali eu ir naquela coisa certa [P: Hum..] E: Não eu está fazendo, depois eu vê que eu fiz errado, ai o professor vem dá outra resposta [P:Hum...Hum] E:Entendeu, eu gosto de pega a explicação pra eu já ir naquele assunto, direto no assunto

P: Certo

E: Porque eu já estou pensando naquela coisa, não depois eu pensei aqui, é esse assunto, aí depois ele dá outro, ai eu falo "Ah não vou ter que esquecer tudo que eu fiz não aquilo é outra coisa."

Nos primeiros dois trechos, o sujeito demonstra o nível de esforço que pretende empreender: "quebra a cabeça um pouquinho". Também, demonstra o nível de concentração: "eu gosto de faze assim uma coisa que eu to sozinha quieta". Sem sombra de dúvidas, este sujeito não se encontra orientado à meta aprender da mesma forma que os sujeitos Del e Au em relação à disposição ao esforço e ao livre pensar. Portanto, parece ser adepta ao mínimo esforço, considerando que este mínimo esforço signifique realizar as tarefas propostas pelo professor do começo ao fim, com certo nível de envolvimento ou concentração, condição razoavelmente melhor se considerarmos aqueles alunos que não pretendem dispensar esforço algum.

Estes trechos esclarecem sua relação com erro, ou seja, sua ocorrência não a faz acreditar que possui alguma incapacidade cognitiva, o que a aproximaria dos sujeitos orientados à meta performance-evitação. Por esta razão, estão ausentes em seu discurso, pelo menos, até este momento, sentimentos de angústia e ansiedade, ou um autoconceito pejorativo sobre si mesmo. 
Nos dois últimos trechos, o sujeito acredita que cometer erros durante a execução de alguma tarefa significaria que ele estaria perdendo tempo: "Entendeu, eu gosto de pega a explicação pra eu já ir naquele assunto, direto no assunto”, corroborando a impressão que tivemos em relação ao trecho 4 desta análise. Obviamente, desta forma, o sujeito escaparia à possibilidade de fracasso e angústia próprias do processo.

Isto posto, estes trechos também fortalecem nossa convicção de que o sujeito aposta em uma epistemologia transmissiva centrada ilusoriamente na atuação da figura do professor conduzindo-a pelo caminho seguro do conhecimento: "o professor vai lá dá aquela, deu aquela explicação então naquilo ali eu ir naquela coisa certa”. Talvez esta ideia opere inconscientemente, constituindo-se uma crença capaz de evitar que o sujeito entre em contato com sentimentos angustiantes em relação à possibilidade de fracasso.

Sendo assim, podemos discutir as possíveis consequências destes condicionantes para o ensino sócio-construtivista, na medida em que esta metodologia aposta no conflito cognitivo como motivador intrínseco, possivelmente este pode produzir ansiedade em relação ao fracasso das ideias alternativas do sujeito. Este poderá vivenciar situações em que será fomentado a sustentar seus argumentos junto aos demais integrantes do grupo, produzindo, até mesmo, algum tipo de conclusão, que poderá ser temporária. Pode haver momentos, durante o processo, em que o sujeito não possa contar com a garantia segura da anuência do professor, logo a metodologia pode produzir sentimentos angustiantes relativos à possibilidade do fracasso. Portanto, o trecho: Porque eu já estou pensando naquela coisa, não depois eu pensei aqui, é esse assunto, aí depois ele dá outro, aí eu falo "Ah não vou ter que esquecer tudo que eu fiz não aquilo é outra coisa", parece ir ao encontro da experiência da professora Ma que pretendia ensinar conceitos de mecânica baseada nesta metodologia.

7 - P: Então mas veja bem, por exemplo: se o professor der tudo, a sua capacidade de pensar?

E:Não, não é que ele vai dar tudo certo... é que ele dá, dê, ele explique.

P: Então imagine a sexta série... Não continue, termine, termine

E: Que ele explique, ai ele explico, mas ele explique assim aquela...uma coisa concreta, sabe naquela explicação pra eu acha a resposta naquilo que ele falo

P: Hum...hum...

E: não que eu fique no ar

P: Porque qual o problema de ficar no ar? 
E: Porque aí eu vou estar pensando, é será que eu fiz certo, será que o professor vai criticar, será que eu fiz errado?

Neste trecho, o sujeito acredita que o professor poderá explicar de forma segura para garantir o aprendizado de forma linear. Portanto, o sujeito não pode se sentir perdido, sem saber, se o caminho que escolheu o levará ao êxito: isto posto, fica claro que o sujeito aposta no modelo tradicional de ensino no qual o principal protagonista é o professor devendo facilitar a transmissão do conhecimento. Consequentemente, o papel do aluno resume-se a executar as orientações do mestre com tal zelo e dedicação efetivando o aprendizado do conteúdo.

Sendo assim, é natural a preocupação do sujeito em relação ao possível julgamento do professor: "será que o professor vai criticar, será que eu fiz errado?". $\mathrm{Na}$ medida em que acredita que ao realizar todas as operações indicadas pelo professor obterá êxito, em acordo com a metodologia tradicional de ensino. Portanto, esta preocupação é bastante diferente dos alunos orientados à meta performance-evitação, pois ao se exporem ao julgamento do professor, eles temem o risco que este venha a saber sobre sua suposta incapacidade cognitiva.

8 - P: Por exemplo, assim é...imagina na sexta série, por exemplo, pelo menos naquela época em que eu fiz foi assim, o professor vinha dava aquele texto pra você copia, depois ele fazia cinco perguntas sobre o texto

E: Certo

P: Para você responde, pronto

$E: E^{\prime}$

P: Mais certo do que isto

$E: \dot{E}$

P: ou mais seguro do que isto, não existe

E: Tipo ó... isso que tá certo, eu gostava, eu gosto tipo de geografia, a gente faz uma geografia e história são desse jeito o professor vai e passa um texto naquele texto ele tira cinco, seis questões ai a gente vai respondendo, ai a gente reponde do nosso jeito [P: Hum] E: respondeu tudo aí[P: Hum.] E: A nossa resposta, ali direitinho, depois o que que acontece, ele vem, vai corrigi, ai a resposta é completamente diferente, então a gente fez aquilo ali, achando que é do nosso jeito, tirando $\mathrm{P}$ (interrompe):

P: Então você lê o texto, entendeu, você lê o texto, onde está a sua condição de pensa?

$E: E$ isso, a gente tira exatamente do texto, coisas que a gente acha do texto o que realmente é, ai ele chega não, inclusive agora mesmo a gente teve um, que ele, eu já não, já não apago aquilo e vou fazer de novo, eu já deixo aquela folha que eu fiz que é pra vê o que eu fiz e respondo a que ele mando [P: Hum...Hum] E: Que é pra eu vê o que eu fiz

P: Pra compara né? 
E: Compara qual é o erro, eu já não apago mais, eu já deixo, inclusive o ano passado eu também fiz isso, eu falei "já não vou apaga mais" que ai eu já sabia a aonde que errei e o que que ele fez de diferente da minha né [P: Hum..hum...]

O sujeito exemplifica como funciona esta metodologia tradicional de ensino, o professor detentor do saber disponibiliza o conhecimento através de um texto, ele então explica fornecendo a interpretação correta. O papel do aluno resume-se a copiar diligentemente as questões da lousa, ler o texto e responder o mais próximo possível do entendimento que teve das explicações do professor: "É isso, a gente tira exatamente do texto, coisas que a gente acha do texto o que realmente é”. Ora, não há um senão em relação à encenação do sujeito, afinal foram anos de treinamento seguindo à risca o roteiro passivo do papel destinado ao aluno pela metodologia tradicional de ensino. $\mathrm{O}$ ato final está linearmente previsto e finalizado pela correção do professor. Durante este processo, o aluno deve manter-se disciplinado, corrigindo copiosamente suas respostas a fim de aproximá-las com as do mestre. Neste modelo, não deve haver ansiedade ou angústias em relação à consecução do objetivo; erros e dúvidas mostram falhas nos procedimentos operacionais devendo ser expurgados do processo.

No parágrafo anterior exageramos em estabelecer a relação entre a falta de autonomia e o papel do aluno no modelo tradicional de ensino. Ora, devemos considerar que os sujeitos Del e $\mathrm{Au}$ foram formados por este modelo e mostrando-se bastante autoconfiantes e consequentemente autônomos. Isto posto, parece que algo ocorreu neste processo permitindo que estes sujeitos se apoiassem no papel do professor, sentiram-se seguros e confiantes nesta relação, esta confiança foi internalizada permitindo aos sujeitos se descolarem do papel do professor. Portanto, em se tratando do modelo tradicional de ensino, podemos considerar que estes sujeitos reescreveram um capítulo a mais referente à autonomia pertinente ao papel do aluno neste modelo. A bem da verdade, o próprio sujeito En parece estar se desenvolvendo neste sentido, pois ao corrigir, compara, ao invés de somente copiar: "já não vou apaga mais” que aí eu já sabia a aonde que errei e o que que ele fez de diferente da minha né”, demonstrando avanço na direção de maior autonomia.

Contudo, será que este avanço permitirá ao sujeito a autonomia mínima para seu envolvimento ativo? Podemos imaginar, por exemplo, o impacto causado pela sensação de desequilíbrio produzida pelo conflito cognitivo em uma experiência crucial. Obviamente, diferentemente de aluno orientado à meta performance-evitação que 
acreditaria que o fracasso se deve a sua inabilidade intelectual, este sujeito adepto à metodologia tradicional poderia criticar a nova metodologia, pois poderia sentir-se angustiado, confuso, perdido, e, como protesto, ao final, perguntaria: "professor, porque o Sr. fez a gente passar por tudo isto, se já sabia a resposta?”

Antes de finalizarmos este trecho, gostaríamos de tecer alguns comentários sobre o auto-conceito e a sensação de auto-eficácia do sujeito. Podemos conjecturar que o rol de estratégias relativas à auto-eficácia do sujeito estejam ligadas ao seu papel de aluno própria do modelo tradicional de ensino, devemos acreditar que o sujeito agiu de acordo com este método e obteve sucesso. O esforço aparece limitado, pois está preso e amalgamado à atuação do professor, pois quanto mais competente for este profissional ao explicar o conteúdo, menor será a quantidade de esforço que este despenderá para aprendê-lo. Sendo assim, é provável que tenha vivido poucos momentos de autonomia, envolvendo-se ativamente em seu processo de aprendizado, pois tem dificuldades em lidar com a ansiedade ou de se sentir perdido durante o processo. Isto posto, o sujeito não deve sentir-se tão confiante para aprender, pois não possui um cabedal relativo à auto-eficácia capaz de lhe garantir maior nível de segurança, inflando seu auto-conceito. Portanto, acredita em si mesmo, empreende esforço, mas é dependente da atuação do professor. Talvez, isto justifique a diferença em relação à autoconfiança em comparação com o sujeito Del e Au.

9 - P: Você acha que aprender é fácil?

E: É dificil

P: Porque?

E: Eu acho difícil, sempre uma coisa nova é dificil.

P: Então, mas o que que é difícil, o que precisa para aprender, o que você acha que é determinante para um aluno aprender?

E: Uma boa explicação, pro aluno aprende direitinho, presta bastante atenção, não tem aquela confusão que tem lá, eu acho que isto ajuda bastante a aprende direito.

P: E que mais?

E: Eu acho que pra mim é só isso.

O sujeito não cita o esforço como uma de suas estratégias para aprender, resume-se a prestar atenção à explicação do professor, confirmando nossa impressão sobre sua dependência em relação à atuação dele; por esta mesma razão, vemos surgir o binômio explicação-aprendizado parecendo estabelecer uma relação de causa e efeito, ou seja, se o professor explicar bem, então aprenderei. Indubitavelmente, para este sujeito o bom professor é aquele que explica bem. 
Obviamente, o que está em jogo aqui é saber o quanto o sujeito acredita nesta ilusão e consequentemente, qual será o comportamento deste, caso não consiga aprender com a explicação do professor, ou seja, ele empreenderá maior esforço ou desistirá? No primeiro caso, esta decisão o iria aproximar da meta aprender, entretanto, como evoluiria, por exemplo, sua sensação de confiança e a manutenção de níveis aceitáveis de ansiedade e angústia durante o processo? Por outro lado, caso desista, será que se culparia pelo fracasso? Ou elegeria o professor como bode expiatório, pois este não foi competente o suficiente em sua explicação para garantir-lhe o sucesso? Ora, estas dúvidas surgem exatamente devido ao fato de o sujeito não se encontrar orientado à meta aprender nos mesmos níveis do sujeito Del e Au, nem tampouco encontra-se motivado à meta performance-evitação conforme os sujeitos Ms e En.

10 - P: Você acha que é necessário esforço?

$E: \dot{E}$

P: Mas em que sentido?

E: Em todos, acho que quanto mais se esforçar, melhor é.

P: Você acha que o professor pode influenciar neste esforço?

E: Eu acho que pode

P: Como?

E: Em primeiro lugar com amizade, amizade vem em primeiro lugar, tem dia que o professor chega na sala e já enfrenta a turma o aluno numa boa, não que já chega criticando, já chega brigando, que tem professor que chega na escola, na sala de aula, já...

P: Atacado

E: Atacado já, já revoltado querendo quebra tudo, acho que isso aí o aluno fica com mais raiva ainda, mais revoltado e ai já que sai da aula antes do tempo.

Até este momento, não havia surgido no discurso do sujeito o binômio esforçoaprendizagem, assim sendo, perguntamos diretamente ao sujeito para que este discorresse sobre esta relação. O sujeito fala genericamente do esforço, mas não estabelece nenhuma relação entre o esforço e seu comportamento para aprender. Por outro lado, quando perguntamos de que forma o professor pode influenciar neste esforço, o aluno espera que o professor seja "amigo", obviamente que, em qualquer modelo de ensino, seja tradicional ou não, um professor que respeita os alunos é fundamental. Entretanto, esperávamos ouvir, por exemplo, que o professor influencia no esforço na medida em que explica bem a matéria, é paciente com as dúvidas, trata os alunos de forma amável, talvez estes atributos estejam embutidos no adjetivo "amigo" utilizado por $E n$. 
Por outro lado, será que todos estes atributos são importantes? Pois se o sujeito espera ser conduzido de forma segura pelo aprendizado, o professor deve ser especialmente sensível a fim de evitar a todo custo que seus alunos se deparem com sentimentos de angústia em relação à possibilidade do fracasso. Portanto, o sujeito confere um peso muito especial ao papel do professor em relação a sua motivação para aprender, conforme Silva (2004 p. 185) concluiu: "Os alunos consideram o professor como um elemento muito importante e o único responsável por sua motivação. Seu discurso raramente atribui a si mesmo esta responsabilidade ou possibilidade, num procedimento que talvez seja mesmo inconsciente, de transferir para o outro a responsabilidade ou a culpa.".

11 - P: Quais estratégias assim, o que você faz pra você aprender? Que tipo de estratégias você faz para aprender?

E: Olha, eu leio muito, eu presto muito atenção, nas aulas, nas explicações, eu não vou fica tirando minha atenção, se eu to ali pra estuda, eu quero tá mesmo ali sabe, eu não quero tá pensando outra coisa, é... vendo outras besteiras que os outros estão fazendo eu quero fica naquele assunto meu pra eu sabe desenvolve direito aquilo ali, entendeu.

O sujeito En neste trecho demonstra o quanto considera importante estudar. Devemos levar em consideração que o sujeito retornou, após anos afastado da sala aula, portanto, é natural que pretenda aprender ao máximo. O sujeito também relata implicitamente a forma de como pretende aplicar seu esforço, ou seja, prestar atenção às explicações do professor, manter a concentração e a disciplina não se distraindo como os demais colegas que ficam: "pensando outra coisa, é... vendo outras besteiras que os outros estão fazendo". Pois, acredita que agindo assim poderá: "desenvolve direito aquilo ali”. Isto posto, acreditamos que neste trecho o sujeito se aproxima da meta aprender, pois além de valorizar o aprendizado, pretende empreender esforço para a obtenção do conhecimento, contudo o nível deste esforço parece estar vinculado fortemente à atuação do professor.

Devemos ressaltar que o esforço do sujeito traduzido na forma deste comportamento está de acordo com o papel do aluno no modelo tradicional de ensino. Neste modelo, a disciplina possui papel importante, agora entendemos porque os alunos sempre apontam como algo que atrapalha muito o aprendizado referindo-se à indisciplina, obviamente, que em meio à confusão não é possível aprender, entretanto a disciplina é nevrálgica neste método. Talvez, isto justifique porque ao agruparmos os 
alunos muitos se ressentem, afinal, em comparação com os alunos enfileirados disciplinarmente, o agrupamento confere maior confusão ao ambiente de aprendizado.

12 - P: Você estuda, assim antes da prova?

E: Estudo, sempre que eu posso eu estudo.

P: Você falou pra mim, por exemplo, agora que você respondeu, por exemplo está errado mas você não apaga o que colocou, você coloca a outra.

E: A outra resposta pra depois.

P: Pra depois.

E: Pra depois eu vê, pra depois eu compara.

P: Hum

E: Pra vê se está correta.

P:Porque você acha que você fez isto?

E: Olha, talvez seja um costume, um hábito que eu já tenho, mas eu quero vê, se eu respondi aquilo ali correto.

P: Isto de ajuda em que você poderia apagar e colocar a resposta certa do professor, no que que isto te ajuda?

E: Isto me ajuda a ver se eu estou sempre errando, se eu estou fazendo alguma coisa está indo em frente, sabe se eu to seguindo o caminho dele, não que eu estou seguindo ele, que eu estou seguindo a resposta certa.

P: Hum.

O sujeito En, diferentemente dos alunos orientados à meta performance-evitação aqui analisados, não desistiu de estudar antes das provas. Além do mais, o sujeito estabeleceu como processo metacognitivo manter suas respostas, ao invés de somente copiar as respostas corretas do professor, pois pretende saber como está evoluindo sua aprendizagem. Assim sendo, este comportamento aproxima o sujeito da meta aprender, pois o sujeito demonstra estar interessado em otimizar seu processo de aprendizagem.

13 - P: O que é um bom professor?

E: Um bom professor é aquele que explica bem, que chega na escola, sabe faze o que ele está fazendo mesmo, não aquele que chega lá e senta e faz de conta que não está fazendo nada, saiba dá uma lição, aos alunos, ao colega, acho que esse sim é um bom professor.

P: Então, o que é um bom aluno?

E: Aquele que chega na escola e sabe o que que, que estuda.

Este trecho vai ao encontro de nossa impressão de que para o sujeito o "bom" professor é aquele que explica bem e domina o que está fazendo. Obviamente, explicar bem e dominar o conteúdo são condições fundamentais para um "bom" professor. Todavia, conforme visto em outras seções desta análise, talvez estas qualidades sejam de suma importância, pois o sujeito acredita que o professor é o responsável em 
transmitir-lhe os conteúdos linearmente, diminuindo a possibilidade de o sujeito entrar em contato com sensações angustiantes próprias do processo de aprendizagem.

Isto posto, já que o professor tem um papel bem definido no modelo tradicional de ensino, é natural supormos que o aluno também o tem. Sendo assim, para que o processo produza êxito, é necessário que o aluno cumpra com seu papel, ou seja, venha à escola para estudar cumprindo com suas obrigações de aluno. Ora, estas condições não são mais possíveis, afinal o professor não possui o poder de disciplinar toda a sala como antigamente, nem tampouco os alunos conseguem prestar atenção mais do que quinze ou vinte minutos à fala do professor. Portanto, parece ser razoável a queixa generalizada: os professores reclamam que não conseguem ensinar devido à indisciplina, ou alunos interessados reclamam que não conseguem aprender devido também à indisciplina, todos parecem olhar nostalgicamente para o passado.

P:Qual a relação entre o bom professor e o bom aluno, existe uma relação entre os dois, existe uma ligação entre os dois?

E: Olha eu acho que é a melhor possivel, bem melhor do que um aluno rebelde chega na escola e encontra um professor bonzinho.

P: Porque você acha que tem aluno rebelde?

E: Eu acho que já vem de longe, já vem de infância, viu

P: Como é que se acha que um aluno fica rebelde, o que você acha assim?

E: A criação professor.

P: Você acha que é a criação?

E: Eu acho que é a criação.

P: O que é que falta? Porque um aluno é rebelde e outros não são?

E: Olha, eu acho que os pais não sabem educa de direito, assim pra um aluno chega na escola e sabe o que ele tá fazendo, tipo uma criança chega na...tá comendo um doce, aí pega aquele papel e joga fora, na rua, se o pai brigasse com ele, pra ele não joga aquele papel na rua, jamais ele ia joga de novo.

P: Às vezes até o pai joga também.

E: Até o pai pega e joga (risos)... aí a criança joga e aí vai, vai indo.

Independentemente da meta, os alunos, de um modo geral, costumam valorizar o papel do professor. Contudo, conforme já foi relatado em outras sessões, os sujeitos orientados à meta aprender valorizam o papel do professor, exatamente pelo fato de estarem interessados em se desenvolver academicamente, logo este profissional deve ser respeitado. Implicitamente, este respeito parece estar ligado a valores desenvolvidos no seio das famílias, logo a rebeldia discente é considerada uma falha na educação por parte dos responsáveis diretos. 
14 - P(interrompe): Às vezes tem algumas coisas que são mais difíceis, não é assim pra aprende, e quando não aprende?

E: Eu tento de novo, a gente quer aprende.

P: Quem é culpado?

E: Eu acho que é o aluno.

P: Porque?

E: Porque às vezes, olha (risos) inclusive matemática é comigo, às vezes matemática tem assunto que entra na minha cabeça tem assunto que não entra na minha cabeça, eu não culpo o professor, eu me culpo.

$\mathrm{P}:$ E o que você sente?

E: Ah, eu fico revoltada porque eu queria sabe, nossa, eu queria sabe faze, eu não consigo faze uma conta que eu não estou contando nos dedos ou não estou pegando numa calculadora, então eu não culpo o professor, eu sempre me culpo.

O sujeito enfatiza querer aprender e sente-se frustrado quando isto não ocorre, considerando a matemática um conteúdo muito difícil, pois afirma: "tem assunto que não entra na minha cabeça", ou seja, será que considera que "sua cabeça é muita dura para aprender" matemática? Esta crença aproximaria o sujeito En da meta performanceevitação, pois acredita não possuir atributos cognitivos para aprender esta disciplina, inclusive direcionando raiva a si mesma: "eu fico revoltada porque eu queria sabe" e culpa-se por esta situação, similar ao comportamento do sujeito Ga orientada à meta performance-evitação. Soma-se a isto o fato de o sujeito em seu discurso não aludir ao esforço, ferramenta capaz de modificar esta situação, portanto talvez o sujeito sinta-se perdendo o controle da situação aproximando-o também do conceito de desamparo.

Entretanto, o sujeito En não parece ficar tão angustiado com estas constatações, também não coloca o mesmo peso nestas situações se comparado às significações presentes nos discursos dos sujeitos Ms e Ga. Tampouco vemos o sujeito elaborar uma trama ilusória na qual está predestinado ao fracasso, consequência de uma suposta inabilidade intelectual. Portanto, será que sua revolta, sua mágoa, surge por não conseguir alcançar os padrões de inteligência que acredita serem necessários para aprender matemática com maior facilidade, ou seja, aprender apenas com a explicação do professor? Ou seja, ela gostaria de ser tão inteligente ao ponto de aprender tudo em acordo com a transmissão do mestre. Veremos se esta inferência é respaldada pelos dados.

15 - P: Você falou que gosta de pensar, não é isso?

E: Gosto

$\mathrm{P}:$ Quando você chega em uma solução, o que você faz?

E: Eu fico feliz, eu me sinto realizada, que eu consegui.

$\mathrm{P}$ : Imagina que você estudou para uma prova, só que você se confundiu e tirou uma nota $\mathrm{C}$, o que você sente? 
E: Eu fico com raiva, estudei pra caramba, dei tudo de mim, chega na hora, às vezes dá um branco e eu faço tudo ao contrário.

P: Então, mas qual sentimento que você sente, assim?

E: Ah, eu fico triste.

Neste trecho, os binômios ansiedade-fracasso estão presentes assim como os sentimentos de raiva. Entendemos aqui ansiedade, como um excesso de energia psíquica acumulada e obstada na forma de preocupações, neste caso, relacionadas à possibilidade do fracasso ou êxito diante de exames ou provas. Portanto, este trecho aproxima o comportamento do sujeito En daqueles orientados à meta performance-evitação, na medida em que o sujeito sucumbe aos sentimentos de ansiedade.

Entretanto, os sujeitos orientados à meta aprender, após estudarem, sentindo-se demasiadamente pressionados, também pode lhes acontecer a perda repentina da memória no momento das provas. Devemos, também, ressaltar sobre a análise realizada até este momento; esta não nos permite ter a convicção de que este sujeito En está convencido de sua suposta incapacidade intelectual. Portanto, o sujeito não está sempre alerta, hipervigilante quanto à possibilidade de que outros venham a saber sobre esta suposta debilidade cognitiva, como é o caso dos sujeitos Ms e Ga ambos orientados à meta performance-evitação. Assim sendo, não surge no discurso do sujeito En um fantasmagórico instrumento de tortura com a qual o sujeito possa se imolar, exemplo: no caso do sujeito Ms, quando tinha que ir para a lousa (grifo nosso): ou, referente à opressão vivida pelo sujeito Ga, pois segundo os diversos relatos destes sujeitos são inúmeras as situações nas quais eles podem ser vítimas do julgamento alheio sentindose oprimidos.

Isto posto, podemos conjecturar sobre o que está realmente reclamando o sujeito En. Nas secções anteriores, concluímos que o sujeito espera ser conduzido de forma segura pelo processo de aprendizado. Portanto, acredita ilusoriamente que o professor poderá impedir-lhe de passar por sentimentos de ansiedade, ou, ainda transmitirá o conhecimento de forma a evitar-lhe sentir-se "perdida" durante processo, pois pretende fazer tudo certo.

Ora, estas crenças sobre ensino-aprendizagem em nosso entender são oriundas do método tradicional de ensino, pois os papéis do professor e do aluno são bem definidos, o primeiro ensina e o segundo aprende. Outra concepção neste método é que os processos avaliativos estão mais preocupados com a performance do sujeito, separando-os de acordo com seu resultado e com o passar do tempo; os alunos são 
divididos em inteligentes, esforçados e inteligentes, alunos medianos e os medíocres. Gustone (obra citada): “[...] encontrou um número considerável de estudantes que acreditam que, para aprender física, é necessário possuir dois atributos: ser muito inteligente [...] “ (grifo nosso). Parece-nos, então, que o sujeito En reclama não porque se considera com alguma suposta debilidade intelectual, pelo contrário, sua reclamação, sua mágoa, sua revolta significa que constatou não ser dotada de grande inteligência, como ela gostaria de ser, tão inteligente ao ponto de captar com facilidade o conhecimento transmitido pelo mestre. Não está interessada em mostrar seu alto cabedal cognitivo como o sujeito $\mathrm{M}$ orientado à meta performance-aproximação. Todavia, caso tivesse uma grande inteligência, imagina que poderia ir bem em todas as provas, sem preocupações, sem angústia, tornando-se a aluna exemplar que todo mestre merece. Entretanto, devemos ressaltar que esta conjectura necessita ser corroborada pelos dados.

Antes de iniciarmos a análise do trecho a seguir, informamos que ele é muito extenso e decidimos dividi-lo.

16 - P: Por exemplo, quando o professor propõe um desafio, como você se sente?

E: Eu topo (risos), eu fico, eu vou à luta, eu fico feliz, eu quero, eu quero vê se eu consigo, eu vou batalha pra consegui.

P: Então... um desafio tem dois lados, não tem?

E:Tem

P:Qual é ...

E: $O$ de consegui e o de não consegui.

$\mathrm{P}: \mathrm{E}$ ai?

E: Ah, se eu não consegui, quando mais eu tentei.

P: Mas, isso vai dizer alguma coisa em relação a sua pessoa?

E: Não, se eu não consegui, eu não vou ter vergonha de não ter conseguido.

P: Mas, assim sei lá, poxa não tenho capacidade pra fazer isso, vai passar este sentimento por você?

E: Não tem um ditado que diz que mais vale uma lágrima de não ter vencido do que a vergonha de não ter lutado né, eu vou chorar por não ter vencido, não por não ter lutado, se eu não tivesse lutado eu teria ficado triste.

Neste trecho, o sujeito afirma que não se sente ansioso temendo o fracasso, quando o professor propõe um desafio, muito pelo contrário, sente-se desafiado e segundo suas palavras: "eu vou à luta, eu fico feliz, eu quero, eu quero vê se eu consigo, eu vou batalha pra consegui". Esta ênfase em seu discurso nos faz lembrar do sujeito Del: "como é que eu vou criar minhas táticas se eu ganho sem dificuldade, sem dificuldade não há vitória, sem guerra não há vitória." (p.110). O sujeito En sente-se forte o suficiente para se colocar à prova, portanto, este trecho aproxima o sujeito da meta aprender, pois os sujeitos acreditam que com esforço e dedicação obterão êxito. 
Este trecho, é oposto a trechos anteriores do discurso nos quais o sujeito mostrou-se revoltado ao cometer erros, afirmou sentir raiva de si mesmo, no caso de não conseguir ir bem nas provas, um sujeito que acredita que tem muita dificuldade para aprender matemática, pois esta disciplina, segundo seu relato: "não entra na minha cabeça”. Ora, todas estas crenças e emoções poderiam sinalizar a possibilidade de o sujeito En desconfiar de uma suposta inabilidade cognitiva, aproximando-o daqueles sujeitos orientados à meta performance-evitação. E, o que dizer sobre o conceito de desamparo, na medida em que o sujeito afirmou não gostar de vivenciar situações em que possa se sentir perdida? De repente, o sujeito dá uma guinada no discurso, e, prontamente, o sujeito $E n$ se apresenta para a batalha sem nenhuma dúvida quanto a sua possibilidade de sucesso, caso advenha o fracasso, filosofa: "eu vou chorar por não ter vencido, não por não ter lutado, se eu não tivesse lutado eu teria ficado triste”.

Isto posto, estas constatações além de afastar o sujeito da meta performanceevitação e do conceito de desamparo, reforçam nossas convicções de que quando este sujeito reclama, de que quando o sujeito se revolta, o faz porque gostaria de ser bastante inteligente para aprender tudo com extrema facilidade.

P: Mas eu não entendo porque você se incomoda tanto com os erros.

E: Porque eu me incomodo, muito, muito, muito com os erros.

P: Porque se por exemplo assim, se o professor propõe um desafio, você deveria dizer assim: "Putz, se eu errar eu estou ferrado" é mas você diz o contrário: "Não se eu errar, paciência pelo menos eu tentei, fazer o que".

E: É mais aí eu fico triste porque eu falo assim "Caramba, eu podia, sabe, será que eu poderia ter me esforçado mais, será que um pouquinho mais eu não ia consegui" [P (interompe)]

P: Mas você... [E: interrompe]

E: Ai eu fico com vergonha de não ter conseguido, mas tudo bem, porque [P(interrompe)]

P: Mas se acha então que com esforço, um pouco mais de esforço talvez

E: Talvez, poderia conseguir, um (fala junto com pesquisador) pouco de atenção a mais

Antes de iniciarmos, devemos esclarecer que fizemos a separação acima propositadamente, pois o sujeito En, agora parece estar orientado à meta performanceevitação, pois diante dos erros o sujeito se entristece, fica incomodado, exceto pelo fato de acreditar que com um pouco mais de esforço talvez obtivesse êxito: "poderia ter me esforçado mais, será que um pouquinho mais eu não ia consegui”, crença pertinente aos sujeitos orientados à meta aprender. 
Sendo assim, podemos perceber que o sujeito órbita entre estas duas metas. Em relação à meta aprender, o sujeito se esforça, mas este esforço é controlado e se liga à atuação do professor, pois acredita que um bom professor poderia transmitir o conhecimento linearmente evitando-lhe despender grandes quantidades de esforço. Sente-se confiante, entretanto, esta confiança não é superestimada como os sujeitos Del e Au que estão convencidos que o esforço é a chave para abrir o arcabouço do conhecimento.

Por outro lado, no tocante à meta performance-evitação, o sujeito tem medo de errar publicamente, pois teme ser alvo da zombaria alheia. O sujeito sente níveis de ansiedade quando percebe que não está aprendendo, ou quando se sente perdido, muitas vezes, parece se sentir desamparado. Entretanto, há um ponto nevrálgico que afasta este sujeito da meta performance-evitação, pois ele não está convicto de sua suposta incapacidade cognitiva. Todavia, parece se ressentir de não possuir um grande cabedal de inteligência. Será que estas constatações se tratam apenas de uma variação da meta aprender ou estamos diante de uma outra meta de realização?

17 - P: Você acha que, por exemplo, você domina seu processo de aprender, assim você acha que você domina isso...por exemplo

E: Eu acho que sim

P: Você se sente responsável pelo seu processo de

E: Eu me sinto.

P: Você sempre tirou nota boa?

E: Sempre [P: (Trecho incompreensível)] E: É, eu nunca fui de repeti, nunca repeti a não ser assim às vezes que eu parava nas, ai eu voltava

P: Aquela dificuldade né

E: $\dot{E}$.

O sujeito afirma que domina seu processo de aprendizado, apesar de não citar o esforço, implicitamente podemos considerar sua existência exatamente pelo fato de nunca ter repetido o ano escolar, indicando possivelmente que em momentos difíceis deve ter utilizado do esforço como estratégia para lhe garantir êxito.

Sendo assim, podemos conjecturar em relação ao conceito de auto-eficácia que o sujeito vivenciou situações em que teve de despender esforço para passar de ano, entretanto, esta situação deve ter sido penosa, por esta razão, talvez o sujeito desejasse possuir uma grande inteligência. Portanto, quando algo começa a ficar muito difícil exigindo maior esforço do sujeito este sente certo incômodo, e conclui: "se eu fosse mais inteligente, não estaria passando por isto". Destarte, este senso de auto-eficácia ao mesmo tempo em que permite ao sujeito sentir-se capaz, paradoxalmente também o faz 
acreditar que se fosse mais inteligente do que é, não necessitaria de tanto esforço para aprender.

18 - P: Bom assim, seus pais se preocupavam com suas notas quando você era criança?

E: Não porque eu nunca dei motivo

P: Mas assim você nunca sei lá, não soube alguma coisa na sala de aula?

E: Não sempre que as professoras me passavam as coisas eu sempre sabia faze, sempre me desenvolvi em qualquer coisa, eu sempre tinha uma resposta para aquele assunto.

A primeira constatação é a de que o sujeito não vivenciou situações vexatórias como aquelas de que foram vítimas os sujeitos Ms e Ga. Entretanto, devemos ressaltar que não necessariamente todo o sujeito orientado à meta performance-evitação passou por alguma situação vexatória.

Por outro lado, o sujeito afirma que sempre se desenvolveu e nunca deixou de dar conta dos conteúdos, obviamente que sente orgulho desta situação. Portanto, devemos perguntar: por que fica tão incomodada com as possibilidades do erro? Por que fica tão enraivecida quando não consegue aprender algum assunto? Ora, devemos considerar que o sujeito, conforme hipótese apresentada em outras seções, ressente-se por acreditar não possuir um alto nível de inteligência. Devemos ressaltar que o sujeito não nasceu com esta crença, mas ela deve ter sido elaborada pelo sujeito graças às interações interpessoais, portanto, possivelmente o fato de não atender com facilidade os altos padrões de excelência propostos por seus professores, levaram-na a acreditar, caso fosse muito inteligente; poderia enfrentar os desafios acadêmicos com maior facilidade.

19 - P: Tem alunos que quando recebem as provas ficam comparando notas (risos) tipo assim: "tiro A o outro tiro E, aaeehh!!" (risos) o que você acha disso?

E: Ah, eu acho legal, porque a gente vai compara quem erro, sabe, a gente vai corrigi o erro

P: Não mais a nota?

E: Não fica triste eu não fico, tipo um colega meu tiro $A$, eu tirei $B$, eu não vou fica triste [P:interrompe]

P: Ele tiro A, você tirou $\mathrm{E}$

E: Eu tirei E (risos)

P: Entendeu?

E: É, mas aí eu não vou fica triste, eu só vou fala: "Caramba, porque que eu errei, aonde foi que eu errei”, eu vou pergunta, olha pra dele pra eu ver onde foi que eu errei P: Mas você não pensa, assim por exemplo: "Poxa, como eu sou burra mesmo", assim uma coisa assim não vai passa pela sua cabeça?

E: Não, não vai passa, foi alguma falha eu errei alguma coisa, talvez estudei mal, talvez não tenha estudado direito, não acha que ele seja melhor do que eu. 
P: Ah, tá, se acha que você? E: Eu sou capaz, eu acho que sou capaz, posso não ter conseguido daquela vez, mas um dia vou conseguir é assim que eu penso.

P: Você vai?

E: Eu vou à luta que eu consigo.

O sujeito a princípio não parece ter entendido nossa pergunta, pois questionamos a respeito do fato de os alunos zombarem daqueles que tiram notas muito abaixo da média. De forma surpreendente, o sujeito então respondeu que aproveitaria a oportunidade para saber onde errou, levando-nos a acreditar que não entendeu a pergunta, afinal ser ridicularizada por uma performance tão medíocre não deve ser uma situação fácil. Além de parecer não entender nossa pergunta, o sujeito modificou-a, pois respondeu que não ficaria triste caso algum colega obtivesse nota máxima e ela uma nota muito próxima desta performance. Esta mudança na pergunta feita pelo sujeito parece sugerir que talvez ela acredite que esta situação seja pouco provável, ou seja, tirar uma nota tão medíocre. Principalmente, se levarmos em consideração trechos anteriores, nos quais, afirmou que nunca repetiu e sempre se desenvolveu em relação aos conteúdos.

Sendo assim, fomos obrigados a enfatizar uma situação hipotética na qual seu colega tira menção máxima e ela a pior performance, o sujeito afirma que mesmo assim irá comparar as notas procurando saber onde errou e não ficando triste. Em seguida, começa a elaborar possíveis justificativas para seu fracasso que vão desde não ter estudado o suficiente, a ter falhado ao estudar. De qualquer forma, estas justificativas são usadas como repostas, pois mencionamos na pergunta que uma nota tão medíocre não a faria pensar que é "burra". O sujeito não só elabora as justificativas relativas ao fracasso, mas também enfatiza: "Eu sou capaz, eu acho que sou capaz, posso não ter conseguido daquela vez, mas um dia vou conseguir". Este revés ao invés de fazê-la desistir aumenta a ainda mais seu desejo em continuar: "Eu vou à luta que eu consigo".

Contudo, esperávamos com esta pergunta que o sujeito reclamasse, sentindo-se indignado, revoltado, pois estudou e não obteve sucesso. Esperávamos ouvi-lo falar sobre seu desânimo por uma performance tão aquém de seus esforços, sentindo-se humilhado por uma menção tão medíocre em comparação com um suposto colega que obteve nota máxima. Pois, em seções anteriores o sujeito havia afirmado (trecho14): “[...] às vezes matemática tem assunto que entra na minha cabeça tem assunto que não entra na minha cabeça” em relação aos erros e ao fracasso afirmou (trecho15): “Eu fico com raiva, estudei pra caramba, dei tudo de mim, chega na hora, às vezes dá um 
branco e eu faço tudo ao contrário”. Agora, o sujeito muda o discurso dizendo não sofrer com tais situações, mas pelo contrário, pois caso ocorram irá se esforçar ainda mais. Novamente, estas constatações levam-nos a reforçar nossa crença de que este sujeito não duvida de sua capacidade intelectual, sua reclamação, sua mágoa se refere ao desejo de possuir um alto quociente de inteligência.

20 - P: Eh...você...O professor faz uma pergunta, você tem certeza da

E: Certo

P: Você responde ou espera que outra pessoa responda?

E: (risos) Olha sempre acontece isto, eu respondo baixinho ai uma pessoa vai " tá certo, vai, vai, vai responde, eu "não" porque eu fico com vergonha, mas eu tenho a resposta, "vai responde", eu falo "não" aí a pessoa vai e fala aquilo que eu falei

P: Hum

E: ai eu fico feliz

P: Porque você...

E: Porque eu acertei e dei um ponto pra alguém e alguém foi e teve a coragem de fazer aquilo que eu não tive

P: Hum, Hum P: Assim você se preocupa, então.... assim você se preocupa em parecer inteligente?

E: Não

P: Mas você se preocupa em não parecer burra

E: (risos) Eu me preocupo, eu me preocupo e às vezes também aquela vergonha de sabe, responder e aí porque eu não respondo certo e aí, o professor olha vai fala assim: "não você respondeu errado", aí os outros alunos vai fala: "aí... você sabia porque você não respondeu então, você respondeu e não respondeu certo"

P: Hum, mas ai...

E: Falam mesmo, sobre você (risos) falam sobre você...

O sujeito tem medo de se expor em público mesmo sabendo a resposta certa, prefere revelar para outra pessoa e fica feliz se esta acertar por ela. Inclusive reconhece a falta de coragem por não enfrentar esta situação: “dei um ponto pra alguém e alguém foi e teve a coragem de fazer aquilo que eu não tive”. Isto posto, quando da análise do sujeito Ms e Ga também encontramos esta ojeriza pela exposição pública e classificamos este comportamento como orientado à meta performance-evitação, pois os sujeitos temem ser considerados incapazes, ou, pior, serem motivo de piada por parte dos demais colegas da turma.

Entretanto, devemos considerar este temor à exposição pública como sintoma de alguém orientado à meta performance-evitação, se e somente se, este medo vem acompanhado de um auto-conceito pejorativo sobre si mesmo, por exemplo, o sujeito se considera incapaz para aprender. Portanto, este cuidado metodológico se faz necessário 
para escaparmos dos casos de indivíduos que sofrem do excesso de timidez. Talvez seja o caso deste sujeito.

Por outro lado, talvez esta reserva, esta timidez aconteça não porque o sujeito se acredite incapaz, mas por outro motivo, talvez o estorvo a impedir que o sujeito En se lance corajosamente nestas situações é a distância que criou entre seu "eu" e a imagem inalcançável de um sujeito idealizado com alto coeficiente de inteligência. Imagem especular refletida por seus professores implicitamente contida nos altos padrões de excelência exigidos pelo modelo tradicional de ensino.

21 - P: Por exemplo, o que você acha do trabalho em grupo?

E: Eu sempre gostei, desde pequena eu sempre fiz trabalho em grupo.

$\mathrm{P}: \mathrm{O}$ que você acha legal?

E (Falou junto com a pergunta do pesquisador): Eu gosto porque a gente aprende mais, a gente desenvolve melhor o assunto.

P: Mas

E: Pra debate um assunto .

P: Mas pra debater um assunto, você tem que ter segurança.

E: É ai que a gente vai consegui a segurança.

P: Mas...

E: Um discutindo com o outro

P: Mas se você tem medo de parece burra, como é que você vai, vai

E: (interrompe)não, mas aí no grupo aquele grupinho ali vai ser um grupinho a gente vai estar desenvolvendo entre nós mesmos...se erra

P: Mas você não vai ter que apresentar lá na frente?

E: não se erra, mais aí se erro foi o grupo inteiro que concordo com o assunto, não fui eu sozinha (muitos risos de ambas as partes).

P: A responsabilidade é (risos)

E: A responsabilidade é do grupo (risos) E: Aí a responsabilidade não é

P: Inclusive eu não tenho nada com isto e vocês fizeram eu colocar (brinca o pesquisador) E: Ééé..., eu falei que isso era certo e você falou que tava errado, mas isso tava certo, então, isso tava errado e você falou que tava certo, então a responsabilidade não é só minha é do grupo inteiro (risos).

O sujeito acredita na importância do grupo, pois a reunião permite desenvolver melhor o conteúdo à medida que os integrantes possam debater o assunto. Entretanto, como o sujeito havia afirmado em outras seções sobre seu medo relativo à exposição pública, perguntamos a ela sobre a possibilidade de sentir-se insegura, ou mesmo, correr o risco de parecer "burra" para os demais integrantes do grupo. O sujeito então justifica que um dos benefícios do agrupamento é distribuir a responsabilidade pelo erro, o que não ocorreria caso estivesse sozinha: "mais ai se erro foi o grupo inteiro que concordo com o assunto, não fui eu sozinha”. Devemos considerar que se o fracasso incidirá 
sobre o grupo, podemos admitir então que o agrupamento permite aos integrantes individualmente dissolverem seus sentimentos de ansiedade sobre a possibilidade do insucesso.

Isto posto, poderíamos ser levados a considerar um desvirtuamento das razões que justificam a organização do trabalho em grupo. Um professor construtivista acredita que o trabalho em grupo pode permitir ao sujeito avanços atitudinais, metodológicos ou conceituais. Afinal, o grupo deverá distribuir as tarefas, o sujeito talvez se sinta obrigado, por exemplo, a rever sua atitude em relação ao mínimo esforço, pois é pouco provável que o restante do grupo se responsabilize pelo excesso de trabalho provocado por este comportamento. O sujeito talvez tenha de realizar diversas negociações, por exemplo, como garantir maior confiança sobre as informações levantadas pelo grupo, produzindo uma mudança metodológica. Conceitualmente, esta configuração pode permitir o levantamento de hipóteses, pois pode ocorrer o choque de ideias, aumentando a possibilidade de ocorrer a evolução conceitual, um dos principais objetivos de um professor adepto desta metodologia.

Assim sendo, poderíamos ser levados a acreditar que o sujeito En defende o trabalho em grupo por motivos diferentes das razões de um professor, exceto pelo fato que ambos acreditam que esta organização permite aos sujeitos desenvolverem melhor os conteúdos. Entretanto, podemos entender de outra maneira, ora podemos dizer que um professor construtivista pode estar interessado em desenvolver os aspectos lógicos deste tipo de organização. Enquanto que o sujeito En apresenta motivos emocionais, na medida em que acredita que esta organização permite aos sujeitos se fortalecerem individualmente ao depositarem no grupo as ansiedades que antes eram vividas de forma solitária. Talvez, então, não só o aumento do poder proporcionado pela reunião das forças, mas também a segurança emocional garantem a supremacia deste tipo de organização social.

22 - P: Você tem alguma dificuldade quando trabalha em grupo?

E: Só quando eu quero uma coisa que o outro discorda.

P: E ai

E: Quando não acha justo, ai eu fico triste, porque eu estou vendo que aquilo tá certo, aí o outro acha que não, aí eu deixo, aí os alunos, eu ponho, vou falar que não, "eu vou deixa, vou".

P: Por exemplo, assim você está trabalhando com pessoas diferentes.

$E: \dot{E}$

P: Isso, então tem esse tipo de coisa, cada um tem uma opinião, então não sei o que, mas todos os alunos trabalham igual dentro do grupo?

E: Não, sempre tem um que dá uma opinião diferente. 
P: Não assim, em relação a esforço?

E: Os meus grupos eu escolho assim, que se esforça direitinho, que saiba faze tudo do mesmo jeito.

P: E como é que você sabe pra escolher?

E: Professor eu já vejo desde que a gente, quando a gente já começa a estuda junto, a gente, no primeiro mês a gente já da pra percebe, qual o aluno que quer estudar e qual é o que não quer, qual é o que quer se esforçar para fazer o trabalho, qual é o aquele que só chega e coloca o nome e sai fora, dá pra gente perceber isto.

P: Mas e aquele aluno, por exemplo que acha que não tem condição de aprender, que se acha meio, sei lá, um cara, aliás você acha que tem aluno que tem este tipo de sentimento? E: Bom tem aquele que não consegue aprender e tem aquele que não quer aprender mesmo por sem-vergonhice mesmo.

P: Hum...

E: Aquele que só vem pra escola pra brinca, quando é aquele aluno que a gente vê que não aprende, vale a pena a gente se esforça e ensina, agora quando é aquele a gente vê que chega ali só pra brinca, só pra bagunça, eu não concordo em pôr no grupo só pra beneficiar ele.

No primeiro trecho, o sujeito apresenta um dos possíveis obstáculos atitudinais a serem desenvolvidos conforme descrito na análise do trecho antecedente, ou seja, o sujeito deve aprender a negociar pontos de vista diferentes dos seus: "Só quando eu quero uma coisa que o outro discorda,". Talvez, este obstáculo deve ser especialmente problemático para este sujeito, pois conforme apresentado em outras seções, ele acredita que o aprendizado deve ser um caminho linear para o conhecimento, visão em acordo com o modelo tradicional de ensino. Portanto, talvez entenda que as discordâncias são representativas de que o grupo está escolhendo o caminho do fracasso, situação considerada desconfortável se levarmos em consideração que En afirmou ficar bastante incomodada ao se sentir perdida.

No mesmo sentido, ou seja, tão importante quanto aprender a negociar os pontos de vista, deve ser lutar em defesa daquilo que se acredita. Infelizmente o sujeito parece sucumbir à pressão do grupo, caso opte em abrir mão de suas convicções. Portanto, este obstáculo atitutinal pode ser trazido à luz durante os trabalhos em grupo para que o próprio sujeito talvez possa refletir sobre esta situação na perspectiva de uma possível evolução. Obviamente, esta situação só pode ocorrer caso o professor seja sensível e considere o desenvolvimento destes aspectos tão importantes quanto o desenvolvimento dos conceitos.

Os trechos que se seguem confirmam a impressão obtida em nosso diário de campo, de que este sujeito escolhe explicitamente os integrantes de seu grupo de trabalho. Os quesitos que devem ser observados pelo candidato a participante neste 
seleto grupo são: "que se esforça direitinho, que saiba faze tudo do mesmo jeito". Ou seja, fica subentendido, o candidato deve esforçar-se de forma recíproca em conformidade com os demais integrantes do grupo: "[...]no primeiro mês a gente já da pra percebe, qual o aluno que quer estudar e qual é o que não quer, qual é o que quer se esforçar para fazer o trabalho, qual é o aquele que só chega e coloca o nome e sai fora, dá pra gente perceber isto". Este critério de exclusão está intimamente ligado à crença de que para aprender é necessário esforço, soma-se a este, o seguinte critério moral: "aprender mesmo por sem-vergonhice, [...] "que chega ali só pra brinca, só pra bagunça, eu não concordo em pôr no grupo só pra beneficiar ele." Assimsendo, com estes critérios de exclusão é bastante natural que os grupos constituídos por este sujeito tornem-se verdadeiros grupos de trabalho.

23 - P: Por exemplo, o professor pede pra você resolver várias questões em um grupo, como o grupo se comporta?

E: Ai, o grupo vai se esforçar

P: O grupo vai senta?

E: O grupo vai senta, se intera do assunto.

P: Você cobra a participação da pessoa.

E: cobro, eu cobro

$\mathrm{P}$ : Se não fizer, você não vai?

E:Se não fizer, eu, tem que ter participação nem que seja pegar um lápis e uma borracha daqui e coloca aqui, eu acho isso correto.

P: Tem que, se tá em grupo?

E: Se tá em grupo tem que tá o grupo reunido.

Este trecho também vai ao encontro das impressões apresentadas em nosso diário de campo de que o elo de ligação que mantém este grupo coeso é seu desejo em realizar as tarefas propostas pelo professor, já que os sujeitos estão reunidos em nome da disponibilidade para o trabalho. Devemos chamar a atenção para este fato, pois, muitas vezes, em sala de aula, o trabalho não é o principal motivo para a organização de um grupo.

Outra confirmação em relação a impressões em nosso diário de campo, é a de que este sujeito é um dos líderes do grupo. Parece-nos que sua principal função é atuar na organização e distribuição das tarefas, outra impressão é a de apaziguadora contornando possíveis conflitos ou aparando arestas entre os diversos integrantes do grupo em nome na consecução do trabalho. Talvez, seja por isto que evite o choque direto, abrindo mão de algo para garantir a coesão do grupo. Entretanto, estas são somente impressões sobre o funcionamento do grupo, não temos a mínima pretensão ou 
condição de confirmá-las, exatamente porque estas questões não se referem ao nosso objeto de estudo.

24 - P: Por exemplo, assim, aí tem essas questões tal como o grupo se comporta, assim, caso vocês não saibam, o quê vocês fazem?

E: Eu vou procura uma ajuda.

P: Isso não desanima?

E: Desanima um pouco, porque a gente queria saber né, a gente queria faze aquilo ali, mas aí no último caso, aí nós vamos apela pra outra coisa.

P: Mas então você faria o quê? Você reclamaria mais, você procuraria ajuda, qual a sua postura quando isso acontece?

E: Eu procuraria ajuda

P: Mas você ia fica reclamando achando que está ruim ou não?

E: Não

P: Mas por quê?

E: Eu não vou acha isso correto.

P: Ah professor, dá logo esta resposta, não sei o que lá?

E: Não eu não acho isso, eu acho que a gente deveria pensar, estuda, conversar e analisar mesmo o assunto pra chega nessa resposta.

P: Então, mas não seria mais fácil, professor, chega lá, "a gente não está conseguindo" dá esta resposta logo e pronto?

E: Não, eu falaria professor explica direito aqui de novo que eu não estou entendendo, professor explica aqui o que é que está acontecendo, talvez seja comigo.

P: Você procura outros alunos também.

E: Procuro, talvez eu procuro outros alunos.

O sujeito, neste trecho, quando não consegue realizar alguma tarefa não demonstra problema em procurar ajuda. Portanto, este procedimento não é interpretado como prova de uma suposta incapacidade. O sujeito, talvez até se sinta desmotivado, ou mesmo, triste, por não conseguir resolver prontamente algum problema, mas esta situação não seria tão grave ao ponto de paralisar sua ação. Em relação a esta ação, ao invés do caminho mais fácil representado pela solução pronta do professor, acredita que seria mais importante para seu desenvolvimento enfrentar as dificuldades inerentes do processo: "eu acho que a gente deveria pensar, estuda, conversar e analisar mesmo o assunto pra chega nessa resposta”.

Em outras seções concluímos que este sujeito ressente-se pelo fato de não ser dotado de um alto quociente de inteligência. Entretanto, seu discurso sugere que valoriza o conhecimento, acreditando que esforço e a dedicação são as ferramentas básicas utilizadas para resolver as dificuldades de aprendizagem. Por outro lado, apesar de se sentir incomodada pela possibilidade de se expor publicamente, não pretende 
desesperadamente evitar que venham a saber sobre seus erros ou falhas no domínio de algum conteúdo.

Assim sendo, talvez este sujeito se sentisse mais seguro caso acreditasse que as dificuldades são inerentes ao processo de aprendizagem, mesmo para aqueles que são bem dotados intelectualmente, e, que estes, neste momento, também devem recorrer ao esforço e à dedicação para solucionar as dificuldades. Portanto, não é somente o quociente de inteligência que faz a diferença, mas, sobretudo, o esforço, a dedicação e o comprometimento que nos ajudam a resolver os problemas relacionados à aprendizagem. Logo, seu auto-conceito seria outro se acreditasse que as dificuldades são inerentes aos processos de aprendizagem independentemente se somos mais dotados ou não intelectualmente. Obviamente que um modelo de ensino no qual se privilegia a performance e a distinção dos mais dotados acabou por contribuir negativamente para formação do seu auto-conceito.

25 - P: Imagina assim, tem lá, você tá lá, resolvendo as questões e de repente tem lá uma continha da quinta série, mas naquele dia da aula você faltou, você não sabe, aquela matéria lá da quinta série, você esqueceu, você não aprendeu direito, e tal o que você faz, você tá no grupo?

E: Eu vou pedi ajuda, o grupo vai tenta me ajuda, se o grupo não conseguiu, a gente vai procura ajuda fora

P: Mas você, vai se sentir, por exemplo, você vai se sentir envergonhada?

E: Envergonhada, humilhada, não, não vou não

P: Você vai se senti sei lá burra, se eu não entendo isso, uma coisa assim.

E: Não, eu não vou me senti, porque eu vou, se tivesse alguém ali que vai sabe explica, que eu vou consegui te ajuda, isso me faz feliz, sabe que tem alguém que é capaz de me ajuda naquilo que eu não sei.

P: Hum.... Se você fosse se coloca dentro de um, se você fosse conceitua, você é o que? você é uma pessoa inteligente que aprende fácil? Inteligente então é mais fácil de aprende, você é uma pessoa com esforço e você aprende ou você me diria que você tem muita dificuldade pra aprender?

E: Olha, depende da matéria, tem coisa que eu aprendo muito fácil, muito fácil mesmo, uma coisa que eu aprendo fácil pra caramba é artes.

P: Educação artística.

E:Artes eu aprendo nossa!

P: Então, mas assim você se considera como uma pessoa que se esforça para aprender, uma pessoa inteligente e aprende fácil ou uma pessoa que tem muita dificuldade para aprender e que às vezes até se sente incapaz?

E: Não, eu me esforço para aprender.

O sujeito En, em acordo com outros trechos, afirma não se sentir humilhado, ou envergonhado, caso os outros venham a tomar ciência de suas possíveis falhas 
relacionadas ao domínio do conteúdo. Muito pelo contrário, ficaria feliz caso encontrasse alguém que pudesse lhe ensinar, demonstrando estar mais preocupado com seu desenvolvimento do que com o possível julgamento negativo. Obviamente o sujeito não pretende passar a imagem de indolente, afinal aposta no esforço como remédio para enfrentar as dificuldades de aprendizagem, também não constaria de ser considerado incapaz exatamente por não possuir esta crença sobre si mesmo.

O sujeito em diversos trechos demonstrou apoiar o trabalho em grupo, sendo assim, podemos conjecturar que o sujeito aposta nos relacionamentos intersubjetivos não só para enfrentar as dificuldades, mas, provavelmente, por valorizar o investimento nos laços de amizade. Portanto, talvez realizar um trabalho seja interessante não somente pelo conteúdo que se aprende, mas pelo laço valoroso de amizade que se cria. Por consequência, podemos admitir que o sujeito move-se em torno da existência do calor humano presente nas relações pautadas pelo amor aproximando-a do conceito de Intimidade.

26 - P: Você nunca passou assim na sua vida assim alguma experiência lá na primeira, ou na quarta série, você se sentiu assim humilhada, assim?

E: Não

P: Você, tipo assim ficou muito magoada com a professora?

E: Eu fiquei magoada uma vez com a professora, aí eu saí da escola, a professora brigoucom a minha irmã e com a minha prima, não foi comigo.

P: Oshi!

E: Não foi comigo, foi com minha irmã e minha prima.

P: Mas não teve nada a ver com o negócio do aprendizado?

E: Não, ela xingou a minha irmã e xingo minha prima, eu peguei e tirei as duas da escola, era as duas mais velha que eu.

P: Mas por exemplo, assim a professora não fez você passa alguma vergonha assim tipo de chamou na lousa?

E: Não

P: pra você...responde, aí ficou aquela sensação ruim, assim?

E: Não, não, a única vez que eu lembro foi essa que ela xingo a minha prima e minha irmã, ai eu quebrei o pau e chamei as duas pra ir embora (risos)

Apesar de o sujeito En se envolver em um embate com tal professora, a ocorrência deste fato desagradável não nos parece ter produzido algum fenômeno impactante na história escolar deste sujeito. Neste trecho, podemos considerar como mais representativo o fato de o sujeito nunca ter se sentido humilhado ou ter sido motivo da zombaria alheia por ter demonstrado alguma falha ou erro em relação ao domínio de algum conteúdo escolar. 
27 - P: Por exemplo, assim quando você tem que fazer uma prova?

E: Ah, eu gosto de se avaliada.

P: Por quê?

E: Porque ali é um meio de avalia a gente, pra sabe que meio a gente tá, em que altura a gente aprendeu.

P: Então, mas você não vai se sentir, "poxa, eu vou ter que faze esta prova, aí se eu for mal eu vou ficar com uma nota baixa, aí os alunos

E: Não

P: vão achar que eu sou burro que eu não consigo faze as coisas

E: Não, nunca passou pela minha cabeça

P: Mas

E: Posso erra, mais eu vou faze, se eu errei paciência, na próxima eu vou tenta melhora, se eu me esforcei $X$, eu vou me esforçar na próxima X e Y pra ver se eu vou [P: hum, hum] E: me sair bem

Antes de iniciarmos a análise deste trecho devemos considerar que a nota obtida em uma avaliação pode expor o sujeito ao julgamento alheio, devemos ter em mente que os alunos têm o péssimo hábito de comparar as notas, e, não raro, zombam daqueles que obtiveram resultados considerados medíocres. O sujeito En demonstrou em seções anteriores ter ojeriza pela exposição pública. Contudo, o sujeito neste trecho afirma não temer a possibilidade de ser exposto caso recebesse uma nota medíocre, pelo contrário, ele aprecia as avaliações, pois pode monitorar o quanto aprendeu, demonstrando, mais uma vez, que o sujeito está mais preocupado com seu desenvolvimento do que a possível imagem negativa produzida por uma menção medíocre.

Isto posto, podemos admitir que esta confiança possa advir por ela acreditar que esta situação tenha pouca probabilidade de ocorrer. Ora, talvez esta crença possa estar relacionada à afirmação (trecho 18) feita pelo sujeito de que nunca repetiu e que sempre aprendeu os conteúdos. Ou ainda, o sujeito talvez aposte em seu esforço e sua dedicação, pois segundo suas palavras: "Posso erra, mais eu vou faze, se eu errei paciência, na próxima eu vou tenta melhora, se eu me esforcei $X$, eu vou me esforçar na próxima X e Y pra ver se eu vou [P: hum, hum] E: me sair bem”.Assim sendo, estas crenças aproximam este sujeito dos comportamentos e crenças daqueles orientados à meta aprender.

28 - P: Por exemplo, assim você trabalha?

E: Trabalho

P: O que é preciso pra vencer na vida?

E:Muito esforço, muita garra, muita coragem (risos)

$\mathrm{P}$ : Mas assim esse 
E: Muita coragem, muita força de vontade

P: Mas assim, esse esforço é...por exemplo, assim, se acha que tem aluno que não consegue aprende?

E: Eu acho que tem, tem aluno que faz isso mesmo, tem aluno que fala que não consegue, que não consegue, que não consegue, mas acho que vem da cabeça da pessoa, quando a pessoa quer, a pessoa consegue.

P: Você acha que pra vence na vida tem que ter esforço.

E: Tem que te esforço

P: Em qualquer ...

E: Em qualquer coisa

P: Aí por exemplo, uma pessoa que se sente, que acha que não pode aprende, ai como é que fica?

E: Para por ai e acha que... acha que tudo acabou, só que eu não acho seguro, eu acho que a pessoa tem que tenta, porque se tenta, a pessoa vai consegui, não se fica parado ali não vai sai mesmo, agora dizem que pé que anda não leva topada [P: hum, hum,] E: você tem que anda pra consegui.

P: Mas se acha que é culpa da pessoa, assim?

E: É comodismo.

Neste trecho, o sujeito apresenta a crença de que o "esforço" é condição capaz de garantir o sucesso e o sacrifício é o caminho para a elevação espiritual, logo as coisas da vida ganham um valor especial se conquistadas com esforço e sacrifício, sendo exemplo "Muito esforço, muita garra, muita coragem".

Assim sendo, este trecho confirma nossa impressão de que este sujeito quer passar a imagem de um aluno dedicado e esforçado. Por esta razão, no início da entrevista, ele esforçou-se em enfatizar que seu atraso escolar se devia às dificuldades que tinha para frequentar as aulas e não por falta de vontade ou por apresentar um comportamento indolente.

29 - P: Por exemplo, assim quando você ia pra escola, você tinha lá seus seis anos de idade lá, a não você foi com oito, nove

E: Com oito, nove anos

P: Nove anos tal, que você ia pra escola a primeira vez, que a sua mãe fez a sua bolsa, você levou lanche.

E: Eu levava lanche, minha mãe fazia aquela sainha de prega.

P: Isso, e lá vai você, aquela coisa ir pra escola, o que você pensava da professora? O que a professora representava pra você?

E: Olha, eu já me sentia feliz, eu gostava porque eu já ia aprende com minha irmã, era minha irmã que ensinava, depois passou a prima [P: (interrompe)]

P: Ah, a sua irmã era professora?

E: A minha irmã era a professora [P: Ah...] E: A primeira professora que eu tive foi ela [P: Ah] E: Ela era que me ensinava, ensinava a gente, então a gente ficava feliz, nossa na hora que saía aquela turma toda pra ir pra escola, com a irmã já era uma segurança né, ai depois passou a prima, ai a prima ia ensina e era aquela festa, ai já não levava lanche porque a tia fazia né.

P: A tia fazia? 
E: A minha tia já fazia o lanche, nossa era muito bom, aí depois foi passando, depois a gente pegou outra professora, que já começou a terceira, quarta série.

P: Hum

E: Aí já era uma amiga, amiga dos meus pais, aí já conheceu a gente do nasce, então já era uma aquela confiança mesmo.

Para este sujeito, segundo este trecho, podemos admitir sobre sua entrada na esfera escolar que esta foi bastante harmoniosa considerando que sua professora era sua irmã. Por conseguinte, o ambiente escolar era realmente uma continuação das relações familiares, portanto, recordar o passado traz memórias agradáveis de afeto que vão desde o cuidado com a roupa, passando pelo lanche carinhosamente preparado por sua tia. Assim sendo, podemos considerar que estudar para este sujeito sempre foi um objeto de valor, pois o estudo esteve intimamente ligado às suas relações de parentesco. Podemos também admitir que o sujeito deve ter se sentido pertencente a este ambiente escolar, considerando-se o afeto que experimentou devido a estas relações familiares. Logo, estes condicionantes aproximam o sujeito do conceito de necessidade de Intimidade. 


\section{Questionário de Acesso às Metas de Realização do Sujeito Des}

\section{Des}

Nome:

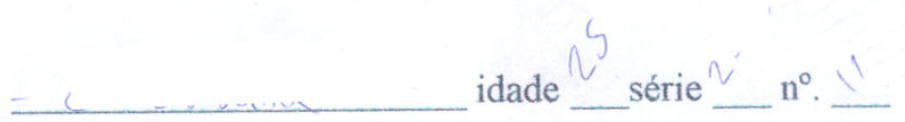

Caso você concorde com as idéias abaixo as classifique colocando (C) que significa concordo, caso contrário, ou seja, se você não concordar coloque (NC) que significa não concordo. Caso você concorde parcialmente classifique as respostas como $(\mathrm{CP})$ que significa concordo em

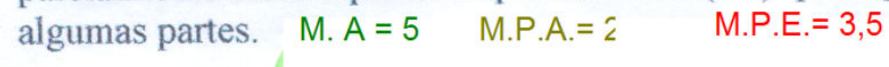

1- Eu gosto de realizar tarefas na escola em que eu realmente aprenderei, mesmo que eu cometa muitos erros. $(C) \perp$

2- Eu me sentiria realmente bom se eu fosse o único que respondesse as perguntas dos professores da classe. (NC)

3. É muito importante quie,eu não seja visto como um estúpido na frente dos meus colegas.(C) 1

4- Uma razão importantê para que eu faça tarefas na escola é porque eu gosto de aprender coisas novas. ( C $) \perp$

5- É importante para mim que os outros estudantes em minha classe pensem que eu sou bom nas tarefas que realizo.( $C P) 05$

6- Uma razão importante para eu faça as tarefas é para que eu não fique envergonhado. (NC)

7- Tarefa que eu gosto de fazer é aquela em que eu possa realmente pensar.(C) 1

8- Eu quero fazer as tarefas melhor do que os outros estudantes da minha classe. ( $C P$ ) 9,5

9. Eu me preocupo quando eu faço meu trabalho se os professores irão pensar que eu sou menos capaz do que os outros. $(C P) 0,5$

10- Uma importante razão para que eu faça a tarefa na escola é porque eu sempre quero melhorar, aprender mais. (C) 1

11- Eu sentiria bem sucedido se eu aprendesse mais do que os outros estudantes. (NC)

12- Uma das razões para que eu faço meu trabalho é porque não quero que pensem que eu sou burro.(NC)

13- Eu faço minha tarefa na escola porque eu estou interessado nela. $(C) \perp$

14- Eu gostaria de mostrar aos meus professores que eu sou o mais esperto da classe. $(C P) 0,50,5$

15- Uma razão que eu não participaria de uma da aula é porque não quero que me vejam como um estúpido (a).(c) 1

16- Uma importante razão para que eu realize uma tarefa na escola é que eu goste dela.(C) 1

17- E importante para mim, fazer as atividades melhor do que os outros alunos. $(C P)$

18- Um de meus objetivos principais é evitar que me vejam como incapaz de realizar minhas tarefas.( C) 1 


\section{Análise dos dados da Entrevista de Validação do Perfil Motivacional de Realização do Sujeito Des}

Para este sujeito, ao invés de apresentarmos toda a análise, optaremos por resumi-la com o propósito de pouparmos o leitor da leitura de todo o processo. Os trechos estão devidamente referenciados através dos símbolos QN, ou seja, Q representa questão, $\mathrm{N}$ representa o seu número. A íntegra da entrevista encontra-se no final desta seção denominada Dados da Entrevista Sujeito Des, caso o leitor tenha o interesse de confirmar a análise.

\section{Resumo da Análise da Entrevista de Validação do Perfil Motivacional de Realização do Sujeito Des}

Des, nas primeiras questões, defende a ideia de que caso o professor fornecesse todas as respostas certas, não se poderia aprender, pois o aprendiz estaria somente copiando. Para ele, Des, aprendizado requer raciocínio. Assim sendo o sujeito aproxima-se da meta aprender, pois o aprendizado melhora a capacidade cognitiva através de ações mentais como o raciocínio.

Em seguida, Des afirma que se deve buscar aquilo que não se sabe, estabelecendo relação entre o aprendizado e o desenvolvimento. Neste trecho, pode também estar fazendo alusão ao trecho antecedente no qual o sujeito afirma ser necessário raciocinar para aprender. Obviamente, o novo carrega a possibilidade do erro, portanto, o sujeito está disposto a correr este risco. Ora, também esta crença aproxima o sujeito da meta aprender, pois os conhecimentos são vistos como capazes de proporcionar desenvolvimento.

Na Q5, Des afirma que o conhecimento se obtém através de muito esforço, repetindo o axioma: diretamente proporcional ao desenvolvimento almejado, será a cota de dificuldade ou do desafio a ser vencido. Esta crença é base fundamental daqueles orientados à meta aprender. Interessante, também, é o fato de o sujeito interessar-se por matemática, pois sabemos que esta disciplina, muitas vezes, causa calafrios em alguns alunos, devido ao árduo caminho trilhado para o seu domínio. Des relata, ainda, que atualmente prefere filosofia; ora tanto a matemática quanto a filosofia são disciplinas bastante abstratas e talvez estas preferências revelem que o sujeito tem certa predileção pelo conhecimento abstrato. 
Des, no trecho referente à Q6 e Q7, exemplifica como o professor pode influenciar no esforço realizado pelo aluno, no caso, tirando suas dúvidas, auxiliando-o nos momentos de maior dificuldade; podemos conjecturar que o sujeito pretende responsabilizar-se pelo seu aprendizado ao solicitar a ajuda do professor. Parece também almejar uma relação de compreensão com o conhecimento. O sujeito não pretende evitar que venham a saber, ou, sente-se envergonhado de que o professor tome ciência de suas dúvidas ou dificuldades, afastando-o do comportamento típico dos sujeitos orientados à meta performance-evitação. Em seu discurso, está claro que a forma como o professor pode incrementar a motivação do aluno liga-se à possibilidade de este obter maior compreensão. Logo, o sujeito está orientado à meta aprender, pois suas ações têm como objetivo alcançar maior domínio do conhecimento através da compreensão. Ele, em seguida, relaciona implicitamente esforço ao ato de aprender amalgamado implicitamente ao verbo praticar, ou seja, repetir várias vezes, até induzir o conhecimento. Esta metodologia está ligada ao modelo tradicional de ensino no qual o aprendiz repete inúmeras vezes através de exercícios o conhecimento transmitido pelo professor, até absorvê-lo. Portanto, Des aproxima-se da meta aprender, pois acredita que para aprender é necessário esforço através da prática de exercícios, exigindo concentração e certo nível de perseverança.

Na Q8, Q9 e Q10, Des estabelece que deve existir uma relação mínima entre disciplina e aprendizagem. Talvez esta conexão seja necessária, pois o sujeito pretende empreender processos nos quais quer raciocinar, logo é necessário um mínimo de ordem para ele concentrar-se naquilo que intenciona aprender. Portanto, Des busca observar regras escolares com o propósito de obter domínio: isto novamente confirma sua aproximação da meta aprender. Ele relaciona aprendizagem à organização, pois como um aluno poderá monitorar o seu aprendizado, se não copia, se não realiza as tarefas, se não estuda? Portanto, o sujeito estabelece ações mínimas capazes de lhe garantir o aprendizado, logo o sujeito age objetivando o conhecimento.

Isto posto, podemos conjecturar que o sujeito possui estratégias mínimas de autoeficácia ligadas a esforço, concentração e organização, capazes de auxiliá-lo em direção ao conhecimento. Assim sendo, estas estratégias estabelecem certo senso de autoconceito no qual o sujeito percebe-se com atributos intelectuais capacitando-o a aprender, portanto, possivelmente afastando-o de comportamentos desesperançados. 
Na Q11,Des confirma nossa impressão de que o esforço proporciona um envolvimento mais íntimo com o conhecimento: "você tem que pensa bem lá do fundo, você vai fazer achando que tá certo, você vai pensando, e dali vai achando um, vai puxando, puxando até que vem uma coisa na tua cabeça”. Ou seja, graças ao esforço eà concentração surge um "insight", demonstrando que o sujeito aprecia ou busca vivenciar estes momentos, logo, faz-se necessário um ambiente com um mínimo de organização capaz de fomentar este estado psíquico. Obviamente, durante a prova, a ansiedade produzida pela preocupação com o resultado pode prejudicar este nível de concentração.

$\mathrm{Na} \mathrm{Q} 12$ e Q13, o sujeito relata seu receio sobre maus resultados relacionados às provas, sentimento natural diante do fracasso. Entretanto, este sentimento não parece paralisar sua ação. O sujeito vivenciou momentos nos quais, mesmo tendo estudado, não obteve bons resultados, contudo, estes resultados não são transformados em motivos para o sujeito se afligir através da elaboração de julgamentos autodepreciativos.

No trecho da Q14, apesar de o sujeito relatar que iniciou seus estudos tardiamente, aos onze, este não parece ter vivenciado grandes dificuldades de aprendizado. Pelo menos, não relata nenhuma situação vexatória capaz de fazê-lo crer que possui alguma falha a ponto de incapacitá-lo para a aprendizagem. Por outro lado, relata ter obtido boas notas nas séries iniciais. Assim sendo, parece-nos que o sujeito acredita possuir atributos intelectuais capazes de garantir a segurança necessária para aprender.

Na Q15 uma informação surpreendente. Des afirma que gostava mais de matemática exatamente porque não era necessário decorar, pois, podemos conjecturar, que o sujeito praticava o conhecimento resolvendo os exercícios. Entretanto, não manteve o mesmo interesse agora no ensino médio, porque o seu interesse mudou para filosofia. Talvez possamos propor alguma explicação. Ora, nas séries iniciais, a matemática é mais concreta, ligada às quatro operações, ou seja, à matemática básica do cotidiano; portanto, podemos conjecturar que o sujeito apreciava a matemática por sua funcionalidade. Agora, no ensino médio, a matemática torna-se mais abstrata talvez então não podendo conectar-se ao cotidiano do sujeito. Por outro lado, a filosofia pode ter tomado este lugar explicando o cotidiano do sujeito Des: "a filosofia mexe com o ser humano, eu acho, na minha opinião[...] Na maneira de pensar, na maneira de agir, na maneira....". Portanto a filosofia permite ao sujeito refletir, raciocinar sobre temas 
ligados à realidade, logo, podemos admitir que o sujeito aprecia um envolvimento mais íntimo com o conhecimento, fazendo-o entender a realidade a sua volta.

Contudo, talvez Des não se tenha sintonizado com a metodologia do professor, ou com seu estilo, pois segundo suas palavras: "quando você tem um professor que explica bem, eu acho que qualquer matéria é boa.". Entretanto, esta explicação não é muito provável, pois Des interessou-se por matemática não por causa de um professor, mas segundo seu relato por si mesmo, portanto, não deposita no outro a responsabilidade pelo seu interesse endereçado à matemática nas séries iniciais.

Por outro lado, neste trecho ele alude à possibilidade de o sujeito valorizar o conhecimento de um modo geral, ao afirmar que o aprendizado é positivo independentemente da disciplina. Todavia, sabe das dificuldades, portanto, faz-se necessário um bom professor, capaz de explicar bem, pois o sujeito está disposto a esforçar-se obedecendo às regras do professor, concentrando-se e realizando os exercícios. Logo, Des parece estar disposto a empreender os caminhos do conhecimento, e acredita que um bom professor pode auxiliá-lo nesta jornada.

Na Q16, Des afirma que tentará responder aos desafios, pois estes não são motivos de angústia ou ansiedade. Contudo, não pretende expor-se, como veremos em seguida: ele considera-se tímido e reservado. Apesar das dificuldades para estudar, o sujeito Des não relata ter sofrido com alguma exposição vexatória. Inclusive, parece lembrar-se desta fase da sua vida com certo ar de saudosismo: pó mano, maior sofrimento, a gente achava bom porque vinha na maior algazarra em cima do carro [...] Conversando, às vezes namorando [...] Pó, aí a gente gostava, mas por outro lado.... Logo, o cotidiano escolar do sujeito não parece ter sido vivenciado com algum tipo de sofrimento.

O relato de Des na Q17 assemelha-se ao relatado de En que também não se considera segura para expor-se publicamente, pois teme ser objeto da zombaria alheia. Assim sendo, este medo pode ter contribuído para a timidez do sujeito; contudo não parece que o sujeito acredite-se incapaz para aprender.Ele narra uma decepção sofrida em relação a sua professora; esta decepção foi forte a ponto de fazê-lo desistir de estudar e pode ter contribuído para sua timidez. Entretanto, ele afirma que nunca repetiu, nunca ficou de recuperação, portanto, ao invés de acreditar-se incapaz ou preterido, não parece ter feito deste episódio razão para o seu sofrimento. 
$\mathrm{Na}$ resposta às Q18 e Q19, Des fala do trabalho em grupo. Ele acredita-se tímido, entretanto, gosta das atividades realizadas em grupo, pois crê poder aprender com o outro. Outra vantagem de trabalhar-se em grupo é exatamente a possibilidade de poder melhorar sua timidez, esforçando-se para aprimorar sua condição. Segundo o sujeito, o aprendizado utilizando o trabalho em grupo é negativo quando os seus integrantes não estão interessados em aprender. Portanto, o sujeito Des utiliza como estratégia para garantir o sucesso do grupo a escolha de seus integrantes. Inclusive, aponta Ga e En como exemplos de alunos interessados em trabalhar. Assim sendo, podemos acreditar que os integrantes deste grupo reconhecem-se mutuamente, comungando das mesmas crenças em relação ao esforço solidário. Des afirma nunca ter se infligido conteúdos autodepreciativos, portanto, isso o afasta das crenças dos sujeitos orientados à meta performance-evitação. Por outro lado, mesmo descrevendo-se como tímido, este não titubeia em pedir ajuda alheia para enfrentar as dificuldades. Logo, o sujeito sente-se seguro o suficiente para buscar seu desenvolvimento acadêmico.

Nas Q20, Q21 e Q22, Des, apesar de acreditar que para aprender é necessária uma boa explicação, este cumprirá sua parte, pois mesmo obtendo uma menção negativa, irá se esforçar em uma próxima oportunidade para melhorar seu desempenho. Ele prefere estudar imediatamente próximo à realização das provas para não se esquecer do conteúdo. Levando-se em consideração sua falta de tempo, podemos admitir que esta estratégia é relativamente positiva, principalmente se obtém resultado. Ele justifica melhor a ideia afirmando que, caso a matéria seja fácil, o sujeito não estuda, agora, nas mais difíceis, ele dedica-se mais, portanto, procura na medida do possível esforçar-se para aprender, estabelecendo uma relação otimizada entre o exigido e o esforço que pode ser ofertado.

Nas respostas às Q23 e Q24, Des reforça a ideia de que aprecia momentos em que realmente possa compenetrar-se na resolução das tarefas escolares, ou, em suas palavras: "você já vai com corpo e alma e vai fazer". No entanto, caso ele não consiga resolver as dificuldades, sente-se desmotivado; contudo, não acredita possuir alguma incapacidade para aprender. Des parece estar bastante tranquilo em relação ao momento vivenciado nesta escola. O grupo do qual faz parte parece tê-lo acolhido, fazendo com que se sinta à vontade, inclusive, tentando resolver sua timidez. Portanto, o sujeito parece estabelecer suas relações em torno do calor humano, da segurança, fortalecendose para enfrentar o cotidiano escolar. Contudo, caso não tivesse encontrado este grupo, talvez não se sentisse tão acolhido, tão seguro, podendo, talvez até desistir de estudar 
devido a sentimentos de solidão. Afinal tem vinte e cinco anos, logo, deve ser um pouco mais difícil estabelecer laços de amizade com os outros alunos em média dez anos mais novos. Portanto, o estabelecimento deste grupo fortalece emocionalmente Des capacitando-o a enfrentar os desafios acadêmicos neste momento de sua vida. Finalmente, Des critica o provão pelo fato de que os alunos podem não fazer as atividades durante o bimestre, e, mesmo assim tirarem uma boa nota. Portanto, caso houvesse provas mensais, a avaliação, em sua visão, poderia ser mais justa. Logo, o sujeito acredita que o aprendizado deve ser algo valorizado e não somente resumir-se à obtenção de uma nota.

O resultado desta análise encontra-se no texto principal desta dissertação na seção Resultado da Análise do Perfil de Realização do Sujeito Des.

\section{Dados da Entrevista de Validação do Perfil Motivacional de Realização do Sujeito Des}

1 - P: Des, né?

E: Isso

P: Você tem quantos anos?

E: Vinte e cinco

P: Vinte e cinco

$E: \dot{E}$

P: Faz muito tempo que você mora aqui no bairro?

E: Quê?, quatro anos

P: Você morava aonde?

E: Eu morava no Ceará, passei sete meses no Rio, ai vim pra cá.

P: Passou sete meses no Rio.

$E: \dot{E}$

P: E você morava lá no Ceará, você estudou até que série lá?

E: Até oitava

P: Até a oitava?

$E: \dot{E}$

P: Você morava na capital ou morava?

E: Eu morava no interior, cidade do interior.

P: Que cidade que era?

E: Eu morava Parizins

P: Muita diferença de lá pra cá?

E: Mais ou menos, mais ou menos, assim eu achava que aqui era mais dificil, né mas aí mais difícil assim no começo né, mas depois se vai se entrosando é melhor, mas é a mesma coisa.

P: E você está trabalhando

E: Estou

P: Trabalha no quê?

E: Eu trabalho de limpador de vidro, por enquanto né. 
2- P: Na pergunta número um aqui você escreveu assim você gosta de realizar tarefas na escola em que realmente aprenderei mesmo que eu cometa muitos erros, você falou que concordava, com isso? Como assim, como você explicaria isso?

E: Porque tipo assim, você vai faze uma coisa, você que fazer, não precisa você, como diz é...certa ou erra

P: Como assim, porque você falou assim: Eu gosto de realizar tarefas na escola em que realmente aprenderei mesmo que eu cometa muitos erros.

E: Isso, isso mesmo que eu cometa muitos erros, então, a gente vai fazendo, vai fazendo na opinião da gente está certo né, na minha opinião estou achando que está certo, mas você via fala isso está errado, mas mesmo assim, a gente vai aprendendo com isso.

$\mathrm{P}$ : Mas errra não é ruim?

E: Não erra é ruim, você sabendo que tá fazendo alguma coisa que tá errada é ruim, mas eu to achando que estou acertando.

P: Que tá fazendo certo

E: Eu estou fazendo certo

P: Então, mas na hora que o professor vai corrigir assim

E: Então a gente...

$\mathrm{P}$ : Mas você não se incomoda assim?

E: Incomodo sim

P: Não mais assim, por exemplo, na hora que você tá fazendo, por exemplo?

E: Na hora que eu estou fazendo, eu estou sabendo que está errado.

P: Não, mas você vai acha que tá certo não é

E: Isso, isso

P: Porque você não sabe

E: É, não sei se tá certo ou se está errado.

$\mathrm{P}$ : Então pra você não tem esse problema assim

E: É não tenho.

3-P: Deixa eu ver aqui assim, e se o professor te desse todas as respostas certas?

E: Eu acharia que não valeria a pena

P: Porquê?

E: Porque você não aprenderia

P:Mas aí você não erraria.

E: Não erraria mas não aprenderia.

P: Não aprendia, mas assim

E: Não aprendia assim, você vai fazendo

P: Hum

E: Tá certo você vai copiando a resposta certa, você não está prestando atenção no que está errado com o que está certo.

P: Hum

E: Entendeu, não está, está só copiando, não tá aliás nem lê você está lendo, pra pode raciociná o que significa aquilo que você está escrevendo[P: Hum] E: Entendeu?

4- P: Aqui se você fosse escolher entre aprender um assunto que você nunca viu ou um outro que você tem alguma noção ou já ouviu falar, qual deles você daria preferência?

E: O que eu nunca vi

P: Por quê? 
E: Porque eu queria aprender

P: Então, não era mais fácil ver uma coisa que você já conhece assim, você já sabe então.

E: Não, mas se eu já sei, eu já sei né, e outro que eu não sei eu quero aprende

P: Uma coisa mais

E: É, porque você vai estuda só aquilo que você já sabe, não adianta você tem busca as coisas que você não sabe ainda até aprende.

5- P: É você colocou aqui, uma razão importante para que eu faça as tarefas na escola é porque eu gosto de aprender coisas novas né?

E: IsSO

P: Você acha que aprender é fácil?

E:Não, na minha opinião não

P: Por quê?

E: Porque pó, pra aprende você tem que batalha bastante, tem que estuda mesmo

P: hum, hum

E: Pó, só você chega e olha e já aprende

P: Não é assim né

E: Claro que não, tem que estuda bastante

P: Que matéria que você mais gosta?

E: É atrás, é... até a sétima série eu gostava de matemática, mas agora eu, agora eu estou preferindo Filosofia.

P: Você gosta de Filosofia?

E: Filosofia

P: Mas você gostava mais de matemática?

E: Matemática

6-P: Você acredita que precisa ter esforço pra aprender?

E: Tem que ter

P: Você acredita em muito esforço

E: bastante

P: Precisa de dedicação

E: Tem que te, senão não aprende

P: Você acha que o professor influencia neste esforço?

E: Sim

P: Como é que o professor influencia neste esforço?

E: Influencia mesmo, você tá na dúvida chega no professor, o professor explica de uma maneira mais clara.

P: Hum

E: Fica mais fácil pra você aprende, tirando suas dúvidas, entendeu

P: Então mas aí se ele explica tudo?

E: Não, não é tudo, é tipo assim, vou dar um exemplo, eu estou lendo um texto [P: Hum] E: uma parte eu estou entendendo, mas naquele texto tem um nome ali que eu passo por cima, aquele que eu passo por cima, eu não, entendeu [P: Você não entendeu] E: Como é que eu vou entender o texto se eu não entender o significado 
daquele letra, daquele nome [P: E ai se acha que] E: Então, dali eu tiraria a dúvida com o professor [P: Você acha legal] E: Daí clareia, ai eu já entendo.

P: Então, você acha que o professor influencia no esforço, seria isso.

E: Acho que sim.

7- P: Você utiliza de alguma estratégia pra você aprender, alguma coisa, você tem alguma estratégia de aprendizado?

E: Sempre a gente tem, mas eu não sei explica.

P: O que você acha que você faz pra você aprende?

E: Na minha opinião eu acho que é prática P: Você acha que?

E: Prática

P: Fazer exercícios, essas coisas seria

E: Praticando até ter terminado.

8- P: Você colocou: "Eu gostaria de mostrar aos meus professores que eu sou o mais esperto da classe", você colocou que concorda parcialmente?

E: Porque eu acho que eu estou na sala de aula não é só pra eu aprende, se fosse só eu aprendendo não está adiantando, tem que todo mundo tem que tá, entrega todo mundo pra pode aprende

P: Tem que tá todo mundo junto né

E: Todo mundo junto, só você tá aprendendo os outros não

$\mathrm{P}$ : Mas se acha o esperto assim, não é legal

E: Não, é legal, vou tá que é legal, mas com outro pô, você está estu, você tá dedicando tal, mas só que você não está vendo que seus colegas também na mesma sala [P: Hum, hum] E: E não tá aprendendo.

P: Aíce acha que?

E: Pra mim não, tem que

P: Hum, hum tem que subi tudo igual P: Hum, Hum

9- P:Pra você qual é o papel do bom professor? O que é um bom pra você, o que você acha que é um bom professor pra você, que você aprendeu, o que você acha assim?

E: É tira minhas dúvidas, quando eu tô

P: Tira as dúvidas né

E: É, ter uma boa explicação na hora que precisa e atencioso também.

P: Você acha que tem se dar uma atenção.

E: Não só pra mim, como pra todos.

P: Pra todos os alunos né.

$E:$ É que às vezes você dá atenção pra um, aí os outros, tá ali que até aprende, mas você tá dando atenção só pra um, aí vai, desiste daquela matéria, fica chateado como o professor.

P: Você acha que os alunos têm essa

E: A maioria faz isso

P: É porque, assim tem quarenta alunos numa sala E: Eu entendo como é que é

$P$ : Então, às vezes, não é que o professor não quer

E: Não é que o professor, eu sei como é que é isso. 
P: É que são tantos, que às vezes o professor naquela coisa que o professor tem que explica a matéria, às vezes

E: Eu sei, porque eu já vi que na nossa sala tem isso também [P: Hum, hum ]

E: Uma menina falou assim: "Ah, eu detesto a professora de Inglês" pô mas tem uns que gostam [P: Hum, hum] E: Às vezes, ela dá mais atenção pra uns, dá não, mas ela acha que dá, mas não.

P: E aí acho que ela fica um pouco de ciúmes.

E: Ai para de gosta da matéria.

P: Aí só por causa disso.

E: Ai quando passa um exercício no quadro não quer copia.

[P: Hum, Hum]

E: Às vezes na aula dela, não que vir na aula.

P: O que é um bom aluno pra você?

E: Um bom aluno é não se bagunceiro na sala, é faze os exercícios, é respeita os outros alunos, principalmente o professor também [P: Hum, hum] E: Entendeu

P: Você acha que lá onde você morava tinha mais bagunça ou menos bagunça que aqui

E: Já eu achava que não, lá tem menos bagunça.

P: Lá tem menos bagunça?

E: Eu acho, até onde eu estudei, acho que tem menos bagunça.

P: Aqui tem mais bagunça

E: Aqui, eu achei, lá, eu não sei que tipo assim, acho que mudo de um estado pro outro, uma maneira de [P: De ensina]

E: De ensina, de, tipo assim, teve um dia lá que o professor tava dando aula, ai já tava na hora de ir embora, ai o moleque falou assim: "Vamos pegar o beco (incompreensível)", pô aí o professor suspendeu ele uma semana, só por causa disso.

$\mathrm{P}:$ Ah é, lá é mais rígido.

E: Mais rígido, isso mesmo.

P: Ah lá é mais

E: Isso

P: se o cara não anda na linha lá, vai pra diretoria.

E: Vai pra diretoria

P: Aqui se acha que

E: Então, meu irmão, um dia, tava fazendo um negócio, uma brincadeirinha lá atrás no papel, a professora colocou ele na diretoria [P: Ah, é ]E: To falando..., mais rígido

10- P: Então, o que é um bom aluno assim, você falou né, respeitar o professor, mas assim em relação a estudar

E: A estudar...

P: Você trabalha o dia inteiro, você não tem tempo pra estuda durante o dia

E: Não, durante o dia não

P: Mas na sala de aula

$E$ : Na sala de aula $\mathrm{P}$ : $\mathrm{O}$ que você acha que o aluno tem que faze pra ele pode aprende, porque o aluno que trabalha o dia inteiro, só vai pode estuda na hora da aula não dá pra fica, ele trabalha.

E: Tem que, tem que presta bastante bem a explicação do professor, fazer seus papéis, suas lições, entendeu [P: Hum, hum] E: Eu acho que isso, que você vem pra sala de aula, não faz suas lições ou alguma coisa assim, você não vai aprende, às vezes você 
tem uma dúvida como é que você vai tira, às vezes você está com seu caderno, com alguma coisa, tem alunos que acha a explicação.

11- P: Você escreveu aqui na pergunta número sete aqui o, tarefa que eu gosto de fazer é aquela que eu possa realmente pensar.

E: Realmente

P: Porque você gosta disso?

E: Porque se você não tá pensando como é que você vai fazer(risos) [P: Ah, Mas não é mais fácil, por exemplo, assim o professor vem passa a resposta, faz uma pergunta e responde, só as respostas assim, pensa, porque fica pensando, o professor já sabe.

E: Eu sei, você tem que pensa bem lá do fundo, pra pode, pra pode faze, tipo assim, você faz uma pergunta sem pensa, ali você vai faze na doida, você vai faze achando que tá certo, você vai pensando, e dali vai achando um, vai puxando, puxando até que vem uma coisa na tua cabeça e uma maneira de você, de você faze, de você responde.

P: Então, você acha assim que você gosta de pensa, você acha legal, você pensa assim, você acha importante.

E: Importante, principalmente se você está só, mas quando tá, tipo assim, na sala aquela bagunça.

P: A bagunça, aí não consegue

E: Aí não consigo

P: Aí distrai né

E: Na hora da prova, também não consigo, às vezes você tá, pra raciocina aquela pergunta pra faze aí não consegue.

12- P: Por exemplo, você falou de prova assim, o que você acha de prova?

E: Como assim prova

P: Prova é uma coisa boa, uma coisa ruim

E: Não prova é uma coisa boa, pra você, pra você avalia o aluno não é

[P: hum, hum] E: Mas só a prova não avalia também eu acho

P: Você fica muito preocupado com prova

E: Não, eu ficava, mas agora não

P: Você tem medo de ir mal assim

E: Não, agora não, antes eu tinha.

13- P: Por exemplo, assim se você estudou para uma prova, mas na hora você se confundiu e conseguiu uma nota $\mathrm{C}$, como você se sente?

E: Sinto mal né, ter estudado e tirado $C$, pô (risos)

$\mathrm{P}$ : Mas você não acha assim que você sei lá, não sabe nada

E: Então, isso não só me sinto mal porque eu estudei, estudei e não

$\mathrm{P}$ : Tirou uma nota $\mathrm{C}$.

$E$ : É, tira um $C$, bom porque às vezes, você vai estuda, estuda, estuda, mas na hora da prova é outra coisa diferente [P: hum, hum] E: Sei lá, aí não consegue.

14- P: Você sempre tirou notas boas?

E: Até, chegando a quarta série sim, depois foi razoável. 
P: Razoável

E: É

P: Até a quarta série, você era um aluno

E: Pó, tirava dez, na época lá, era dez né, dez, oito a nota que eu tirava

P: Então, quando você era garoto, você era um aluno, você sentava na frente ou atrás?

E: Como assim, sentava?

$\mathrm{P}:$ É, você sentava assim mais na frente

E: Eu sento, igual eu sento agora, no meio

P: No meio

E: É no meio, e no canto, porque fica no meio, fica muito bagunça, muita bagunça eu não gosto, fica mais no canto, eu comecei estuda, ia faze onze anos, comecei estuda, na época lá passei três anos, eu acho que é três anos na

P: Mas porque você só foi estuda com onze anos?

E: Porque lá você sabe como é que é né

P: É difícil né

E: Lá você não tem

P: Escola é difícil

E: Não tem formação, você, fui estuda, meu irmão que me chamo, me chamo pra ir pra sala de aula, ai eu peguei fui, peguei um caderninho, comecei a estuda e aí, mas lá na época lá, as professora lá, a segunda série tem professora que não sabia nem a segunda série que estuda, não tinha to falando.

P: Mas você era um bom aluno?

E: Mais ou menos

P: Não, mas você

E: Não, na época lá, na minha sala eu era um bom aluno

P: Sempre você

$E: \dot{E}$

15-P: Quem fez você gosta de matemática, na época

E: Eu mesmo [P: Não, mas] E: Eu gostei do que o número é mais fácil de você aprende

P: Você acha que o número é mais fácil?

E: Não precisa decora [P: Ah...]E: Eu acho que não precisa decora número [P: Faze conta assim] E: Não precisa, a conta você faz na cabeça tal

P: Então, mas agora você tá falando que gosta de Filosofia, Filosofia não.....

E: Então, mas agora, na minha maneira de pensa é mais fácil agora

P: Filosofia

$E: \dot{E}$

P: Mas não tem que dec, não Filosofia não

E: Não, Filosofia não precisa decora, Filosofia acho que é uma coisa que acontece no dia a dia, a gente vai estudando.

P: Você pensa ali

E: $\dot{E}$

P: O que você acha que tem diferente entre Filosofia e Matemática, você vê alguma diferença, assim, porque é diferente Filosofia é uma coisa, o que você acha que seria mais diferente assim?

E: Porque matemática é agora, é complicado, porque a matemática, mexe com problema com número essas coisas e a filosofia não, a filosofia mexe com o ser humano, eu acho, na minha opinião.

P: Isso 
E: Na maneira de pensa, na maneira de agi, na maneira do

P: Porque é assim, se você tá constando mais $E$ : $\dot{E}$, também tem a ver mais da maneira que o professor explica né, [P: Hum, hum] E: quando você tem um professor que explica bem, eu acho que qualquer uma matéria é boa.

15- P: É..., quando o professor propõe um desafio, como você se sente, por exemplo, assim, o professor diz assim "Pessoal quem consegui responde esta pergunta aqui, esta pergunta difícil, quero sabe quem consegue responde", como é que você se sente?

E: Quem consegue responde e se eu responde certo

P: Não, não, o professor chega na sala e diz assim "Gente oh, tem um problema pra vocês resolverem, um desafio pra vocês", como é que você se sente, não se você vai ter que responde certo ou errado, não é essa intenção, mas na hora que ele faz isso como é que você se sente?

E: Não, na hora eu fico quieto, eu acho que eu fico quieto, mas tentando responde

P: Mas cê acha que você se sente mal, assim, tipo assim, vai erra, alguma coisa assim

E: Não, mal não, mal eu não sinto, sinto vontade de faze e faze certo, só isso

16- P: Quando você era... seus pais se preocupavam com as notas de vocês, com

E: Se preocupavam

P: De vez em quando levava uma coça também

E: Não, isso não

P: Não davam uns pega não

E: Uma, uma

P: Mas como é que seus pais faziam pra cobra as notas

E: Não, tinha vez que a gente faltava na aula, aí ele pegava no pé ou às vezes você ia pra roça e lá a gente trabalha na roça né, aí chegava maior cansado aí a gente não queria ir pra escola [P: Ficava cansado] E: Porque lá é pesado, eu estudei até a sétima série, da quinta à sétima série na cidade [P: Hum, hum]

E: Era, você sabe o que é légua, três léguas, mais ou menos seis quilômetros.

P: Você tinha que andar até lá

E: A gente andava três léguas e meia em cima de um caminhão, o banco era de madeira, na poeira, era pulando, a gente pulava bem em alto, todo dia, todo dia, aí quando chovia aqui um rio no meio, teve um dia que choveu um rio no meio a gente só atravessava só de canoa, na frente, ai vinha na frente, vinha outro rio, aí não dava pra passa, porque não tinha canoa, nós dormiu no meio da chuva.

P: Nossa senhora, o pessoal daqui não sabe o que é

E: Sofrimento, lógico, pó mano, maior sofrimento, a gente achava bom porque vinha na maior algazarra em cima do carro [P: Conversando e tal] E: Conversando, às vezes namorando [P: Aquela festa né] E: Pó, aí a gente gostava, mas por outro lado.

Apesar das dificuldades para estudar, o sujeito Des não relata ter sofrido com alguma exposição vexatória. Inclusive, parece lembrar-se desta fase da sua vida com certo ar de saudosismo: pó mano, maior sofrimento, a gente achava bom porque vinha na maior algazarra em cima do carro [...] Conversando, às vezes namorando [...] Pó, aí a gente gostava, mas por outro lado. Logo, o cotidiano escolar do sujeito não parece ter sido vivenciado com algum tipo de sofrimento. 
17- P: Assim tem alguns alunos que quando recebem as provas eles ficam comparando nota, o que você acha disso?

E: Isso, às vezes eu faço (risos), você percebeu às vezes que eu comparei com a menina,

P: Não, não

E: Não lembra

P: Não lembro

E: No ano passado, eu acho, comparei com a da Ga(Sujeito da pesquisa)

[P: Ah...]

E: Acho que você tinha colocado errado na minha, comparei com a dela e na dela tava certo, aí eu comparei, eu falei pra você e você falou que não P: Ah, me lembro

E: pode faze isso

P: Não, mais ou menos assim: tem aluno que tira nota $A$, aí tem aluno que tira nota vermelha, aí fica assim "Aí tá vendo, não sei o que lá, você é burrão, não sei o que lá, tirei nota A"

E: Ah, não eu fico quieto, eu fico quieto

P: Mas tem um pessoal que faz isso não faz?

E: Eu não faço, agora tem gente que faz

P: Você acha isso legal, isso

E: Eu não acho legal, você fica tirando uma com a cara do cara porque o cara não fez, pó, às vezes não tá estudando nem no grupo, às vezes a pessoa não faz porque aconteceu alguma coisa, mas não é porque ela não sabe.

P: O professor faz uma pergunta, você tem quase certeza da resposta, você arrisca e responde ou espera que alguém responda pra você?

E: Eu espero que alguém responda, eu espero.

P: Porque

E: Espero, desde criança eu acho que eu tenho medo de erra e aí alguém fica zuando, eu acho que é assim

P: Mas porque assim, você tem medo de erra

E: Eu não sei, eu acho que sou assim mesmo

P: Porque o professor não vai

E: Eu sou assim

P: Se você responde, você acha que o pessoal vai tira barato ali, se você erra, você fica

E: Às vezes, nem eu tendo certeza, às vezes eu respondo, não sei porque, sério mesmo

P: Mas se teve alguma coisa, quando você era jovem na escola, quando você respondeu, você passou por algum momento difícil na escola alguma vez assim, ter tirado uma nota muito baixa.

E: Eu passei um momento na escola, mas eu acho que não tem nada a ver não, uma vez eu tava fazendo uma prova, essa professora, ela tem um filho na escola né, ai na prova eu pedi pra ela dá uma explicação, dá exemplo pra mim pode faze, ai nisso ela tava explicando pro filho dela, pô, eu fiquei com tanta raiva que rasquei a prova e saí pra fora e não fiz mais, isso era o meio do ano e eu não fui estuda mais.

P: Você parou de estuda, por causa disso.E: Parei de estuda, na metade do ano.

P: Que série você estava

E: Tava na primeira série

P: Na primeira série

E: Minha mãe foi lá 
P: Logo na primeira série!

E: A minha mãe foi lá no final do aluno, minha mãe foi lá conversou com ela, ela olhou minha nota, e nota já tinha dado pra mim passa o ano todo.

P: Tinha dado pra você passa já

E: Ela passou pra segunda série, aí a segunda série, ai de lá pra cá não repeti mais

P: Não repeti mais, mas você passou normal

E: É, normal

P: Então, assim porque você acha assim, então, que você tem assim

E: Nunca fiquei de recuperação

P: Mas porque você acha que você tem, por exemplo, você sabe a resposta

E: Eu acho que é porque eu sou tímido, eu acho que é isso

P: Você acha que é a sua timidez, não é isso

E: Eu acho

P: O fato assim de você vir do Ceará, isso, você ser do Ceará, você está em São Paulo, você acha que isso dificulta, você a fala, por exemplo,

E: Não P: Você ficar E: Não P: com vergonha dos paulistas $E$ : Não P: Não E: Lá eu acho que ainda era pior P: Era E: É, eu acho que lá era pior ainda P: Você falava menos lá ainda $E$ : Lá eu falava menos, até às vezes com os colegas ali, pô, criado junto, às vezes eu, pancava(trecho confuso) mesmo.

18- P: O que você acha do trabalho em grupo?

E: Legal, legal, você vai discutindo e vai aprendendo com o outro né

$\mathrm{P}: \mathrm{Na}$ hora que você vai discutindo

$E$ : É, você vai discutindo as ideias e se dá uma ideia, dá o outro, vai ver que a do outro tá certo né, você vai aprende com o cara não é

P: Hum, mas se você fica com vergonha como é que?

E: Se você fica com vergonha pó, mas no grupo tem que (risos)

P: No grupo se (risos)

E: Tem que conversa (risos)

P: Mas se você não fala homem de Deus como é que você?

E: Se eu não fala, mas tem que conversa, quero ver se converso

P: Mas se acha importante, o

E: Mas, eu acho importante, só assim vai acabando minha timidez (risos)

P: Mas, assim e pra arruma uma namorada heim, como é que fica?

E: Pó, pra arruma namorada é diferente (risos), aí acaba a timidez

P: Aaaahh (risos)

E: Pra falar a verdade nunca cheguei numa menina não

P: Não

E: Não, aliás cheguei uma vez só

$\mathrm{P}$ : Você vai em forró essas coisas assim

E: Vou, vou

P: E pra dançá

E: as meninas que chegam em mim, mano

P: E pra dançá

E: Pra dançá é diferente, você já chega e chama pra dançá, mas pra namorá não

P: Aí é difícil,

E: Não

P: Timidez 
E: Não, lá o pessoal não chega, não chama ninguém pra namorá não, já chega e já começa logo a beijá (risos) e vai rolando

$\mathrm{P}$ : É mais rápido né (risos), não tem essa coisa

E: É, é rápido, pô, ainda mais lá que tem esse negócio do forró lá, uma dança colada né e ali você já vai

P: Conversando ali, rolando aquela coisa ali

E: No esquenta ali (risos) P: Heee E: Hoo

19- P: O que de bom tem trabalha em grupo eu já perguntei, você tem alguma dificuldade quando trabalha em grupo?

E: Tem, tem

P: Qual dificuldade que você tem

E: Eu tenho dificuldade.... né....essa mesma de conversa, mas não temdificuldade...agora me pego

P: Não porque você falou assim que troca ideias

E: É troca ideias

P: Essa é a parte boa

E: Essa é a parte boa

$\mathrm{P}:$ Qual seria a dificuldade de trabalho em grupo, pode ser que você não tenha nenhum, mas se você fosse colocar alguma dificuldade, qual que você colocaria?....P: Ou o melhor, por exemplo, você preferia que o professor explicasse tudo na lousa, ou trabalha em grupo, discutindo o que você preferia dos dois

E: Não, todos os dois é melhor, mas só que no grupo eu acho que você aprende mais, mas a parte ruim é que você, pô, a parte ruim tem, mas só que num, só sei fala na hora [P: hum, hum]

E: Na hora você vai pensando

$\mathrm{P}:$ Você já pegou grupo ruim de trabalhar?

E: Já, já peguei P: Qual?

P: Grupo que não faz nada assim

E: Não faz nada, faz nada, uma vez eu peguei

P: E aí?

E: Só você faz, só você pensa e aí vezes nem P: E aí?

E: Aí não dava, por isso que às vezes a gente vai fazer dever, a gente escolhe as pessoas, muito mais fácil com quem

P: Vocês escolhem as pessoas, lá no seu grupo

E: É o grupo, é até a Ga e a En escolhe também, porque elas quando vai fazer, elas fazem mesmo, interessadas tudo

P:Hum, hum, você gosta deste grupo que você está?

E: Esse grupo que eu tô, eu gosto porque trabalha, procura aprende legal e não fica esperando pelos outros

19- P: Você acha que o trabalho em grupo ajuda?

E: Ajuda

P: Professor pede pra você resolverem várias questões em grupo, como o grupo se comporta esse seu grupo, como é que se comportam, como é que eles agem, como é que eles fazem as coisas, você acha que faz mesmo, ou cê acha que o pessoal fica com o corpo mole? 
E: Sempre no grupo, eu acho que tem um que fica de corpo mole, eu acho, sempre um tem que fica com o corpo mole.

P: Então, mas nesse grupo agora que você tá, tem alguém assim

E: No meu acho que não

P: Nesse agora, você acha

E: Acho que não, até agora não

P: Por exemplo, assim você está em grupo né, aí imagina que nem você nem seu amigo sabe a resposta, às vezes tem umas perguntas lá, meu Deus do céu

E: É verdade,

$\mathrm{P}:$ E aí que que faz?

E: Tem que consulta o professor

P: Aí chama o professor

E: Tem que chama

P: Mas aí vocês não ficam com uma sensação ruim assim “ pó, eu sou burro, eu não sei” não dá essa

E: Ah, isso não passa pela minha cabeça, nunca passou pela cabeça, eu tô fazendo ali eu não sei, mas não passa pela minha cabeça se eu sou burro (risos)

P: Não, tipo assim, "Ah, eu não consigo mesmo faze isso aqui, eu não consigo faze nada, nunca passo isso na sua cabeça?

E: Não, nunca passei

P: Você está resolvendo em grupo algumas questões de matemática, você tá lá, no segundo colegial, aí tem uma questãozinha lá da quinta série, só que você não foi naquela aula, faltou, não entendeu, não sabe faze, mas a pergunta é lá da quinta série o que você faz, você não sabe, só você que não sabe do grupo, todo mundo sabe, você não sabe, o que você faz?

E: Eu, eu deixo pra procura em casa, pra consulta em casa.

P: Você não pergunta pro grupo

E: Mas se o grupo sabe?

P: O grupo sabe

E: Ah, então eu pergunto pro grupo, se o grupo não soube, eu chego e vou consulta em casa.

P: Então, você não chama o professor

E: Não, primeiro eu consulto o grupo, se o grupo não sabe

P: Então, você não vai fica achando assim, sei lá, o pessoal vai acha você burro, porque você não sabe aquela questãozinha?

E: Vai depende da pessoa que você tá perguntando né, você vai pergunta pra pessoa que você já tem mais intimidade.

P: No caso do seu grupo assim você perguntaria.

E: É, pergunto, mas pra outra pessoa que não tem tanta intimidade assim que não seja do grupo eu não pergunto, eu pergunto pro professor.

20- P: Você sabe que alguns alunos tiram barato quando é, quando os alunos respondem errado, o que você acha disso?

E: Na minha opinião, eu acho horrivel

P: Você já passou por isso, já alguma vez

E: Não, eu não passei por isso, porque como eu falei pra você eu não respondo

P: Você é tímido

E: Mas eu já vi gente fazendo isso, mas eu não gosto, eu não gosto mesmo. 
P: Você nunca passou por uma situação quando você era menino assim, algum professor manda você ir na lousa, e você não, e chega lá e você não consegue responde e você fica preocupado assim, já aconteceu isto com você, que você se lembra?

E: Não, não

P: Ficou preocupado?

E: Não

P: Alguma prova, você ficou morrendo de medo o professor deu uma nota vermelha, assim você achou meio burro assim "Meu Deus do céu eu não consigo aprende isso" você já, alguma vez, você já passou por isso, alguma vez?

E: Eu só fico chateado de ter tirado aquela nota baixa [P: Ah] E: Mas na esperança, da próxima prova eu recupera aquela nota.

P: Você acha que é preciso o que então pra aprende assim, o que se acha pra aprende precisa do quê?

E: Uma boa explicação

P: Mas, por exemplo, por parte do aluno, por que é parte do professor?

E: Ah, por parte do aluno

$\mathrm{P}$ : No seu caso, assim você tirou nota $\mathrm{C}$, que não é uma nota vermelha, não é um $\mathrm{A}$, mas também não é uma nota vermelha.

E: Ai eu me proponho a melhorar

P: O que é procura melhorar, pra você, o que você vai faze pra procura melhora?

$E$ : É, em cima daquela prova que você fez, em cima daquelas perguntas, você pesquisa e procura e responde e também aprende né o que eu fiz na prova e fica mais esperto.

21- P: Você assim, que nem a semana do provão agora, como é que você fez pra estuda

E: Provão

$\mathrm{P}:$ Você estudou, não estudou

E: Não, não estudei, aliás eu estudei uma horinha, eu chego em casa, eu estudo só naquela hora

P: Porque não dá tempo né

E: Não dá tempo, quem nem o sábado eu não estudo e no domingo também não

P: Aí você descansa né

E: Só estudo uma hora antes

P: Só estuda uma hora antes

E: que nem se eu estuda, tipo assim, a prova vai se hoje, ontem, eu não consigo, eu esqueço tudo, eu acho melhor estuda na hora.

22- P: Pra você assim, você acha que precisa assim, de mais esforço pra estuda, pra aprende tem que ter esforço, como é que é, ou não você acha que você aprende mais fácil?

E: Depende das matérias também, tem umas matérias que você tem que tem esforço, agora tem uma matérias que você aprende mais fácil.

P: Você acha que tem matéria que é fácil

E: Tem matéria que é fácil, só uma olhada que já dá, já pega tudo.

P: Mas as mais difíceis aí

E: Tem que ter esforço, tem que...é até por isso que na, quando eu vou faze prova, eu procuro as matérias mais dificeis pra mim estuda.

P: Porque daí né 
E: É, as outras é..., procuro as mais difíceis.

23- P: Uma razão importante para que eu realize uma tarefa na escola é que eu goste dela?

E: No caso eu?

P: Você colocou isso, é, você gosta dela é uma razão legal pra você

E: Como assim?

P: Não, você colocou assim que pra você realizar uma tarefa na escola, você acha importante que

E: Que eu goste dela [P:É] E: Isso mesmo, porque facilita mais na maneira de eu pensa, de eu faze.

P: Mas porque você acha que facilita, "gosta" facilita

E: Porque você gostando, você já vai com, mesmo que você não sabe, você já vai com corpo e alma e vai faze

P: Você vai com a...

E: Com certeza que você vai faze e vai consegui e quando você não gosta, você vai ali, quando você vê que não sabe, você desanima.

$\mathrm{P}: \mathrm{O}$ que faria você não gostar de uma matéria

E: Matéria

P: Não gosta, o que te faria não gostar de uma matéria?

E: Eu acho que...., por partes também deve ser tem o professor, às vezes tem o professor, que é, não é chato é que às vezes não explica da maneira que se pegue [P: entendi] $E$ : bem

P: Você acha que entende é uma coisa que faz gosta?

E: É, eu acho que a matéria pode ser dificil, mas se você ter uma maneira mais, mais suave de explica pro aluno pega melhor, eu acho que ela se torna fácil [P: Hum, hum]

E: Eu acho assim

P: Mais você não vê assim, nenhuma dificuldade em aprende as coisas assim

E: Não, não eu não acho não

$\mathrm{P}:$ Você acha que é pra você é normal assim, você não acha por exemplo assim, "Ah, eu sou ruim de matemática que eu não sei pensa em matemática" você não pensa essas coisas assim

E: Não

P: Eu sou burro assim eu não consigo faze isso, nunca aconteceu

E: Não, não passa pela minha cabeça não, se eu for, se passa pela minha cabeça aí pronto ai eu num estudo mesmo.

P: Aí você não estuda mesmo

E: Aí eu não estudo (risos)

$\mathrm{P}$ : Eu estou perguntando isso, porque têm alguns alunos que pensam isso em relação à matemática né, matemática às vezes é uma matéria um pouco difícil então cara pensa: "Meu Deus, eu não consigo, eu não consigo", o cara nem viu a matéria, mas o cara já, né E: Eu sei

P: Já fica parece que tem um trauma

E: É verdade

P: Parece, entendeu, por isso eu quero saber se alguns alunos

E: É verdade

$\mathrm{P}$ : Pensam assim, mas eu acho que você não pensa isso

E: Não, eu não penso não, eu da maneira que eu to aprendendo, vendo que eu to aprendendo e eu acho que tá sendo válido. 
24- P: Você está indo bem na escola, você está indo tranquilo na escola?

E: Estou indo tranquilo

P: Você está bem aqui tal?

E: Eu graças a Deus to bem

$\mathrm{P}$ : O que bom, eu gostei muito do grupo que você arrumou, acho que esse grupo arrumou, você pode aprende muito com esse grupo, o grupo também com você também $E: \dot{E}$

P: Vocês são um ótimo grupo, vocês são um exemplo de grupo pra escola.

E: Então, eles é que estão me ajudando a tirar essa timidez[P:É (risos)] E: $O$ ano passado eu cheguei aqui e não conhecia ninguém mano, era para eu ter começado o ano retrasado né aí fiquei com minha prima que estudava aqui aí eu vinha mais ela e não vim, não sei se você conhece ela a Nome

P: Não sei, são tantos alunos que...a da $\mathrm{Pa}$... aqui

E: É

P: Não

E: Não, não, uma moreninha, Pa..., Ti...[P: Conheço]E: Então, são meus primos (risos)

P: Então, tá bom Des obrigadão heim, eu não vou mais encher o saco de vocês,

E: Não, não esquenta não

P: Desculpa aí, fica toda hora, vamos lá, não sei o que, obrigadão viu tá

E: Sobre este negócio do provão, na minha opinião eu não gosto

P: Você acha que era melhor não ter provas?

E: Eu acho melhor ter provas todo mês, uma provinha todo mês, não provão

$\mathrm{P}:$ Ah, você acha que deveria ter prova todo mês

E: Todo mês

P: Tipo assim, cada matéria faz várias provas e pronto

$E: \dot{E}, \dot{e}$

P: Do que uma só

E: É, porque o provão, você faz o provão, tem gente que nem faz nada né aí na hora do provão, às vezes tira uma letra A, entendeu, como é que você vai sabe se ele estudo ou se não

P: É porque, ai não é justo né

E: Não é justo P: Porque no caso?

E: Porque, todo mês você vai pegando ali, você vai acompanhado passo a passo, entendeu eu acho assim, porque lá onde eu estudava era assim

P: Provão você acha quê?

E: Provão acho que é só pra faze mesmo, na minha opinião...

P: Você acha que não?

E: Teria que se nada

P: Obrigadão, viu e eu concordo com você

E: É verdade...

\footnotetext{
${ }^{6}$ Nome suprimido para garantir o anonimato.
} 
Dissertação de Mestrado

Conflito Cognitivo e Metas de Realização: uma Experiência nas Aulas de Física do Ensino Médio

\section{(Apêndice)}

Sérgio Antônio da Silva

\section{Orientador: Prof. Dr.: Alberto Villani}

São Paulo, 2013 